Biotechnology in a Global Economy

October 1991

OTA-BA-494

NTIS order \#PB92-115823

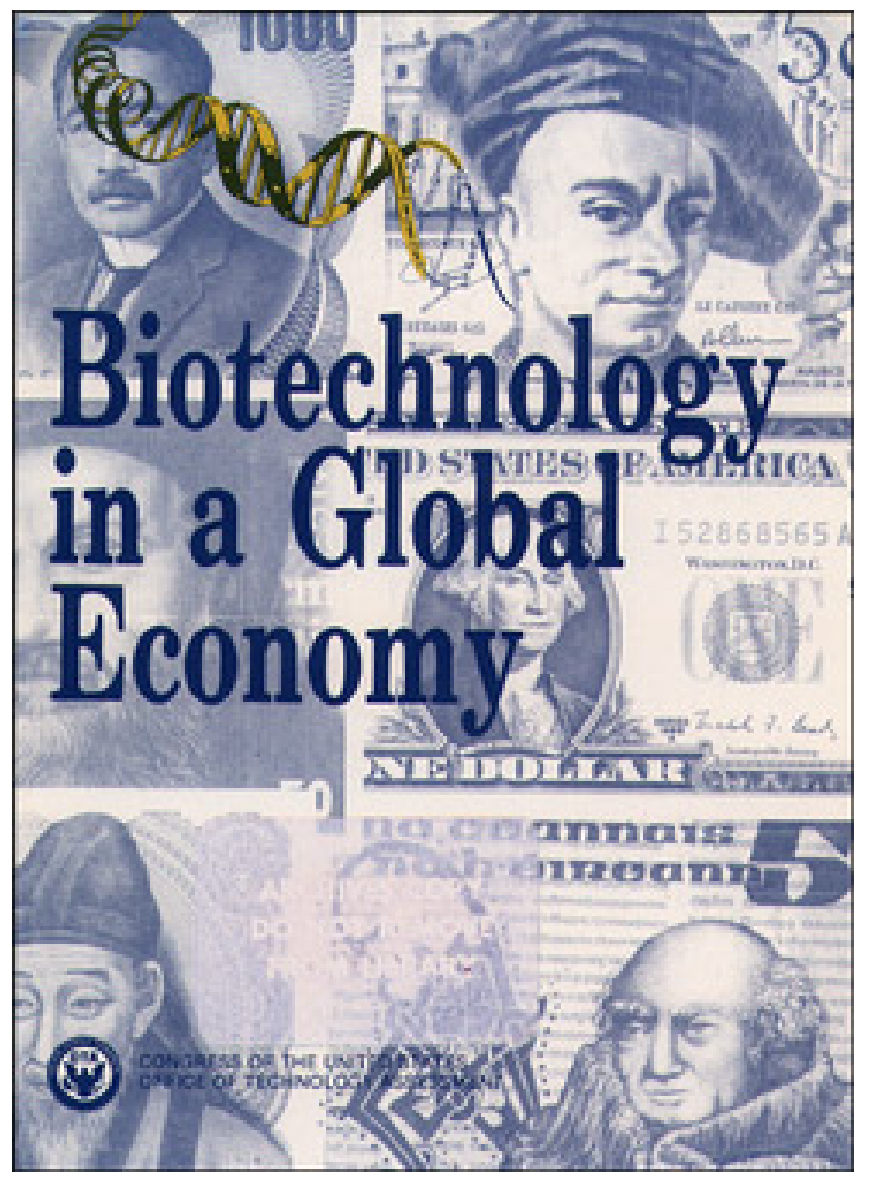




\section{Recommended Citation:}

U.S. Congress, Office of Technology Assessment, Biotechnology in a Global Economy, OTA-BA-494 (Washington, DC: U.S. Government Printing Office, October 1991).

For sale by the U.S. Government Printing Office

Superintendent of Documents, Mail Stop: SSOP, Washington, DC 20402-9328

$$
\text { ISBN } \quad 0-16 \quad-035541-9
$$




\section{Foreword}

Since the discovery of recombinant DNA technology in the early 1970s, biotechnology has become an essential tool for many researchers and the underpinning of new industrial firms. Biotechnology-which has the potential to improve the Nation's health, food supply, and the quality of the environment-is viewed by several countries as a key to the marketplace of the 21st century. In order to understand the potential of biotechnology in a global economy, it is first necessary to identify current and potential applications of biotechnology, and to learn how various Nations support and regulate the uses of biotechnology in commerce.

This report examines the impact of biotechnology in several industries, including pharmaceuticals, chemicals, agriculture, and hazardous waste clean-up; the efforts of 16 Nations to develop commercial uses of biotechnology; and the actions, both direct and indirect, taken by various governments that influence innovation in biotechnology.

The report was requested by the House Committee on Science, Space, and Technology; the Senate Committee on Agriculture, Nutrition, and Forestry; the Senate Committee on the Budget; and the Senate Committee on Governmental Affairs. OTA was assisted in preparing this study by a panel of advisers, experts from 16 countries who participated in an international conference, two workshop groups, and more than 140 reviewers selected for their expertise and diverse points of view on the issues covered in the report. OTA gratefully acknowledges the contributions of each of these individuals. As with all OTA reports, responsibility for the content of the final report is OTA's alone. The report does not necessarily constitute the consensus or endorsement of the advisory panel, the workshop groups, or the Technology Assessment Board.

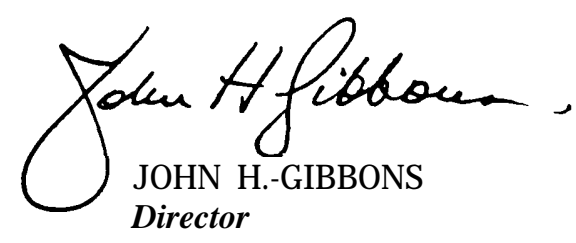




\title{
Biotechnology in a Global Economy Advisory Panel
}

\author{
Robert Reich, Chair \\ J ohn F. Kennedy School of Government \\ Harvard University \\ Cambridge, MA
}

\author{
Alberto Adam \\ Vice President \\ International Agricultural Division \\ American Cyanamid Co. \\ Wayne, NJ \\ Brian Ager \\ Director, Senior Advisory Group on Biotechnology \\ Brussels, Belgium \\ Robert $\mathrm{H}$. Benson \\ Senior Patent Attorney \\ Genentech, Inc. \\ South San Francisco, CA \\ Stephen A. Bent, Partner \\ Foley \& Lardner \\ Alexandria, VA \\ J erry Caulder \\ Chairman, President, and Chief Executive Officer \\ Mycogen Corp. \\ San Diego, CA \\ Peter F. Drake \\ Executive Vice President and \\ Director of Equity Research \\ Vector Securities International, Inc. \\ Deerfield, IL \\ Anne K. Hollander \\ Washington, DC \\ Michael Hsu \\ President \\ Asia/Pacific Bioventures Co. \\ New York, NY \\ Dennis N. Longstreet \\ President \\ Ortho Biotech \\ Raritan, NJ \\ Kenneth J . Macek \\ President \\ TMS Management Consulting \\ Framingham, MA
}

Lita L. Nelsen

Associate Director

Technology Licensing Office

Massachusetts Institute of Technology

Cambridge, MA

Richard K. Quisenberry

Vice President, Central Research and Development

DuPont Experimental Station

Wilmington, DE

Sarah Sheaf Cabot

Biotechnology Licensing Consultant

Malvern, PA

J ames 3?. Sherblom

Chairman and Chief Executive Officer

TSI Corp.

Worcester, MA

Donna M. Tanguay,

Willian, Brinks, Olds, Hofer, Gilson, \& Lione

Washington, DC

William J. Walsh

Executive Vice President and Chairman

Currents International, Inc.

Oakton, VA

Thomas C. Wiegele*

Director

program for Biosocial Research

Northern Illinois University

DeKalb, IL

W. Wayne Withers,

Senior Vice President, Secretary and

General Counsel

Emerson Electric Co.

St. Louis, MO

\section{${ }^{*}$ Deceased.}

NOTE: OTA appreciates and is grateful for the valuable assistance and thoughtful critiques provided by the advisory panel members. The panel does not, however, necessarily approve, disapprove, or endorse this report. OTA assumes full responsibility for the report and the accuracy of its contents. 


\section{OTA Project Staff-Biotechnology in a Global Economy}

Roger C. Herdman, Assistant Director, OTA

Health and Life Sciences Division

Michael Gough, Biological Applications Program Manager

Gretchen S. Kolsrud, Biological Applications Program Manager

Kevin W. O'Connor, Project Director

Kathi E. Hanna, Senior Analyst

Margaret MCLaughlin, Analyst

Randolph R. Snell, Analyst ${ }^{2}$

Suzie Rubin, Research Analyst

\section{Editor}

Bart Brown, Washington, DC

\section{Support Staff}

Cecile Parker, Office Administrator

Linda Rayford-J ourniette, Administrative Secretary

Jene Lewis, Secretary

\section{Contractors}

Evan Berman, Arlington, VA

Sue Markland Day, University of Tennessee

Genesis Technology Group, Cambridge, MA

Kathi E. Hanna, Churchton, MD

Gregory J. Mertz, Washington, DC

Michael K. Hsu, Asia/Pacific Bioventures Co.

Tai Sire, Washington, DC

Paul J . Tauber, Ithaca, NY

William J. Walsh, Oakton, VA

Hal Wegner, Washington, DC

Aki Yoshikawa, University of California, Berkeley

${ }^{1}$ Through September 1989.

${ }^{2}$ Through April 1990. 


\section{Contents}

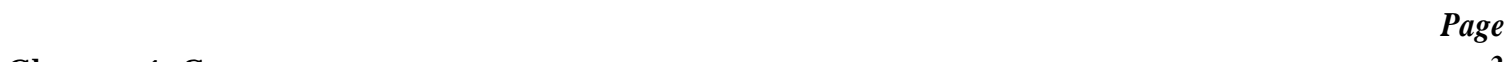

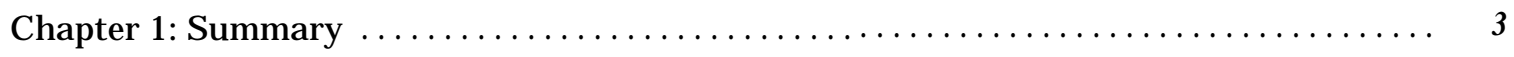

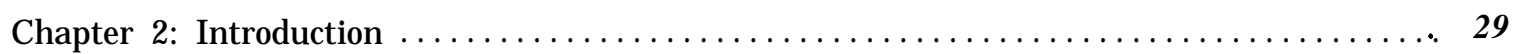

Part I: Commercial Activity

Chapter 3: Introduction: Commercial Activity ........................... 39

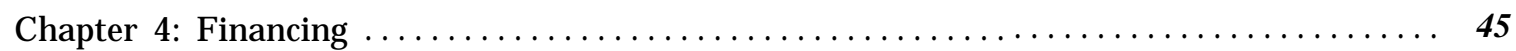

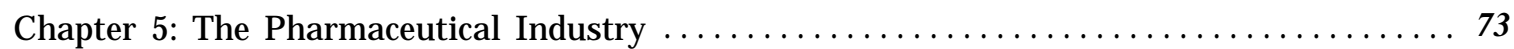

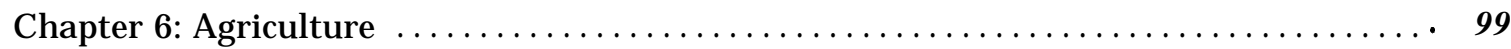

Chapter 7: The Chemical Industry . . . . . . . . . . . . . . . . . . . . 119

Chapter 8: Environmental Applications ...............*............... 129

Part II: Industrial Policy

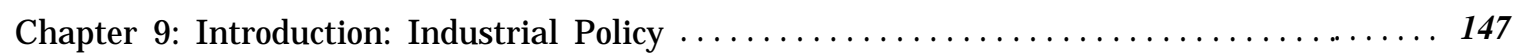

Chapter 10: Science and Technology Policies ............................ 151

Chapter 11: Regulations .......................................... 173

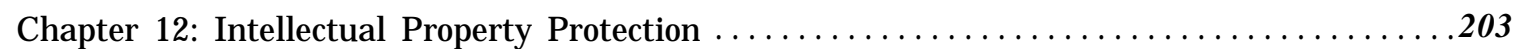

Appendix A: A Global Perspective: Biotechnology in 14 Countries . . . . . . . . . . . 229

Appendix B: Comparative Analysis: J apan ........................... 243

Appendix C: Federal Funding of Biotechnology, FY 1990/1991 ................. 249

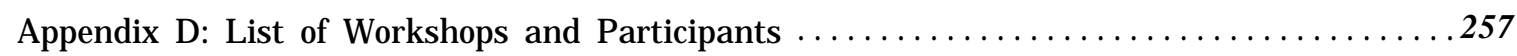

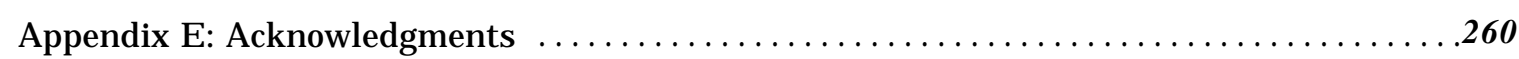

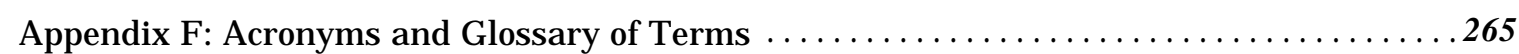

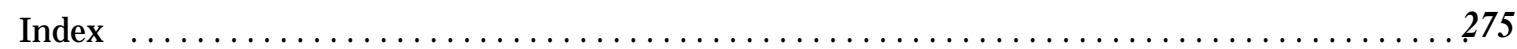




\section{Chapter 1}

\section{Summary}

"As we move through the next millennium, biotechnology will be as important as the computer."

J ohn Naisbitt \& Patricia Aburdene

Megatrends 2000

"Biotechnology-the very word was invented on Wall Street-is a set of techniques, or tools, not a pure science like much of academic biology."

Robert Teitelman Gene Dreams 


\section{CONTENTS}

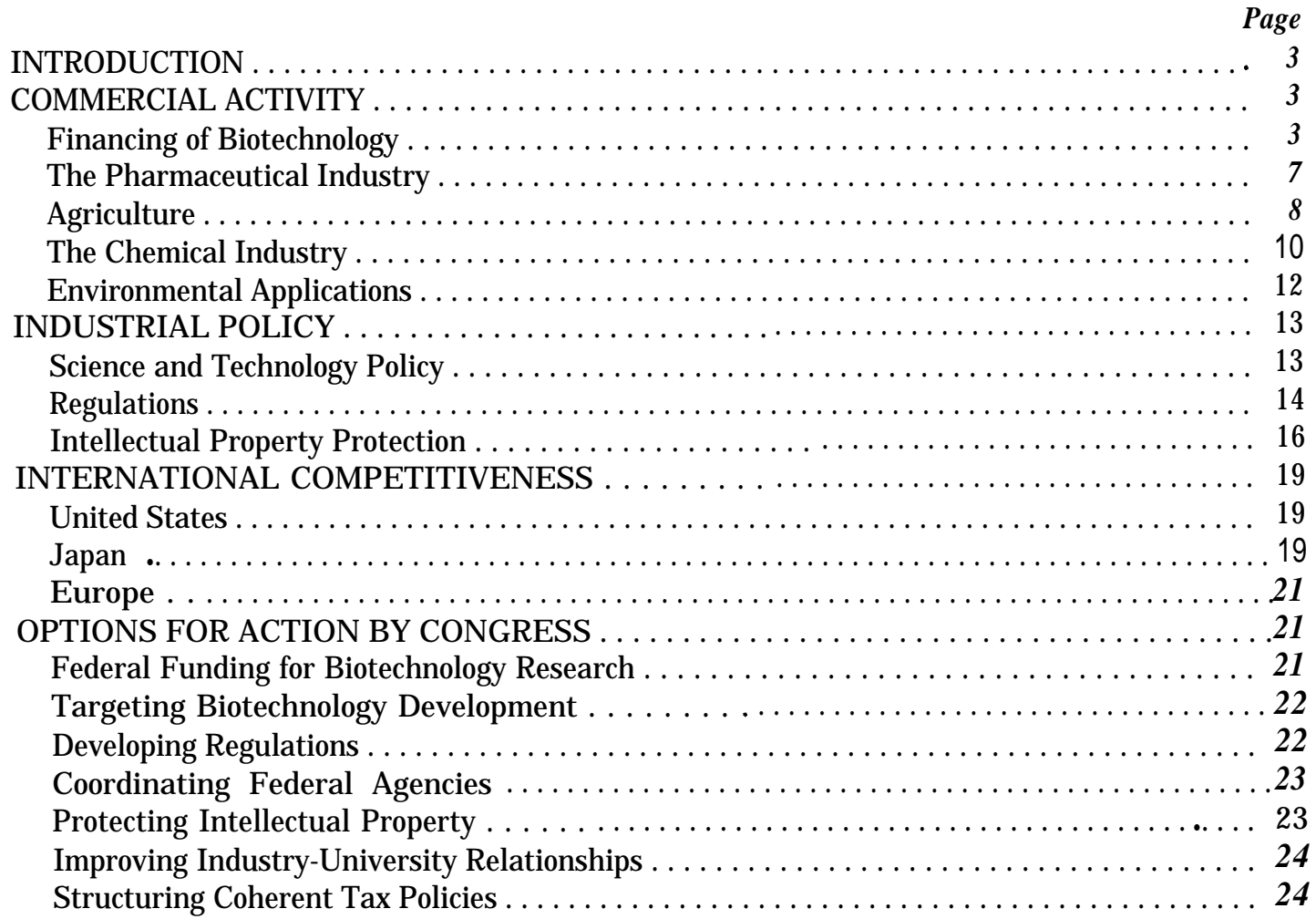

Boxes

Box Page

I-A. Defining Biotechnology $\ldots \ldots \ldots \ldots \ldots \ldots \ldots \ldots \ldots \ldots \ldots \ldots \ldots \ldots \ldots \ldots \ldots \ldots \ldots \ldots \ldots, 5$

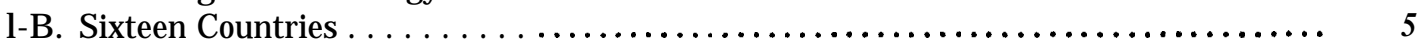

I-C. Biotech's 1991 Stock Boom ......................................... 7

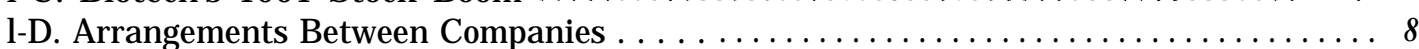

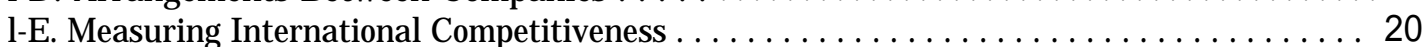

Figure

Figure

I-1. States Where Releases of Genetically Engineered Organisms Have

Been Approved . . . . . . . . . . . . . . . . . . . . . . . . . . . . . . . . . . . . . . . . . 17

\section{Tables}

Table Page

I-1. Major Events in the Commercialization of Biotechnology $\ldots \ldots \ldots \ldots \ldots \ldots \ldots 2$

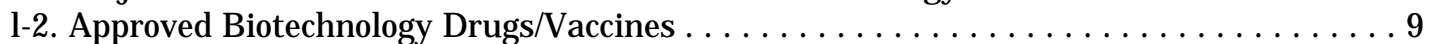

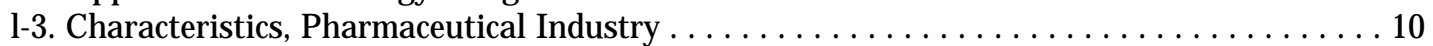

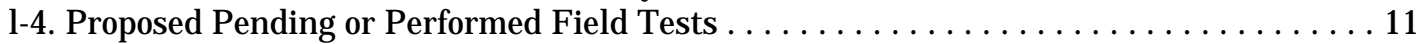

I-5. U.S. Federal Funding for Biotechnology, Fiscal Year $1990 \ldots \ldots \ldots \ldots \ldots \ldots \ldots . . \ldots 20$ 


\section{INTRODUCTION}

Biotechnology-both as a scientific art and commercial entity-is less than 20 years old (see table I-I). In that short period of time, however, it has revolutionized the way scientists view living matter and has resulted in research and development $(R \& D)$ that may lead to commercialization of products that can dramatically improve human and animal health, the food supply, and the quality of the environment (see box I-A). Developed Primarily in U.S. laboratories, many applications of biotechnology are now viewed by companies and governments throughout the world as essential for economic growth in several different, seemingly disparate industries.

To what degree is biotechnology being used as a tool in basic research, product development, and manufacturing? In what industries is biotechnology being used, and how are various national governments promoting and regulating its uses? Will the United States retain its preeminence in biotechnology, or will the products and services created by biotechnology be more successfully commercialized in other nations? What is the role played by multinational corporations, and how is international biotechnology $R \& D$ funded? Because of its importance to U.S. competitiveness in an increasingly global economy, biotechnology is viewed as one of the keys to U.S. competitiveness during the years ahead. This report describes the increasing international use of commercial biotechnology in industrialized and newly industrializing countries (NICS) (see box I-B) and the ways governments promote and regulate the uses of biotechnology.

\section{COMMERCIAL ACTIVITY}

Biotechnology is not an industry. It is, instead, a set of biological techniques, developed through decades of basic research, that are now being applied to research and product development in several existing industrial sectors. Biotechnology provides the potential to produce new, improved, safer, and less expensive products and processes. Pharmaceuticals and diagnostics for humans and animals, seeds, entire plants, animals, fertilizers, food additives, industrial enzymes, and oil-eating and other pollution degrading microbes are just a few of the things that can be created or enhanced through the use of biotechnology.

Many early claims about biotechnology, seen in retrospect, were premature. Products have not been developed and marketed as quickly as previously thought possible, and many scientific and public policy issues remain to be settled. However, biotechnology has arrived as an important tool for both scientific research and economic development. Its effect on the world's economy will certainly grow in the years ahead, as research leads to new products, processes, and services.

\section{Financing of Biotechnology}

The competitiveness of U.S.-developed biotechnology products and processes may ultimately depend on broad issues, e.g., fair trade practices, protection of intellectual property, regulatory climate, and tax policies. The competitiveness of U.S. innovation, however, could very well rely on the ability of biotechnology companies to stay in business. Because biotechnology is capitalintensive, staying in business means raising substantial sums of cash. Start-up companies' fundamental need for cash, coupled with the desire of venture capitalists in the United States to profit from the creation of high-value-added products (based' on cutting-edge technology) have led to the financial community's substantial involvement in the formation of biotechnology-based firms.

\section{Venture Capital and the Dedicated Biotechnology Company}

The United States has led the world in the commercial development of biotechnology because of its strong research base-most notably in biomedical sciences--and the ability of entrepreneurs to finance their ideas. During the early 1980s, a combination of large-scale Federal funding for basic biomedical research, hype surrounding commercial potential, and readily available venture capital funding led to the creation of hundreds of dedicated biotechnology companies (DBCs).

Dedicated biotechnology companies are almost exclusively a U.S. phenomenon; no other country has a remotely comparable number. Biotechnology companies are created specifically to exploit the 
Table I-I-Major Events in the Commercialization of Biotechnology

\begin{tabular}{|c|c|}
\hline 1973 & First cloning of a gene. \\
\hline 1974 & Recombinant DNA (rDNA) experiments first discussed in a public forum (Gordon Conference). \\
\hline 1975 & $\begin{array}{l}\text { U.S. guidelines for rDNA research outlined (Asilomar Conference). } \\
\text { First hybridoma created. }\end{array}$ \\
\hline 1976 & $\begin{array}{l}\text { First firm to exploit rDNA technology founded in the United States (Genentech). } \\
\text { Genetic Manipulation Advisory Group started in the United Kingdom. }\end{array}$ \\
\hline 1980 & $\begin{array}{l}\text { Diamond v. Chakrabarty--U.S. Supreme Court rules that micro-organisms can be patented. } \\
\text { Cohen/Boyer patent issued on the technique for the construction of rDNA. } \\
\text { United Kingdom targets biotechnology for research and development (Spinks' report). } \\
\text { Federal Republic of Germany targets biotechnology for R\&D (Leistungsplan). } \\
\text { initial public offering by Genentech sets Wall Street record for fastest price per share increase ( } \$ 35 \text { to } \$ 89 \text { in } 20 \text { minutes) }\end{array}$ \\
\hline
\end{tabular}

1981 First monoclonal antibody diagnostic kits approved for use in the United States.

First automated gene synthesizer marketed.

Japan targets biotechnology (Ministry of international Trade and Technology declares 1981, "The Year of Biotechnology"). initial public offering by Cetus sets WallStreet record for the largest amount of money raked in an initial public offering (\$1 15 million).

Over 80 new biotechnology firms formed by the end of the year.

1982 First rDNA animal vaccine (for colibacillosis) approved for use in Europe.

First rDNA pharmaceutical product (human insulin) approved for use in the United States and the United Kingdom.

1983 First expression of a plant gene in a plant of a different species.

New biotechnology firms raise $\$ 500$ million in U.S. public markets.

1984 California Assembly passes resolution establishing the creation of a task force on biotechnology. Two years later, a guide clarifying the regulatory procedures for biotechnology is published.

1985 Advanced Genetic Sciences, inc. receives first experimental use permit issued by EPA for small-scale environmental release of a genetically altered organism (strains $\boldsymbol{P}$. syringae and $\mathrm{P}$. fluorescens from which the gene for ice-nucleation protein had been deleted.

1986 Coordinated Framework for the Regulation of Biotechnology published by Office of Science and Technology Policy. Technology Transfer Act of 1986 provides expanded rights for companies to commercialize government-sponsored research.

1987 U.S. Patent and Trademark Office announces that nonhuman animals are patentable subject matter.

October 19th-Dow Jones Industrial Average plunged a record 508 points. initial public offerings in biotechnology-based companies virtually cease for 2 years.

$1988 \quad$ NIH establishes program to map the human genome.

First U.S. patent on an animal--transgenic mouse engineered to contain cancer genes.

1989 Bioremediation gains attention, as microbe-enhanced fertilizers are used to battle Exxon Valdezoil spill.

Court in Federal Republic of Germany stops construction of a test plant for producing genetically engineered human insulin. Gen-Probe is first U.S. biotechnology company to be purchased by a Japanese company (Chugai Pharmaceuticals).

1990 FDA approves recombinant renin, an enzyme used to produce cheese; first bioengineered food additive to be approved in the United States.

Federal Republic of Germany enacts Gene Law to govern use of biotechnology.

Hoffman-LaRoche (Basel, Switzerland) announces intent to purchase a majority interest in Genentech.

Mycogen becomes first company to begin large-scale testing of genetically engineered biopesticide, following EPA approval. First approval of human gene therapy clinical trial.

$1991 \quad$ Biotechnology companies sell $\$ 17.7$ billion in new stock, the highest 5-month total in history.

Chiron Corp. acquires Cetus Corp. for $\$ 660$ million in the largest merger yet between two biotechnology companies. EPA approves the first genetically engineered biopesticide for sale in the United States.

SOURCE: Office of Technology Assessment, 1991. 


\section{Box 1-A-Defining Biotechnology}

The first challenge in describing the effect of biotechnology on a global economy is to define what biotechnology is. The term "biotechnology" means different things to different people. Some view biotechnology as all forms of biological research, be it cheesemaking and brewing or recombinant DNA (rDNA) technology. Others, only view biotechnology as including modern biological techniques (e.g., rDNA, hybridoma technology, and monoclonal antibodies). Some people have analogized biotechnology to a set of new tools in the biologist's tool box by referring to "biotechnologies.' To Wall Street financiers and venture capitalists who invested in the creation of companies in this area, biotechnology represents a hot new source of financial risk and opportunity. Congress, increasingly invoked in public policy questions raised by biotechnology, in one statute referred to products "primarily manufactured using recombinant DNA recombinant RNA, hybridoma technology, or other processes involving site specific genetic manipulation techniques" (35 U.S.C. 156(2)(B)).

In 1984, OTA arrived at two definitions of biotechnology. The first definition--broad in scope--described biotechnology as any technique that uses living organisms (or Parts of organisms) to make or mod@ products, to improve plants or animals, or to develop micro-organisms for specific uses. This definition encompassed both new biological tools as well as ancient uses of selecting organisms fur improving agriculture, animal husbandry, or brewing. A second, more narrow definition refers only to "new" biotechnology: the industrial use of rDNA, cell fusion, and novel bioprocessing techniques. It is the development and uses of the new biotechnology that has captured the imagination of scientists, financiers, policymakers journalists, and the public. As in earlier OTA reports, the term biotechnology, unless otherwise specified, is wed in reference to new biotechnology.

SOURCE: Office of Technology Assessment, 1991.

commercial potential of biotechnology. These companies generally start as research organizations with science and technology but without products. They do not undertake R\&Don nearly so broad a scale as established companies. Instead, they focus on specific technologies, particular products, and niche markets. The companies must fund the initial costs of infrastructure development-including buildings,

\section{Box 1-B--Sixteen Countries}

In compiling this report, OTA focused on biotechnology-related developments in the following countries:

\section{Australia \\ Brazil \\ Canada}

Denmark

Federal Republic of Germany

France

Ireland

J apan

The Netherlands

Singapore

South Korea

Sweden

Switzerland

Taiwan (Republic of China)

Unịted Kingdom

united states

In addition, the biotechnology-related activities of the European Community (EC) as a whole are considered. The countries chosen are representative of a range of commercial and governmental activity. This roster is not exhaustive; biotechnology plays an important role in many other nations. As this report was compiled, major political changes occurred including the merging of the Federal Republic of Germany and the German Democratic Republic. The merger of both countries raises many questions regarding industrial competitiveness that are beyond the scope of this report.

SOURCE: Office of Technology Assessment, 1991.

plants, equipment, and people-without the benefit of internally generated revenues. They depend on venture capital, stock offerings, and relationships with established companies for their financing needs.

The boom era for founding DBCs occurred between 1980 and 1984, when approximately 60 percent of existing companies were founded. In 1988, the Office of Technology Assessment (OTA) verified that there were 403 DBCs in existence and over 70 major corporations with significant investments in biotechnology. The majority of these companies have a strong focus on human health care products, largely because capital availability has been greater for pharmaceuticals than for food or agricultural products, due to the prospect of greater and faster market reward. 
In the early 1980s, companies had little trouble raising cash, often obtained by licensing away key first-generation products and vital market segments. As time passed, the term "biotechnology" lost its ability to turn promises of future products into instant cash. Several factors have been cited for tightened availability of venture capital financing:

- Basic gene-splicing technology became readily available to an increasing number of companies, both in the United States and abroad.

- Product development was slower than expected (e.g., unforeseen technical problems, slow regulatory approval and patent issuance, and difficulties in scale-up and in obtaining meaningful clinical results).

- The 1987 stock market crash slammed shut opportunities for initial public offerings, and for 18 months biotechnology companies had to get by with little new public financing.

- Expected returns on investments have not materialized as expected.

To date, most U.S. biotechnology companies have no sales and have been losing money since their inceptions. Capital and market value are concentrated in only a few of the hundreds of firms involved in biotechnology. Only one-fifth of biotechnology companies surveyed in 1990 were profitable. Most companies are still several years away from profitability and positive cash flow, but the top 20 firms could last more than 3 years on current cash levels without needing to raise additional money.

Despite the slower-than-expected commercialization of biotechnology, start-up firms have been able to raise cash in the initial stages of operation. Second and third rounds of needed financing, that are necessary to bridge the gap between basic research and a marketable product, are more difficult to come by. While the venture capital community has become more conservative in where they choose to invest, viable opportunities appear to remain for entrepreneurs with good ideas. However, a bottleneck is developing as start-up companies attempt to move forward toward development, testing, and marketing-the expensive part of the process. As much as $\$ 5$ to $\$ 10$ billion may be needed just to develop the 100 biotechnology products currently in human clinical trials.

Companies fortunate enough to have gone public before 1987 are generally able to obtain needed cash through limited partnerships, secondary public offerings, and strategic alliances. The stock market crash in October 1987 virtually stopped all initial public offerings in biotechnology-based companies. By 1991, however, stock offerings were again in vogue, both for new and established firms (see box I-C). The top DBCs will most likely remain stable, surrounded by an ever-changing backdrop of startup companies. Those DBCs that do survive will rely on corporate relationships of every form and combination of forms imaginable (see box I-D).

\section{Consolidation}

Start-up companies will continue to appear, but these new DBCs will likely face the reality of merger or acquisition. Only a dramatic surge in the public markets or the creation of breakthrough products or processes will save some of these companies from this fate. Consolidation of DBCs is inevitable, most likely necessary, and desirable for some companies. What concerns some observers is the role that foreign acquisition and investment will play in the fate of many of these vulnerable fins. Although it is true that joint activity between firms has been on the rise (involving both U.S. companies with foreign firms and between U.S.-based firms themselves), much of this activity is necessary to conduct business in a global market, i.e., licensing, marketing, and co-marketing agreements. Currently, there is insufficient evidence to state that U.S. commercial interests in biotechnology are threatened by foreign acquisition. To date, most corporations have avoided this mechanism. As U.S. DBCs move closer to product reality, however, foreign corporations with large pools of cash may be more willing to pursue acquisition in order to ensure manufacturing rights. Executives of DBCs tend to feel that manufacturing rights will be crucial for the viability of their companies.

The recent merger of the United States' largest biotechnology company, Genentech, with Swissowned Hoffmann-LaRoche, has increased public interest and concern in foreign acquisition of U.S. biotechnology concerns. While some foreign firms (usually large, multinational corporations) are actively investing in U.S. DBCS, approximately three-quarters of all mergers and acquisitions involving biotechnology companies are between U.S.-based firms (e.g., the 1991 merger between Chiron and Cetus). However, U.S. corporations are disadvantaged when it comes to acquisition because 


\section{Box 1-C-Biotech's 1991 Stock Boom}

On October 19, 1987, the Dow J ones I ndustrial Average plunged a record 508 points. Following the stock market crash, there was little interest on Wall ${ }_{1600}$ Street in stock offerings for biotechnology-related companies. By early 1991, however, the U.S. market 1400 for new stock offerings had heated up to a record pace, 1200 . despite the fact that the U.S. economy was in a recession and stock sales in general were sluggish.

Between J anuary and May 1991, companies sold almost $\$ 18$ billion in new stock the highest 5-month total in history. Various reasons were cited by analysts for the hot market: the approval by FDA of new products, the durability of health-related stocks during economic hard times, and pent-up demand following slow stock activity over a 3-year period.

Unlike earlier bull markets for biotechnology stocks, however, analysts generally view the 1991 boom as short term in nature. By the end of May, there were signs that the stock demand was cooling. For example, Regeneron Pharmaceuticals (Tarrytown, Biotech's Surprising Stock Market Boom NY), a start-up company that had set a record for biotechnology companies by raising $\$ 99$ million in its initial public offering in April (4.5 million shares sold at $\$ 22$ per share), saw its stock value drop to $\$ 12$ per share by the end of May after reporting first-quarter losses of $\$ 1.1$ million.

SOURCE: Office of Technology Assessment, 1991, adapted from IDD Information Services; R. Rhein, "Biotech Stocks: Let the Good Times Roll," Journal of NIH Research, July 1991, pp. 54-55; Biotechnology, "Regeneron Gets Rich, Offerings Abound," vol. 9, May 1991, p. 404.

American accounting practices prevent them from deducting the full expense of acquisition in the year that it occurs. Some analysts believe that this difference in accounting practices allows foreign corporations to move more rapidly toward acquisition. In addition, the cost of capital in the United States makes it harder for U.S. corporations to save the sums needed for acquisition and more difficult for DBCs to raise the cash needed to take biotechnology products to market.

\section{The Pharmaceutical Industry}

Although the arrival of products has been slower than expected, the development of biotechnology-based pharmaceutical products is flourishing. To date, 15 biotechnology-based drugs and vaccines are on the market (see table 1-2). Both DBCs and established multinational pharmaceutical companies are utilizing the tools and techniques of biotechnology in their drug development efforts. Revenues in the United States from biotechnologyderived products were estimated to be approximately $\$ 1.5$ billion in 1989, and \$2 billion in 1990. Many new products are in the pipeline, and several are in the final stages of testing. Of the more than 100 biotechnology drugs and vaccines undergoing human testing for a variety of conditions, 18 have essentially completed clinical trials and are awaiting Food and Drug Administration (FDA) approval. Biotechnology is particularly important for research involving drug discovery as it allows for a molecular and cellular level approach to understanding disease, drug-disease interaction, and drug design. Biotechnology is likely to be the principal scientific driving force for the discovery of new drugs and therapeutic chemical entities as the industry enters the 21st century.

The modern pharmaceutical industry is a global, competitive, high-risk, high-return industry that develops and sells innovative high-value-added products in a tightly regulated process (see table 1-3). Because of the strong barriers to entry which characterize the global pharmaceutical industry, many DBCs are focusing on niche markets and developing biotechnology-based pharmaceutical products. Established pharmaceutical companies have been increasingly developing in-house capabilities to complement their conventional research with 


\section{Box 1-D--Arrangements Between Companies}

Acquisition. One company taking over controlling interest in another company. Investors are al ways looking for companies that are likely to be acquired, because those who want to acquire such companies are often willing to pay more than the market price for the shares they need to complete the acquisition.

Merger. Combination of two or more companies, either through a pooling of interests, where the accounts are combined; a purchase, where the amount paid over and above the acquired company's book value is carried on the books of the purchaser as goodwill; or a consolidation, where a new company is formed to acquire the net assets of the combining companies.

Strategic alliances. Associations between separate business entities that fall short of a formal merger but that unite certain agreed on resources of each entity for a limited purpose. Examples are equity purchase, licensing and marketing agreements, research contracts, and joint ventures.

SOURCE: Office of Technology Assessment, 1991.

biotechnological techniques for use as research tools. Strategic alliances and mergers between major multinational pharmaceutical companies and DBCs allow both to compete in the industry and combine their strengths: the innovative technologies and products of those DBCs with financial and marketing power blended with the development and regulatory experience of the major companies.

The original intent of many of the early DBCs was to become fully integrated, competitive pharmaceutical companies, but the economic realities of the pharmaceutical business will likely deny this opportunity to most DBCs. Biotechnology, while not likely to fundamentally change the structure of the pharmaceutical industry, has provided a much needed source of innovation for both research and product development. Currently, much of the success or failure with the commercialization of biotechnology in the pharmaceutical industry rests on economic, market, scientific, and technical considerations. Government policies that affect these conditions contribute to, but are not likely to independently determine, success or failure.

\section{Agriculture}

Biotechnology has the potential to be the latest in a series of technologies that have led to astonishing increases in the productivity of world agriculture in recent decades. Biotechnology can increase food production by contributing to further gains in yield, by lowering the cost of agricultural inputs; and by contributing to the development of new high-value-added products to meet the needs of consumers and food processors. These potential products include agricultural input (e.g., seeds and pesticides), veterinary diagnostics and therapeutics, food additives and food processing enzymes, more nutritious foods, and crops with improved food processing qualities. Thus far, $R \& D$ has focused on crops and traits that are easiest to manipulate, particularly single-gene traits in certain vegetable crops. As technical roadblocks are lifted, research is likely to increase and spread to other crops and other traits.

In the United States, DBCs are applying biotechnology to agriculture, and well-established firms are adapting biotechnology to their existing research programs. The ability to profit from new products depends on a variety of factors, such as the potential size of the market for these products, the existence of substitutes, the rate at which new products and technologies are adopted, the potential for repeat sales using patent or technical protection, the existence of regulatory hurdles, and the prospect for consumer acceptance of these new foods. Because these factors vary considerably from country-to-

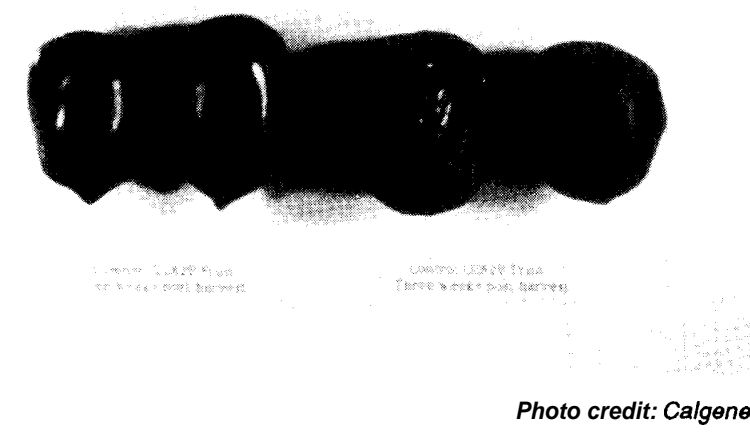

Tomatoes, 25 days postharvest. The transgenic tomatoes, left, have not deteriorated, contrasted to the nonengineered tomatoes, right. 
Table 1-2-Approved Biotechnology Drugs/Vaccines

\begin{tabular}{|c|c|c|c|c|c|}
\hline Product name & Company & Indication & U.S. approval & $\begin{array}{c}\text { Revenues }^{*} \\
1989\end{array}$ & $\begin{array}{c}\text { Revenues* }^{*} \\
1990\end{array}$ \\
\hline $\begin{array}{l}\text { Epogen (tin) }{ }^{\star *} \\
\text { Epoetin Alfa }\end{array}$ & $\begin{array}{l}\text { Amgen } \\
\text { Thousand Oaks, CA }\end{array}$ & Dialysis anemia & June 1989 & 95 & 300 \\
\hline $\begin{array}{l}\text { Neupogen }{ }^{\star *} \\
\text { Granulocyte colony } \\
\text { stimulating factor } \\
\text { G-CSF }\end{array}$ & $\begin{array}{l}\text { Amgen } \\
\text { Thousand Oaks, CA }\end{array}$ & $\begin{array}{l}\text { Chemotherapy } \\
\text { effects }\end{array}$ & February 1891 & NA & NA \\
\hline $\begin{array}{l}\text { Humatrope }(\mathbf{R})^{\star \star} \\
\text { Somatotropin } \\
\text { rDNA origin for } \\
\text { injection }\end{array}$ & $\begin{array}{l}\text { Eli Lilly } \\
\text { Indianapolis, IN }\end{array}$ & $\begin{array}{l}\text { Human growth } \\
\text { hormone deficiency } \\
\text { in children }\end{array}$ & March 1987 & 40 & 50 \\
\hline $\begin{array}{l}\text { Humulln(R) } \\
\text { Human insulin } \\
\text { rDNA origin }\end{array}$ & $\begin{array}{l}\text { Eli Lilly } \\
\text { Indianapolis, IN }\end{array}$ & Diabetes & October 1982 & 200 & 250 \\
\hline $\begin{array}{l}\text { Actimmune }{ }^{\star *} \\
\text { Interferon gamma 1-b }\end{array}$ & $\begin{array}{l}\text { Genentech } \\
\text { San Francisco, CA }\end{array}$ & $\begin{array}{l}\text { Infection/chronic } \\
\text { granulomatous disease }\end{array}$ & December 1990 & NA & NA \\
\hline $\begin{array}{l}\text { Activase }(\mathrm{R}) \\
\text { Alteplase, rDNA origin }\end{array}$ & $\begin{array}{l}\text { Genentech } \\
\text { San Francisco, CA }\end{array}$ & $\begin{array}{l}\text { Acute myocardial } \\
\text { infarction }\end{array}$ & November 1987 & 175 & 200 \\
\hline $\begin{array}{l}\text { Protropln }(\mathbf{R})^{\star *} \\
\text { Somatrem for injection }\end{array}$ & $\begin{array}{l}\text { Genentech } \\
\text { San Francisco, CA }\end{array}$ & $\begin{array}{l}\text { Human growth } \\
\text { hormone deficiency } \\
\text { in children }\end{array}$ & October 1985 & 100 & 120 \\
\hline $\begin{array}{l}\text { Roferon (R)-A } A^{* *} \\
\text { Interferon alfa-2a } \\
\text { (recombinant/Roche) }\end{array}$ & $\begin{array}{l}\text { Hoffmann-La Roche } \\
\text { Nutley, NJ }\end{array}$ & $\begin{array}{l}\text { Hairy cell } \\
\text { leukemia } \\
\text { AIDS-related } \\
\text { Kaposi's sarcoma }\end{array}$ & $\begin{array}{l}\text { June } 1986 \\
\text { November } 1988\end{array}$ & 40 & 60 \\
\hline $\begin{array}{l}\text { Leukine }^{\star \star} \\
\text { Granulocyte microphage } \\
\text { colony stimulating } \\
\text { factor GM-CSF }\end{array}$ & $\begin{array}{l}\text { Immunex } \\
\text { Seattle, wA }\end{array}$ & $\begin{array}{l}\text { Infection related to } \\
\text { bone marrow transplant }\end{array}$ & March 1991 & NA & NA \\
\hline $\begin{array}{l}\text { Recombivax HB (R) } \\
\text { Hepatitis B vaccine } \\
\text { (recombinant MSD) }\end{array}$ & $\begin{array}{l}\text { Merck } \\
\text { Rahway, NJ }\end{array}$ & $\begin{array}{l}\text { Hepatitis B } \\
\text { prevention }\end{array}$ & July 1986 & 100 & 110 \\
\hline $\begin{array}{l}\text { Orthoclone } \mathrm{OKT}(\mathrm{R}) 3 \\
\text { Muromonab CD3 }\end{array}$ & $\begin{array}{l}\text { Ortho Biotech } \\
\text { Raritan, NJ }\end{array}$ & $\begin{array}{l}\text { Kidney transplant } \\
\text { rejection }\end{array}$ & June 1986 & 30 & 35 \\
\hline $\begin{array}{l}\text { Procrit }^{\star *} \\
\text { Erythropoietin }\end{array}$ & $\begin{array}{l}\text { Ortho Biotech } \\
\text { Raritan, NJ }\end{array}$ & $\begin{array}{l}\text { AIDS-related } \\
\text { anemia } \\
\text { Pre-dialysis anemia }\end{array}$ & December 1990 & NA & NA \\
\hline $\begin{array}{l}\text { HibTiter (tin) } \\
\text { Haemophilus B } \\
\text { conjugate vaccine }\end{array}$ & $\begin{array}{l}\text { Praxis Biologics } \\
\text { Rochester, NY }\end{array}$ & $\begin{array}{l}\text { Haemophilus } \\
\text { influenza type B }\end{array}$ & December 1988 & 10 & 30 \\
\hline \multirow[t]{3}{*}{$\begin{array}{l}\text { Intron }(R) A^{* *} \\
\text { Interferon-alpha2b }\end{array}$} & $\begin{array}{l}\text { Schering-Plough } \\
\text { Madison, NJ }\end{array}$ & $\begin{array}{l}\text { Hairy cell } \\
\text { leukemia }\end{array}$ & June 1986 & 60 & 80 \\
\hline & & $\begin{array}{l}\text { Genital warts } \\
\text { AIDS-related } \\
\text { Kaposi's sarcoma }\end{array}$ & $\begin{array}{l}\text { June } 1988 \\
\text { November } 1988\end{array}$ & & \\
\hline & & Hepatitis C & February 1991 & NA & NA \\
\hline $\begin{array}{l}\text { Energix-B } \\
\text { Hepatitis B vaccine } \\
\text { (recombinant) }\end{array}$ & $\begin{array}{l}\text { SmithKline Beecham } \\
\text { Philadelphia PA }\end{array}$ & Hepatitis B & September 1989 & 20 & 30 \\
\hline \multicolumn{6}{|c|}{$\begin{array}{l}\text { Estimated U.S. revenues in millions of dollars } \\
\text { *Orphan Drug } \\
\text { NA = not applicable }\end{array}$} \\
\hline $\begin{array}{r}\text { SOURCE: Office of Techn } \\
1990 \text { Annual Sur }\end{array}$ & Assessment, 1991; ad & from Pharmaceutical Manufa & rs Association-Biotech & logy Medicines & Development \\
\hline
\end{tabular}


Table 1-3-Characteristics, Pharmaceutical Industry

- Top firms are huge, multinational firms primarily based in the United States and Europe.

- Significant entry barriers; very expensive to develop, test, and market new products.

- Not particularly concentrated.

- Tightly regulated.

- Development of high-value-added products.

- Consolidation of companies occurring.

- Size of global market in 1989: $\$ 150$ billion.

- United States the largest market; combined EC is second; Japan is second largest single country.

- Major companies are financially strong and vertically integrated firms, controlling all aspects of business (R\&D, manufacturing, and marketing).

- Main competitors for the world pharmaceutical market: huge, multinational companies based in the United States, Switzerland, the United Kingdom, Germany, and increasingly, Japan.

- Japanese market historically difficult to enter; U.S. and European companies, to ensure market presence, have collaborated with those Japanese companies that dominate their domestic market. Japanese companies are now beginning to globalize their operations.

SOURCE: Office of Technology Assessment, 1991.

country, the climate for application of biotechnology to agriculture also varies. These applications are being explored throughout the world, mainly in developed countries that are major food exporters (e.g., Australia, Canada, France, and the United States).

Because most biotechnology products for agricultural use are still being devel oped, comparison of numbers of products actually manufactured in different countries is not yet meaningful. However, since field tests of many potential plant products are regulated by national agricultural or environmental authorities, comparison of some test numbers is possible. As of 1990, over 60 percent of all field tests worldwide (most involving transgenic plants) have occurred in the United States (see table 1-4).

Although there is much active European agricultural biotechnology research in northern Europe, particularly Germany and Denmark, public concern about possible environmental risks and ethical issues associated with biotechnology has translated into regulations that discourage field testing of genetically engineered organisms. The lack of patent protection for transgenic organisms also tends to inhibit investment in transgenic plants in Europe. In $\mathrm{J}$ apan and other Asian countries, public perception of biotechnol ogy appears to be mixed. Biotechnological methods used to produce pharmaceuticals and industrial and food processing enzymes are ac- cepted, however, agricultural applications are less so. Consequently, relatively little attention has been paid to transgenic plants and animals in Asia. One exception is work on plants, especially rice, derived from plant cell cultures. The application of biotechnology to food processing has received a great deal of interest in J apan, where the country's expertise in fermentation is likely to be applied to food production.

\section{The Chemical Industry}

The chemical industry is one of the largest manufacturing industries in the United States and Europe. Currently, over 50,000 chemicals and formulations are produced in the United States. The consumption of chemical products by industry gives these products a degree of anonymity as they usually reach consumers in altered forms or as parts of other goods.

Biotechnology has a limited, though varied, role in chemical production. The production of some chemicals now produced by fermentation, such as amino acids and industrial enzymes, may be improved using biotechnology. Similarly, biotechnology can be used to produce enzymes with altered characteristics (e.g., greater" stability in harsh solvents or greater heat resistance). In many instances, biotechnology products will probably be developed and introduced by major firms without the fanfare that has accompanied other biotechnology developments and, like much of chemical production, will remain unknown to those outside the industry. The

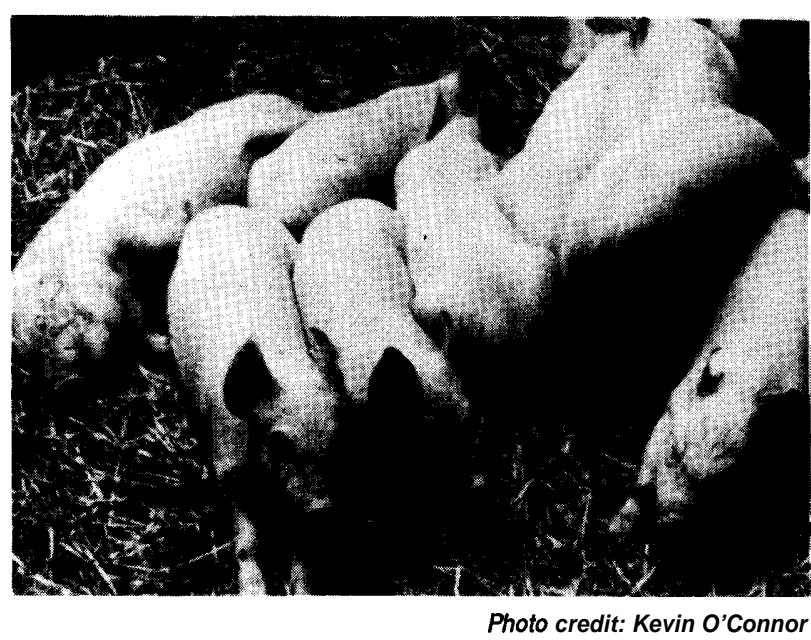

Transgenic pigs born with a bovine growth hormone gene inserted in the embryo. 
Table 1-4-Proposed Pending or Performed Field Tests

\begin{tabular}{|c|c|c|c|c|c|c|}
\hline 1986 & 1987 & 1988 & 1989 & 1990 & Undated & Total \\
\hline Australia $\ldots \ldots \ldots \ldots \ldots \ldots \ldots \ldots$ & 1 & 一 & - & - & 4 & 5 \\
\hline Belgium $\ldots \ldots \ldots \ldots \ldots \ldots \ldots \ldots$ & 2 & 6 & 5 & - & - & 14 \\
\hline Canada...$\ldots \ldots \ldots \ldots \ldots \ldots \ldots$ & 一 & 4 & 14 & 一 & 3 & 21 \\
\hline Denmark $\ldots \ldots \ldots \ldots \ldots \ldots \ldots$ & - & - & - & 2 & - & 2 \\
\hline Finland $\ldots \ldots \ldots \ldots \ldots \ldots \ldots$ & - & - & - & 一 & 1 & 1 \\
\hline France $\ldots \ldots \ldots \ldots \ldots \ldots \ldots \ldots$ & 2 & 4 & 3 & 一 & - & 10 \\
\hline Ireland $\ldots \ldots \ldots \ldots \ldots \ldots \ldots$ & - & - & - & - & 1 & 1 \\
\hline tidy $\ldots \ldots \ldots \ldots \ldots \ldots \ldots \ldots$ & - & 1 & - & - & 1 & 2 \\
\hline The Netherlands $\ldots \ldots \ldots \ldots \ldots \ldots \ldots$ - & - & 1 & 1 & - & 2 & 4 \\
\hline New Zealand $\ldots \ldots \ldots \ldots \ldots \ldots \ldots$ & - & 1 & 1 & - & 4 & 6 \\
\hline Spain $\ldots \ldots \ldots \ldots \ldots \ldots \ldots \ldots \ldots$ & 一 & 2 & 1 & - & - & 3 \\
\hline Sweden $\ldots \ldots \ldots \ldots \ldots \ldots \ldots \ldots$ & - & - & 1 & - & - & 1 \\
\hline United Kingdom . . . . . . . . . . . . . 1 & 4 & 1 & 4 & - & 一 & 10 \\
\hline United States $\ldots \ldots \ldots \ldots \ldots \ldots \ldots$ & 15 & 34 & 56 & 一 & 23 & 132 \\
\hline Total $\ldots \ldots \ldots \ldots \ldots \ldots \ldots$ & 24 & 54 & 86 & 2 & 39 & 212 \\
\hline
\end{tabular}

SOURCE: Organization for Economic Co-operation and Development, 1990.
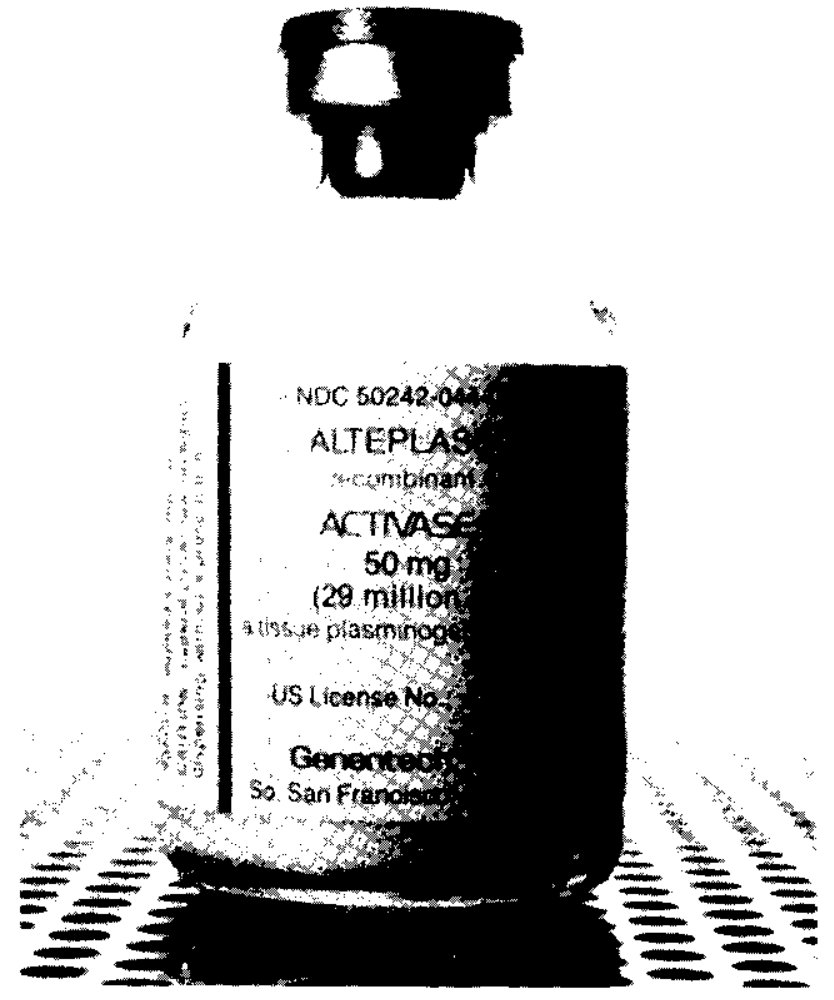

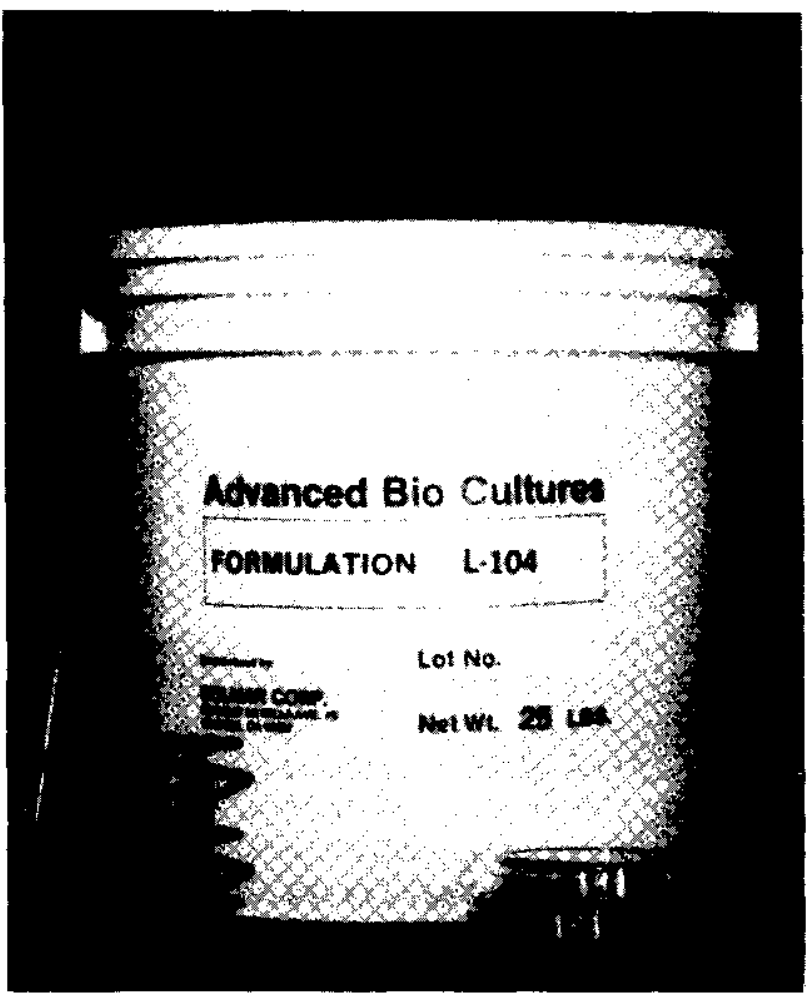

Photo credit: Genentech, Solmar Corp.

The abilityto produce high-value-added products is one reason the pharmaceutical industry is attractiveto venture capitalists. Genentech's tissue plasminogen activator (left) costs $\$ 2,200$ per dose. In contrast, Solmar Corp's. Bio Cultures, used in waste cleanup (right) sells for approximately $\$ 400$ per 25 -pound container.

chemical industry's greatest use of biotechnology may be the result of the industry's expanding investment in pharmaceuticals and agriculture. This reflects the industry's shift away from the production of bulk chemicals and toward investment in research-intensive, high-value-added products; the worldwide industry response to oil shocks, recessions, and increasing competition.

The use of biochemistry or fermentation to produce chemicals has historically received a great deal of attention in Japan, and the Ministry of 
International Trade and I ndustry (MITI) targeted improvements in these processes through biotechnology in 1980. Another application that has received particular attention in J apan is the biosensor (a device that uses immobilized biomolecules to interact with specific environmental chemicals and then detects and quantifies either the interaction itself or the product of the interaction, e.g., a change in color, fluorescence, temperature, current, or voltage).

In the very long run, biotechnology may have a major impact in shifting the production of fuel and bulk chemicals away from reliance on nonrenewable resources (e.g., oil) and toward renewable resources (e.g., biomass). However, current work in this field appears to be limited, in part, because the international price of oil has remained too low to encourage investment in alternatives, and, in part, because the chemical industry throughout the world has restructured during the last 10 years, moving away from bulk chemical production and toward the production of specialty chemicals, pharmaceuticals, and agricultural products.

\section{Environmental Applications}

Although biotechnology has several potential environmental applications-including pollution control, crop enhancement, pest control, mining, and microbial enhanced oil recovery (MEOR)commercial activity to date is minuscule compared to other industrial sectors. Bioremediation, efforts to use biotechnology for waste cleanup, has received public attention recently because of the use of naturally occurring micro-organisms in oil-spill cleanups. The U.S. bioremediation industry includes more than 130 firms, but it is the focus of few DBCs. Nevertheless, though small, the size of the commercial bioremediation sector in the United States far exceeds activity in other nations.

Although bioremediation offers several advantages over more conventional waste treatment technologies, several factors hinder its widespread use. Relatively little is known about the effects of micro-organisms in various ecosystems. Research data are not disseminated as well as research in other industrial sectors because of limited Federal funding of basic research and the proprietary nature of business relationships under which bioremediation is most often used. Regulations provide a market for bioremediation by dictating what must be cleaned

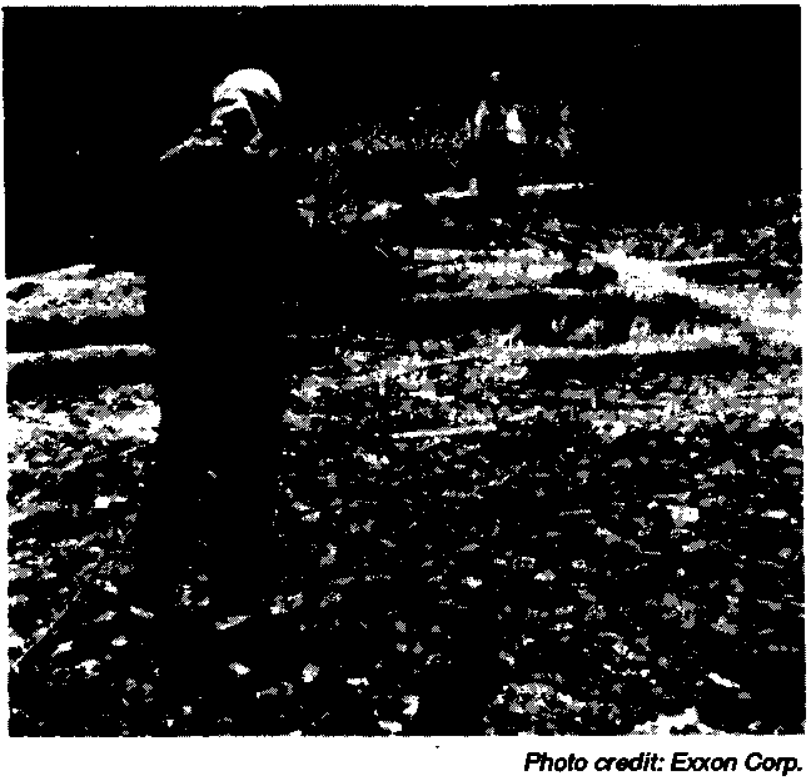

Worker applying fertilizer to the cobble beaches of Princo William Sound.

up, how clean it must be, and which cleanup methods may be used; but regulations also hinder commercial development, due to their sheer volume and lack of standards governing biological waste treatment.

Bioremediation, unlike the pharmaceutical industry, does not result in the production of high-valueadded products. Thus, venture capital has been slow to invest in the technology, and little incentive exists for product development. The majority of the bioremediation firms are small and lack sufficient capital to finance sophisticated research and product development programs. Bioremediation primarily depends on trade secrets, not patents, for intellectual property protection.

Although some research is being conducted on genetically engineered organisms for use in bioremediation, today's bioremediation sector relies on naturally occurring micro-organisms. Scientific, economic, regulatory, and public perception limitations that were viewed as barriers to the development of bioremediation a decade ago still exist. Thus, the commercial use of bioengineered micro-organisms for environmental cleanup is not likely for the near future. 


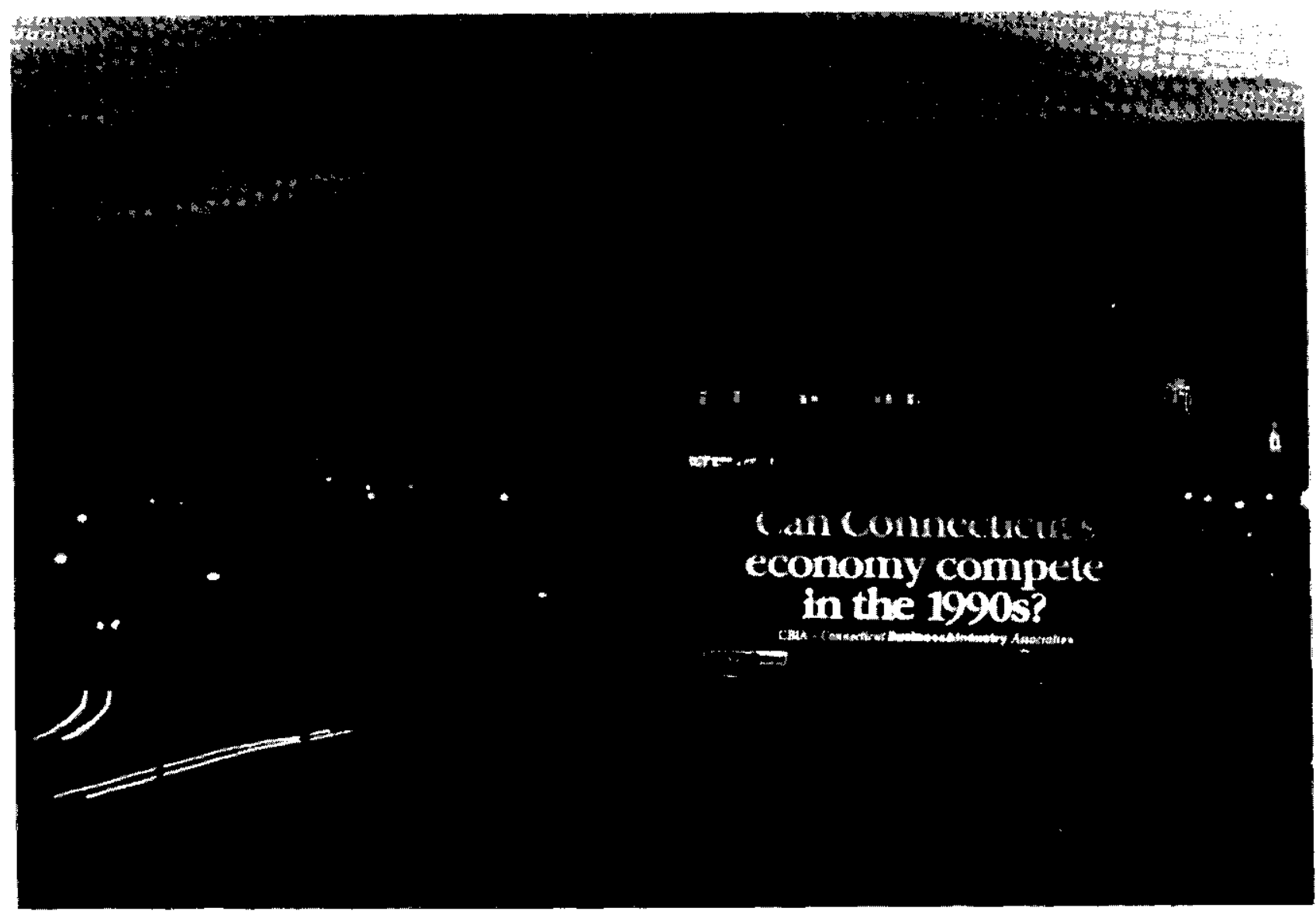

Photo credit: CBIA

Billboard, Hartford, CT.

\section{INDUSTRIAL POLICY}

Industrial policy is the deliberate attempt by a government to influence the level and composition of a nation's industrial output. Industrial policies can be implemented through measures such as allocation of R\&D funds, subsidies, tax incentives, industry regulation, protection of intellectual property, and trade actions.

Industrial policies in the United States are complex, fragmented, continually evolving, and rarely targeted comprehensively at a specific industry. There is no industrial policy pertaining to biotechnology per se, but rather, a series of policies formulated by various agencies to encourage growth, innovation, and capital formation in various hightechnology industries. And, just as there is no biotechnology policy in the United States, biotech- nology companies tend to behave not as an industry but rather, as agrichemical firms, diagnostic firms, or human therapeutic firms. Biotechnology companies have been built on a unique system of financing, but they largely confront the same regulatory, intellectual property, and trade policies faced by other U.S. high-technology firms. There may be a need for the Federal bureaucracy to fine-tune its policies as biotechnology moves through the system, but, to date, Federal agencies have not seen the need to revolutionize their practices for biotechnology.

\section{Science and Technology Policy}

National policies promoting biotechnology $R \& D$ can be categorized as targeted or diffuse. In general, countries that have targeted biotechnology (e.g., J apan, Korea, Singapore, and Taiwan) share an 
emphasis on export-driven growth, and they view comprehensive government policies strongly promoting biotechnology and other critical technologies as key to future development. In the United States and much of Europe, in contrast, growth promotion is less prominent and is one of many competing social concerns. In these countries, fundamental goals are more diffuse.

A challenge to the adoption of a national biotechnology policy is the increasing internationalization of research, development, and product commercialization. The advent of EC 1992 has led to the creation of unique regional biotechnology research programs that offer yet another approach to strategic planning. These programs are currently modest in size, and their eventual success will likely hinge on political and economic integration of the European Community (EC).

Government targeting of biotechnology for special support is one of the least significant factors affecting competitiveness in the technology. Many components of targeting strategies such as the emphasis on technology transfer, the development of incubator facilities and venture capital for start-up fins, and the establishment of interdisciplinary centers for research are certainly helpful for focusing attention. However, in a sense, they operate at the margins.

There are two prerequisites for a nation to fully compete in biotechnology: 1) a strong research base and 2) the industrial capacity to convert the basic research into products. A strong research base is the first priority, allowing small companies and venture capitalists the opportunity to take risks. Without this, industry-oriented programs will not be very successful. Targeted national biotechnology strategies have been generally unsuccessful, in large part because of the way biotechnology arose out of basic biomedical research only to become fully integrated into the various fields of life sciences. The term 'biotechnol ogy' retains coherence only to the extent that regulation, public perception, and intellectual property law deal with specific biotechnology techniques as something unique.

A major challenge for national governments is to sort out national from private interests, a task that will become more difficult as competitiveness is used as a justification for particular expenditures. Economic nationalism may be particularly difficult to define and pursue, given the pluralistic, incre- mental, and increasingly global nature of the world's $R \& D$ system. In the emerging gl obal research and commercial environment, aggressive companies, whether large multinationals or savvy newcomers, seek the best ideas regardless of nationality. Likewise, they produce goods and services to effectively compete in international markets regardless of nationality. It is no longer always clear what constitutes an American firm in a global economy.

\section{Regulations}

Governments impose regulations to avert the costs associated with mitigating adverse effects expected to result from the use of the technology. But, developing regulations is difficult when a technology is new and the risks associated with it are uncertain or poorly understood. Because there have been no examples of adverse effects caused by biotechnology, projecting potential hazards rests on extrapolations from problems that have arisen using naturally occurring organisms. The consensus among scientists is that risks associated with genetically engineered organisms are similar to those associated with nonengineered organisms or organisms genetically modified by traditional methods, and that they may be assessed in the same way. Where similar technologies have been used extensively, past experience can be an important guide for risk assessment.

Many countries, in addition to the United States, have adapted existing laws and institutions to accommodate advances in biotechnology. However, it is no simple matter to base scientifically sound biotechnology regulation on legislation written for other purposes. The differences in approach from nation to nation, particularly through their effects on investment and innovation, will influence the ability of the United States to remain competitive in biotechnology on the international scene.

Worldwide, there have been three basic approaches to the regulation of biotechnology:

- No regulations. A number of countries with active investment in biotechnology have no regulations specific to biotechnology. In most of the growth-oriented countries of the Pacific Rim, such as Taiwan, South Korea, and Singapore, biotechnology has been targeted as a strategic industry. Some industrialized European nations, including Italy and Spain, which have no regulations specifically dealing with 

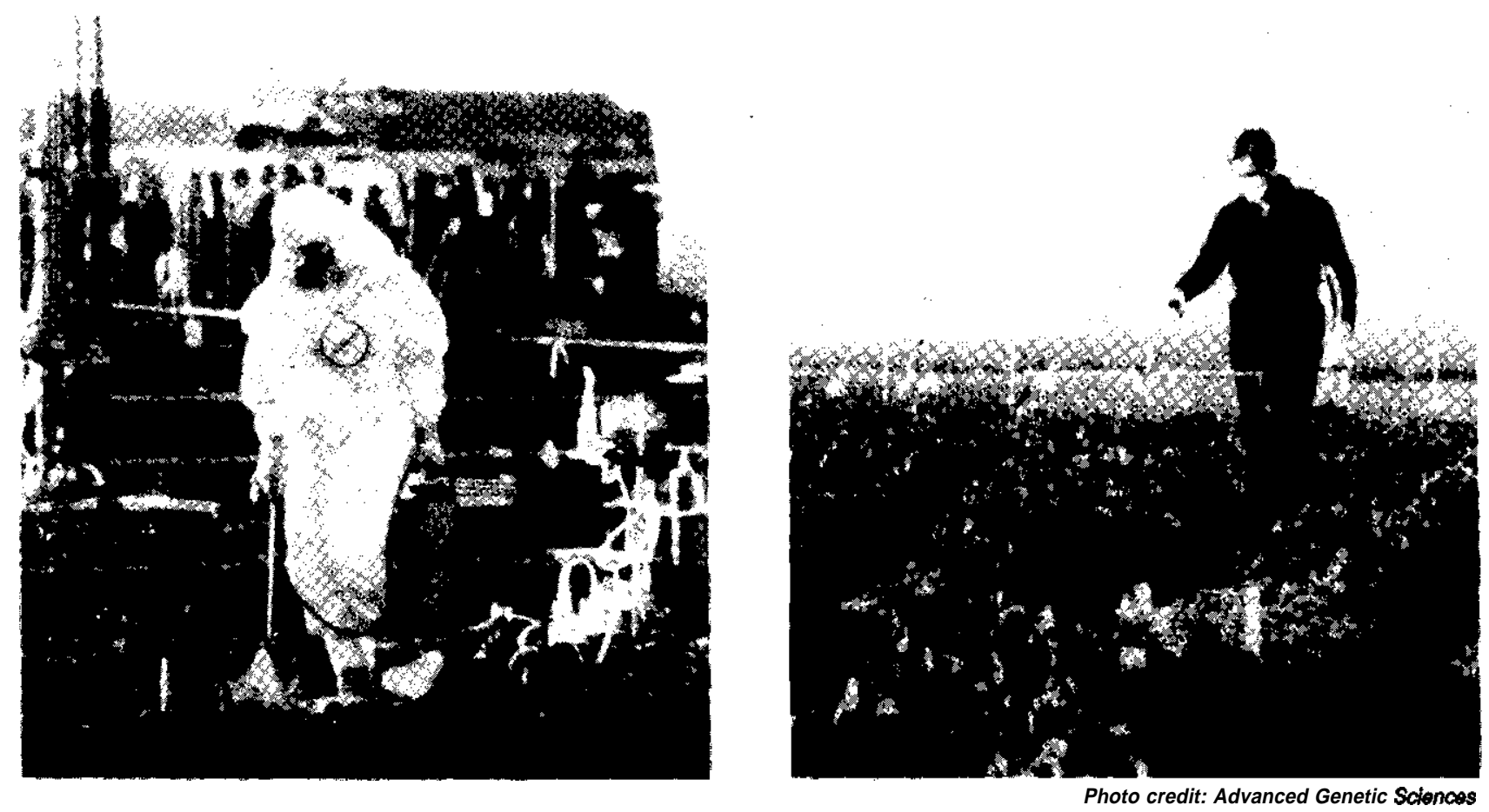

Two applications of "ice-minus" bacteria at Advanced Genetic Sciences in 1987 reflect varying requirements of regulation. At left, worker in protective clothing applies bacteria on strawberry test plot in April 1987; at right, worker in minimal protective gear applies bacteria on strawberry test plot in December 1987.

biotechnology, expect to develop them to harmonize with EC directives on biotechnology.

- Stringent biotechnology-specific regulations. Some northern European countries have responded to public pressure to impose stringent regulations specific to biotechnology by enacting new legislation. Under a 1986 law, Denmark prohibits the deliberate release of genetically engineered organisms without the express permission of the Minister of the Environment. Germany enacted new legislation imposing tight restrictions, in 1990. The EC's 1990 directives on contained use and deliberate release of modified organisms, while not as restrictive as the Danish or German laws, follow a similar approach in regulating products based on the means by which they were produced, rather than based on their intended use.

- Limited restrictions. Australia, Brazil, France, J apan, The Netherlands, the United Kingdom, and the United States allow the use of biotechnology with some restrictions and oversight. In these countries, regulations based on existing or amended legislation governing drugs, worker health and safety, agriculture, and environmental protection are being applied to the use of biotechnology. Stringency varies, as do the enforcement mechanisms.

In 1986, the Office of Science and Technology Policy (OSTP) of the White House described the regulatory policy of the Federal agencies in the Coordinated Framework for Regulation of Biotechnology. Recognizing that biotechnology is basically a set of techniques for producing new biochemical and altered organisms, and that chemicals and organisms are usually regulated according to their intended use and not their method of production; Federal policy fit the products of biotechnology into the existing web of Federal legislation and regulation. The framework also outlined the approach to interagency coordination, identifying the lead agency in several areas of overlapping jurisdiction.

Under the existing Framework for Regulation of Biotechnology, FDA has approved hundreds of diagnostic kits, 15 drugs and biologics, and 1 food additive; the Department of Agriculture (USDA) and the Environmental Protection Agency (EPA) 
have established procedures for reviewing field tests of modified plants and micro-organisms, and have approved 236 field tests as of May 1991 (see figure I-I). Although farm activists are concerned about the potential economic effects of bovine somatotropin (bST), public concern about the contained uses of modified organisms and their testing in the field has dissipated in the United States. However, some problems remain:

- Mechanisms established to provide Federal coordination of activities related to biotechnology have instead become the center of interagency ideological disputes over the scope of proposed regulations.

- The time required for clinical trials necessary for FDA approval of new drugs and biologics hurts young firms attempting to commercialize their first products.

- EPA has yet to publish proposed rules for the regulation of micro-organisms under the Toxic Substances Control Act of 1976 (TSCA) and Federal Insecticide, Fungicide, and Rodenticide Act (FIFRA).

- EPA considers micro-organisms to be chemical substances subject to TSCA, an interpretation that could be legally challenged.

- There is little funding for research that would support risk assessment of planned introductions.

- FDA has given little indication of its intentions for the development of regulations and procedures for evaluating the food safety of genetically modified plants and animals.

- Field-testing requirements have been criticized as too burdensome, especially for the academic community, and disproportionate to the small risk associated with these organisms, particularly transgenic crops with no nearby wild, weedy relatives.

The problems associated with developing regulations add to the costs borne by firms, and is especially burdensome for small biotechnologybased firms. Despite these difficulties, however, there is anecdotal evidence that some European firms have decided to open research and production facilities in J apan and the United States, in part because of the more favorable regulatory climate.

\section{Intellectual Property Protection}

Intellectual-property law, which provides a personal property interest in the work of the mind, is of increasing importance to people using biotechnology to create new inventions. Intellectual property involves several areas of the law: patent, copyright, trademark, trade secret, and plant variety protection. All affect emerging high-technology industries because they provide incentives for individuals and organizations to invest in and carry out R\&D. Many see protection of intellectual property as a paramount consideration when discussing a nation's competitiveness in industries fostered by the new biology.

Broad patent protection exists for all types of biotechnology-related inventions in the United States. The Supreme Court decision in Diamond $v$. Chakrabarty, that a living organism was patentable, along with action by Congress and the executive branch changing Federal policy to increase opportunities for patenting products and processes resulting from federally funded research have spurred biotechnology-related patent activity. Internationally, several agreements (e.g., the Paris Union Convention, the Patent Cooperation Treaty, the Budapest Treaty, the Union for the Protection of New Varieties of Plants, and the European Patent Convention) provide substantive and procedural protection for inventions created through the use of biotechnology.

Despite a generally favorable international climate, a number of elements affect U.S. competitiveness in protecting intellectual property. The patent application backlog at the Patent and Trademark Office (PTO), domestic and international uncertainties regarding what constitutes patentable subject matter, procedural distinctions in U.S. Iaw (e.g., first-to-invent versus frost-to-file, priority dates, grace periods, secrecy of patent applications, and deposit considerations), uncertainties in interpreting process patent protection, and the spate of patent infringement litigation, all constitute unsettled areas that could affect incentives for developing new inventions.

The backlog of patent applications at PTO is frequently cited as the primary impediment to commercialization of biotechnology-related processes and products. Recent studies reveal that the pendency period for biotechnology patent applications is longer than that of any other technology. 
Figure 1-1--States Where Releases of Genetically Engineered Organisms Have Been Approved

The number in each state equals the number of tests approved by USDA and EPA in that state as of May 15, 1991.

Total tests .236

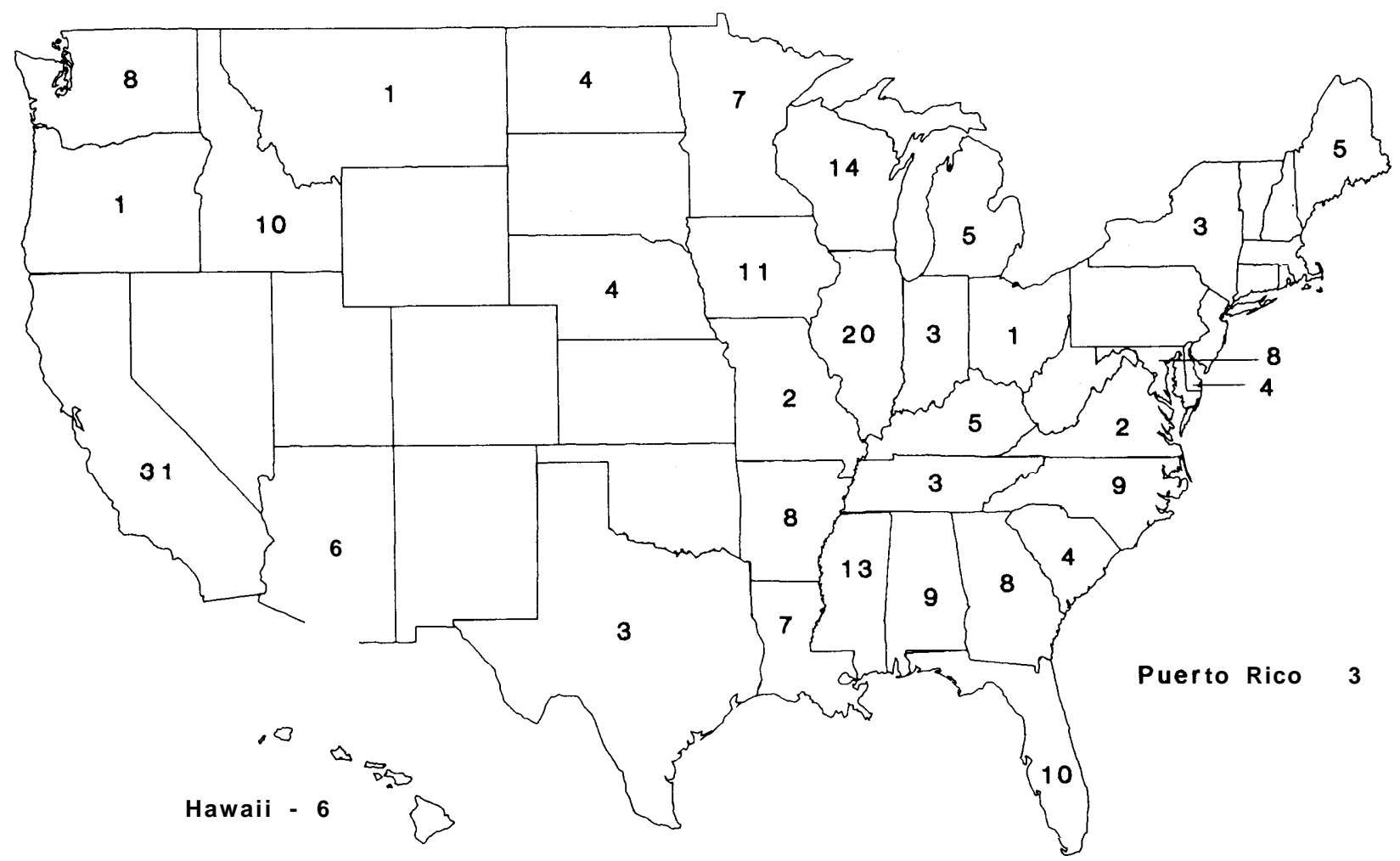

SOURCE: National Wildlife Federation, 1991, adapted from data provided by U.S. Department of Agriculture and U.S. Environmental Protection Agency.

IWO, in an effort to reduce the backlog, created a special biotechnology examining group and instituted an action plan to reduce the average pendancy. The PTO plan, while showing some promise, stands little chance of significantly reducing the backlog for two reasons: the number of filed biotechnology patent applications grows at a significantly higher average rate than that for all other types of patent applications, and PTO is unable to train and keep qualified patent examiners. The backlog creates uncertainty for business planning and a disincentive for proceeding with some $R \& D$ projects; however, there is no evidence to suggest that it significantly affects international competitiveness in biotechnology. Accelerated examination, a procedural option open to those needing expedited examination of a patent application, is rarely used for biotechnology applications. When compared to other countries, biotechnology patents are granted faster in the United States than in any major examining office in the world. And, for products that have a long regulatory approval time, the delay in obtaining a patent can result in an extended length of protection, since the 17-year term does not begin until the patent is actually issued.

Subject matter protection-what can and cannot be patented-is an issue that has received much attention because of the types of inventions created through biotechnology. U.S. Iaw is the broadest and most inventor-generous statute in the world; in addition to processes, patents have now issued for microbes, plants, and, in one instance, a transgenic animal. The subject of patenting plant and animal varieties (permitted in the United States but not in most other countries) and products (pharma- 


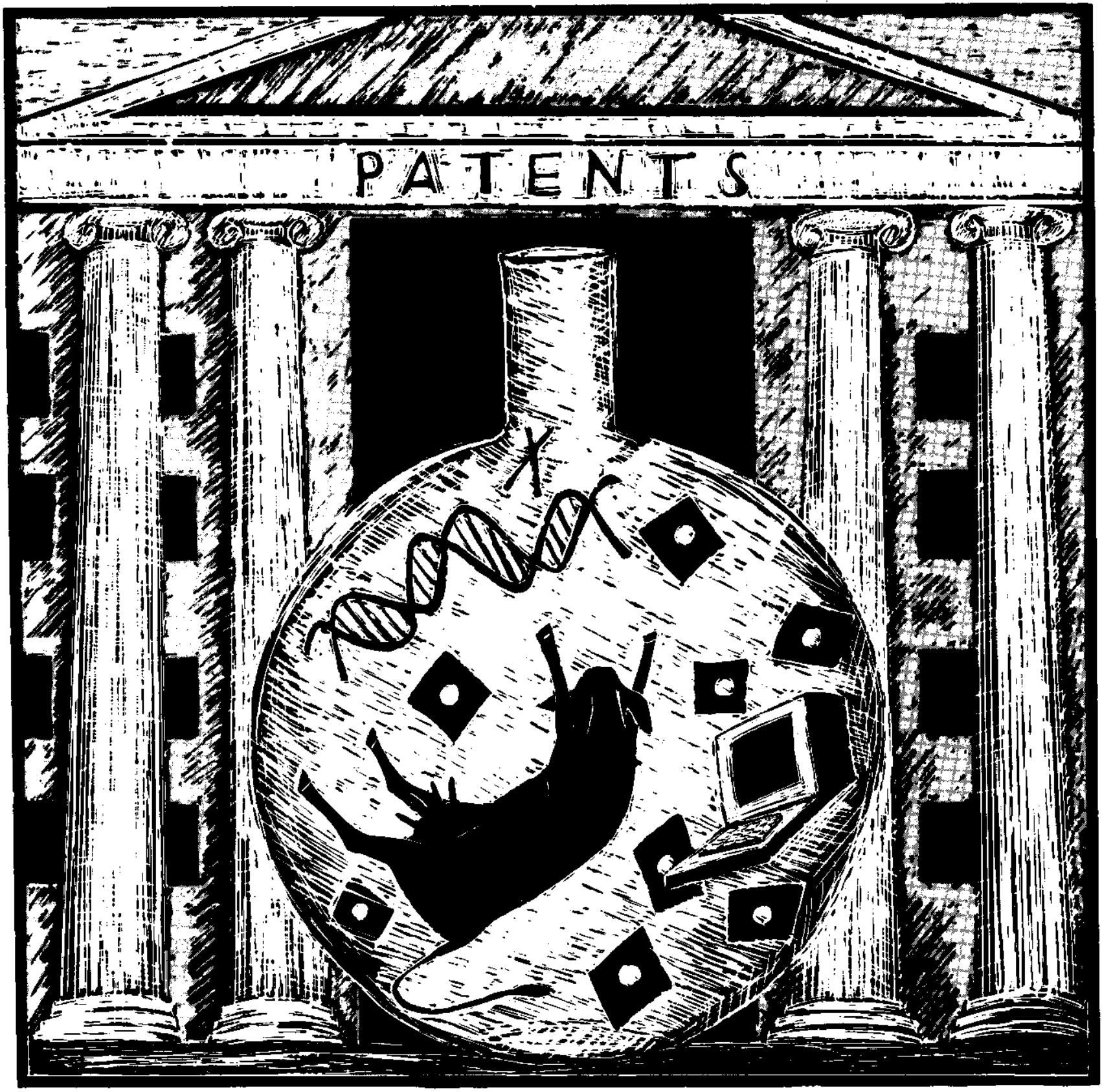

Photo credit: Claudia TantilloWaters

ceuticals, for example, are patentable in some countries but not in others) is of concern to those who seek consistent worldwide protection for their inventions.

Procedural distinctions between the laws of various nations are receiving increased attention in forums convened to harmonize international patent law. The ability of inventors to understand and easily meet the procedural requirements of various patent offices may, in the long term, be the issue of most importance to inventors of biotechnology products and processes. Procedural issues currently under debate in international forums inelude: determining how a priority date is set, establishing a consistent grace period, determining 
requirements for publication of patent applications, and standardizing translation requirements of applications.

A major concern of U.S. biotechnology companies is the adequacy of U.S. laws to protect against patent piracy. Process patents constitute the majority of patents issued in the biotechnology area. Such patents can be vital, especially if they cover a new process for making a known product. Congress enacted legislation in 1988 to address concerns regarding process patent protection. Debate, however, continues as to whether additional protection is needed. The large number of patents in the emerging biotechnology field has resulted in a surge of litigation as companies seek to enforce their rights against infringement and defend the patent grant in opposition or revocation proceedings. Such litigation is not surprising given the web of partially overlapping patent claims, the high-value products, the problem of prior publication, and the fact that many companies are interested in the same products. Litigation, while important to those staking their property claims, is extremely expensive and a major drain on finances that could otherwise be directed toward R\&D.

\section{INTERNATIONAL COMPETITIVENESS}

Industrial competitiveness is viewed by some as the ability of companies in one country to develop, produce, and market equivalent goods or services at lower costs than firms in other countries. The increasingly global economy, however, makes it more difficult to view industrial competitiveness this way. Many companies actively investing in biotechnology are multinational, conducting research, manufacturing, and marketing throughout the world. These companies contribute to the economies of nations other than the one in which they are headquartered. Despite these complications, it is still possible to broadly discuss strengths and weaknesses in various countries with respect to biotechnology.

A number of nations have targeted biotechnology as being critical for future economic growth. Nationally based $R \& D$ programs have arisen in several countries, and biotechnology has been singled out in many public policy debates as having economic, social, ethical, and legal consequences. Using a number of measures (see box I-E), in 1984 OTA found that the United States was at the forefront in the commercialization of biotechnology, that J apan was likely to be the leading competitor of the United States, and that European countries were not moving as rapidly toward commercialization of biotechnology as either the United States or J apan.

\section{United States}

In retrospect, the diffusion of biotechnology into several industrial sectors in many nations makes it difficult to define what constitutes a strong national program in biotechnology and to rank the countries in competitive order. By many measures, the United States remains preeminent in biotechnology, based on strong research programs and well-established foundations in pharmaceuticals and agriculture. Broad-based, federally funded basic research-especially in biomedicine-is a hallmark of U.S. capability in biotechnology. In fiscal year 1990 alone, the Federal Government spent more than $\$ 3.4$ billion to support $R \& D$ in biotechnology-related areas (see table 1-5).

Dedicated biotechnology companies, a uniquely American phenomenon, aided by the vast resources of venture capital and public markets have provided innovation to a number of preexisting industries. U.S. patent law provides generous protection for all kinds of biotechnology-derived inventions, and laws and regulations are largely in place to protect the public health and the environment. Public concern regarding the uses of biotechnology is minimal when compared to many other nations.

\section{Japan}

In 1981, J apan's MITI announced that biotechnology, along with microelectronics and new materials, was a key technology for future industries. The announcement attracted interest and concern abroad, largely because of the key role MITI played in guiding J apan's economic growth in the postwar period. While government policies encouraged biotechnology investment by a large variety of companies, J apanese investment in biotechnology predates MITI's 1981 action. Regardless of earlier actions, MITI's naming of biotechnology as an area of interest probably gave it the legitimacy it previously lacked and eased financing for private investmentas it had done earlier for other industries and technologies. As in the United States and elsewhere, however, the broad range of potential biotechnology applications has led to a wide variety of frequently 


\section{Box 1-E-Measuring International Competitiveness}

In investigating intemational competitiveness in biotechnology, in 1984 OTA used the following approach.

The first step in the analysis of international competitiveness in biotechnology was to consider the aggregate level of industrial activity and the number and kinds of firms commercializing biotechnology in the competitor countries. The industrial analysis was approached from three perspectives:

- the number and kinds of companies commercializing biotechnology,

- the markets targeted by industrial biotechnology R\&D, and

- the interrelationships among companies applying biotechnology, and the overall organization of the commercial effort.

The second step in providing an overall picture of competitiveness in biotechnology involved the evaluation of 10 factors identified as potentially important in determining the future position of the United States and other countries in the commercialization of biotechnology: govermment funding of applied and basic research; personnel availability and training; financing and tax incentives for firms; health, safety, and environmental regulation; intellectual property law; university/industry relationships; targeting policies in biotechnology; intemational technology transfer, investment, and trade; antitrust law, and public perceptions.

Additional considerations taken into account in the analysis were historical pattems of industrial commercialization, the lack or abundance of particular natural resources, and the tendency toward risk taking in various countries.

SOURCE: Office of Technology Assessment, 1984.

overlapping initiatives by various J apanese agencies.

Today, MITI is continuing to support R\&D efforts in areas such as: marine biotechnology and biodegradable plastics, addressing relevant industrial policy (e.g., tax incentives, J apan Development Bank, and Small Business Finance Corp. Ioans, and promotion of industry standards), improving safety measures (new contained-use regulations and developing lists of industrially exploitable organisms), and internationalization (regulatory harmonization, international $R \& D$ cooperation, and funding devel-
Table 1-5--U.S. Federal Funding for Biotechnology, Fiscal Year 1990 (millions of dollars)

\begin{tabular}{|c|c|}
\hline Agency & Amount \\
\hline National Institutes of Health. & $\$ 2,900.0$ \\
\hline National Science Foundation & 167.9 \\
\hline Department of Agriculture .. & 116.0 \\
\hline Department of Defense. ..... & 98.0 \\
\hline Department of Energy...... & 82.2 \\
\hline Agency for International Development ......... & 28.7 \\
\hline Food and Drug Administration. . . . $\ldots \ldots \ldots \ldots$ & 19.4 \\
\hline Environmental Protection Agency. . & 8.3 \\
\hline Veterans Administration $\ldots \ldots \ldots \ldots \ldots \ldots \ldots$ & 7.5 \\
\hline National Institute of Standards and Technology. . . & 4.8 \\
\hline National Aeronautics and Space Administration .. & 4.5 \\
\hline National Oceanic and Atmospheric Administration. & 2.0 \\
\hline Total . & $\$ 3,439.3$ \\
\hline
\end{tabular}

SOURCE: Office of Technology Assessment, 1991.

oping country research). However, in contrast to the United States, J apan suffers from the lack of a strong research base, which has led firms to seek access to research and training abroad, especially in the U nited States.

J apan also suffers some weaknesses in the industrial sectors to which biotechnology is most applicable. J apan's pharmaceutical industry, for example, was sheltered from international competition until recently and is only now beginning to develop international skills in drug development, testing, and marketing. In agriculture, research is limited to specialized areas (e.g., rice), as J apan is not a food exporting country. Additionally, concern regarding field testing of genetically modified organisms is pervasive; governmental approval for the first environmental release of a genetically engineered organism-a transgenic tomato---did not occur until J anuary 1991.

J apan is, however, effectively combining biotechnology with its traditional strength in fermentation, especially in the production of amino acids and industrial enzymes. There is also active research with biosensors, based on J apan's strength in micro-electronics. The efforts of MITI to promote biotechnology as a key technology, intergrate biotechnology into existing industrial sectors, while at the same time bearing some fruit, clearly has been less successful than many anticipated. As in the United States and Europe, commercialization has taken longer, been more technically difficult, and been more dependent on factors unique to each industrial sector than expected. Biotechnology has not yet achieved the spectacular success for J apanese 
industry that other fields have in the past. For the foreseeable future, corporate strategies, rather than MITI initiatives, will likely determine J apan's investment in biotechnology.

\section{Europe}

A number of European countries have technology policies that resemble those of the United States National policies, however, are becoming less distinctive as Europe moves closer to economic integration.

Unlike J apan, Europe's strengths in pharmaceuticals and agriculture lend themselves to the adoption of biotechnology. Germany, Switzerland, and the United Kingdom are home to major multinational pharmaceutical companies. These companies are investing heavily in both in-house and collaborative research in biotechnology, with much of the latter conducted with U.S. DBCs. Promising research in agricultural biotechnology is under way in several countries, especially Belgium, France, Germany, and the United Kingdom. The picture is clouded, however, by several factors: the fragmentation of research efforts, adverse public opinion, and uncertain effects of recently enacted European Community directives on field testing of genetically modified organisms.

While many countries are targeting biotechnology, those that have not developed a research base and the industrial capacity to convert basic research into products are not likely to be serious commercial competitors in the near future.

\section{OPTIONS FOR ACTION BY CONGRESS}

There is no way to directly measure a nation's competitiveness in biotechnology. Modern biology is being used in many nations, by many multinational corporations, and in many industrial sectors. In addition, there is no consensus as to what constitutes the so-called "national interest" in promoting a technology. Some view competitiveness in terms of who ultimately owns a company (i.e., where do the profits eventually go), while others view competitiveness as where jobs and skills are located.

U.S. competitiveness in the global commercialization of biotechnology has come to the attention of Congress for three reasons. First, the U.S. Govern- ment indirectly supports industrial applications of biotechnology by funding basic research in a wide range of relevant disciplines. Second, Federal agencies have the authority to regulate the commercial development of biotechnology. Third, international economic competitiveness in various technologies, including biotechnology, has emerged as a key bipartisan concern.

In all three areas, Congress plays a direct role. Through its annual appropriations to Federal agencies, it increases or decreases the level of research and regulatory oversight. Through its authorization powers, Congress can create programs and set priorities for Federal agencies. Through oversight of agencies' conduct of research and regulatory programs, Congress can express its enthusiasm and concern.

Seven policy issues relevant to U.S. competitiveness in biotechnology were identified during the course of this study:

- Federal funding for biotechnology research,

- targeting biotechnology development,

- developing regulations,

- coordinating Federal agencies,

- protecting intellectual property,

- improving industry-university relationships, and

- structuring coherent tax policies.

Options for congressional action discussed here build on the discussion in chapters 3 through 12 of this report. Some options are oriented toward the actions of the executive branch but involve congressional oversight or direction. The order in which the options are presented does not imply their priority. Moreover, the options are not mutually exclusive.

\section{Federal Funding for Biotechnology Research}

$\boldsymbol{A n}$ issue central to the competitive position of U.S. efforts in biotechnology is a sufficient and stable level of funding for areas of science crucial to the field. In relative and absolute terms, the United States supports more research relevant to biotechnology than any other country. Clearly, intensive and sustained Federal investment in applications of biotechnology to the life sciences has been transformed into commercial products in some industries faster than others. Commercial applications continue to be more advanced in areas such as human therapeutics and diagnostics, largely due to the high 
levels of funding of basic biological research by the National Institutes of Health ( $\mathrm{NIH})$. Other areas, such as agriculture, chemicals, and waste degradation, have not come close to approaching the same levels of funding enjoyed by the biomedical sciences. In some cases, such as agriculture and waste degradation, slow progress in commercial activity could be due in part to insufficient funds for basic research; in other cases, such as chemicals, potential products are simply not being developed because industry does not consider the biotechnology products or processes sufficiently better (either functionally or economically) than those that already exist.

Congress could determine that Federal levels of investment in $R \& D$ over recent years have adequately supported the forward integration of biotechnology into many sectors and have contributed to the commercial successes of U.S. biotechnology companies. Proceeding with the current funding patterns would ensure a stable level of research relevant to biotechnology and its applications. Such an approach, however, would perpetuate current disparities in research emphases, with biomedicine continuing to fare better than agriculture and waste management.

Congress could conclude that because of social, economic, and strategic importance, biotechnology research relevant to agriculture, chemicals, and waste management deserves additional support. Or it could direct Federal agencies to dedicate more of their budgets to applied and multidisciplinary research in biotechnology critical to those industries at a competitive disadvantage. This option would not necessarily require new money but would direct agencies to identify areas of applied research in biotechnology where awards could be made. Applied areas deserving increased funding could be identified by committees of peers comprised of government, academic, and industrial scientists. In addition, areas of research that require multidisciplinary involvement could receive higher levels of support. However, any effort to increase emphases on applied research carries the risk of harming the support base for basic research. Each agency needs to consider the balance of support between basic and applied work within its mission.

\section{Targeting Biotechnology Development}

Because it encompasses several processes that have applications to many sectors of the U.S. economy, some argue that biotechnology should be targeted by the Federal Government for aggressive government support and promotion. Currently, U.S. industrial growth depends on private sector entrepreneurship, Federal funding of research, and regulatory oversight of various research applications and commercial development.

Congress could target biotechnology through legislation that broadly singles it out for favorable treatment, or through measures that address specific problems faced by researchers and companies seeking to commercialize products developed through biotechnology. Legislative attempts to target biotechnology have focused on the establishment of national biotechnology policy boards and advisory panels for specific areas of research interest (e.g., agriculture, human genome, and biomedical ethics) and development of a national center for biotechnology information. Those who argue against targeting biotechnology say that it is not the role of the Federal Government to pick winners and losers in the world of commerce, that such efforts have more often failed than succeeded, and that attempts to target biotechnology cannot succeed due to the number of industries involved, all of which face different scientific, regulatory, patent, and commercial problems. Targeting biotechnology alone cannot assure increased competitiveness; fostering a research base (funding, training, and personnel) and maintaining an industrial capacity to convert basic research into products also is required.

\section{Developing Regulations}

Six years after the Coordinated F ramework for Regulation of Biotechnology was first proposed and 4 years after it became final, regulations for genetically modified pesticides and for certain microorganisms have yet to be issued. This is due to disagreements among some Federal agencies about the need for and appropriate scope of regulations. The failure to promulgate final regulations has led to complaints by industry representatives that the regulatory approval process is unclear and inhibits investment. Manufacturers have also complained of a lack of guidance on food biotechnology and a lack of information on FDA's regulatory intentions. The Biotechnology Science Coordinating Committee (BSCC), in one of its last acts before disbanding, issued a policy statement giving guidance on the scope of organisms to be regulated. But still no proposed rules are in sight. Congress could decide to 
use its oversight authority to encourage the agencies to give informal guidance to manufacturers and to encourage the rapid development of rules.

TSCA includes a regulatory scheme to screen new chemicals for their potential to cause unreasonable risk to human health and the environment. Manufacturers and importers must notify EPA 90 days before manufacturing or importing a new chemical or before a chemical is put to a 'significant new use.' If EPA determines that the chemical poses an unreasonable risk of injury to health or the environment, EPA can prohibit or limit its manufacture, import, or use. As a matter of policy, EPA considers micro-organisms to be chemical substances subject to TSCA. EPA's interpretation has not been challenged in court, and it is not clear how the courts would rule if it were challenged. Congress could decide to amend TSCA to specifically include micro-organisms within its scope. This would assure EPA review of micro-organisms not fitting under the jurisdiction of other statutes prior to field testing.

\section{Coordinating Federal Agencies}

There will be a continuing need for interagency consideration of scientific advances, research needs, and regulatory jurisdiction. OSTP founded the Biotechnology Science Coordinating Committee (BSCC) to provide a formal mechanism for discussion of these issues. BSCC became embroiled in questions of agency policy, specifically in the content of EPA's proposed rules, which caused it to neglect its role as a forum for discussion of broad scientific issues and as a mechanism for interagency cooperation. BSCC was also criticized for conducting many of its activities away from public view. OSTP disbanded the BSCC and replaced it with the Biotechnology Research Subcommittee (BRS). BRS has been asked to focus on scientific issues, but the subcommittee will continue to be involved in regulatory matters as well. However, BRS has no statutory authority nor was its formation or purpose published in the Federal Register. It is not clear what measures are being taken to ensure that BRS avoids the difficulties that stymied its predecessor, nor is it clear that steps are being taken to open its activities to public scrutiny.

Congress could decides that interagency coordination is adequate or that problems of coordination are best resolved through Congress' oversight authority.

\section{Protecting Intellectual Property}

Many researchers and companies cite protection of intellectual property as being of utmost importance to preserving competitiveness in biotechnology. This is less a domestic issue than an international one as U.S. law provides broad protection for those who invent new and useful processes and products. However, as markets in biotechnology become increasingly gl obal, issues arise regarding subject matter protection, harmonization of patent procedure, and the context of intellectual property in international trade.

U.S. law permits patents to issue for any new, useful and unobvious process, machine, manufacture, composition of matter, or new and useful improvement of these items. As a result, U.S. Iaw has permitted the patenting of micro-organisms, plants, and nonhuman animals. The patenting of nonhuman animals has led to legislative debate regarding subject matter protection. Options for congressional action-which included discussion on issues such as deposit considerations and exemptions from infringement for certain classes of users-were presented in an earlier OTA report (New Developments in Biotechnology: Patenting Life) and are incorporated here by reference. In terms of patentable subject matter, U.S. patent law is the most inventor-friendly statute in the world; it is unique in that it makes no exceptions to patentability, which are often found in the statutes of other countries (e.g., animal and plant varieties, public order or morality, and products such as pharmaceuticals and foods). If Congress takes no action regarding patentable subject matter, broad protection for inventions created by biotechnology will continue. Laws created by Congress to regulate interstate commerce would be relied on to govern the development, approval, sale, and use of such inventions. Congress could, either through moratorium or prohibition, specifically bar patents from issuing for nonhuman animals or human beings. Such action would clarify congressional intent regarding the limits of subject matter protection, but it would also create the precedent of using patent law, rather than laws regulating commerce, to limit the creation of certain types of inventions.

Harmonization of U.S. patent law with the laws of other nations is likely to come to Congress' attention as a result of several ongoing efforts: the General Agreement on Tariffs and Trade, the World Intellec- 
tual Property Organization, amendments to the Union for the Protection of New Varieties of Plants, and other bilateral and multilateral trade discussions. It is too early to predict specific options arising from each of these forums. In all cases, the goal of harmonization should be the creation of consistent laws addressing substantive and procedural issues in patent practice.

Process patent protection is also of increasing importance to industry. Legislation was introduced in the 101st and 102d Congresses to grant the International Trade Commission the right to bar entry into the United States products made using any component manufactured in violation of a U.S. patent and to allow process patent protection on biotechnology production processes as long as the starting material is novel. I ssues related to the scope of process patents, obviousness, and import into the United States of products containing patented parts will continue to arise. Consensus among companies is unlikely in many of these policy disputes as many of these problems involve competing biotechnology companies that are staking out corporate competitive positions.

\section{Improving Industry-University Relationships}

Through a series of actions, both Congress and the executive branch have encouraged the transfer of research findings into commercial applications. Industrial sponsorship of university-based biotechnology research has become a widespread and generally accepted phenomenon over the past 10 years. The resulting links between academic-based biotechnology research and industry have several beneficial effects (e.g., additional resources for $R \& D$ and training, more focus on applied research, and the development and use of patented inventions). Questions have been recently raised about possible negative affects of some of these relationships, particularly the conflicts that could arise when a researcher is involved in trials or testing of new drugs developed by companies in which they have a personal financial or fiduciary interest. Some industrialists have expressed concern that guidelines or regulations requiring disclosure of potential conflicts of interest for federally funded scientists will have a negative impact on the ability of U.S. biotechnology firms to transfer the results of federally funded research into commercial application.
Currently, NIH and the Alcohol, Drug Abuse, and Mental Health Administration have no rules concerning conflicts of interest for grantees, although $\mathrm{NIH}$ must approve any outside financial arrangements for its employees that could pose potential conflicts of interest. To date, the Public Health Service (PHS) has only proposed that investigators who design, conduct, or report research disclose financial interests to institutions. Comments on the proposal were received at a November 1990 public meeting.

Congress could take no action if it concludes that the number of cases of alleged conflict of interest and misconduct have been too few to warrant legislative action, or that oversight of conflict of interest is best managed at the university level. If Congress decides that action is needed, it could direct the Department of Health and Human Services (DHHS) to promulgate PHS regulations that clearly spell out or restrict financial ties for researchers who conduct evaluations of a product or treatment in which they have a vested interest. In the absence of action by DHHS, Congress could also enact legislation to achieve the same goal.

Legislation that restricts the ability of publicly funded researchers to collaborate with industry could discourage the entrepreneurial initiative of scientists and possibly limit the value of government-sponsored research. However, a lack of action by either Congress or executive agencies to clarify the limits of such collaboration could result in cases of actual or perceived conflict of interest with resulting public concern about the safety of some biotechnology-derived products.

\section{Structuring Coherent Tax Policies}

The Tax Reform Act of 1986 (Public Law 99-514) contained numerous provisions, including extension and reduction from 25 to 20 percent of the $R \& D$ tax credit, repeal of the investment tax credit for equipment investment, and abolition of the preferential treatment for capital gains. Five options for congressional action were presented in an earlier OTA report (New Developments in Biotechnology: U.S. Investment in Biotechnology). One of the options-restoration of preferential treatment of capital gains-was addressed by the 101st Congress.

Other options discussed the R\&D tax credit, which is designed to provide an incentive to companies to increase their commitment to indus- 
trial $R \& D$. Firms that annually increase $R \& D$ spending can apply for an $R \& D$ tax credit against Federal income taxes. The credit has been available since 1981 but is not a permanent part of the tax code, rather it has been extended several times through various legislation. Most recently it was extended through December 31, 1991, by the Omnibus Budget Reconciliation Act of 1990. Congress could grant the R\&D tax credit permanent status when it expires at the end of 1991. A permanent credit would reduce the uncertainty that exists for industrial $R \& D$ planners concerning the credit's future existence.

The statutory rate of the credit is 20 percent, and the credit is calculated based on the excess of qualified research over abase amount linked to $R \& D$ spending in a specific historical period. The base amount is figured by multiplying a "fixed-base percentage" by a firm's average gross receipts over the preceding 4 years. As currently structured, companies that do not have positive gross receipts for the preceding 4 years are not eligible to receive the $R \& D$ credit in the same year as the research expenses are made. The credit is not refundable in the current year, so only firms with positive tax liabilities can use it immediately. Those companies without current tax liabilities, which include many DBCs, can carry forward tax credits to offset taxes up to 15 years in the future. For a DBC, this carried-forward credit is less valuable than a refundable credit, that would provide immediate returns. In addition, when considering the time-value of money, carried-forward tax benefits are less valuable than tax benefits rendered in the current year. Despite these facts, some successful biotechnology companies have expressed the opinion that the R\&D tax credit is beneficial and that it does factor into their decisionmaking practices in terms of $R \& D$ expenditures. Congress may wish to consider changing the structure of the $R \& D$ credit to provide more immediate benefits to biotechnology and other small high-technology companies that are not yet profitable, by making the credit refundable in the year of research expenditures.

One particular accounting standard that has received recent attention is the inability of U.S. firms to amortize goodwill for tax purposes as quickly as foreign firms. Amortization refers to an accounting procedure that gradually reduces the cost-value of a limited-life or intangible asset through periodic charges to income. Goodwill is a term used in acquisition accounting to refer to the going-concern value (defined as the value of a company as an operating business to another company or individual) in excess of asset value and is considered an intangible asset. Goodwill represents things such as the value of a well-respected business name, good customer relations, and other intangible factors that lead to greater than normal earning power. Goodwill has no independent market or liquidation value and must be written off over time, or amortized. Accounting standards are set by the Financial Accounting Standards Board (FASB), an independent professional board over which Congress has no authority. Foreign companies are not held to FASB rules and are not required to amortize goodwill, rather they can write it off immediately as an expense and in some cases receive a tax deduction. This gives foreign companies an advantage over U.S. companies with respect to acquisitions because the former do not have to carry a balance sheet of goodwill over time. Since Congress has no legislative authority over the FASB, there is no specific legislative action that can be taken to change FASB's rules. Congress could, however, change the tax code to offer a tax deduction on goodwill that is amortized. Such action would recognize the disadvantage that U.S. companies are facing in acquiring U.S. assets, but it could also fuel further controversial corporate acquisitions in a number of industries. 


\section{Chapter 2}

\section{Introduction}

"The United States is the world leader in biotechnology. This $\$ 2$ billion domestic industry is expected to increase to $\$ 50$ billion by the year $2000 . "$

Vice President Dan Quayle The President's Council on Competitiveness Report on National Biotechnology Policy

"It is industries, not nations, that compete globally." 


\section{CONTENTS}

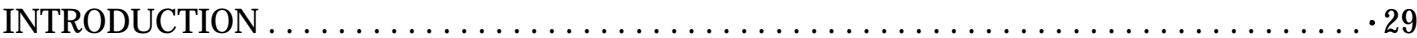

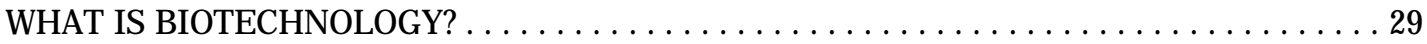

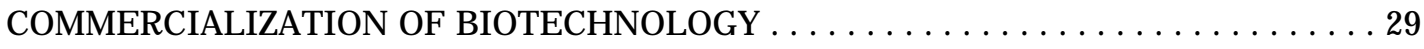

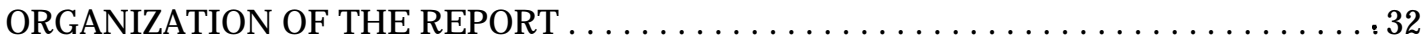

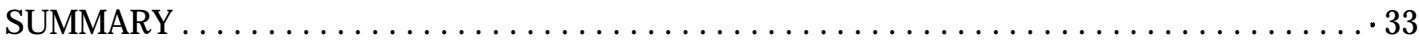

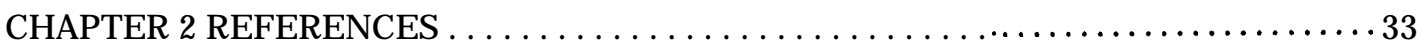

Box

Box Page

2-A. Three Kinds of Research $\ldots \ldots \ldots \ldots \ldots \ldots \ldots \ldots \ldots \ldots \ldots \ldots \ldots \ldots \ldots \ldots \ldots$

Figure

Figure Page

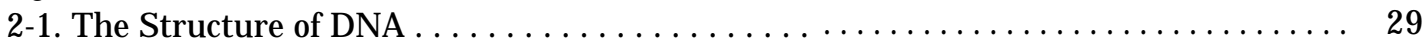

\section{Tables}

Table Page

2-1. Major Events in the Commercialization of Biotechnology $\ldots \ldots \ldots \ldots \ldots \ldots \ldots, 30$

2-2. Some Factors That Can Affect Commercialization of Biotechnology . . . . . . . . 32

2-3. Requesters of OTA Assessment, Biotechnology in a Global Economy ......... 33 


\section{INTRODUCTION}

This report examines international trends in biotechnology-related commercial activity and governmental approaches to promotion and regulation of biotechnology. This introductory chapter provides a context for the report's more technical chapters by explaining and defining what biotechnology is, by outlining some factors that influence competitiveness in biotechnology, and by describing the congressional request for this report and the organization of the Office of Technology Assessment's (OTA's) assessment of issues raised by the requesters of this report.

\section{WHAT IS BIOTECHNOLOGY?}

The first challenge in describing the effect of biotechnology on a global economy is to define biotechnology. The term "biotechnology" means different things to different people. Some view biotechnology as all forms of biological research. To others, biotechnology includes the use of classical breeding techniques that have been used for years to create new plants, animals (e.g., improved livestock), and foods (e.g., baking and brewing). Others view biotechnology as comprising modern biological techniques (e.g., rDNA, hybridoma technology, or monoclinal antibodies) that have resulted in greatly increased understanding of the genetic and molecular basis of life (see figure 2-I). Some people have analogized biotechnology to a set of new tools in the biologist's tool box, by referring to "biotechnol ogies. To Wall Street financiers and venture capitalists who invested in the creation of companies in this area, biotechnology represents a hot, new source of financial risk and opportunity. Congress, increasingly involved in public policy questions raised by biotechnology, in one statute referred to products "primarily manufactured using recombinant DNA, recombinant RNA, hybridoma technology, or other processes involving site-specific genetic manipulation techniques' (35 U.S.C. 156(2)(B)).

In a 1984 report, after extensive canvassing of academicians, industrialists, and government officials involved in biotechnology, OTA arrived at two definitions of biotechnology (3). The first defini- tion-broad in scope-described biotechnology as any technique that uses living organisms (or parts of organisms) to make or modify products, to improve plants or animals, or to develop micro-organisms for specific uses. This definition encompasses both new biological tools as well as traditional uses of selecting organisms for improving agriculture, animal husbandry, or brewing. A second, more narrow definition refers only to "new" biotechnology: the industrial use of rDNA, cell fusion, and novel bioprocessing techniques. It is the development and uses of this new biotechnology that has captured the imagination of scientists, financiers, policymakers, journalists, and the public. As in earlier OTA reports, the term "biotechnology," unless otherwise specified, is used in reference to new biotechnology.

\section{COMMERCIALIZATION OF BIOTECHNOLOGY}

Biotechnology-both as a scientific art and commercial entity-is less than 20 years old (see table 2-I). Science, however, can find roots in the

Figure 2-I-The Structure of DNA

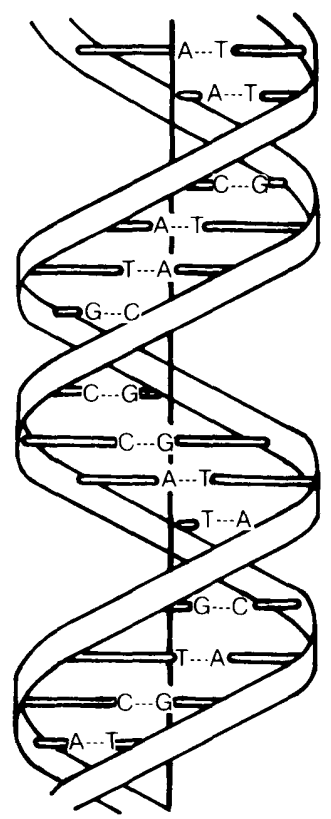

SOURCE: Office of Technology Assessment, 1991. 
Table 2-I-Major Events in the Commercialization of Biotechnology

\begin{tabular}{|c|c|}
\hline 1973 & First cloning of a gene. \\
\hline 1974 & Recombinant DNA (rDNA) experiments first discussed in a public forum (Gordon Conference). \\
\hline 1975 & $\begin{array}{l}\text { U.S. guidelines for rDNA research outlined (Asilomar Conference). } \\
\text { First hybridoma created. }\end{array}$ \\
\hline 1976 & $\begin{array}{l}\text { First firm to exploit rDNA technology founded in the United States (Genentech). } \\
\text { Genetic Manipulation Advisory Group started in the United Kingdom. }\end{array}$ \\
\hline 1980 & $\begin{array}{l}\text { Diamond v. Chakrabarty--U.S. Supreme Court rules that micro-organisms can be patented. } \\
\text { Cohen/Boyer patent issued on the technique for the construction of rDNA. } \\
\text { United Kingdom targets biotechnology for research and development (Spinks' report). } \\
\text { Federal Republic of Germany targets biotechnology for R\&D (Leistungsplan). } \\
\text { Initial public offering by Genentech sets Wall Street record for fastest price per share increase ( } \$ 35 \text { to } \$ 89 \text { in } 20 \text { minutes). }\end{array}$ \\
\hline 1981 & $\begin{array}{l}\text { First monoclinal antibody diagnostic kits approved for use in the United States. } \\
\text { First automated gene synthesizer marketed. } \\
\text { Japan targets biotechnology (Ministry of International Trade and Technology declares 1981, "The Year of Biotechnology"). } \\
\text { Initial public offering by Cetus sets Wall Street record for the largest amount of money raised in an initial public offering ( } \$ 115 \\
\text { million). } \\
\text { Over } 80 \text { new biotechnology firms formed by the end of the year. }\end{array}$ \\
\hline 1982 & $\begin{array}{l}\text { First rDNA animal vaccine (for colibacillosis) approved for use in Europe. } \\
\text { First rDNA pharmaceutioal product (human insulin) approved for use in the United States and the United Kingdom. }\end{array}$ \\
\hline 1983 & $\begin{array}{l}\text { First expression of a plant gene in a plant of a different species. } \\
\text { New biotechnology firms raise } \$ 500 \text { million in U.S. public markets. }\end{array}$ \\
\hline 1984 & $\begin{array}{l}\text { California Assembly passes resolution establishing the creation of a task force on biotechnology. Two years later, a guide } \\
\text { clarifying the regulatory procedures for biotechnology is published. }\end{array}$ \\
\hline 1985 & $\begin{array}{l}\text { Advanced Genetic Sciences, Inc. receives first experimental use permit issued by EPA for small-scale environmental release } \\
\text { of a genetically altered organism (strains P. syringae and P. fluorescens from which the gene for ice-nucleation protein had } \\
\text { been deleted. }\end{array}$ \\
\hline 1986 & $\begin{array}{l}\text { Coordinated Framework for the Regulation of Biotechnology published by Office of Science and Technology Policy. } \\
\text { Technology Transfer Act of } 1986 \text { provides expanded rights for companies to commercialize government-sponsored } \\
\text { research. }\end{array}$ \\
\hline 1987 & $\begin{array}{l}\text { U.S. Patent and Trademark Office announces that nonhuman animals are patentable subject matter. } \\
\text { October 19th-Dow Jones Industrial Average plunged a record } 508 \text { points. Initial public offerings in biotechnology-based } \\
\text { companies virtually cease for } 2 \text { years. }\end{array}$ \\
\hline 1988 & $\begin{array}{l}\mathrm{NIH} \text { establishes program to map the human genome. } \\
\text { First U.S. patent on an animal-transgenic mouse engineered to contain cancer genes. }\end{array}$ \\
\hline 1989 & $\begin{array}{l}\text { Bioremediation gains attention, as microbe-enhanced fertilizers are used to battle Exxon Valdez oil spill. } \\
\text { Court in Federal Republic of Germany stops construction of a test plant for producing genetically engineered human insulin. } \\
\text { Gen-Probe is first U.S. biotechnology company to be purchased by a Japanese company (Chugai Pharmaceuticals). }\end{array}$ \\
\hline 1990 & $\begin{array}{l}\text { FDA approves recombinant renin, an enzyme used to produce cheese; first bioengineered food additive to be approved in } \\
\text { the United States } \\
\text { Federal Republic of Germany enacts Gene Law to govern use of biotechnology. } \\
\text { Hoffman-LaRoche (Basel, Switzerland) announces intent to purchase a majority interest in Genentech. } \\
\text { Mycogen becomes first company to begin large-scale testing of genetically engineered biopesticide, following EPA approval. } \\
\text { First approval of human gene therapy clinical trial. }\end{array}$ \\
\hline 1991 & $\begin{array}{l}\text { Biotechnology companies sell } \$ 17.7 \text { billion in new stock, the highest } 5 \text {-month total in history. } \\
\text { Chiron Corp. acquires Cetus Corp. for } \$ 660 \text { million in the largest merger yet between two biotechnology companies. } \\
\text { EPA approves the first genetically engineered biopesticide for sale in the United States. }\end{array}$ \\
\hline
\end{tabular}


discovery of the replication process of deoxyribonucleic acid (DNA)--first proposed nearly 40 years ago by Francis H.C. Crick and J ames D. Watson $(1,10,11)$-and commerce in standard fermentation techniques, which is centuries old.

The commercialization of biotechnology, both in terms of research and the development of products and services, has received increased attention during the 1980s. The promotion of high-technology is of increasing concern-both in terms of alleviating social problems such as hunger, disease, and pollution-and in terms of creating new sources of wealth for national economies. In a short period of time, biotechnology has joined a menu of other hightechnology fields, viewed as being important to the future development of the U.S. economy.

Three main areas of research relevant to biotechnology can be described (see box 2-A). Biotechnology provides the potential to produce new, improved, safer, and less expensive products and processes. Pharmaceuticals and diagnostics for humans and animals, seeds, whole plants, fertilizers, food additives, industrial enzymes, and oil-eating microbes are just a few of the things that can be created or enhanced through biotechnology.

It is convenient to refer to biotechnology as though it were a singular, coherent entity, and in some respects, commercial activity in biotechnology is unique. Federal spending for biotechnologyrelated research can be estimated, and the linking of such activities under the term "biotechnology' is seen by many as useful for obtaining adequate research and development (R\&D) funding. At least 33 States are actively engaged in some form of promotion of biotechnology $R \& D$. Such efforts are seen as a means to achieve academic excellence in their colleges and universities, as a path to economic development, or both. In U.S. industry, OTA has identified more than 400 dedicated biotechnology companies (DBCs) and 70 established corporations with significant investments in biotechnology (8). Many of these companies, especially the DBCs, share common political concerns (as represented by the formation of various biotechnology organizations) and business traits (e.g., methods of financing or means of product development). On Wall Street, biotechnology is recognized in some business reports as a portfolio of stocks-in much the same manner as other technologies and industrial sectors are so recognized.

\section{Box 2-A-Three Kinds of Research}

Basic research involves biotechnology by using its component tools (e.g., recombinant DNA and hybridomas) to study the different ways in which biological systems work and to identify the mechanisms that govern how they work. Included in this category are studies that address such questions as: how viruses infect cells, how immunity to pathogens is acquired, and how fertilized egg cells develop into highly complex and specialized organisms? Biotechnology is used in a broad range of scientific disciplines, ranging from microbiology (the study of micro-organisms, such as viruses and bacteria) to biophysics (the use of physical and chemical theories to study biological processes at the molecular (evel). A greater understanding of the mechanisms of evolution and the resilience of ecosystems will also come from biotechnol ogy.

Generic applied research is a useful term for describing research that bridges the gap between basic science, done mostly in universities, and applied, proprietary science, done in industry for the development of specific products. Various groups have coined alternative phrases, such as "bridge" research, "technical" research, and "strategic" research. Examples of generic applied biotechnology research include---the development of general methods for protein engineering and large-scale mammali'an or plant coll-culturing.

Applied research is directed toward a very specific goal. The use of rDNA to develop vaccines for specific antigens, such as malaria or the human immunodeficiency virus (HIV) responsible for acquired immunodeficiency syndrome (AIDS); the transfer of herbicide or pesticide resistance to a particular plant species; and the use of monoclonal antibodies as purification tools in bioprocessing are all examples of biotechnology use in applied research.

SOURCE: Office of Technology A ssessment, 1991.

Because biotechnology has become an essential tool for many existing industries, there is no such entity as the biotechnology industry. Rather, biotechnology is employed by several industrial sectors, each with its own advantages and obstacles in the race to market (see table 2-2). As DBCs develop products and services, these companies are facing many of the opportunities and obstacles faced by the industrial sector in which they seek to compete. 
Table 2-2-Some Factors That Can Affect Commercialization of Biotechnology

\begin{tabular}{l}
\hline Antitrust law \\
Applied research \\
Basic research \\
Collaborative ventures \\
Congressional interest \\
Coordination between agencies \\
Cost of capital \\
Environmental control \\
Equipment \\
Export controls \\
Gaps in knowledge \\
Government targeting policies \\
Industrial capability \\
Intellectual property protection \\
Joint ventures \\
Legislation \\
Marketing agreements \\
Mergers \\
Personnel availability \\
Public and private funding \\
Public opinion \\
Regulations \\
Statutes \\
Tax incentives \\
Technology licensing \\
Technology transfer \\
Trade \\
Undergraduate and graduate education \\
University/industry relationships \\
SOURCE: Office of Technology Assessment, 1991.
\end{tabular}

As commercial biotechnology expands in size and scope, its effect on the international economy is likely to increase. Biotechnology is likely to be seen as a national asset by more nations-both as a way to develop a high-technology base and to increase market share in several international industrial sectors. As the use of biotechnology expands, various factors and barriers come into play. Some of these factors are business-specific, some industrywide-specific, and some recognizable across the range of industries affected by biotechnology.

\section{ORGANIZATION OF THE REPORT}

The report, which was requested by several congressional committees (see table 2-3), has two parts. The first part, Commercial Activity, examines some of the ways biotechnology has influenced the following sectors: financing, health, agriculture and food, chemicals, and environmental applications. The second part, Industrial Policy, examines the role of government in forming policies concerning science and technology, regulations, and intellectual property. Appendixes focus on a summary of
Table 2-3-Requesters of OTA Assessment, Biotechnology in a Global Economy

\author{
Senate \\ Committee on Agriculture, Nutrition, and Forestry \\ Committee on the Budget \\ Committee on Governmental Affairs \\ House \\ Committee on Science, Space, and Technology \\ SOURCE: Office of Technology Assessment, 1991.
}

biotechnology in 14 countries, U.S. Federal Government funding of biotechnology $R \& D$, and a comparison of biotechnology in the United States and J apan.

Because biotechnology is so ubiquitous and its applications so far-reaching, it is impossible to study in depth all the ways it may be used and all the ways it may affect the economies of various nations. Instead, this report focuses on general trends in each area and uses case studies, as appropriate, to highlight relevant economic and policy considerations.

This report is the latest in a series of OTA reports on the subject of biotechnology. Earlier reports addressed: Impacts of Applied Genetics (2), Commercial Biotechnology (3), New Developments in Biotechnology $(4,5,7,8,9)$, and Mapping of the Human Genome (6). This report does not focus on specific issues addressed in earlier OTA reports, but rather, draws on them to examine some of the emerging issues related to the globalization of biotechnology. Its primary focus is on the description and analysis of commercial activity in biotechnology-related services and products-in both industrialized and newly industrializing nations. Issues solely related to biotechnology development in Third World nations is beyond the scope of this report.

Three public meetings were conducted by OTA in order to develop information for this report. A workshop of Federal agency representatives was held in May 1989. A 2-day international conference was held in J uly 1989 that brought together representatives from 16 nations. A workshop on financing issues was held in September 1990 (see app. D for the participants of these meetings). The proceedings of the international conference as well as other selected contract documents are available through the National Technical Information Service (see app. F). 


\section{SUMMARY}

Biotechnology, broadly defined, includes any technique that uses living organisms (or parts of organisms) to make or modify products, to improve plants or animals, or to develop micro-organisms for specific purposes. Although traditional uses of biotechnology are centuries old (e.g., baking and brewing), it is the so-called new biotechnology involving the uses of modern scientific techniques, such as rDNA technology, hybridoma technology, and bioprocess technology, that leads to issues affecting international commercialization of research and products and is the focus of this report.

Biotechnology is not an industry. It is, instead, a set of biological techniques developed through decades of basic research that is now being applied to research and product development in several existing industrial sectors. The arrival of biotechnology has resulted in the development of products and processes that have the potential to alleviate many of mankind's problems, e.g., malnutrition, disease, and pollution. This report examines international trends in biotechnology-related commercial activity and industrial policy.

\section{CHAPTER 2 REFERENCES}

1. Crick, F.H., and Watson, J.D., "The Complementary Structure of Deoxyribonucleic Acid," Proceedings of the Royal Society (A), vol. 223, 1954, pp. 80-96.

2. U.S. Congress, Office of Technology Assessment, Impacts of Applied Genetics: Micro-Organisms, Plants, and Animals (Springfield, VA: National Technical Information Service, April 1981).

3. U.S. Congress, Office of Technology Assessment, Commercial Biotechnology: An International Analy- sis (Elmsford, NY: Pergamon Press, Inc., J anuary 1984).

4. U.S. Congress, Office of Technology Assessment, New Developments in Biotechnology: Ownership of Human Tissues and Cells—Special Report, OTABA-337 (Washington, DC: U.S. Government Printing Office, March 1987).

5. U.S. Congress, Office of Technology Assessment, Background Paper: New Developments in Biotechnology: Public Perceptions of Biotechnology, OTABA-BP-BA-45 (Washington, DC: U.S. Government Printing Office, May 1987).

6. U.S. Congress, Office of Technology Assessment, Mapping Our Genes-The Genome Projects: How Big? How Fast? OTA-BA-373 (Washington, DC: U.S. Government Printing Office, April 1988).

7. U.S. Congress, Office of Technology Assessment, $\mathrm{New}$ Developments in Biotechnology-Field-Testing Engineered Organisms: Genetic and Ecological Issues, OTA-BA-350 (Lancaster, PA: Technomic Publishing Co., Inc., May 1988).

8. U.S. Congress, Office of Technology Assessment, New Developments in Biotechnology: U.S. Investment-Special Report, OTA-BA-360 (Springfield, VA: National Technical Information Service, J uly 1988).

9. U.S. Congress, Office of Technology Assessment, New Developments in Biotechnology: Patenting Life-Special Report, OTA-BA-370 (Washington, DC: U.S. Government Printing Office, April 1989).

10. Watson, J.D., and Crick, F.H., "Genetic Implications of the Structure of Deoxyribose Nucleic Acid," Nature, vol. 171, 1953, pp. 964-967.

11. Watson, J.D., and Crick, F.H., "Molecular Structure of Nucleic Acids: A Structure for Deoxyribose Nucleic Acid," Nature, vol. 171,1953, pp. 737-738. 


\section{Part I: Commercial Activity}




\section{Chapter 3}

\section{Introduction: Commercial Activity}

"I fentrepreneurs and arbitrageurs were our heroes of the '80s, we hope scientists and engineers will be the stars of the "90s."

Mary Ann Liebert

Genetic Engineering News, January 1990 


\section{CONTENTS}

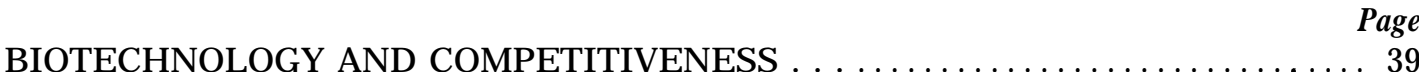

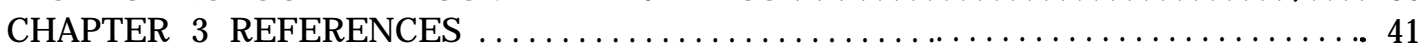




\section{BIOTECHNOLOGY AND COMPETITIVENESS}

Biotechnology is a new set of techniques that can be used in basic research, product development, and manufacturing in several different industries. Although it was primarily developed in the United States, funded mainly through government support for basic biomedical research, there are growing concerns that, like some other native technologies, biotechnology will be rapidly adopted and commercially applied elsewhere, leading to a loss of U.S. preeminence in this area.

Biotechnology was first applied commercially in producing diagnostics and therapeutics. These applications were the most obvious because most of the developers of the new techniques were conducting basic biomedical research. Most recently, genetically engineered biopesticides have won regulatory approval in the United States. Further agricultural applications are expected within the next 10 years.

In the United States, the earliest firms to exploit these new techniques were the dedicated biotechnology companies (DBCs). Financed with venture capital, they were founded in the late 1970s and early 1980s to apply the new techniques to the development of diagnostics, pharmaceuticals, pesticides, plants, and other products. Although these firms are often referred to collectively as the "biotech industry," the dedicated biotechnology firms are, in fact, developing products and competing with firms in existing industries. DBCs, regardless of the products they make, share some characteristics and certainly compete with each other for capital. But industries are defined primarily by the products they produce and the markets in which they compete. As DBCs develop and become engaged in commercializing products, the problems they face are characteristic of the existing industries to which they belong. Thus, their problems become more understandable if DBCs are regarded not as "biotech companies' but as young firms in, for example, the pharmaceutical, agricultural, or waste treatment industries.

Although DBCs have actively applied biotechnology to existing industries, more and more, estab- lished multinational firms in these industries are investing in biotechnology, either through investment in in-house research programs or through linkages with small firms. Over the last 10 years, as it has become clearer which applications are potentially useful and which are not, the research and development $(R \& D)$ conducted by small firms has become more narrowly focused, and investments of larger firms have become more aligned with their long-term strategies.

Increasingly, biotechnology is becoming part of the mainstream of $R \& D$ in several industries. In assessing its ultimate impact on industry and productivity, it is less useful to ask, "Is the United States competitive in biotechnology?" and more useful to ask, "How can biotechnology contribute to the competitiveness of the industrial sectors in which it can be used?" and, "What factors influence the adoption of biotechnology in these industries?" To understand the adoption of biotechnology by these industries requires some understanding of the organization of the industries and the role of innovation and R\&D.

Like other new technologies that have the potential for major effects on a number of industries, the ultimate impact of biotechnology is impossible to predict. But, as with other new technologies, its incorporation into research, product development, and manufacturing is likely to be gradual $(1,2)$. A number of factors influence investment in biotechnology and its diffusion into new industries, including:

Technical feasibility. The earliest research projects in every industry have been chosen mainly for ease of accomplishment because new companies or new research teams need to demonstrate their competence and achieve commercial success in a relatively short time. Beyond initial projects, technical limits constrain the projects that may be done. Work in agriculture, for example, has been limited because of difficulties in transferring deoxyribonucleic acid (DNA) into the cells of major cereal crops and the relative lack of basic knowledge of plant genetics and biochemistry 
compared to knowledge of common microorganisms and mammals.

- Ability to recoup investment in $R \& D$ and capture profits. In some industries, biotechnology can provide an alternative production process for a marketable product (e.g., insulin or growth hormone), the development of improved versions of current products (e.g., tomatoes or cotton), or the development of novel products (e.g., tissue plasminogen activator (tPA) or biopesticides). But in some cases the new production processes are not competitive with current technology. For other products that are technically feasible, the potential size of the market is too small to justify the investment in $R \& D$ needed to bring the product to market. The cost of research can be offset by marketing products more widely, especially through exports. The ability to protect technology investments by patenting also influences a firm's ability to capture markets and therefore profits.

- Availability of a research base and labor pool. In the United States, federally funded basic research in biomedical sciences has provided a wealth of information that can be exploited by industrial research teams. Much less basic research has been conducted in plant biology and microbial ecology. Federal funding of research has also resulted in the training of scientists with skills useful to some industries. The European research base is not as extensive as that in the United States, and in $J$ apan and other Asian countries there is relatively little public funding of basic research in biology. Scientists in these countries must often go abroad to obtain training.

- Availability of capital. The development of biotechnology in the United States coincided with the availability of a high level of funding for new firms from venture capitalists and public equity markets. In Europe and J apan, venture capital and public equity have played a much smaller role. Outside the United States, industrial biotechnology is largely confined to the research laboratories of major corporations.

- Fit with industry or company strategy. The chemical industry inmost industrial nations has undergone a restructuring in the last 10 to 20 years. Many major corporations have been reducing their operations in commodity chemicals while investing in specialty chemicals and life sciences, including pharmaceuticals. Investment has followed this corporate strategy. Investment in biotechnology by pharmaceutical firms is also made to complement existing product lines and research needs. Seed firms use biotechnology to complement their efforts in plant breeding.

- Public acceptance. In the United States, farmer resistance to the use of bovine somatotropin (bST), a protein hormone that increases milk production, has delayed its introduction and may deter investment in the development of similar products. In some parts of Europe, particularly Germany, public concerns about the use of biotechnol ogy has slowed commercial development. On the other hand, consumers have favored the development of new drugs, diagnostic products, and environmentally benign biopesticides.

- Regulations. Regulations can delay the introduction of new products and thus delay returns on investment. For example, the lengthy process for obtaining drug approval in the United States has been widely criticized. The time it is taking the Environmental Protection Agency (EPA) to develop regulations for field-testing genetically modified micro-organisms is thought to have had a negative impact on investment in this area. The development of biotechnology regulations in Europe and J apan has also been slow and, especially in Denmark and Germany, has been thought to inhibit investment.

- Effects of other government programs. Agricultural programs that affect acreage planted or that protect farmers can influence investment in agricultural biotechnology. Laws on environmental protection affect the use of bioremediation. The Orphan Drug Act and the Plant Variety Protection Act (PVPA) are intended to encourage investment in new drug and new plant development, respectively. Other examples of government policies that influence. investment in biotechnology include tax policies and laws on intellectual property protection.

The ensuing five chapters are not intended to be exhaustive descriptions of the industries or the applications of biotechnology. The intention is to give a fuller explanation of forces that affect 
adoption of biotechnology. In each sector, market forces beyond the scope of government authority largely determine the use of biotechnology.Governments can influence the climate for technology development and adoption as they influence the climate for all business activity. Congress can influence technology adoption through its activities concerning basic scientific research and training, regulations, patents, and in legislation that specifically affects the industries in which biotechnology will be used.

\section{CHAPTER 3 REFERENCES}

"David, P.A., "Technology Diffusion, Public Policy, and Industrial Competitiveness," The Positive-Sum Strategy: Harnessing Technology for Economic Growth, R. Landau and N. Rosenberg (eds.) (Washington, DC: National Academy Press, 1986).

Rosenberg, N., Perspectives on Technology (Armor\& NY: M.E. Sharpe, Inc., 1985). 


\section{Chapter 4}

\section{Financing}

"In this entrepreneurial world, the venture capitalist occupies an ambivalent position. Like a gigolo, he's involved, but not involved. He's part entrepreneur, part accountant. He's Santa Claus and Ebenezer Scrooge."

Robert Teitelman Gene Dreams

"Interferon is a substance you rub on stockbrokers.'

A scientist quoted in Forbes, September 1980 


\section{CONTENTS}

INTRODUCTION. .45

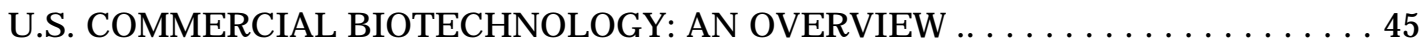

FINANCIAL STATUS OF U.S. BIOTECHNOLOGY COMPANIES $\ldots \ldots \ldots \ldots \ldots \ldots 48$

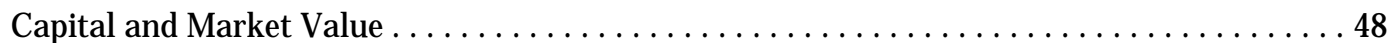

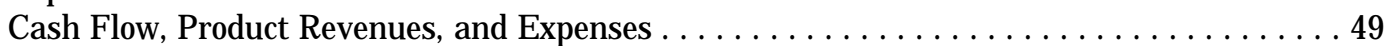

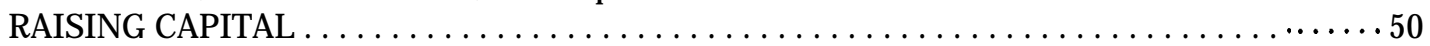

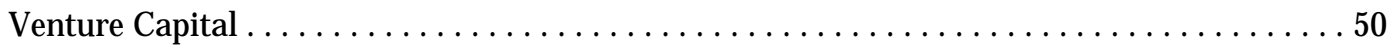

Research and Development Limited Partnerships ........................ 53

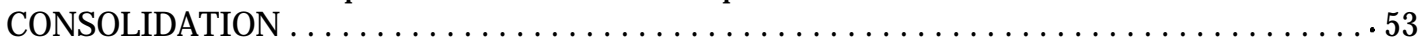

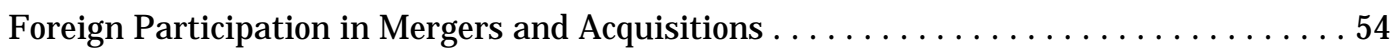

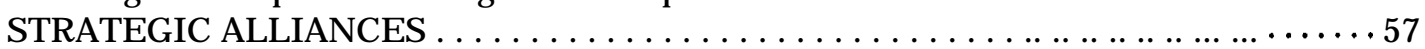

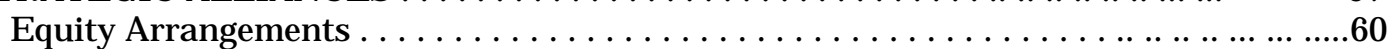

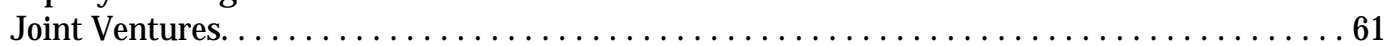

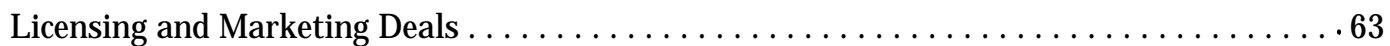

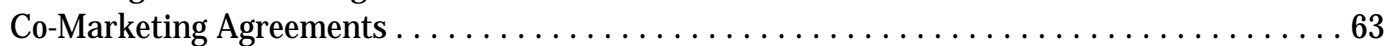

TAX POLICY AND ITS EFFECTS ON FINANCING R\&D $\ldots \ldots \ldots \ldots \ldots \ldots \ldots \ldots .64$

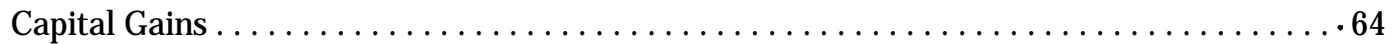

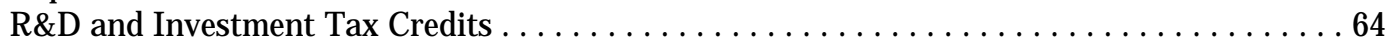

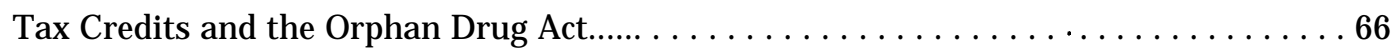

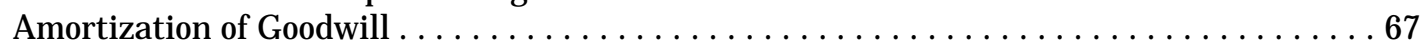

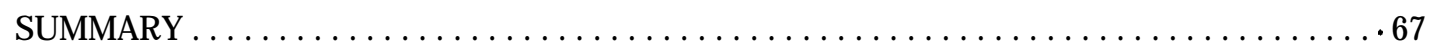

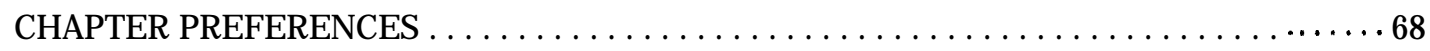

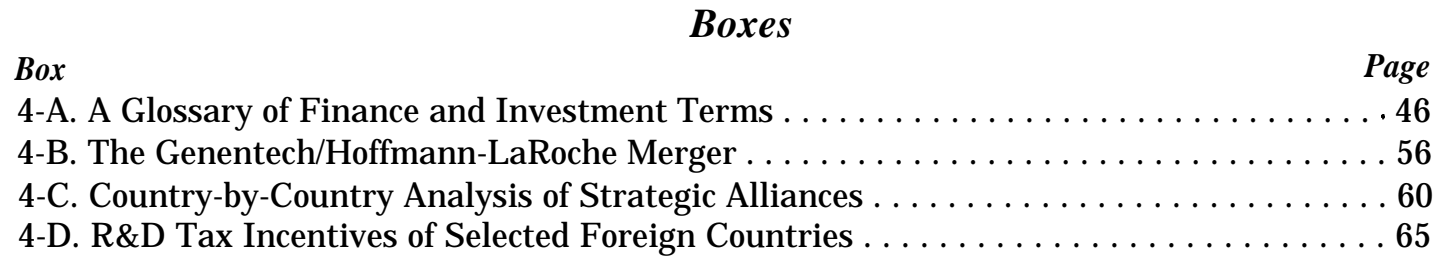

Figure
Figures
Page

4-1. Market Capitalization of 42 Publicly Traded US. Firms . . . . . . . . . . . . 49

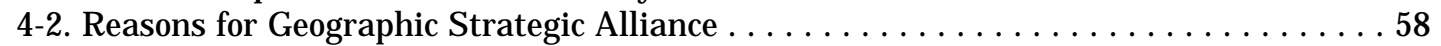

4-I. Areas of Primary R\&D Focus by Biotechnology Companies (1988) . . . . . . . . . . . 45

4-2. Profile of Market Segmentation (1990) . . . . . . . . . . . . . . . . . . . . . 46

4-3. Financial Profile of Leading Public Firms in $1990 \ldots \ldots \ldots \ldots \ldots \ldots \ldots \ldots \ldots$

4-4. Cost of Capital for R\&D Projects With 10-Year Payoff Lag in Four Countries . . . 51

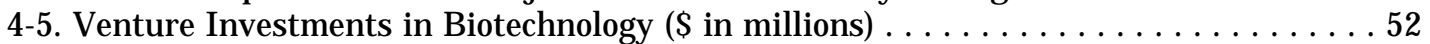

4-6. Acquisitions of U.S. Biotechnol ogy Companies, $1989-90 \ldots \ldots \ldots \ldots \ldots \ldots \ldots$

4-7. Breakdown of the Number of Alliances With 46 Publidy Held U.S.

Biotechnology Companies With European or Asian Partners . . . . . . . . . . . . . . 59

4-8. Number of Agreements With European and Asian Partners for 46 Publidy

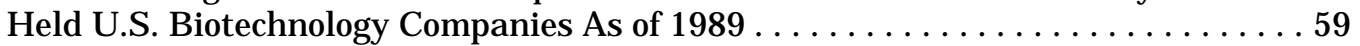

4-9. Equity Participations in 46 Publicly Held U.S. Biotechnology Companies by European and Asian Partners . . . . . . . . . . . . . . . . . 61 


\section{INTRODUCTION}

Until recently, genetic engineering was largely commercialized in the United States, mainly in top-notch academic departments and an exponentially expanding troupe of biotechnology entrepre neurial firms. In the last few years, large, established U.S. corporations have increasingly invested in these technologies, both in-house and through a variety of arrangements with dedicated biotechnology companies (DBCs). The markets for new biotechnology-derived medical and agricultural products are worldwide, and now the innovations themselves are starting to be developed throughout all parts of the globe.

Although biotechnology per se is not a single industry but a tool of industry, the financial community has had considerable interest in and effect on the formation and survival of firms commercializing biotechnology. While major corporations, both domestic and foreign, are spending considerable sums to exploit the new techniques, much of the innovation in research continues to come from the smaller firms dedicated to biotechnology. Large, established corporations can rely on revenues from existing operations to fund innovation, but DBCs do not have as wide a comfort zone and, in the absence of product revenues, must rely on equity investors for survival (see box 4-A for a glossary of financial terms). The competitiveness of U.S.-developed biotechnology products and processes may ultimately depend on broader issues, such as fair trade practices, protection of intellectual property, and the regulatory climate. The competitiveness of U.S. innovation, however, could very well rely on the ability of DBCs to stay in business. Because biotechnology is capitalintensive, staying in business means raising substantial sums of cash.

This chapter focuses on the current financial status of the leading U.S. DBCs and addresses the ability of new firms to enter the market and raise cash. The status and importance of strategic alliances, both domestic and foreign, and direct foreign investment in U.S. biotechnology also are discussed. Finally, the effects of specific tax policies on the ability of firms worldwide to raise cash are reviewed.

\section{U.S. COMMERCIAL BIOTECHNOLOGY: AN OVERVIEW}

The boom for founding DBCs in the United States occurred between 1980 and 1984. During these years, approximately 60 percent of existing companies were founded (54). In a 1988 report, the Office of Technology Assessment (OTA) verified that there were 403 DBCs in existence and over 70 major corporations with significant investments in biotechnology (54). Although these numbers have most likely grown since that time, the areas of primary research and development (R\&D) focus of these firms have not changed radically. In 1988, OTA found that human health care was the focus of research for most companies, whether large or small. Agriculture and chemicals were the focus of far fewer firms, and environmental applications of biotechnology were even less well represented (see table 4-I). A 1990 survey by Ernst \& Young drawn from a large sample of firms (based on a broader definition of biotechnology) revealed similar segmentation of primary markets (see table 4-2) (19). Companies continue to have a strong focus on human health care products, largely because capital availability has been greater for pharmaceuticals than for food or agriculture, due to the prospect of greater market reward $(54,57)$. Thus,

Table 4-I-Areas of Primary R\&D Focus by Biotechnology Companies (1988)

\begin{tabular}{|c|c|c|}
\hline Research area & $\begin{array}{c}\text { Dedicated } \\
\text { biotechnology } \\
\text { companies } \\
\text { Number (percent) }\end{array}$ & $\begin{array}{c}\text { Large } \\
\text { diversified } \\
\text { companies } \\
\text { Number (percent) }\end{array}$ \\
\hline 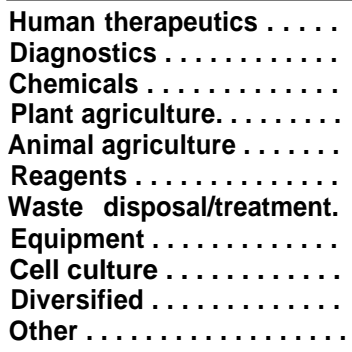 & $\begin{array}{l}63(21) \\
52(18) \\
20(7) \\
24(8) \\
19(6) \\
34(12) \\
3(1) \\
12(4) \\
5(2) \\
13(4) \\
51(18)\end{array}$ & $\begin{array}{r}14(26) \\
6(11) \\
11(21) \\
7(13) \\
4(8) \\
2(4) \\
1(2) \\
1(2) \\
2(2) \\
6(11) \\
0(0) \\
\end{array}$ \\
\hline Total . . . . . . . . . . . & $\overline{296(100)}$ & 53 (100) \\
\hline
\end{tabular}




\section{Box 4-A-A Glossary of Finance and Investment Terms}

Acquisition. One company taking over controlling interest in another company. Investors are al ways looking for companies that are likely to be acquired, because those who want to acquire such companies are often willing to pay more than the market price for the shares they need to complete the acquisition.

Amortization. Accounting procedure that gradually reduces the cost-value of a limited life or intangible asset through periodic charges to income.

Assets. Anything having commercial or exchange value that is owned by a business, institution, or individual.

Black Monday. October 19, 1987, when the Dow J ones Industrial Average plunged a record 508 points following sharp drops the previous week-reflecting investor anxiety about inflated stock price levels, Federal budget arid trade deficits, and foreign market activity.

Book value. Net asset value of a company's securities, calculated as total assets minus intangible assets (goodwill, patents, etc.), minus current liabilities, minus any long-term liabilities and equity issues that have prior claim. The total net asset figure, divided by the number of bonds, shares of preferred stock, or shares of common stock, gives the net asset value, or book value, per bond or per share of preferred or common stock. Book value can be a guide in selecting stocks and is an indication of the ultimate value of securities in liquidation. positive.

Capital gain. The difference between an asset's purchase price and selling price, when the difference is

Cash burn rate. The rate at which a company uses cash, i.e., cash flow. Biotechnology companies are generally cash users, not generators. Cash burn rates are very high in the years before the first profits are made.

Common stock. Units of ownership of a public corporation. Owners typically are entitled to vote on the selection of directors and other important matters as well as to receive dividends on their holdings. In the event that a corporation is liquidated, the claims of secured and unsecured creditors and owners of bonds and preferred stock take precedence over the claims of those who own common stock. For the most part, however, common stock has more potential for appreciation.

Convertible debt. Debt that is exchangeable in another form for a prestated price. Convertible debt is appropriate for investors who want higher income than is available from common stock, Most commonly, corporate securities (usually preferred shares or bonds) are purchased and later traded for common shares.

Cost of' capital. The rate of return that a business could earn if it chose another investment with equivalent risk-in other words, the opportunity cost of the funds employed as the result of an investment decision or actual debt costs as part of the capital structure of the company.

Equity. Ownership interest possessed by shareholders in a corporation stock as opposed to bonds. Shares can be common or preferred.

(Continued on next page)

Table 4-2-Profile of Market Segmentation (1990)

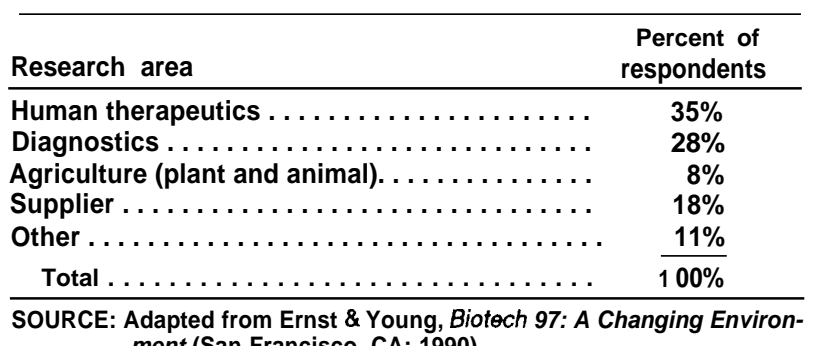
ment (San Francisco, CA: 1990).

most discussions about the financing of biotechnology tend to be skewed toward companies working in human therapeutics and diagnostics because that is where most of the activity has been (23). And while the methods used by various DBCs to raise cash generally have been similar, DBCs not working in human health have had a more difficult time and have had to follow different routes at different times.

While more companies may have been formed in the early 1980s than the late 1980s, the amount of money invested per company (and dedicated to biotechnology in general) increased significantly. As a result, and despite the lack of private late-stage capital resulting from the market crash in 1987, many of the companies formed late in the 1980s have had somewhat greater staying power than their earlier competitors. In addition, due to having larger amounts of capital at an earlier stage, some of these companies may generate products more quickly (5).

In the early 1980s, fledgling genetic engineering firms would do almost anything to raise cash, often licensing away key first-generation products and 
Exit opportunities. A term commonly used by venture capitalists to describe opportunities for investors to realize their investment or pull out of a deal. Examples are the public markets, mergers, and acquisitions.

Liquidity. Ability of an individual or company to convert assets into cash or cash equivalents without significant loss. Having a good amount of liquidity means being able to meet maturing obligations promptly, earn trade discounts, benefit from a good credit rating, and take advantage of market opportunities.

Market capitalization. Valueof a corporation as determinedly the market price of its issued and outstanding common stock. It is calcuated by multiplying the number of outstanding shares by the current market price of a share. institutional investors often use market capitalization as one investment criterion. Analysts look at market capitalization in relation to book or accounting value for an indication of how investors value a company's future prospects.

Merger. Combination of two or more companies, either through a pooling of interests, where the accounts are combined; a purchase, where the amount paid over and above the acquired company's book value is carried on the books of the purchaser as goodwill; or a consolidation, where a new company is formed to acquire the net assets of the combining companies.

Operating profit (or loss). The difference between the revenues of a business and the related costs and expenses, excluding income derived from sources other than its regular activities and before income deductions.

Preferred stock. A class of stock that pays dividends at a specific rate and that has preference over common stock in the payment of dividends and the liquidation of assets. Preferred stock does not ordinarily carry voting rights.

Royalty. Payment to the holder for the right to use property such as a patent, copyrighted material, or natural resources, Royalties are set in advance as a percentage of income arising from the commercialization of the owner's rights or property.

Strategic alliances. Associations between separate business entities that fall short of a formal merger but that unite certain agreed on resources of each entity for a limited purpose. Examples are equity purchase, licensing and marketing agreements, research contracts, and joint ventures.

Venture capital, An important source of financing for start-up companies that entails some investment risk but offers the potential for above-average future profits.

SOURCE: Office of Technology Assessment, 1991, adapted from Barren's Dictionary of Finance and Investment Terms, $2 \mathrm{~d}$ ed. (New York, NY: Barren's, 198'7).

vital market segments in order to obtain the necessary cash to survive. Some call this mortgaging the future-more enthusiastic chief executives describe it as leveraging the technology. In any case, frontrunning companies, like Genentech, Genex, and Biogen, lined up numerous corporate partners with relative ease, only to find later that a deal with a major international corporation did not necessarily prove adequate for survival. Many pharmaceutical firms learned the hard way that biotechnology products represented no magic bullet, and that some of their products would succeed while many others were destined to fail.

As time passed, the term biotechnology lost its ability to turn promises-for-tomorrow into instant cash today. Several changes occurred at the same time. Basic gene-splicing technology became readily available to scientists at large pharmaceutical companies in the United States and overseas. However, unforeseen technical problems in gene expression, in scale-up, and in obtaining meaningful clinical results created a slowing of developments and expectations. Despite technical problems and slower-than-expected product development, the innovative U.S. financial markets supplied the growing number of genetic engineering firms with the increased funding needed to survive. Research and development limited partnerships (RDLPs), both large and small, provided funds between lucrative public offerings, and the venture capital community continued to invest money in new start-up operations.

The 1980s may prove to have been the high water mark for formation of DBCs. A critical event affecting the financial strategies of DBCs came on October 17, 1987, or "Black Monday," when the stock market crashed. Biotechnology companies faced a severe problem: the fabled window for public offerings-particularly initial public offerings-was slammed firmly shut. Although that 


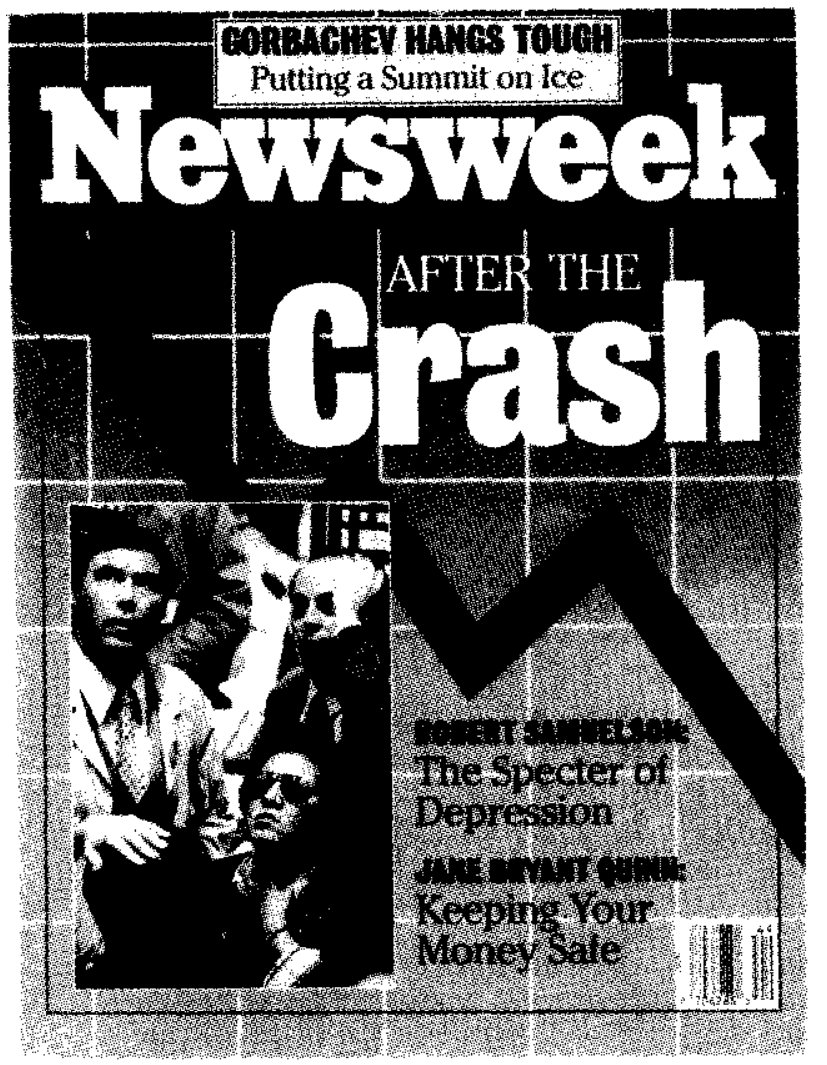

Photo credit: Newsweek, Nov. 2, 1987

Media coverage of the 1987 stock market crash.

window seemed to have slightly opened again by the summer of 1989 (especially for convertible debt issues for the more established companies in the U nited States and E urope), biotechnol ogy companies had to weather a full 18 months without public financing. Some firms retrenched and focused on their most promising or near-term projects. Others, notably Genentech, had product revenues. Still others, e.g., Cetus, Genetics Institute, and Mycogen, maintained hefty bank accounts accumulated in the early 1980s to carry them through all but the most protracted public equity droughts. But all biotechnology firms reexamined the possibility of alliances with major corporations. As time passed, deals were signed increasingly between DBCs and domestic and foreign pharmaceutical and chemical companies (19). Top-tier DBCs, however, often find themselves on more equal footing with their partners than in the past. These DBCs, having a greater understanding of the powers and limitations of biotechnology have used this knowledge combined with their financial resources to demand clauses securing manufacturing rights or rights to key geographic areas or market segments (31).

\section{FINANCIAL STATUS OF U.S. BIOTECHNOLOGY COMPANIES}

To date, most U.S. biotechnology companies have no sales and have been losing money since their inceptions. According to a 1989 survey of 93 biotechnology companies, about one-fourth reported net profits (18). An updated survey in 1990 found that only 21 percent of all companies are profitable, even though overall sales increased by 13 percent (19). Therefore, standard accounting tools, which measure expenses and assets as a function of sales and earnings, are not useful in determining the value or stability of a DBC (46). However, the leading public biotechnology companies have high liquidity and can generate cash once product revenues begin to flow. While most companies are still several years away from profitability and positive cash flow, the top 20 firms could last more than 3 years on current cash levels without raising anymore money (46).

\section{Capital and Market Value}

Capital and market value are concentrated in few of the over 400 firms involved in biotechnology. Individual companies that top the list in market values are generally the same ones that lead the industry in total assets, book value, $R \& D$ spending, and total employment (see table 4-3). As of early 1990, public market values ranged from less than $\$ 5$ million to \$1.9 billion (only two companiesGenentech and Amgen--had market values of $\$ 1$ billion or more, while the rest were valued significantly less). In a survey of 42 publicly traded companies, total market capitalization totaled $\$ 6.9$ billion, and two companies-Genentech and Amgen-together accounted for 42 percent of the total market capitalization (46) (see figure 4-I). The top seven companies have market values ranging from $\$ 500$ million to $\$ 2.5$ billion (47).

Most of the companies in a Shearson Lehman Hutton survey showed strong cash positions, with 10 having cash balances above $\$ 50$ million by the end of 1989 (47). Again, only three companiesGenentech, Amgen, and Chiron--produced profits in 1990, leading the industry in revenues as well as $R \& D$ spending $(5,47)$. With just two products it markets plus two products from which it receives 
Table 4-3-Financial Profile of Leading Public Firms in 1990

\begin{tabular}{|c|c|c|c|c|c|c|}
\hline & $\begin{array}{c}\text { Percent } \\
\text { price change } \\
\text { in stock } \\
\text { performance } \\
6 / 30 / 89-6 / 29 / 90\end{array}$ & $\begin{array}{c}\text { Market } \\
\text { capitalization } \\
\text { (\$ million) } \\
6 / 29 / 90\end{array}$ & $\begin{array}{c}\text { Book value } \\
\text { (\$ million) } \\
12 / 31 / 89\end{array}$ & $\begin{array}{l}\text { Years of } \\
\text { cash left } \\
\text { at net } \\
\text { burn rate }\end{array}$ & $\begin{array}{c}\text { R\&D expense } \\
\text { (calendar } \\
\text { year 1989) } \\
\text { (\$ million) }\end{array}$ & $\begin{array}{c}\text { Net } \\
\text { income } \\
\text { (calendar } \\
\text { year 1989) } \\
\text { (\$ million) }\end{array}$ \\
\hline \multicolumn{7}{|l|}{ Pharmaceuticals } \\
\hline Genentech $^{*} \ldots \ldots \ldots \ldots \ldots$. . . . & $55 \%$ & $\$ 2,454$ & $\$ 469$ & INF & $\$ 156.9$ & $\$ 44.0$ \\
\hline Amgen $\ldots \ldots \ldots \ldots \ldots \ldots$ & $80 \%$ & 1,526 & 180 & INF & 63.6 & 3.8 \\
\hline Genetics Institute . . . . . . . . . . & $41 \%$ & 520 & 138 & INF & 59.4 & (28.7) \\
\hline Cetus $\ldots \ldots \ldots \ldots \ldots \ldots \ldots$ & $43 \%$ & 649 & 92 & 6.2 & 52.3 & (64.9) \\
\hline Biogen . . . . . . . . . . . . . . & $112 \%$ & 546 & 74 & INF & 28.5 & $(0.2)$ \\
\hline 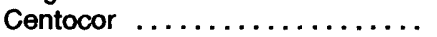 & $160 \%$ & 578 & 133 & INF & 45.4 & $(0.1)$ \\
\hline XOMA $\ldots \ldots \ldots \ldots \ldots \ldots$ & $35 \%$ & 316 & 27 & INF & 25.6 & $(18.9)$ \\
\hline \multicolumn{7}{|l|}{ Agriculture } \\
\hline 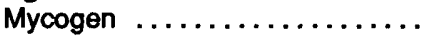 & $103 \%$ & 197 & 27 & INF & 7.8 & $(1.4)$ \\
\hline DNA Plant Tech. . . . . . . . . . . & $49 \%$ & 143 & 38 & 9.9 & 12.0 & (2.9) \\
\hline Crop Genetics . . . . . . . . . . & $-11 \%$ & 37 & 13 & 1.3 & 5.4 & (6.1) \\
\hline
\end{tabular}

INF = Intinite

SOURCE: Adapted from Shearson Lehman Hutton, Bio-Financials: Midyear Supplement, July 6, 1990.

Figure 4-1-Market Capitalization of 42 Publicly Traded U.S. Firms
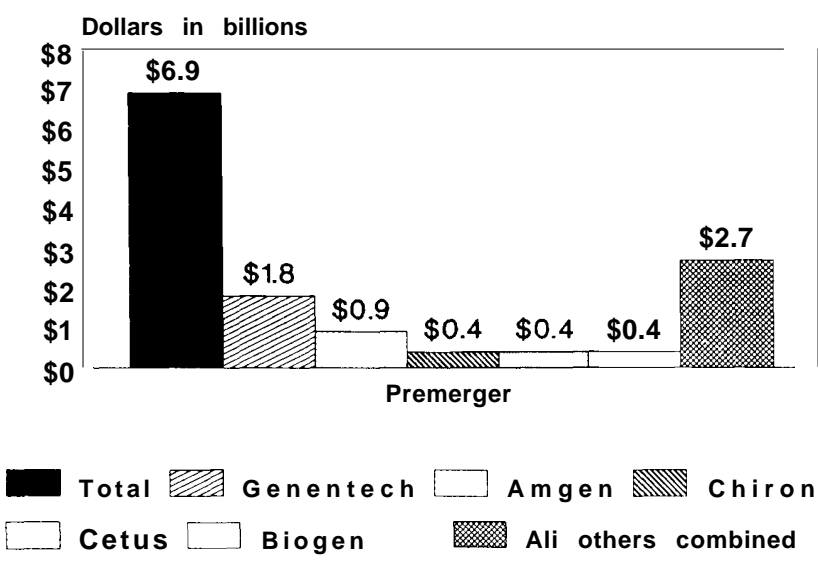

SOURCE: ShearsonLehman Hutton, 1990.

substantial royalties, Genentech accounted for more than half of 1989 product sales for the 20 companies reporting sales (50).

What remains remarkable has been the health of biotechnology stocks. While the Standard and Poors 500 advanced 12.6 percent between J une 1989 and J une 1990, health care biotechnology stocks rose an average of 77 percent and agricultural biotechnology stocks rose 38 percent. The medical biotechnology sector grew by 36.7 percent in 1990 and was the number one stock performer $(20,36)$.
Cash Flow, Product Revenues, and Expenses

Although biotechnology companies have high liquidity (on average, companies have 50 percent of their assets as cash), in their early years they tend to burn more cash than they generate. In 1989, only Genentech and Amgen generated meaningful levels of cash from operations $(40,46)$. One reason that biotechnology companies use their cash reserves so rapidly is the intensity of $R \& D$ investment; prior to product commercialization some companies dedicate nearly 65 percent of all expenses to $R \& D$. In 1989, Genentech's R\&D expenditures, at 42 percent of sales, were almost as much as those of the next three companies combined (see table 4-3).

Estimates by Wall Street analysts predict that the leading public firms have a mean of just over 3 years and a median of 2.3 years of cash left, at either current or average burn rate (46). Past experience shows that the leading biotechnology companies have been extraordinarily successful at financing virtually all of their cash-flow needs. It is not clear how much longer this success will last, and there is evidence that a two-tiered structure has evolved among DBCs, where leading firms are able to raise cash and the havenets find sources increasingly unavailable (57). Some analysts believe that only a few biotechnology firms will generate significant annual revenues and thus be able to survive over the longer term (17). This is reflected in a recent trend toward steady financial backing for a few larger 
firms and lesser amounts of capital available for smaller, less successful fins.

As would be expected, companies focusing on human health care products have larger cash reserves than those focused on other industries. The average, or mean, cash balance of 34 publidy traded health-based biotechnology companies was $\$ 38$ million in early 1990; the median was $\$ 18$ million. The figures were $\$ 13$ million and $\$ 10$ million respectively for agricultural companies (46).

Limited product sales hurt cash flows. In 1989, only eight companies had product sales over $\$ 10$ million (46). A 1989 survey showed that 5-year sales-growth projections had dropped. Yet sales overall are still expected to more than double over the next 2 years (19). Companies continue to survive on cash obtained from $R \& D$ contracts, corporate alliances, interest income, and occasionally a common or preferred stock issue. Total industry revenues in 64 public companies reached $\$ 1$ billion in 1989, up 67 percent since 1987. According to Ernst $\&$ Young, which casts a wider net in its survey, product sales in 1990 were $\$ 2.9$ billion. Genentech and Amgen comprised the bulk of those sales (46).

\section{RAISING CAPITAL}

Biotechnology companies in the United States have relied heavily on the investment community for their survival. Despite the relatively high cost of capital in the United States compared to other countries (see table 4-4), U.S. firms have been remarkably successful in attracting investors in the start-up phase. The high cost of capital, however, may put U.S. firms at a disadvantage in the long term. The cost of capital is less important for shorter projects but becomes increasingly important over time. J apanese and German fins, with lower costs, may face fewer risks (22). ${ }^{1}$ And, although J apanese corporations are finding it easier than U.S. firms to raise relatively cheap capital (48), U.S. biotechnology companies to date have been able to raise funds through creative financing. This type of financing, however, is very costly in the long term due to the high royalty rates and significant capital required for the companies to buy back the product rights normally transferred to $R \& D$ financing vehicles.
It is not clear how long DBCs can go to venture funds and the public markets. According to a 1988 survey, 62 percent of all companies needed major financing of a few million dollars each by the end of 1990, and 90 percent will need financing by the end of 1991 (18). In a 1989 survey, the average company projected a need for $\$ 3$ million in financing during 1991 and $\$ 32$ million in total over the next 10 years (19). Some analysts estimate that it will take $\$ 5$ billion to $\$ 10$ billion to develop the 100 products now inhuman clinical trials in the therapeutic sector of biotechnology $(16,33)$.

Biotechnology companies continue to be financed primarily through equity (about 75 percent), usually in the form of common stock (46). Debt financing is still relatively rare. In addition to being rare, debt financing has been relatively unsuccessful when used. The convertible debt instruments that were employed counted on appreciation in equity. If this did not occur, the company was forced to service the debt while still operating on a negative cash-flow basis (32). Forty percent of the companies surveyed by Shearson Lehman Hutton had no debt at all.

As biotechnology moves through the 1990s, strategic alliances will be the most reliable, and perhaps sensible, source of needed capital. Strategic alliances may be the only way for some firms to prevent takeover, bankruptcy, or liquidation as they reach the most expensive stages of development.

The following sections cover the current state of private and public equity funds available for biotechnology as well as recent developments in strategic alliances between U.S. firms and between U.S. and foreign fins.

\section{Venture Capital}

Venture capital has been the prime source of early stage financing for new and young companies seeking to grow rapidly. It has been a significant source of capital for biotechnology start-ups in the 1980s. The importance of venture capital to U.S. commercial biotechnology reflects the growth, in general, of the venture capital industry. Biotechnology, conveniently, arrived at the right time.

\footnotetext{
1 The costs of debt and equity in Germany and Japan are generally lower than that in the United States. This combined with cheaper corporate funding result in a lower cost of funds and a lower cost of capital.
} 
Table 4-4-Cost of Capital for R\&D Projects With 10-Year Payoff Lag in Four Countries

\begin{tabular}{|c|c|c|c|c|c|c|c|c|c|c|c|}
\hline 1977 & 1978 & 1979 & 1980 & 1981 & 1982 & 1983 & 1984 & 1985 & 1986 & 1987 & 1988 \\
\hline $\begin{array}{lr} & 12.5 \\
\text { United States } \ldots \ldots \ldots \\
\end{array}$ & $\begin{array}{r}12.9 \\
5.7\end{array}$ & $\begin{array}{r}11.9 \\
6.5\end{array}$ & $\begin{aligned} 12.4 \\
7.3\end{aligned}$ & $\begin{array}{l}8.3 \\
8.0\end{array}$ & $\begin{array}{r}18.4 \\
8.3\end{array}$ & $\begin{array}{r}15.2 \\
8.7\end{array}$ & $\begin{array}{r}20.3 \\
7.7\end{array}$ & $\begin{array}{r}20.2 \\
9.2\end{array}$ & $\begin{array}{r}16.8 \\
9.4\end{array}$ & $\begin{array}{r}18.2 \\
8.4\end{array}$ & $\begin{array}{r}20.3 \\
8.7\end{array}$ \\
\hline Germany . . . . . . . 13.4 & $\hat{1} \overline{3} . \overline{8}$ & $i \overline{3} . \overline{3}$ & $1 \overline{5} . \overline{6}$ & $1 \overline{5} . \overline{7}$ & 14.7 & 13.9 & 14.6 & 13.9 & 13.2 & 14.4 & 14.8 \\
\hline United Kingdom . . 18.2 & 28.4 & 21.1 & 33.4 & 24.2 & 29.5 & 28.2 & 24.4 & 25.4 & 18.9 & 20.6 & 23.7 \\
\hline
\end{tabular}

SOURCE: Federal Reserve Bank of New York staff estimates, 19S9. The rankings reflect the required real pre-tax rate of return on an investment in plant or equipment.

United States

Despite fluctuations through the 1980s, due, according to some analysts, to excesses and overvaluations in the mid-1980s, the venture capital community is operating in a stable, if not more conservative, environment (57). The pool of funds in the United States managed by organized venture capital exceeds $\$ 31$ billion (28). Venture funds are still available for biotechnology but have become increasingly concentrated and more readily available to firms or individuals with a proven track record $(57,14)$. Of the over 800 U.S. and Canadian venture capital companies listed in a comprehensive directory of such firms, nearly half indicated a preference for genetic engineering for possible investment (35). A 1989 trade journal listing of venture capital funds with interests in biotechnology showed 86 entries (24). Between 1985 and 1989, about $\$ 1.1$ billion in venture capital was invested in biotechnology (see table 4-5). Some regions of the United States are particularly well endowed with venture funds for biotechnology. For example, biotechnology companies remained the principal recipients of venture funds in the San Diego area in the last half of 1989, during which time 13 San Diego biotechnology companies raised $\$ 113$ million (44).

But growth companies, such as biotechnology, require continuing financing, sometimes requiring almost twice as much equity financing between the $3 r d$ and 6 th years as required during the frost 3 years (34). Venture capital has been available for biotechnology companies at the founding stage, but it is increasingly difficult to come by during the development stage, which is more expensive than the discovery stage (23). The new conservatism in venture markets has resulted from lower rates of return (30) and lowered likelihood that venture capitalists will support a firm where exit might be difficult. Small companies have been hardest hit by constriction in the venture markets (19).
Opportunities for venture capitalists to realize their return through sale of equity via the public market have been limited since the stock market crash of 1987. Until 1987, the public was willing to play the role of late-stage venture capitalists by buying stocks in companies far from profitable (23). Today, initial public offerings are harder to come by, and many companies are stuck pre-public. One biotechnology executive testified in May 1989 that after the 1987 crash, equity capital was no longer available to small companies, and his company was forced to form limited partnerships with J apanese companies (9). United States firms were not the only ones to suffer the consequences of the October 1987 crash. Foreign firms have also been affected. Acquiring risk capital in Sweden was not difficult prior to that time; Swedish biotechnology firms, comprised largely of small- to medium-sized firms, are now having trouble raising cash (55).

One analyst estimates that public equity became a less favorable strategy for financing for as many as 75 percent of DBCs, whereas strategic alliances gained in favor by as much as 60 percent (I). This does not mean that all biotechnology companies al ready traded publicly are being hurt. In fact, overall, biotechnology stocks performed well in the last years of the 1980s. Still, the largest source of funding for biotechnology companies is established corporations (20).

Despite positive stock activity, the valuations for the public companies may have peaked as they have finally reached the product stage. For smaller private companies wanting to enter the public market, leveling off of valuation has brought increasing demands for greater maturity before public funds can be raised. One analyst reported that before some firms are willing to underwrite an initial public offering for a health biotechnology company, the company should have positive Food and Drug Administration (FDA) Phase II clinical trial data (4) indicating the product is close to the marketing phase. 
Table 4-5-Venture Investments in Biotechnology (\$in millions)

\begin{tabular}{|c|c|c|c|c|c|c|c|c|c|c|c|}
\hline & 1979 & 1980 & 1981 & 1982 & 1983 & 1984 & 1985 & 1986 & 1987 & 1988 & 1989 \\
\hline \multicolumn{12}{|l|}{ vẻnture capitál Indiusitry } \\
\hline $\begin{array}{l}\text { Total dollars raised } \ldots \ldots \\
\text { Total capital invested } \ldots \\
\text { Total number of }\end{array}$ & $\begin{array}{l}\$ 300 \\
\$ 458\end{array}$ & $\begin{array}{l}\$ 700 \\
\$ 608\end{array}$ & $\begin{array}{l}\$ 1,300 \\
\$ 1,159\end{array}$ & $\begin{array}{l}\$ 1,800 \\
\$ 1,453\end{array}$ & $\begin{array}{l}\$ 4,500 \\
\$ 2,584\end{array}$ & $\begin{array}{l}\$ 4,200 \\
\$ 2,756\end{array}$ & $\begin{array}{l}\$ 3,300 \\
\$ 2,670\end{array}$ & $\begin{array}{l}\$ 4,500 \\
\$ 3,230\end{array}$ & $\begin{array}{l}\$ 4,900 \\
\$ 3,940\end{array}$ & $\begin{array}{l}\$ 2,100 \\
\$ 3,650\end{array}$ & $\begin{array}{l}\$ 2,200 \\
\$ 3,260\end{array}$ \\
\hline companies . . . . . . . . & 375 & 504 & 797 & 918 & 1,320 & 1,469 & 1,377 & 1,504 & 1,729 & 1,472 & 1,355 \\
\hline \multicolumn{12}{|l|}{ Biotechnology industry } \\
\hline $\begin{array}{l}\text { Dollars invested } \\
\quad \text { New companies } \ldots \ldots \\
\text { Total companies } \ldots \ldots\end{array}$ & $\begin{array}{l}\text { NA } \\
\text { NA }\end{array}$ & $\begin{array}{l}\text { NA } \\
\text { NA }\end{array}$ & $\begin{array}{l}\text { NA } \\
\text { NA }\end{array}$ & $\begin{array}{l}\text { NA } \\
\text { NA }\end{array}$ & $\begin{array}{l}\text { NA } \\
\text { NA }\end{array}$ & $\begin{array}{l}\text { NA } \\
\text { NA }\end{array}$ & $\begin{array}{r}\$ 13.60 \\
\$ 100.59\end{array}$ & $\begin{array}{r}\$ 40.15 \\
\$ 186.18\end{array}$ & $\begin{array}{r}\$ 54.17 \\
\$ 255.19\end{array}$ & $\begin{array}{r}\$ 41.28 \\
\$ 311.21\end{array}$ & $\begin{array}{r}\$ 57.83 \\
\$ 250.85\end{array}$ \\
\hline \multicolumn{12}{|l|}{$\begin{array}{l}\text { Percent of total capital } \\
\text { invested }\end{array}$} \\
\hline $\begin{array}{l}\text { New companies } . . . . . \\
\text { Total companies . . . . }\end{array}$ & $\begin{array}{l}\text { NA } \\
\text { NA }\end{array}$ & $\begin{array}{l}\text { NA } \\
\text { NA }\end{array}$ & $\begin{array}{l}\text { NA } \\
\text { NA }\end{array}$ & $\begin{array}{l}\text { NA } \\
\text { NA }\end{array}$ & $\begin{array}{l}\text { NA } \\
\text { NA }\end{array}$ & $\begin{array}{l}\text { NA } \\
\text { NA }\end{array}$ & $\begin{array}{l}0.51 \% \\
3.77 \%\end{array}$ & $\begin{array}{l}1.24 \% \\
5.76 \%\end{array}$ & $\begin{array}{l}1.37 \% \\
6.48 \%\end{array}$ & $\begin{array}{l}1.13 \% \\
8.53 \%\end{array}$ & $\begin{array}{l}1.77 \% \\
7.69 \%\end{array}$ \\
\hline $\begin{array}{l}\text { Number of companies .... } \\
\text { Total companies ........ }\end{array}$ & $\begin{array}{l}\text { NA } \\
\text { NA }\end{array}$ & $\begin{array}{l}\text { NA } \\
\text { NA }\end{array}$ & $\begin{array}{l}\text { NA } \\
\text { NA }\end{array}$ & $\begin{array}{l}\text { NA } \\
\text { NA }\end{array}$ & $\begin{array}{l}\text { NA } \\
\text { NA }\end{array}$ & $\begin{array}{l}\text { NA } \\
\text { NA }\end{array}$ & $\begin{array}{l}21 \\
65\end{array}$ & $\begin{array}{l}25 \\
83\end{array}$ & $\begin{array}{r}44 \\
118\end{array}$ & $\begin{array}{r}40 \\
110\end{array}$ & $\begin{array}{l}22 \\
97\end{array}$ \\
\hline \multicolumn{12}{|l|}{$\begin{array}{l}\text { Percent of total number } \\
\text { of companies }\end{array}$} \\
\hline \multicolumn{12}{|l|}{$\begin{array}{l}\text { Dollars invested } \\
\text { Per company }\end{array}$} \\
\hline $\begin{array}{l}\text { New companies ....... } \\
\text { Total Companies ..... }\end{array}$ & $\begin{array}{l}\text { NA } \\
\text { NA }\end{array}$ & $\begin{array}{l}\text { NA } \\
\text { NA }\end{array}$ & $\begin{array}{l}\text { NA } \\
\text { NA }\end{array}$ & $\begin{array}{l}\text { NA } \\
\text { NA }\end{array}$ & $\begin{array}{l}\text { NA } \\
\text { NA }\end{array}$ & $\begin{array}{l}\text { NA } \\
\text { NA }\end{array}$ & $\begin{array}{r}\$ 0.65 \\
1.55\end{array}$ & $\begin{array}{r}\$ 1.61 \\
2.24\end{array}$ & $\begin{array}{r}\$ 1.23 \\
2.16 \\
\end{array}$ & $\begin{array}{r}\$ 1.03 \\
2.83 \\
\end{array}$ & $\begin{array}{r}\$ 2.63 \\
2.59 \\
\end{array}$ \\
\hline
\end{tabular}

NA = not available

SOURCE: S.P.Galante, Venture Capita/ Journal, August 1990.

\section{Internationally}

Investment in biotechnology in other countries has been very different from that in the United States. There are few DBCs. Most of the investment has come from large pharmaceutical, chemical, and agricultural corporations spending money on in-house research and strategic alliances with DBCs. It is not clear whether more venture capital availability would result in the formation of DBCs because the culture for innovation and entrepreneurialism is different. The venture phenomenon has been uniquely American, but the past decade has seen an increase in venture activity overseas. In 1988, venture capitalists in the United Kingdom (U.K.) invested over $\mathrm{fl}$ billion, a 27percent increase over 1987 and more than twice as much as in 1986. United Kingdom investors tend to place their money within the United Kingdom (89 percent), but nearly 10 percent has been invested in the United States. Still, less than 10 percent of venture funds have been invested in biotechnology (2).

The sources of venture funds vary between countries. In the United States, pension funds are a significant source of funds for venture capital. Deregulation of types of investments allowed by pension funds released a large pool of cash for venture use. In general, pension funds are not a source of venture capital in other countries. In the United States, independent private venture capital firms (typically organized as limited partnerships) provide about 83 percent of the total venture capital pool (28). Banks tend to be the main sources of venture capital in the United Kingdom (about 25 percent), Denmark (50 percent), and Germany (56 percent). The government provides as much as 73 percent of venture capital in countries such as Belgium and Luxembourg and nearly 40 percent of the funds in The Netherlands. In France, insurance companies provide 23 percent of venture capital (37). In other European countries, venture capital companies are relatively new. Nearly all of the 40 companies in Germany, for example, are less than 7 years old and have yet to fully realize their investments. Most venture capital investments by European Community (EC) countries have gone to computer-related firms or industrial products. Biotechnology has historically received about 3 percent of the disbursements (37).

The EC has recognized the shortage of start-up and early stage financing across Europe and has recently launched two initiatives: Seed Capital and Eurotech Capital. The Seed Capital project supports 24 new seed capital funds across the EC, seeking to stimulate cross-border investment. Eurotech Capital 
attempts to encourage financial institutions to increase their investment in cross-border, hightechnology projects by means of investment subsidies ranging from 4 to 50 percent (2).

Some countries' efforts are so new it is impossible to predict how successful they will be. In Taiwan, for example, a venture capital funding system was recently developed to help finance new start-up companies. Government banks led the investment effort, and special income tax exemptions were launched. Thirteen venture capital firms have been established since 1986 under this program (51). In Australia, in an effort to encourage a more healthy venture industry, the government provides tax benefits for those who invest in licensed venture capital companies. This scheme, however, has not been helpful in raising biotechnology venture capital. Of the 44 investment firms listed in a 1988 directory, only 4 stated a preference for biotechnology investment. The average investment of 5 percent is low when compared with a 15-percent investment in the information industries (27).

In J apan, where most of the capital is heavily concentrated in the banking system, venture capital has played a limited role in high-technology financing. Because large companies devel op biotechnology, financing traditionally has taken place with debt finance. In the early 1970s, about eight venture capital companies were established, but they functioned more as loan agents than as investors. In the 1980s, venture capital companies were organized in limited partnerships, which provided better exits for investors and changed the tax rate in a favorable way (37).

In general, venture capital sources in J apan are very different from those in the United States. Most J apanese venture capital fund managers lack entrepreneurial management skills and usually operate out of their parent headquarters (which tend to be banks, security houses, or giant corporations such as Kirin or Mitsubishi) and invest conservatively. Most American venture capitalists would claim that J apanese venture capital really isn't venture capital at all. For example, J apanese venture capitalists are willing to accept returns two-fifths of the level that U.S. venture capitalists typically expect. Several other reasons exist for the conservative nature of $J$ apanese venture capitalists-such as the stigma of failure and an emphasis on personal relationships rather than depersonalized sales of equity, which result in sales of equity primarily between cooperating firms. And, although the Nakasone government exempted taxes on capital gains of individual investors, corporations are taxed at a rate as high as 42 percent (37). While the J apanese may be moving rapidly into biotechnology through the efforts of academia, governmentsupported laboratories, and their major corporations, they have been unable (and perhaps unwilling) to imitate the unique relationships that exist in the United States between DBCs and venture capitalists.

\section{Research and Development Limited Partnerships}

Until recent changes in U.S. tax law, research and development limited partnerships (RDLPS) allowed individuals or companies to invest in a fro's R\&D and write-off the investment as an expense. Investors became limited partners and were entitled to royalty payments from future sales. But current tax laws effectively prohibit individuals from writingoff the investment as an expense. Investors do not become limited partners until royalty payments are received but technically become owners of the technology to either exploit or sell back to the company for a fixed payment plus royalties. According to some industry executives, the current tax rules governing these partnerships are unclear and further complicate successful transactions (26). This means that RDLPs have to stand on their own merits, and all deals must include equity incentives (32).

Although the dollar amount that can be raised from RDLPs is potentially high, participants at a September 1990 OTA workshop agreed that these partnerships remain a valuable funding vehicle only for established firms with a proven track record and are not widely available (57). In 1989, Genentech raised $\$ 72$ million in an RDLP to research and develop its CD4-based acquired immunodeficiency syndrome (AIDS) treatment. Even so, executives of Genentech reported difficulties in raising this amount (6), and most biotechnology companies would be fortunate to raise a sum that large (11). RDLPs are not currently a good money raising method--even for established companies (5).

\section{CONSOLIDATION}

Consolidation within industries occurs when competition between companies becomes extreme, when marketing of existing products becomes more important than the development of new products, 
when the costs for $R \& D$ of new products increase faster than the level of sales, or when it is difficult to raise cash. Such consolidations can take the form of buyouts or mergers. Typically, larger companies take over or merge with smaller companies that do not have the marketing power of the larger firms or that have not met the challenges posed by the level of competition. In the 1980s, several industries experienced consolidations, including high-technology areas, such as mainframe computer software, cellular telephones, and semiconductors.

A general trend in high-technology-including biotechnology-is that the basic technology is relatively inexpensive for firms to develop. Several factors may contribute to this phenomenon. First, the Federal Government supports basic research through grants to universities-the results of which become public knowledge. Second, there are few regulations affecting basic research. Small companies with innovative ideas can compete successfully by exploiting their narrow specialty. However, as ideas approach the market, the capital required to make improvements and start production increases dramatically. Undoubtedly, the cost of developing biotechnology products is rising rapidly; enough to concern the largest DBC. Although start-up companies will continue to play a crucial role in the development of biotechnology, mergers and takeovers will become more common as the market limits capital availability and the costs of developing and marketing new products increases while cash supplies become limited.

Mergers will allow large corporations to lead in the effort to develop commercial biotechnology products immediately, without having to engage in basic research that is often not applicable to a commercial product. Because of the relatively low cost at which technology can be acquired, large foreign- and domestic-based pharmaceutical and pesticide firms will likely be active in takeovers and mergers of biotechnology firms in the United States. Moreover, foreign multinationals view U.S. firms as particularly attractive, given the size, affluence, and openness of the U.S. market, as well as the foundation of basic research techniques and knowledge that many companies possess. To date, there have been no hostile takeovers in biotechnology, largely because the assets (people) have no obligation to stay and many takeover opportunities exist elsewhere (40).
The recent $\$ 660$ million merger of Chiron and Cetus is symptomatic of the consolidation beginning to occur among companies involved in biotechnology. One of the frost takeovers of a biotechnology company occurred in 1982 when Schering-Plough Corp. acquired DNAX (Palo Alto, CA) for $\$ 29$ million (3). In 1986, two important buyouts of biotechnology companies took place. Hybritech (San Diego, CA) was bought by Eli Lilly for $\$ 500$ million, and Genetic Systems was acquired by Bristol-Myers for nearly $\$ 300$ million (3). A few buyouts have occurred between foreign and U.S. fins. For example, in 1988, Denmark's NovoNordisk purchased a Seattle-based biotechnology firm, Zymogenetics. In 1989, Gen-Probe, Inc. (San Diego, CA) was sold to J apan's Chugai Pharmaceutical for \$110 million (39), and Seradyn, Inc. was bought by Mitsubishi Kasei. In 1990, Schering AG purchased Codon Corp. and Triton Biosciences. A sampling of acquisitions can be found in table 4-6. Further consolidation is inevitable.

\section{Foreign Participation in Mergers and Acquisitions}

Relationships between U.S. biotechnology companies and foreign corporations have taken virtually every form and combination of forms imaginable, including: acquisition, merger, equity investment, joint venture, co-marketing, technology licensing, product licensing, and research sponsorship. Obviously, mergers and acquisitions are the most extreme interactions that can take place between two companies. The case of Genentech and HoffmannLaRoche is the most notable (see box 4-B). Other consolidation occurring today within the pharmaceutical industry is illustrated by Eastman Kodak's purchase of Sterling Drug, the trans-Atlantic merger between SmithKline Beckman and the Beecham Group, the union of Squibb Corp. and BristolMyers, the Marion Laboratories merger with Merrell-Dow, and the Rhone-Poulenc acquisition of Rorer. But these are big companies merging with other big companies. While drug companies are teaming-up for potential synergies and improved competitiveness in an increasingly global marketplace, traditional reasoning has long proposed that financial pressure would eventually force biotechnology companies to sell out in order to survive. Financing has been particularly tight ever since the stock market crash of 1987, and the majority of biotechnology concerns have nervously watched 
Table 4-6-Acquisitions of U.S. Biotechnology Companies, 1989-90

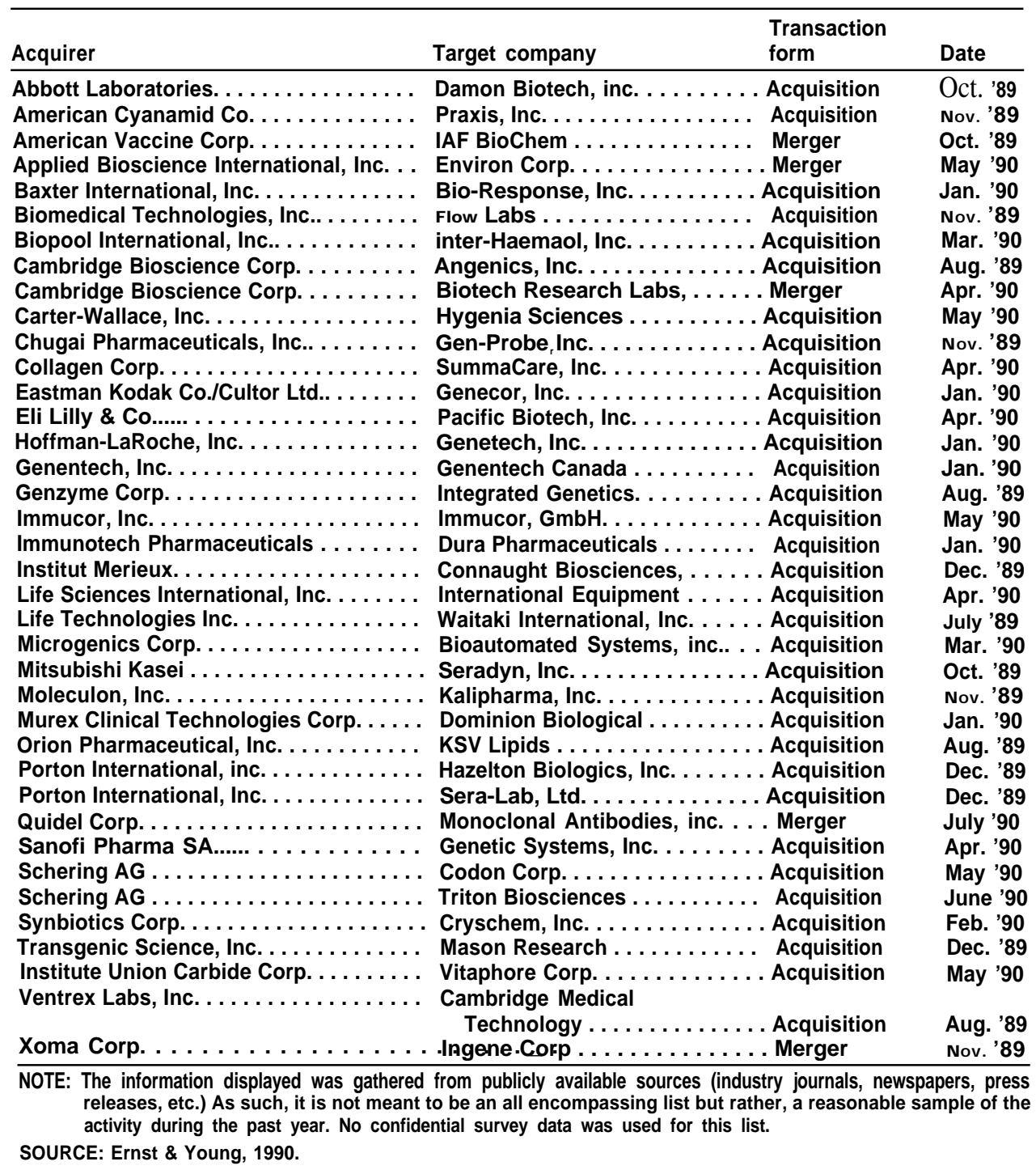

their bank accounts dwindle since then. For many such start-up companies the choice has been one of cutting $R \& D$ or turning to corporate sources for various types of financial assistance.

The North Carolina Biotechnology Center (NCBC) maintains a database that monitors public literature citations to take a much broader approach to biotechnology agreements. The center includes a deal if either one of the firms involved has some biotechnology activities. As a result, more agreements are included within the NCBC database, which tracks more than 550 small and large firms that work with recombinant DNA (rDNA), monoclonal antibodies, or new cell culture technologies.
For the years 1982 to 1988, a total of 33 biotechnology-related acquisitions involved a firm from the United States and a firm from E urope, while only three involved combinations of U.S. and Asian companies. Many of these deals consisted of multinationals on both sides of the Atlantic exchanging divisions, with biotechnology often an unimportant part of the buyouts. In the three Asian acquisitions, for example, biotechnology played virtually no role whatsoever (31).

The long-awaited biotechnology consolidation has been less than dramatic so far, but worldwide acquisitions were on the rise in 1989 and 1990 (see table 4-6). Of these deals, few involve a foreign 


\section{Box 4-B-The Genentech/Hoffmann-LaRoche Merger}

In February 1990, the biotechnology community was stunned when the Swiss pharmaceutical company Roche Holdings, Basel, announced that it was acquiring $\mathbf{6 0}$ percent of Genentech for $\mathbf{\$ 2 . 1}$ billion. Roche Holding Ltd. is the parent company of Hoffmann-LaRoche. In principal, the arrangement is a merger rather than a takeover and Roche's investment represents a much greater interest in biotechnology than it has previously taken. Hoffmann-La Roche has joint ventures to develop specific products with at least 13 other companies and owns 4 percent of Cetus. The announcement was met with dismay by some because of rising concern about foreign investment in the U.S. economy; Japanese firms were actively purchasing U.S. assets, including Sony's highly publicized acquisition of Columbia Pictures 4 months prior to Roche's announcement.

The merger agreement was overwhelmingly approved by Genentech shareholders and passed Federal Trade Commission (FTC) review in September 1990. Under the terms of the agreement, Roche Holdings will exchange every two shams of Genentech stock for $\$ 36$ cash plus one share of Genentech redeemable stock. Roche has the right to buy all of the redeemable stock at various dates between December 1990 and June 1995 at prices ranging from $\$ 38$ to $\$ 60$ per share.

Genentech was the largest and most successful independent U.S. biotechnology company and had become symbolic of American superiority in the field. The biotechnology-based pharmaceutical company was founded in 1976 using venture capital. In October 1980, Genentech was able to capitalize on the biotechnology hype during the public offering of its shares. During the first 20 minutes of trading, the stock rose from the initial offering price of $\$ 35$ to $\$ 89$. This was especially surprising given that investors' decisions were based on expected profits from products that were not yet developed, approved, or marketed. Nevertheless, investors were lured to Robert A. Swanson's dream to "build a fully integrated, independent pharmaceutical company. Swanson hoped that Genentech would achieve a billion dollars in annual sales by 1990.

Genentech's success is considered extraordinary because it pioneered four of the first six genetically engineered pharmaceutical products available on the market. The first three commercial successes for Genentech were human growth hormone, human insulin, and alpha interferon. Genentech's largest effort was in the development of tissue Plasminogen Activator (tPA). By 1989, Genentech's product and licensing royalties revenues had grown to $\$ 400$ million from its products-the aforementioned human insulin, human growth hormone, alpha interferon, and tPA. While revenue increased steadily, costs of research, development, and litigation also rose. In 1989, Genentech spent 40 percent of its revenues on research and development, amounting to $\$ 155$ million.

Genentech was the primary company to develop Activase (the brand name for tPA). Sales of Activase, Genentech's main product, were much slower than expected because of delays in Food and Drug Administration (FDA) approval, scientific studies questioning its effectiveness, and the availability of an inexpensive, low-technology competing product. The inability of Activase to live up to original expectations combined with increased costs of bringing new products to the market may have spurred Genentech's efforts to find a partner.

Genentech executives report that they looked for a U.S. partner before approaching Roche Holdings. Roche was deemed suitable because, among other things, it took a long-term view on the merger, it needed to take a major step forward with its comparatively slow-moving internal biotechnology efforts, and was apparently less concerned with quarterly performance. In addition, Genentech wanted to expand the sale of its products overseas very quickly.

During the next few years, the daily management of Genentech is expected to change little. Roche Holdings has said that Genentech will continue to have a high degree of flexibility and independence; Roche will appoint only 2 of the 13 members of Genentech's board of directors. How long this relationship will last is unclear. The main benefit for Genentech appears to be an immediate infusion of $\$ 492$ million. Genentech executives noted that the company simultaneously gained the capital to finance its long-term drug development plans and reduced its need to worry about volatility in quarterly profits. Kirk Raab, CEO and President of Genentech, implied that fluctuations in eamings were hurting Genentech's ability to conduct its programs and secure financing. In essence, Genentech is gaining a degree of security that will offset its lost independence. In addition, Genentech will have access to Roche's large international sales staff. Sales of Genentech's products are likely to show strong growth, especially overseas; currently only 20 percent of Genentech's revenues originate from sales outside the United States.

Nearly all of Genentech's 1,850 employees hold stock options. The day the merger was completed, Genentech gave its employees a cash windfall of approximately $\$ 120$ million, or $\$ 60,000$ each. Kirk Raab stands to gain $\$ 7.9$ million in stock options while Chairman and cofounder, Robert Swanson, would receive $\$ 4.2$ million in cash on top of stock options. Herbert Boyer, cofounder and co-patentee on the most famous recombinant patent, will collect $\$ 36$ million in cash for turning in his 2 million shams.

SOURCES: Office of Technology Assessment, 1991, based on Associated Press wire story, Sept. 9, 1990; Business Week, "Roche's Big Buy May Set Off a Shopping Frenzy," Feb. 19,1990; M. Chase, "Genentech Plans To Sell 60 Percent Stake to Roche Holdings for $\$ 2.1$ Billion" Wall Street Journal, Feb. 5, 1990; M. Ratner, "New Era for Genentech, and So It Goes," Biotechnology, March 1990; R.A. Swanson, "Remarks Before the Vice President's Council on Competitiveness," February 1990. 
acquisitor. In fact, in the case of Genzyme's proposed takeover of I ntegrated Genetics, it was the small U.S. acquisitor outbidding the large I talian pharmaceutical concern, the Ares-Serono Group. Rather than demonstrating any international trend, 1989 and 1990 proved to be the years of the teamup between U.S. biotechnology companies: the years' deals involve U.S. biotechnology companies on both sides of the contracts. A 1990 survey of biotechnology companies revealed that within the next 5 years nearly half expect to acquire another company and 39 percent expect to be acquired (19).

With such a small number of acquisitions by foreign firms it is difficult to identify temporal trends. It seems certain, however, that overall buyout activity is heating up, with half the total number of biotechnology acquisitions being made (or being proposed) within the past 2 years. Nevertheless, it would seem that if an onslaught of biotechnologyhungry multinationals acquiring cash-strapped biotechnology companies was going to occur, the trend would likely have become quite evident by now. The key is, if American biotechnology companies remain willing to arrange deals for single products or product lines at reasonable prices, why should a foreign firm go through all the trouble and expense of making a complete acquisition (25). In a 1990 survey, three-quarters of the companies surveyed believe it does not matter whether an acquirer is foreign or domestic (19).

Analysts expect that many struggling, cash-short American biotechnology firms will command some of the richest takeover premiums in the years ahead (15). The Premiums paid for recent acquisitions have been high. Hoffmann-LaRoche acquired 60 percent of Genentech at a 40-percent premium over its market valuation. Chugai paid a 92-percent premium for Gen-Probe, and American Cyanamid paid a 175-percent premium for Praxis Biologics (19).

Many industry observers disagree, however, on the likelihood of a spate of foreign biotechnology takeovers (57). One argument proposes that the major assets of U.S. genetic engineering firms are their young, energetic scientists. These assets walk out of the building every night, and they would likely move to another start-up company if they didn't like the corporate atmosphere following a takeover. That reasoning may carry somewhat less weight today than previously, however, as a number of biotechnology companies are beginning to show product revenues and operating profits and therefore have tangible worth in addition to their scientific expertise. But, with companies spending 70 percent of their revenues on research, this argument is still relevant (40).

With any takeover, be it foreign or domestic, the new parent is likely to put in place new management and infrastructure. An action that could have negative consequences on an entrepreneurial, researchbased biotechnology fro-these problems are multiplied if the parent company is headquartered overseas. This may be one reason why J apanese firms prefer strategic alliances over total acquisition. In general, strategic alliances expose the parent company to less risk than acquisition.

\section{STRATEGIC ALLIANCES}

As venture funds become more conservative and the public market more difficult to penetrate, U.S. companies increasingly rely on strategic alliances with both domestic and foreign firms to raise much-needed cash. While policymakers may be concerned about asymmetrical deals wherein the foreign firm gains more than the U.S. firm, U.S. companies enter into alliances that offer the most cash with the greatest flexibility. A 1989 survey examined the reasons that biotechnology companies turn to foreign partners for strategic alliances in the first place (19). United States firms cite marketing expertise as the prime reason for foreign ties, followed by the availability of capital and the regulatory expertise necessary to market products in foreign countries (see figure 4-2).

It is surprisingly difficult to define exactly what constitutes an alliance between a U.S. biotechnology company and a European or Asian partner. For example, the research collaboration that Cetus signed with Hoffmann-La Roche in early 1990 covering human diagnostics based on polymerase chain reaction (PCR) technology is really with the New J ersey-based H offmann-La Roche, Inc. subsidiary of the Swiss-based parent. Nevertheless, researchers at Roche's world headquarters in Basel probably have a much better handle on PCR technology than if Cetus' deal was with a totally unrelated company. Similarly, if Nova Pharmaceutical's major collaboration with SmithK line Beckman was an all-American deal when it was first signed, does anything change now that SmithKline has merged with England's Beecham Group? 
Figure 4-2-Reasons for Geographic Strategic Alliance

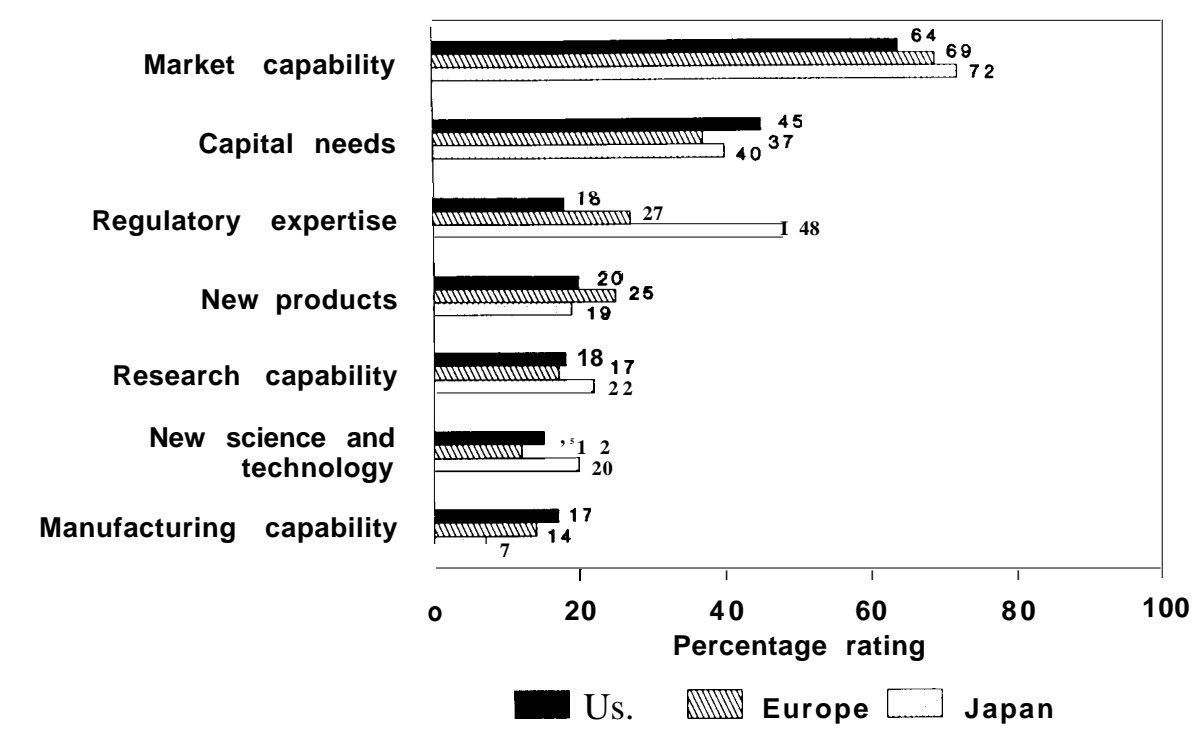

SOURCE: Ernst \& Young, Biotech 91: A Changing Environment (San Francisco, CA: 1990).

Keeping track of new alliances is often a relatively straightforward procedure because of the publicity surrounding such announcements. Monitoring the termination of such deals, however, is much more difficult. For example, 46 publicly held biotechnology companies tracked by Shearson participated in 65 deals that terminated during 1988. European partners were involved in eight of those teruminations; Asian partners participated in four. Reasons for ending agreements include a change in focus on the part of one of the partners, unsatisfactory $R \& D$ progress, or the planned conclusion of $R \& D$ contracts for better or worse. For example, in Pharmacia's termination of agreements with Biotechnology General and Chiron, analysts point to major corporate restructuring going on within the Swedish company (46).

A further difficulty with deal-counting is that one agreement may cover just a single protein while another may involve a whole range of products. For example, Chiron Corp. 's joint venture with Switzerland's Ciba-Geigy includes a variety of biotechnology-derived vaccines; by comparison, Amgen and Kirin have actually made three separate agreements (plus one more between Amgen and the KirinAmgen joint venture) with each covering a specific therapeutic product obtained using a DNA technology.

Despite these difficulties and limitations, it is instructive to step back and examine the overall numbers of agreements forged between U.S. biotechnology companies and European and Asian partners. The investment bank Shearson Lehman Hutton has kept track of the various domestic and foreign alliances currently in place for 46 publicly traded U.S. biotechnology fins. It lists transactions that have taken place from the inception of the biotechnology companies through February 1,1989. Biotechnology firms have an average of six corporate partners each. The average number of foreign alliances for each U.S. biotechnology company is 3.5, which includes an average of 2.1 European alliances and 1.4 deals with Asian companies, almost al ways J apanese firms (see table 4-7). These figures have been confirmed in a separate survey by Ernst \& Young (1990).

A half-dozen biotechnology companies have forged an extraordinary number of foreign ties; Chiron, Biogen, and Genentech lead the way (see table 4-8). The data reveal several different strategies for foreign strategic alliances: some U.S. firms have emphasized European accords (e.g., Chiron and Immunex), others have stressed Asian over European alliances (e.g., Amgen, Bio-Technology General Corp., and The Liposome Co.), and still others have opted for a balanced approach (e.g., Biotech Research Labs, Genentech, Integrated Genetics, and Mycogen).

Timing the tables and examining the situation from the perspective of the foreign partners reveals 
Table 4-7-Breakdown of the Number of Alliances With 46 Publicly Held U.S. Biotechnology Companies With European or Asian Partners

\begin{tabular}{ccc}
\hline $\begin{array}{c}\text { Total number } \\
\text { of alliances }\end{array}$ & $\begin{array}{c}\text { Number with } \\
\text { European firms }\end{array}$ & $\begin{array}{c}\text { Number with } \\
\text { Asian firms }\end{array}$ \\
\hline 1 & 28 & 18 \\
2 & 9 & 11 \\
3 & 4 & 2 \\
4 & 0 & 3 \\
5 & 0 & 0 \\
6 & 0 & 1 \\
7 & 3 & 0 \\
$8+$ & 1 & 0 \\
\hline
\end{tabular}

SOURCE: Teөna Lerner, Shearson Lehman Hutton, 1990.

that 62 percent of European firms that have made deals with U.S. biotechnology companies have made just one such accord, while 91 percent have made three or fewer; the average number of deals per European company is two. The European outliers are Switzerland's H offmann-La Roche (13 deals), Ciba-Geigy (7 deals), Sandoz (7 deals), and Germany's Hoechst (7 deals). Although these represent a large number of alliances, the European corporate dealmakers have struck nowhere near the number of biotechnology accords as the most active of U.S.based multinationals, such as J ohnson $\& \mathrm{~J}$ ohnson (23 deals) and Eastman Kodak (20 deals) (46). A country-by-country analysis of strategic alliances appears in box 4-C.

As for Asian firms, the overall pattern is similar. Some 51 percent of those companies that do have strategic alliances with biotechnology companies have only one agreement, with all but one Asian company having four deals or fewer. The one Asian outlier is Kirin Brewery, which has six agreements (four with Amgen and the remaining two with Plant Genetics, Inc.). Other major J apanese corporations entering into alliances are Green Cross, Mitsubishi Chemical, and Yamanouchi Pharmaceutical, each with four agreements.

The Shearson data are useful as far as they go, but they were constructed specifically to track and evaluate publicly held biotechnology companies, rather than monitoring the actual technologies involved. With over 400 U.S. companies dedicated to biotechnology, the Shearson figures clearly leave out small, public biotechnology companies as well as privately held concerns. In addition, established U.S. pharmaceutical, chemical, and other companies with significant in-house biotechnology expertise are also ignored.
Table 4-8-Number of Agreements With European and Asian Partners for 46 Publicly Held U.S. Biotechnology Companies As of 1989

\begin{tabular}{|c|c|c|c|}
\hline U.S. company & $\begin{array}{l}\text { Number of } \\
\text { European } \\
\text { deals }\end{array}$ & $\begin{array}{l}\text { umber of } \\
\text { Asian } \\
\text { deals }\end{array}$ & $\begin{array}{l}\text { al number } \\
\text { foreign } \\
\text { deals }\end{array}$ \\
\hline Amgen . . . . . . . . . . . . & 1 & 4 & 5 \\
\hline Bio-Response . . . . . . . . & 0 & 0 & 0 \\
\hline $\begin{array}{l}\text { Biogen } \ldots \ldots \ldots \ldots \ldots \\
\text { Biotech Research }\end{array}$ & 8 & 7 & 15 \\
\hline $\begin{array}{l}\text { Labs . . . . . . . . . . } \\
\text { BioTechnica }\end{array}$ & 0 & 0 & 0 \\
\hline $\begin{array}{l}\text { International . . . . . . } \\
\text { Bio-Technoloqy }\end{array}$ & 2 & 0 & 2 \\
\hline General . . . . . . . . . . & 0 & 4 & 4 \\
\hline $\begin{array}{l}\text { Calgene } \\
\text { California }\end{array}$ & 4 & 1 & 5 \\
\hline $\begin{array}{l}\text { Biotechnology } \ldots \ldots \text {. } \\
\text { Cambridge }\end{array}$ & 3 & 2 & 5 \\
\hline Bioscience . . . . . . . . & 1 & 1 & 2 \\
\hline Centocor . . . . . . . . . & 4 & 4 & 8 \\
\hline Cetus . . . . . . . . . . . & 3 & 1 & 4 \\
\hline $\begin{array}{l}\text { Chiron ............. } \\
\text { Collaborative }\end{array}$ & 12 & 4 & 16 \\
\hline Research . . . . . . . . & 2 & 1 & 3 \\
\hline Crop Genetics . . . . . . . . & 0 & 0 & 0 \\
\hline Cytogen $\ldots \ldots \ldots \ldots$ & 1 & 0 & 1 \\
\hline Damon Biotech . . . . . . . . & 1 & 0 & 1 \\
\hline DNA Plant Technology . . & 4 & 0 & 4 \\
\hline Ecogen $\ldots \ldots \ldots \ldots$ & 0 & 0 & 0 \\
\hline Enzo Biochem . . . . . . . & 0 & 0 & 0 \\
\hline Epitope ........... & 2 & 1 & 3 \\
\hline Escagenetics. . . . . . . . & 1 & 1 & 2 \\
\hline Genentech . . . . . . . . & 7 & 6 & 13 \\
\hline Genetics Institute . . . . . & 6 & 3 & 9 \\
\hline Genex . . . . . . . . . . . & 3 & 1 & 4 \\
\hline Genzyme . . . . . . . . . & 2 & 2 & 4 \\
\hline Gen-Probe . . . . . . . . . & 4 & 1 & 5 \\
\hline Immunex . . . . . . . . & 5 & 0 & 5 \\
\hline Imre............. & 0 & 2 & 2 \\
\hline Integrated Genetics . . . . & 3 & 4 & 7 \\
\hline Ingene . . . . . . . . . . & 0 & 1 & 1 \\
\hline $\begin{array}{l}\text { Invitron } \ldots \ldots \ldots \ldots \\
\text { Lipsome Technology, }\end{array}$ & 0 & 0 & 0 \\
\hline Inc. . . . . . . . . . & 1 & 0 & 1 \\
\hline Molecular Genetics . . . . . & 2 & 0 & 2 \\
\hline Monoclonal Antibodies.. & 1 & 0 & 1 \\
\hline Mycogen $\ldots \ldots \ldots \ldots$ & 0 & 1 & 1 \\
\hline NeoRx . . . . . . . . . . & 0 & 0 & 0 \\
\hline Nova Pharmaceutical . . . & 0 & 0 & 0 \\
\hline Oncogene Sciences . . . . & 0 & 0 & 0 \\
\hline Plant Genetics . . . . . . . . & 1 & 3 & 4 \\
\hline Repligen $\ldots \ldots \ldots \ldots$ & 4 & 1 & 5 \\
\hline Synergen . . . . . . . . . & 1 & 0 & 1 \\
\hline Syntro $\ldots \ldots \ldots \ldots \ldots$ & 1 & 1 & 2 \\
\hline $\begin{array}{l}\text { T Cell Sciences . . . . . . . } \\
\text { The Liposome }\end{array}$ & 0 & 3 & 3 \\
\hline co.............. & 0 & 5 & 5 \\
\hline Vestar . . . . . . . . . & 3 & 0 & 3 \\
\hline Xoma .............. & 3 & 0 & 3 \\
\hline
\end{tabular}

SOURCE: Teena Lerner, Shearson Lehman Hutton, $19 \mathrm{~S} 9$.

The NCBC data that were sorted under contract specifically for this report show that from 1982 to 1989 both European and J apanese firms have had significant interactions with U.S. companies. Ap- 


\section{Box 4-C-Country-by-Country Analysis of Strategic Alliances}

Analysis of the countries involved in U.S.-Asian alliances shows J apan involved in 94 percent of the 195 deals made from 1982 through 1988. In 1988, there was a record 52 U.S.-J apanese deals struck; but some of the other Asian countries also signed agreements with U.S. firms. The half-dozen non-J apanese deals signed last year involved companies from China, Israel, Singapore, Korea, and Pakistan.

Alliances between biotechnology companies from Western countries and the Soviet Union are also becoming more common of late. In one such arrangement, Monsanto agreed to contribute $\$ 500,000$ toward joint research at the U. S. S.R. 's Shenyakin Institute for Bio-Organic Chemistry involving neurobiological processes, human and animal growth hormones, and plant genetic engineering. In another 1989 pact, Millipore and the Soviet Institute of Genetics opened a joint R\&D facility in Moscow that will initially develop separation processes for alpha-interferon and the amino acid L-threonine.

The leading players in U.S.-European alliances are the United Kingdom (74 deals), Switzerland (63), and Germany (45). Even though companies from each of these countries posted a record number of trans-Atlantic biotechnology accords last year, the U nited Kingdom and Germany have clearly boosted their participation, while Switzerland's presence has been more steady throughout the 7-year period. This may have something to do with far-sighted Swiss pharmaceutical giants like Hoffmann-La Roche, Sandoz, and Ciba-Geigy having played such active partnership roles from the beginning.

The European countries that make up the second-tier in terms of U.S. alliance activity are Sweden (28 deals), France (28), Italy (25), and The Netherlands (24). French, Italian, and Dutch accords are clearly on the rise, while Swedish participation has been more evenly spread over the analysis years.

Belgium and Denmark, with 10 agreements apiece, make up a third tier of countries when it comes to U.S.-European deals; Czechoslovakia, Finland, Ireland, Norway, and Spain represents the fourth tier, with companies from each country having signed between one and three pacts.

In Germany, industry invests heavily in $R \& D-58$ percent of the national total-and the pattern extends to biotechnology. The majority of biotechnology activities are being conducted by large firms including: Bayer, BASF, Boehringer Ingel heim, Hoechst, and Schering. Some of the firms, such as Bayer and Hoechst, are funding biotechnology R\&D at the rate of $\$ 70$ to $\$ 100$ million a year-amounts equivalent to U.S. companies, such as DuPont and Monsanto. Licensing agreements, strategic alliances, and even acquisitions involving U.S. firms (e.g., BASF's $\$ 1$ billion acquisition of Inmont) may help German firms gain access to cutting-edge technology. In addition, German firms are locating biotechnology facilities in the United States, such as BASF 's production facilities in Massachusetts. Wellcome has a joint venture manufacturing facility in the United States with Genetics Institute.

In Switzerland, where the pharmaceutical industry is very strong, industry accounts for 75 percent of all R\&D investment (approximately US $\$ 3.25$ billion annually). Commercial investment in biotechnology goes toward basic research. Because of production costs and a small internal market, most Swiss companies prefer to produce products abroad.

SOURCE: Office of Technology Assessment, 1991, adapted from data obtained from the North Carolina BiotechnologyCenter, Decision Resources, Selected Company Liaisons in Biotechnology, First Quarter 1989 (San Francisco, CA: Arthur D. Little, 1989).

proximately 366 European-U.S. biotechnology accords and some 266 Japanese-U.S. biotechnology deals were struck during the 7-year period.

\section{Equity Arrangements}

Biotechnology companies are always looking for money; selling equity to major U.S. and foreign corporations has always been an important part of this fundraising, often accompanying strategic marketing or distribution deals. Using data on 46 publicly traded U.S. biotechnology companies show seven instances of equity participation in a U.S. biotechnology firm by an overseas investor (table 4-Y). This means that foreign firms accounted for 18 percent of the total 38 equity investments listed. As with outright acquisitions, the small number of these deals indicates that this mute has not been an important one for European and Asian companies as they try to compete in biotechnology. A General Accounting Office (GAO) report confirms the relatively minor part that foreign direct investment has played in U,S. biotechnology (52).

The NCBC databases reveal 25 cases of U. S.European equity arrangements and 12 cases of 
Table 4-9-Equity Participations in 46 Publicly Held U.S. Biotechnology Companies by European and Asian Partners

\begin{tabular}{|c|c|c|}
\hline U.S. firm & Partner & Description \\
\hline Cefus $\ldots . . .$. & $\begin{array}{l}\text { Hơffmann- } \\
\text { LaRoche }\end{array}$ & $\begin{array}{l}\text { Purchased } 950,000 \text { Cêtus } \\
\text { shares }(3.6 \%) \text { in Jan. } 1989 \\
\text { for } \$ 15 \text { per share }\end{array}$ \\
\hline Chiron.. & Ciba-Geigy & $\begin{array}{l}\text { Paid } \$ 20 \text { million for } 1 \text { million } \\
\text { Chiron shares in Dec. } 1988\end{array}$ \\
\hline $\begin{array}{l}\text { DNA Plant Tech. } \\
\text { DNA Plant Tech. }\end{array}$ & $\begin{array}{l}\text { Adron AB } \\
\text {. Hilleshog } \\
\text { Research } \\
\text { AB }\end{array}$ & $\begin{array}{l}\text { Owns } 2.3 \% \text { of DNAP } \\
\text { Owns } 6 \% \text { of DNAP }\end{array}$ \\
\hline Imre $\ldots \ldots \ldots$ & $\begin{array}{l}\text { Takeda } \\
\text { Chemical }\end{array}$ & $\begin{array}{l}\text { Takeda increased its equity } \\
\text { ownership to } 10 \% \text { in Aug. } \\
1988\end{array}$ \\
\hline Nova Pharm. . . . & . Celanese & $\begin{array}{l}\text { Celanese, which was } \\
\text { acquired by West } \\
\text { Germany's Hoechst, } \\
\text { purchased } \$ 10 \text { million } \\
\text { Nova shares in } 1987\end{array}$ \\
\hline Plant Genetics . & $\begin{array}{l}\text { Kirin } \\
\text { Brewery }\end{array}$ & $\begin{array}{l}\text { in } 1986 \text { Kirin purchased a } \\
\text { total of almost } 95,000 \\
\text { shares of various classes of } \\
\text { preferred stock }\end{array}$ \\
\hline
\end{tabular}

SOURCE: Teena Lorner, Sheareon Lehman Hutton, 1990.

U.S.-J apanese deals. The European data show a recent increase in this activity, with 13 deals being made in the last 2 years; however, the U.S. firm was acting as the equity purchaser in more than half of these 13 instances. Four deals involving equity buy-ins into U.K. biotechnology companies Celltech and British Biotechnology Ltd. clearly illustrate the fact that recognized genetic engineering expertise is no longer limited to U.S. shores.

Of 25 U.S.-E uropean equity arrangements, five contain an explicitly mentioned marketing or distribution agreement. Interestingly, however, of the 15 deals made in the last 3 years, only 1 involves such a dual function, indicating, perhaps, U.S.-European equity investments are now being made for their own sake, rather than as part of a window on technology or market access approach. On the J apanese side of things, 6 of 12 equity deals explicitly mention marketing or research funding with no trend away from dual agreements in the last few years. This seems indicative of the fact that the J apanese market is still inaccessible to most biotechnology companies by any route other than teaming up with a large J apanese corporation.

\section{Joint Ventures}

With the exception of complete acquisition, the most intimate relationship two companies can have is a joint venture. In most cases, these arrangements consist of both parties contributing a corporate strength. In biotechnology, the genetic engineering company invariably contributes the necessary technology; and the partner contributes financing, perhaps some development skills, and marketing capacity down the line. For most biotechnology companies, joint ventures are almost always preferred over licensing arrangements as they give the start-up firm opportunity to finance internal infrastructure consistent with becoming vertically integrated and a share in profits rather than receiving only a small royalty on eventual sales.

Joint ventures now account for most international alliance activity in terms of dollars, while marketing arrangements are still number one in terms of overall numbers of deals made (58). Many of these agreements, especially in the early years, involved major American companies, such as Squibb, Corning Glass, Abbott Laboratories, and DuPont; but as time passed, the biotechnology companies began to play a growing role, especially the larger, big-name companies like Genetics Institute, Chiron, Amgen, and, of course, Genentech. Whether the U.S. biotechnology company is dealing with Europe or J apan, the more the firm can bring to the partnership the better are its chances of negotiating a full-scale joint venture, as opposed to a limited and less valuable licensing or marketing arrangement. Although it would seem that U.S. biotechnology companies would be maturing over the last year or two to the point where more of them could pull their own weight in a joint venture involving an overseas partner, the evidence does not point to any large increase in such joint ventures.

If one particular joint venture were to be singled out as a model for biotechnology companies to examine, the Kirin-Amgen venture would be a good place to start. According to Amgen president Harry Hixson, it took the two companies just 8 weeks in 1984 to arrange the deal from beginning to end (29). Kirin put up $\$ 12$ million and Amgen contributed patent rights, technology, and (somewhat unusually) $\$ 4$ million in its own funding. Research took place on both sides of the Pacific, and the companies divided up worldwide marketing rights as follows: Amgen kept U.S. rights, Kirin took J apanese rights, and the Kirin-Amgen joint venture itself held onto rights for the rest of the world. J ohnson \& J ohnson later bargained for European marketing rights from Kirin-Amgen as well as rights to certain U.S. 


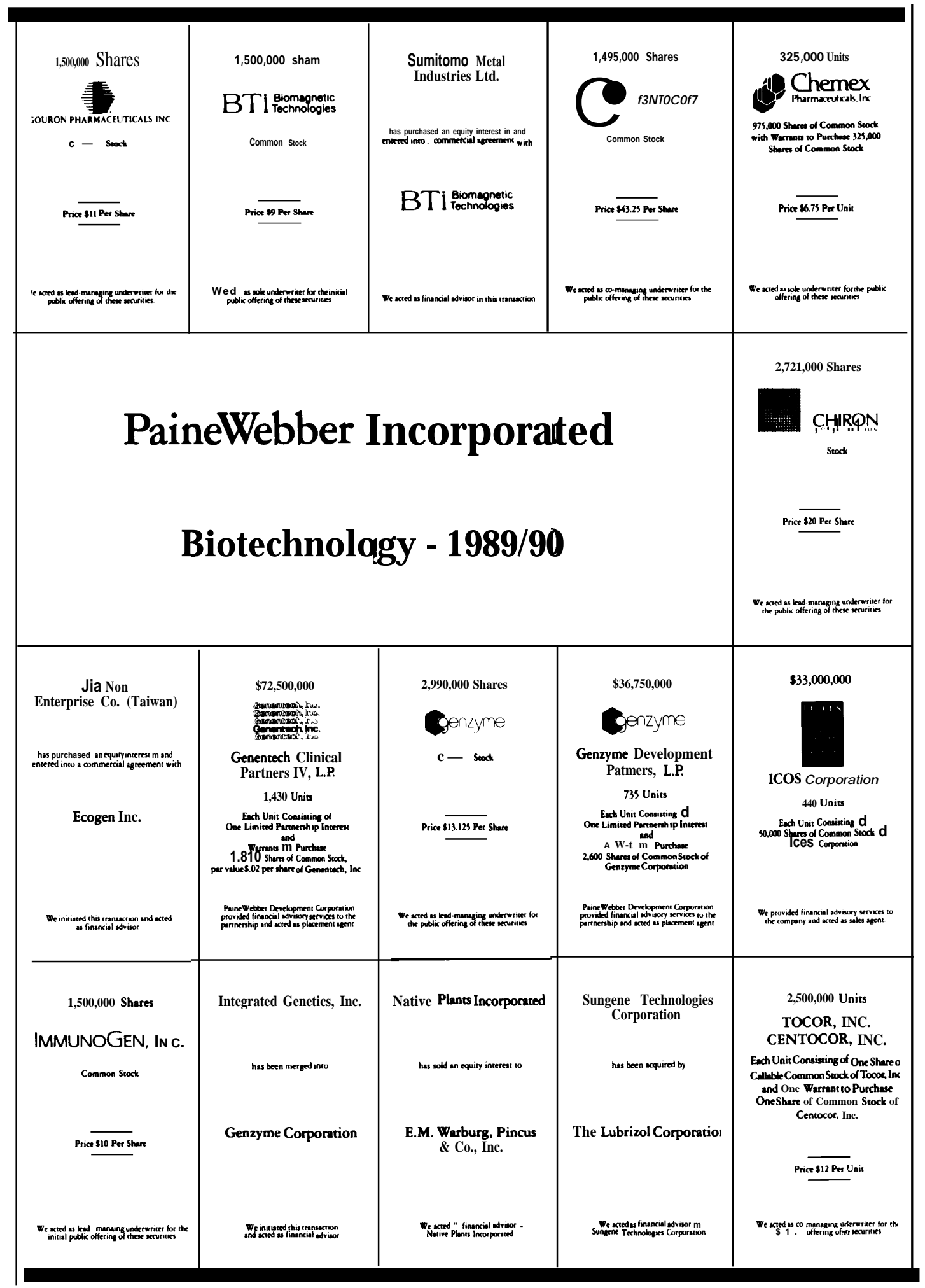

Photo credit: PaineWebber Inc.

Advertisement, financial services for biotechnology companies. 
markets from Amgen. The key factor in making the arrangement a success was the potential success of the product, erythropoietin (EPO), a protein that stimulates the production of red blood cells. Erythropoietin is approved for use in close to a dozen European countries. In J une 1989, E PO received marketing clearance from the U.S. FDA for treatment of renal dialysis patients who suffer anemias due to their inability to produce red blood cells.

Even this joint venture wasn't perfect. For example, one of the reasons that Amgen was able to negotiate such a favorable arrangement was that Kirin sells a lot more beer than it does drugs, so this company would not immediately be considered the best of marketing partners for a biotechnologyderived therapeutic. In fact, this marketing weakness probably played a role in the joint venture's eventual decision to license European rights to EPO.

\section{Licensing and Marketing Deals}

Licensing, whether it involves technology itself or the marketing rights to eventual products that result from $R \& D$, has been an important source of funds since the inception of commercialized molecular biology.

Despite their popularity in terms of numbers of deals, licensing agreements do not receive raves from biotechnology executives. These arrangements, if made with a large pharmaceutical company, provide the large pharmaceutical company very good downside protection with milestone payments often eliminated if the research is not going well. The biotechnology companies, however, gain somewhat limited upside potential from these deals, because if the product is successful it will be the pharmaceutical company that reaps the lion's share of the profits (41).

So why are there so many licensing deals? The problem, according to one executive, is that partnerships and joint ventures cannot be completed until a company has financed its own risk capital and has come up with a product or service in which someone has an interest. If the primary objective is to raise cash, a company is at a negotiating disadvantage from the beginning (9). Mycogen, an agricultural biotechnology company, was able to raise $\$ 18$ million in its initial public offering and has been able to add about that much again in funding from three major international collaborations. These were with Kuboto (covering bio-insecticides in J apan), Royal
Dutch Shell (for bioinsecticides in the rest of the world, except North America), and J apan Tobacco (for bioherbicides worldwide) (8).

As for new trends, some companies are now actually more willing to give up certain enabling technol ogy as part of an agreement than in previous years. In this scheme the technology per se is not so valuable, but rather, the products; the technology is seen as something that will become available anyway (42). The key, however, is when a company licenses out the use of tools, such as specific promoters and transformation systems, it does so for clearly restricted areas of research.

Another trend developing as biotechnology companies grow, have product sales, and develop their own sales forces is some of the marketing agreements can switch direction. For example, in 1987 the J apanese pharmaceutical firm Mitsubishi Kasei selected Genentech to devel op and market some of its products in the United States. However, Genentech was one of the few DBCs that had developed a major marketing staff in the United States. While companies such as Amgen, Immunex, and Cetus have developed smaller sales forces, it is unlikely that many similar agreements will be developed in the near term (59).

\section{Co-Marketing Agreements}

In order for biotechnology companies to participate in co-marketing agreements, they need two key, but relatively rare, components--a product and a marketing staff. Marketing is expensive and requires a sales force, something most DBCs do not have. Not surprisingly, then, only a few such deals have been struck. Each deal is different, but all involve the larger, more advanced biotechnol ogy firms. Because Genentech and Amgen have the highest market capitalization and are widely considered bellweather biotechnology companies, their deals are worthy of a closer look as they may predict future activity.

As an example, Amgen created Kirin Amgen as a joint venture with Kirin Brewery in J apan to develop EPO and subsequently elected to include granulocyte-colony stimulating factor (G-CSF). This time, Amgen held onto markets in the United States, Canada, Australia, New Zealand, and Europe, while Kirin took the marketing rights in J apan, Korea, and Taiwan; with the rights to the rest of the world assigned to the joint venture. Later, Kirin forged a co-marketing arrangement with the Sankyo Co. for 
J apanese distribution of G-CSF, and in 1989 Amgen and Hoffmann-La Roche agreed to a 10-year copromotion deal in Europe under which the product will be sold under Amgen's name. After this 10-year period, Amgen has the right to take over exclusive European sales and marketing.

As for Genentech, under a co-promotion agreement signed in February 1989 with Boehringer Ingelheim Pharmaceuticals, Boehringer's 475person U.S. sales force joined Genentech's sales force in promoting Activase, tissue plasminogen activator (tPA), to office-based physicians in the United States. Boehringer Ingel heim Pharmaceuticals is the Connecticut-based affiliate of Germany's Boehringer Ingelheim International $\mathrm{GmbH}$, which is Genentech's tPA licensee for all countries except the United States, Canada, and J apan. The co-promotion agreement was to run through the end of 1991 but was eventually bought out by Genentech.

\section{TAX POLICY AND ITS EFFECTS ON FINANCING R\&D}

Biotechnology companies require higher levels of $R \& D$ investment than companies in other industrial sectors. Tax relief is one of the methods the Federal Government uses to reduce the financial burden on $R \& D$-intensive industries. The justification for tax relief programs is based on the premise that such investment results in public benefits and in a greater rate of industrial innovation than would have occurred otherwise. Taxes and effects on investment in biotechnology were discussed in detail in a 1988 OTA report (54). More general discussion of the relationships between tax policy and innovation can be found in a 1990 OTA report (56). Tax issues that have emerged since 1988 and are specific to biotechnology are discussed in the following section. In addition, tax policies of other countries are examined.

\section{Capital Gains}

Capital gains are profits obtained from the sale of capital assets, such as stocks and real estate. Capital gains are taxed in most industrialized countries, al beit to differing extents. In fact, most Western European countries and J apan have systems of capital gains taxation that are more complicated and differentiated than that in the United States (38).

After the Tax Reform Act of 1986, these gains in the U nited States were taxed at a maximum of 28 percent in 1987 and at ordinary income rates starting in 1988. Substantial capital gains are rare for most people. In 1988, Americans filed 109.8 million tax returns; only 7.8 million returns accounted for all $\$ 159$ billion of capital gains, equivalent to 7 percent of the tax returns filed (43). Debate during the fiscal year 1991 budget negotiations focused, in part, on a proposal to cut the top rate for capital gains taxes. While lowering the rate would likely stimulate stock trading, past experience with lowering the rate has shown that it does little to induce savings and thus capital investment (43). One argument for cutting the tax rate has been to encourage venture capital. But venture capital accounts for only a small fraction of total capital gains. Most of the venture capital comes from investors not subject to taxes anyway, such as foreigners, pension funds, and college endowments (7).

The tax rate on capital gains is only one factor driving venture capital. The total amount of professionally managed venture capital is an extremely small factor in the overall economic picture, even if it is critically important to biotechnology start-ups. Nonetheless, should the capital gains rate be lowered, the rise in investment in both RDLPs and venture funds will no doubt have a beneficial effect on biotechnology companies seeking capital.

\section{$R \& D$ and Investment Tax Credits}

The R\&D tax credit lowers the cost of investment in research activities by providing a 20-percent tax credit on incremental $R \& D$ spending. The statutory rate of 20 percent is calculated based on the excess of qualified research over a base amount which is linked to $R \& D$ spending in a specific historical period. The base amount is figured by multiplying a freed-base percentage by a firm's average gross receipts over the preceding 4 years. The effective rate of the credit is much lower than 20 percent as it is based only on incremental spending, and the amount of the credit is disallowed as a tax deduction. The effective rate of the credit is, therefore, approximately 5 percent (26). The incremental nature of the credit ties it to increasing research expenditures rather than total expenditures made in a year, thus encouraging companies to increase their $R \& D$ commitment. Several other countries have similar tax incentives (see box 4-D).

To date, the R\&D tax credit has been of little use to many U.S. biotechnology companies, be- 


\section{Box 4-D-R\&D Tax Incentives of Selected Foreign Countries}

Australia. In Australia, biotechnology firms can avail themselves of the benefits of several industry-wide programs, including an $R \& D$ taxation incentive (companies undertaking appropriate research can receive a tax break at 150 percent of the value of the research), grants, and a range of consulting services through the National Industries Extension Service.

Canada. In Canada, immediate expensing of costs for both current and capital expenditures for R\&D purposes is allowed. Canada provides for an indefinite carry-forward of excess R\&D deductions. Canada also offers a 20-percent flat rate tax credit for $R \& D$ activities based on a firm's total $R \& D$ spending. Canada's $R \& D$ credit is unique in reducing $R \& D$ deductions correspondingly on a dollar-for-dollar basis.

France. French tax law provides for the full deduction of current $R \& D$ expenses in the year in which they are incurred. Until recently, buildings used solely for scientific and technical research were eligible for a special accelerated depreciation allowance, under which 50 percent of the cost of the building was deductible over the remaining useful life of the asset. In 1983, the special depreciation allowance was replaced by a 25-percent incremental tax credit (very similar in structure to the U.S. R\&D credit). France has adopted a generally applicable system of accelerated depreciation in the first year of service of the assets. Finally, France also maintains a system of cash grants for $R \& D$, under which companies creating or expanding scientific or technical research departments may be entitled to a taxable cash grant of 15 to 20 percent of the value of such expenditures to a maximum of 25,000 francs per-job created.

$J$ apan. J apanese corporations undertaking R\&D in J apan may deduct their current $R \& D$ expenses in full in the year in which such expenses are incurred, with a carryover of unused deductions for up to 5 years. Since 1966, $J$ apan has had an $R \& D$ tax credit for current $R \& D$ expenditures equal to 20 percent of the excess of current $R \& D$ expenditures over the largest amount of such expenditures incurred in any single prior tax year since 1966. In addition, J apan allows a special deduction of up to 40 percent of corporate income for firms that derive some portion or all of their income from "overseas transactions in technical services. " Small firms which export products are allowed special reserves, deductible at rates ranging from 0.25 to 1.4 percent of income from exports, for the development of overseas markets.

Taiwan. In Taiwan, current expenditures on $R \& D$ are deductible in the year in which they are incurred. $R \& D$ equipment is eligible for accelerated depreciation as well as an investment tax credit of 15 percent (in the case of domestically produced equipment) and 5 percent of the acquisition cost (in the case of imported equipment). Technology-intensive industries are eligible for a special reduced corporate income tax rate of 22 percent. A 20-percent incremental credit is available over the highest credit of the past 5 years. If no R\&D was conducted during the past 5 years, a tax credit for $R \& D$ in excess of 5 percent of current year revenues is available.

United Kingdom. In the United Kingdom, current expenditures on R\&D are fully deductible in the year they are incurred. In addition, capital expenditures incurred in $R \& D$ activities are fully allowable as a deduction in the year such expenditures are incurred. Unused deductions may be carried forward for a period of up to 5 years.

Germany. The Federal Republic of Germany provides for the deduction of current $R \& D$ expenditures from taxable income in the year they are incurred. While capital expenditures on $R \& D$, generally must be depreciated over the economic life of the assets, accelerated depreciation of R\&D assets at rates up to 40 percent over the first 5 years are permitted with respect to personal property,

SOURCE: E. Palmer, “Antitrust, Capital Gains, and Research and Development Tax Benefits in Several Industrialized Nations," European Law Division, Law Library of Congress, April 1990.

cause they are not profitable enough to generate a credit. The credit, however, can be carried forward for 15 years and provides a strong incentive as it increases earnings over the long term by reducing the tax burden. The tax reductions come at a critical time, when a company starts earning money and selling products (26). The lower tax rate provides a company needed earnings. Still, smaller, newer companies are at a disadvantage, because the government is, in effect, subsidizing $\mathrm{R} \& \mathrm{D}$ of larger companies but not of smaller ones (10). And, when considering the time-value of money carried-forward tax benefits are less valuable than tax benefits rendered in the current year.

The investment tax credit was one of the first specific tax incentives that the Federal Government established to encourage investment in physical plants and equipment, allowing the company to 
deduct a 10-percent credit for the cost of qualified property that was either constructed or purchased. The credit was eliminated in 1986 in favor of an overall reduction in the corporate tax rate, as it was unclear how effective the tax credit was at stimulating capital investment. In addition, the costs were deemed greater than the benefits (56). Several studies have attempted to measure the benefits of the investment tax credit; estimates of the additional investment range from $\$ 0.12$ to $\$ 0.80$ for each dollar not collected in taxes (56). Estimates of the actual increase in R\&D spending from 1981 to 1985 as a result of the tax credit, range from $\$ 500$ million to $\$ 2.9$ billion annually (53). The investment tax credit, therefore, resulted in lost revenue of between $\$ 13$ billion and $\$ 37$ billion to the government over a 5-year period (56).

One of the most controversial tax-related issues has been whether or not $R \& D$ tax credits and investment tax credits induce more investment. And, if the tax credits encourage investment, does this additional investment activity have any measurable effect on the U.S. economy? Following the introduction of the $R \& D$ tax credit, private $R \& D$ spending doubled from 1980 to 1986, amounting to nearly $\$ 60$ billion (45).

The R\&D tax credit remains controversial to a Congress constantly faced with a budget deficit. The total amount of revenue lost as a result of the subsidy was approximately $\$ 700$ million in 1985 (56) and as high as \$1.8 billion in 1989 (53). The Treasury Department projected that a permanent extension of the credit would reduce Federal revenues by $\$ 500$ million in fiscal year 1992,\$1 billion in 1993, $\$ 1.3$ billion in 1991, $\$ 1.6$ billion in 1995, and $\$ 1.8$ billion in 1996 (21). Estimates on the effect of the credit indicate that between $\$ 0.35$ and $\$ 0.99$ of additional $R \& D$ spending is generated for every dollar not collected in taxes. The main obstacle to the enactment of a permanent $R \& D$ tax credit is that it is very difficult to measure its effectiveness. And, although available since 1981, the $R \& D$ tax credit is not a permanent part of the tax code. Most recently it was extended through December 31, 1991, by the Omnibus Budget Reconciliation Act of 1990. Thus, companies are unable to take full advantage of the program because of the uncertainties. Despite the obvious popularity of the $R \& D$ tax credit, Congress has not yet made it a permanent part of the tax code. Many biotechnology companies feel that a permanent $R \& D$ tax credit would allow companies to plan, rather than to guess, what their financial commitments will be when investing in long-term, high-risk endeavors (9). The President's budget request for fiscal year 1992 included a provision to make the credit permanent and expand it to cover 100 percent of applicable research expenses.

\section{Tax Credits and the Orphan Drug Act}

Prior to 1983, U.S. pharmaceutical companies had little incentive to invest in developing drugs likely to yield only limited financial profit. Small biotechnology companies developing innovative new techniques were even less likely to invest any of their limited $R \& D$ budgets in any potentially unprofitable human therapeutic. Drugs available or to be made available for such rare afflictions as Huntington's disease, that affect only a small population, are commonly known as "orphan drugs" (see ch. 5 for further discussion of orphan drugs). In 1983, Congress amended the Federal Food, Drug, and Cosmetics Act with the Orphan Drug Act (Public Law 97-414) to provide incentives for developing drugs for rare diseases that would otherwise not be developed. A 50-percent tax credit for the cost of conducting clinical trials and 7-year market exclusivity were the key incentives provided in the act. The 7-year market exclusivity provision of the act was designed to protect companies selling drugs that were ineligible for product or use patents, were off patent, or had little patent term outstanding. The act has been amended twice, and there is momentum in the direction of another amendment.

A 1984 amendment (Public Law 98-551) defines a rare disease or condition as that which affects fewer than 200,000 persons in the United States--or more than 200,000 persons when it is clear that the cost of developing the drug will not be recovered by sales of the drug in the United States. A 1985 amendment (Public Law 99-91) authorizes 7 years of exclusive marketing approval for all orphan drugs, regardless of their patentability, with the intention of encouraging private pharmaceutical companies to invest more in orphan drug development.

In late 1990, Congress approved a measure that would tighten the requirements under which companies will be eligible for this 7-year market exclusivity-withdrawing orphan drug status for drugs when the patient population grows beyond 200,000 . This provision came amidst charges that some companies 
were earning unexpectedly high profits from the sale of orphan drugs. The House-approved bill also would allow more than one company to market different versions of a drug granted orphan status in instances where the companies developed the drug simultaneously. A similar version of the bill passed the Senate in fall 1990 but was vetoed by the President in December 1990.

\section{Amortization of Goodwill}

If company $\mathrm{A}$ has tangible assets valued at $\$ 2$ million and company $B$ is willing to pay $\$ 3$ million to acquire company $A$, the excess $\$ 1$ million company $B$ is willing to pay is treated as an intangible asset, or goodwill, on company B's balance sheet. Goodwill is generally understood to represent the reputation of the firm and the continuing loyalty of their customers. Because this intangible asset has no independent market or liquidation value, generally accepted accounting principles promulgated by the Financial Accounting Standards Board require that goodwill (the differential between the purchase price of an acquired company and its book value) be amortized through their earnings stream over a period of time. Some analysts believe this requirement hurts the competitive status of American companies wanting to acquire firms (23). These analysts believe it penalizes companies by lowering their earnings enough to upset Wall Street. This is particularly true since there is no tax deduction for the writeoff of goodwill. Thus, earnings are penalized for the total amount of the goodwill writeoff rather than the tax-effected amount of the writeoff (26). This contrasts with the rules in England. A British firm, for example, can write-off goodwill immediately and get a tax deduction. Participants at a September 1990 OTA workshop on financing biotechnology, raised the concern that the current requirement, that goodwill be amortized, could lead to the sale of major assets overseas.

\section{SUMMARY}

Commercial activity in biotechnology in the United States has led the world because of excellent science and the ability of entrepreneurs to finance their ideas. The U.S. venture capital pool is unparalleled, and the magnitude of the federally funded research base that fuels the DBC research agenda is unique. Despite long delays in product development and considerable regulatory hurdles, start-up firms have been able to raise cash in the initial stages of operation. While the venture community has become more conservative in where it chooses to invest, there appears to remain viable opportunities for entrepreneurs with good ideas. Where there is a choke point, however, is in the ability of start-up companies to move forward into development, testing, and marketing of their products-the expensive part of the process. As much as $\$ 30$ billion may be needed just to develop the 100 biotechnology products currently in human clinical trials.

Some private firms are caught pre-public, as the public market is less likely to play the role of risk-taker since Black M onday. This has left most firms cash poor and unable to move into development. The companies fortunate enough to have gone public well before 1987 are, on average, able to generate cash when needed through limited partnerships, secondary public offerings, and strategic alliances. The top 20 firms will most likely remain stable, surrounded by an ever-changing backdrop of DBCs. Start-ups will continue to appear, but these companies will likely face the reality of merger or acquisition. Only a dramatic surge in the public markets will dislodge some of these companies from this fate.

Consolidation of existing companies is inevitable and most likely necessary. What concerns some observers is the role that foreign acquisition and investment will play in the fate of many of these vulnerable fins. Although it is true that the amount of joint activity between U.S. firms and foreign firms has been on the rise, much of this activity is necessary to conduct business in a global market, i.e., licensing, marketing, and co-marketing agreements. To date, there is insufficient evidence to state that U.S. commercial interests in biotechnology are currently threatened by foreign competition. Acquisition is a costly and risky means to acquire a technology, and most corporations have avoided this mechanism. As U.S. DBCs move closer to product reality, however, foreign corporations with large pools of cash may be more willing to pursue acquisition to obtain and ensure manufacturing rights. Executives of DBCs tend to feel that manufacturing rights will be crucial for the viability of their companies.

While some foreign firms-usually the big companies such as Kirin, Ciba-Geigy, HoffmannLaRoche, and Hoechst-are actively investing in 
U.S. DBCs, so are American firms such as Lilly, Monsanto, J ohnson \& J ohnson, and Eastman Kodak. United States corporations are slightly disadvantaged when it comes to acquisition, however, because American accounting and tax practices prevent them from deducting the full expense of acquisition in the year it occurs. Some analysts feel this practice allows foreign corporations to move more rapidly toward acquisition. In addition, the relatively high cost of capital in the United States makes it harder for U.S. corporations to save the sums needed for acquisition and for DBCs to raise the cash needed to take biotechnol ogy products to market.

\section{CHAPTER 4 REFERENCES}

1. Arthur Young High-Technology Group, Biotech 89: Commercialization (New York, NY: Mary Ann Liebert, Inc., 1988).

2. Bank of England, "Venture Capital in the United Kingdom," Bank of England Quarterly Bulletin, vol. 30, No. 1, February 1990.

3. Barinaga, M., "Biotechnology on the Auction Block," Science, vol. 247, No. 4945, Feb. 23, 1990.

4. Behrens, M. K., comments during workshop on "Financial I ssues Affecting Biotechnology: At Home and Abroad," U.S. Congress, Office of Technology Assessment, Sept. 13, 1990.

5. Behrens, M.K., partner, Robertson, Coleman, \& Stephens, personal communication, November 1990.

6. Beier, D., vice president, governmental affairs, Genentech, personal communication, November 1990.

7. Blinder, A.S., "101 More Reasons Not To Cut Capital-Gains Taxes, "Business Week, Sept. 4,1989.

8. Caulder, J ., president, Mycogen, personal communication, 1989.

9. Caulder, J ., president, Mycogen, testimony at hearings before the House Subcommittee on Science, Research, and Technology, Stimulating Investment in Research and Development, May 18, 1989 (Washington, DC: U.S. Government Printing Office, 1989).

10. Caulder, J., president, Mycogen, personal communication, November 1990.

11. Chase, M., "Genentech Plans To Sell 60 Percent Stake to Roche Holdings for \$2.1 Billion, "Wall Street Journal, Feb. 5, 1990, p. A3.

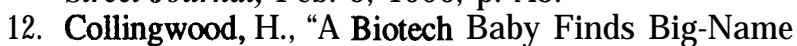
Backing," Business Week, J uly 16, 1990.

13. Collingwood, H., "Splicing Together Biotech Firms," Business Week, vol. 3171, July 30, 1990, p. 28.

14. Crispin, J .E., and Brereton, J ., "The Role of Venture Capital in High-Technology Finance," Utah Eco- nomic and Business Review, vol. 48, No. 5, May 1988, pp. 1-13.

15. Curran, J.J., "What Foreigners Will Buy Next," Fortune, vol.119, No. 4, Feb. 13,1989, pp. 94-98.

16. Drake, P., comments during workshop on "Financial I ssues Affecting Biotechnology: At Home and Abroad," U.S. Congress, Office of Technology Assessment, Sept. 13, 1990.

17. Economist, "The Money-Guzzling Genius of Biotechnology," vol. 311, No. 7602, May 13, 1989, pp. 69-70.

18. Ernst \& Young, BioFinancials 1989 (San Francisco, CA: 1989).

19. Ernst \& Young, Biotech 91: A Changing Environment (San Francisco, CA: 1990).

20. F-D-C Reports, "Biotech Industry Funding From Private Placements May Reach $\$ 300$ Million," Dec. 10, 1990, T\&G-8.

21. F-D-C Reports, "R\&D Tax Credit Would Be Permanent and Extended To Cover 100 Percent of Applicable Research in Bush Budget Proposal: Administration Cites Weakened Incentives," Feb. 11, 1991, p. 7.

22. Federal Reserve Bank of New York, "Explaining International Differences in the Cost of Capital," FRBNY Quarterly Review, vol. 14, Summer 1989, pp. 7-28.

23. Frank, F., comments during workshop on "Financial I ssues Affecting Biotechnology: At Home and Abroad," U.S. Congress, Office of Technology Assessment, Sept. 13, 1990.

24. Genetic Engineering News, "GEN Guide to Venture Capital Companies With Interests in Biotechnology," May 1989.

25. Gilbert, D., Montgomery Securities, personal communication, 1989.

26. Glick, M., Genentech, personal communication, November 1990.

27. Green, G., "Biotechnology in Australia-1990, The Genetic Engineer \& Biotechnologist, vol. 10, No. 2, May/) une 1990 (GB Biotechnology LKt, Swansea, Great Britain).

28. Henderson, Y. K., "The Emergence of the Venture Capital Industry," New England Economic Review, vol. J I, J uly-August 1989.

29. Hixson, H., Amgen, personal communication, 1989.

30. Kiely, T., "Venture Grows Up," Boston Magazine, J anuary 1989, pp. 41-49.

31. Klausner, A., 'An Analysis of Strategic Alliances in Biotechnology Between U.S. Firms and Those in Europe and J apan," contractor report prepared for the Office of Technology Assessment, August 1989.

32. Klausner, A., Domain Associates, written communication, December 1990.

33. Longstreet, D., president, Ortho Biotech, personal communication, February 1991. 
34. McMurtry, B.J., "Tax Policy Influence on Venture Capital," Technology and Economic Policy, R. Landau and D.W.J orgenson (eds.) (Cambridge, MA: Ballinger Publishing Group, 1986).

35. Morns, J.K. (cd.), Pratt's Guide to Venture Capital Sources, 12th ed. (Wellesley Hills, MA: Venture Economics, 1988).

36. Newman, A., "Managers Trim Biotech Holdings As Outlook Clouds," Wall Street Journal, Feb. 11, 1991.

37. Ooghe, H., Bekaert, A., and van den Bossche, P., "Venture Capital in the United States, Europe, and J apan," MIR, vol. 29, No. 1, 1989, pp. 29-45.

38. Palmer, E., "Antitrust, Capital Gains, and Research and Development Tax Benefits in Several Industrialized Nations, ' European Law Division, Law Library of Congress (Washington, DC, LL90-26, April 1990).

39. Peterson, T., and Armstrong, L., "Roche's Big Buy May Set Off a Shopping Frenzy," Business Week, vol. 3146, Feb. 19, 1990, p. 38.

40. Raines, L., director, governmental relations, Industrial Biotechnology Association, personal communication, November 1990.

41. Rathmann, G., Amgen, personal communication, 1990.

42. Salquist, R., Calgene, personal communication, 1989.

43. Samuelson, R.J ., ' "Bush's Capital Gains Obsession," Newsweek, Oct. 1, 1990, p. 32.

44. San Diego Business Journal, vol. 11, No. 27, J uly 2, 1990, p. 8.

45. SCRIP, No. 1526, J une 27, 1990, p. 18.

46. Shearson Lehman Hutton, Bio-Financials (New York, NY: J an. 11, 1990).

47. Shearson Lehman Hutton, Bio-Financials: Midyear Supplement (New York, NY: J uly 6, 1990).

48. Sterngold, J., "I apan Leading U.S. in Raising Capital for Corporations,' New York Times, Oct. 27, 1989, p. 1.
49. Swanson, R. A., remarks before the Vice President's Council on Competitiveness, February 1990.

50. Thayer, A.M., "Many Biotech Companies Enter '90s With Sharply Higher Revenues," Chemical and Engineering News, Apr. 2, 1990, pp. 9-11.

51. Tien, W., president, Development Center for Biotechnology, Taipai, Taiwan, Republic of China, presentation before U.S. Congress, Office of Technology Assessment, International Conference on Biotechnology in a Global E conomy, J uly 6, 1989.

52. U.S. Congress, General Accounting Office, Foreign Investment: Concerns in the Banking, Petroleum, Chemicals, and Biotechnology Sectors, GAO/ NSIAD-90-129 (Washington, DC: U.S. Government Printing Office, May 1990).

53. U.S. Congress, House of Representatives, Committee on Science, Space, and Technology, Subcommittee on Science, Research and Technology, Stimulating Investment in Research and Development, hearings May 18, 1989 (Washington, DC: U.S. Government Printing Office, 1989).

54. U.S. Congress, Office of Technology Assessment, New Developments in Biotechnology: U.S. Investment in Biotechnology, OTA-BA-360 (Washington, DC: U.S. Government Printing Office, J uly 1988).

55. U.S. Congress, Office of Technology Assessment, International Conference on Biotechnology in a Global Economy, J uly 6, 1989.

56. U.S. Congress, Office of Technology Assessment, Making Things Better: Competing in Manufacturing, OTA-ITE-443 (Washington, DC: U.S. Government Printing Office, March 1990).

57. U.S. Congress, Office of Technology Assessment, "Financial Issues Affecting Biotechnology: At Home and Abroad," transcript of a workshop held Sept. 13, 1990.

58. Webb, N., Hybridon, personal communication, 1989.

59. Wolnak, B., Wolnak Associates, personal communication, November 1990. 


\section{Chapter 5}

\section{The Pharmaceutical Industry}

"It has now been more than fifteen years since Robert Swanson, a young man who understood both finance and science, invited Herbert Boyer, a shy molecular biologist at the University of California, San Francisco, out for a beer. Swanson described his vision to Boyer: that the techniques and ideas that Boyer had devised for manipulating DNA could be translated into products at a private company yet to be established. As a result of that meeting, Genentech, the first well-known biotechnology corporation, was founded; Swanson and Boyer made their fortunes; and profound changes ensued in academic biomedical research, ' 


\section{Boxes}

Box

Page

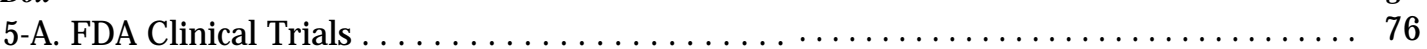

5 -B. Types of Biotechnology Products in Development $\ldots \ldots \ldots \ldots \ldots \ldots \ldots \ldots \ldots$

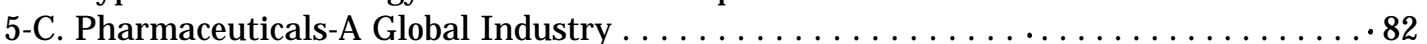

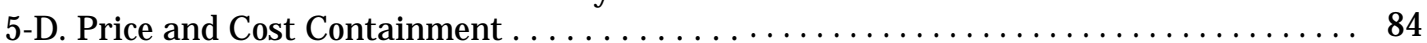

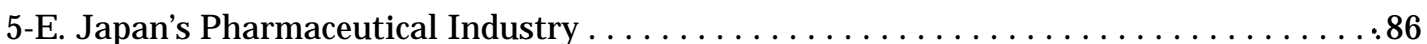

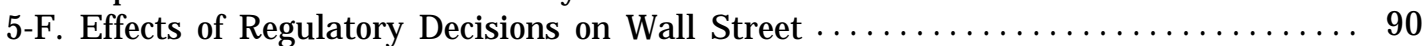

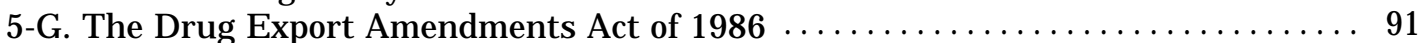

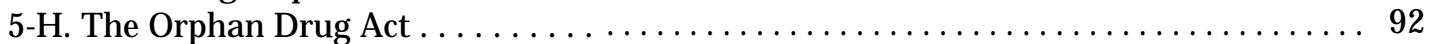

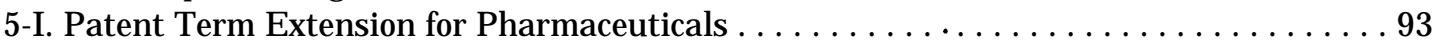

Tables

Table Page

5-1. Approved Biotechnology Drugs/Naccines $\ldots . \ldots \ldots \ldots \ldots \ldots \ldots \ldots \ldots \ldots . \ldots 7$

5-2. Conditions for Which Biotechnology-Derived Drugs Are Under Development . . 78

5-3. Testing for Additional Indications for Approved Drugs $\ldots \ldots \ldots \ldots \ldots \ldots \ldots . \ldots 78$

5-4. Marketing of Approved Biotechnology-Derived Drugs $\ldots \ldots \ldots \ldots \ldots \ldots \ldots \ldots . \ldots 1$

5-5. Company Rank by Pharmaceutical Sales $1989 \ldots \ldots \ldots \ldots \ldots \ldots \ldots \ldots \ldots \ldots \ldots . \ldots . \ldots \ldots$

5-6. Merger and Acquisition Activity in the Pharmaceutical Industry . . . . . . . . 87 


\section{INTRODUCTION}

The development of biotechnology-based pharmaceutical products is flourishing. Since the early 1970s, independent, dedicated biotechnology companies (DBCs) have been examining the technology's potential for commercial development, and in more recent years, the technology has diffused into research laboratories and the development processes of most major companies in the pharmaceutical industry. Currently, both dedicated bi otechnology companies and established, multinational pharmaceutical companies are using the tools and techniques of biotechnology in their drug discovery and development efforts.

Despite the strong barriers to entry, characteristic of the global pharmaceutical industry, there are many DBCs focusing on niche markets and developing biotechnology-based pharmaceutical products. Established pharmaceutical companies use biotechnology as a research tool and are increasingly developing in-house capabilities to complement their conventional research. Strategic alliances and mergers between major, multinational pharmaceutical companies use biotechnology as a research tool and DBCs allow both to compete in the industry and combine their strengths-the innovative technologies and products of the DBCs blended with the financial and marketing power and development and regulatory experience of the major companies.

This chapter examines dedicated biotechnology companies, specifically with respect to human therapeutics and the diffusion of biotechnology into established pharmaceutical companies. The chapter also discusses the dynamics and economics of the pharmaceutical industry as they influence the adoption and commercialization of biotechnology.

\section{RESEARCH AND DEVELOPMENT}

Pharmaceutical research and development $(R \& D)$ is a risky business. Scientifically, the research and discovery of new drugs is interdisciplinary, involving medicinal chemistry, molecular biology, biochemistry, physics, pharmacology, and other sciences and technologies. Biotechnology has proven to be a source of innovation in pharmaceutical
$R \& D$, contributing as both a production technology and a research tool. It is particularly important in drug discovery, as it enables scientists to study the molecular basis for disease and to design drugs that respond to a particular disease process. Once the drug discovery process is completed, the product development process and cycle are virtually the same for biotechnology-derived drugs and conventionally derived drugs. The development process is lengthy and tightly regulated, requiring significant investment in time and money (7). Drug development includes clinical research and trials and the completion of regulatory requirements.

\section{Drug Discovery}

Pharmaceutical research began as a chemical science, focusing on chemical structures and corresponding activity, dominated by medicinal and organic chemists. Little was known about the biology, biochemistry, and pharmacology of early products, and drug development in the days following World War II was speculative, based on massscreening of chemical compounds (56). Since then, the development of physiology, biochemistry, genetics, and other biological sciences-including biotechnology-has provided information at the molecular and cellular level. This has contributed to increased understanding of the relationships between chemical structure and biological activity

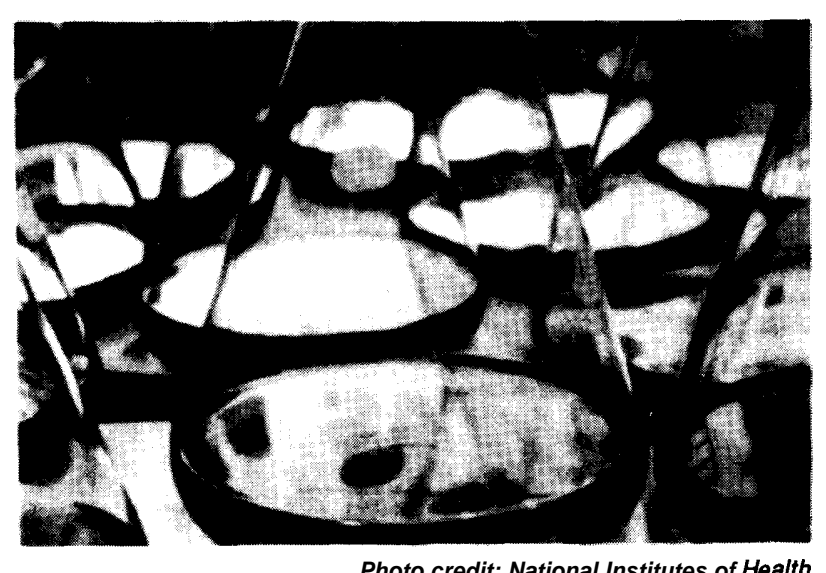

Flasks filled with microbes that have been genetically engineered to produce interferon. 
necessary for the discovery and development of new pharmaceutical products (14).

Pharmaceutical $R \& D$ is now an interdisciplinary process in which a rational approach to drug design, based on an improved understanding of the biological mechanisms of disease and drug interactions, is increasingly used to complement conventional chemical investigation. Biotechnology is likely to be the principal scientific driving force for the discovery of new drugs as we enter the 21st century, and the impact of biotechnology on the discovery of new therapeutic entities is difficult to underestimate (28).

\section{Conventional Screening}

Traditional approaches to discovering new drugs include continued research on existing products, the investigation and characterization of natural products, and the screening of synthetic chemicals and compounds for medicinal and pharmacologic activity (14). Existing drugs will always be researched for possible improvements, be they in terms of dosage, side effects, or increased activity. Screening compounds, both natural and synthetic, for biological and pharmacological activity is the conventional approach to drug discovery (55).

Thousands of natural and synthetic chemicals and compounds are screened every year for biological and pharmacological activity. Natural products have been used to devel op many new medicines. Examples include: molds, bacteria, plant products, venoms, and toxins. Penicillins were developed from penicillium mold, and other antibiotics, including streptomycin and bacitracin, were discovered by screening soil samples for biological activity. Plant products often have pharmacological activity and can be used to develop medicines. Morphine and heroin, for example, axe derived from the opium poppy. The study of venoms and toxins has led to muscle relaxants, anticoagulants, and ion-channel blockers. Screening and modification of synthetic chemicals have also resulted in the development of important drugs, including chemotherapeutic drugs, sulphonamide antibacterial, and nonsteroidal antiinflammatory drugs (14).

Screening is a massive, time-consuming, random, and very risky effort. About 10,000 compounds are screened every year, one or two of which will eventually be marketed as a drug (54). Despite the poor odds associated with conventional screening, these methods have worked well and provided the industry with many drugs. Since the 1950s and 1960s, the most fruitful period of drug discovery using conventional screening, this traditional route toward the discovery of new chemical entities has become more costly and has provided fewer drugs (39).

\section{Rational Drug Design}

Conventional screening is increasingly being augmented and complemented by biological sciences that allow a more mechanistic and physiological approach to drug discovery and design. This rational approach to drug design requires close collaboration between many scientific disciplines and is characteristic of drug development efforts of many biotechnology companies and, increasingly, established pharmaceutical companies.

Rational drug design depends on an increased knowledge of cellular mechanisms and control. This contributes not only to the discovery of new drugs, but also improves the understanding of the mode of action of existing drugs (25). Rational drug design focuses on understanding the physiological basis of disease; and research concentrates, in part, on the activity of enzymes, hormones and hormone receptors, cell replication and protein synthesis, and other molecular-level aspects of disease and drug treatment $(9,14)$. The techniques of biotechnology, specifically recombinant DNA (rDNA) and hybridoma technology, are important research tools for rational drug design. Biotechnology can provide information about both the state and mechanism of disease, allowing the discovery aspect of pharmaceutical research to be more specific and targeted. For an in-depth discussion of the use and potential of biotechnology for therapeutic development see OTA's 1988 report, U.S. Investment in Biotechnology (48).

The pharmaceutical industry uses biotechnology for both its products and techniques, and there axe two basic approaches to its use in drug development. First, biotechnology can be a production technology using rDNA techniques to manufacture otherwise unmakeable human proteins, such as human growth hormone. The majority of biotechnology-based drugs currently on the market are natural human proteins that, before rDNA, were not available in sufficient quantities to use as drugs. The second way biotechnology is used is in the rational design of synthetic molecules (33). An example is the use of 
biotechnologies to clone and express genes that produce receptors. These receptors are then used to screen for receptor-binding compounds that will either enhance or inhibit receptor-ligand performance. In this case, biotechnology is used to research the disease mechanism and to design drugs to interact in the disease process. The product ultimately derived from this discovery effort will generally be a synthesized chemical, but its discovery depended on biotechnologies (40). This exemplifies the use of biotechnology as a research tool.

Rational drug design has been made possible by the increase in information about the physiological mechanisms of disease--providing additional approaches (aside from conventional screening) to drug discovery. However, there is much more still unknown, and drug discovery remains highly speculative, risky, and uncertain.

\section{Drug Development}

Once drug discovery is complete, the devel opment process begins. This is a very lengthy, expensive, and tightly regulated process. Companies spend much of the product development time conducting clinical trials required to prove the safety, efficacy, and quality of the drug (see box 5-A) and waiting for Food and Drug Administration (FDA) review and approval. The actual drug development process, in terms of procedure, regulatory requirements, time, and expense, is very similar for biotechnology-derived drugs and conventional products. However, while the process and the issues are the same for both, the major competitive pharmaceutical companies have the resources, which most DBCs lack, to conduct clinical trials, research new products, and market existing products. Whereas some DBCs have funded and conducted the research and discovery portion independently, the expense, time requirements, and complicated regulatory process lead them to collaborate with established pharmaceutical companies to complete the actual clinical research and product development.

Product development time, for a specific product, has been estimated to be as long as 10 to 12 years (6). In estimating the cost of drug development, an attempt is made to include expenses for products and projects that are not successful and never reach the market. However, the actual cost for developing a new drug is not known and estimates vary.
In the United States, FDA regulates $R \& D$, testing, manufacturing, qual ity control, labeling, marketing, and postmarketing studies of drugs. Biotechnologyderived drugs must go through the same FDA process as conventional pharmaceuticals, however the actual products are evaluated by different divisions within FDA. Biotechnology-derived drugs, most often classified as biologics, are evaluated by the Center for Biologic Evaluation and Research; conventionally derived drugs are evaluated by the Center for Drug Evaluation and Research. FDA has made its intent to regulate the product, not the process, clear, and has said it sees no need to institute new procedures or requirements for new biotechnology products (46). FDA's final policy statement regarding biotechnology indicated that it would not classify products of rDNA or hybridoma technologies any differently from those produced by traditional techniques and that such products are already covered under existing statutory provisions and regulations for drugs and biologics for human use $(48,46)$.

Drug development requires time, financial resources, and regulatory expertise. DBCs have been extremely successful and innovative in the discovery phase but often lack the resources to independently develop the products. The majority of biotechnology derived drugs, both approved and in development, were discovered by DBCs and are being jointly developed with established pharmaceutical companies.

\section{BIOTECHNOLOGY-DERIVED DRUGS}

In 1982, the first biotechnology-based drug, recombinant human insulin, was approved in the United States by FDA. As of August 1991, 15 biotechnology-based drugs and vaccines were on the market (see table 5-I). The drugs are all large proteins which, before advances in biotechnology, were either not available at all, not available in large enough quantities, or not of sufficient purity for wide use as treatments. The exception, insulin, was available from pig and bovine pancreases.

Many new products are in the pipeline, and several are in the final stages of testing. According to the most recent survey of the Pharmaceutical Manufacturer\% Association (PMA), there are over 100 biotechnology drugs and vaccines in human testing for a variety of conditions (see 


\section{Box 5-A-FDA Clinical Trials}

In the United States, new drugs must be approved by the Food and Drug Administration (FDA). Conducting clinical trials and obtaining FDA approval is a rigorous process that can take as long as 10 to 12 years to complete. After completion of preclinical and clinical testing, companies may be required to conduct post-marketing surveillance. The human testing is done on both healthy and patient volunteers. Throughout the process, the drug companies work with FDA to design clinical trials and organize their material and studies. FDA uses expert advisory committees in addition to staff scientists to review new drugs. A brief discussion of the process follows.

Initially there is predinical testing that involves laboratory and animal testing to determine the compound's biological activity and safety. This stage takes approximately 1 to 2 years after which the sponsoring company applies for permission to test the compound in humans. The company files an Investigational New Drug (IND) application with FDA that provides information on drug composition, manufacturing data, data on experimental controls, results from laboratory and animal testing, intended procedures for obtaining the consent of subjects and protecting their rights, and an overall plan for human clinical studies. The FDA has 30 days in which to act on the IND application, after which the company can begin human clinical testing.

Human clinical testing is done in three phases, which can take up to 6 years or more to complete. Phase I studies involve safety and pharmacol ogical profiling of the drug. The studies are designed to determine safe dosage range, and how the drug is absorbed, distributed, metabolized, and excreted, as well as its duration in the body. Typically, a small number of healthy subjects, not patients, are involved in Phase I testing, which usually is completed within 1 year. Phase II testing consists of control led studies in an average of 200 to 300 patients to determine the drug's effectiveness. Additional safety studies are also done on both animals and humans. Phase II testing usually requires 2 to 4 years to complete. Phase III studies require a large number of patients: from 1,000 to 3,000 volunteers are involved. Practicing physicians administer the drug to patients suffering from the indication for which the drug is being tested. Phase III studies are designed to confirm Phase II efficacy studies and identify adverse reactions. These usually take about 3 years to complete.

After the successful completion of the three phases of clinical testing, the sponsoring company submits a New Drug Application (NDA), or a Product License Application (PLA) (in the case of biologic), to FDA that includes all information collected during the trials. The information not only includes all preclinical and clinical test results on the drug's safety and efficacy, but also includes the drug's chemical structure and formulation, manufacturing, production, and labeling details. Average NDA approval time runs 2 to 3 years. After NDA approval is given, companies maintain contact with FDA and provide information on adverse reactions, production, quality control, and distribution records, Post-marketing surveillance is sometimes formalized in what are known as Phase IV studies, which provide the information from studies on the long-term effects fo the drug's use to FDA.

FDA instituted anew process, known as the Treatment IND process, in 1989 for drugs used for lifethreatening and severely debilitating diseases, the goal being to reduce approval time. The Treatment IND process allows for broader access to experimental drugs and allows a company to recoup some of its investment while continuing clinical investigation and preparation of its NDA or PLA. Under the plan, if a drug shows particular promise after Phase I clinical trials, then Phase II and Phase III maybe combined, saving several years time.

SOURCE: Pharmaceutical Manufacturers Association, 1990.

table 5-2). Over half of the drugs in development target cancer or cancer-related conditions, and vaccine research is heavily concentrated on finding a vaccine to combat acquired immunodeficiency syndrome (AIDS) (32). A brief description of the types of products in development (see box 5-B) reveals the potential variety of biotechnology-derived therapeutics. Both biotechnology companies and established pharmaceutical companies are involved in the research and development of these products, indicating a commitment by both to use the latest available technology.
Several approved drugs are replacement therapies for patients who lack the biochemical capability to produce or process the necessary proteins. These include insulin for diabetics and human growth hormone for children with growth deficiency. Tissue plasminogen activator (tPA) is used to treat acute myocardial infarction and works to dissolve blood clots, which are causative agents for many heart attacks (56). Other products are approved for specific conditions, and research is continuing to find new indications for their use. Alpha interferon is used to treat hairy cell leukemia, AIDS-related 
Table 5-I-Approved Biotechnology Drugs/Vaccines

\begin{tabular}{|c|c|c|c|c|c|}
\hline Product name & Company & Indication & U.S. approval & $\begin{array}{c}\text { Revenues" } \\
1989\end{array}$ & $\begin{array}{c}\text { Revenues" } \\
1990\end{array}$ \\
\hline $\begin{array}{l}\text { Epogen (tin) } \\
\text { Epoetin Alfa }\end{array}$ & $\begin{array}{l}\text { Amgen } \\
\text { Thousand Oaks, CA }\end{array}$ & Dialysis anemia & June 1989 & 95 & 300 \\
\hline $\begin{array}{l}\text { Neupogen }{ }^{\star *} \\
\text { Granulocyte colony } \\
\text { stimulating factor } \\
\text { G-CSF }\end{array}$ & $\begin{array}{l}\text { Amgen } \\
\text { Thousand Oaks, CA }\end{array}$ & $\begin{array}{l}\text { Chemotherapy } \\
\text { effects }\end{array}$ & February 1991 & NA & NA \\
\hline $\begin{array}{l}\text { Humatrope }(\mathbf{R})^{\star} \text {, } \\
\text { Somatotropin } \\
\text { rDNA origin for } \\
\text { injection }\end{array}$ & $\begin{array}{l}\text { Eli Lilly } \\
\text { Indianapolis, IN }\end{array}$ & $\begin{array}{l}\text { Human growth } \\
\text { hormone deficiency } \\
\text { in children }\end{array}$ & March 1987 & 40 & 50 \\
\hline $\begin{array}{l}\text { Humulin(R) } \\
\text { Human insulin } \\
\text { rDNA origin }\end{array}$ & $\begin{array}{l}\text { Eli Lilly } \\
\text { Indianapolis, IN }\end{array}$ & Diabetes & October 1982 & 200 & 250 \\
\hline $\begin{array}{l}\text { Actimmune } \\
\text { Interferon gamma 1-b }\end{array}$ & $\begin{array}{l}\text { Genentech } \\
\text { San Francisco, CA }\end{array}$ & $\begin{array}{l}\text { Infection/chronic } \\
\text { granulomatous disease }\end{array}$ & December 1990 & NA & NA \\
\hline $\begin{array}{l}\text { Activase }(\mathbf{R}) \\
\text { Alteplase, rDNA origin }\end{array}$ & $\begin{array}{l}\text { Genentech } \\
\text { San Francisco, CA }\end{array}$ & $\begin{array}{l}\text { Acute myocardial } \\
\text { infarction }\end{array}$ & November 1987 & 175 & 200 \\
\hline $\begin{array}{l}\text { Protropin }(\mathbf{R})^{\star \star} \\
\text { Somatrem for injection }\end{array}$ & $\begin{array}{l}\text { Genentech } \\
\text { San Francisco, CA }\end{array}$ & $\begin{array}{l}\text { Human growth } \\
\text { hormone deficiency } \\
\text { in children }\end{array}$ & October 1985 & 100 & 120 \\
\hline $\begin{array}{l}\text { Roferon }(\mathrm{R})-\mathrm{A}^{\star *} \\
\text { Interferon alfa-2a } \\
\text { (recombinant/Roche) }\end{array}$ & $\begin{array}{l}\text { Hoffmann-La Roche } \\
\text { Nutley, NJ }\end{array}$ & $\begin{array}{l}\text { Hairy cell } \\
\text { leukemia } \\
\text { AIDS-related } \\
\text { Kaposi's sarcoma }\end{array}$ & $\begin{array}{l}\text { June } 1986 \\
\text { November } 1988\end{array}$ & 40 & 60 \\
\hline $\begin{array}{l}\text { Leukine }^{\star *} \\
\text { Granulocyte microphage } \\
\text { colony stimulating } \\
\text { factor GM-CSF }\end{array}$ & $\begin{array}{l}\text { Immunex } \\
\text { Seattle, WA }\end{array}$ & $\begin{array}{l}\text { Infection related to } \\
\text { bone marrow transplant }\end{array}$ & March 1991 & NA & NA \\
\hline $\begin{array}{l}\text { Recombivax HB (R) } \\
\text { Hepatitis B vaccine } \\
\text { (recombinant MSD) }\end{array}$ & $\begin{array}{l}\text { Merck } \\
\text { Rahway, NJ }\end{array}$ & $\begin{array}{l}\text { Hepatitis B } \\
\text { prevention }\end{array}$ & July 1986 & 100 & 110 \\
\hline $\begin{array}{l}\text { Orthoclone OKT(R)3 } \\
\text { Muromonab CD3 }\end{array}$ & $\begin{array}{l}\text { Ortho Biotech } \\
\text { Raritan, NJ }\end{array}$ & $\begin{array}{l}\text { Kidney transplant } \\
\text { rejection }\end{array}$ & June 1986 & 30 & 35 \\
\hline $\begin{array}{l}\text { Procrit }^{\star \star} \\
\text { Erythropoietin }\end{array}$ & $\begin{array}{l}\text { Ortho Biotech } \\
\text { Raritan, NJ }\end{array}$ & $\begin{array}{l}\text { AIDS-related } \\
\text { anemia } \\
\text { Pre-dialysis anemia }\end{array}$ & December 1990 & NA & NA \\
\hline $\begin{array}{l}\text { HibTiter (tin) } \\
\text { Haemophilus B } \\
\text { conjugate vaccine }\end{array}$ & $\begin{array}{l}\text { Praxis Biologics } \\
\text { Rochester, NY }\end{array}$ & $\begin{array}{l}\text { Haemophilus } \\
\text { influenza type B }\end{array}$ & December 1988 & 10 & 30 \\
\hline \multirow[t]{3}{*}{$\begin{array}{l}\text { Intron }(\mathbf{R}) A^{\star *} \\
\text { Interferon-alpha2b }\end{array}$} & $\begin{array}{l}\text { Schering-Plough } \\
\text { Madison, NJ }\end{array}$ & $\begin{array}{l}\text { Hairy cell } \\
\text { leukemia }\end{array}$ & June 1986 & 60 & 80 \\
\hline & & $\begin{array}{l}\text { Genital warts } \\
\text { AIDS-related } \\
\text { Kaposi's sarcoma }\end{array}$ & $\begin{array}{l}\text { June } 1988 \\
\text { November } 1988\end{array}$ & & \\
\hline & & Hepatitis C & February 1991 & NA & NA \\
\hline $\begin{array}{l}\text { Energix-B } \\
\text { Hepatitis B vaccine } \\
\text { (recombinant) }\end{array}$ & $\begin{array}{l}\text { SmithKline Beecham } \\
\text { Philadelphia, PA }\end{array}$ & Hepatitis B & September 1989 & 20 & 30 \\
\hline \multicolumn{6}{|c|}{$\begin{array}{l}\text { Estimated U.S. revenues in millions of dollars } \\
{ }^{*} \text { Orphan Drug } \\
\text { NA = not applicable }\end{array}$} \\
\hline
\end{tabular}


Table 5-2-Conditions for Which BiotechnologyDerived Drugs Are Under Development

\begin{tabular}{l}
\hline AIDS and AIDS Related Complex (ARC) \\
Chemotherapy effects \\
Leukemia \\
Aplastic anemia \\
Cancer \\
Bone marrow transplant \\
Hematologic neoplasms \\
Neutropenia \\
Myelodysplastic syndrome \\
Infectious diseases \\
Thermal injury \\
Reperfusion injury related to myocardial infarction and renal \\
transplantation \\
Anemia secondary to kidney disease, AIDS, premature infants, \\
chemotherapy, rheumatoid arthritis \\
Autologous transfusion \\
Hemophilia \\
Corneal transplants \\
Wound healing \\
Chronic soft tissue ulcers \\
Diabetes \\
Wasting syndromes \\
Nutritional and growth disorders \\
Venous stasis \\
Turner's syndrome \\
Burns \\
Venereal warts \\
Herpes simplex 2 \\
Hepatitis-B, non-A, non-B hepatitis \\
Hypertension \\
Platelet deficiencies \\
Septic shock \\
Pseudomonas infections \\
Heart and liver transplant rejection \\
Malaria \\
Cervical ripening to facilitate childbirth in women experiencing \\
certain implications \\
Myocardial infarction \\
Deep vein thrombosis \\
Acute stroke \\
Pulmonary embolism \\
SOURCE: Pharmaceutical Manufacturers Association, Biotechnology \\
Medicines in Development, 1990 Annual Survey. \\
The
\end{tabular}

Kaposi's sarcoma, genital warts, and Hepatitis C. Erythropoietin (EPO) is used to treat anemia associated with end-stage renal disease and AIDS. Many of these drugs also have other potential uses for which they are being tested (see table 5-3) and, if approved, will increase their potential market values.

The market for many biotechnology-derived drugs is potentially large. Much of this drug development is market-driven, with a defined and expectant market. Examples include erythropoietin, human growth hormone, insulin, and tissue plasminogen activator, as well as recombinant Hepatitis B vaccines. All have performed well and are significant and much needed new drugs. Some signifi-
Table 5-3-Testing for Additional Indications for Approved Drugs

\begin{tabular}{|c|c|c|}
\hline Drug & Approved use & Additional indications \\
\hline EPO & $\begin{array}{l}\text { Dialysis anemia, } \\
\text { AIDS related } \\
\text { anemia }\end{array}$ & $\begin{array}{l}\text { Autologous transfusion, } \\
\text { Premature infants, } \\
\text { Rheumatoid arthritis, } \\
\text { chemotherapy, pre- and } \\
\text { post-surgical use }\end{array}$ \\
\hline tPA & $\begin{array}{l}\text { Acute myocardial } \\
\text { infarction }\end{array}$ & $\begin{array}{l}\text { Deep vein thrombosis, } \\
\text { acute stroke, pulmonary } \\
\text { embolism }\end{array}$ \\
\hline $\begin{array}{l}\text { Interferon } \\
\text { alpha-2a }\end{array}$ & $\begin{array}{l}\text { Hairy cell leukemia, } \\
\text { AIDS-related } \\
\text { Kaposi's } \\
\text { Sarcoma, Hepatitis } \\
\text { C }\end{array}$ & $\begin{array}{l}\text { Cancer, infectious disease, } \\
\text { Genital herpes, colorectal } \\
\text { cancer, Chronic and acute } \\
\text { hepatitis B, Chronic } \\
\text { myelogenous leukemia } \\
\text { gastric Malignancies, HIV } \\
\text { positive ARC, AIDS }\end{array}$ \\
\hline $\begin{array}{l}\text { Interferon } \\
\text { alpha } 2 b\end{array}$ & $\begin{array}{l}\text { Hairy cell leukemia, } \\
\text { Genital warts, } \\
\text { AIDS-related } \\
\text { Kaposi's } \\
\text { sarcoma }\end{array}$ & $\begin{array}{l}\text { Genital herpes, superficial } \\
\text { bladder cancer, basal cell } \\
\text { carcinoma, chronic and } \\
\text { acute hepatitis B, non-A, } \\
\text { and non-B hepatitis, delta } \\
\text { hepatitis, chronic } \\
\text { myelogenous leukemia HIV }\end{array}$ \\
\hline
\end{tabular}

cantly smaller development is more technologydriven, with a less defined market opportunity (56). An example is alpha interferon, which appeared to be a promising treatment for a variety of diseases because of its antiviral activity. Before biotechnology, it was not possible to isolate enough natural alpha interferon to conduct research to determine its biological activities and potential therapeutic benefits. Using rDNA techniques, alpha interferon is now mass-produced and research is continuing. As research and clinical trials have progressed, however, it has become obvious that much more must be learned about the drug's activity and mechanism of action, with respect to disease, before its use and effectiveness can be better defined.

Interleukin II (several different interleukins, at least 10, have been identified) is another example of a naturally occurring immune system protein with somewhat uncertain actions that is, however, potentially effective in the treatment of cancer (28). Once again, neither the market nor the drug's mechanism of action is as yet particularly well defined, thus its ultimate marketplace success is unpredictable. It is important to differentiate between these drugs (interferon, interleukin, tumor necrosis factor, and others), now being researched, whose development is more technology-driven, and other biotechnology drugs 


\section{Box 5-B-Types of Biotechnology Products in Development}

According to a 1990 Pharmaceutical Manufacturers Association survey of biotechnology products in development, PMA member companies have over 100 new biotechnology-derived drugs and vaccines in human clinical testing. Many of the products are being developed by multiple companies, and they can be placed in several defined categories. Research continues on several of the already approved products, including erythropoietin, tissue plasminogen activator, growth hormone, and interferon. A brief description of the other types of products in development follows.

Seven different Colony Stimulating Factors are being developed to treat white blood cell disorders including: some cancers, AIDS, aplastic anemia, bone marrow transplants, neutropenia (a condition characterized by a decrease in the number of neutrophilic leukocytes in the blood), and thermal injury. These products stimulate bone marrow to increase blood cell production and restore white cell counts.

Two companies are competing in the development of Superoxide Dismutase indicated for the treatment of conditions related to myocardial infarction and renal transplantation, as well as oxygen toxicity in premature infants.

Hemophiliacs lack the blood clotting protein Factor VIII and are susceptible to severe, life-threatening internal bleeding. Factor VIII can be genetically engineered, resulting in a pure protein in sufficient quantities for treatment. Two companies have applications submitted to the Food and Drug Administration (FDA) and are awaiting final marketing approval.

Growth Factors regulate cell proliferation, function, and differentiation. There are several different types of growth factors that are involved indifferent cellular processes and operate in distinct cells. Several growth factors, including epidermal growth factor, transforming growth factor, fibroblast growth factor, and insulin-like growth factor, are being developed by companies to treat a variety of conditions. Growth factors have many potential uses: including wound healing and the treatment of diabetes, growth disorders, ulcers, wounds, and transplants.

Interleukin is a natural substance that seems to have a wide potential variety of uses but is poorly understood. Interleukins appear to be useful in treating disorders of the immune system. Seven companies have one form of Interleukin or another in clinical testing. Recently, Cetus' Proleukin (interleukin-2) New Drug Application was turned down by FDA. FDA requested more information and additional testing to determine subsets of kidney cancer patients that will benefit from Proleukin treatment. Many of the indications for which interleukins are being tested have no alternative treatment, and thus, interleukin, while mechanistically poorly understood, is the only potential therapeutic treatment.

Monoclinal antibodies are protein molecules produced by white blood cells that can recognize and target foreign matter (antigens) in the cells. As such, there is potential for monoclonal antibodies to be able to target the delivery of drugs to particular cells on the basis of antigen recognition. One monoclinal antibody-based therapeutic, Ortho's Orthoclone OKT-3, is available on the market for treatment of kidney transplant rejection. Eighteen companies have other monoclinal antibody-based therapeutics in clinical trials for a variety of indications, including: treatment of graft-host disease, cancer and, septic shock, as well as prevention of blood clots, pseudomonas infections, rheumatoid arthritis, and diabetes. Centocor's Centoxin and Xoma's Xomen-E5 are both awaiting approval for the treatment of septic shock, and the two companies are already engaged in a patent dispute. A large market is anticipated for these two products in particular. As with interferon and interleukins, the market potential for monoclinal antibodies is promising but somewhat unclear.

Three companies are testing Tumor Necrosis Factor (TNF) for the treatment of cancer, and all are in early stages of clinical testing. TNF is a cellular messenger involved in the triggering of immune defenses. It damages tumor-related blood vessels and interferes with the blood supply and nourishment of the tumor. Again, research continues in efforts to determine exact mechanisms of action, and market potential at this point is relatively unknown as efficacy studies are continuing.

Research and early clinical testing on Recombinant Soluble CD4s for the treatment of AIDS are being conducted by several companies. CD4s are cell surface receptors believed to be involved with the AIDS virus' (HIV) cell surface binding. Research concentrates on creating an analog to the naturally occurring CD4 receptor that will bind to HIV and prevent it from binding to the cell receptor, thus inactivating the virus. CD4 research represents just one use of biotechnology in AIDS research.

Vaccine research has been greatly enhanced with the advent of biotechnology. Biotechnology allows for the design and production of subunit vaccines, which are much safer than conventional vaccines that incorporate the actual virus. Subunit vaccines are developed from the viral protein coat, which by itself is incapable of reproducing and infecting the patient. Two vaccines for Hepatitis-B are available on the market, and testing is continuing on a variety of potential AIDS, malaria, and herpes vaccines. The market for these vaccines is very large, and if safe and effective vaccines are produced, their manufacturers should be richly rewarded by a most-welcoming marketplace.

Several other products are in early clinical testing as well. The market potential for many of the drugs described is very large. Infectious disease, cancer, and AIDS all lack effective conventional treatments. If the mechanism of action and the function of the naturally occurring proteins being studied for use as therapeutics are further delineated, a realistic market and demand can be estimated. Right now, some of the products being developed are being pulled by the market, while others are more research driven and their commercial potential is difficult to evaluate as further scientific understanding is still needed.

SOURCE: Pharmaceutical Manufacturers Association\% 1990. 


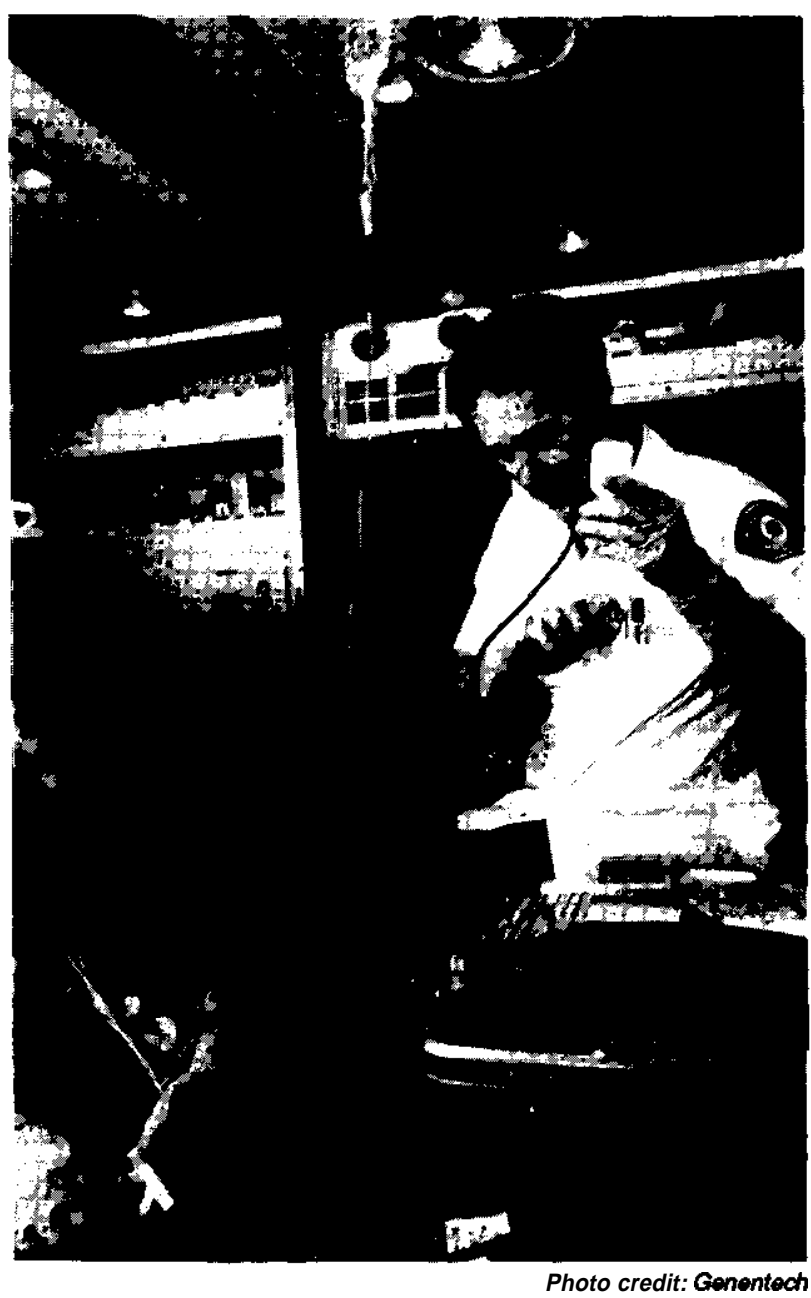

Since its approval in 1987, Genentech's Activase brand tPA has been used to treat heart attack victims.

(erythropoietin, insulin, and human growth hormone), whose development is both technology and market-driven. The questionable therapeutic potential of the former drugs, along with regulatory uncertainty, make it difficult to predict future sales and success of such biotechnology drugs. It is clear, however, that without biotechnology there would have been no opportunity to study many of these products.

Another way to describe the difference between products that are market-driven and those that are more technology-driven is to think in terms of diseases looking for drugs and drugs looking for diseases. In the case of tPA, human growth hormone, human insulin, and erythropoietin, the action of the protein was fairly well understood, allowing a focus on one or more specific diseases. In the case of Interleukin-2, Tumor Necrosis Factor (TNF), and the like, complicated, multiple biological effects have been exhibited, and researchers have had to search for relevant diseases to address (21).

Estimates of the market value of biotechnology products, including drugs, vaccines, and diagnostics, vary. Revenues in the United States from biotechnology-derived products were estimated to have been $\$ 1.5$ billion in 1989 and $\$ 2$ billion in 1990 $(50,51)$. Competitive factors, such as marketing, will play a large role in determining the market share of these drugs. Major, established pharmaceutical companies have primary marketing rights to 8 of the 15 approved biotechnology-derived therapeutics (see table 5-4), and they have licensed development and marketing rights to many of the products under devel opment. Almost all of the 15 approved drugs were invented by DBCs but needed the aid of larger companies' funding and expertise in the development, regulatory, and marketing stages. These agreements were necessitated by the fact that DBCs lacked sales forces in the early 1980s. Now that some companies have the resources to field sales representatives, there will likely be more products marketed, at least in part, by the companies that developed the products (2).

Amgen's EPO and granulocyte colony stimulating factor (G/CSF); Genentech's tPA, human growth hormone, and gamma interferon; Praxis Biologics'(now owned by Lederlee, a subsidiary of American Cyanamid) haemophilus influenza type $B$ vaccine; and Immunex's granulocyte microphage colony stimulating factor (GM/CSF) are, in part, marketed by the biotechnology companies that discovered them. These companies also have agreements with established companies for marketing their products outside of the United States and, in some cases, co-marketing in the United States. Eli Lilly, Hoffmann-La Roche, Merck, Ortho Biotech, Schering-Plough, and SmithKline Beecham--all established pharmaceutical companies-have licensed marketing rights to the other approved products from the DBCs that developed them.

These arrangements demonstrate the aforementioned dependence of biotechnol ogy companies on pharmaceutical companies for clinical development and marketing resources, as well as the established companies' commitments to making biotechnologyderived drugs part of their product portfolios. While 
Table 5-4-Marketing of Approved Biotechnology-Derived Drugs

\begin{tabular}{ll}
\hline Drug & Marketer \\
\hline Amgen-erythropoietin & $\begin{array}{l}\text { Amgen-United States for } \\
\text { treatment of dialysis anemia. } \\
\text { Ortho Biotech--United States } \\
\text { for nondialysis anemia, AIDS } \\
\text { related anemia and all other } \\
\text { indications awaiting FDA } \\
\text { approval. All ex-U.S. market } \\
\text { territories except Japan and } \\
\text { China for all indications. }\end{array}$ \\
& $\begin{array}{l}\text { Kirin Brewery Ltd.-Japan and } \\
\text { China for all indications. }\end{array}$ \\
Genentech-human growth & Eli Lilly \\
hormone & Eli Lilly \\
Genentech-human insulin & Genentech \\
Genentech-tPA & Boehringer-Ingelheim \\
Genentech-alpha interferon & Hoffmann-La Roche \\
Chiron-Hepatitis B vaccine & Merck \\
Ortho-OKT-3 & Ortho \\
Praxis Biologics-Haemophilus & Praxis (bought by Lederlee) \\
B vaccine & \\
\hline SOURCE: Office of Technology Assessment 1991
\end{tabular}

SOURCE: Office of Technology Assessment, 1991.

large companies have demonstrated successful re cords in conducting clinical trials with drugs discovered elsewhere (in DBCs, universities, and government laboratories for example), they have not historically been as successful in innovation (33). This may change as the established companies continue to develop in-house capabilities in biotechnology and to integrate biotechnology into their $R \& D$ programs, while, at the same time, complementing these efforts by collaboration with biotechnology companies.

\section{COMPETITIVE FACTORS}

Analysis of the diffusion of biotechnology into the development of human therapeutics and of the United States' competitiveness with respect to global commercialization of biotechnology requires an understanding of the structure and economics of the pharmaceutical industry. The pharmaceutical industry's approach to biotechnology is two-fold and includes efforts by both established pharmaceutical companies and biotechnology companies. Many industry characteristics serve both to determine an established firm's competitiveness and to bar entry by new firms. These include $R \& D$, marketing, and related costs. A description of the structure and economics of the pharmaceutical industry follows. This will illustrate the difficulties faced by small biotechnology companies and will serve to introduce and help explain the different approaches taken toward biotechnology by DBCs and established pharmaceutical companies.

\section{Industry Overview}

The modern pharmaceutical industry is a global, competitive, high-risk, and high-return industry that develops and sells innovative, highvalue-added products in a tightly regulated process. Competitiveness results from the successful introduction of new products, a dynamic process revolving around innovative $R \& D$ in the major global markets. Major industry players are financially strong, vertically integrated firms that control all aspects of the business, from $R \& D$, to manufacturing, to marketing (43). Many of the top firms, especially U. S., Swiss, and British firms, are multinational, with $R \& D$, manufacturing, and marketing operations spread around the globe (see box 5-C). There are also many companies that are more regional, maintaining fully integrated operations only in their home market. The top companies have financial, scientific, regulatory, and marketing resources, enabling them to compete worldwide on the basis of existing products and, importantly, new product introduction.

The industry has faced increased competitive pressure in recent years, leading to a wave of consolidation among established companies. DBCs are trying to enter a high-cost, high-risk, and very competitive industry characterized by lengthy product development schedules and delays between discovery and marketing, which postpone return on investment and require both time and money from participating companies. The costs, risks, and time frame required for drug development can act to bar new companies' entrance into the pharmaceutical industry and affect both DBCs and established pharmaceutical companies with respect to commercialization of biotechnology.

\section{Research and Development}

Success and competitiveness in the pharmaceutical business depends on research and new product development, followed by successful marketing. In 1990, the top U.S. pharmaceutical companies spent almost 17 percent of sales on $R \& D$, up from 12 percent in $1980(44,51)$. The proportion 


\section{Box 5-C-Pharmaceuticals-A Global Industry}

When Roche Holdings, Ltd. of Basel, Switzerland bought a 60-percent share of Genentech of San Francisco, $\mathrm{CA}$, concern was raised about the foreign acquisition of the United States' leading biotechnology company. However, Roche, although based in Switzerland, has more operations outside of its small home market than inside. Roche, like most of the top companies in the pharmaceutical industry, operates on a global basis, and has significant U.S. operations, including its wholly owned subsidiary, Hoffman LaRoche, in Nutley, NJ . The head of international drug research and development for Roche operates, not out of Basel, but in the United States, where Roche's worldwide $R \& D$ efforts are coordinated. So one may ask, should Roche really be viewed as a Swiss company? How much significance can be attached to the home country of any of the top pharmaceutical companies?

In 1989,4 of the top 10 ranked pharmaceutical companies in terms of sales (see table 5-5) were U.S. companies; two were German, two were Swiss, one was British, and the remaining, SmithKline Beecham, was both a U.S. and a British company created by the merger of SmithKline Beckman of the United States and Beecham of the United Kingdom. All of these companies operate on a global basis with fully integrated operations in countries outside of their home base. These companies do more than just sell their products on a global basis. They conduct R\&D, manufacture products, and employ local citizens around the world.

Glaxo, based in the United Kingdom, is the second-ranked company in terms of pharmaceutical sales and is a good example of a company that operates on a global basis. A look at Glaxo's worldwide R\&D personnel reveals significant operations outside of the United Kingdom, Glaxo has 3,529 R\&D staff in the United Kingdom, 740 in the United States, 353 in Italy, 210 in J apan, 185 in France, 134 in Switzerland, 70 in Canada, 68 in Germany, 54 in Spain, and 379 elsewhere in the world. Glaxo's manufacturing efforts are al so multinational, with plants in the U.K., Taiwan, Indonesia, Spain, Scotland, and another being developed in Singapore. Sales are undertaken on a global basis as well, and Glaxo controls approximately 3.5 percent of the world pharmaceutical market. Glaxo's U.S. operations are located in Research Triangle Park, NC, alongside Burroughs Wellcome, which is the U.S. subsidiary of The Wellcome Foundation Ltd. of the United Kingdom, and Ciba-Geigy, whose parent company is Swiss.

J ohnson \& J ohnson, a U.S. company based in New Brunswick NJ , has 175 operating units in 55 countries. Merck \& Co., Inc. of Rahway, NJ , has research labs in seven countries, experimental farms in six countries, and manufacturing plants in 18 countries. SmithKline Beecham, of Philadelphia, PA and the United Kingdom, has principal operating units in 28 countries. Syntex Corp. has its head office in Panama, its principal U.S. office in Palo Alto, CA, and production facilities in 11 countries. With an increasing percentage of sales overseas, companies are choosing more often to establish their own sales forces in foreign markets rather than licensing their products to foreign companies for royalties. Having operating units abroad supports companies' efforts to obtain foreign regulatory approval. Investment in pharmaceutical operations, including sales and R\&D, in J apan, which is well recognized as being a difficult market to enter, is rapidly increasing.

Conspicuously absent from this type and extent of global pursuit of pharmaceutical operations is J apan. J apan's major companies have begun to internationalize their operations, however, no J apanese companies currently have global representation comparable to the top U.S. and European companies.

SOURCES: Office of Technology Assessment, 1991, based on *'Glaxo Stresses International Presence," Scrip, No. 1558, Oct. 17, 1990, p. 14; "Roche's Worldwide Pharmaceutical R\&D Will Be Directed From U.S.," F-D-C Reports, Sept. 3, 1990, pp. T\&G 1-2; Merck\& Co., Inc. Annual Report 1989, SmithKline Beckman Annual Report 1989, Syntex Annual Report 1989; and M. Freudenheim, "Global Push for Profit at Johnson," New York Times, Aug. 3, 1990.

of income spent on R\&D has increased over the last 30 years, due, at least in part, to both the increased concern about the safety and efficacy of new drugs (which has promoted increased regulatory scrutiny) and the diminished returns from conventional screening techniques of drug discovery. The latter has resulted in increased time and effort for drug discovery and has led to the development and incorporation of new technologies (38). The spending ratio of $\mathrm{R} \& \mathrm{D}$ to sales is much higher for $\mathrm{DBCs}$, many of which do not currently have products on the market. According to a recent survey conducted by Ernst \& Young, therapeutically oriented biotechnology firms spend an average of 69 percent of revenues on $R \& D(13)$.

Pharmaceutical R\&D is very risky and companies are not guaranteed any return for several years, if at all. There is no assurance that any project will lead to a marketable product (42). Only 1 drug in 10 that enters clinical trials will make it to market, and only 
30 percent of marketed drugs recover their $R \& D$ costs (6). Due to the high risk involved, companies must have diverse $R \& D$ capabilities to ensure product differentiation $(16,1)$. In 1989, worldwide pharmaceutical $R \& D$ spending was estimated to be $\$ 16$ billion (37). The U.S. pharmaceutical industry invested an estimated $\$ 8.3$ billion on R\&D in 1990, up from $\$ 7.3$ billion in $1989(50,51)$. Seven countries-the United States, J apan, the United Kingdom, Germany, Switzerland, France, and Italyaccounted for approximately 80 percent of $R \& D$ spending (37).

Barriers to entry in the pharmaceutical industry related to $R \& D$ are not so much a result of the demands for resources to conduct research, but rather, for development. DBCs can usually secure enough initial or first-round financing to conduct at least the research part of the $R \& D$. With no sales contributing revenue, when full-scale development begins, many companies find themselves in financial straits with neither enough money nor experience to conduct the necessary clinical trials (47). At this point, many DBCs turn to pharmaceutical companies for joint product development.

\section{Marketing}

Marketing is an extremely expensive aspect of the pharmaceutical business. Companies have increased spending in recent years as they increased the size of their sales forces to cover world markets. Large, multinational companies have the resources to market their products in each major market. Foreign markets can differ from domestic markets in many ways, including cultural differences, distribution, pricing, payment, and regulatory requirements. Penetrating a foreign market often requires local expertise and local sales forces (22). Companies access foreign markets by licensing marketing rights to products, acquiring local companies, and/or locating new facilities abroad (I).

Drug companies tend to make the bulk of their profits from only a few products, which adds to the riskiness of $R \& D$ and the need to spread money into many areas and compounds with the expectation that only a few will bring big results. The dependence on a few products makes effective marketing, including advertising and promotion, important. Pharmaceutical companies market to doctors, which requires office visits by salespeople. In 1989, representatives of pharmaceutical companies made nearly 30 million visits to U.S. doctors' offices. Marketing costs

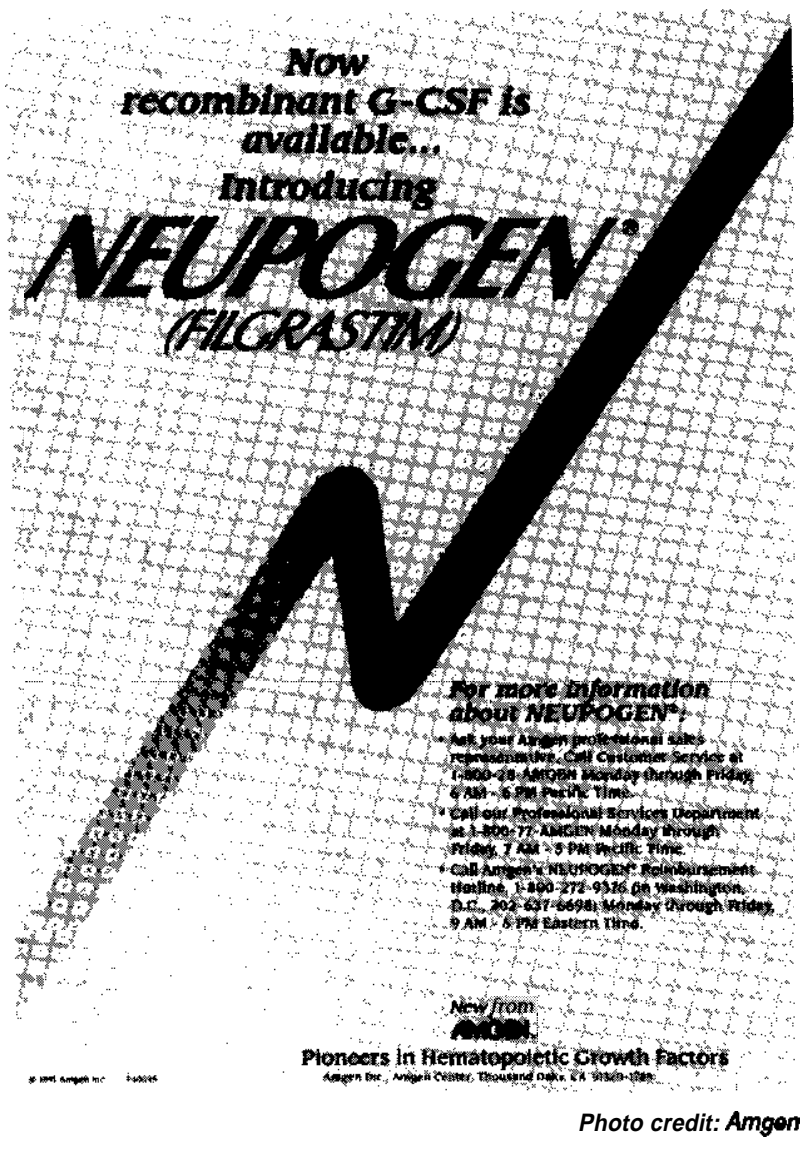

Advertisement for recombinant G-CSF.

represent about 24 percent of drug revenues, twice what was spent 10 years ago (11). The pharmaceutical industry, in the United States alone, spends over $\$ 5$ billion a year on promotional activities (49).

The industry is unique in that companies do not market directly to the consumer; rather, there is an indirect relationship between the company, the prescriber (the doctor), and the payer (patient or third party.) The industry markets to hospitals and doctors that prescribe drugs but do not pay for them. This has, historically, allowed companies to focus on the quality and efficacy of a drug--not on the price (20). However, with the increased worldwide emphasis on health care cost containment, and the increased presence and control of third-party payers in the purchasing decision-insurance companies and Medicare in the United States and national health policies in other countries-pharmaceutical companies are being pressured to develop cost-effective therapies, and price has become a sensitive issue (see box 5-D). 


\section{Box 5-D--Price and Cost Containment}

Pharmaceutical companies and DBCs are operating in an increasingly cost-conscious environment. Governments worldwide are trying to decrease health care expenditures and are cutting reimbursement prices on drugs. Governments are increasingly looking (at least indirectly) at drugs' economic benefits, in addition to their therapeutic benefits, and are becoming more discriminating in their payment decisions. Price controls are used to contain escalating costs of health care, but they also raise the level of financial risk involved in new drug development. Should they excessively hinder return on investment, price controls have the potential to deter investment, and thus, decrease innovation.

Many countries control the prices of prescription pharmaceuticals under their national health policies and insurance programs. Several countries, including Brazil, J apan, and Canada, impose strict price controls on pharmaceuticals, resulting in both unprofitable production and decreased investment by companies. There are several different approaches taken to cut the cost of pharmaceuticals. Some countries, including Denmark and France, do not include all drugs under their national health policies. They exclude particularly costly drugs from reimbursement. The creation of formularies, lists of specific drugs that qualify for reimbursement, is also being considered by Medicaid and Medicare programs in the United States, with the latest step taken being the passage of the Medicare Pharmaceutical and Prudent Purchasing Act by the 101st Congress. Other cost-cutting measures included price freezes in The Netherlands, Greece, and I taly; the allowance of higher prices in return for increased $R \& D$ spending in Australia; and higher prices allowed for innovative drugs in J apan to stimulate $R \& D$. The United Kingdom controls pharmaceuticals, not by price controls but by profit controls, limiting the amount of profit made by pharmaceutical manufacturers.

Pricing and reimbursement policies by third-party payers have already been an issue with biotechnologyderived drugs, many of which are very expensive. Amgen's erythropoietin, used to treat dialysis and AIDS patients' anemia, costs approximately $\$ 5,000$ per year for dialysis patients. Human growth hormone, used to treat human growth hormone deficiency in children, costs approximately $\$ 10,000$ per year. Genentech's recombinant tissue plasminogen activator (Activase), used to treat acute myocardial infarction, costs $\$ 2,200$ per dose.

If companies cannot expect to charge reasonable sums for their products or cannot be guaranteed third-party reimbursement, the incentive for further efforts is decreased and the viability of the firms maybe compromised. The downward pressure on pricing affects both large, multinational pharmaceutical companies and DBCs. In response to pricing pressure and cost-containment efforts, companies developing pharmaceuticals will increasingly be conducting cost/benefit analyses al ong with $R \& D$ to justify the expense of product development and the high prices they charge and to determine the potential for return on investment.

SOURCES: Derived from: "The New World of Drugs," The Economist, vol. 310, No. 7588, Feb. 4, 1989; pp. 63-64; "Managing R\&D-No Easy Solution," Scrip, No.1502, Apr. 4, 1990, pp. 4-6; Scrip review issue, 1989; Ernst \& Young, Biotech 91: A Changing Environment (San Francisco, CA: 1990); G. Omenn, dean, School of Public Health and Community Medicine, University of Washington, Seattle, WA, personal communication, 1990.

In recent years the trend has been to increase the size of the marketing forces by adding new sales representatives in all the major markets. In addition, co-promotion has been a new phenomenon in which companies share the responsibility for marketing each other's products. This allows sales representatives to market more products using established contacts with doctors and hospitals. In addition, access to a familiar market and success in the domestic market is extremely important. Sales are easier in this market than in foreign markets because there is no language or cultural barrier and domestic sales can support international sales (2).

Few DBCs, perhaps only Genentech (S. San Francisco, CA), Centocor (Malvern, PA), and Amgen (Thousand Oaks, CA) have marketing staffs and established distribution routes for their products. At the same time, many of the biotechnology-derived drugs on the market are entirely new therapeutic products. For these drugs, including erythropoietin, alpha interferon, Interleukin II, and others, doctors must be educated about entirely new classes of products, their uses, and their potential for effective treatment. This can be accomplished most effectively by very large marketing organizations (23). Most DBCs with approved products have licensed marketing rights to established pharmaceutical companies.

There are obvious advantages to teaming up with an established pharmaceutical company for marketing purposes. For example, Centocor (Malvern, PA) and Xoma (Berkeley, CA) both have products in 
development to treat gram negative sepsis septic shock. Centocor plans to market its product, Centoxin, with its own sales force consisting of 75 sales representatives in the United States and 45 in Europe. Xoma plans to market its product, XomenE5, under a licensing agreement with Pfizer's Roerig subsidiary using the latter's 750 sales representatives. Xoma is benefiting from an established sales force and distribution network and Roerig's familiarity with the medical community. The obvious disadvantage of licensing agreements is that DBCs retain only a portion of the profits from the drug's sale (4) (see ch. 4).

\section{Market}

The size of the global pharmaceutical market was estimated to be $\$ 150$ billion in 1989 (50). The United States is the largest drug market, accounting for approximately 30 percent of the world market (3). The European Community (EC) is the second largest total market. J apan is the second largest single-country market, with an approximate 17.6 percent market share (57). Pharmaceutical products are marketed globally and, in 1989, 34.4 percent of the $\$ 51.2$ billion in sales by U.S. drug companies were overseas $(8,6)$. The main competitors for the world pharmaceutical market are principally U.S. and European companies (see table 5-5), more specifically the multinational firms based in Switzerland, the United Kingdom (U.K.), and Germany, which are huge, multinational organizations with research, manufacturing, and marketing operations worldwide. Focus on penetrating world markets, not only domestic markets, is crucial to success in the pharmaceutical industry (18).

The J apanese market has, historically, been difficult to enter without a J apanese partner; thus, U.S. and European companies, to ensure market presence, have collaborated with J apanese companies that dominate their domestic market. For many years U.S. and European companies increased their presence in J apan by establishing their own marketing forces. In recent years, in a few cases, they built research facilities, e.g., Roche, or acquired a J apanese company, e.g., Merck, which bought Banyu Pharmaceutical in 1983 (56,12). Currently, 24 U.S. pharmaceutical companies operate in J apan and account for about 15 percent of the $\$ 33$ billion J apanese market. The domestic market is still dominated by J apanese companies, and no American or European company is among the top 10 in
Table 5-5-Company Rank by Pharmaceutical Sales 1989

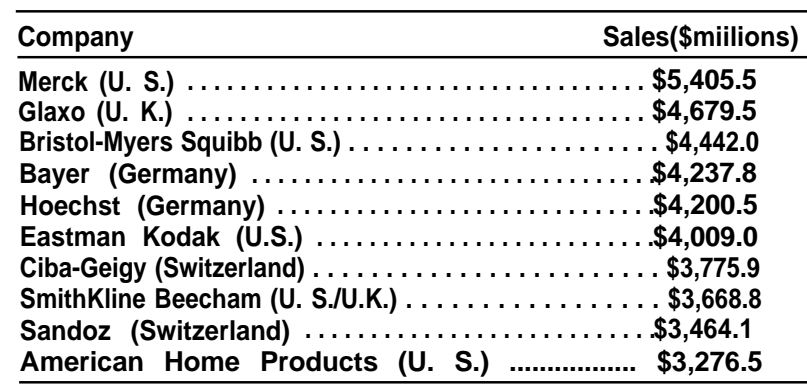

SOURCE: "Merger Effect on Top Pharma Firms," Scrip, No. 1570, Nov. 28, 1990, p. 13.

J apan (29). At the same time, J apanese companies, which for the most part are not multinational, are now pushing to increase their export markets and are beginning to globalize their operations (41) (see box $5-E)$.

The pharmaceutical industry, despite high-entry barriers, is not particularly concentrated. No company holds even a 5-percent share of the world market $(26,30)$. In 1987, the largest 10 firms held only 27.6 percent of the world market (38). The four largest firms in the PMA account for only 25 percent of sales in the United States; the top 8 account for under 50 percent, and the top 21 for only 75 percent (29). However, it is important to recognize that there is neither a central product in the pharmaceutical market nor a long-term product leader (27). Availability of financial resources can serve both to determine existing fins' competitiveness and to bar new entrants, including biotechnology companies. Because comparatively few drugs maintain large market shares for extended time periods, companies must aggressively market approved products and develop innovative new ones in order to compete. Competition is both static and dynamic. In the static sense, competition is based on product differentiation, but not price. Dynamic competition is derived from $R \& D$ and new product introduction. Market share, which changes with new product introduction, also is a measure of competition $(16,38)$.

\section{Consolidation}

In recent years, the industry has experienced two rather opposite phenomenons: consolidation and the development of small startups focusing on biotechnology derived therapeutics. Together, these illustrate the increased resources demanded by the competitive nature of the industry and the need 


\section{Box 5-E_Japan's Pharmaceutical Industry}

Japan is the second largest pharmaceutical market in the world behind the United States. The domestic market is dominated by Japanese companies that are relatively big, although smaller than the top U.S. companies, and profitable at home, but that lack a significant global presence. Historically, the Japanese pharmaceutical market was protected by the government, and foreign penetration was very difficult. Since the mid-1980s, this has begun to change, increasing the competitiveness of the Japanese pharmaceutical market and driving Japanese companies toward globalization.

Before 1986, foreign drug companies were required to conduct clinical trials in Japan, on Japanese, and submit the data in Japanese. Companies were not allowed to apply directly to the Japanese Government, specifically the Ministry of Health and Welfare, for drug approval (shonin) and license (kyoka), but were required to have a Japanese partner. These requirements were changed and foreign companies are now allowed to apply directly to the government for new drug approvals. However, the changed laws applied only to new products, so firms had to maintain their contracts with Japanese partners for old products. After the 1985 Market-Oriented Sector-Selective (MOSS) talks, bilateral trade negotiations between the United States and Japan, some of the problems related to market access and regulatory processes were resolved and the Japanese market opened significantly to foreign entrants.

There are several significant differences between the pharmaceutical industry in Japan and that of other countries, aside from language and cultural differences. In the United States, doctors prescribe, but do not sell drugs to patients, and they do not earn money by prescribing any particular drug. In Japan, pharmaceutical companies sell the drugs to doctors or hospitals, which often have in-house pharmacies, at prices below the government's official price. The doctor or hospital then sells the drugs to patients at the government price, thus making a profit from the sale of the drugs. Another difference is the research intensity of Japanese firms vis-a-vis American and European companies. Japanese pharmaceutical companies historically conducted little basic research and were not known for their R\&D capabilities. They tended to license new drugs from foreign firms that needed a partner to penetrate the market.

The direct entrance of foreign firms into the Japanese market, combined with efforts, since 1980, to control pharmaceutical prices in Japan, resulted in increased competition. The domestic firms that dominated the market had, until this point, been protected from foreign competition by the Japanese Government. Japan now reduces the government price for pharmaceuticals biennially. Japanese companies also export few drugs, selling abroad only about 2 percent of the total domestic pharmaceutical production. In the face of increased competition, Japanese companies have sought export markets and have begun to globalize their operations.

Japanese companies are now seeking to penetrate global markets, through both increased export and by locating operations outside of Japan. Japanese companies have established joint ventures with foreign companies and are establishing sales forces in Europe and the United States. Japanese companies are also investing in U.S. biotechnology companies and licensing the Japanese and Far East marketing rights to new biotechnology-derived drugs. To increase their R\&D capabilities, Japanese companies are funding research at American universities and biotechnology companies. Japanese companies maintain significantly smaller R\&D budgets than their U.S. and European counterparts.

A recent Japanese survey examined Japanese pharmaceutical companies' representation in foreign countries. The survey counted joint ventures, research centers, and subsidiary companies, but not local distributors or licensees. Thirteen Japanese companies had a total of 24 offices, research centers, joint ventures, or wholly owned subsidiaries in the United States. Sixteen companies had direct representation in Taiwan; nine in Germany; eight in the United Kingdom; seven in Thailand; six in Indonesia; and five in South Korea. This demonstrates Japanese companies' efforts to globalize their businesses and locate operations at sites around the world. However, these efforts do not nearly meet the already established global operations of the top U.S. and European companies, some of which operate at fully integrated levels in 20 or more countries.

The Japanese market is becoming more competitive and so are Japanese pharmaceutical companies, which are increasing their presence in international markets. While the pharmaceutical market in Japan is still dominated by domestic firms, foreign firms are now able to establish their own facilities and sales forces in what was previously a tightly protected market. The increase in foreign competition, along with increased cost-containment pressure, have driven the historically domestic Japanese companies to seek foreign markets in order to increase their competition with U.S. and European companies.

It is important to note that while Japanese companies are entering the global marketplace, significant differences remain between them and their international competitors. U.S. and European companies maintain a significant scientific and technological edge over their Japanese counterparts and are more R\&D-intensive. Japanese companies face a significant reorganizational challenge by trying to improve their research capabilities and globalize their operations at the same time, and globalization is sure to be more difficult and slower than it has been in other Japanese industries.

SOURCES: Office of Technology Assessment, 1991 derived from: A. Yoshikawa, "The Other Drug War. U.S.-Japan Trade in Pharmaceuticals," California ManagementReview, vol. 31, No. 2, winter 1989; "Japanese Pharma. Firms Overseas," Scrip, No. 1535, July 27,1990, p. 23; G. Mossinghoff, statement before the International Trade Commission, Jan. 17, 1991; D. Swinbanks, "Huge Profit From Drugs," Nature, vol. 342, No. 23, November 1989, p. 333. 
Table 5-6-Merger and Acquisition Activity in the Pharmaceutical Industry

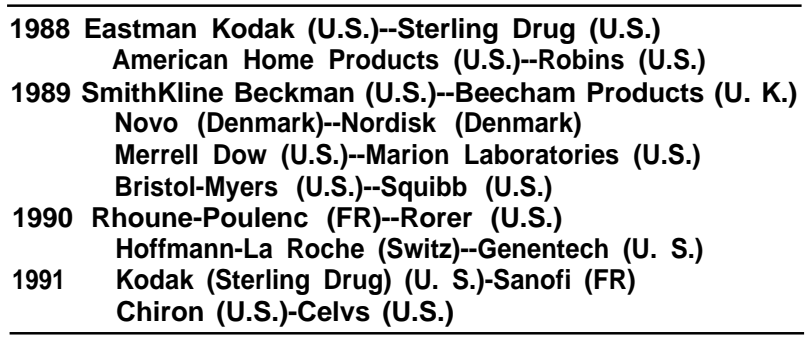

SOURCE Office of Technology Assessment, 1991.

for innovative $R \& D$ and new products. In the last several years, there has been significant merger and acquisition activity between established firms (see table 5-6) (11). Consolidation strengthens the scientific base, expands the technology and product portfolios of the companies, and reflects the increased costs of doing business-especially $R \& D$ and marketing.

By pooling $R \& D$ budgets, companies can ensure a broad R\&D program, covering many therapeutic categories, and a more complete product portfolio. With the increased resources of what used to be two separate $R \& D$ budgets, companies can ensure the breadth of $R \& D$ necessary to devel op products for the many therapeutic submarkets and spread risk, increasing the chances of developing a successful product (43). These mergers have, in some cases, resulted in more than doubling the size of companies' sales forces and providing an economy of scale. The larger sales forces enable companies to reach more doctors and hospitals, further penetrate markets, and enter markets in which they previously had no representation. This is especially true of foreign markets (19).

\section{Dedicated Biotechnology Companies and the Pharmaceutical Industry}

DBCs are almost exclusively a U.S. phenomenon. No other country has a remotely comparable number. Biotechnology companies are created specifically to exploit the commercial potential of biotechnology. These companies start as research institutions with science and technology but without products. They do not undertake R\&Don nearly as broad a scale as established companies. Instead, they pursue niche markets by focusing either in specific technologies (e.g., drug delivery) or particular products (e.g., growth factors). The companies must fund the initial costs of infrastructure development, in-

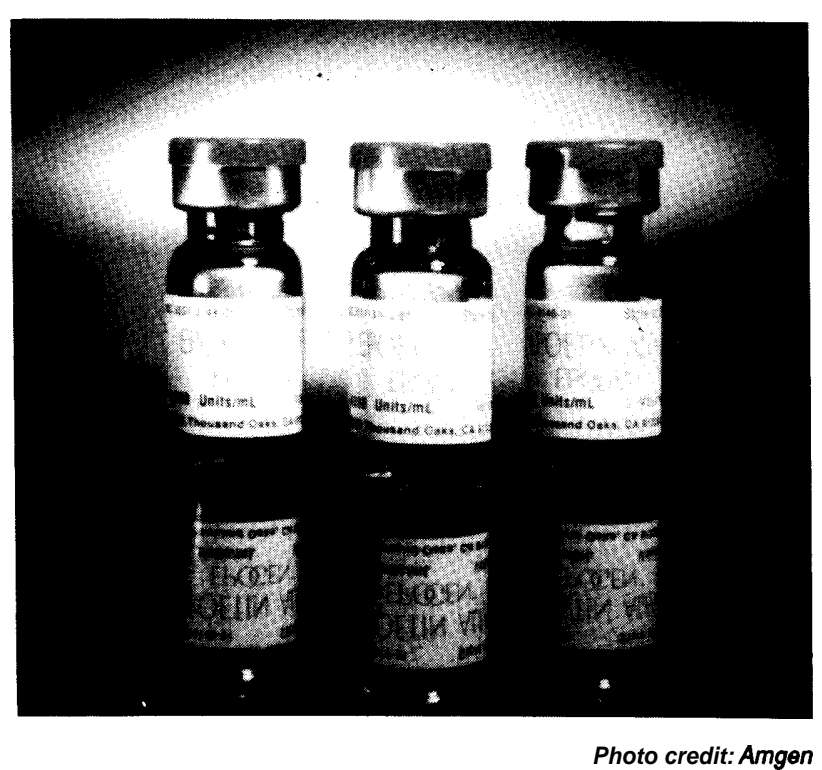

Since FDA approval in 1989 , more than 90,000 patients have used EPOGEN brand recombinant EPO, the best selling biotechnology-derived drug to date.

eluding buildings, plants, equipment, and people (scientists, managers, salespeople, and lawyers), without the benefit of internally generated revenues. They depend on venture capital, stock offerings, and relationships with established pharmaceutical companies for their financing needs.

Biotechnology companies are fully capable and competitive when it comes to research and applications of technologies. However, the very fact that their expertise is focused in biotechnology and related niche areas of pharmaceutical research illustrates the difference between them and large pharmaceutical companies. Established pharmaceutical companies maintain a greater breadth of $R \& D$, work to penetrate multiple therapeutic markets worldwide, and devote major resources to product development and, at the same time, can integrate and implement newer aspects of biotechnology to complement their conventional research capabilities. Biotechnology is being introduced into the pharmaceutical industry as it proves itself, as products are developed and technologies perfected, and as their potential for use in the industry is observed (9).

DBCs are attempting to break into an industry marked by high costs and risks, in which successful, established pharmaceutical companies with large $R \& D$ budgets and marketing clout feel pressure to consolidate to be competitive. While some companies have been successful operating at all levels, 
from $R \& D$ to manufacturing to marketing, none compete head-to-head with major established companies except in niche markets and on a product-byproduct basis (21). DBCs that are able to vertically integrate their operations, as Genentech and Amgen have done, are likely to continue to concentrate on niche markets.

The original intent of many of the early DBCs was to become fully integrated, competitive pharmaceutical companies, but the economics of the pharmaceutical industry may very well deny this opportunity to most. Perhaps in recognition of those barriers, many of the newer companies were founded with the intention of developing one idea or targeting a niche market and, perhaps, being acquired. The latter was true for Hybritech, which was acquired by Eli Lilly, and Genetic Systems, which was bought by BristolMyers (now Bristol-Myers Squibb) and recently sold to the Sanofi of France. According to a recent Ernst \& Young survey, 39 percent of all companies surveyed expect to be acquired by a large firm within the next 5 years, and 32 percent expect to merge with an equal-size firm in the same period (13).

\section{Strategic Alliances}

DBCs have been able to secure initial financing and certainly have excellent scientific and technological capabilities, but they often lack other important resources. The vast majority of DBCs lack the money to fund clinical development and to successfully market their products worldwide. It is for these reasons that DBCs team up with major pharmaceutical companies (19). Biotechnology companies that do not turn to larger drug companies for help are usually forced to hold special public offerings to raise the capital for clinical development. Such public financing has been in the form of $R \& D$ limited partnerships, debt offerings, or new stock offerings (2).

There are several reasons for companies in the pharmaceutical industry to collaborate, be it with another established pharmaceutical firm or a biotechnology company. Collaboration creates access to markets, access to technological skills and competences that may not be developed in-house, and an opportunity to share the costs and risks associated with the devel opment of new drugs and the use of new technologies. When DBCs were first created in the 1970s, the risks were very high as the potential for commercial development and profits was unproven. It was not known if biotechnology could be successfully used to develop and produce new drugs, and the costs of scaling-up biotechnological production methods were unknown. Due to these unknowns, many pharmaceutical companies did not choose to pursue the development of biotechnology, at least in-house, until the early 1980s when the initial uncertainties about the technology were resolved. Another reason for this delay was that most established firms did not have the personnel or interdisciplinary expertise required to use and devel op the technology. Pharmaceutical companies needed to restructure their research departments and programs and hire skilled personnel before they could integrate biotechnology into their drug development efforts (38).

Strategic alliances are often established after DBCs have conducted significant research and development on particular products. The pharmaceutical company uses its established resources to further develop the drug and conduct clinical trials, thus gaining new products without having to make the initial investment and assume the entire risk inherent in new product development. DBCs receive necessary financing and devel opment, regulatory, and marketing expertise, while pharmaceutical companies are able to complement their in-house $R \& D$ activities and add innovative new products to increase the breadth of their product portfolios. Often, the pharmaceutical company will take full responsibility for putting the drug through the regulatory process (the U.S. FDA and foreign regulatory approval) and for introducing the drug in foreign markets. Increasingly, the more successful biotechnology companies maintain U.S. marketing rights to their products, allowing both DBCs and established firms to receive revenues from product sales.

There are many types of strategic alliances between DBCs and pharmaceutical companies. They include agreements to exchange technology, joint ventures, equity arrangements, and $R \& D$ contracts (38). At the current level of commercialization, the most common type of agreement is licensing, which can include joint development of specific products as well as the exchange of marketing rights for financial support. Examples of U.S. pharmaceutical companies' alliances with DBCs include Ortho Biotech, a subsidiary of J ohnson \& $J$ ohnson, which has agreements with Xoma (Berkeley, CA) and Amgen (Thousand Oaks, CA), among others; Pfizer's subsidiary, Roerig's, agree 
ment with Xoma; Merck \& Co.'s agreements with Genentech (S. San Francisco, CA), California Biotechnology, Inc. (Mountain View, CA), Immunomedics, Inc. (Warren, NJ), Repligen, Inc. (Cambridge, MA), and Chiron (Emery vine, CA); Hoffmann-La Roche's licensing agreements with Cetus Corp. (Emeryville, CA) and Genetics Institute, Inc. (Cambridge, MA); SmithK line Beecham PLC's agreements with Nova Pharmaceutical Corp. (Baltimore, MD), and T Cell Sciences, Inc. (Cambridge, MA) and others (13).

European companies tend to depend both on strategic alliances and, more so than U.S. companies, on in-house capabilities in biotechnology. There are few European DBCs with which to collaborate, and the majority of European companies' strategic alliances are with U.S. DBCs. Some recent strategic alliances include Sandoz's \$30 million investment in Cytel (La J olla, CA), CibaGeigy's investment in Texas-based Tanox Biosystems (Houston, TX), and Glaxo's \$20 million investment in Gilead Sciences (Foster City, CA) (34). In addition, many European pharmaceutical companies have licensed European marketing rights from U.S. DBCs. Examples include Boehringer Mannheim's agreement with Genetics I nstitute to market EPO in Europe and Boehringer Ingel heim's arrangements for marketing Genentech's tPA.

European companies, such as Bayer, Ciba-Geigy, Roche, and Sandoz have developed significant in-house capabilities in biotechnology and maintain large biotechnology R\&D budgets. Bayer has a biotechnology research budget of $\$ 100$ million and Ciba-Geigy recently spent $\$ 60$ million on a new central biotechnology research unit. Roche, in addition to acquiring Genentech, spent between $\$ 130$ million and \$140 million on biotechnology in 1989. Sandoz expects to invest $\$ 150$ million in biotechnology in 1991 and a total of \$1 billion by 1995 in biotechnology $R \& D$, including both in-house and collaborative activities. European companies' expenditures for biotechnology are global. Roche, for example, funds $R \& D$ not only in its native Switzerland but also in the United States, the United Kingdom, and J apan. Sandoz conducts research in Switzerland, the United States, the United Kingdom, and Austria $(17,36)$.

J apanese companies, in addition to increasing exports and their presence overseas, are also investing in U.S. DBCs. Examples include the following:
Chugai Pharmaceutical's deals with Genetics Institute and Upjohn and its $\$ 110$ million acquisition of Gen-Probe (San Diego, CA); Tokyo's Institute for Immunology's \$20 million investment in IDEC Pharmaceuticals (La J olla, CA); and Genetics Institute's collaboration with J apan's Yamanouchi Pharmaceutical Co. (34).

\section{Competitive Influence of Government Policies}

At the current level of commercialization, most of the factors influencing the competitiveness of U.S. pharmaceutical and dedicated biotechnology companies with respect to biotechnology are market forces and general economic variables. There are many U.S. Government policies that influence businesses based on health and life sciences without addressing biotechnology specifically. Federal funding for biomedical research, regulatory policies, and intellectual property protection are important public policies that affect the commercialization and competitiveness of U.S. biotechnology.

\section{Federal Funding for Basic Research}

The United States' lead in biotechnology is due in large part to strong government support for basic research in biological and biomedical sciences. The vast majority of Federal research support in the biological sciences goes to university scientists conducting basic research, whereas applied research and development has always been considered the responsibility of industry (48). Industry worldwide, including DBCs and pharmaceutical companies, has benefited from the strong research base funded by the U.S. Government (see app. C). Technology transferred between government laboratories, universities, and industry enables applied research and commercial development of biotechnology. Continued funding for basic research in biological sciences will be important for the future of biotechnology.

\section{Regulation}

The regulatory component of the human therapeutic development process is perceived, by both entrepreneurial and established companies, as the major factor influencing the time required to develop a pharmaceutical product. The debate over the rigorous and lengthy drug regulatory process has gone on for years. Arguments have been made that when too strict, regulation becomes prohibitive to pharmaceutical development. Overly stringent regulation could impede international competitiveness 
and compromise human health by reducing the availability of therapeutic products. However, the importance of protecting the public from unsafe or ineffective drugs is stressed (48).

The FDA, its mission, responsibilities, and structure, is currently under review by an advisory committee of the U.S. Department of Health and Human Services (U.S. DHHS) which is addressing many of the concerns of industry, government, and the public (52). Representatives of the pharmaceutical industry and biotechnology firms, testifying before the advisory committee's drugs and biologics subcommittee, raised several issues of concern, including: the increased workload and resources of the Center for Biologics Evaluation and Research, responsible for reviewing biotechnology-derived therapeutics, the use of advisory committees, and the need for sufficient resources in terms of both personnel and equipment (15).

The regulatory process is a burden for both established pharmaceutical companies and DBCs. The time delay and lack of regulatory approval can be damaging to both DBCs and established companies, but, arguably, perhaps more so to a DBC. Very few DBCs benefit from product sales and profits to support $R \& D$, and for many, FDA approval is the first positive sign of potential earning power-an important characteristic required for financing. Companies have expressed concern that FDA delays have negatively affected their ability to gain financing, especially from Wall Street (see box 5-F). However, thus far, the experience with biotechnology drugs has been mostly positive, with many biotechnology-derived drugs experiencing significantly shorter approval times than conventional drugs. According to the FDA Office of Biotechnology, marketing approval times for new biotechnology products have averaged about half of the mean 32 months (for approval of the New Drug Application which is fried after all clinical trials have been completed) required for approval of nonbiotechnology products (46).

In order to introduce products in markets worldwide, pharmaceutical companies and DBCs must obtain regulatory approval h-em each individual country in which they choose to market a drug. The drug approval process is different in each major market, and attempts are being made to harmonize regulatory procedures. Drug approval often takes longest in the United States. Of the 135 new drugs

\section{Box 5-F-Effects of Regulatory Decisions on Wall Street}

A lack of regulatory approval is a setback for any drug developer, but for biotechnology companies it is potentially devastating, Wall Street, a primary source of financing for many biotechnology companies, places great importance on the Food and Drug Administration's (FDA) actions and often uses the administration's decisions as a basis for their stock recommendations for biotechnology companies, in lieu of product performance. Thus, a negative reaction from FDA leaves biotechnology companies, seeking their first product approval, much more vulnerable than an established company with a significant product portfolio currently generating revenue.

For example, in May 1987 an FDA advisory committee recommended against approval of Genentech's tissue plasminogen activator (tPA) (later approved and now on the market). Genentech's stock dropped 14 points in 2 days and lost 25 percent of its value. A more recent example is FDA's 1990 recommendation against Cetus' Interleukin-2 for the treatment of kidney cancer. In the 2 weeks surrounding FDA's decision, Cetus' stock dropped over 40 percent. After FDA's decision, Cetus' stock price fell from its 52-week high of $\$ 22.50$ to $\$ 8.63$. Since Wall Street cannot evaluate companies without products on the basis of sales, revenues, and profits, it must value them on the basis of research, people, potential, and scientific promise. FDA approval, or lack thereof, reflects on a company's scientific and product development ability; thus, when FDA approval is not granted, the value given the company by Wall Street drops.

SOURCES: R, Baum, "Biotech Industry Moving Pharmaceuti-
cal Products to Mark\%," Chemical and Engineer-
ing News, vol. 65, No. 29, July 20, 1987, pp. 11-14,
20, 28-32; "Cetus Lass Widened in Fiscal 4th
Quarter, Drug Costs Are Cited," Wall Street
Journal, Aug. 8, 1990, p. B4; L. Christensen, "Cetus
Considers Strategic Options After the Delay in
FDA's Approval of Proleukin IL-2," Genetic Engi-
neering News, vol. 10, No, 9, October 1990, pp. 1,
40, 48; B. Culliton, "Cetus's Costly Stumble on
IL-2, "Science, vol. 250, No. 4977, Oct.5, 1990,pp.
20-21; U.S. Congress, Office of Technology As-
sessment, "Financial issues Affecting Biotechnol-
ogy: At Home and Abroad," transcript of a
workshop held Sept. 13, 1990.

approved by FDA during the period 1984 to 1989 , 106 were first approved abroad; in 1990, 18 of 23 drugs approved in the United States were frost approved abroad (29,5 1). Until 1986, with the 


\section{Box 5-G-The Drug Export Amendments Act of 1986}

The Drug Export Amendments Act of 1986 allows the export of new drugs not yet approved by the Food and Drug Administration (FDA) for use in the United States. Export is restricted to 21 countries that have sophisticated drug approval processes and is dependent on the individual country's approval. The importer must sign a written agreement guaranteeing that they will not re-export the drug to countries other than the 21 approved.

FDA approval often takes longer than approval outside the United States. Before the act was passed, export of unapproved drugs was not allowed, and companies were forced to manufacture drugs abroad or license their technology to foreign firms in order to enter the marketplace. The amended act allows companies to recoup research and development costs and generate income sooner than if they had to wait for FDA.

The act holds particular importance for biotechnology companies, which in the early stages of development often lack the resources to establish manufacturing facilities abroad. Before the act was passed in 1986, biotechnology companies had to forfeit the proprietary rights to their technology to multinational partners overseas in order to ensure supply of the product and guarantee access to foreign markets and return on investment. Although many companies still license technology and marketing rights abroad, since 1986 many biotechnology companies have been able to preserve the right to supply their products from the United States. This change in the law is of considerable significance to international trade. Cetus has taken advantage of the act by exporting Proleukin (Interleukin-II) to several European countries, which have approved the drug, while waiting for FDA approval in the United States.

The Drug Export Amendments Act of 1986 applies only to human drugs. The export of drugs not registered in the United States for use in animals is not permitted. This maybe of significance to biotechnology in the future, as biotechnology has applications to veterinary medicine and animal health.

SOURCES: Drug Exports Amendments Act of 1986, Public Law 99-660; B. Andrews, vice president, Agricultural Division, Cyanamid International, Wayne, NJ, personal communication Aug. 6, 1990; G. Rathmann, chairman emeritus, Amgen Inc., Thousand Oaks, CA, personal communication Aug. 3, 1990.

passage of the Drug Export Amendments Act, it was against the law to export drugs from the United States not approved by FDA (see box 5-G).

Inconsistent worldwide regulations and the lack of acceptance of foreign clinical trial test data in particular, have caused problems for the pharmaceutical industry. The latter has, in the past, been a significant problem in Japan, where the U.S. Trade Representative concluded in 1989 that this, along with the difficulty of obtaining regulatory approval for drugs, increases the cost of doing business in Japan. The industry is somewhat protected by both the Standards Code, and the Technical Barriers to Trade Code of the General Agreement on Tariffs and Trade (GATT), which refers to the application of technical standards to products, ineluding testing, labeling, and certification. It requires that standards are applied so as not to discriminate against imported products (45). This code is very important in ensuring that health and safety regulations are not used as trade barriers to discriminate against imported products (53).

Governments' approach to pharmaceutical regulation, including both the lengthy approval times and the inconsistency of worldwide regulations, influ- ence the competitiveness of pharmaceutical fins. Attempts to harmonize regulations and improve the current drug approval processes will benefit all companies, independent of national origin, in their introduction of new products in global markets.

\section{Intellectual Property Rights Protection}

Patent protection has been judged to be of substantial importance to innovation, new product development, and new product introduction in several industries-including pharmaceuticals (24). Intellectual property protection, in the form of patents and orphan drug market exclusivity (see box $5-\mathrm{H}$ ), is critical to the pharmaceutical industry for two primary reasons:

- It can provide the temporary market monopoly necessary to recoup the high costs of R\&D.

- Drugs with new therapeutic values depend on patent protection in order to capture and hold a significant market share. Patent expiration allows competing products, either generics or brand names from other companies, to enter the market (43).

Patents contribute to market success by denying market access to those products that will infringe a

292-87[) - $91-4:$ QL 3 


\section{Box 5-H-The Orphan Drug Act}

The 1983 Orphan Drug Act seeks to induce the development of drugs for rare diseases. Rare diseases are defined by the legislation as conditions that affect fewer than 200,000 people in the United States. The act offers incentives to invest in orphan product development that, due to the small patient population, is not likely to offer a full return on investment to the company. The government offers grants, tax breaks, and most importantly, 7 years of market exclusivity to the first manufacturer to gain the Food and Drug Administration's (FDA) approval for a product with orphan designation. The market exclusivity provision is a form of intellectual property protection and has proven to be controversial.

Since the act was passed in 1983, over 375 products have received orphan designation from FDA, and over 40 orphan drugs are on the market. Nine of the 15 biotechnology-derived drugs on the market have orphan drug status, as do 19 additional biotechnology-derived drugs currently under development. Controversy was raised in the 101st Congress over three orphan drugs that turned out to be very profitable: 1) aerosol pentamidine, 2) erythropoietin (EPO), and 3) human growth hormone. The latter two are biotechnology-derived drugs. Arguments were made that these drugs would have been developed without the Orphan Drug Act incentives because there was great opportunity for profit.

The U.S. House of Representatives and the Senate passed amendments to the Orphan Drug Act that would have removed orphan drug status if the patient population exceeds 200,000 and also would have allowed for shared market exclusivity if another company could prove it was devel oping the same orphan drug simultaneously to the first company that received FDA approval. After much debate, and divided industry lobbying, the final bill applied only to new orphan products and not to the three drugs that spurred the debate. The bill, as passed, would have allowed market competition for products that proved to be particularly profitable. The President vetoed the legislation, claiming the shared exclusivity provision would remove incentive for developing orphan products.

The case of EPO is particularly controversial and complicated. Amgen (Thousand Oaks, CA) received FDA approval in J une 1989 to market its EPO to dialysis patients suffering from anemia associated with end-stage renal disease, a patient population of under 200,000. EPO, paid for mostly by the government's Medicare program that covers dialysis patients, costs about $\$ 5,000$ per patient per year, and Amgen has sold over $\$ 300$ million worth of the drug. Amgen received 7 years of marketing exclusivity, under the Orphan Drug Act, for EPO used to treat chronic kidney failure. Genetics Institute (Cambridge, MA) also has developed EPO as an orphan drug, but the company has yet to receive FDA approval due in large part to Amgen's orphan drug claims.

SOURCE: Office of Technology Assessment, 1991.

patent position during the lifetime of the patent. A U.S. patent provides 17 years of protection, but since the patent is usually applied for prior to broad testing, several of the initial 17 years of protection granted are lost during the years of clinical development. The regulatory process reduces the effective patent life to approximately 9 to 10 years, resulting in shorter protected market time and increased difficulty in obtaining return on investment (5).

In the 1980s, legislation was passed in the United States and J apan, and draft legislation is now being considered by the EC to extend patent protection to make up for at least some of the years lost during clinical development (see box 5-I). This extension of effective patent life recognizes the importance of patent protection, the effect of the regulatory process on new product development, and the need for public policies to provide incentives for companies to continue investing in $R \& D$.

Intellectual property protection has historically been a problem for the pharmaceutical industry. Many countries, particularly newly industrializing countries (NICs) such as India, Argentina, and other South American countries, do not provide patent protection for pharmaceuticals. Their reasoning includes the desire to protect domestic industries from competition, to encourage domestic production without the need to pay hard currency royalties to other countries (10), and to reduce or control retail prices (31). Copying pharmaceuticals is relatively easy, and companies have lost significant sales and revenues to patent infringers and markets where patent protection is not available or effective (37).

Until recently, neither Brazil nor Canada granted pharmaceutical patents. Brazil is working on a draft 


\section{Box 5-I-Patent Term Extension for Pharmaceuticals}

Drug companies usually secure patent protection early in drug development, before the drug enters the regulatory process. Regulatory approval for new drugs takes, on average, 7 to 10 years to complete. This translates into a 7- to 10-year reduction in patent protection for pharmaceutical products when they reach the market, leaving such products with, on average, 9 years of protected life. In response, the United States and J apan passed legislation allowing the extension of patent terms for pharmaceuticals. Similar legislation in being considered by the European community (EC).

In 1984, the Unites States passed the Drug Price Competition and Patent Term Restoration Act of 1984. The act restores part of the patent life lost due to lengthy regulatory approval The act allows extension of the patent term for up to 5 years, but it does not allow extension beyond 14 years of effective patent life. The actualextension granted is equal to the total time taken by the Food and Drug Admirstration (FDA) to review the New Drug Application, plus onehalf of the clinical testing time. In addition, the act promotes generic competition by providing FDA with an Abbreviated New Drug Application (ANDA) process. This process facilitates the approval of generic drugs by eliminating the need for costly clinical studies. An ANDA does require the sponsoring company to demonstrate its generic's bioequivalence to the pioneer drug. This is much less costly and time-consuming than complete clinical trials and facilitates the market entrance of generic drugs.

J apan also allows similar patent term extension for pharmaceuticals. In 1988, revisions were made to J apanese patent law to allow for an extension of the patent term for pharmaceutical products. Extension can be granted for periods up to 5 years, on the basis of time lost during the required drug approval procedures.

Pressure has been put on the European Commission to amend its patent law to allow for patent term extension similar to that offered by the United States and J apan. France and Belgium provided the first draft legislation to the commission, which responded with a proposal for a supplementary protection certificate (SPC). It was adopted in 1990 and currently is in front of the European Parliament. The proposal would provide effective protection for 16 years by granting a supplementary certificate to holders of a basic European patent. The guaranteed 16-year monopoly is longer than that created by the U.S. and J apanese patent term extensions.

The formula for deriving the extension is somewhat complex. The SPC takes effect the day after the basic patent expires and will be equal to the time elapsed between the filing of an application for a basic patent and the date of the first marketing approval in the EC, minus 4 years. The term for a European patent is 20 years, thus SPC will guarantee a monopoly of 16 years after marketing approval in almost all cases. The maximum length of an SPC is 10 years, thus for all cases in which marketing authorization is given up to 15 years after the basic patent application is filed, the company will be granted a 16-year monopoly. If 15 or more years pass, the company will not be given a 16-year monopoly, but it will receive a maximum SPC of 10 years.

Patent term extension in the United States and J apan and the proposed legislation in Europe recognize the importance of patent protection and market exclusivity for pharmaceutical producers, and acknowledge the burden of regulation.

SOURCES: H, Grabowski and J. Vernon, "Longer Patents for Lower Imitation Barriers: The 1984 Drug Act," American Economic Review, vol. 76, No. 2, May 1986, AEA Papers and Proceeditl gs, pp. 195-198; R. Whaite and N. Jones, "Supplementary protection Certificates-Restoration of the Patent Term for pharmaceutical, The European Commission's proposed Regulation," Linklaters $\&$ Paines, 199\& M. Fujii, “Government's Support for Pharmaceutical Industry," Business Japan, vol. 33, Issue 7, July 1988, pp. 80-83.

law that will provide both product and process patents for pharmaceutical products and which may be approved in 1991. In response, the United States has lifted sanctions against Brazilian pharmaceutical products, levied in 1988 in response to Brazilian companies' infringement on U.S. pharmaceutical patents. Canada has tied patent protection to an increase in $R \& D$ within the country. Bill C-22, passed in 1987, provides 10 years of patent protection to companies in return for an increase in their $R \& D$ spending in Canada as a percentage of sales: from 4.9 percent in 1986, to 8 percent in 1991, 9 percent in 1994, and 10 percent in 1996. The incentive has worked, with Merck Frosst (Canadian subsidiary of Merck \& Co.), Glaxo, and Sandoz, among others, making substantial R\&D investments in Canada (35).

\section{SUMMARY}

Biotechnology has found its place in the researchbased pharmaceutical industry, both as a production technology and a research tool. Biotechnology is 
particularly important for research and drug discovery as it allows for a molecular- and cellular-level approach to disease, drug-disease interaction, and drug design. Biotechnology is likely to be the principal scientific driving force for the discovery of new drugs as we enter the 21st century, and the impact of biotechnology on the discovery of new therapeutic chemical entities is difficult to overestimate.

Dedicated biotechnology companies and established pharmaceutical companies are pursuing the commercial development of biotechnology independently and through joint efforts. While the future of the technology itself is bright, that of the pioneering, innovative DBCs is less clear. The pharmaceutical industry is highly competitive, global, and risky and requires significant resources. The markets are global, the $R \& D$ and marketing are expensive, the regulatory requirements axe strict, and the financiers of biotechnol ogy companies are becoming more discriminatory in their funding.

DBCs and pharmaceutical companies often work in concert, each contributing valuable assets required for new drug development. DBCs' strengths include innovative research and technological capabilities which, when combined with the monetary, regulatory, and marketing strengths of established pharmaceutical companies, translate into new pharmaceutical products. The majority of DBCs, which focus exclusively on the commercialization of biotechnology, could not survive without strategic alliances. Pharmaceutical companies, which are increasingly integrating biotechnology into their in-house research programs, use biotechnology to complement traditional approaches to drug discovery and depend on strategic alliances for innovative new products and technological know-how.

At this point in the commercialization of biotechnology, much of the success or failure rests on economic and market forces, in addition to scientific and technological feasibility. Government policies that affect these conditions contribute to, but are not likely to independently determine, the success or failure of either the companies or the technology itself. Several government policies that are affecting the successful commercialization of biotechnology and the competitiveness of the U.S. pharmaceutical industry as a whole have been identified. These policies include:
- government support for basic research in biological and biomedical science,

- regulatory policies for the approval of new drugs and biologics, and

- intellectual property rights protection.

Continued support for basic research in biological and biomedical sciences is essential to maintain the strong scientific base that has given the United States the acknowledged lead in biotechnology. Improved intellectual property protection at home and abroad and efforts to harmonize worldwide patent polices will benefit both DBCs and pharmaceutical companies in their drug development efforts. Scrutiny and improvement of regulatory policies, especially the length of time required to obtain FDA approval, will contribute to increased competitiveness of U.S. industry. Action on these points would likely contribute to U.S. competitiveness in the commercialization of biotechnology, which, at this stage, is highly dependent on market forces.

\section{CHAPTER 5 REFERENCES}

1. "An Anti-Depressant for Americans Drug Industry," The Economist, vol. 294, No. 7376, J an. 12,1985, pp. 70-71.

2. Beier, D., vice president, Governmental Affairs, Genentech, Inc., personal communication, Dec. 6, 1990.

3. Business Technology Research, Inc., Drug Delivery Systems (Wellesley Hills, MA: Business Technology Research, 1988).

4. "Centocor Still Awaiting Centoxin FDA Advisory Committee Review," F-D-C Reports, Inc., vol. 52, No. 49, Dec. 3, 1990, p. T\&G-1.

5. Cocks, D.L., "Economic and Competitive Aspects of the Pharmaceutical Industry," in M.C. Smith, Ph.D., Principles of Pharmaceutical Marketing, 3d ed. (Philadel phia, PA: Lea \& Febiger, 1983).

6. Copmann, T., Pharmaceutical Manufacturers Association, personal communication, December 1990.

7. Crombie, L., "Sugared Pill," Nature, vol. 347, No. 6289, Sept. 13, 1990, p. 137.

8. Cutaia, J.H., "In the Pink-Except for a Case of Nerves," Business Week, No. 3140, J an. 8, 1990, p. 102.

9. Dart, E. C., "Exploitation of Biotechnology in a Large Company, "Phil. Trans. R. Soc. Lond. B 324, 1989, pp. 599-611.

10. Ditzel, R., director, University of California Technology Management, personal communication, December 1990.

11. "The Doctor's Dilemma," The Economist, vol. 314, No. 7639, J an. 27, 1990, pp. 69-70. 
12. Eisenstodt, G., "A Different Kind of Drug Problem (Inroads Into American Market by J apanese Pharmaceutical Companies)," Forbes, vol. 145, No. 2, J an. 22, 1990, pp. 4041.

13. JE rnst \& Young, Biotech 91: A Changing Environment (San Francisco, CA: Ernst \& Young, 1990).

14. Ganellin, C.R., FRS, "Discovering New Medicines,' Chemistry and Industry, No. 1 (London, 1989), pp. 9-15.

15. Godown, R.D., president, Industrial Biotechnology Association, statement before the Subcommittee on Drugs and Biologics of the Advisory Committee on the Food and Drug Administration, U.S. Department of Health and Human Services, Nov. 8, 1990, La J olla, CA.

16. Grabowski, H.G., "AnAnalysis of U.S. International Competitiveness in Pharmaceuticals," Managerial and Decision Economics, special issue, spring 1989, pp. 27-33.

17. Hodgson, J., "European Biopharmaceutical Culture," Biotechnology, vol. 8, No. 8, August 1990, pp. $720-723$.

18. Hoff, L. C., "External Factors Will Shape Pharmaceutical Industry Future," Financier, vol. 11, I ssue 12, December 1987, pp. 3640.

19. Howells, J., "The Globalisation of Research and Development: A New Era of Change?" Science and Public Policy, vol. 17, No. 4, October 1990, pp. 273-285.

20. Jadlow, J .M., "A Summary and Critique of Economic Studies of the Ethical Drug Industry: 1\%21968," R.I. Chien (cd.), Issues in Pharmaceutical Economics (Lexington, MA: Lexington Books, 1979).

21. Klausner, A., director of research, Domain Associates, personal communication, November 1990.

22. Layman, P.L., "Global Pharmaceutical Industry Undergoing Major Shifts," Chemical and Engineering News, vol. 66, No. 35, Aug. 29, 1988, pp. 16-17.

23. Macek, K., president, TMS Management, Duxbury, MA, personal communication, December 1990.

24. Mansfield, E., "Patents and Innovation: An Empirical Study," Management Science, vol. 32, N o. 2, February 1986, pp. 173-181.

25. Marsh, P., "Biotechnology and the Drug Industry," British Medical Journal, vol. 300, No. 6718, J an. 20, 1990, pp. 146-147.

26. Merck\& Co., Inc., Rahway, NJ , 1989 Annual Report.

27. Miller, W.R., "Productivity and Competition: A Look at the Pharmaceutical Industry," Columbia Journal of WorldBusiness, vol.23, Issue 3, fall 1988, pp. 85-88.

28. Montague, M., research operations director, Monsanto Co., personal communication, December 1990.

29. Mossinghoff, G.J., president, Pharmaceutical Manufacturers Association, statement at hearings before the International Trade Commission, J an. 17, 1991.

30. "The New World of Drugs," The Economist, vol. 310, No. 7588, Feb. 4,1989, pp. 63-64.

31. Omenn, G., dean, School of Public Health and Community Medicine, University of Washington, personal communication, December 1990.

32. Pharmaceutical Manufacturers Association, Washington, DC, "Biotechnology Medicines in Development, 1990 Annual Survey."

33. Raines, L., director, governmental relations, Industrial Biotechnology Association, personal communication, Nov. 27, 1990.

34. Ratner, M., "The Year in Review: Perspectives on Biobusiness 90," Biotechnology, vol. 8, No. 10, October 1990, pp. 913-914.

35. Reisch, M.S., ' 'Canada's M erck Frosst Plans Major Pharmaceutical R\&D Expansion," Chemical and Engineering News, vol. 67, No. 49, Dec. 4,1989, pp. 16-17.

36. "Sandoz 'I nnovascan' Biotechnol ogy Discovery I nitiative," F-D-C Reports, Inc., vol. 53, No. 6, Feb. 11, 1991, pp. T\&G-7-8.

37. Scrip, Review Issue 1989.

38. Sharp, M., "Collaboration and the Pharmaceutical Industry-Is it the Way Forward," DRC discussion paper No. 71, Science Policy Research Unit, University of Sussex, May 1989.

39. Sharp, M., "Technological Trajectories and Corporate Strategies in the Diffusion of Biotechnology," DRC discussion paper No. 74, Science Policy Research Unit, University of Sussex, paper for Royal Swedish Academy of Engineering Sciences and OECD conference on Technology and Investment: Crucial Issues for the 1990s, Stockholm, J an. 21-24, 1990.

40. Stucki, J ., vice president, pharmaceutical research, retired, Upjohn Co., personal communication, November 1990.

41. "Surviving the Changes of the '90s," Scrip, No. 1523, J une 15, 1990, pp. 16-17.

42. Syntex Corp., Palo Alto, CA, 1989 Annual Report.

43. Temin, P., "Technology, Regulation, and Market Structure in the Modern Pharmaceutical Industry," Bell Journal of Economics, vol. 10, autumn 1979, pp. 426446.

44. Thayer, A., "Many Biotech Companies Enter '90s With Sharply Higher Revenues," Chemical and Engineering News, vol. 68, No. 14, Apr. 2, 1990, p. 9-11.

45. U.S. Congress, Congressional Budget Office, The GATT Negotiations and U.S. Trade Policy (Washington, DC: Congressional Budget Office, J une 1987).

46. U.S. Congress, Office of Technology Assessment, "Biotechnology in a Global Economy: Options for 
U.S. Strategy," transcript of a workshop held May 2, 1989.

47. U.S. Congress, Office of Technology Assessment, "Financial Issues Affecting Biotechnology: At Home and Abroad," transcript of a workshop held Sept. 13, 1990.

48. U.S. Congress, Office of Technology Assessment, New Developments in Biotechnology: U.S. Investment in Biotechnology, OTA-BA-360 (Springfield, VA: National Technical Information Service, J uly 1988.

49. U.S. Congress, Senate Committee on Labor and Human Resources, Hearings on the Advertising, Marketing, and Promotional Practices of the Pharmaceutical Industry, Serial No. 101-1217, December 1990.

50. U.S. Department of Commerce, International Trade Administration, 1990 U.S. Industrial Outlook (Washington, DC: U.S. Government Printing Office, J anuary 1990).

51. U.S. Department of Commerce, International Trade Administration, 1991 U.S. Industrial Outlook
(Washington, DC: U.S. Government Printing Office, J anuary 1991).

52. U.S. Department of Health and Human Services, Advisory Committee on the Food and Drug Adminisration, "Interim Progress Report to the U.S. Department of Health and Human Services,' September 1990.

53. United States Office of the U.S. Trade Representative, 1989 National Trade Estimate Report on Foieign Trade Barriers (U. S., GPO).

54. Warden, W.M., "The History of Drug Discovery, Development, and Regulation," R.I. Chien (cd.), Issues in Pharmaceutical Economics (Lexington, MA: Lexington Books, 1979).

55. Werner, R.G., "Biobusiness in the Pharmaceutical Industry," Arzneimittel-Forschung, vol. 37 (II), No. 9, 1987, pp. 1086-93.

56. Wolnack, B., president, Wolnack \& Associates, personal communication, December 1990.

57. "World Pharma Market Estimates," Scrip, No. 1555, Oct. 5, 1990, p. 20. 


\section{Chapter 6}

\section{Agriculture}

"Biotechnology has been a vital part of human activity for many thousands of years. In all probability the first biotechnologists were Neolithic men and women who may well have preferred the taste of fermented cereals to raw groin."

Industrial Biotechnology Association Biotechnology. . . in Perspective

"I suspect that virtually all of our current policy thinking about agriculture is very near in time to being totally irrelevant. Major crops such as corn and wheat could see thousandfold increases in yield through genetic manipulation.

Terry Sharrer

Smithsonian Institution curator of agriculture 


\section{CONTENTS}

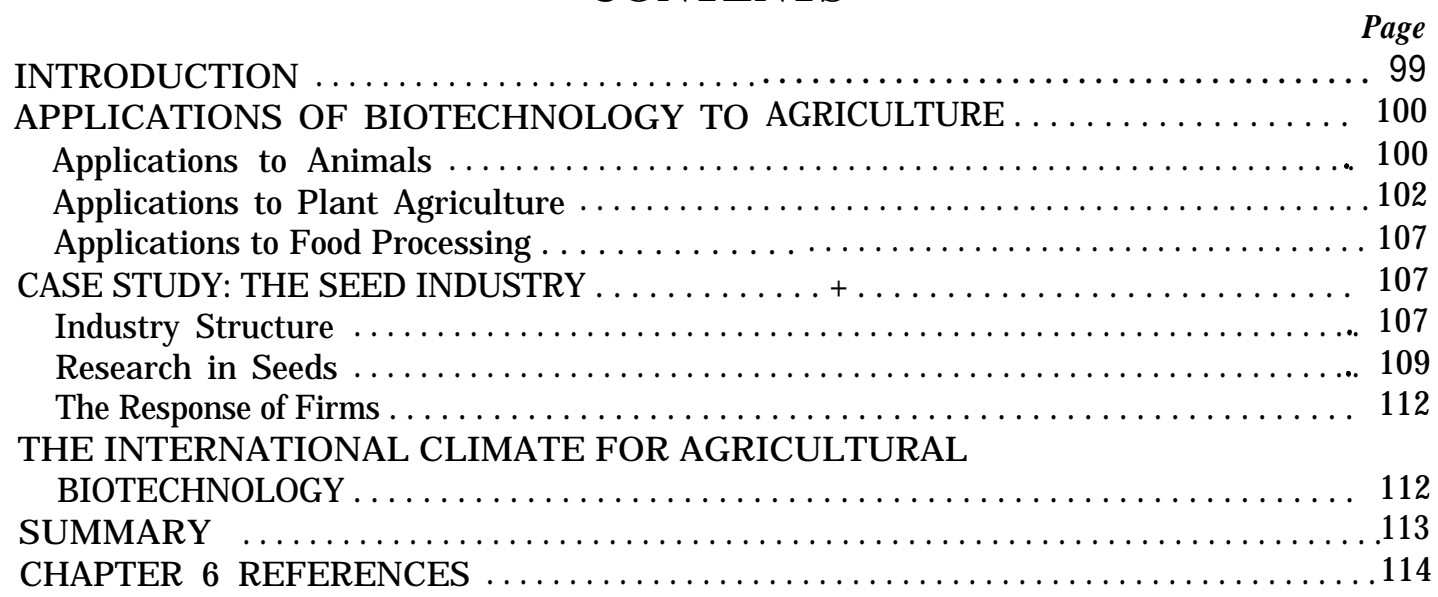

Box

Boxes

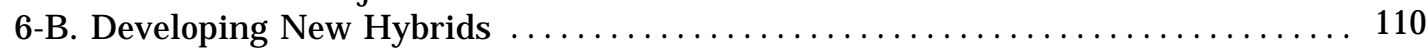

Figure $\quad$ Page

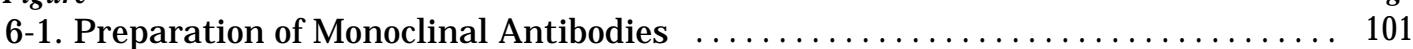

6-2. Plant Propagation: From Single Cells To Whole Plants ................ 105

\section{Tables}

Table Page

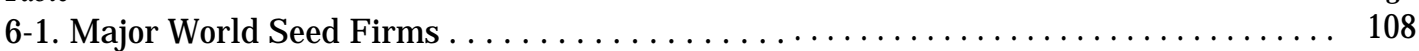

6-2. Major Exporters of Basic Agricultural Commodities Traded Worldwide . . . . . . . 113

6-3. Field Tests, by Country (summer 1990) . . . . . . . . . . . . . . . . . . . . 113 


\section{INTRODUCTION}

Biotechnology has the potential to be the latest in a series of technologies that have led to astonishing increases in productivity of world agriculture in recent decades. Since 1948, for example, the widespread use of fertilizers, synthetic chemical pesticides, and high-yielding varieties of major grain crops have produced yield increases in the United States of about 2-percent per acre annually. The use of farm machinery of steadily increasing power has led to a sharp decrease in labor needed to farm an acre of land. Since 1940, labor requirements in the United States have decreased 75 percent, while output per acre has doubled. The decreasing amount of labor required to produce increasing amounts of products has allowed farm size to increase about three fold over the years, while the total number of farms declined. Total harvested acreage in the United States, however, has remained relatively constant at approximately 340 million acres. Access to farm equipment, better seeds, and other inputs has led to productivity gains in other major agricultural exporting nations as well $(6,11,51)$.

Until about 10 years ago, U.S. agricultural research was directed toward maximizing yield-the quantity of production per acre. But, to compete with agricultural producers in developing countries where land and labor are cheap and to compete with producers in developed countries with access to sophisticated technology, U.S. farmers will have to produce their crops more efficiently. Today there is increased interest in the development of technologies that will help to reduce the cost of agricultural production (42). There is also research in the development of new, higher value-added products. Biotechnology can contribute to agriculture in each of these ways:

. The application of biotechnology to agriculture can result in further gains in yield. Some examples include new animal health care products, new plants that are more resistant to environmental stresses (e.g., frost or drought), or the use of new reproductive technologies to develop higher producing dairy cows.

. Biotechnology can also contribute to productivity by lowering the cost. of agricultural inputs. For example, plants that are resistant to pests may require less treatment with chemical pesticides resulting in savings in chemicals and labor costs.

- There is also the potential for the development of higher quality foods and new higher value-added products to meet the needs of consumers and food processors. These include lower fat meats, oilseeds with altered fat content, or vegetables with a longer shelf life.

- It is also hoped that biotechnology will contribute to the development of environmentally benign methods of managing weeds and insect pests through such new products as pest resistant crops.

Biotechnology is being applied to agriculture by new firms dedicated to the use of biotechnology and by well-established firms adapting biotechnology to their existing research programs. The potential products vary considerably, from agricultural inputs (e.g., seeds and pesticides) to veterinary diagnostics and therapeutics, to food processing enzymes, to products with improved food processing qualities. Animal health products are often manufactured by pharmaceutical firms, since there are strong similarities in the research required for developing human drugs, vaccines, and diagnostics and those products intended for livestock. Established research-based seed companies are expanding into biotechnology, while small, new firms attempt to develop products in this area as well. Both small dedicated biotechnology firms (DBCs) and established agrochemical firms are exploring biotechnological approaches to pesticides (25).

Investment in biotechnology, by both small and large firms, depends on the potential for the development of commercial products based on research and development $(R \& D)$. The potential for profiting from these new products depends on a variety of factors, such as the potential size of the market for the products and the rate at which new products and technologies are likely to be adopted, the potential for repeat sales, the existence of regulatory hurdles, and the possibility of public opposition.

Biotechnology applications to agriculture are being explored throughout the world but mainly in 


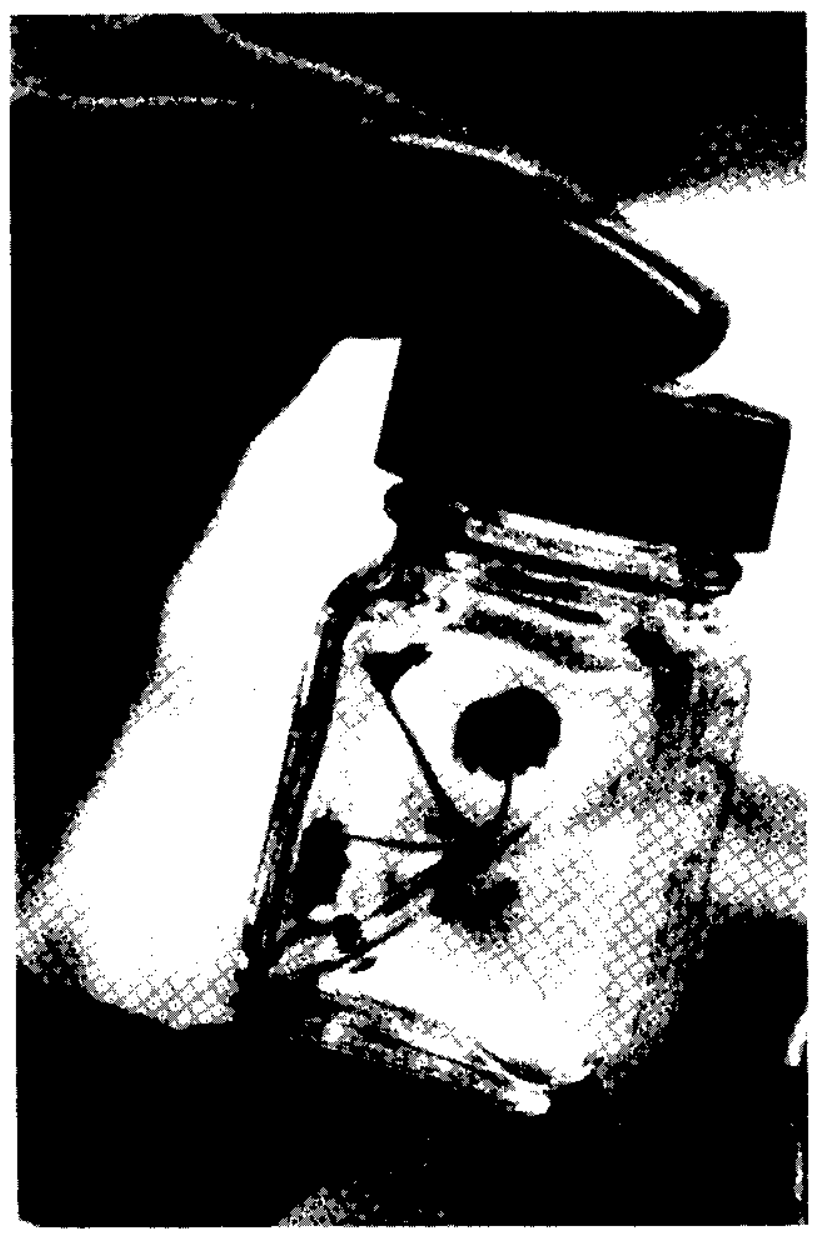

Photo credit: U.S. Department of Agriculture

Cloned strawberry plants in a growth chamber.

developed countries. Although few products are currently available, it is possible to get an indication of activities in different countries through surveys of field tests reviewed by national authorities. The climate for developing agricultural biotechnology varies considerably from country-to-country, depending, especially, on differences in intellectual property protection, regulations, and public perception.

\section{APPLICATIONS OF BIOTECHNOLOGY TO AGRICULTURE}

While there are many promising applications of biotechnology to agriculture, biotechnology is neither a panacea nor a replacement for established tools. It provides an additional approach to agricultural problems. For example, leaner meats can be produced by altering animal nutrition, through selective breeding or by the administration of hormones-some of which might be produced through biotechnology. Eventually, transgenic animals that contain less fat may be produced. Ultimately, the best route may be a combination of techniques including biotechnological methods. Similarly, new plants can be produced through selective breeding, cell culture techniques, or through genetic engineering techniques. Genetic engineering extends the range of new traits that may be introduced into a plant to include traits from other species.

The first products being developed are animal diagnostic and therapeutic products that are al ready on the market and biopesticides, the first of which have won regulatory approval. Transgenic plants are currently being field tested and are likely to be available within a few years. Transgenic animals will first be developed for laboratory uses; technologies for producing transgenic livestock for food will probably not be available until after the turn of the century.

\section{Applications to Animals}

\section{Reproductive Technologies}

A variety of new reproductive technologies may have an important impact on animal production. Some technologies that do not depend on biotechnology are already in use. Artificial insemination, using semen from genetically superior bulls, is routine in the dairy industry today. Technologies are also available, although none has been widely adopted, that separate sperm to allow sex determination in artificial insemination. Sex selection would be valuable for dairy farmers, for example.

Traits from genetically superior female animals can be propagated using embryo transfer techniques. Cows treated with hormones produce several eggs which are fertilized by artificial insemination, collected, and transferred to surrogates. Laboratory techniques are also available that permit the embryos to be split into multiple, identical copies (43).

\section{Animal Health Products}

The application of biotechnology to animal health care products is similar to $R \& D$ in health products for humans, and often these products are developed by the same fins. Monoclinal antibodies, for example, may be developed into new diagnostic 
Figure 6-I-Preparation of Monoclinal Antibodies
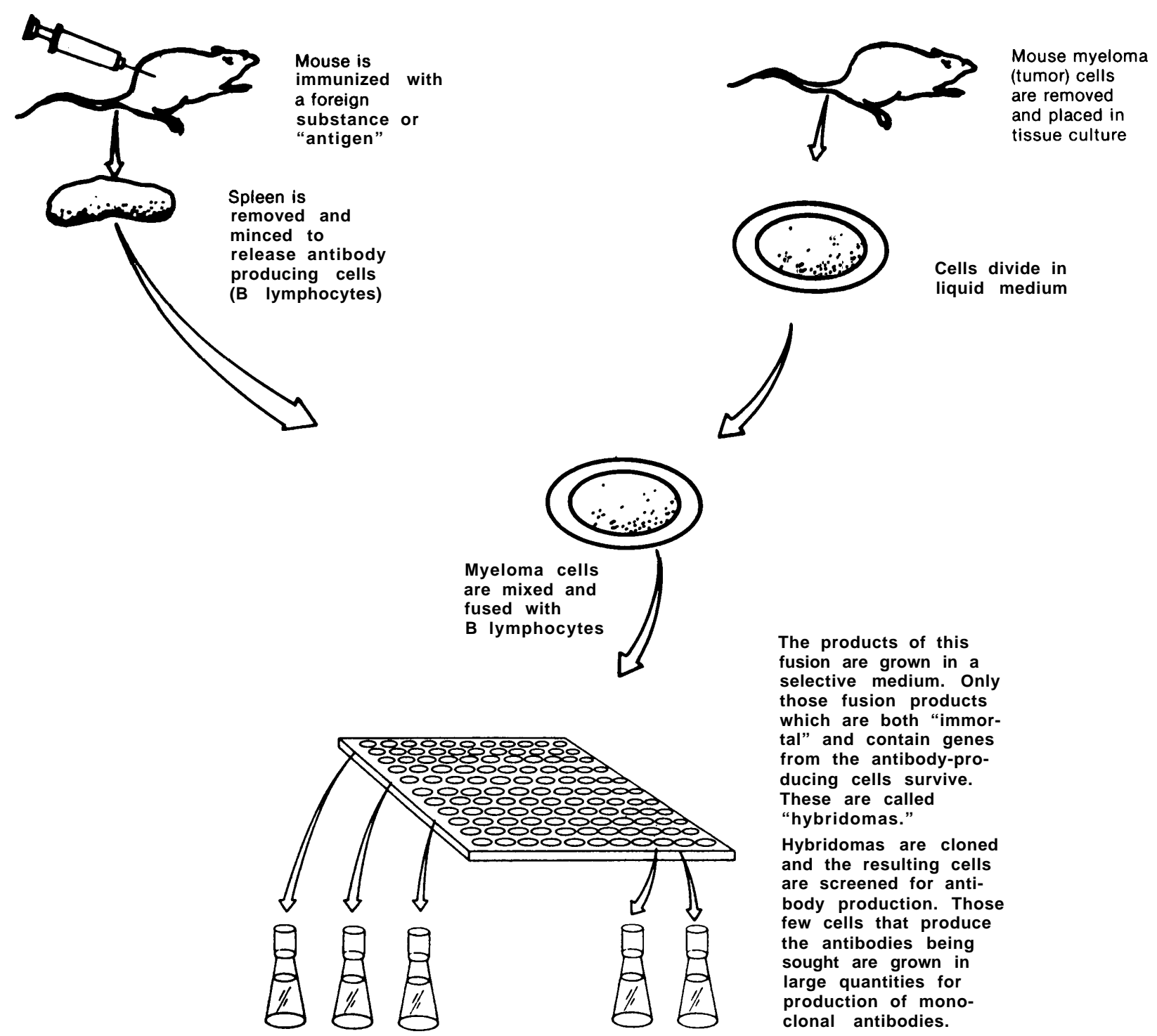

SOURCE: Office of Technology Assessment, 1991.

products for animal diseases just as they are used in tests for human disease (see figure 6-I). New, safer animal vaccines have also been developed. The first genetically engineered vaccine, introduced by Molecular Genetics in 1984, protects against scours (a disease in calves and piglets). A genetically engineered swine pseudorabies vaccine was approved in the United States in 1987, and rabies vaccines are being tested in the United States, Canada, and Europe $(12,14,53)$.

Although the technical possibilities for animal health products may be similar to human products, and the R\&D investment required may also be similar, their profitability is not similar. Unlike human health care products, the decision to use animal health care products is essentially a business 
decision. Animal products do not command prices comparable to those of human health products.

\section{Growth Hormones}

Bovine growth hormone, or bovine somatotropin (bST), which stimulates milk production is under development by four U.S. firms. The Food and Drug Administration (FDA) found in 1985 that the milk and meat from treated cows were safe for human consumption, and that finding was confirmed by a committee assembled by the National Institutes of Health (NIH) in 1990. Some farm organizations, however, concerned about the possible toxic effects of BST, its possible rejection by consumers, its effects on animal welfare, and the ultimate effects of increased efficiency of milk production on the survival of marginal dairy farmers, have opposed BST, leading to moratoriums on its use in Wisconsin and Minnesota. Similar concerns have resulted in a moratorium on BST use in the European Community $(\mathrm{EC})(7,34)$.

Animal growth hormones are also being studied as a method to produce leaner meats. The variation in body composition among animals of the same species depends on the growth stage of the animals, their nutritional history, and their genetic base. The production of leaner meats can be accomplished by manipulating these variables through selective breeding, nutrient management, and hormone administration. For example, selective breeding has resulted in the production of modern, leaner hogs. Also, leaner beef has been produced by breeding cattle of larger frame size. The administration of porcine growth hormone, produced through genetic engineering, can speed the growth of hogs, improve feed efficiency, and result in leaner meat (32).

\section{Transgenic Animals}

An alternative to treatment with growth hormones is transferring growth hormone genes directly into the genomes of animals, so the additional hormone is supplied endogenously rather than administered by the farmer. Early experiments, however, have shown that simply transferring the genes is not effective, and further fine-tuning of the regulation of the genes' expression is necessary (8). Other genes, such as the human estrogen receptor and insulin-like growth factor, have been transferred to cattle in attempts to produce faster growing animals $(8,34)$. Using transgenic livestock as food, however, is not expected before the end of the century. In the near

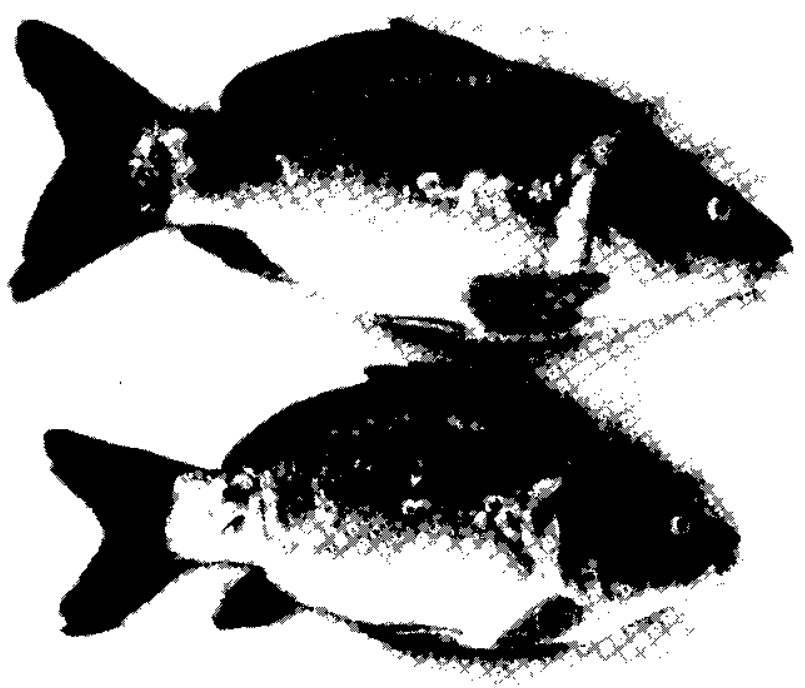

Photo credit: Rex Dunham, Auburn University

At top, a transgenic carp containing trout growth hormone gene; bottom, normal carp.

term, transgenic animals are being developed for nonagricultural purposes, including models for human disease and for use in toxicity testing. For example, one transgenic mouse line produces human sickle cell hemoglobin (40). Other mice, including the frost patented transgenic animal, have been given genes important in cancer development (55). These may eventually be used to identify carcinogens in a shorter the than is now possible and to facilitate studies of oncogenes. Another nonagricultural application of transgenic animals is their use in the production of pharmaceutical proteins. A gene encoding a protein can be transferred to animals that then produce the desired protein in their milk, from which the protein can be purified (30).

\section{Applications to Plant Agriculture}

Microbial Pesticides and Other Micro-organisms

The frost biotechnology-based products for plant agriculture to be commercialized were biopesticides. Many nonengineered biopesticides based on Bacillus thuringiensis (BT), a bacterium that produces a protein toxic to the larvae of many butterflies and moths, have been in use since the early 1960s (31). Biopesticides, however, represent a tiny fraction of the international pesticide market that is dominated by chemical pesticides (49). Over 600 chemical pesticides have been approved by the Environmental Protection Agency (EPA). 
Nonrecombinant biopesticides based on BT have some advantages over chemical pesticides: they are highly toxic to specific pests, leaving humans, crops, wildlife, and beneficial insects unharmed; they do not persist in the environment; and they can be produced using fermentation processes $(21,31)$. But commercial weaknesses have prevented their widespread use. Each pesticide is active against relatively few pests, so the potential market for many pesticides is small. In addition, naturally occurring microbial pesticides often work too slowly and degrade too rapidly in the field. Biotechnology offers a means of addressing these commercial drawbacks. Eventually, more than one pesticidal protein will be engineered into a micro-organism, thereby increasing its host range. The gene for the protein can also be modified, allowing more of the pesticide to be produced and increasing its effectiveness against pests (21). In addition, pesticides can be formulated and delivered to increase their persistence in the environment.

For example, two U.S. firms, Mycogen and Crop Genetics International, are exploring new delivery systems. Mycogen is developing a series of biopesticides designed to protect vegetable crops. Mycogen scientists inserted a gene that encodes a BT toxin into a different bacterium that produces more of the toxin. After the bacteria produce the toxin, the bacteria are killed and treated to fix the cell walls. This leaves a particle containing crystalline toxin within a long-lasting protective coat (47). The dead bacteria are sprayed on plants as a topical insecticide, killing susceptible insects that eat the sprayed plants. Although dead bacteria are not as long lasting as live, reproducing bacteria, the use of killed bacteria makes the regulatory approval process simpler and faster.

Crop Genetics I nternational, Inc. (CGI) has explored a different method of delivering BT toxins. CGI has used micro-organisms called endophytes that live and reproduce inside the vascular system of plants. CGI scientists inserted a gene for a BT toxin into the genome of an endophyte that was then inoculated into seeds. When the seeds were planted the endophytes multiplied inside the plants. The firm has field-tested corn and rice containing an endophyte with a BT gene that protects the plants against the European corn borer and the rice stem borer. The field tests have shown that the endophyte does not survive outside the plant, nor is the endophyte transferred to nearby uninoculated plants. CGI has agreements with four seed companies that plan to use CGI's technology to introduce the endophytes into their existing seed products. The company expects to extend this technology to other major crops (49).

Microbial biopesticides compete in the marketplace with chemical pesticides, and eventually, they will compete with plants that have been made pest resistant through the incorporation of $B T$ genes directly into their genomes. Biopesticides have the advantage of being widely applicable to many varieties without extensive multiyear breeding programs necessary for developing transgenic plants. On the other hand, both the plants containing endophytes and the transgenic plants are resistant to pests without the labor of spraying crops. The pesticide contained in dead bacteria has a strong advantage, however, in its relatively quick regulatory approval time. EPA approved two of Mycogen's recombinant biopesticides in J une 1991.

Other useful micro-organisms, such as improved nitrogen-fixing bacteria, are also being field-tested. These bacteria live in nodules on the roots of legumes, such as peas and beans. The bacteria convert nitrogen in the air into a form that the plants can absorb and use. Research is directed at developing strains of bacteria that fix nitrogen more efficiently and that can effectively compete with indigenous soil bacteria in forming nodules thereby being better able to support a healthy crop of legumes (3).

\section{Plant Research}

Scientists also use biotechnology as a tool for basic research on plant growth and development. One technique, restriction fragment length polymorphism (RFLP) analysis, shows particular promise in speeding conventional plant breeding and, eventually easing breeding involving complex multigenic traits. An RFLP map consists of a set of cloned deoxyribonucleic acid (DNA) fragments from chromosomal locations throughout a plant's genome. A RFLP marker, or one DNA fragment, can be used as a tool to follow the inheritance of the particular region of the genome in which the marker is located. This procedure can then be used as a guide to selecting plants that possess specific genetic attributes desired in a seed product (see box 6-A).

A good example is the application of RFLP analysis to backcross breeding. Many of the im- 


\section{Box 6-A-Plant Genome Projects}

To identify and characterize genes that are agriculturally important, the United States and several other countries have begun to fund research on plant genomes. The U.S. Department of Agriculture's (USDA) Plant Genome Mapping Program is the largest of these programs, with a budget of $\$ 11$ million in research funds for the 1991 fiscal year. Its specific objectives are construction of high-resolution gene maps for those plants species with sufficient background information al ready available (e.g., tomato, corn, and rice); development of low resolution maps for all major crop species important to the United States (about which little information is available at the moment); high-resolution mapping and sequencing of specific regions of the chromosome for investigating specific genes of economic interest (e.g., hybrid vigor, disease resistance, and drought resistance); and a complete sequencing of the Arabidopsis genome. In addition, the USDA's Agricultural Research Service has received a \$3.7 million appropriation in fiscal year 1991 to manage dissemination of information generated by the program (using such tools as databases and publications). Eventually, it is hoped that the gene maps and sequences will be used to identify and manipulate genes that encode important traits.

The National Science Foundation (NSF), the National Institutes of Health $(\mathrm{NIH})$, and the Department of Energy (DOE) have also funded research on Arabidopsis thaliana, an agriculturally unimportant member of the mustard family increasingly being used as a model system by plant scientists (just as fruit flies are used by animal geneticists). Arabidopsis is a small plant with a small genome (about 10 percent that of the human genome), small seeds, and a short life cycle (about 6 weeks). These qualities allow it to be grown in large numbers in greenhouses and rapidly screened for mutations. In addition, DNA can be transferred into Arabidopsis plants using Agrobacterium vectors, and viable plants can be regenerated from cultured cells. Scientists can study genes important to plant growth and development, for example, in this small, easily manipulated plant and then apply this new knowledge to agriculturally important crop plants. The NSF is spending \$4.4 million in fiscal year 1991 on studies of the Arabidopsis genome through its existing research programs. The European Community, through its Biotechnology Research for Industrial Development and Growth in Europe (BRIDGE) program, is also funding gene mapping studies on the Arabidopsis genome, allocating ECU 3 million for 1991-92. The United "Kingdom, in addition to participating in BRIDGE, funds research and postdoctoral fellowships for work on Arabidopsis.

$J$ apan's Ministry of Education and the Ministry of Agriculture, Forestry, and Fisheries (MAFF) fund studies on plant genomes, particularly rice. The MAFF plans a 10-year project on the rice genome to begin in 1991. The MAFF also plans to construct a rice research facility in Tsukuba, J apan's "Science City."

SOURCES: U.S. Department of Agriculture, 1991; National Science Foundation, 1991; Kagaku Kogyo Nippo, Aug. 31, 1990; A. Vassarotti et al., "Genome Research Activities in the EC," Biofutur, October 1990, pp. 1-4; "Genome Research," European Biotechnology Information Service, vol. 1, No. 17, 1991, p. 17.

provements introduced into modern crop plants originated in related varieties, races, or species. Traditionally, a plant containing one desirable trait, such as disease or pest resistance, was crossed with a plant from a standard line into which the desired trait was being introduced. In backcross breeding, the offspring of this cross (containing the desirable trait) would be grown and crossed again with a plant from the standard line. Offspring from this cross containing the desirable trait would again be crossed with the parent line. After several generations, plants will be obtained that are nearly identical with the original, standard line but which now will contain the desirable trait. RFLP markers can be used to identify offspring that have inherited the desirable trait but that, by chance, also have inherited much of the genome derived from the standard line. One group has estimated, using computer simulation, that this technique can be used in breeding tomatoes, cutting the number of crosses from six to-three (46).

\section{Cell Culture}

Plant cells grown in culture can be an alternative source of valuable substances that are now isolated from whole plants. Vanilla, for example, is usually extracted from the beans of the vanilla plant. Vanilla isolated from cultured cells of the vanilla plant can be produced less expensively than traditional vanilla extract, according to a firm that has developed a process for producing vanilla in commercial quantities. Other substances, including pigments and fragrances, have also been isolated from cultured plants cells $(9,45)$.

New plants can also be developed from cultured plant cells (see figure 6-2). Unlike cultured animal cells, some cultured plant cells treated with a mixture of nutrients, minerals, and hormones will 
Figure 6-2-Plant Propagation: From Single Cells To Whole Plants

The process of plant regeneration from single cells in culture

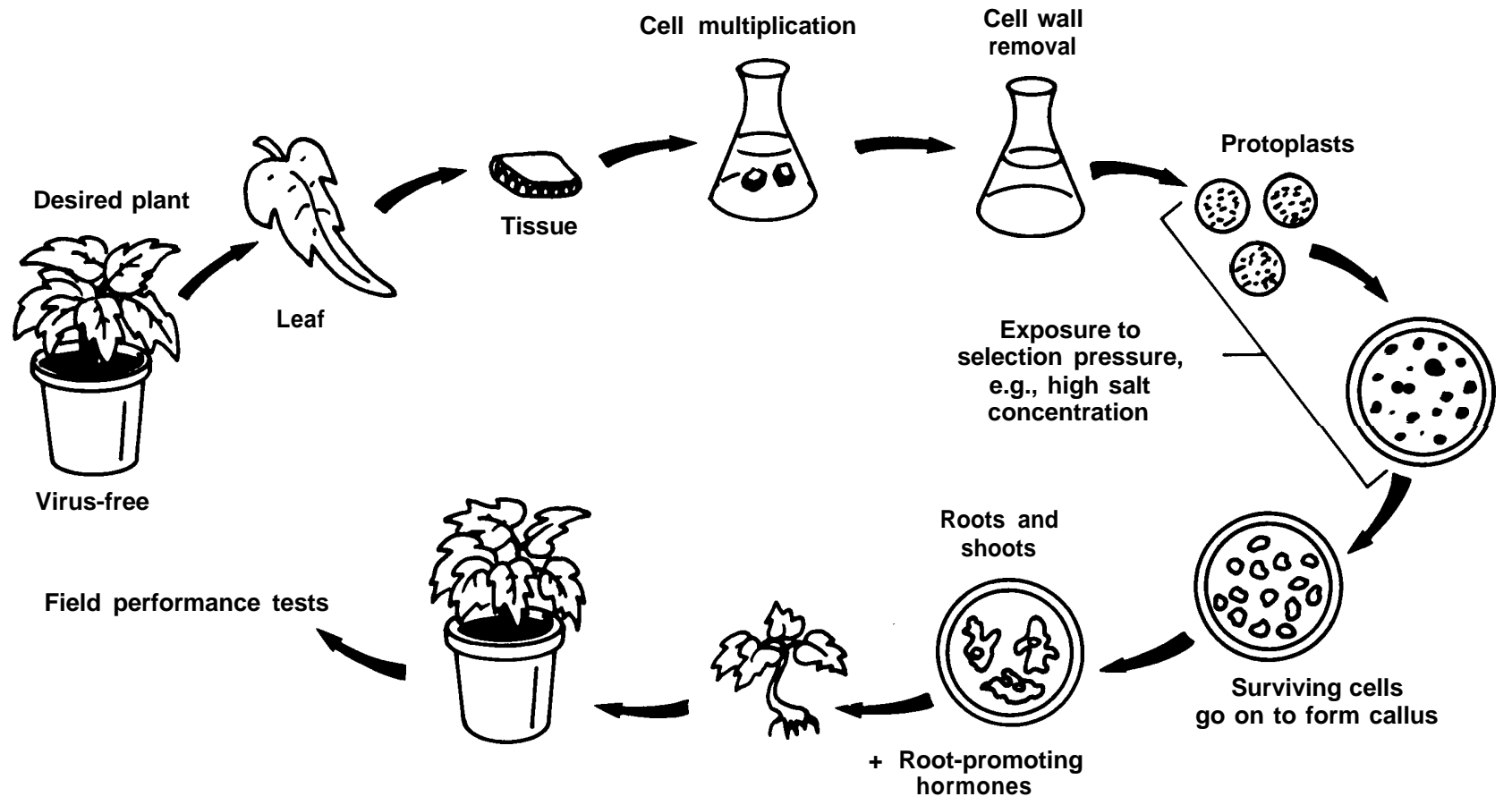

The process of plant regeneration from single cells or plant tissue in culture.

SOURCE: Office of Technology Assessment, 1991.

form roots and shoots and grow into viable organisms. Plants derived from these cultured cells may contain mutations resulting in altered traits. These new plants can then be screened for desirable traits. For example, FreshWorld, a joint venture between DuPont and DNA Plant Technology, is selling crisper, sweeter carrots and celery regenerated from cultured cells. DNA Plant Technology is using the same techniques to devel op tomatoes having higher solids content-a product useful to food processors. In J apan, a late-maturing variety of rice was developed using these techniques by a joint venture company formed by Mitsubishi Chemical Industries and the Mitsubishi Corp., and a short-stemmed variety was developed by the Mitsui Toatsu Chemical co. (19).

\section{Transgenic Plants}

The ability to insert foreign genes into plants, using recombinant DNA (rDNA) methods, provides plant breeders with new strategies for plant modification and improvement. Research and field-testing have recently been dominated by plants exhibiting three kinds of new traits: herbicide resistance, insect resistance, and viral resistance. Altering other plant traits important for plant growth and development, such as those affecting plant tolerance of environmental stress (e.g., drought and salinity) or traits that add to value, often require better understanding of the molecular basis of these traits-many of which may be multigenic and, therefore, more difficult to transfer.

Genes that confer resistance to several classes of herbicides have been isolated and transferred to a number of plants, including tomato, tobacco, cotton, oilseed rape, soybeans, sugar beets, and alfalfa. Herbicides are widely used in agriculture, leading to increased crop yields that result when weeds competing for soil, light, and nutrients are removed. Herbicides also contribute to soil conservation by permitting no-till practices in which weeds are controlled through herbicide use rather than by plowing. The herbicide-resistant gene enables a crop plant to tolerate the toxic effects of a herbicide applied to kill surrounding weeds. Chemicals are currently available to control most weeds, but 


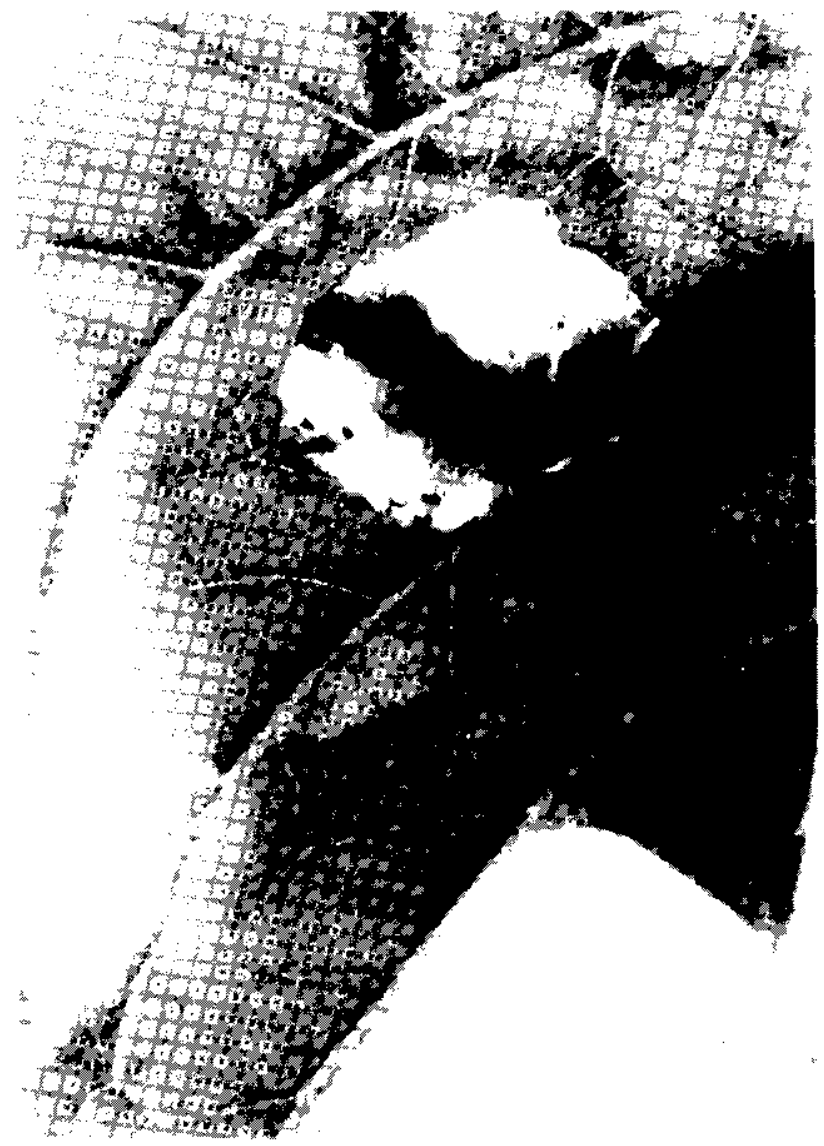

Photo credit:Rohm \& Haas Co.

\begin{abstract}
Manduca sexta (tobacco hornworm) larva at work. The moth will consume 95 percent of its entire life cycle's food supply while in the larval stage of development. Moth larvae are the most destructive insects to world agriculture and forestry.
\end{abstract}

developing herbicideresistant plants increases the variety of crops to which a particular chemical may be applied. It is possible that this could lead to increased use of chemical herbicides. However, if troublesome chemicals can be displaced by increasing the use of herbicides that require lower application rates, do not persist in the environment, and have fewer toxic side effects, then there will be an environmental benefit (27).

The first successful transfer of an insectresistance gene to a plant was done with tobacco by a Bel gian firm, Plant Genetic Systems, in 1987 (54). Insect resistance has now been transferred to a number of plant species by transferring genes for pesticidal proteins isolated from BT (31). Because any particular toxin is effective only against specific insects, chemicals may still be necessary for control

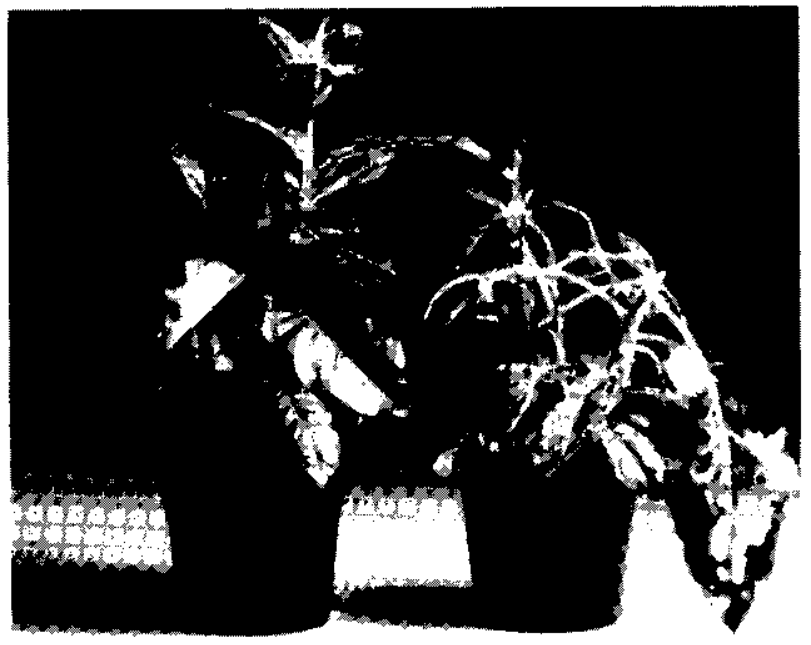

Photo credit: Rohm \& Haas Co.

The effects of the BT gene transfer on laboratory tobacco plants can be easily seen in the plant on the left which was infested with 20 tobacco hornworm larvae. Within $\mathbf{4 0}$ hours the hornworms were killed by the BT protein in the plant tissue they ingested, leaving the plant virtually undamaged. The other plant, which did not have the gene transfer, shows total destruction by the same number of insects in the same time period.

of multiple pests. Broader spectrum pest control may eventually be achieved by transfers of several insectresistance genes. It is possible, however, that increased use of plants containing BT toxins will result in BT-resistant pests.

Within the last few years, it has been learned that introducing genes that encode viral proteins can make plants resistant to virus infection(I). Although the mechanism of viral resistance is not well understood, this is an area of active research and field-testing. Its commercial prospects are limited to specific crops in specific regions where viral diseases present a significant problem, such as wheat in the United States and cassava in the tropics.

Traits such as insect or disease resistance can increase the value of plants to farmers. Other new plants are being developed, however, with traits that are not aimed at increased yields or lower input costs for farmers. These traits are intended to meet the needs of food processors and consumers. These new plants have traits that change the nutritional content of a plant, alter its processing qualities, or increase its consumer appeal. For example, genetically engineered tomatoes, developed by Calgene and now being tested, have a gene that interferes with the 
ripening process that causes tomatoes to become soft. In the future, additional products based on a deeper understanding of molecular mechanisms may be developed. For example, the nutritional content of corn may be enhanced by increasing the amount of the amino acids lysine and methionine in the seeds. Work is underway to produce coffee with lower caffeine content. Oilseeds with higher oil contents, altered ratios of fatty acids (for enhanced nutritional properties), or longer shelf lives will be developed. Genes that control flower colors are being transferred to develop new ornamental. Some of these traits can be modified through traditional breeding programs, but biotechnology can improve the efficiency of making changes and extend the range of possible modifications (5).

\section{Applications to Food Processing}

Biotechnology can contribute to food processing in various ways, but most current applications emphasize cost reduction. Biotechnology can be used to improve the production of existing goods currently made using fermentation, such as vitamins and amino acids used as additives in food and animal feed. Biotechnology can also be used for the production of food processing enzymes. One food enzyme, chymosin, used in cheesemaking, was traditionally extracted from calves' stomachs and sold as part of a mixture called remet. Rennet varied in quality from batch-to-batch, and its scarcity led to rising prices in recent years. Researchers at Pfizer, Inc. transferred the gene encoding chymosin to bacteria that could be grown in large fermentation tanks, yielding large amounts of chymosin. The enzyme was approved for food use by the FDA in 1990 (55 F ed. Reg. 10932).

Micro-organisms are widely used in baking and brewing. A baker's yeast altered using biotechnology has been approved for use in the United Kingdom (U.K.). There is also interest in developing genetically engineered micro-organisms for the production of high-value compounds currently isolated from plants. Among these products are dyes, vitamin s, flavors, colors, lipids, steroids, and biopolymers $(16,39,44)$.

The application of biotechnology to food processing has received a great deal of interest in J apan. $\mathrm{J}$ apan leads in world production of amino acids and fermented food products. Their expertise in fermen- tation makes biotechnology a natural extension of their current strength (16).

\section{CASE STUDY: THE SEED INDUSTRY}

Whether or how biotechnology is used by a firm depends on a variety of factors, among them:

- The potential for profits from the investment. This depends on the size of the market, rates of adoption, intellectual property protection, the existence of substitutes, and public acceptance of new products.

- The role of $R \& D$ in the industry. This may depend on competitive pressures to develop new products.

- The time it takes to realize a return from such an investment. Anything that delays the return on the investment, such as regulations, may inhibit investment. A more detailed description of the seed industry provides an illustration of interplay between the forces that influence the use of biotechnology.

\section{Industry Structure}

In 1988, U.S. farmers spent $\$ 3.7$ billion on seeds (52). The worldwide market has been estimated at $\$ 12$ billion to $\$ 15$ billion. But these estimates exclude the extensive informal seed market. Farmers often plant seed saved from a previous harvest or purchase seed from another farmer. Estimates of the total seed market vary considerably, ranging as high as $\$ 62$ billion (41).

The seed industry has many markets, including those for grass, forage, vegetable, flower, and field seeds, each having its own supply, demand, price, and organizational characteristics. Many seed producers are small firms that grow and distribute common varieties of seed for regional markets. The small firms conduct little or no research, but they effectively market new technologies provided by public or private seed suppliers.

A portion of the seed industry consists of larger firms with resources to invest in the long-term research necessary to produce genetically improved seeds (see table 6-I). These are the firms likely to benefit from the use of biotechnology. For these fins, however, investment in research has historically been less than 5 percent of revenues (13). Today, investment in research is higher; in 1989, 
Table 6-I-Major World Seed Firms

\begin{tabular}{|c|c|}
\hline 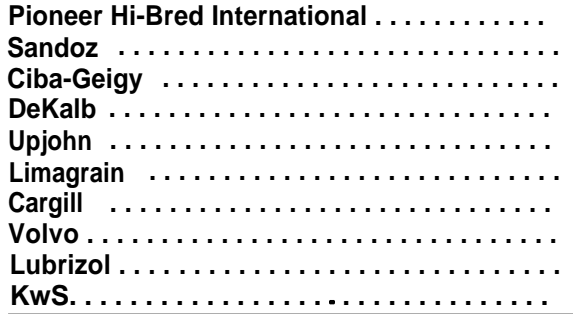 & $\begin{array}{l}\text { United States } \\
\text { Switzerland } \\
\text { Switzerland } \\
\text { UnitedStates } \\
\text { United States } \\
\text { France } \\
\text { United States } \\
\text { Sweden } \\
\text { UnitedStates } \\
\text { Germany }\end{array}$ \\
\hline
\end{tabular}

SOURCE: Office of Technology Assessment, 1991.

Pioneer Hi-Bred International invested 7.6 percent of total revenue in $R \& D$ (37). Most seed research is based on selective breeding programs used to develop seeds that are high yielding or have other advantageous traits.

\section{Internationalization and Consolidation}

Over the last 30 years, the seed industry has been marked by increasing internationalization. During the 1960s, major U.S. firms began exporting seeds, particularly the better hybrids, into Latin America and Europe. This was followed, in the 1970s, by increasing acquisitions of small firms, as U.S. firms expanded into Europe and large European seed firms invested in the United States. The major firms also developed subsidiaries in Australia and Latin America-especially in Argentina, Brazil, and Mexico. The French firm Limagrain, for example, has subsidiaries in Australia, Brazil, Chile, Germany, Italy, Mexico, Morocco, The Netherlands, Spain, Tunisia, Turkey, and the United States. The U.S. firm Pioneer Hi-Bred International, Inc. sells seed in 80 countries worldwide and has subsidiaries in Argentina, Australia, Austria, Brazil, Canada, France, Germany, India, Italy, J apan, Mexico, the Philippines, Spain, and Thailand (41).

Seed companies were, historically, closely held businesses. Increasingly, however, both small and large seed firms have been acquired, not only by other seed firms but by other major multinational companies. Since the mid-1960s, over 100 seed companies have been acquired by multinational chemical, pharmaceutical, and oil corporationsoften those with agricultural chemical subsidiaries. Few major seed companies remain independent: the U.S. firms Pioneer Hi-Bred International, Holden's Foundation Corn Seeds, and DeKalb; the French firm, Limagrain; and the Brazilian firm, Agroceres $\mathrm{SA}$, have managed to continue independently. Other major research-based firms are now subsidiaries of

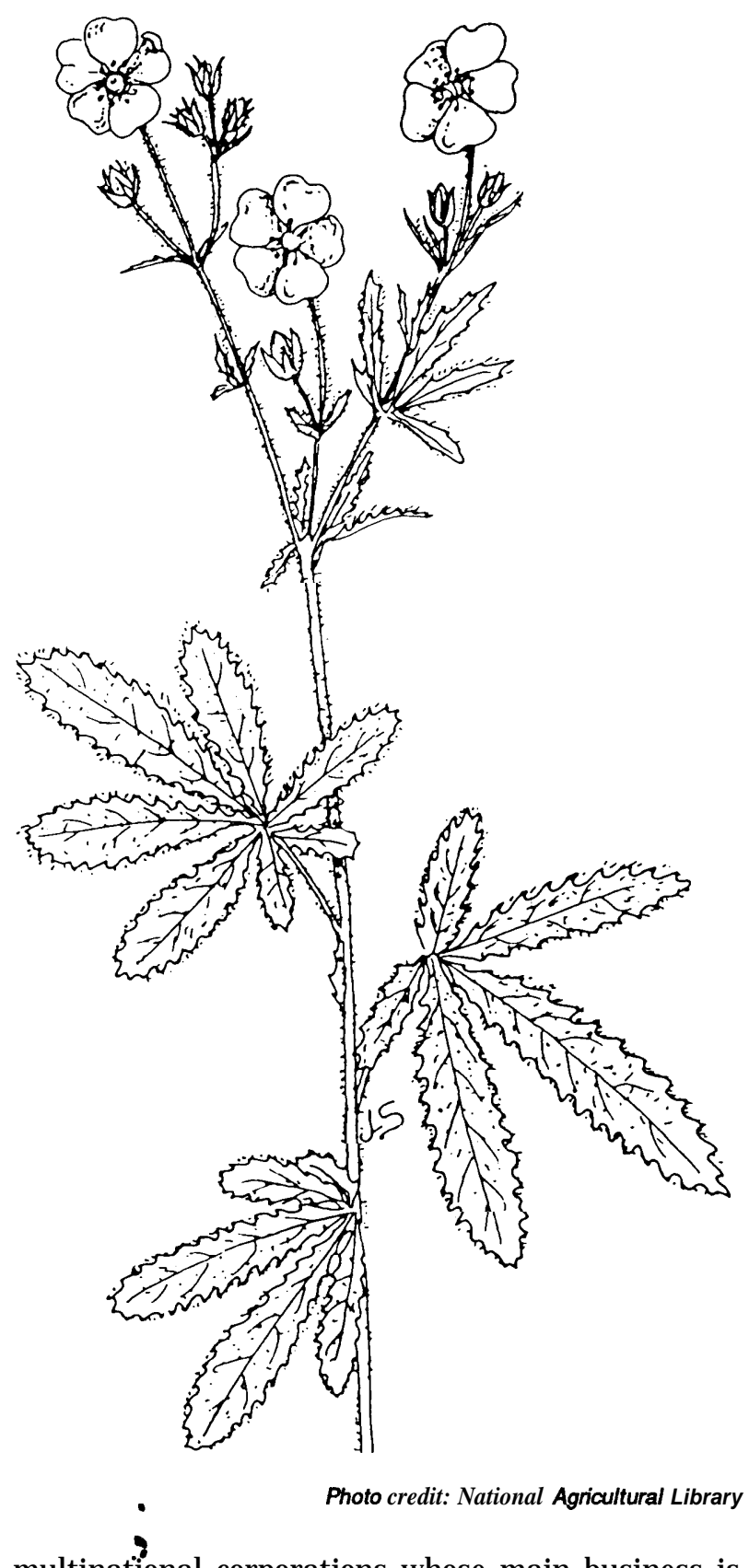

multinational corporations whose main business is not seeds.

Many of the corporations that chose to invest in seed companies were E uropean firms that lead in world sales of pesticides and fertilizers. The Swiss firm, Ciba-Geigy, for example, acquired the U.S. seed firm, Funk, in 1974. The British chemical firm $\mathrm{ICl}$ has acquired six seed companies, including Garst, one of the leading U.S. firms. Rhone-Poulenc has recently acquired five seed firms, including 
Clause, an important French company. The U.S. chemical firm Lubrizol owns eight seed firms through its Agrigenetics subsidiary. Corporations best known for producing pharmaceuticals have also invested in seed firms. Upjohn owns Asgrow Seeds, and Sandoz acquired eight seed subsidiaries from 1976 to 1988, including Northrup King and Stauffer Seeds in the United States. There are also examples of major cereal and sugar producers acquiring seed firms. Cargill, the major U.S. food producer, specializes in seeds of corn, wheat, and sunflowers and has subsidiaries in nine countries. Cardo, a major Swedish sugar producer and now a subsidiary of Volvo, has invested heavily in the production of sugar beet seed. More recently, biotechnology firms have begun to acquire seed firms, seeking outlets for their technology. For example, Calgene has purchased Stoneville, and Biotechnica has purchased five regional seed companies $(17,20,41)$.

This recent consolidation has made the researchbased sector of the seed industry extremely concentrated. For example, in 1985, four firms supplied 64 percent of corn seed in the U nited States; Pioneer $\mathrm{Hi}$-Bred, alone, supplied 38 percent. Pioneer also led in providing corn seed in France, where it held 55 percent of the market, followed by Limagrain with 15 percent. In Brazil, 34 percent of corn seed was supplied by Agroceres. In France, sunflower seed sales were dominated by Cargill, which held 75 percent of the market in 1985 (41).

\section{Research in Seeds}

Keeping market share requires constant development of new, improved products. For example, in 1989, Pioneer released 24 new corn hybrids. A new hybrid is usually marketed for about 7 or 8 years before it is superseded by improved hybrids. A hybrid's lifetime depends on how unusual it is, how much competition there is (if a market is large, competitors will develop similar hybrids), and how insect and disease pressures change over time. A few exceptional hybrids have been sold for more than 20 years, because they have qualities that make them suitable for a particular region (28). A number of other factors influence the types of research projects that a seed firm may choose to undertake. Among these are: the potential market size, the time it will take to realize a return on investment, the availability of intellectual property protection, and technical constraints.
Hybrid Seed

The research-based sector of the industry grew with the introduction of hybrid corn in the 1920s. Hybrid seeds are the first generation of a cross between two unrelated strains of a plant. Some hybrids have much higher yields than conventional seed and, therefore, command high prices. The high yields more than offset the higher prices firms charge for the seeds.

Hybrids do not breed true. The high yield is obtained only in the first generation. To obtain the high yield, farmers must purchase seed from suppliers each year. In the U nited States, 95 percent of corn planted each year is grown using seed purchased from seed suppliers. The assurance of repeat business gives seed firms a strong incentive to continue research into better yielding hybrid seeds. Corn, grain sorghum, sunflowers, and some vegetables are typically sold as hybrids (2).

Most other crop species are naturally selfpollinated. For many of them it is difficult to produce hybrid seeds on a large scale for commercial purposes (see box 6-B). Unlike hybrids, selfpollinated varieties breed true. Farmers can choose to buy fresh seed or to plant seed saved from the previous year's harvest with little difference in yield. Although there are advantages to buying fresh seed, which has an assurance of purity and has been cleaned and tested for germination, or seed of a newly available, higher yielding variety, farmers often choose to plant saved seed. As a result, only 35 percent of wheat and 50 percent of cotton seeds are purchased from suppliers each year (2).

Firms do research on self-pollinated crops, but there is much less incentive to invest heavily because the companies cannot capture profits as they can with hybrids. Competition with saved seed also depresses the prices firms can charge for their seed $(2,23)$.

The repeat business associated with hybrid seeds guarantees a sizable market. The market size also depends on how widely the crop plant is grown. Most research, using both biotechnological and traditional approaches, is performed only on those crops that offer markets of sufficient size to enable returns on $R \& D$ investment. 


\section{Box 6-B-Developing New Hybrids}

Some plants readily lend themselves to hybrid production. In corn, for example, the structures that produce pollen, the anthers, are located at the top of the plant on the tassels. If a plant's tassels are physically removed or if a mutant is grown that does not produce pollen, all the eggs will be fertilized by pollen from neighboring plants. By growing plants of one strain of corn near plants that are genetically male-sterile or hand-emasculated, hybrid seed can be obtained

In many plants, however, there are no genetic male-sterile varieties. In addition, many of these plants have small, delicate flowers, and it is difficult and time-consuming to remove anthers by hand. Some chemical treatments are available for producing sterile plants (and have been used in the production of hybrid wheat). For many plants, however, producing hybrids on a commercial scale is not practical.

Recently, however, scientists from a Belgian firm, Plant Genetic Systems NV, collaborating with scientists at UCLA have developed a general method for producing male-sterile varieties. The scientists transferred a gene that prevents anther development into otherwise normal tobacco and oilseed rape plants, resulting in male-sterile plants. The extension of this technology to additional crops has the potential to extend the benefits of hybrid production to other species. It is hoped that some of these new hybrids may show the increases in yield typical of hybrid corn.

SOURCE: C. Mariani et al., "Induction of Male Sterility in Plants by a Chimaeric Ribonuclease Gene," Nature vol. 347, 1990, pp. 737-741.

\section{Intellectual Property}

To stimulate private-sector research on nonhybrids, Congress passed the Plant Variety Protection Act (PVPA) in 1970. PVPA extends patent-like protection to sexually reproducing plant varieties outside the existing patent system. PVPA is administered by the U.S. Department of Agriculture (USDA) rather than by the U.S. Patent and Trademark Office (PTO). It gives the owner of a protected variety the right to exclude others from selling, reproducing, importing, or exporting the protected variety for 18 years. But, there are two important exceptions: farmers may save or sell seed they have produced themselves for future planting, and researchers, including competitors, may also use protected varieties in their research programs to develop new seed products. A system establishing similar breeders' rights was created in Europe by a 1961 treaty establishing the International Union for the Protection of Plant Varieties (UPOV).

A survey of seed companies, conducted in 1980, reported growth in the number of research programs on nonhybrid crops and increases in total research expenditures on nonhybrid crops after PVPA was enacted in 1970. For example, of the 21 soybean breeding programs the surveyors found existing in 1979, only four had existed before 1970 and some of those were founded with the expectation that PVPA would be enacted. Increases in cereal research were also noted, while forage-breeding programs had increased slightly and seemed to be unaffected by passage of the new law (36).

Seed firms face difficulties enforcing provisions of PVPA. If another firm sells a protected variety, the seed company that owns the variety must find the seed pirate and sue for damages. Although the extent of infringements is unknown, it occurs often enough that seed firms are taking action. Asgrow Seed Co. has found violators advertising Asgrow varieties in local newspapers, but protected seed sold less blatantly, under a new name, is harder to track (24).

PVPA is limited in its protection of products developed using biotechnology. It extends protection to a single variety only. Today, utility patents may also be obtained for plants and plant parts as a result of a 1985 Supreme Court ruling (10). Utility patents offer broader protection than does PVPA; there is no farmer or research exemption. Finns have filed patent applications for, among other things, DNA sequences, plant cells, gene isolation processes, DNA transfer processes, whole plants, and other plant parts. Questions remain, however, about the scope of patent coverage, and in the absence of new legislation they will be answered as the courts resolve disputes (31).

In Europe, intellectual property protection for plants remains confined to protection for plant varieties established by UPOV, although DNA sequences, plasmids, and plant cells are patentable. Plant and animal varieties are generally excluded from patent protection in European countries. Patent laws in Australia and Japan, on the other hand, do not exclude plants and animals (4). 


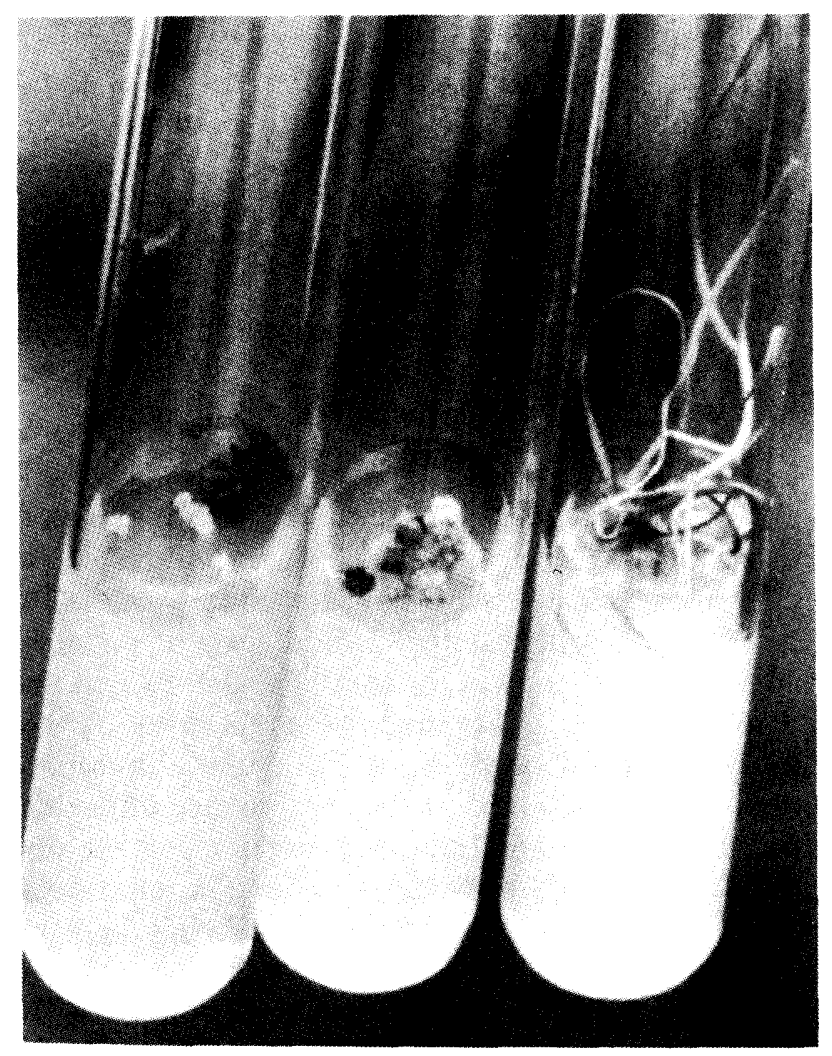

Photo credit: Diversity, Genetic Resources Communications Systems, Inc.

Plant culture.

Regulations

In conventional plant breeding programs, potentially useful new traits are bred into plants that have other important agronomic traits, and the plants are then field tested in different climates. The most successful varieties are then bred for several years to produce commercial volumes of seed. This process, from the initial breeding to product introduction, takes 10 to 15 years (5). For genetically engineered plants, this process is lengthened because of requirements for field testing to demonstrate safety. In addition, firms have to obtain regulatory clearance before marketing a new product. These increases in the time it takes to develop new products have their greatest impact on cash-starved, small fins. It is also unclear how the FDA will evaluate food plants, although the FDA has made clear its intention to use its existing authority under the Food, Drug, and Cosmetic Act $(15,48)$.

Regulations on field testing genetically modified plants are particularly strict in northern Europe, due to adverse public opinion. In J apan, regulations for field-testing genetically modified plants were issued by the Ministry of Agriculture, Forestry, and Fisheries in the summer of 1989, but, so far, only a single test has been reported.

\section{Technical Constraints}

Technical constraints have, over the last several years, limited the ability of seed firms to apply biotechnology to the most valuable potential projects. Of the plants that have been field-tested in the United States, the vast majority have been vegetable crops altered to make them herbicide, insect, or virus resistant. There has been heavy emphasis on applying biotechnology to vegetables, because they are the easiest crops into which to transfer DNA. The most widely used method of transferring DNA into plant cells depends on the use of an infectious bacteria, Agrobacterium tumefaciens, which, on infection, transfers DNA into the genome of the plant. Altered forms of the bacteria have been developed that allow researchers to transfer specific DNA fragments that confer useful, new traits into a plant. But, these bacteria do not infect cereal plants $(56,57)$. Only recently have researchers reported a new technique for DNA transfer into plants using a particle delivery, or ballistic, system (22). Three firms have reported the successful application of this technique to corn, followed by regeneration of viable plants with new genes incorporated stably into nuclear DNA. The variety of plants to which biotechnology can be applied will expand in time, but needed gains in transformation efficiency must be made for the true potential of gene-transfer technology to be realized.

The number of traits that researchers alter is also likely to increase. Such qualities as herbicide, insect, and virus resistance are relatively easy to transfer, because they are carried by single genes. Many other important traits, however, are probably affected by multiple genes and are not well-understood genetically or biochemically. Manipulating these traits requires a long-term investment in fundamental plant metabolism research in order to understand the molecular basis of these traits.

The Congress, responding to criticism of the USDA's funding of basic research, has recently increased the USDA's funding for competitive grants (33). The National Research Initiative is being funded at $\$ 73$ million in fiscal year 1991, and its budget will increase to $\$ 500$ million in 5 years. 


\section{The Response of Firms}

In this market, few direct paths are open to firms. A number of companies, both large and small, have been developing plants with improved agronomic traits. For large firms, biotechnology presents an opportunity for growth and a way of protecting market share. Large firms with many popular high-yielding products and established distribution systems can incorporate these new traits into their products. But new dedicated biotechnology firms do not have the same access to quality germplasm or distribution outlets. For them, biotechnology presents growth opportunities, but it is important to develop partnerships with larger firms (38). In some cases, small biotechnology firms have sought eventual outlets for their technology through purchases of small seed firms.

Some small firms survive solely by isolating new genes or developing new technology that can be licensed to larger firms. These alliances, between large and small firms, provide sorely needed financing to small firms while providing large firms with wider access to new technology. But, as large firms develop more in-house expertise, these strategic alliances may become more focused and less available.

Some firms plan to invest in the long-term research necessary to develop plants with improvements in nutritional content or processing qualities. Few firms can afford the substantial investment or the long wait required until this research results in commercial products. In addition, marketing these products presents new challenges. Traditionally, seed companies have generally sold their products to farmers, with little emphasis on the development of plants with traits important to their eventual users. But developing and selling a product with properties of interest to particular end-users (e.g., an oilseed with altered composition making it useful to producers of commercial fried foods), require the development of close working relationships between breeders and end-users (13).

\section{THE INTERNATIONAL CLIMATE FOR AGRICULTURAL BIOTECHNOLOGY}

The major food exporting nations consist of a handful of developed countries (see table 6-2). Some developing nations, such as Argentina, Brazil, and
Thailand, are also important exporters of grains, feeds, and tropical products. Exports tend to be concentrated among a very few countries: five countries are responsible for over 90 percent of wheat exports; seven for over 90 percent of feed grain exports, such as corn, barley, sorghum, and oats; and four countries account for over 95 percent of soybean and soy product exports. Similarly, the EC and Eastern Europe account for over 85 percent of pork exports, and six countries provide over 80 percent of beef exports (26).

Because biotechnology products for agricultural use are still in development, it is not possible to compare the numbers of products actually manufactured in different countries. Field trials of potential plant products, however, are regulated by national agricultural or environmental authorities. These trials are outdoor tests of genetically modified organisms, conducted to gain experience important for future commercial development or to test the new plant under field conditions. There is no official census of such tests, but the USDA has kept an unofficial tally that gives a rough estimate of activities in different countries (see table 6-3). Unfortunately, little is known about testing in the Third World.

Through the summer of 1990,93 field tests of transgenic plants had been approved in the United States, far more than in any other country. In the EC, 62 tests had been approved, including 28 in France and 12 in Belgium. Canada and Australia, major agricultural exporting nations, had approved 18 and 4 tests, respectively. There is little activity elsewhere. In general, transgenic plants are being developed in nations that are major exporters of agricultural products, with the greatest activity in the United States.

In northern Europe, particularly Germany and Denmark, public concern about possible environmental risks and ethical issues associated with biotechnology has translated into regulations that discourage field testing of genetically engineered organisms. The lack of patent protection for transgenic organisms also tends to inhibit investment in transgenic plants in Europe.

In J apan and other Asian countries, public perception of biotechnology appears to be mixed. The use of biotechnology to produce pharmaceuticals and industrial and food processing enzymes is well accepted, but agricultural applications are less so 
Table 6-2-Major Exporters of Basic Agricultural Commodities Traded Worldwide

\begin{tabular}{|c|c|c|c|c|}
\hline Wheat & Feed grains & $\begin{array}{l}\text { Soybeans } \\
\text { and soybean } \\
\text { products }\end{array}$ & Beef & Pork \\
\hline $\begin{array}{l}\text { United States } \\
\text { Canada } \\
\text { Australia } \\
\text { France } \\
\text { Argentina }\end{array}$ & $\begin{array}{l}\text { United States } \\
\text { Argentina } \\
\text { Canada } \\
\text { South Africa } \\
\text { Thailand } \\
\text { Australia } \\
\text { France }\end{array}$ & $\begin{array}{l}\text { United States } \\
\text { Brazil } \\
\text { Argentina } \\
\text { European } \\
\text { Community }\end{array}$ & $\begin{array}{l}\text { European } \\
\quad \text { Community } \\
\text { Australia } \\
\text { Argentina } \\
\text { New Zealand } \\
\text { Brazil } \\
\text { Canada }\end{array}$ & $\begin{array}{l}\text { European } \\
\text { Community } \\
\text { Eastern } \\
\text { Europe }\end{array}$ \\
\hline
\end{tabular}

SOURCE: U.S. Department of Agriculture, Agricultural Yearbook 1985.

Table 6-3-Field Tests, by Country (summer 1990)

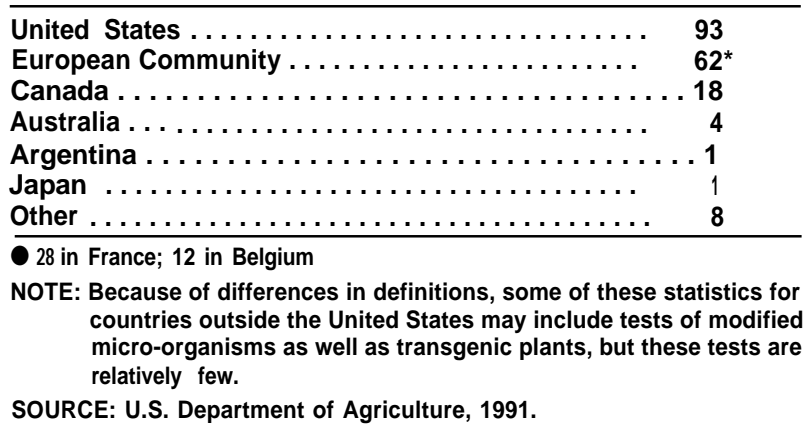

(18). In Japan, there has even been an historical aversion to the use of nonengineered microbial pesticides. Their use is permitted but much more strictly regulated than in Europe or the United States. This is partly because BT was originally isolated in Japan as a potent pathogen of silkworms. Although strains nontoxic to silkworms have been developed, the use of BT in Japan was banned until 1971, and the first permits for its use were not granted until 1982. It is thought that the stringency of the regulations has inhibited corporate interest and investment in the development and improvement of biopesticides in Japan (50). Japanese surveys have also reported concern about environmental releases and food uses of transgenic plants and animals (29). A survey of Japanese businesses found that only 38 percent of the 66 responding agricultural firms considered biotechnology decidedly or fairly important for their company's future; in contrast, 89 percent of manufacturers of drugs and diagnostics took that position (35).

\section{SUMMARY}

Like other technical innovations, biotechnology has the potential to improve the productivity of agriculture by increasing yields, decreasing costs, and providing new products. Applications include animal health products, hormones, transgenic animals, biopesticides, and transgenic plants. Surveys of field tests of transgenic plants reviewed by national authorities show that the United States leads in this activity, followed by the EC (especially France), and then by Canada. Activity is greatest in countries that have access to biotechnology research, that are leading agricultural producers, and where there is little public concern about the applications of biotechnology to agriculture.

In the seed industry, research investment has traditionally been heaviest in crops sold as hybrids, particularly corn, because these crops offer the most opportunities for profit. But corn, the crop that has drawn the most research in the past, has not been amenable to biotechnological manipulation until recently. Therefore, research has focused on crops and traits that are easier to manipulate. As technical roadblocks are lifted, research is likely to increase on other crops and on more complex traits. Other roadblocks exist:

- More basic research is needed on fundamental plant biochemistry, genetics, and physiologyin addition to plant biotechnology. This research would help in identifying and manipulating genes involved in producing complex traits of agricultural importance. Congress has begun to address the need for basic research by increasing funding for competitive grants administered by the USDA.

- The FDA has given industry little indication of its approach concerning food safety of genetically modified plants, making it difficult for industry to plan commercial introduction of new foods.

- Intellectual property protection is lacking for plants and animals in Europe and in less developed countries. 
Currently, small dedicated biotechnology firms are isolating genes, developing new techniques, and working with larger firms to commercialize their technology. A number of small firms are also acquiring small seed firms as future outlets for their technology. Large seed firms and agrochemical firms are building in-house expertise and exploring technology through their relationships with small firms.

\section{CHAPTER 6 REFERENCES}

1. Beachy, R., Loesch-Fries, S., and Tumer, N.E., "Coat Protein-Mediated Resistance Against Virus Infection," Annual Review of Phytopathology, vol. 28,1990, pp. 451-474.

2. Daberkow, S., Agricultural Input Industry Indicators in 1974-85: Expansion and Contraction, Agriculture Information Bulletin No. 534 (Washington, DC: Resources and Technology Division, Economic Research Service, U.S. Department of Agriculture, November 1987).

3. Dowling, D.N., and Broughton, W.J ., "Competition for Nodulation of Legumes," Annual Review of Microbiology, vol. 40, 1986, pp. 131-157.

4. Duffey, W., Monsanto, personal communication, December 1990.

5. Duvick, D.N., personal communication, December 1990.

6. Duvick, D.N., "Plant Breeding: Past Achievements and Expectations for the Future,' Economic Botany, vol. 40, 1986, pp. 289-297.

7. "Bad Moos," The Economist, vol. 316, №. 7667, Aug. 11, 1990, pp. 66-70.

8. Erickson, D., "Down on the Pharm," Scientific American, vol. 263, No. 2, 1990, pp. 102-103.

9. ESCAgenetics Corp., 1990 Annual Report.

10. Ex parte Hibberd, 227 USPQ 443 (PTO Bd.App. \& Int. 1985).

11. Fehr, W.R., Genetic Contributions to Yield Gains of Five Major Crop Plants (Madison, WI: Crop Science Society of America and American Society of Agronomy, 1984).

12. Fox, J .L., "U.S. Test Languishes, Europeans Proceeding," Biotechnology, vol. 8, 1990, p. 495.

13. Frey, N., personal communication, August 1990

14. Gershon, D., "Better Late Than Never for Start of Tests," Nature, vol. 346, 1990, p. 785.

15. Glass, D.J., Testimony before the House Agriculture Committee, Subcommittee on Department Operations, Research, and Foreign Agriculture, Oct. 2, 1990.

16. Harlander, S.K., and Labuza, T.P. (eds.), Biotechnology in Food Processing (Park Ridge, NJ : Noyes Publications, 1986).
17. Hodgson, J., "Growing Plants \& Growing Companies," Biotechnology, vol. 8, 1990, pp. 625-628.

18. Hsu, M., President, Asia/Pacific Bioventures, Inc., personal communication, December 1990.

19. Kagaku Kogyo Nippo, Sept. 13,1990, p. 9.

20. Kidd, G.H., "Macroeconomics of Seed \& Plant Biotechnology in the 1990s," Agricultural Economics \& Technology, Proceedings of the Conference held at Biotech 87, London, May 1987, The World Biotech Report 1987, vol. 1, No. 4, pp. 1-8.

21. Kim, L., "Biological Pesticides: Present and Future," Agricultural Economics \& Technology, Proceedings of the Conference held at Biotech 87, London, May 1987, The World Biotech Report 1987, vol. 1, No. 4, pp. 15-20.

22. Klein, TM., Wolf, E.D., Wu, R., et. al., "HighVelocity Microprojectiles for Delivering Nucleic Acids Into Living Cells," Nature, vol. 327,1987, pp. 70-73.

23. Knudson, M.K., and Ruttan, V.W., "Research and Development of a Biological Innovation: Commercial Hybrid Wheat," Food Research Institute Studies, vol. 21, 1988, pp. 45-68.

24. Lane, M., "Pursuing Seed Pirates," Agri Marketing, vol. 27, No. 5, 1989, p. 46.

25. Laster, R., "Growing a Biotech Business," Chemtech, vol. 19, No. 11, 1989, pp. 664-666.

26. Marton, L.B. (cd.), U.S. Agriculture in a Global Economy: 1985 Yearbook of Agriculture (Washington, DC: U.S. Government Printing Office, 1985).

27. Mazur, B.J ., and Falco, S. C., "The Development of Herbicide Resistant Crops," Annual Review of Plant Physiology and Plant Molecular Biology, vol. 40, 1989, pp. 441-470.

28. McConnell, R., Pioneer Hi-Bred, personal communication, August 1990.

29. McCormick, D., "Not As Easy As It Looked," Biotechnology, vol. 7, 1989, p. 629.

30. Meade, H., Gates, L., Lacy, E., et al., "Bovine Alpha $_{\text {s1 }}$-Casein Gene Sequences Direct High Level Expression of Active Human Urokinase in Mouse Milk," Biotechnology, vol. 8, 1990, pp. 43446.

31. Meeusen, R.L., and Warren, G., "Insect Control With Genetically Engineered Crops," Annual Review of Entomology, vol. 34, 1989, pp. 373-381.

32. National Academy of Sciences, Designing Foods: Animal Product Options in the Marketplace (Washington, DC: National Academy Press, 1988).

33. National Research Council, Board on Agriculture, Investing in Research: A Proposal To Strengthen the Agricultural, Food, and Environmental System (Washington, DC: National Academy Press, 1989).

34. "Thumbs Down for Milk Hormone," New Scientist, vol. 127, No. 1728, Aug. 4, 1990, p. 25.

35. "Bio-Industry's R\&D Trends Surveyed," Nikkei Biotechnology, Apr. 23, 1990, pp. BI1-BI8. 
36. Perrin, R.K., Kunnings, K.A., and Ihnen, L.A., Some Effects of the U.S. Plant Variety Protection Act of 1970, Economics Research Report No. 46, Department of Economics and Business, North Carolina State University, August 1983.

37. Pioneer Hi-Bred International, Inc., 1989 Annual Report.

38. Ratner, M., "Crop Biotech '89: Research Efforts Are Market Driven," Biotechnology, vol. 7, 1989, pp. 337-341.

39. Rogers, P.L., and Fleet, G.H., Biotechnology and the Food Industry (New York, NY: Gordon \& Breach Science Publishers, 1989).

40. Ryan, TM., Townes, TM., Reilly, M.D., et al., "Human Sickle Hemoglobin in Transgenic Mice," Science, vol. 247,1990, pp. 566-568.

41. Sant'Ana, A., and Sasson, A., Production et Commercialisation des Semences: Le Nouveau Paysage Industrial et les Nouvelles Strat gies d'Entreprises (Paris: l'Association Pour la Diffusion de l'Information Technologique, November 1987).

42. Schneiderman, H.A., "Innovation in Agriculture," Technology and Agricultural Policy (Washington, DC: National Academy Press, 1990).

43. Seidel, G.E., "Geneticists in the Pasture," Technology Review, vol. 92, No. 3, 1989, pp. 43-53.

44. Shamel, R.E., and Chow, J .J ., "Biotech's Potential Impact on the Chemical Industry," Biotechnology, vol. 6, 1988, pp. 681-682.

45. Shannon, C. "Growing Vanilla Down on the Factory Farm," New Scientist, vol. 129, No. 1750, Jan. 5, 1991, p. 24.

46. Tanksley, S.D., Young, N.D., Paterson, A.H., et al., "RFLP Mapping in Plant Breeding: New Tools for and Old Science," Biotechnology, vol. 7, pp. 257-264.

47. Thayer, A.M., "Mycogen Poised To Launch New Generation of Biopesticides," Chemical \& Engi- neering News, vol. 68, No. 18, Apr. 30, 1990, pp. 18-20.

48. Townsend, R., Testimony before the House Agriculture Committee, Subcommittee on Department Operations, Research, and Foreign Agriculture, Oct. 2, 1990.

49. Twornbley, R., "Firms F oresee High Stakes in Emerging Biopesticide Market," The Scientist, vol. 4, No. 14, July 9, 1990, p. 1.

50. Uchida, H., "Evolution of Recombinant DNA Guidelines in Japan," Safety Assurance for Environmental Introductions of Genetically-Engineered Organisms, J. Fiksel and V.T. Covello (eds.) (New York, NY: Springer-Verlag, 1988).

51. U.S. Department of Agriculture, Economic Research Service, Economic Indicators of the Farm Sector: National Financial Summary, 1986, ECIFS 6-2, 1987.

52. U.S. Department of Agriculture, E conomic Research Service, Resources and Technology Division, Agricultural Resources: Inputs Situation and Outlook Report, AR-15, August 1989.

53. U.S. Department of Commerce, U.S. Industrial Outlook 1991 (Washington, DC: U.S. Government Printing Office, 1991).

54. Vaeck, M., Reynaerts, A., Hoffe, H., et al., "Transgenic Plants Protected From Insect Attack," Nature, vol. 328, 1987, pp. 33-37.

55. Van Brunt, J., "Transgenics: Primed for Research," Biotechnology, vol. 8, 1990, pp. 725-728.

56. Weising, K., Schell, J ., and Kahl, G., "Foreign Genes in Plants: Transfer, Structure, Expression and Applications," Annual Review of Genetics, vol.22, 1988, pp. 421-478.

57. Zambryski, P., "Basic Processes Underlying Agrobacterium-Mediated DNA Transfer to Plant Cells," Annual Review of Genetics, vol. 22, 1988, pp. 1-30. 


\section{Chapter 7}

\section{The Chemical Industry}

"Why, after so much promise . . . has the harvest in the chemical area been so thin? Three basic, interrelated reasons give rise to the shortfall: 1 ) false expectations, which 2) in turn tended to obscure the inherent limitations in the technology, and 3) led to underestimating the difficulty of competing with the power of organic chemistry and entrenched chemical manufacturing processes.

Richard L. Hinman vice president of chemical products, Pfizer 


\section{CONTENTS}

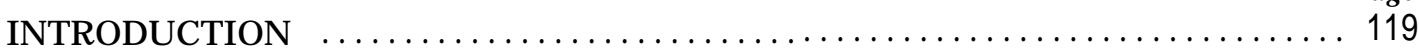

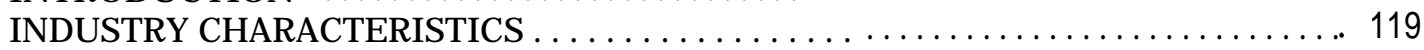

BIOTECHNOLOGY APPLICATIONS $\ldots \ldots \ldots \ldots \ldots \ldots \ldots \ldots \ldots \ldots \ldots \ldots \ldots \ldots \ldots$

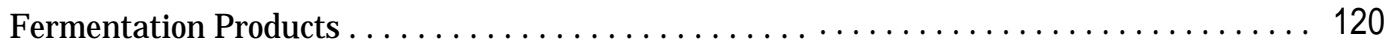

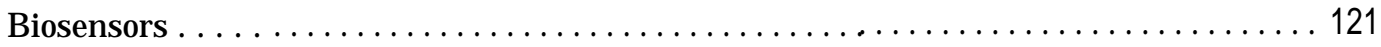

Applications to Chemical Synthesis . . . . . . . . . . . . . . . . . . . . . . . . . . 122

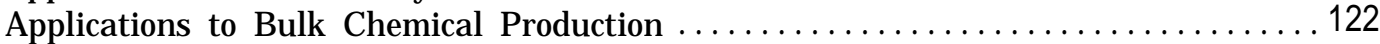

GLOBAL RESTRUCTURING . . . . . . . . . . . . . . . . . . . . . . . . . . . 122

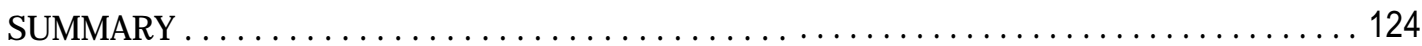

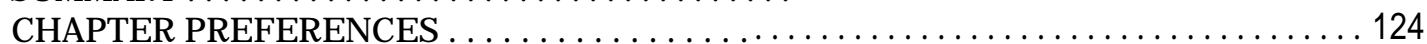

Box

Box Page

7-A. L-tryptophan and E osinophilia-Myalgia Syndrome . . . . . . . . . . . . . . . . . . . 120

Tables

Table Page

7-1. World's Largest Chemical Producers . . . . . . . . . . . . . . . . . . . . . . . . . . . . . . 119

7-2. Sectors of the Chemical Industry $\ldots \ldots \ldots \ldots \ldots \ldots \ldots \ldots \ldots \ldots \ldots \ldots \ldots$ 


\section{INTRODUCTION}

Biotechnology has a number of applications to chemical production. Clearly, it will be used to improve production of biochemical currently produced using fermentation, such as industrial enzymes. In addition, there are also limited applications to the production of fine chemicals currently produced synthetically. Chemical firms are beginning to invest in these obvious applications.

In the long term, biotechnology maybe important in the production of bulk chemicals and fuels. But there is limited investment in this field due to the relatively low price of oil and the recent restructuring of the chemical industry.

\section{INDUSTRY CHARACTERISTICS}

The chemical industry is one of the Nation's largest manufacturing industries, with 1990 shipments estimated at $\$ 297$ billion (24). It employs over 1 million people, representing about 5 percent of U.S. employment in manufacturing $(4,25)$. Yet, the largest chemical companies are European (see table 7-1).

The chemical industry produces a huge and ever changing variety of products. More than 50,000 chemicals and formulations are currently produced in the United States (24). Three-quarters of the industry's output is used within the chemical industry to produce more complex chemicals or is sold to other manufacturing industries. Only a quarter of output is sold to consumers, purchased by government, or entered into foreign trade (16).

The consumption of chemical products by industry gives these products a degree of anonymity because they usually reach consumers in altered forms or as parts of other goods. Basic, raw materials, such as crude oil, are transformed through a complex series of interlocking steps into intermediate chemicals (e.g., benzene and acetylene) and eventually into complex final products (e.g., plastics and fibers). Often, several possible routes of chemical synthesis, using different feedstocks, can be used to produce a final product. Because chemical processors can substitute different feedstocks or intermediates for one another, they have considerable flexibil- ity in adjusting to changes in price or availability of raw materials. Finished products can also substitute for one another. Different plastics, for example, can be used as packaging materials. The ease of substitution among raw materials and finished products results in intense competition within the industry.

Driven by competition, manufacturers constantly explore new feedstocks and develop new products. The resulting diversity of the industry has made its definition difficult. The Department of Commerce divides the chemical industry according to product classes in its standard industrial classification (SIC) system (see table 7-2).

Frequently, however, the chemical industry is divided according to the intensity of research and development $(R \& D)$. Some segments of the industry produce standard, high-volume, low-value-added bulk chemicals, such as ethylene or sulfuric acid. Because the quality of these chemicals is high and

Table 7-I-World's Largest Chemical Producers

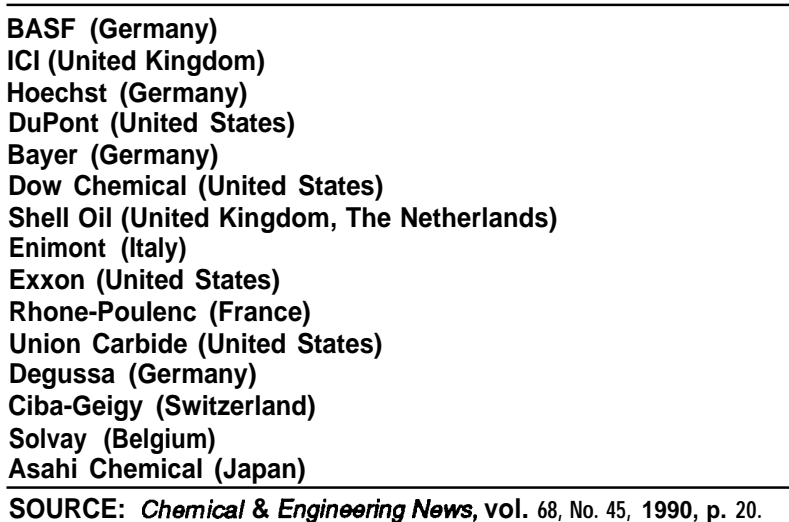

Table 7-2-Sectors of the Chemical Industry

\begin{tabular}{|c|c|}
\hline SIC Code & Industry \\
\hline SIC 28 & Chemicals and allied products \\
\hline SIC 281 & Industrial inorganic chemicals \\
\hline SIC 282 & $\begin{array}{l}\text { Plastic materials, synthetic rubber, manmade } \\
\text { fibers }\end{array}$ \\
\hline SIC 283 & Drugs \\
\hline SIC 284 & Soaps, cleaners, and toilet goods \\
\hline SIC 285 & Paints and allied products \\
\hline SIC 286 & Industrial organic chemicals \\
\hline SIC 287 & Agricultural chemicals \\
\hline SIC 289 & Miscellaneous chemical products \\
\hline
\end{tabular}


consistent, these manufacturers compete almost entirely on price which, in turn, depends on the cost of raw materials and the development of new process technology. At the other extreme are higher value-added specialty chemicals, such as catalysts, food additives, and industrial coatings. The highest value-added products include pharmaceuticals and pesticides (described in chs. 5 and 6). Manufacturers of specialty chemicals compete by investing in $R \& D$ in an effort to develop superior new products to meet market needs.

\section{BIOTECHNOLOGY APPLICATIONS}

Biotechnology will be used within the chemical industry mainly in the production of chemicals currently produced through fermentation, such as industrial enzymes. There are more limited applications to the synthesis of complex chemicals and to the production of bulk chemicals.

Most of these applications will be developed to improve production processes used by major chemical companies. They will, probably, be introduced without the fanfare that has accompanied other biotechnology developments. The use of biotechnology in the chemical industry is publicized only when a problem arises (see box 7-A).

\section{Fermentation Products}

Some chemicals are currently produced by growing micro-organisms in large fermentation vats and isolating the products from the final fermentation mixture. Biotechnology can be used to improve yields of these chemicals.

\section{Amino Acids}

Amino acids are used mainly as food additives and animal feed supplements, but they have other uses as well. The sweetener Aspartame is made from two amino acids: aspartic acid and phenylalanine. The food additive monosodium glutamate (MSG) is probably the best known amino acid. The world market is estimated at $\$ 800$ million and is growing at 3 percent annually, although the U.S. market is growing slowly or not at all (27).

The use of biochemistry and fermentation to produce chemicals has historically received a great deal of attention in Japan. Unlike Germany and the United States, Japan is resource-poor, lacking large deposits of coal and oil, the raw materials on which

\section{Box 7-A-L-tryptophan and Eosinophilia- Myalgia Syndrome}

The amino acid L-tryptophan has been widely available, mainly in health food stores, as a food supplement. It was often recommended as a treatment for insomnia, depression, and premenstrual syndrome. In 1989, ingestion of L-tryptophan was linked to an increase in the number of cases of a rare blood disorder, Eosinophilia-Myalgia Syndrome (EMS). In November 1989, the Food and Drug Administration (FDA) recalled all products containing L-trytophan as a major component, and in March 1990, the FDA extended the recall to nearly all products containing L-tryptophan. Over 1,500 cases of EMS and 27 deaths in the United States were eventually traced to several lots of Ltryptophan produced by a single company, J apan's fourth largest chemical firm Showa Denko. Lots of L-tryptophan associated with EMS contained small amounts of a contaminant.

Like many other amino acids, L-tryptophan had been manufactured by growing bacteria that produce L-tryptophan in large fermentation tanks and purifying the compound from the broth. In late 1988, however, Showa Denko made two changes in its L-tryptophan manufacturing process. It replaced its original strain of bacteria with a strain genetically engineered to enable it to produce more L-tryptophan; changes were also made in the purification process.

In October 1990, the contaminant associated with EMS was identified by Showa Denko scientists as an L-tryptophan dimer linked by ethylidene. The company announced that the contaminantt was not produced by the bacteria during the fermentation process but was formed during the L-tryptophan purification process.

SOURCES: Centers for Disease Control, "Update: Eosinophilia-Myalgia Syndrome Associated With Ingestion of L-Tryptophan-United States, through Aug. 24, 1990," Morbidity and Mortality Weekly Report, vol. 38, 1990, pp. 587-589; E.A. Belongia et al., "An Investigation of the Cause of the EosinophiliaMyalgia Syndrome Associated with Tryptophan Use," The New England Journal of Medicine, VOL 323, 1990, pp. 357-365; A.N. Mayeno et al., "Characterization of Peak 'E,' a Novel Amino Acid Associated with Eosinophilia-Myalgia Syndrome," Science, vol. 250,1990, pp. 1707-1708..

the chemical industry in the rest of the world was based; thus, Japanese firms have always had a financial incentive to explore alternatives. When Japan's Ministry of International Trade and Industry 
(MITI) targeted biotechnology in 1980, three research areas were specifically named: 1 ) recombinant DNA (rDNA), 2) mass cell culture, and 3) bioreactors. Although in the United States, the word "bioreactor" usually refers to large chambers used for mass cell culture, MITI defines bioreactors, more generally, as any fermentation vessel. The more advanced research in bioreactor development, funded by MITI, emphasized the use of microorganisms or immobilized enzymes for the production of fine chemicals. Since 1981, six J apanese chemical firms have participated in a governmentsponsored joint research effort in this area $(15,28)$. So far, this consortium has conducted research but has not produced any commercially useful products or processes (27).

\section{Industrial Enzymes}

Enzymes are biochemical catalysts. Of the approximately 18 commercially available in bulk, five are most important. These are amylases, which produce simple sugars from more complex ones, and are used in the starch industry; bacterial proteases, which digest protein, and are used in detergents; papain, for dehazing beer and tenderizing meat; glucose isomerase, for making high-fructose corn syrup; and rennin and chymosin, both used in cheesemaking (10). A variety of enzymes have been developed for other industrial uses. For example, one bacteria-derived enzyme, cellulase, which breaks down cellulose, the molecular base of cotton, has been used to soften new blue jeans as an alternative to harsh stone-washing (12).

The major producers of commercial enzymes are Novo-N ordisk (Denmark) which has about 40 percent of the market, and Gist Brocades (Belgium) which has about 20 percent of the market, followed by Rohm (Germany), Miles (United States), and Hansens (The Netherlands) (10). The current world market for industrial enzymes is over $\$ 650$ million per year (27).

Biotechnology can be used to improve the yield of an enzyme through transfer of the gene encoding the enzyme to a micro-organism capable of producing the enzyme in larger amounts. Novo-Nordisk researchers, for example, identified a fungal, fatdigesting enzyme, lipase, that helps breakdown fats typically found in human food. To produce it in commercial amounts as a detergent additive, however, they transferred the gene from the fungus in which it occurs naturally (in small amounts), to a fungus that will produce lipase in higher quantities. A detergent containing this enzyme was first introduced in J apan (26).

But biotechnology can contribute more to the production of industrial enzymes than yield enhancement. The gene encoding the enzyme can be modified to encode an enzyme with altered characteristics. Research is being conducted to develop enzymes that are more stable in harsh solvents, are more heat resistant, or that react with different substrates. For example, one enzyme used in detergents, subtilisin, degrades proteins such as those found in blood or food stains. Because the enzyme is sensitive to bleach, a common ingredient in many detergent formulations, variants have been generated using biotechnology, that are more resistant to bleach than is the original enzyme (2).

\section{Biosensors}

Biosensors combine biotechnology with materials science and electronics to produce sophisticated monitoring devices. This is an area of active research throughout the world but especially in J apan (19).

A biosensor consists of two basic parts: one layer that responds to the presence of a specific chemical (e.g., a layer of enzymes that react with the chemical to be measured or antibodies that bind specifically to it) and a second layer that consists of a transducer that translates this specific interaction into electric signals proportional to the concentration of the chemical in the sample. The electronic part of the biosensor measures voltage, current, light, sound, temperature, or mass.

Currently, most biosensors are used to detect biological materials. Much research is directed toward the development of biosensors for diabetics, that could monitor glucose levels and control an insulin pump. But biosensors have many other potential applications in medicine and industry. Eventually, biosensors will be developed to detect cholesterol, narcotics, or substances associated with early disease diagnosis. In industry, biosensors will monitor and control industrial effluents, fermentation processes, and food quality. Biosensors will also be devel oped to monitor the presence of toxic substances in water supplies and organic solvents in air (1 1).

Most existing biosensors have drawbacks. They are bulky, need frequent calibration, and have a short 
useful lifespan. $R \& D$ is aimed at improvements in these areas, to eventually develop disposable biosensors and, for some applications, sterilizable biosensors.

\section{Applications to Chemical Synthesis}

Some chemicals are manufactured in a series of complex chemical reactions. Under certain conditions it might be practical to replace one or more of these reactions (those that are expensive or particularly difficult to control) with reactions controlled by enzymes, which are biochemical catalysts. Reactions controlled by enzymes have some advantages, e.g., they work at mild temperatures, they can often be used to perform more limited reactions, they can be used to produce chiral compounds, they are biodegradable, they require no organic solvents, and they are very reaction-specific. But these situations are limited. Enzymes, altered using biotechnology or not, are unlikely to make a big impact in this area in the new future (13).

\section{Applications to Bulk Chemical Production}

Although it is technically feasible to produce many high-volume, low-value-added chemicals through fermentation, these methods are not economically competitive with established petrochemical processes. This area is also unlikely to receive much $R \& D$ investment, as the major multinational

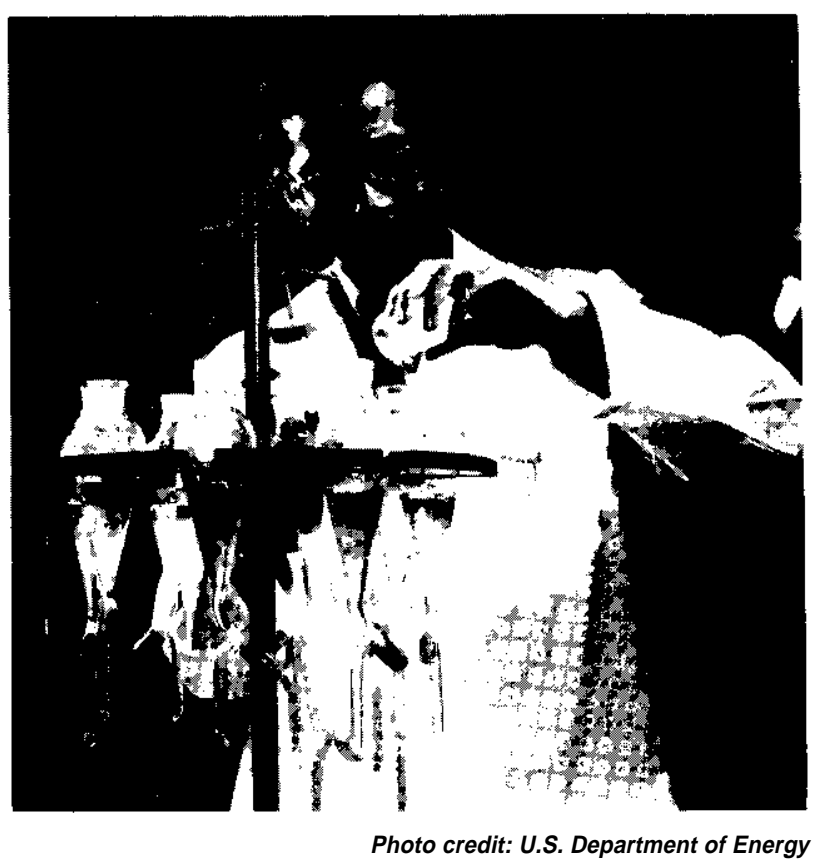

Scientist mixes a chemical sample. firms have been decreasing their interest in bulk chemical production $(17,20)$.

\section{GLOBAL RESTRUCTURING}

In the very long run, biotechnology may have a major impact in shifting the production of fuel and bulk chemicals from reliance on nonrenewable resources, such as oil, to renewable resources, such as biomass (14). There does not, however, appear to be much industrial interest in these applications, in part, because the international price of oil has remained too low to encourage investment in alternatives and, in part, because the chemical industry throughout the world has restructured during the last 10 years. As major oil companies have increased their bulk chemical production, chemical firms have decreased their share of the bulk chemical market and increased their interests in the production of specialty chemicals, pharmaceuticals, and agricultural products.

The industry's restructuring has been a strategic response to worldwide pressures, stemming from fluctuating oil prices, recessions, and increasing competition. Historically, the industry's annual industrial growth rate averaged two to three times the rise in Gross National Product (GNP). During the 1970s the industry began to decline worldwide. Industrial growth fell and became even with the growth in GNP (7). Chemical production decreased for a number of reasons.

- Most importantly, the industry had reached technological maturity. Innovation in products and manufacturing processes had declined. In addition, substitution of synthetics for natural materials had leveled off; for example, by 1970 , synthetic detergents had taken 85 percent of the market for domestic and industrial cleansers (3).

- Manufacturers faced erratic fluctuations in the price of oil, which is important, both as a source of energy and as a basic feedstock, for the production of bulk chemicals. Oil supplied by the Organization of Petroleum Exporting Countries (OPEC) constituted about 80 percent of the raw materials used by the U.S. chemical industry (7).

- Chemical companies were also facing new costs, in the form of environmental protection regulations, particularly in the United States. 
- New competition came from multinational oil companies diversifying into the production of bulk chemicals. These firms built petrochemical plants in Indonesia, Mexico, and the Middle East producing chemicals from natural gas and waste gases derived from oil processing and refining. Chemical companies in major industrial nations often had no sources of raw materials as inexpensive as those in oil-rich nations $(1,3)$

- The chemical industry was particularly hurt by the worldwide recession in the early 1980s. Demand for petrochemicals slumped, along with the profits of the chemical industry.

Chemical companies reduced operations in bulk chemicals, generally retaining production of chemicals in which they were market leader or in which they had a price advantage based on proprietary technology (7). Other operations were sold. Between 1981 and 1986, Dow sold more than $\$ 1.8$ billion in assets and wrote-off most of its oil and gas business. Bulk, low-value chemicals once provided 61 percent of Monsanto's profits; the proportion shrank to 35 percent in a 4-year period. American Cyanamid once consisted of four roughly equal segments: medical, agricultural, chemical, and consumer products. By 1987, medical and agricultural products made up about 75 to 80 percent of its business (9). American fins, which had dominated bulk chemical production in Europe during the 1950s and 1960s, gradually withdrew, selling their assets to local firms (3).

During the same period, chemical firms expanded into the two sectors, pharmaceuticals and specialty chemicals, which continued to be quite profitable and recession-resistant. Most of this expansion came through acquisition. Major producers of agricultural chemicals have diversified into seed production, and chemical firms have also expanded their interests in advanced materials and instrumentation. Restructuring has been successful, in that industry profits recovered from the slump of the early 1980s. More recently, however, recession and rising oil prices once again have hurt the industry.

There are many examples of chemical industry restructuring and resulting investment in researchintensive fields. Since 1985, Monsanto, the St. Louis-based chemical firm, has shut down or sold more than 20 businesses that were largely producers of high-volume, low-value-added chemicals. They have, simultaneously, acquired firms producing

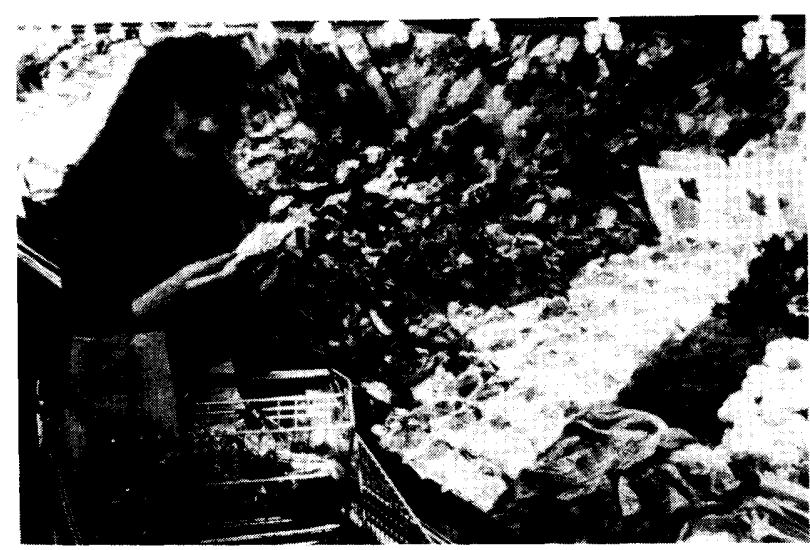

Photo credit: DNAP

FreshWorld, a joint venture between DNA Plant Technology and DuPont, has been marketing VegiSnax brand carrot and celery sticks.

specialty products, including pharmaceuticals, food additives, and detergent chemicals (22). Similarly, Dow's managers decided in 1978 to cut back on bulk chemicals and extend the fro's interests in specialty chemicals and related high-value areas. Dow acquired Merrill, a U.S. pharmaceutical firm, in 1981, and in 1984 it acquired an 84-percent interest in a small J apanese pharmaceutical firm, Funai Pharmaceuticals Co., Ltd. Dow has also expanded its interests in household cleaning products, polymers, and advanced ceramics (3). DuPont recently joined with Merck to form a new pharmaceutical firm. It has also joined with DNA Plant Technology in its FreshWorld venture, selling branded vegetable produce $(3,8)$. Rohm \& Haas has invested in agricultural biotechnology firms in the United States and Belgium.

Restructuring in Europe and J apan had similar results. The major European chemical firms have redistributed their assets and, like American firms, have invested heavily in R\&D-intensive products (8). For example, Hoechst, a large German chemical manufacturer, purchased Celanese in 1986, acquiring its advanced facilities for the production of fibers, chemicals, and plastics. Hoechst also placed a major emphasis on the production of pharmaceuticals, which represent 17 percent of its world sales (3). Hoechst was also one of the earliest big investors in biotechnology, providing $\$ 70$ million to Massachusetts General Hospital in 1980 in exchange for the right to license research results and to send its own scientists for training. The British firm ICl has developed its presence in agricultural products

292-870 - 91 - 5 : QL 3 
through acquisition of seed companies and by expanding its existing research in plant biology (6).

In addition to acquiring pharmaceutical and agricultural firms, some American and European chemical companies have invested heavily in internal research in the life sciences. Among these are: Monsanto, DuPont, Lubrizol, Royal Dutch-Shell, $\mathrm{ICl}$, and the French companies, Elf-Aquitaine and Rhone-Poulenc (18). The petrochemical company, Lubrizol, acquired the plant biotechnology firm, Agrigenetics, in 1988.

Although outright acquisitions of biotechnology firms are rare, other relationships between chemical companies and small biotechnology firms are quite common. DuPont, for example, has R\&D, marketing, and licensing agreements with several small firms, including American Bionetics, Applied Biotechnology, BioTechnology General Corp., Cellular Products, Cistron, Genofit SA, Molecular Biosystems, and Synergen. American Cyanamid has agreements with Biotechnology General Corp., BioProbe, Cytogen Corp., and Molecular Genetics, Inc. European and J apanese firms have also contracted with or invested in many small U.S. firms specializing in biotechnology, but they have not fostered the development of similar small firms in Europe or J apan $(21,23)$. A recent study has shown that chemical companies provided 63 percent of the research funds spent by the top 15 plant biotechnology firms in 1989. The leading investors were Monsanto (U.S.), Enimont (Italy), DuPont (U.S.), Sandoz (Switzerland), and ICI (U.K.) (5).

Global restructuring of the chemical industry in the last 10 years has resulted in investment in high-value-added products, such as pharmaceuticals, agrochemicals, and other specialty chemicals. As firms decrease investments in the production of low-value-added chemicals, it becomes less likely that research in biotechnology applications to biomass-based production will be funded by the private sector

\section{SUMMARY}

Biotechnology has a limited role in chemical production. Production of some chemicals now produced by fermentation, such as amino acids, could be affected through improvements in microorganisms or production processes. Similarly, biotechnology can be used to improve yields of industrial and food enzymes isolated from micro- organisms. In addition, biotechnology could be used to produce enzymes with altered characteristics. Biotechnology can also be applied to the development of enzymes that might be used to replace expensive or difficult steps in chemical synthesis. In all of these cases, however, the impact of biotechnology will be incremental and unheralded, resulting in improvements in productivity. Biotechnology is unlikely to be applied to the production of fuels or bulk chemicals in the foreseeable future, because it is not financially or technically competitive with current chemical methods of production (20).

The chemical industry's greatest impact on the use of biotechnology, however, is likely to have little to do with industrial chemical production per se. Indeed, its greatest impact may be the result of the industry's expanding investment in pharmaceuticals and agriculture. This investment has taken the form of increased in-house research and links with smaller research-intensive firms.

\section{CHAPTER 7 REFERENCES}

1. Bennett, M.J., and Klein, C.H., "Chemicals: An Industry Sheds I ts Smokestack I mage," Technology Review, vol. 90, No. 5, J uly 1987, pp. 37-45.

2. Bluestone, M., Brand, R., and Kapstein, J ., "Designer Proteins: The Next Boom in Biotech,' Business Week, Apr. 13, 1987, pp. 94-95.

3. Bozdogan, K., "The Transformation of the U.S. Chemicals Industry," The Working Papers of the MIT Commission on Industrial Productivity, 2 vols. (Cambridge: MIT Press, 1989).

4. Chemical \& Engineering News, "Facts and Figures for the Chemical Industry," Chemical \& Engineering News, vol. 68, No. 25, J une 1990, pp. 34-83.

5. Chemical Week, "Chemical Firms Feed Plant Biotech," Chemical Week, vol. 147, No. 21, November 1990, p. 93.

6. Dart, E.C., "Exploitation of Biotechnology in a Large Company," Phil. Trans. R. Soc. Lend. B, vol. 324, 1989, pp. 599-611.

7. DeYoung, H.G., "Chemical Makers Get in Shape for the '90s," High Technology, vol. 7, No. 5,1987, pp. 28-32.

8. The Economist, "European Chemicals: Shake, Heat, Squeaky-Pop," The Economist, vol. 308, No. 7559, July 1988, pp. 68-69.

9. Gibson, W.D., and Brockinton, L.C., "American Cyanamid: Moving the culture in a Different Direction," Chemical Week, vol. 141, No. 12, 1987, pp. 40-46.

10. Greenshiel ds, R. (ed.), Resources and Applications of Biotechnology: The New Wave (New York, NY: Stockton Press, 1988). 
11. Krull, U.J ., "Biosensors for chemical Analysis," Chemtech, vol. 20, 1990, pp. 372-377.

12. Lubove, S., "Enzyme-eaten J eans," Forbes, vol. 146, No. 10, Oct. 29, 1990, pp. 140-141.

13. Marrs, B., DuPont Experimental Station, personal communication, May 1990 .

14. Newell, N., Synertech Group, Inc., personal communication, December 1990.

15. Nikkei Sangyo Shimbun, "Bioreactor Developments Examined," Nikkei Sangyo Shimbun, May 2, 1989.

16. Planting, M.A., "Input-Output Accounts of the U.S. Economy, 1981," Survey of Current Business, vol. 67, No. 1,1987, pp. 42-58.

17. Quisenberry, R., director, central research and development department, DuPont Experimental Station, personal communication, February 1990.

18. Sant'Ana, A., and Sasson, A., Production et Commercialisation des Semences: Le Nouveau Paysage Industrial et les Nouvelles Strat gies d'Entreprises (Paris: I'Association Pour la Diffusion de l'Information Technologique, November 1987).

19. Science Watch, "Four Fields Where J apan Leads and U.S. Lags," Science Watch, vol. 1, No. 2, 1990, pp. 1-2.

20. Shamel, R.E., and Chow, J J., "'Biotech's Potential Impact on the Chemical Industry," Bio/Technology, vol. 6, 1988, pp. 681-682.

21. Sharp, M., "David, Goliath and the Biotechnology Business," The OECD Observer, vol. 164,1990, pp. 22-24.
22. Storck, W.J ., "Streamlined, Diversified Monsanto Becomes More Recession Resistant," Chemical \& Engineering News, vol. 68, No. 2, J an. 8, 1990, pp. 16-17.

23. U.S. Congress, Office of Technology Assessment, New Developments in Biotechnology: U.S. Investment in Biotechnology, OTA-BA-360 (Springfield, VA: National Technical Information Service, J uly 1988).

24. U.S. Department of Commerce, U.S. Industrial Outlook 1991 (Washington, DC: U.S. Government Printing Office, 1991).

25. U.S. Department of Commerce, Bureau of the Census, 1985 Annual Survey of Manufactures, Statistics for Industry Groups and Industries (Including Supplemental Labor, Fuel, and Electric Energy Costs), M85(AS)-1 (Washington, DC: U.S. Government Printing Office, 1987).

26. Watts, S., "Engineered Enzyme Washes Whiter than White," N ew Scientist vol. 123, No. 1671, J uly 1, 1989, p. 45.

27. Wolnak, B., Wolnak \& Associates, personal communication, December 1990.

28. Yoshikawa, A., "The J apanese Challenge in Biotechnology: Industrial Policy," BRIE Working Paper \#29, Berkeley Round Table on the International Economy, University of California, Berkeley, September 1987. 


\section{Chapter 8}

\section{Environmental Applications}

"If it wasn't for the high cost of the alternative, this (bioremediation) wouldn't be worth considering at all.'

Perry L. McCarty

Stanford University, 1987 


\section{CONTENTS}

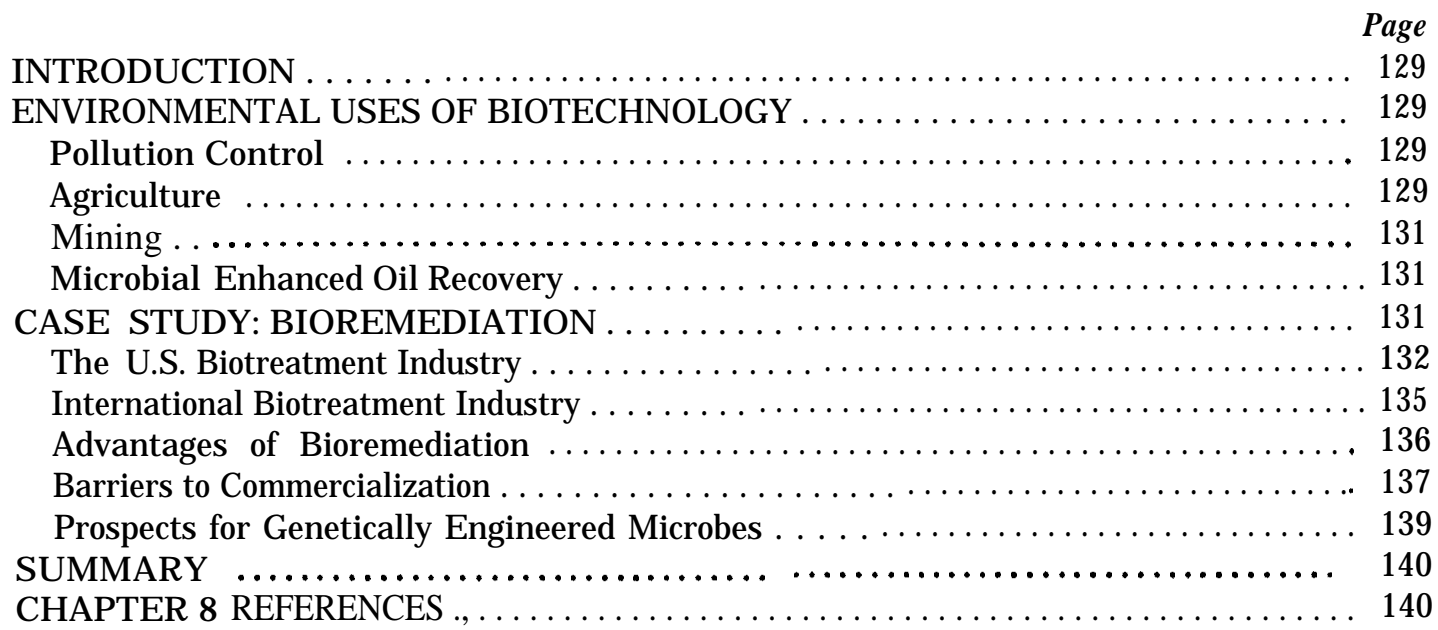

Box

\section{Boxes}

8-A. The Exxon Valdez Bioremediation Project .......................... 134

8-B. International R\&D, Improved Waste Treatment Processes . . . . . . . . . . . . . . 135

8-C. Federal Statutes Relevant to Bioremediation ........................ 138

Figure Page

8-1. Laboratory Selection and Enhancement of Micro-organisms $\ldots \ldots \ldots \ldots \ldots \ldots .133$

Table Page

8-1. Challenges for Pollution Control and Toxic Waste Treatment $\ldots \ldots \ldots \ldots \ldots \ldots . .29$

8-2. Some Potential Environmental Applications of Genetically Engineered

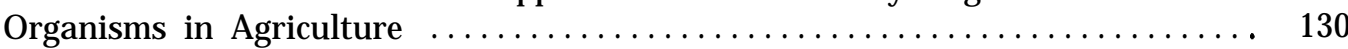

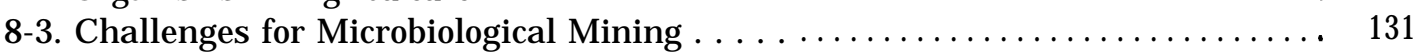

8-4. Challenges for Microbial Enhanced Oil Recovery $\ldots \ldots \ldots \ldots \ldots \ldots \ldots \ldots \ldots . \ldots \ldots$ 


\section{Environmental Applications}

\section{INTRODUCTION}

Micro-organisms have several potential uses in the environment, for purposes as diverse as agriculture, pollution control, mining, and oil recovery. With the arrival of biotechnology, the potential of improving micro-organisms for selected uses has received increased attention and speculation. However, research and product development in the environmental sectors are minuscule compared to more commercially lucrative sectors influenced by biotechnology, and international activity to date is limited. This chapter summarizes some potential environmental uses of biotechnology and uses a case study approach to analyze bioremediation efforts to commercialize biotechnology for hazardous waste management.

\section{ENVIRONMENTAL USES OF BIOTECHNOLOGY}

Biotechnology has several potential applications, including pollution control, agriculture, mining, and microbial enhanced oil recovery (MEOR). For all four areas, commercial hurdles exist: technical, research funding and priorities, scale-up, regulatory approvals, and economics.

\section{Pollution Control}

Biotechnology has several applications for pollution control, including solid and liquid waste treatment, hazardous waste management, slime control (e.g., manufacture of paper), and grease decomposition (e.g., meats and certain foods, and waste water collection) (13).

Current commercial applications of biotechnology rely on conventional techniques of genetic manipulation and microbiology; the use of recombinant DNA (rDNA) to develop microbes with special capabilities for waste degradation has been limited. As of 1988, 65 companies were involved in some aspect of biotechnology for waste management (15). None is currently using or even testing genetically engineered micro-organisms in the environment, although research is going on in the lab (see table 8-I).

The Exxon Valdez oil spill in Prince William Sound in 1989 focused public attention on the use of
Table 8-I-Challenges for Pollution Control and Toxic Waste Treatment

- The isolation and characterization of enzymes to degrade low molecular weight organic compounds.

- Better characterization of metallothioneins (proteins that have a high affinity for heavy metals) from various species.

. The identification of polysaccharides to serve as bioflocculants (materials that thicken sludges for separation treatment).

- The development of enzymes for sludge dewatering.

. The development of microbial strains or enzymes that degrade toxic compounds.

. The development of improved polysaccharide hydrolyses to degrade slimes.

. To decrease regulatory uncertainty.

SOURCE: Office of Technology Assessment, 1991.

bioremediation for oil-spill cleanups. Of the various environmental applications possible through biotechnology, oil-spill cleanup and hazardous waste treatment constitute the only major commercial activities to date.

\section{Agriculture}

Potential environmental applications of genetically engineered organisms in agriculture are varied (see table 8-2). Genes have been introduced into

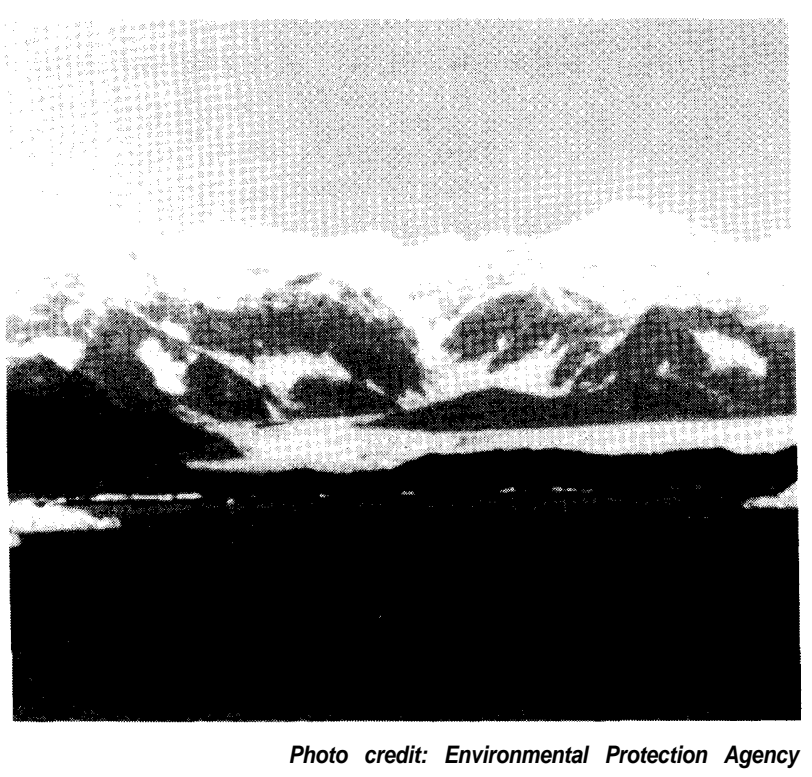

Prince William Sound, Alaska site of the extensive bioremediation experiments carried out by the Environmental Protection Agency, Exxon, and the State of Alaska. 
Table 8-2-Some Potential Environmental Applications of Genetically Engineered Organisms in Agriculture

Bacteria as pesticides:

Micro-organisms

"Ice-minus" bacteria to reduce frost damage to agricultural crops.

Bacteria carrying Bacillus thuringiensis toxin to reduce loss of crops to dozens of insects.

Mycorrhizal fungi to increase plant growth rates by improving efficiency of root uptake of nutrients.

Nitrogen-fixing bacteria to increase nitrogen available to plants and decrease the need for fertilizers.

Viruses as pesticides:

Insect viruses with narrowed host specificity or increased virulence for use against specific agricultural insect pests, including cabbage looper, pine beauty moth, cutworms, and other pests.

Vaccines against animal diseases:

Swine pseudorabies

Swine rotavirus

Vesicular stomatitis (cattle)

Foot and mouth disease (cattle)

Bovine rotavirus

Rabies

Sheep foot rot

Infectious bronchitis virus (chickens)

Avian erythroblastosis

Sindbis virus (sheep, cattle, chickens)

\section{Plants}

Herbicide resistance or tolerance to:

Glyphostae

Atrazine

Imidazolinone

Bromoxynil

Phosphinotricin

Disease resistance to:

Crown gall disease (tobacco)

Tobacco mosaic virus

Pest resistance:

BT-toxin protected crops, including tobacco (principally as research tool) and tomato.

Seeds with enhanced antifeedant content to reduce losses to insects while in storage.

Enhanced tolerance to environmental factors, including:

Salt

Drought

Temperature

Heavy metals

Enhanced marine algae:

Algae enhanced to increase production of such compounds as B-carotene and agar or to enhance ability to sequester heavy metals (e.g., gold and cobalt) from seawater.

Forestry;

Trees engineered to be resistant to disease or herbicides, to grow faster, or to be more tolerant to environmental stresses.

\section{Animals}

Livestock and poultry:

Livestock species engineered to enhance weight gain or growth rates, reproductive performance, disease resistance, or coat characteristics.

Livestock animals engineered to function as producers for pharmaceutical drugs.

Fish:

Triploid salmon produced by heat shock for use as game fish in lakes and streams.

Fish with enhanced growth rates, cold tolerance, or disease resistance for use in aquiculture. Triploid grass carp for use as aquatic weed control agents.

SOURCE: Office of Technology Assessment, 1991. 
several plant species to confer resistance or tolerance to certain herbicides. Plants have also been better engineered to resist disease and to confer pest resistance. Most deoxyribonucleic acid (DNA) work on animals focuses on altering livestock, poultry, or fish to improve reproductive performance, weight gain, or disease resistance. Many promising environmental applications of engineered micro-organisms are also being developed.

Planned introductions of genetically engineered organisms into the environment, often called deliberate release, was the focus of an earlier Office of Technology Assessment (OTA) report (14). Commercialization in agriculture is discussed elsewhere in this report (see ch. 6).

\section{Mining}

Natural micro-organisms have been used for mineral leaching and metal concentration processes. No Federal funding directly supports microbiological mining, however, and commercial activity is sparse (see table 8-3).

Limited international research in the field of biohydrometallurgy is proceeding. Canada, South Africa, the United Kingdom (U.K.), and the United States have ongoing programs in biohydrometallurgy. The Canadian Center for Mineral and Energy Technology is the leading governmental research agency in this area. One area of focus for the Canadians is uranium biol eaching; one mine is now bioleaching 90,000 pounds of uranium per month. The biological mitigation of acid mine drainage is another Canadian project (7). Research is slow, however, because of economic aspects in the mineral market. As long as metals are plentiful and easily mined, no economic advantage is realized by microbiological mining.

\section{Microbial Enhanced Oil Recovery}

It has been estimated that more than 300 billion barrels of U.S. oil cannot be recovered by conventional technology but may be accessible through enhanced oil production. This volume is 2.5 times as large as the amount of oil produced by the United States since 1983. The actual enhanced oil recovery production has been low, no greater than 5 percent of total U.S. production, even though a variety of Department of Energy (DOE) incentives have been available. Other countries, such as Canada, have projected that by the year 2010, one-third of its oil

\section{Table 8-3-Challenges for Microbiological Mining}

. The development of micro-organisms that could leach valuable metals, such as thorium, silver, mercury, gold, platinum, and cadmium.

- A better understanding of the interactions between the microorganisms and the mineral substances.

- The development of DNA transfer technologies for use at low $\mathrm{pH}$.

SOURCE: Office of Technology Assessment, 1991.

recovery will utilize enhanced techniques. In recent years, advanced oil-drilling techniques have enhanced overall yield, and it is expected that these techniques, not micro-organisms, may satisfy oil companies' needs for greater yield in the short term.

Although most of the major oil companies have in-house staff investigating and perfecting MEOR, the methodology's low cost may appeal more to small-field operators, who have already pumped and sold the easy-to-get component of their field (8). MEOR is not predictable; just like the use of micro-organisms for hazardous waste remediation, the use of micro-organisms for oil recovery is site-specific. Individual oil deposits have unique characteristics that affect the ability of microorganisms to mobilize and displace oil. An understanding of the microbial ecology of petroleum reservoirs is a prerequisite to the development of any MEOR process, whether microbial or not, since an inappropriate design may accelerate the detrimental activities of micro-organisms (e.g., corrosion, reservoir souring, and microbial degradation of crude oil) (I). Basic environmental biotechnology research underway for contaminated soil and groundwater will provide much needed information to those working on MEOR (see table 8-4).

\section{CASE STUDY: BIOREMEDIATION}

Cost estimates for the cleanup of contaminated soils and groundwater and the routine disposal of industrial and municipal wastes, range up to $\$ 23$ billion for the United States and $\$ 60$ billion for Western European countries $(3,6)$. The price tag for construction and maintenance of treatment systems used for continually produced waste is unknown. In the search for a cleaner environment, claims have been made that biotechnology holds great promise for hazardous waste reduction and cleanup as well as permanent restoration of air, water, and soil. 


\section{Table 8-4-Challenges for Microbial Enhanced Oil Recovery}

\footnotetext{
. Better biochemical and physiological understanding of microorganisms already present in oil reservoirs.

. Development of micro-organisms that degrade only the less useful components of oil.

- Screening of micro-organisms for production of surfactants and viscosity enhancers and decreases.

SOURCE: Office of Technology Assessment, 1991.
}

Bioremediation is a term that refers to efforts to use biotechnology to cleanup waste. These efforts involve the engineering of systems that use biological processes to degrade, detoxify, or accumulate contaminants. These systems can use naturally occurring or laboratory-altered microbes or both. Current applications rely on conventional techniques of genetic manipulation and microbiology; the use of rDNA to devel op microbes with specific capabilities for waste degradation has been limited (see figure 8-I).

Bioremediation can be used at a variety of sites and in a variety of applications, including wastestream cleanup, wood treatment-site cleanup, degradation of polychlorinated biphenyls (PCBs), groundwater treatment, and cleanup of chemical manufacturing wastes. The rationale for using micro-organisms to degrade pollutants comes from experience with nature. Micro-organisms have a variety of capabilities that can be exploited for waste management and disposal. Many organic compounds of biological origin are readily degraded. Industrial chemicals similar in structure to natural compounds are also frequently biodegraded (15).

The recent use of naturally occurring microbes in oil-spill cleanup--off the coasts of Alaska and Texas--has focused public attention on commercial uses of bioremediation. This attention is enhanced by frequent claims that biotechnology can be used to mitigate environmental pollution (see box 8-A).

This section describes the U.S. and international biotreatment industries, the advantages and barriers facing the commercialization of bioremediation, and the prospects for using genetically engineered organisms for hazardous waste cleanup.

\section{The U.S. Biotreatment Industry}

The frost U.S. company to produce microbes for waste treatment opened in the early 1950s. Over the next 20 years, the U.S. biotreatment market ex- panded to a handful of companies specializing in the production of microbial "cocktails" for municipal sewage treatment plants and odor control. In 1970, the establishment of the Environmental Protection Agency (EPA) and the creation of Federal and State environmental statutes governing the treatment of wastes guaranteed a market for the environmental services industry, to which bioremediation firms belong. Today, the U.S. biotreatment industry includes 134 firms and has evolved into four segments: bioremediation services, multidisciplinary environmental services, products, and waste generators.

\section{Bioremediation Services}

Firms specializing in biotreatment services make up the majority of the U.S. market in this area. These firms are small and are generally founded by a scientist or engineer convinced that biology-based waste management can be commercially viable. Some firms began in university laboratories, while others spun-off from larger companies. Most of these specialized companies have relied on laboratory analytical services or equipment sales to maintain income as they develop their bioremediation services component. Only a few have had venture capital support. These small companies serve as a pool of expertise for larger, full-service engineering and consulting firms. Contract and subcontracting activities between companies are common.

Diagnosis and treatment services are provided by bioremediation firms. Diagnosis of a waste problem can include analyzing the site or waste treatment facility for indigenous microbial activity, adequate nutrients, suitable moisture, and appropriate oxygen. Treatment may involve enhancement of indigenous micro-organisms by nutrient addition, batching preconditioned organisms found at the site, or using selected off-the-shelf microbes.

\section{Multidisciplinary Environmental Services}

In 1988, few multidisciplinary environmental companies offered bioremediation expertise. Bioremediation was typically used by firms competing in the wastewater treatment sector but not by firms focusing on hazardous waste markets. Growing optimism that bioremediation can be used to tackle hazardous waste problems has led to increased involvement by multidisciplinary firms incorporating bioremediation expertise. Growth in this sector has generally occurred in one of three ways: 
Figure 8-I-Laboratory Selection and Enhancement of Micro-organisms
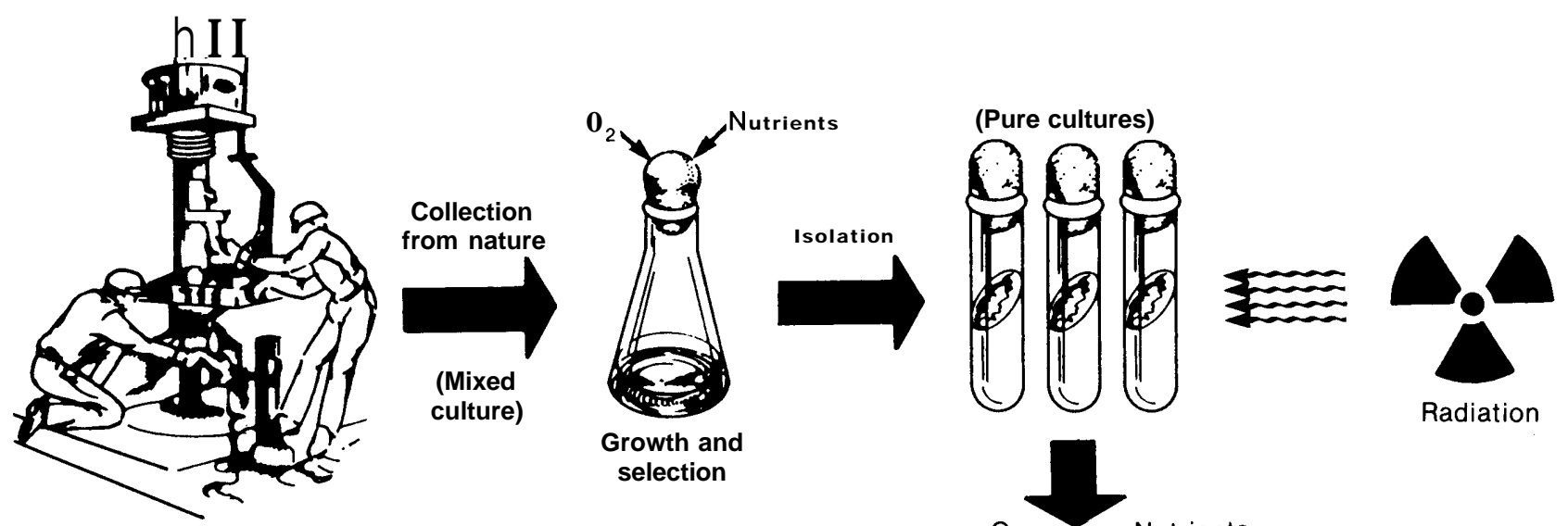

Radiation
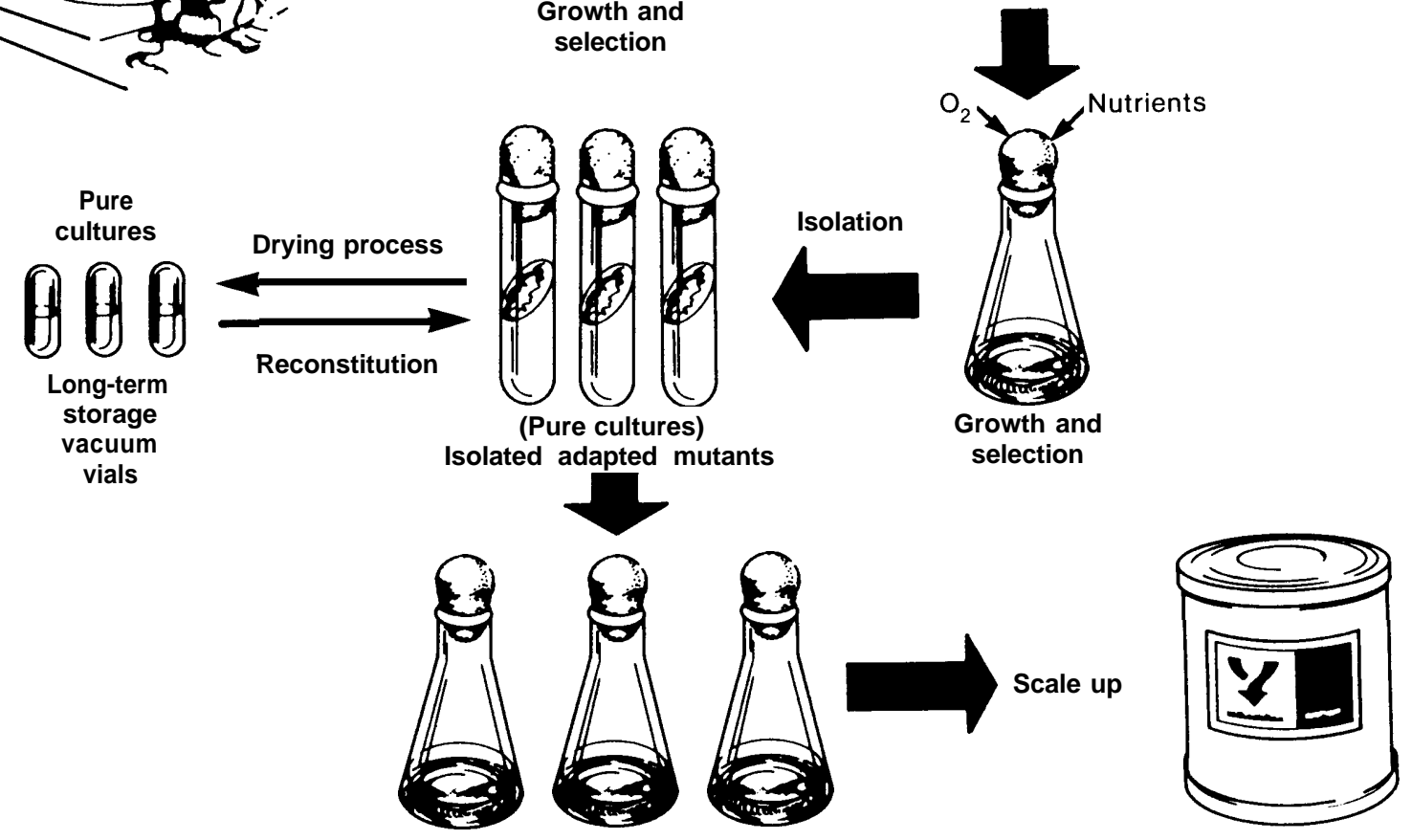

Dry

blend

Shake flasks

store

Micro-organisms indigenous to various environmental sites can be isolated and screened for degradative capabilities. This figure shows how naturally occurring organisms can be selected in the laboratory and, if desired, subjected to mutagenizing agents such as radiation. This imprecise method can sometimes produce new strains of organisms with enhanced capabilities.

SOURCE: Polybac Corp.

1. consolidation of large environmental firms with smaller biotreatment firms (e.g., themerger of Theme Environmental with Biota);

2. creation of biotreatment groups in larger environmental service firms; or

3. hiring of a limited number of bioremediation professionals to recommend appropriate proj- ects and to handle subcontracts with bioremediation specialty firms.

\section{Products}

Approximately one dozen companies manufacture organisms that are sold as biological treatment products. Most of these products consist of preselected mixtures of naturally occurring micro- 


\section{Box 8-A-The Exxon Valdez Bioremediation Project}

On March 23,1989, the Exxon Valdez tanker, freshly loaded with 1.2 million barrels of crude oil, left Alaska's south coast headed for California Twenty-five miles out, the ship ran into a reef at. Bligh I sland in Prince William Sound. The accident resulted in the largest oil spill in U.S. history and the first major spill to foul the waters off Alaska's coast. Patches of oil and water-in-oil emulsion spread over 3,000 square miles and onto unestimated 1,000 miles of shoreline.

Environmental factors have been substantial obstacles in the Alaska cleanup. Alaskan waters are extremely cold and there had been little experience with oil spills in subarctic conditions. Only a half-dozen or so tanker spills had been studied, and most occurred in temperate waters, The surface water temperature in Prince William Sound is approximately 3 degree Celsius in mid-April. At that temperature, degradation by micro-organisms, which ultimately removes much spilled oil, takes twice as long as it does at 10 degree Celsius.

The Valdez spill prompted a monumental cleanup effort and launched significant scientific research efforts. In addition the traditional methods (i.e., containment, skimming, and burning) of oil cleanup, the EPA Office of Research and Development initiated a bioremediation study to determine the feasibility of using nutrients to enhance micro-organisms' degradation of oil on the shorelines of Prince William Sound A major portion of this venture was funded by the Exxon Corp. In 1989, Exxon contributed approximately $\$ 3$ million, and EPA contributed approximately $\$ 1.6$ million.

The major portion of the Alaskan oil spill bioremediation project involved a field test to determine if adding fertilizer to contaminated beaches would effectively stimulate native bacteria to breakdown the oil. The EPA selected two sites-Passage Cove and Snug Harbor-based on type of shoreline, area, size, and uniformity of oil conlamination. It was determined that two types of fertilizer would be needed to release nitrogen and phosphorous nutrients over an extended period of time. One type was a solid, slow-releasing briquette fertilizer that released nutrients slowly from point sources distributed over the beach through tidal action. The second type, a liquid ol eophilic fertilizer, dissolved into the oil covering rock and gravel surfaces.

Before the fertilizer was applied, each beach was hosed down to disperse the oil across the beach. Researchers packed the fertilizer briquettes into biodegradable sacks and tied the sacks to pipes anchored in the test site beach, Over the course of a month, wave and tidal action flushed the slowly dissolving fertilizer back-and-forth across the shoreline.

Both EPA and Exxon officials acknowledged that the use of fertilizers could pose a risk to some sea life. To determine the potential toxicity of the fertilizers to native organisms, a wide range of species were tested. The results demonstrated that certain components of the ol eophilic fertilizer were mildly toxic when first applied to the most sensitive marine species. Tidal action, however, quickly diluted these toxic components to nontoxic levels.

Approximately two weeks after the fertilizer was applied to the test plots in Snug Harbor, scientists observed reductions in the amount of oil on rock surfaces. All other plots, however, appeared as oiled as they had been at the beginning of the field study. Toward the end of the summer season, the entire test area became steadily cleaner. In contrast, an untreated area of Snug Harbor remained considerably contaminated.

By the end of September 1989, Exxon and EPA had treated 70 million miles of shoreline in the largest bioremediation project ever conducted. The initial findings from the study indicate that using nutrients to enhance microbial degradation are effective and environmentally safe.

SOURCE: Office of Technology Assessment, 1991.

organisms advertised as additives to improve performance. Product uses include: decreasing pipes, degrading food processing facility wastes, odor control, and remediating oil spills.

Microbial cocktails, the commercial name for combinations of microbes packaged for sale for specific uses, are available from companies in the United States, Japan, and Europe. Because information about sales of such products is proprietary, no reliable data exist regarding the volume of sales of these products.

\section{Waste Generators}

Significant fourth players are generators of hazardous wastes. In addition to employing biological treatment staffs, some chemical and energy companies are supporting in-house research to perfect biodegradation of their specific production facilities' wastes. Such research may result in biology- 
based treatment methods and products that can be marketed directly or licensed to bioremediation vendors.

\section{International Biotreatment Industry}

Despite the limited size of the bioremediation industry in the United States, U.S. commercial activity far exceeds that of other nations. Four factors account for the United States' lead in this area:

1. The size and scope of U.S. environmental law exceeds that of other nations.

2. The majority of research has been conducted in the United States.

3. The size of the biotreatment industrial sector in the United States, albeit small, exceeds that of other nations.

4. Public acceptance of bioremediation in the United States has been spurred by recent, well-publicized uses of bioremediation for oil spill cleanup.

\section{Research and Industrial Development}

The existence of environmental laws and regulations are prerequisites to the formation of a waste treatment market. Although several nations have enacted environmental regulatory programs, enforcement of regulations and funding of hazardous waste infrastructures are often not sufficient. A barrier to the international use of bioremediation is the view, held by many, that pollution control costs industry money and makes industry, in its own view, less competitive in world markets. To some, investment in and operation of effluent treatment facilities is money down the drain (5).

Several Organization of Economic Co-operation and Development (OECD) countries have been pursuing biotechnology research and development $(R \& D)$ in improved waste treatment, notably The Netherlands, France, J apan, and Germany (see box 8-B). Still, research efforts are generally minimal in many countries, and the diffusion of research results into commercial applications is negligible when compared to other sectors affected by biotechnology. This is due to lax regulations that encourage the payment of fines by industry for waste emission rather than the use of systems to reduce or cleanup pollution (1 1 ). In the United States, by comparison, several Federal agencies support biological research related to waste

\section{Box 84?-international R\&D, Improved Waste Treatment Processes}

The Netherlands. Companies, such as GistBriocades use and are attempting to market advanced anaerobic waste water cleanup processes. The Dutch Government supports research in soil biodegradation and the development of systems to convert farm waste in small fermenters into marketable fertilizers for export to developing countries.

United Kingdom. Research and Development efforts are being undertaken by several small companies and regional water authorities. The use of waste treatment processes by industry is minimal, due to a less stringent regulatory climate and weak incentives for efficient industrial cleanup.

J apan. A 5-year, V5 billion project on waste water treatment through biotechnological processes was launched in the 1980s by the Ministry of Construction.

Germany. The Ministry for Research and Technology plans to introduce a program supporting risk assessment research.

SOURCE: organization for Economic Co-operation and Development, Biotechnology and the Changing Role of Government, 1988.

management. In 1987, eight Federal agencies spent $\$ 11$ million on such research (15).

In order to provide equal access to waste treatment for all industrial sectors, The Netherlands, Belgium, Denmark, and Germany have centralized waste treatment facilities. Those handling recurrent, solid hazardous waste do not appear to utilize biological treatment at this time; however, these countries have well-maintained wastewater treatment systems that rely on micro-organisms. The primary bioremediation focus in these countries is the use of biostimulation to encourage indigenous organisms to degrade wastes in contaminated soils and groundwater. In contrast to publicly run treatment and disposal facilities found in northern Europe, Italy prefers private-sector waste management and cleanup services. The Italian tourist industry has created a market for environmental restoration. Work is underway at a popular beach to biologically disperse algae. France has diversified privately run waste management and remediation services, and French firms dominate the private-sector market.

Although stronger enforcement could generate more demand for waste treatment, public expecta- 


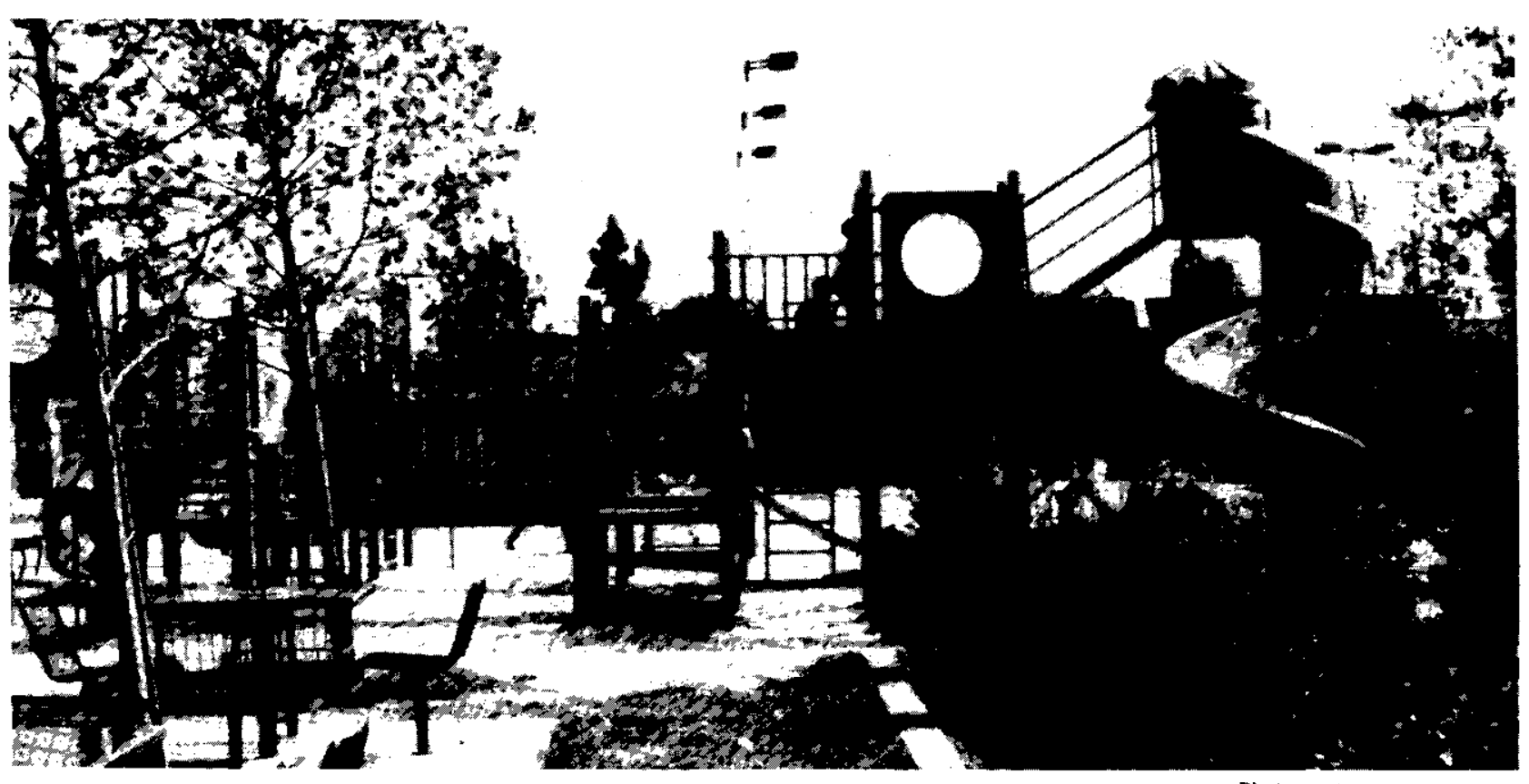

Photo credit: Kevin O'Connor

This park in Torrance, California, was once the site of an oil refinery. After several years of bioremediation, a community center, several ballfields, and a playground were constructed.

tions in both Pacific Rim countries and the European Community (EC) are forcing some governments to inventory contamination problems, actively participate in cleaning up existing pollution, and monitorthe effectiveness of waste treatment for newly created wastes.

The United States, in contrast, has an elaborate environmental protection program already in place. Unlike many other countries, the enforcement of that program is generating a market for environmental cleanup. Cleanup goals and the size of the problem-the universe of waste management facilities, leaking underground storage tanks, and abandoned sites with contaminated soils and groundwater--are better defined for the United States than for other countries surveyed.

\section{Advantages of Bioremediation}

Depending on the situation and type of site, bioremediation offers several advantages over more conventional waste treatment technologies, such as incineration or chemical fixation, these include:

Minimal disruption. Bioremediation generally involves only minimal, if any, physical disruption of a site. This can be very important on beaches where other available cleanup technologies (e.g., high- and low-pressure spraying, steam cleaning, manual scrubbing, and raking of congealed oil) may cause additional damage to beach-dwelling biota (2).

- Permanency. Micro-organisms can convert a selected number of wastes into carbon dioxide, water, and cell mass. For these completely biodegradable wastes, no toxic residues remain to manage. For other wastes that are not completely mineralized by biological actions, biodegradation can transform hazardous chemicals into stable, more benign, and less-toxic compounds.

- Lower costs. The capital costs of biologybased systems are relatively low, compared to other treatment technologies. The microbes used are generally inexpensive, and once applied, they self-replicate. In some cases, in situ bioremediation may be utilized without excavation or demolition of buildings. For these reasons, the costs of bioremediation should be lower than those systems with more expensive input requirements.

- Public acceptability. Bioremediation offers the public a treatment process that relies on natural degradation, transformingg hazardous wastes into familiar compounds, such as carbon 
dioxide and water. The biotreatment system design, itself, is nonthreatening. For example, some bioremediation systems may only require the removal of contaminated soils and groundwater to a tank, which looks like the usual sewage treatment plant, or a vat as used to make beer or wine. In situ bioremediation does not even require moving toxic wastes or siting a treatment unit. Such in-place treatment minimizes the public and environmental risks created by the handling of waste.

\section{Barriers to Commercialization}

Despite the advantages of bioremediationresearch, technical, and regulatory barriers hinder the use of biotechnology for hazardous waste cleanup.

\section{Research Barriers}

Much needs to be learned regarding the scientific underpinnings of bioremediation. Waste takes on many forms, occurs in many sites, and is subject to varying environmental conditions. To date, promising targets for use of bioremediation include oil spills, point sources of industrial effluents with high concentrations of specific chemicals, spills of particular chemicals in contained areas, and dump sites being prepared for encapsulation or excavation $(9,10)$.

To assess the feasibility of biotreatment, several areas of science and engineering must be understood.

- Microbial physiology, biochemistry, and genetics, to understand the metabolic processes leading to detoxification and the genetics controlling the enzyme functions involved.

- Microbial ecology, to appreciate the structure and fiction of indigenous or inoculated microbial communities and the microenvironment in which treatment must be effective.

- Field-site engineering, to implement the desired biodegradation scheme, to maintain optimal growth conditions, and to combine physical and chemical methods (10).

The application of biotechnology to waste disposal is still largely experimental, and investment is small compared with efforts in pharmaceuticals and agriculture. Two significant perceptual problems have been voiced repeatedly to OTA: 1 ) because pharmaceuticals and agriculture are seen as being areas of greater promise (e.g., ability to produce high-value-added products), those areas attract more dollars and more highly trained personnel than programs involved in research targeted toward the cleanup of waste; and 2) fears of regulatory barriers, especially for the development of genetically engineered organisms for use in the environment, discourage researchers from investigating genetic engineering as a way to discover potentially beneficial organisms.

The EPA is the lead agency in conducting $R \& D$ in waste disposal. However, EPA's current investment in $R \& D$ for biotechnology--\$8.3 million in fiscal year 1990-is small compared to other Federal agencies. Additionally, there has existed a widespread feeling that EPA is biased against biological approaches to waste disposal and is unwilling to support approaches involving biotechnology (15). Some researchers, however, say this bias is changing, pointing to EPA involvement in the Valdez oil spill cleanup and strong statements by EPA officials touting the use of bioremediation.

Another significant research problem is the paucity of published scientific literature on the results of bioremediation. Much of the activity in this area is conducted by private businesses engaged in contractor-client relationships. As such, the results of many small-scale uses of bioremediation constitute privately held business information or trade secrets and, thus, remain hidden from competitors and researchers alike. As one company executive noted, some clients want to have hazardous waste removed from their property, but they do not want their neighbors to know about the scope of the problem or the nature of treatment undertaken (4).

\section{Technical Barriers}

Several technical problems hinder the broader application of biology to waste treatment and cleanup:

- Although bioremediation works faster than natural biodegradation, it is generally slower to implement than "burn or bury" technologies that are the most likely alternatives to biotreatment.

- Bioremediation must be specifically tailored to each polluted site. Each waste site presents unique facts, requiring individualized attention. Not enough is known about bioremedia- 


\section{Box 8-C-Federal Statutes Relevant to Bioremediation}

Several Federal environmental laws are relevant to biology-based waste treatment, including:

Comprehensive Environmental Response, Compensation, and Liability Act (CERCLA). The 1986 amendments to CERCLA (Public Law 99-499) state" [t]he President shall select a remedial action that is protective of human health and the environment, that is cost effective, and that utilizes permanent solutions and alternative treatment technologies. . . to the maximum extent practicable.'

Toxic Substances Control Act (TSCA). The TSCA was enacted by Congress in 1976 (Public Law 94-469). In contrast to other environmental statutes specifically regulating the quality of air, water, or other natural resources, TSCA gave EPA broad authority to regulate "chemical substances and mixtures." Under TSCA, the manufacturer of a new chemical must submit a premanufacture notice to EPA that describes test data referring to identity, use, amount, disposal, and so forth. EPA then has 90 days to consider the notice and decide whether to approve production. Under the Coordinated Framework for Regulation of Biotechnology, EPA notified the public that biotechnology processes and products not covered or regulated by other Federal agencies would be included under the jurisdiction of TSCA.

Clean Water Act (CWA). CWA'S pretreatment program's J uly 24, 1990, final rule states". . . the Industrial User shall certify that it has a program in place to reduce the volume and toxicity of hazardous wastes generated to the degree it has determined to be economically practical."

Resource Conservation and Recovery Act (RCRA). The Hazardous and Solid Waste Amendments to RCRA, enacted by Congress in 1984 (Public Law 98-616), emphasize permanent treatment technologies. Congress declared "it to be the national policy of the United States that, wherever feasible, the generation of hazardous waste is to be reduced or eliminated as expeditiously as possible. Waste that is nevertheless generated should be treated, stored or disposed of so as to minimize the present and future threat to human health and the environment."

Superfund Amendments and Reauthorization Act (SARA). SARA directs that "[remedial actions in which treatment which permanently and significantly reduces the volume, toxicity, pollutants, and contaminants is a principal element, are to be preferred over remedial actions not involving such treatment. "

SOURCE: Office of Technology Assessment, 1991.

tion to be able to predict results in specific situations with a high degree of accuracy.

- Successful mineralization of pollutants has been limited to relatively easy-to-degrade compounds (12).

- There are no official scientific measures for evaluating the success or failure of bioremediation. The only well-known successful use of bioremediation has been for the cleanup of oil spills.

\section{Regulatory Barriers}

Regulations both drive and constrain the use of bioremediation. Regulation creates the bioremediation market by dictating what must be cleaned up, how clean it must be, and which cleanup methods may be used. A number of Federal statutes and relevant regulations control waste disposal activities (see box 8-C). The passage of Federal statutes has increased pressure on waste generators to reduce waste and to find permanent solutions to waste that is generated. Although these laws can apply to all permanent waste treatment methodologies, biology- based approaches offer destruction of selected hazardous wastes without toxic residues-a result certainly in accordance with the intent of these laws.

However, several regulatory barriers hinder the commercialization of bioremediation:

- Cleanup standards. How clean is clean? The achievable endpoint for biodegradation may be limited for specific pollutants. Biology-based remediations maybe able to reach health-based standards but not lower residue levels resulting from thermal treatment technologies, such as incineration.

- Standards are still under development. Treatability studies used by regulatory agencies to determine the efficacy of a waste treatment regime have not been standardized for biological treatment.

Little biotreatment permit experience. The permitting of biotreatment activities today relies on individuals' best professional judgment. Based on the small number of permits issued to date, experience in the approval of 


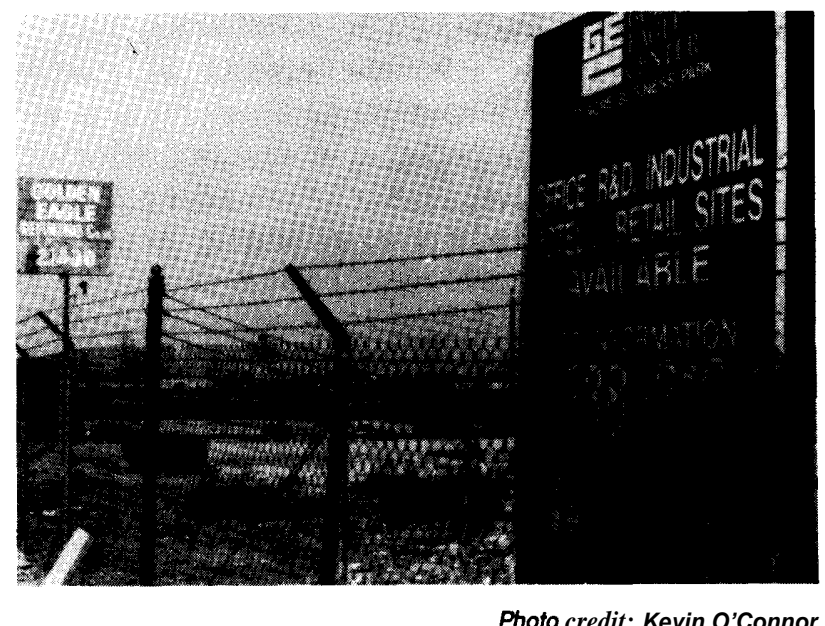

Through bioremediation, former industrial sites such as this may be used for other purposes.

treatment protocols using naturally occurring and recombinant micro-organisms is limited.

- Land disposal regulations limit reactor design. Recent land disposal regulations promulgated by EPA's Office of Solid Waste prohibit the recirculation of contaminated groundwater through an in situ bioreactor arrangement, a common design for bioremediation of contaminated soils and groundwater.

\section{Economic Barriers}

Unlike the pharmaceutical industry, bioremediation does not result in the production of high-value-added products. Thus, venture capital has been slow to invest in the technology, and commercial activity in research and product development has lagged far behind other industrial sectors.

The majority of the bioremediation firms are small and lack sufficient capital to finance sophisticated research and product development programs. In addition, bioremediation lacks a strong, publicly funded research base. Federal research dollars have been scarce to support discovery or improvements of biology-based waste treatment.

Because basic research is limited and most products and processes are developed by small entrepreneurs or companies, bioremediation relies on trade secrets, not patents, for intellectual property protection. Biological treatment currently relies on naturally occurring organisms that cannot be patented and can be reproduced by one's competitors.
This lack of intellectual property protection subjects the industry to constant competitor stress. Further, many clients of bioremediation companies do not want public attention focused on hazardous waste cleanups. This results in proprietary business relationships that do not foster the sharing of scientific and business practices.

Experienced personnel are in short supply. University programs are now being establishing for bioremediation specialists, but continuing education programs are not common. Marketing of products and services has, historically, been done by individual companies. Few firms exist that act as brokers for the technology. Such an arrangement is personnelintensive.

The key marketing promise of the biotreatment industry is less cost through remediation. No academic or regulatory agency has published a study analyzing the costs of biological treatment compared with other technologies, such as incineration. The only information currently available is found in individual companies' marketing materials.

\section{Prospects for Genetically Engineered Microbes}

Some basic research is underway on the use of genetically engineered microbes for waste cleanup. The first out-of-laboratory applications of genetically engineered microbes for waste cleanup will be done in bioreactors, because conditions for microbial survival and monitoring are easier to control in a closed system then in an open field. Today's bioremediation sector continues to rely on naturally occurring micro-organisms. Due to scientific, economic, regulatory, and public perception reasons, the imminent use of bioengineered micro-organisms for environmental cleanup is not likely to happen in the near future. More needs to be learned about naturally occurring microbes-much less those that are genetically engineered. The lack of a strong research infrastructure, the predominance of small companies, the lack of data sharing, and the existence of regulatory hurdles all serve as dominant barriers to commercial use of genetically engineered organisms.

The potential savings from the use of biologybased treatments, compared to conventional incineration, and the interest of generators to limit their long-term liability for wastes are positive reasons for the development and use of genetically engineered 
microbes. In the United States and the European Community, government, private, and academic institutions are increasingly confident that environmental biotechnology offers a more ecologically sound approach to waste remediation. This may play the most important role in moving genetically engineered microbes into the field.

The majority of current bioremediation firms are small and lack sufficient capital to finance sophisticated research and product development programs. This is a problem when using naturally occurring organisms, but a crisis for the development of bioengineered products and related services. Until barriers to development are reduced, widespread commercial use of genetically engineered organisms for environmental waste reduction is unlikely.

\section{SUMMARY}

Biotechnology has several potential environmental applications, these include: pollution control, agriculture, mining, and microbial enhanced oil recovery. Bioremediation--efforts to use biotechnology for waste cleanup-has received public attention recently because of the use of naturally occurring micro-organisms in oil-spill cleanups. Bioremediation can be used at a variety of sites and in a variety of applications, among these are wastestream cleanup, wood treatment-site cleanup, PCB degradation, groundwater treatment, and chemical cleanup of manufacturing wastes. The rationale for using micro-organisms to degrade pollutants stems from experience with nature. Micro-organisms have a variety of capabilities that can be exploited for waste management and disposal.

The use of bioremediation in the United States is increasing. Today, the U.S. biotreatment industry includes more than 130 firms and has evolved into four segments: bioremediation services, multidisciplinary environmental services, products, and waste generators. The commercial bioremediation sector in the United States, though small, far exceeds activity in other nations. Four factors account for the United States' lead: the size and scope of U.S. environmental law, more advanced research, the number of companies, and public acceptance, spurred by recent uses of bioremediation for oil-spill cleanup.

Although bioremediation offers several advantages over conventional waste treatment technologies, several factors hinder widespread use of biotechnology for waste cleanup. Relatively little is known about the scientific effects of microorganisms in various ecosystems. Research data are not disseminated as well as with research affecting other industrial sectors. This is caused by limited Federal funding of basic research and the proprietary nature of the business relationships under which bioremediation is usually used. Regulations provide a market for bioremediation by dictating what must be cleaned up, how clean it must be, and which cleanup methods may be used; but regulations also hinder commercial development due to their sheer volume and the lack of standards for biological waste treatment.

Bioremediation, unlike the pharmaceutical and agricultural industries, does not result in the production of high-value-added products. Thus, venture capital has been slow to invest in the technology, and little incentive exists for product development. The majority of bioremediation firms are small and lack sufficient capital to finance sophisticated research and product development programs. Bioremediation primarily depends on trade secrets, not patents, for intellectual property protection.

Although some research is being conducted on the use of genetically engineer ed organisms for use in bioremediation, today's bioremediation sector relies on naturally occurring micro-organisms. Scientific, economic, regulatory, and public perception limitations that were viewed as barriers to the development of bioremediation a decade ago still exist. Thus, the commercial use of bioengineered microorganisms for environmental cleanup is not likely in the near future

\section{CHAPTER 8 REFERENCES}

1. Ehrlich, H.L., and Brierly, C. (eds.), Environmental Biotechnology: Microbial Mineral Recovery (New York, NY: McGraw Hill, 1990).

2. Foster, M. S., et al., "To Clean or Not To Clean: The Rationale, Methods, and Consequences of Removing Oil From Temperate Shores," The Northwest Environmental Journal, vol. 6, 1990, pp. 105-120.

3. Granger, T., EBASCO Environmental, personal communication, August 1990.

4. Grubbs, J ., president, Solmar Corp., personal communication, October 1990.

5. Harrier, G., "The Impact of Government Legislation on Industrial Effluent Treatment,' Conservation and Recycling, vol 8, Nos. 1/2, 1985, p. 27. 
6. Henley, M., "Europe Poses Multi-billion Environmental Market," WasteTech News, vol. 2, No. 24, Aug. 13, 1990.

7. McCready, D., director, Canadian Center for Mineral Energy Technology, personal communication, September 1990.

8. McInerney, M. J., University of Oklahoma, personal communication, September 1990.

9. Omenn, G.S. (cd.), Environmental Biotechnology: Reducing Risks from Environmental Chemicals Through Biotechnology (New York, NY: Plenum Press, 1988).

10. Omenn, G. S., professor and dean, School of Public Health \& Community Medicine, University of Washington, "Environmental Biotechnology: Biotechnology Solutions for Hazardous chemical Wastes and Oil Spill Clean-up," presentation at Biotechnology Forum on Oil Spills in Marine Environments, Cincinnati, OH, September 1990.

11. Organization for Economic Co-operation and Development, Biotechnology and the Changing Role of
Government (Paris, France: OECD Publications Office, 1988).

12. Rochkind, M.L., et al., Microbial Decomposition of Chlorinated Aromatic Compounds, EPA-600 (Washington, DC: EPA Publications Office, February 1986) p. 90.

13. U.S. Congress, Office of Technology Assessment, Commercial Biotechnology: An International Analysis (Elmsford, NY: Pergamon Press, Inc., January 1984).

14. U.S. Congress, Office of Technology Assessment, New Developments in Biotechnology: Field-Testing Engineered Organisms: Genetic and Ecological Issues, OTA-BA-350 (Springfield, VA: National Technical Information Service, May 1988).

15. U.S. Congress, Office of Technology Assessment, New Developments in Biotechnology: U.S. Investment-Special Report OTA-BA-360 (Spring field, VA: National Technical Information Service, July 1988). 


\section{Part II: Industrial Policy}




\title{
Chapter 9
}

\section{Introduction: Industrial Policy}

"The USA has become the technology colony for the rest of the world. We supply the raw materials (technology), they add the value and sell to us and keep the profits! We have to change that system if we want to be competitive."

\author{
J erry Caulder \\ president, Mycogen, February 1991.
}

"In some respects, American competitiveness and Yankee ingenuity are stronger than ever. True, many of the nation's institutions have come up for a reappraisal. But what institution shouldn't come up for appraisal every 50 years or so?"

David Warsh Columnist, Boston Globe, June 1991.

"The most potent influences of government in advanced nations are often slow and indirect." The Competitive Advantage of Nations 


\section{CONTENTS}

Page

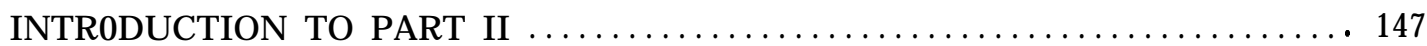

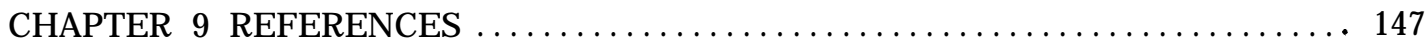




\section{Introduction: Industrial Policy}

\section{INTRODUCTION TO PART II}

Although the concept of industrial policy has been around in the United States since the New Deal of the 1930s, it has more recently returned to the national agenda as concern has risen about U.S. competitive status in a number of industries. Industrial policy, in broad terms, is the deliberate attempt by a government to influence the level and composition of a nation's industrial output. These actions can include improving the industrial infrastructure, training workers, shifting resources to activities that will use them more efficiently, or maintaining resources in existing activities deemed important for national or economic security. Industrial policies can be implemented through domestic measures such as: allocation of Federal funds, subsidies, tax incentives, regulation of industry, and protection of intellectual property; or policies can be affected through trade actions, such as tariffs and quantitative import restrictions (I). Government can also play a central role in productivity through its economic policies-the manner in which it deploys the Nation's resources (labor and capital) and assists industry in adjustment to change (3).

The science and technology policy of the U.S. Government has traditionally been concerned with basic science, health, energy, agriculture, and defense. It has been described as big science deployed to meet big problems (4) and as mission-oriented rather than diffusion-oriented (2). The U.S. Government, in contrast to other governments, rarely takes deliberate actions to improve the use of technology by U.S. manufacturers. Other government actions intended to improve industrial performance work more indirectly-tax and trade policies and intellectual property protection are examples of indirect actions. Industrial policies in technology-intensive industries, such as biotechnology, rarely fit easily into existing frameworks.

Industrial policies in the United States are complex, fragmented, continually evolving, and rarely targeted comprehensively at a specific industry. There is no industrial policy pertaining to biotechnology per se, but rather a series of policies formulated by various agencies to encourage growth, innovation, and capital formation in all high-technology industries. And, just as there is no biotechnology policy in the United States, biotechnology companies tend not to behave as an industry, but rather as agrichemical, diagnostic, or human therapeutic fins. Biotechnology companies have been built on a unique system of financing, but they confront the same regulatory, intellectual property, and trade policies faced by other U.S. firms. There may be a need for the Federal bureaucracy to fine-tune its policies as biotechnology moves through the system with its unique challenges, but to date (with the possible exception of the Federal research system), Federal agencies have not seen the need to revolutionize their practices for biotechnology.

Part I of this report addressed commercial activity in biotechnology, recognizing that biotechnology has become an important tool in several traditional U.S. industrial sectors.

Part II addresses the actions, both direct and indirect, taken by the United States and other governments that have influenced the commercialization and integration of biotechnology. Specifically, the importance of developing a science and technology infrastructure, regulatory practices, intellectual property protection, and trade issues. Tax law, which is an expression of industrial policy, is discussed in Part I, chapter 4 because of the importance of tax laws on financial practices in biotechnology.

\section{CHAPTER 9 REFERENCES}

1. Boonekamp, C., "Industrial Policies of Industrial Countries," Finance and Development, March 1989.

2. Ergas, H., "Does Technology Matter?" Technology and Global Industry: Companies and Nations in the World Economy, B.R. Guile and H. Brooks (eds.) (Washington, DC: National Academy Press, 1987).

3. Porter, M., The Competitive Advantage of Nations (New York, NY: The Free Press, 1990).

4. Weinberg, A.M., Reflections on Big Science (Oxford: Pergamon Press, 1967). 


\section{Chapter 10}

\section{Science and Technology Policies}

"It is my personal conclusion that no plans, either present or contemplated, will prevent our gradual loss of leadership in biotechnology unless they provide for extensive and fundamental changes in the conduct of government supported research in the United States."

Norman G. Anderson hearing before the Technology Policy Task Force, July 1987.

"A rosy glow has long suffused our vision of biotechnology in J apan: government support, public acceptance, highly motivated researchers, the happy reports of American research executives with joint development agreements-it sounded ideal, a model and a challenge. So it was a shock to discover. . . that the country may not be the land of tPA milk and recombinant honey."

Douglas McCormick Bio/Technology, July 1989

"Although the EC has the human, scientific and material resources to compete globally in the biotechnological race, it has failed so far to match strides with its main rivals-the United States and J apan. " 


\section{CONTENTS}

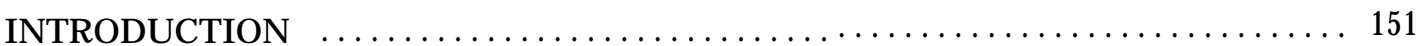

NATIONAL POLICIES . . ...................................... 152

J apan: A Targeted Approach . . . . . . . . . . . . . . . . . . . . . . . . . . . . . 153

Europe: Moving Toward a Regional Strategy? .......................... 158

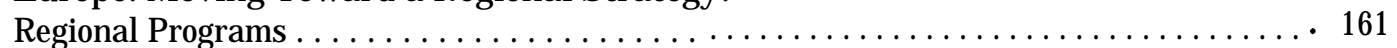

The United States: A Diffuse Approach $\ldots \ldots \ldots \ldots \ldots \ldots \ldots \ldots \ldots \ldots \ldots \ldots \ldots \ldots \ldots \ldots$

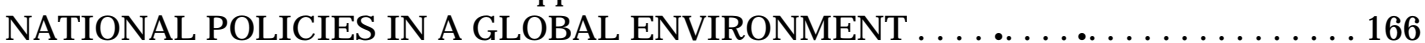

Domestic University-Foreign Industry Relations ........................ 167

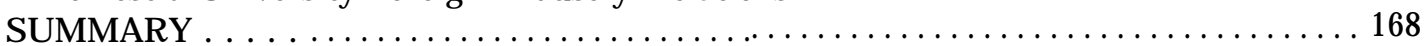

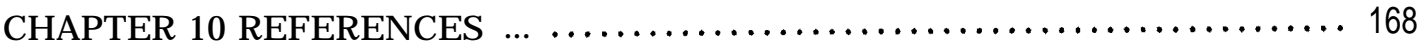

\section{Boxes}

Box $\quad$ Page

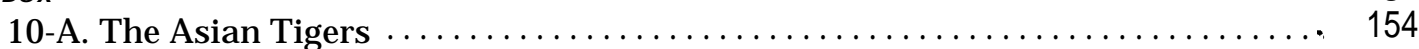

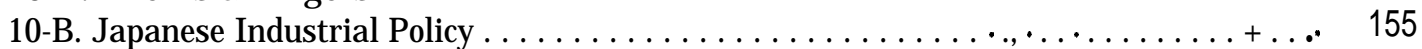

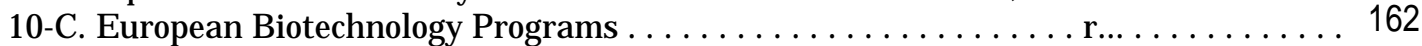

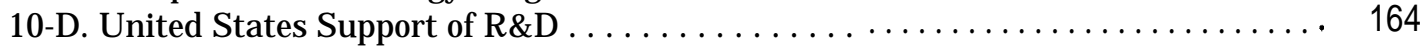




\section{Science and Technology Policies}

\section{INTRODUCTION}

For most governments, including the United States, research spending serves diverse goals. Enhancing national defense, improving public health, training new scientists, and ensuring an adequate food supply are four common examples. Publicly funded research in these areas is expected to support economic growth and the strength of domestic industry, in great part through the creation of a research and technology infrastructure. This infrastructure includes training young scientists and technicians through support of basic research. Some governments put less emphasis on goal-or missionoriented research and more on encouraging a broad capacity for industry to adjust to technological change through education, devel opment of technical standards, and decentralized research activities (10). Governments generally fund basic research, for which there is little incentive for funding in the private sector or that is beyond the financial capacity of industry. The results of such research are generally published openly and made available to everyone, regardless of nationality. Sometimes, however, governments fund research closer to the market, occasionally with the express purpose of aiding or encouraging investment by domestic industries in specific technologies.

National policies that bear on biotechnology research and training vary around the world in design and execution, for a variety of reasons. These include the state of the existing science base, structure and orientation of industry, mix of resources and markets, role of public perceptions, regulations, and relationships among government, industry, and universities.

Many countries without a previous strong foundation in the biological and biochemical sciences, for example, are building research infrastructures. Industrializing Pacific Rim countries are encouraging research and commercial activities appropriate to local and regional markets, such as hepatitis vaccine development and production. Countries without a strong tradition of university-industry cooperation have established programs to reorient the research community and encourage university-industry ties. Australia, lacking a large domestic market, encour- ages its firms to establish commercial ties and develop markets abroad. Denmark, with a small domestic market and research base, actively promotes international research efforts through a number of successful, international companies. Cooperative research programs between and among European countries are growing in size and, perhaps, in importance; however, their significance lies less in immediate results than in the breakdown of social, cultural, and political barriers to cooperation and in the creation of translational research networks, which are distinct European concerns.

A challenge to the adoption of a national biotechnol ogy policy is the internationalization of research, development, and product commercialization. If basic research, by its nature, flows easily across borders, to what extent does the funding country benefit from its investment? In the emerging global research and commercial environment, aggressive companies, whether large multinationals or savvy newcomers, seek the best ideas regardless of nationality. Likewise, they produce goods and services to effectively compete in international markets regardless of nationality. It is no longer always clear what constitutes an American firm in a global economy. Because technology, goods, and capital, flow more easily across borders than people; national interest may be best defined by focusing on the education and training of the workforce, rather than on firms themselves (35).

In 1984, the Office of Technology Assessment (OTA) found that government targeting of biotechnology for special support was one of the least significant factors affecting competitiveness in biotechnology (44). This finding remains valid today. Government targeting efforts everywhere, including J apan, seem to have had marginal impact, at best. One reason may be that "biotechnology" is a buzzword whose usefulness has passed. A more accurate term is 'biotechnologies,' that is a series of research and industrial techniques. It is difficult to talk about biotechnology per se because the techniques have been integrated into distinct and very different industrial sectors with unique technical issues and distinct investment and market environments (45). These developments make it difficult, and possibly futile, for any nation 
to craft and implement a coordinated biotechnology strategy. Continued integration will make the task more difficult. More important will be the identification of key biotechnologies that need government support and industry encouragement.

Previous OTA reports have pointed out the relative underfunding in the United States of biotechnology-related agricultural, environmental, and risk assessment research, when compared with biomedicine (45). Although it has been helpful to look at biotechnology-related expenditures in different areas of application, questions raised by such analyses relate more to the differences between various fields than to biotechnology as a distinct entity. Biotechniques are an important part, but not the only part, of research in these fields. They may be significant to a number of industrial sectors but by themselves will not revolutionize existing structures. Their industrial significance, though potentially powerful, will be evolutionary and must be viewed in the context of all factorstechnical, economic, and structural-affecting such industries.

This chapter looks primarily at direct government efforts aimed at promoting biotechnology research, such as funding and training of scientists. Governments also have indirect means for encouraging or discouraging industrial research, such as regulation of research and products, trade and tax policy, and intellectual property protection. These issues are discussed elsewhere in this report (see chs. 4,11, $12,13)$.

\section{NATIONAL POLICIES}

National policies to promote biotechnology research and development (R\&D) can be categorized as targeted; coordinated through academia, the state, or industry; or laissez-faire. In general, countries that have targeted biotechnology for development do so because the techniques are perceived to permit economies in other industries, have important linkages to the rest of the economy, or because they might establish a niche in the international market that will yield continuing income. Although nations share a number of common issues and patterns of government involvement, specific policies, adapted to unique needs and circumstances, may not be easily adaptable elsewhere.

A number of countries, principally J apan and the Newly Industrializing Countries (NICS) of the Pa-

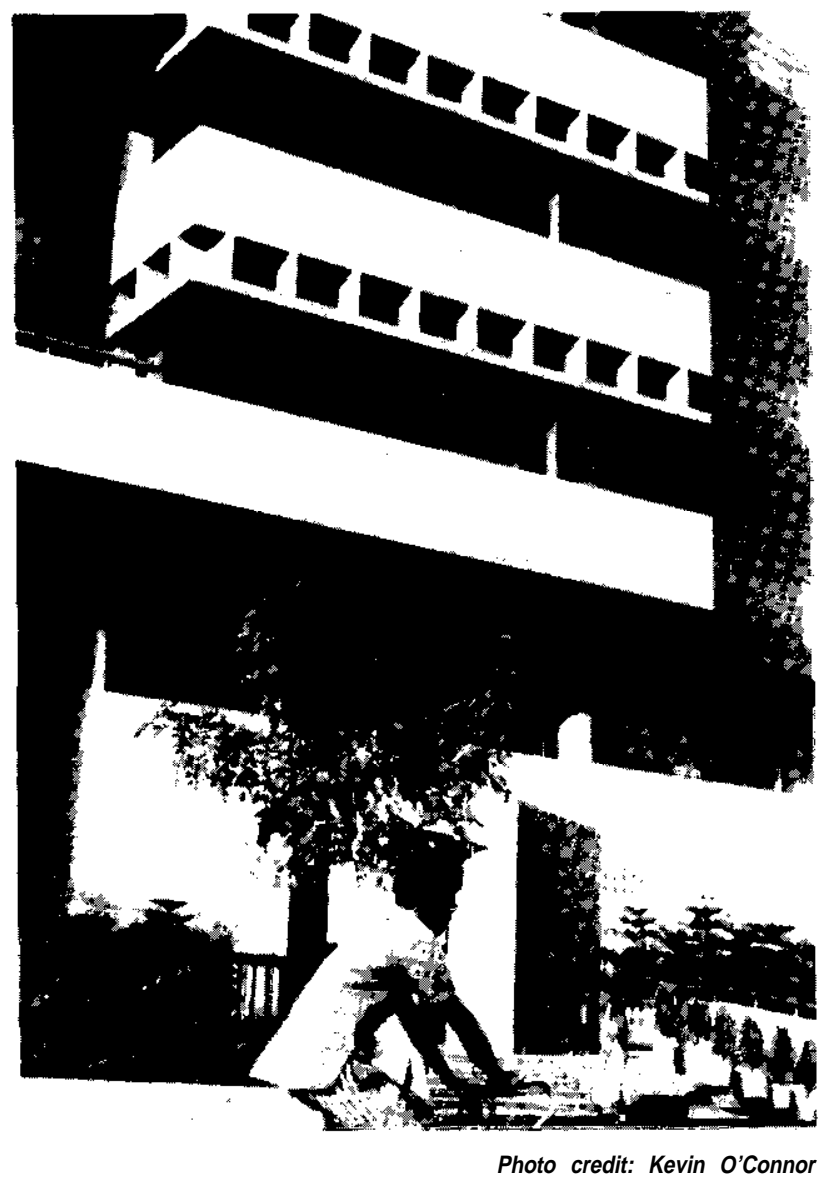

The Development Center for Biotechnology (DCB) is housed in this building in Taipei. DCB was established by the Republic of China in 1984 to promote biotechnology and develop internationally competitive products.

cific Rim, have established comprehensive government policies strongly promoting economic growth (see box 10-A). In the United States and much of Europe, growth promotion is less prominent and is one of many competing social concerns. As a result, fundamental goals are more diffuse and, therefore, less obvious than in a country like J apan.

There is considerable disagreement over what constitutes "the J apanese model." But J apan's industrial success, the extent to which other Pacific Rim countries are trying to imitate that success, and the interest in how other countries are adopting J apanese practices, necessitate a closer look at $\mathrm{J}$ apanese industrial and research policies. This section, therefore, examines $R \& D$ policies in the United States, J apan, and selected European countries. Appendix A provides more detailed informa- 
tion of biotechnology industrial policies in several other countries.

\section{Japan: A Targeted Approach}

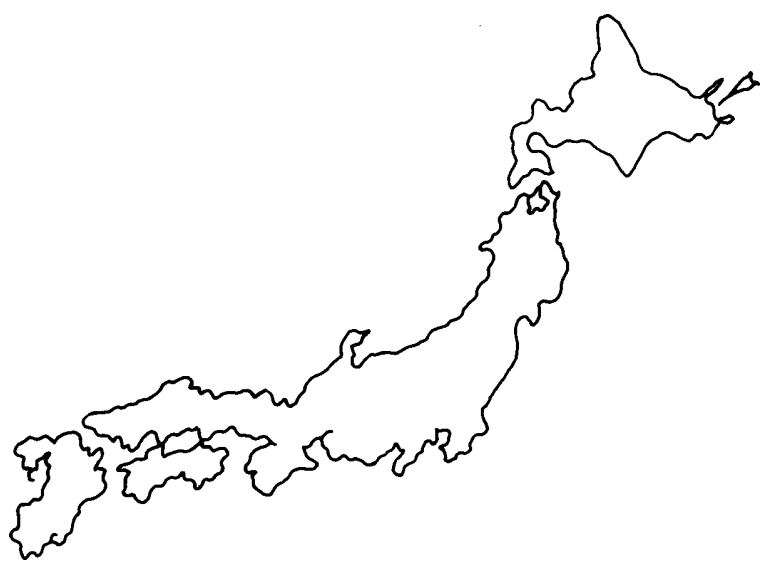

In 1981, J apan's Ministry of International Trade and Industry (MITI) announced that biotechnology, along with microelectronics and new materials, was a key technology for future industries. The announcement attracted interest and concern abroad, largely because of the key role MITI played in guiding J apan's economic growth in the postwar period (see box 10-B). It was frequently predicted that inclusion of biotechnology in MITI's Next Generation project, combined with a variety of incentives from MITI and other agencies (e.g., tax breaks for research investments and seed money for cooperative research projects) would prompt J apanese investment and eventual dominance in biotechnology (44).

There is little doubt that government policies, including the Next Generation project, encouraged biotechnology investment by a large variety of chemical, food, and fermentation companies, as well as by traditional pharmaceutical firms in J apan.
J apanese investment in biotechnology, however, predates MITI's Next Generation project. New initiatives in the life sciences came earlier from the Science and Technology Agency (STA) and the Ministry of Education and Culture, which fund J apanese university research (7). A number of companies made substantial investments in biotechnology prior to 1981. Mitsubishi Kasei Corp. 's Institute of Life Sciences was setup in 1971, about the time that Cetus was established in the United States (49).

Regardless of earlier actions, MITI's naming biotechnology as an area of interest probably gave it the legitimacy that it previously lacked and eased financing for private investment-as it had done earlier for other industries and technologies. It seems likely that some firms entered biotechnology research as a result of government policies. It seems also plausible, however, that MITI jumped on the biotechnology bandwagon because it did not want to be left behind.

As in the United States and elsewhere, the broad range of potential biotechnology applications has led to a wide variety of, frequently overlapping, initiatives by various J apanese agencies.

\section{Ministry of International Trade and Industry}

Of 12 initial Next Generation research projects proposed in 1981, three (bioreactor, mass cell culture, and recombinant DNA application) were in biotechnology. Concomitant with these proposals was the establishment of a Biotechnology J oint Research Association consisting of 14 companies, divided into three research groups, each associated with a research institution of MITI's Agency of Industrial Science and Technology. Most of the companies were in the chemical or food business, and most of the frost product goals were recombinant DNA (rDNA) or monoclinal antibody pharmaceuticals and diagnostics (7). Takeda, J apan's largest drug firm, was the only pharmaceutical company in the Next Generation initiative and is also the only pharmaceutical company participating in the Protein Engineering Research Institute (PERI), which is discussed in greater detail below.

The MITI faced a serious organizational problem. In contrast to previous government initiatives, particularly in manufacturing technologies, the incentive for cooperation between competing firms was lessened by the problem of proprietary rights. 


\section{Box 10-A-The Asian Tigers}

The Newly Industrializing Countries (NICS) of the Pacific Rim share with J apan an emphasis on export-driven growth. These countries have also developed patterns of government-industry cooperation, although these patterns differ significantly from those in J apan. There is a high degree of activism on the part of governments, particularly in Korea, Taiwan, and Singapore. All use licensing of foreign technology and repatriation of foreign-trained nationals to build their domestic research infrastructure.

Korea shares with J apan a strong bias toward applied research, apparently in large part, because of an underdevel oped research base. As in J apan, the bulk of R\&D is done by industry, and several chaebols (large industrial combines) and pharmaceutical companies have facilities in the United States to transfer technology and develop their internal resources. Licensing agreements with U.S. and J apanese firms area clear part of this strategy. The government directly subsidizes some industry research, including up to 30 percent of selected proposals from member companies of the Korea Genetic Research Association (KOGERA).

In contrast, Singapore is emphasizing basic research (roughly 80 percent of that country's annual biotechnology-relevant research budget) and creation of a research infrastructure through training and repatriation. Singapore's National Program in Biotechnology also features favorable tax incentives for domestic and foreign investment. Although the program recognizes the need for multinational investment, the main goal is the development of biotechnology-based local industry. The new Institute of Molecular and Cell Biology at the National University of Singapore will have 21 research teams carrying out basic research in underlying disciplines. Glaxo, a large, British-based pharmaceutical company, will provide a $\$ 50$ million trust fund to underwrite neurobiology research at the institute over the next 15 years.

Taiwan, like Singapore, is employing repatriated nationals to the fullest extent possible to help build their research base. One of the best developed research establishments in Asia is further strengthened by the large pool of Tai wanese scientists in the United States. In addition, investment capital is readily available. The country has roughly $\$ 75$ billion in foreign reserve holdings, second only to J apan, and has invested in several U.S. high-technology firms. Nevertheless, Taiwan seems to be making more of an effort than Singapore to reach midstream development; roughly 80 percent of biotechnology-relevant funding is devoted to applied research. (This is probably part of a strategy to develop products, such as Hepatitis B vaccine, which are significant to domestic and regional markets.) Of all the Asian NICS, Taiwan appears to be in the best position to take commercial advantage of biotechnology. But, Taiwan's emphasis on publicly funded midstream and applied research could reflect the reluctance of Taiwanese industry, dominated by small and medium-size manufacturing firms, to invest in $R \& D$,

SOURCE: Office of Technology Assessment, 1991, adapted from 1989 International Conference on Biotechnology in a Global Economy; and E. Richards, "Taiwan's Latest Export: Money, " The Washington Post, May 26, 1989.

Therefore, MITI tried to focus projects on areas in which Japan seemed clearly behind the United States and Europe. The level of success achieved in these projects was disappointing. The MITI, for example, abandoned a bioreactor project, due to industry's reluctance to cooperate (49).

The years 1986 to 1988 saw the establishment of bio-industry, with MITI setting regulatory guidelines for industrial uses of biotechnology in amino acid, enzyme, detergent, and cosmetic production. Today, MITI is continuing to support R\&D efforts in areas such as: marine biotechnology and biodegradable plastics, addressing relevant industrial policy (e.g., tax incentives and Japan Development Bank and Small Business Finance Corp. loans, and promotion of industry standards), improving safety measures (new contained-use regulations and developing lists of industrially exploitable organisms), internationalization (regulatory harmonization, and international $R \& D$ cooperation, and funding developing country research) (25). MITI's patent office continues to play a central role in biotechnology developments. The MITI planned to spend \$58 million on biotechnology in 1990, including funding dozens of public-private research projects, ranging from waste water treatment systems to biosensors.

\section{Ministry of Education, Science, and Culture}

The Ministry of Education, Science and Culture (MESC) is the largest single source of life/science research funding in Japan. Its Bureau of Science and International Affairs administers university grants, training programs, and international exchange and collaboration. The MESC also has authority over the national universities, i.e., the Universities of Tokyo, Osaka, Kyoto, and Nogoya; the National Institute of Genetics; and the Okazaki National Research Insti- 


\section{Box 10-B-Japanese Industrial Policy}

Japan's development into a major economic power was neither accidental nor inevitable. One analyst of postwar J apan argues that a system encouraging rapid economic growth resulted from three fundamental sources. First, a popular consensus on the need for economic priorities was dictated by the harsh conditions of the 1940s and J apan's unique situation: late industrialization, limited natural resources, a large population, the need to trade, and the constraints of the international balance of payments. Second, an organizational inheritance dating back to the 1930s included experiments with control of the economy, first by powerful industrial groups and then by the State. These experiences encouraged a convergence of views on the part of bureaucratic and business elites, as did cross-penetration of these elites, due to recruitment of politicians and managers from government bureaucracies. Third, a conscious pursuit of economic growth fostered the manipulation of institutions toward this end.

A system of government-industry cooperation, based on the zaibatsu working with the government over many years, became even more important following World War II. At its best, it seemed to harness intense competition between firms within agreed areas of development. Although a number of strong bureaucracies, especially the Ministry of Finance, played critical roles, it was the Ministry of International Trade and Industry (MITI) that became a kind of 'economic general staff. MITI used powerful tools, including control of foreign trade and introduction of foreign technology through the 1960s, thereby protecting domestic industry and providing domestic firms with relatively cheap, foreign technology through licensing. But, it was primarily the development of indirect market-conforming tools (particularly informal "administrative guidance' that allowed MITI to play a key role in restructuring the J apanese economy-first into heavy industries and then into knowledge-based, high-technol ogy industries. MITI transformed itself to match J apan's changing needs and role in the global economy. It served not so much as a director of competition but, as a player itself, with its own purposes and its own means of intervening in the market to achieve its goals.

Broadly speaking, public policy in J apan has been characterized by a great degree of discretion yielded to elite and competing bureaucracies, with conflict between bureaucracies and between these bureaucracies and strong industries dominating policy development. Except for business, interest groups in the U.S. pluralistic sense have played a relatively minor role in policy development, forcing political intervention and bureaucratic change only in extreme cases. For example, in the 1960s, industrial pollution stimulated public concern and resentment.

Apart from assisting structural changes, MITI, like its prewar and wartime predecessors, and other agencies, such as the Ministry of Health and Welfare, have encouraged improved management, production techniques and applications of new technologies within specific industries. Such assistance, especially to small and medium-size manufacturing firms, maybe carried out through industry associations.

Although catching up with Western technology provided a clear goal for J apan through the 1970s, by the end of that decade this goal had been or soon would be reached in many areas. MITI's Next Generation program marked a shift toward an entrepreneurial approach to technology and economic development, supporting efforts far less certain of success. One account, from 1986, quotes a MITI technical official, lamenting reduced funding, as saying "the era of next-generation projects and grand projects is already over." Today, it appears MITI's role is far less significant than it once was and certainly quite different from that commonly believed in the United States.

SOURCES: Office of Technology Assessment, 1991, adapted from C. Johnson, MITI and the Japanese Miracle: The Growth of Industrial Policy, 1925-1975 (Stanford, CA: Stanford University Press, 1982); Nihon Kogyo Shimbun, "Follow MITT's Example," May 6, 1986, p. 3; L. Tyson and J. Zysman "Politics and Productivity: Developmental Strategy and Production Innovation in Japan," BRIE Working Paper No. 30, Berkeley Roundtable on the International Economy, Berkeley, CA, 1987.

tute (8). The rigid, noncompetitive nature of this research funding seems to limit the effectiveness of these expenditures $(7,29)$.

In 1987, a general overhaul of Japan's universities was proposed by the Provisional Council for Educational Reform, appointed by Prime Minister Nakasone. Suggestions to change entrance requirements, encourage more international exchange, and foster creativity and individuality are still being studied (13). Anecdotal evidence suggests that some researchers have left universities for industry because of poor funding, inadequate equipment, and restrictive research environments wherein originality and creativity are not rewarded. University research contributes far less to the total research base of Japan than does university research in the United States. 
Ministry of Health and Welfare

In 1986, MHW established the J apan Health Sciences Foundation to promote biomedical and pharmaceutical research. Some observers feel this move was not only an attempt to meet J apan's growing health needs, made more pressing by a rapidly aging population, but also a response to MITI's biotechnology initiatives (30).

This foundation emphasizes small, cooperative $R \& D$ efforts involving companies, universities, and government institutes. Industry funds two-thirds of project costs. More than 100 firms, including several foreign fins, and approximately 400 researchers were involved by early 1990. Separate programs target biotechnology, medical materials, and immune mechanisms (12). In J uly 1989, Genentech received a small grant to study Werner syndrome, thus becoming the first U.S. firm to receive direct funding from $\mathrm{MHW}(2)$.

More significant to pharmaceutical companies are changes in J apanese drug pricing by the MHW national health insurance agency. Prices have been systematically lowered for older drugs, and new drugs are given premium pricing (see ch. 5 for further discussion of pricing). The result is pressure and incentive for greater innovation and higher $R \& D$ expenditures. These higher expenditures are forcing companies to seek larger markets, contributing to the continuing internationalization of J apanese pharmaceutical companies. The J apanese market for pharmaceuticals, on the other hand, is the world's second largest after the United States; Western companies, that have operated in J apan since World War II and new companies entering the world market directly are creating additional pressure on existing $\mathrm{J}$ apanese firms (48).

\section{Science and Technology Agency}

The Science and Technology Agency (STA) carries primary responsibility for funding basic research and coordinating basic science and technology expenditures. Similar to the situation with other independent agencies attached to the office of the Prime Minister, control of STA is fought over by other, more powerful agencies, such as, MITI and the Ministry of Education and Culture, which are responsible for staffing many positions (23). General policies are set by the Council for Science and Technology, chaired by the Prime Minister. The council has relied heavily on its advisory Policy
Committee, consisting of senior industry executives. The council's influence is seen most directly in its Special Promotion Fund for Science and Technology, established in 1981 (49).

One project of interest was the human genome mapping and sequencing initiative, begun in 1981. This project focused on automating the sequencing process, with companies, such as Hitachi, Seiko, Fuji Film, Toyo Soda, and Mitsui Knowledge Industry, receiving funding from both the Special Promotion Fund and the J apan Research Development Corp. This frost-generation project, based on approaches quickly outdated by innovations in the United States, nevertheless caused considerable concern abroad. It was used by proponents of genome initiatives in the United States to generate public and private support for a human genome project in the United States. As in the United States, $\mathrm{J}$ apan's genome activities have been the subject of bureaucratic infighting and are controversial within J apan's scientific community. On the commercial front, Hitachi's second-generation sequencer had, as of early 1990, been made available only to J apanese Government scientists, and Applied Biosystems, a small California firm, remained the primary supplier of sequencers in J apan.

Another STA program is the System for Promotion of Exploratory Research for Advanced Technology (ERATO), established in 1981 to foster interdisciplinary, advanced research and technology. ERATO projects focus on technology development and are carried out in the private sector over 5-year periods by teams of about 15 scientists. Projects are funded by the Research Development Corp. of J apan (J RDC), a government-funded public corporation set up in 1961 to promote commercial use of government-developed technologies. Nearly half of the 14 current projects are relevant to biotechnology (20).

\section{Ministry of Agriculture, Forestry, and Fisheries}

In 1984, MAFF created a new Biotechnology Division, and the government declared biotechnology development to be the principal strategy for agricultural $R \& D(21)$. A basic research group made up of 14 firms was organized to carry out research. None of the firms was a traditional seed or nursery company, and many were participating in other biotechnology projects organized by other ministries (49). Private-sector research is further promoted by the Bio-oriented Technology Research 
Advancement Institution, which provides up to 70 percent of finding for research projects and new ventures (21). Most of MAFF's 13 specialized research institutes and 6 regional experimental stations are involved in biotechnology-related research; the National Institute of Agrobiological Resources holds lead responsibility. The MAFF also funds university research (21).

\section{Research Associations and Cooperative Research}

In J apan, the typical cooperative project $^{1}$ is neither intensive nor high profile; although the large-scale integration semiconductor effort, mounted in the late 1970s, received much attention in the United States. It is touted by many as an example of how government-industry cooperation can forge technology breakthroughs (16). Most biotechnology-related projects in J apan are organized by government-sponsored research associations which coordinate modest projects carried out by researchers at member companies. According to some analysts, the participation of major J apanese companies in such projects has led outside observers to overestimate the project's importance. Cooperative research in J apan is thwarted by the same barriers found elsewhere: reluctance of the leading firms involved in the program to share information, difficulties over intellectual property rights, and, in the case of special research centers, failure of companies to supply their best scientists. Projects, therefore, tend to address potentially interesting but commercially low-priority targets.

An exception may be projects funded by Key Technology Center, which provides up to 70 percent of the cost of industry joint research projects. The center, which is a response to concerns about venture capital shortages for investment in emerging technologies, is largely financed by privatization of Nippon Telephone and Telegraph. The Protein Engineering Research Institute (PERI) project in Osaka will receive $\$ 150$ million in government funding over a 10-year period. PERI, which involves 14 chemical, pharmaceutical, and food companies, has received a great deal of attention in the United States and Europe. Roughly 70 researchers are studying structure-function relationships with the ultimate goal, according to Katsura Morita of
Takeda Chemical Industries, of fostering a strategic edge in protein engineering technology (28). Such research is critical to a number of important biotechnology applications. However, though the potential for PERI is great, to date there is little to show, which is not surprising since it is a long-term project.

Other officials point out the modest industry funding of most government-organized projects and suggest that companies take part in cooperative projects to get along with government ministries, but have little expectation of commercial return. At least one pharmaceutical company has refrained from participating in any J apan Health Sciences Foundation projects (organized by MHW) because managers believe it is better to concentrate on their own commercial research (43).

Research associations and cooperative projects can serve as a means to disseminate knowledge throughout an industry, a role played in the United States by an open university system and more flexible employment practices. However, lead companies (in J apan and in the U nited States) are often reluctant to share knowledge with competitors. Cooperative projects may have helped some firms acquire technical expertise. Their significance has shifted, however, with the commercial success and increased research intensity of J apanese industry and should not be overstated. There is no evidence that they have played a major role in the development of $\mathrm{J}$ apanese industrial biotechnology expertise.

\section{Government-Industry Relations}

Research and industry associations, along with numerous advisory groups, play an important part in a continuing dialogue between industry and government ministries. There is dynamic tension in the relationship between ministries and "their" industries. Formation of the Biotechnology Development Center (BIDEC) in 1982, under auspices of the J apan Association of Industrial Fermentation, was clearly a MITI initiative. MITI's influence is seen in BIDEC's activities, such as the organization of international conferences. It would, however, be wrong to assume that MITI controls companies in any way. MITI's current biotechnology plans are not greatly respected by many J apanese executives in biotechnology-related companies. MITI's influence depends on a variety of factors, not least of which is

\footnotetext{
1Cooperative research in this chapter refers to research involving three or more companies. It should not be confused with joint ventures, joint product development, contract R\&D, or licensing agreements that typically involve only twofirms.
} 
the perceived quality of MITI's analysis, programs, and funding, and funding capabilities. Members of BIDEC use the association to influence policy to their advantage and tailor modest cooperative projects to their interests, if possible.

It now appears that J apanese industry is generally too successful and too powerful to be unwillingly guided into targeted investments. The power of the ministries may well have decreased with time. On the other hand, ministries such as MITI and MHW still have powerful regulatory roles. There are strong linkages between research and regulatory policies as is seen most clearly in MHW manipulation of drug prices to encourage innovation. When asked what policies most affect their companies, the overwhelming majority of $\mathrm{J}$ apanese executives interviewed by OTA in preparing this report named regulatory and pricing policies.

\section{Conclusions}

J apan's publicly funded basic research is weak when compared to U.S. efforts. Despite calls by the Science Council of J apan and recommendations in MITI white papers, the Ministry of Finance has not made funding increases. Initiatives such as PERI and the various ERATO projects, although significant, are still rare. Reform toward more creative and innovative research and training of creative and original thinking scientists in J apan's universities has only just begun.

$J$ apan's strength is clearly in industrial $R \& D$. The wide variety of companies attempting to utilize biotechnology in some way is impressive, from traditional sake and miso producers to J apan's largest multinationals. However, a number of companies, such as Kawasaki Steel, are pulling back from their biotechnology ventures (24). For such companies, diversification into biotechnology was a disappointment. Commercialization has taken longer, been more technically difficult, and been more dependent on factors unique to each industrial sector than expected. Biotechnology has not achieved the spectacular success that other fields have for J apanese industry.

J apanese high-profile, though modestly funded, industrial and research policies encouraged investment by a wide variety of companies. However, $\mathrm{J}$ apanese chemical companies were moving into higher value-added products, such as pharmaceuticals, prior to government initiatives. J apanese food processors have historically invested more heavily in $R \& D$, compared to their counterparts in the United States and Europe. J apanese pharmaceutical companies now seem to view biotechnology in the same way as their counterparts abroad--i.e., as a powerful tool to supplement other research. Those companies, while more cautious than in the past, are continuing biotechnology research in terms of individual corporate strategies and assessments of commercial potential. For the foreseeable future, corporate strategies, rather than MITI initiatives, will likely determine J apan's investment in biotechnology.

\section{Europe: Moving Toward a Regional Strategy?}

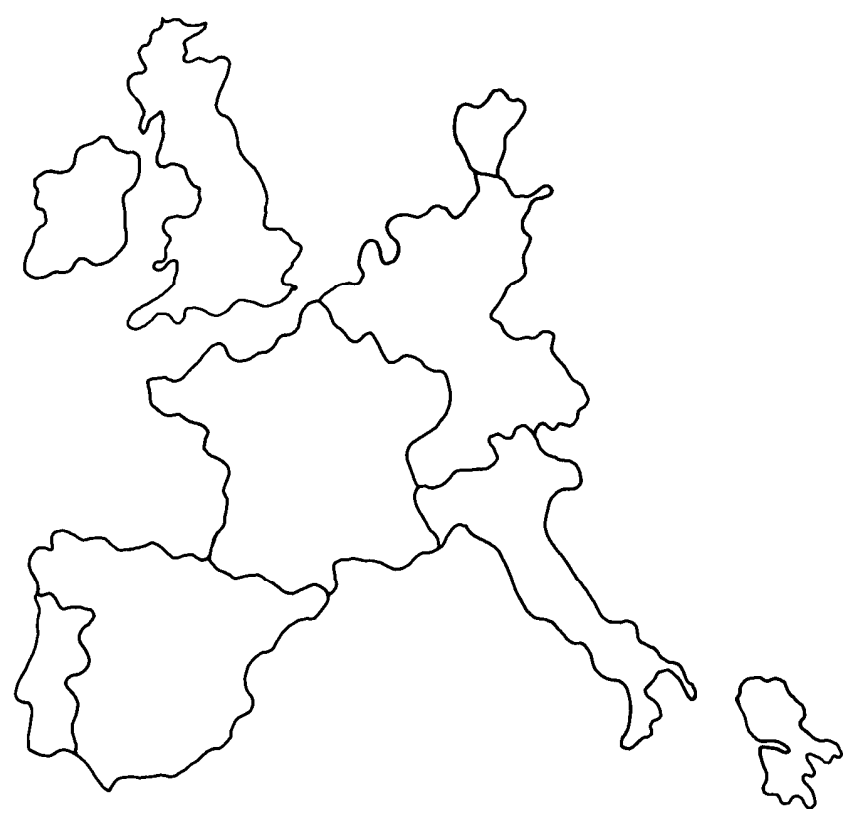

A number of European countries have technology policies that resemble those of the United States. National policies, however, are becoming less distinctive as Europe moves closer to economic integration. The effectiveness of national technology policies is limited by the evolution of an economically united European Community (EC) and, even more fundamentally, by the larger force of international competition. 
If European national technology policies seem less significant than they were once thought to be, it is not yet clear that specific, regional policies for biotechnol ogy-related fields will emerge. The research and commercial resources of EC countries, however, are enormous. Modest EC research programs currently underway aim to breakdown barriers to the effective utilization of those resources. Integration will also directly affect the non-EC European countries.

Each country promoting biotechnology illustrates a variation on how to promote science and technology of economic or strategic interest. The initial impetus may have been born in the government bureaucracy, in the academic community, or in industry. Where initial activities began, continue to influence how a country continues to pursue biotechnology R\&D. Four European countriesFrance, the United Kingdom (U.K.), Germany, and Switzerland-are described in order to illustrate a variety of strategies. Regional programs, unique to Western Europe, offgret another approach to strategic planning.

\section{France: State-I nitiated}

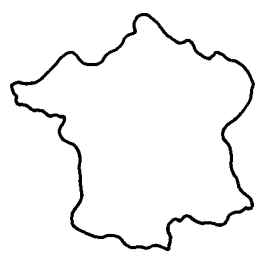

In 1979, the French Government responded to President Giscard d'Estaing's interest in ethanol fuels by producing a wideranging series of reports. The reports out"bed energy research as well as the potential for biology to change the relationship between humans and the environment, particularly in agriculture. The Mobilization Program, implemented in 1982, set for France the ambitious goal of achieving 10 percent of the world's biologically based production by 1990 (39).

Several research areas were targeted. Firms were to collaborate with various research institutes on a number of projects, and regional research and technology-transfer centers were to be established. Today, of the European nations, France is the leader in agricultural biotechnology. Biotechnology centers are well funded and staffed, and French seed companies have made major investments in biotechnology (41).

The French Government also attempted to reorient French researchers toward new biotechnology- related disciplines and more industrially relevant work. Unlike the situation in the United States, France's research strength lies not in its universities but in its government research institutes. Funding for all research, including research relevant to biotechnology, grew through 1985 but fell steadily after that. Still, new emphasis has been put on molecular biology, enzymology, immunology, plant genetics, and bioprocess engineering (42).

French planners thought that biotechnology would be essential to economic strength and national sovereignty. However, the various mechanisms established to achieve rather lofty goals have had limited success in areas other than agriculture and have been hampered by inconsistent government funding. France has had modest success in pharmaceutical applications of biotechnology-success that cannot be ascribed solely, if at all, to the Mobilization Program. While the large seed companies have invested in biotechnology $R \& D$, the small and medium-sized firms, which make up the majority of the industry, continue to spend little on research (39). Of more significance now, may be regional policies. France is an enthusiastic participant in EC research programs and has pursued biotechnology through the French-inspired EUREKA initiative.

\section{United Kingdom: Academic-I nitiated}

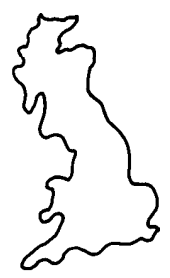

The United Kingdom most closely parallels the United States, with a strong research base, an emphasis on basic research (approximately 70 percent of government biotechnology funding), and a reluctance on the part of government to articulate a clear research or industrial policy. Britain does not have the advantages of scale available to the United States, and funding decisions have been difficult. The academic community, itself, was the force behind government initiatives, recommending a coordinated biotechnology policy to the reluctant, new Thatcher government in 1980 (39). But policy in the 1980's can best be described as "muddling through," with tight research budgets causing struggles among funding research councils, a situation exacerbated by modest initiatives for more industrially relevant, precompetitive research. 
The most notable U.K. initiative has been the Biotechnol ogy Directorate, established by the Science and Engineering Research Council in 1981. The research agenda, crafted by a steering committee of university scientists and industrialists, has moved steadily toward important biotechnology areas, such as protein engineering (38). In 1990, the United Kingdom formed a Biotechnology J oint Advisory Board, which is working toward coordinated research strategies between its various research councils (9).

British research is well-regarded and attractive to foreign, as well as British, companies. (Major British pharmaceutical and chemical fins, in fact, have been criticized for insufficient interest in the existing and available academic resources.) Many major foreign companies have established relationships with British institutions. Monsanto, for example, has a f20-million agreement with Oxford University. But poor salaries, combined with limited expectations for growth in research budgets, have caused a brain-drain of experienced researchers from the United Kingdom and a consequent crisis in recruitment that may make it difficult for Britain to maintain the quality of its science base (38).

Germany: Industry-I nitiated

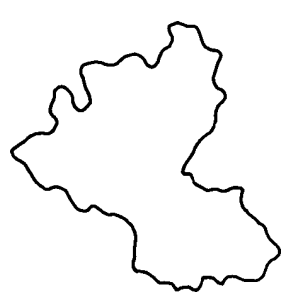

The 1974 creation of the world's first national biotechnology program, the German Society for Chemical Equipment, Chemical Technology and Biotechnology (DECHEMA) was backed by West Germany's large chemical and pharmaceutical companies and an effective trade association. Members were primarily interested in new fermentation techniques; it was not until the early 1980s that recombinant DNA (rDNA) and cell fusion were given equal treatment in targeted biotechnology spending by the Federal Ministry of Research and Technology (BMFT) (50). Nevertheless, today's reunified Germany has a strong, diverse base in underlying disciplines, a flexible and relatively diffuse research structure with substantial Federal and State support, and interactions between industry, universities, and research institutes that provide support to the country's strong group of large and medium-sized companies. Biotechnology techniques are well-integrated into those companies, and larger German firms have established research facilities in other EC countries, the United States, and J apan (37). However, Federal and State initiatives to encourage small biotechnology-based startup firms have had minimal success.

In August 1990, the German Federal Government approved a new biotechnology $R \& D$ program known as "Biotechnology 2000." The program's financial allocation for the period 1990 to 1994 is DME1.5 billion (approximately US\$855 million). Although the program is designed to promote biotechnology research in the areas of the environment, public health, nutrition, energy, and natural resources pharmaceuticals will be a primary focus. As a result of Germany's reunification, biotechnology will also be promoted in what was formerly East Germany. Research institutes and businesses in the East will be eligible to apply for grants. It is expected that there will be active involvement in the program by industry (22).

German policies clearly arose from the private sector. They were built on an established research and educational infrastructure with less clear linkages to trade and regulatory policies. As discussed in chapter 11, acceptance of biotechnology by the German public remains problematic, and the German regulatory outlook is evolving.

Switzerland: Industry- and Academic-I nitiated

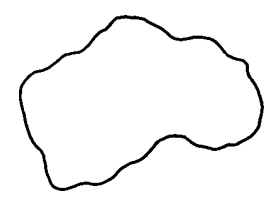

Switzerland shares with Germany a strong emphasis on education and close ties between large Swiss chemical and pharmaceutical companies, such as Sandoz, Ciba-Geigy, and Hoffmann-LaRoche, as well as national universities and research institutes. Those ties, however, do not imply that universities emphasize developmental or applied research over fundamental science; firms support fundamental research at public institutions (19). Industry itself, carries out or funds around 75 percent of total country $R \& D$. There is no formalized biotechnology strategy or articulated industrial policy. But Swiss industry, with its proven strength and willingness to develop and apply basic advances at Swiss or foreign laboratories and, typically, in foreign rather than Swiss production facilities, funds around 15 percent of university research-roughly three times more than industrial funding in the 
United States (10). It is ironic that Swiss government incentives for industry participation in biotechnology research centers elsewhere in Europe may divert some research out of the country (19).

\section{Regional Programs}

The objectives of EC biotechnology programs (see box 10-C) are to mobilize the European research effort, target precompetitive research, and enhance the competitiveness of European industry. Several weaknesses are evident, however. Investment levels, for example, have been extremely low compared to other industrial areas. Altogether, the EC manages only about 3 percent of the community's total $R \& D$ expenditures; the rest are controlled by national governments (14) The new Biotechnological Research for Industrial Development and Growth in Europe (BRIDGE) program, which budgeted ECU 25 million (approximately US\$30 million) per year from 1990 to 1993, is the most ambitious effort yet. It remains to be seen whether the program will maintain industrial relevance with high levels of industry participation. (Administrators hope that the new BRIDGE program will have greater industry participation.) Although most of these programs seek to stimulate participation by small and medium-size firms, this, to date, has not been the case.

Over time, however, the creation of regional research networks could enhance Europe's overall research capabilities and, through regional training and technology transfer, build the research capabilities of lagging countries. According to EC managers, the creation of various forms of translational cooperation, in and of itself, constitutes the main justification for the programs. The commission attempts to breakdown research barriers by connecting research centers (5).

Some observers fear that regional European research initiatives could provide European firms with advantages over their international competitors, thus aiding in the creation of "European champions. There is also concern that U.S. and $\mathrm{J}$ apanese scientists will be blocked from participating in European initiatives (I). In the short run, however, it seems likely that new regional biotechnology research initiatives will be less significant for industry than the regulatory, legal, and trade issues surrounding the drive to create a free internal European market by the end of 1992.

\section{Mixed Messages}

The proposed links between biotechnology research and other EC policy areas as of now are contradictory. European Community directives for contained use and deliberate release of genetically modified organisms, for example, have come under criticism from both promoters and critics of biotechnology. Despite the creation, in 1984, of a Biotechnology Steering Committee and establishment of the Concertation Unit for Biotechnology in Europe (CUBE) within the Directorate General for Science, Research, and Development (DG XXII), the very nature of biotechnology makes coordination difficult. Decisions having real, immediate impact on research investment and commercialization are driven by other concerns-e. g., policies on health, agriculture, and the environment-within the jurisdiction of separate Directorates-General (4).

The most striking contradiction in EC policy goals comes in the agriculture-food sector. Like U.S. farm programs, the Community's Common Agricultural Policy (CAP) has succeeded in easing the impact of technological change on the countryside. However, the price paid was surpluses, massive public expenditures, higher food prices, and, cumulatively, a hidden transfer of wealth from urban to rural regions. Biotechnology products that improve production yields, directly or indirectly (e.g., through improved animal health), run counter to CAP objectives. Suggestions that future animal health products show not only safety and efficacy but a positive socioeconomic impact might have a chilling effect on all new products, especially on biotechnology-related products (see ch. 11).

Continued debates on various directives needed to complete the internal market by 1992 reflect the rivalry among European interests. Outside observers should keep in mind the extent to which various directorates-general, themselves, represent distinct points of view or, as in the case of agriculture, are identified with a distinct political and economic group. The year 1992 is not so much a firm date as a process, and the creation of strategic policies at the regional level will be incremental before and after that date.

\section{The United States: A Diffuse Approach}

J apan's biotechnology fever in the early 1980s was in large part a response to the biotechnology boom in the United States. A series of startup 


\section{Box 10-C-European Biotechnology Programs}

European Community (EC) Research Initiatives. European Community biotechnology research programs began with the Bimolecular Engineering Program (BEP). It dispensed ECU15 million (ECU1= @ US\$1) in support of basic research from 1982 to 1986. Although funded by the EC commission, it was not a translational program. Rather, through competitive grants, BEP supported individual research groups performing isolated projects within the respective EC member countries. Funding amounted to 50 percent of project costs.

BEP was followed in 1986 by the 4-year Biotechnology Action program (BAP). This initiative differed from BEP in several ways. First, it focused on precompetitive research emphasizing the development of novel processes. Second, it supported translational cooperation by requiring more than one group from more than one EC member State participate in each project. Third, through its training stimulation scheme, it encouraged scientists to work in other EC laboratories outside their native countries. Finally, it enjoyed a generous annual budget of ECU13.75 million per year.

Under BAP, expenditures continued to cover 50 percent of the cost for $R \& D$ ventures. Roughly 123 projects, involving 413 laboratories, were funded. France and the United Kingdom were the largest beneficiaries, each receiving roughly 18 percent of total dispersals through BAP's competitive granting scheme. Portugal received the smallest share, acquiring 2 percent of the cumulative expenditure.

BAP's emphasis on translational activities gave birth to the concept of "laboratories without walls," whereby scientific organizations from various EC counties participate in joint research projects. One such project, the lactic acid bacteria cluster, links I reland, the United Kingdom, The Netherlands, and Germany in R\&D projects focusing on gene cloning systems, efficient gene expression, protein secretion, plasma replication, and the improvement of various starter cultures. These efforts encourage the exchange of information, technology, materials, and staff; they are designed to eliminate bottlenecks within the scientific community. As research matures, the efforts may take on independent lives, e.g., spawning more applied research or proprietary relationships between participating laboratories, scientists, and industry.

The Biotechnological Research for Industrial Development and Growth in Europe program (BRIDGE) is planned for 1990 through 1993. Its research areas include the information infrastructure, enabling technologies, and cellular biology. I ts 5-year budget will total ECU100 million, at ECU20 million per year. Support will continue to be awarded on a competitive basis and, like the BAP, will cover 50 percent of R\&D costs.

BRIDGE's objectives are to further strengthen industrial applications of biotechnology and to enhance translational research. To this end, it will incorporate projects that focus on providing a link between basic and applied research. A minimum of 10 to 20 laboratories will participate jointly in these ventures. Annual expenditures are expected to run ECU1 million to ECU3 million per project per year.

companies, founded in the United States in the late 1970 s and 1980s, commercialized research breakthroughs. Nearly 70 new firms were begun in 1981 alone (45). Companies such as Genentech went public and were able to raise substantial amounts of cash (see ch. 4). Established chemical, pharmaceutical, and seed companies entered into research agreements with the new firms, established biotechnology research groups, or acquired startup fins. First entry of products created by rDNA technology fed expectations of near-term revolutionary changes in the pharmaceutical industry and other sectors, that now seem premature.

In Japan, relevant policymaking is dominated by tension between competing bureaucracies and powerful industries. In the United States, policymaking is driven by the dynamics of interest-group politics. Although Japan is far from monolithic, the sheer number of actors in the United States makes achieving consensus and continuity much more difficult. Pluralism is reflected throughout the political process of budgeting and appropriating funds. Although business interests play a strong role in this process, they are not as dominant as in Japan (see app. B). Congress plays a far stronger role in funding and oversight than does the Japanese Diet, and executive agencies have markedly less discretion or authority than their counterparts in Japan.

The structure of the U.S. research and technology base is, also, vastly different. As noted previously, the Federal Government provides, in both relative and absolute amounts, significantly more funding than does the government of Japan; and a much higher percentage of nondefense R\&D goes to basic research (see box 1O-D). The U.S. Government funds roughly half of the Nation's total $R \& D$, and 
One project of particular interest will concentrate on sequencing the yeast genome and will involve 28 laboratories throughout the EC. The total EC contribution to this project should reach ECU8 million. A second initiative will focus on the molecular identification of new plant genes. The EC investment in this effort will come to ECU5 million.

Two EC agricultural programs support biotechnology research. European Collaborative Linkage of Agriculture and Industry through Research (ECLAIR) has a 4-year budget of ECU80 million and aims at improving the integration of farm activities with upstream (supply) and downstream (processing) industries. The related Food-Linked Agro-I ndustrial Research (FLAIR) program will run through 1993; it is aimed at improving food quality, safety, and diversity-rather than agricultural productivity. Funding is ECU 25 million.

EUREKA. EUREKA (European Research Coordination Agency) was originally created in 1985, allegedly in response to the U.S. Strategic Defense Initiative (SDI). It has since evolved into a coordinating agency linking advanced technology projects being carried out by European industry. EUREKA projects are not limited to EC countries, and also include Norway, Sweden, Finland, Switzerland, Austria, Iceland, and Turkey.

\begin{tabular}{|c|c|c|c|}
\hline Project area & $\begin{array}{l}\text { Number of } \\
\text { projects }\end{array}$ & $\begin{array}{c}\text { Participating } \\
\text { companies and labs }\end{array}$ & $\begin{array}{l}\text { Approved budget } \\
\text { (in million ECUs) }\end{array}$ \\
\hline $\begin{array}{l}\text { Agro-Food } \ldots \ldots \ldots \ldots \ldots \ldots \ldots \\
\text { Agronomy and aqua culture } \ldots \ldots \ldots \\
\text { Biochemical engineering and }\end{array}$ & $\begin{array}{l}3 \\
9\end{array}$ & $\begin{array}{r}6 \\
27\end{array}$ & $\begin{array}{r}5.4 \\
55.7\end{array}$ \\
\hline cell culture $\ldots \ldots \ldots \ldots \ldots \ldots$ & 8 & 25 & 124.2 \\
\hline Biomedical engineering...$\ldots \ldots \ldots$ & 7 & 18 & 55.2 \\
\hline 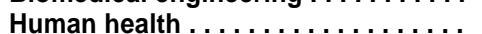 & 12 & 28 & 88.9 \\
\hline Protein design $\ldots \ldots \ldots \ldots \ldots \ldots \ldots$ & 1 & 3 & 16 \\
\hline
\end{tabular}

SOURCE: Biofutur (Biofutur, April 1989).

Although biology was not an initial priority, as of mid-1989 EUREKA had approximately40 biotechnology, food, and biomedical projects (of over 210 total projects). They areas follows:

Although the EUREKA's focus on commercially significant research and translational industry cooperation could have more immediate impact than the EC programs, it is still too early to evaluate its effectiveness. Public funding for EUREKA projects has been less than anticipated, and the most recent approvals may not reach 50 percent.

SOURCE : Office of Technology Assessment, 1991, adapted from E. Magnien et. al., "Les Laboratoires Europ ens saris Murs," Biofutur," R. van der Meer,"Biotechnology in the Netherlands"; paper presented at OTA international conference on Biotechnology in a Global Economy, vol. S4, November 1989, pp. 17-29.

OTA estimates that the Federal Government funds more than half of total biotechnology-related research (45). The United States has a decentralized research system, and several cabinet-level departments have internal research divisions responsible for the research needs of their particular missions, such as enhancing health (46).

The system for setting research budgets in the United States is inherently political. Constituencies advise agencies informally and through official advisory boards and committees. The constituencies support their own spending priorities during the budget and appropriations process. The role of Federal agencies is crucial to the success of Federal research efforts, as the agencies are intricately involved in the day-to-day operations of the research system. Each agency has its own culture. These cultures contribute to their success, perhaps simply by embodying the way things are done.' However, the cultures are powerful determinants of future directions, and specific goals may only be reflected in the collective knowledge of agency personnel (46).

\section{Overall Funding Trends for Biotechnology}

Historically, the United States, both in absolute dollar amounts and as a percentage of its research budget, has had the largest commitment to basic research in biological sciences worldwide. In 1988, OTA found that 12 Federal agencies and one cross-agency program, the Small Business Innovation Research Program (SBIR), spend research dollars on biotechnology (45). The National Institutes of Health (NIH) funds nearly 85 percent of all federally funded biotechnology, thus playing the 


\section{Box 10-D-United States Support of R\&D}

In 1990, the United States spent an estimated $\$ 150$ billion on research and development ( R\&D). This represents an annual real increase (in constant dollars) of 1.3 percent-the 15th consecutive year in which the national R\&D effort grew faster than inflation. This extraordinary record was comprised of a period of consistent growth above inflation in the late 1970s and early 1980s, then a short spurt of tremendous growth in the mid-1980s, and over the past few years, a shift toward modest growth rates--around 1 percent above the inflation rate.

The United States devotes more resources to supporting R\&D than any nation in the world. The estimated $\$ 150$ billion to be spent in fiscal year 1990 is more money than the combined R\&D spending of Japan, Germany, the United Kingdom, and France. As a percentage of Gross National Product (GNP), however, the United States is not so dominant. Over the past 20 years the United States has consistently spent a larger share of its GNP on R\&D than some nations (like the United Kingdom and France), but since the late 1970s, West Germany and Japan have increased their R\&D/GNP ratios considerably. By 1988, these two nations and the United States were spending between 2.7 and 2.9 percent of their respective GNPs. In 1990, the estimated R\&D effort in the United States of $\$ 150$ billion represents 2.7 percent of the American GNP. This ratio is up from the 1971 low of 2.1 percent (which followed cuts in defense and space programs), and it is just shy of the peak level of 2.9 percent achieved in 1964. Considering only nondefense $R \& D$ spending, however, the situation is somewhat different. While the ratio of nondefense R\&D to GNP in the United States is still larger than the United Kingdom and France, Japan and Germany have much higher ratios, these have been consistently higher than the U.S. ratio over the past 20 years.

The national R\&D effort is shouldered primarily by the Federal Government, industry, and academic institutions. In 1990, industry and the Federal Government together accounted for nearly 96 percent of total support, with universities and colleges contributing 3 percent, and other nonprofit institutions funding 1 percent. Today, industry is the largest single source of R\&D funds, providing $\$ 74$ billion compared to the Federal Government's $\$ 69$ billion. The past decade represents a period of great growth in industrial R\&D spending, as only since 1980 has industry spent more than the Federal Government on R\&D.

SOURCE: Office of Technology Assessment, Federally FundedResearch: Decisions For A Decade, 1991,

special role described below. The other agency programs are described in appendix $\mathrm{C}$.

The National Institutes of Health-The NIH is the largest research agency in dollars awarded to basic and applied research in the Federal Government. Of fiscal year 1990's appropriation to NIH, $\$ 2.9$ billion was biotechnology-related. NIH is the principal biomedical research arm of the Department of Health and Human Services (DHHS), and it funds biomedical and basic research related to a broad spectrum of diseases and health problems in both its own research facilities and at outside organizations. The NIH has been the principal funding source for biotechnology across all fields. But should, or can NIH continue this role? This is not a new question; in 1984 and 1985, considerable public discussion on the role of NIH took place between the President's Science Adviser, George Keyworth, and NIH Director, James Wyngaarden. Keyworth pushed for a broader NIH role in meeting nonmedical biotechnology needs, while Wyngaarden resisted this expanded NIH role (6). At a 1985 NIH Advisory Committee conference, some consensus was reached on the need for expanded, interdisciplinary training for biotechnology, but calls for an expanded role in more applied or intermediate research were resisted (47). At the time, concerns about the effect of more targeted research on basic research funding were expressed, with industry coming to the aid of academic science in supporting the importance of NIH's commitment to funding basic science. More recently, parts of the scientific community balked at the prospect of an ambitious effort to map and sequence the human genome, fearing that such directed research detracts and subtracts from resources for fundamental research.

These concerns not only remain pertinent but also have become more acute in light of budget constraints. Despite real growth over the last decade, NIH views itself as being in a steady state and finds itself under strain. With biotechnology increasingly integrating into other research fields, and with budget pressures building, it will be difficult for $\mathrm{NIH}$ to support biotechnology across all fields. Until 1990, scientists in plant and animal science, who have relied on NIH for funds because there have been no other sources, were fearful that budget constraints could imperil their only source of 
funding as NIH eliminates or cuts back on projects not central to its mission (51). But the $1990 \mathrm{Farm}$ Bill and the 1991 U.S. Department of Agriculture (USDA) budget showed major increases for competitive grants in these areas.

\section{From the Laboratory to the Market}

University-based research was the foundation of U.S. leadership in initial commercial applications of biotechnology. Indeed, biotechnology in the United States is, in many respects, an example of successful technology transfer. Venture-funded startup firms first brought advances in the biological sciences into the commercial arena in the 1970s; today, university researchers often move easily between academic and commercial pursuits. Universities themselves are seeking more financial returns from the products of their intellectual capital. This is not a surprising phenomenon, given the closeness between biological research and application.

Recent trends in the biological sciences indicate a move away from broad, lengthy agreements between universities and industry and toward numerous specific agreements. Genentech, until 1990 one of the largest and most visible independent biotechnology-based pharmaceutical companies, may have up to 500 active agreements at any one time (15). Agreements such as the one between Monsanto and Washington University (initiated in 1982 and scheduled to run through 1994, involving over $\$ 100$ million) are the exception, not the rule.

Extensive university-industry ties in the biological sciences have highlighted concerns common to a number of fields. Some critics wonder if Congress and the executive branch have gone too far in encouraging the commercial exploitation of university research. Recent congressional hearings have focused on personal and institutional conflicts of interest--questioning whether the integrity of university or government laboratory research has been compromised by allowing private gain from public investment. Critics of aggressive technology transfer out of the universities have asked whether scientists with a substantial financial stake in research outcomes can be objective in reporting research results. These questions, mentioned in an earlier OTA report (45), remain largely unresolved. In response to these criticisms, however, universities and professional journals have developed disclosure guidelines for making public the personal and financial interests of researchers. Until recently, such disclosure was strongly resisted (15). The NIH responded to mounting concern by proposing, in September 1989, guidelines for university researchers receiving Federal funds. Industry opposed the initial guidelines, which were withdrawn in December 1989, as a threat to commercialization of university biological research. In addition, the 1990 Farm Bill contains a provision that requires landgrant universities to establish conflict of interest policies.

Subtle questions are raised as universities attempt to profit from research relationships. Are the factors that make such relationships attractive-including an atmosphere fostering innovation through the free and easy flow of ideas--threatened by agreements that are overly protective of a university's financial interests? Also, should U.S. academic institutionsencouraged by congressional, executive branch, and State actions to license technology-be criticized when the licensee is foreign, even when U.S. firms expressed no interest in the technology?

\section{Consortia, Centers, and Cooperative Research}

In recent years, the U.S. science community has engaged in an ongoing debate over the appropriate size and organization of research efforts-particularly in the life sciences. Proponents of more directed research criticize the traditional investigator-initiated, individually funded approach typical of federally funded biomedical research (3). The biological sciences remain, for the most part, wedded to this approach, although other disciplines have come to rely more on fewer, but more expensive, facilities and larger research teams (the so-called "big science' '). Some argue that the interdisciplinary nature of modern biological research requires a shift toward big science. Others suggest that efforts requiring large amounts of time-consuming, repetitive work, such as mapping and sequencing the human genome, would be best carried out in centralized facilities with large data-handling capabilities. Flexibility has been urged by many, who point out that different approaches could be necessary for different types of research. A larger critical mass of researchers might be appropriate for some types of generic, applied, or intermediate work; and individuals or small teams might be more likely to generate both basic innovations and specific applications.

A more concentrated approach could be desirable for certain bottleneck areas of basic or applied 
research. Although some advocate the establishment of industrial consortia to achieve those purposes (26), others argue that because so much of commercial significance comes out of basic research itself, cooperative research on a large scale is difficult if not impossible (27). In fact, some believe that innovative new companies may have little to gain from participating in consortia with larger but less innovative companies (34).

In 1987, an effort to create an industry-based consortium for protein engineering research in the United States failed. Although supported by researchers at a number of U.S. companies, participants say that upper management was concerned about consortium funding and the sharing of information coming out of joint research (11).

Consortia have been touted by some as a cure-all for the perceived weaknesses of U.S. hightechnology industries (36). In the United States, cooperative research usually takes the form of a "center" that is mostly university-or government laboratory-based, low profile, and modestly funded. The primary function is to provide companies with a window on new technology and access to research conducted at the center. A center may also give companies access to personnel. These consortia or centers are typically organized by enterprising university or government laboratory entrepreneurs, who utilize public funds as an incentive for private investment in university or government laboratory biotechnology centers. Frequently, centers are part of State or local economic development efforts (45). An exception to this is the Midwest Plant Biotechnology Consortium (MPBC) involving 12 States, over 15 universities, 3 Federal laboratories, and nearly 40 agribusiness corporations. The MPBC carries out research in plant biotechnology, encompassing Midwestern crops and cropping practices.

Universities have attempted to provide a forum where companies can truly cooperate in precompetitive research. However, frequently, little cooperative research occurs and, instead, a series of agreements develop between university management and individual companies. Any cooperative work is financed through a general membership fee paid by industrial participants, few of which have much riding on the outcome of such projects. Membership takes many forms, sometimes as industrial liaison programs. One executive of a large chemical company said that his firm participates in a number of university-based consortia, but that in most cases it is token participation through payment of a small annual fee. Smaller companies may find even a small fee prohibitive. Companies may feel such participation is good for public relations, but have little expectation for tangible benefits. On the other hand, a few projects are quite serious; in general, they involve fewer industrial partners, who have specific expectations and are contributing significant amounts of money (33).

Although several limited consortia have been formed in biotechnology, broad-based consortia in biotechnology are not likely to emerge unless there are clear technical advantages that cannot be easily solved by companies working alone, a strong challenge is posed by foreign industry, or government funding is provided as an incentive to cooperation. Otherwise, cooperative initiatives are likely be the exception, not the rule, and large-scale projects few in number.

\section{NATIONAL POLICIES IN A GLOBAL ENVIRONMENT}

What is the national interest in a global research and commercial environment? This question is becoming more difficult for national governments to answer. National interests affect decisions on research priorities, training programs, and relationships between universities and research institutes with domestic and foreign fins.

In general, U.S. policy toward nonmilitary $R \& D$ has been to support basic research, with the expectation that industry will develop and apply that research in the marketplace. United States priorities, however, are brought into question by the commercial success of companies in countries such as J apan, that benefit from a greater emphasis in governmentfunded programs on applied research and technology than on basic science. The one exception maybe U.S. biotechnology, which has grown out of the large federally funded biomedical research base.

For several promising application areas, especially human health, agriculture, and environmental protection, certain applications of biotechnology have the potential to address social needs. To some, this role indicates a moral imperative to advance knowledge, regardless of political borders or economic issues. This is especially an issue for the United States, which spends significantly more than 
other countries on biomedical research. J udging by citations in published scientific articles, biomedical research is markedly international (46). Few scientists would support limits on communication and collaboration. Many would argue that the volume and extent of information flows, regardless of borders, have greatly speeded the advance of knowledge.

In addition, there is common interest in establishing new, international databases for research and regulatory purposes and in developing appropriate technologies for the Third World. Scientists in a number of countries are exploring ways to cooperate on mapping and sequencing the human genome. Threats by the United States to limit access to U.S. prepublication results have caused concern at home and abroad. Such restrictions would have a greater effect on small foreign companies than on multinationals with U.S. operations (18).

\section{Domestic University-Foreign Industry Relations}

Restricting foreign access to, and funding of, domestic research might be feasible if a country has the following:

- a clear technology lead,

- firms that have little to gain by similar access abroad,

- domestic companies supporting domestic research and licensing available technology, and

- a clear distinction between domestic and foreign firms.

These conditions, however, seldom apply.

The United States may have a clear advantage in many areas of biomedical research, but it may not have such an advantage in other fields where biotechniques are being developed. Significant work is also carried out in foreign institutions in almost all areas, and U.S.-based firms have established relationships with foreign universities and research institutes. Monsanto's arrangement with Oxford University has already been mentioned. Calgene has licensing and technology-transfer agreements with universities in Canada, France, J apan, and the United Kingdom. Mycogen has agreements with $\mathrm{J}$ apanese and European firms. Genentech received a small grant from the J apanese MHW for cooperative research on premature aging, and also has several agreements with J apanese universities. United States and European pharmaceutical firms have established research facilities in J apan.

There are a number of long-term agreements between foreign firms and U.S. universities. Hitachi is building a new research facility at the University of California-Irvine that will become fully owned by the university in 30 years. Several European firms have established research facilities in the United States and fired university research in this country.

Under the pressure of international competition, companies are obliged to take advantage of innovation quickly-regardless of origin. According to one observer: "Both multinational corporations and new biotechnology firms choose their academic partners irrespective of national borders" (17). Some U.S. industry and university observers feel that the real question is not why U.S. universities are doing business with foreign companies, but rather, why more U.S. firms are not taking full advantage of U.S. universities.

Some university administrators also point out that U.S. firms, themselves, frequently license technology to and from foreign countries. Such agreements reflect the financing needs and marketing strategies of small and large firms. This situation raises the underlying question of national interest in a global, commercial environment. Is funding for U.S. research to be rejected because it comes from a foreign-based company? Will access to publicly funded research be restricted to U.S. firms that may license products abroad or carry out substantial research or commercial activities abroad? United States law requires inventions developed with Federal funds to be manufactured domestically for U.S. markets (Public Law 96-517).

Basic research's significance for current biotechnology products makes these questions more difficult to answer, as do the different roles and degrees of access to universities in various countries. Research in Japanese universities, for example, is not comparable to that in the United States. Some people in industry say that advocates of an open, international research and commercial environment are naive, and that the only way to have any success is to keep new and important technology stateside (32). However, other industry observers say that science is a lousy place to say "buy American" (40). 


\section{SUMMARY}

When recombinant DNA and cell fusion techniques were developed during the 1970s, the potential of biotechnology excited scientists, industrialists, and government officials. But, as with other profound advances in knowledge, developments have confounded the predictions and expectations of even the best/informed observers. In some ways, early commercialization of proteins, derived from genetically modified organisms, fed expectations of scientists, financiers, business people, and, not least, government officials. The expectations were unrealistic. Biotechnology may prove to be the last great revolution in knowledge in the 20th century and a significant underlying technology for the 21 st century, but its full impact has not yet been felt.

Many governments, enamored by biotechnology's potential and concerned that their domestic industry not lose out in developing anew field, have launched specific biotechnology development efforts. Governments everywhere are realizing that high-technology helps drive industrial competitiveness and economic strength. For many, biotechnology became a test case, not only at the national level, but in many States (i.e., North Carolina, Maryland, and Massachusetts).

Many components of such strategies, such as: the emphasis on technology transfer, development of incubator facilities and venture capital for startup fins, and establishment of interdisciplinary centers for research are certainly helpful for focusing attention. However, in a sense, they operate at the margins. In 1984, OTA found that government expenditures on research (and the concomitant development of trained scientists) were among the most significant factors influencing competitiveness in biotechnology. A strong research base is the first priority allowing small companies and venture capitalists the opportunity to take risks. Without this, industry-oriented programs will not be very successful. Observers concerned about Japan may note that Japan is now working hard to train scientists although spending on basic research still lags, as compared to the United States.

If targeted biotechnology strategies have been largely unsuccessful, some of the reason may be because of the way biotechnology arose out of basic biomedical research, only to become fully integrated into the various fields of life sciences. The term biotechnology retains coherence only to the extent that regulations, public perceptions, and intellectual property law deal with specific biotechnology techniques as something unique.

The challenge, then, for national governments is to sort out national from private interests. A task that will become more difficult as competitiveness is used as a justification for particular expenditures. For the most part, political support of research in this country is based on perceived social needs-fear of disease, concern for an adequate food supply or the environment, and national defense. Economic nationalism may be particularly difficult to define and pursue, given the pluralistic, incremental, and increasingly global nature of the world's R\&D system.

\section{CHAPTER 10 REFERENCES}

1. Anderson, G., "EC Looks to Shut Out U.S. Science," The Scientist, vol. 3, No. 21, Oct. 30, 1989, pp. 1 (col. 3).

2. Barnum, A., "Genentech Wins First Grant From Japan to Foreign Firm," San Jose Mercury News, July 18, 1989.

3. Bazell, B, "Medicine Show," The New Republic, vol. 202, No. 3 Jan. 22, 1990, p. 16.

4. Cantley, M., "Managing an Invisible Elephant," Biofutur, vol. 84, November 1989, pp. 8-16.

5. Commission of the European Communities, Biotechnology Action Programme: Progress Report 1988, EUR 11650 EN/l Brussels, 1988.

6. Culliton, B., "NIH Role in Biotechnology Debated," Science, vol. 229, J uly 12, 1985, pp. 147-148.

7. Dibner, M., and White, R., Biotechnology Japan (New York, NY: McGraw Hill, 1989).

8. Dibner, M., "J apan's Biotechnology Industry: Focus on Pharmaceuticals,' Drug News and Perspectives vol. 3, No. 2, 1990, pp. 85-89.

9. Dietz, R., chemist, Laboratory of the Government, personal communication, November 1990.

10. Ergas, H., "Does Technology Policy Matter?" Technology and Global Industry, B.R. Guile and H. Brooks (eds.) (Washington, DC: National Academy Press, 1987).

11. Fox, J., director, Corporate Molecular Biology, Abbott Laboratories, personal communication, June 1989.

12. Fujii, M., director, Office of Advanced Research \& Technology, Pharmaceutical Affairs Bureau, Japanese Ministry of Health and Welfare, personal communication, July 1989.

13. Gittelsohn, J., "Japan's Universities, Taking A Cue From National Politics, Now Face Their Own Crisis of Complacency, Analysts Say," The Chronicle of Higher Education, vol. 45, No. 48, Sept. 20, 1989. 
14. Greenberg, D., "U.S., EEC Leaders Ponder Impact on '92 on Science," Science \& Government Report, Mar. 15, 1990.

15. Hanna, K., "Recent Trends in University-Industry Research Relationships in Biotechnology," contract report prepared for OTA, August 1989.

16. Heaton, G., Jr., "The Truth About Japan's Cooperative R\&D," Issues in Science and Technology, fall 1988.

17. Heusler, K., "The Commercialization of Government and University Research," Biotechnology and the Changing Role of Government, Organization for Economic Cooperation and Development, Paris, 1988.

18. Hodgson, J ., "Europeans Feel U.S. Squeeze," Biol Technology, vol. 8, No. 1, January 1990, p. 15.

19. $\mathrm{H}$ tter, R., vice president for research, ETH Z rich, remarks at Biotechnology in a Global Economy International Conference, July 6, 1989.

20. Japan Research Development Corporation, ERATO: Exploratory Research for Advanced Technology, program description, 1988.

21. J apanese Ministry of Agriculture, Forestry, and Fisheries, "Biotechnology Research and Development in Agriculture, Forestry, Fisheries and the Food Industry in Japan," Tokyo, 1989.

22. JPRS Report: Science \&Technology, Europe, "Germany: Government Funds Genetic Engineering Research Program,' JPRS-EST-90-023, Nov. 27,1990.

23. Johnson, C., MITI and the Japanese Miracle: The Growth of Industrial Policy, 1925-1975 (Stanford, CA: Stanford University Press, 1982).

24. Martin, C., "Japan Evaluates Its Commitment to Biotech as Ways Are Sought To Reorient Bioindustry," Genetic Engineering News, September 1989, p. 1 (col. 3).

25. Masuda, M., director, Bioindustry Office, Ministry of InternationalTrade and Industry, personal communication, July 1989.

26. McConnell, J., corporate director, Advanced Technology, Johnson \& Johnson, New Brunswick, NJ, address to the conference 'Unlocking Potential: The Promise of the Human Genome Initiative," Washington, D. C., Apr. 24, 1989.

27. Morioka, S., president, Yamanouchi Pharmaceutical Co., Ltd., personal communication, July 1989.

28. Morita, K., senior managing director, Takeda Chemical Industries, Osaka, address to the conference "Advancing Biomedical Science in the Twenty-First Century: Competition and Collaboration, Harvard School of Public Health, May 31, 1989.

29. National Research Council, The Working Environment for Research in U.S. and Japanese Universities (Washington, DC: National Academy Press, 1989).

30. Nihon Kogyo Shimbun, "F ollow MITI's Example," May 6, 1986, p. 3.
31. Nihon Kogyo Shirnbun, "Strong Emphasis on Basic Technologies," Mar. 18,1986, p. 3.

32. Pennisi, E., "I apanese Companies Are Gearing Up to Challenge U.S. Biotechnology I\&ad,' The Scientist, vol. 3, No. 17, Sept. 4, 1989, p. 1 (col.1).

33. Quisenberry, R., director, Central Research and Development Department, DuPont Experimental Station, personal communication, August 1988.

34. Rathmann, G., chairman, Amgen, personal communication, April 1989.

35. Reich, R., "Who is Us?" Harvard Business Review, J anuary-February 1990, pp. 53-64.

36. Richards, E., "Taiwan' sLatestExport: Money," The Washington Post, April 9, 1989.

37. Schmid, R., "Biotechnology in West Germany," paper presented at Bio Symposium Tokyo' 88, Oct. 19-22, 1988.

38. Sharp, M., remarks at OTA conference "Biotechnology in a Global Economy," July 6-7, 1989.

39. Sharp, M., and Holmes, P. (eds.), StrategiesforNew Technology (Hertfordshire, UK: Philip Allan, 1989).

40. Sherblom, J., Transgenic Sciences, Inc., personal communication, July 1989.

41. Steinbock, M., international affairs specialist, U.S. department of Agriculture, persoanl communication, November 1990

42. Thomas, D., remarks at OTA international conference, July 6, 1989.

43. Tokura, S., manager, Research Planning, Fujisawa Pharmaceutical Co., Ltd., personal communication, August 1989.

44. U.S. Congress, Office of Technology Assessment, Commercial Biotechnology: An International Analysis, OTA-BA-218 (Elmsford, NY: Pergamon Press, Inc., January 1984).

45. U.S. Congress, Office of Technology Assessment, New Developments in Biotechnology: U.S. Investment in Biotechnology, OTA-BA-360 (Springfield, VA: National Technical Information Service, J uly 1988).

46. U.S. Congress, Office of Technology Assessment, Federally Funded Research : Decisions for a Decade, OTA-SET-490 (Washington, DC: U.S. Government Printing Office, May 1991).

47. U.S. Department of Health and Human Services, Public Health Service, National Institutes of Health, "The NIH Role in Fostering the Nation's Leadership in Biotechnology,' Proceedings of the 51st meeting of the Advisory Committee to the Director of the National Institutes of Health," unpublished, Bethesda, MD, October 1985.

48. Yoshikawa, A., Commercial Biotechnology in Japan, contract report submitted to the Office of Technology Assessment, September 1989.

49. Yoshikawa, A., "The Japanese Challenge in Biotechnology: Industrial Policy,” BRIE Working Paper, 
Berkeley, CA, 1987.

50. Ziehr, H., remarks at OTA conference "Biotechnology in a Global Economy," J uly 6-7, 1989.
51. Zimbelman, executive vice president, American Society of Animal Science, personal communication, J uly 1990. 


\section{Chapter 11}

\section{Regulations}

"One must learn by doing the thing, for although you think you know it you may have no certainty until you try."

Sophocles

"I'm drawing up the Whole Risk catalog. Under D, I have dogs, doctors, dioxin. Where do I put DNA? Very low." 


\section{CONTENTS}

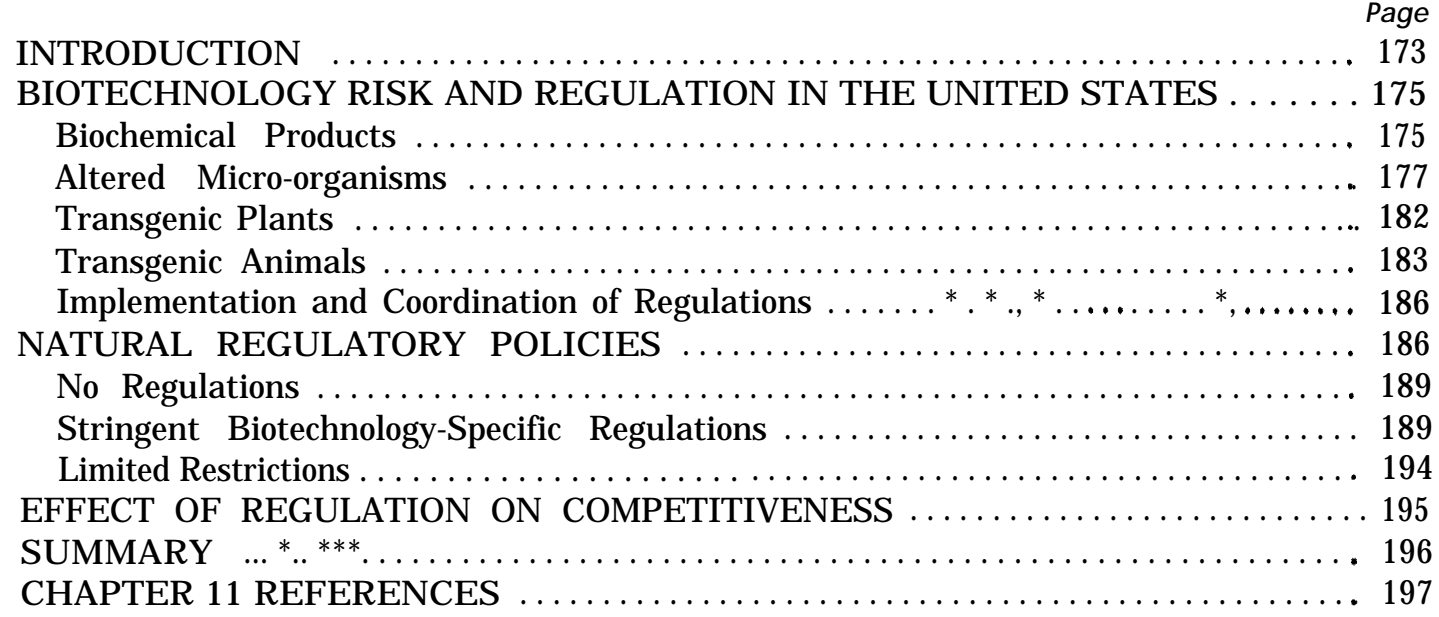

\section{Boxes}

Box Page

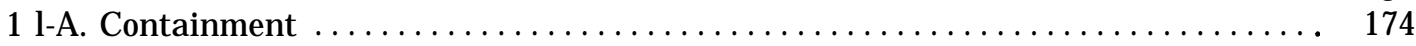

11-B. Federal Coordination .................................... 176

11-C. Regulation Under the Federal Plant Pest Act and the Plant Quarantine Act . . . 180

11-D. Green Parties ................................................ 187

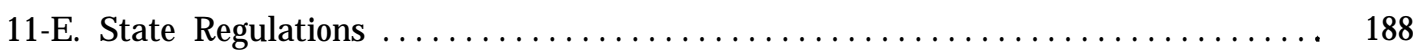

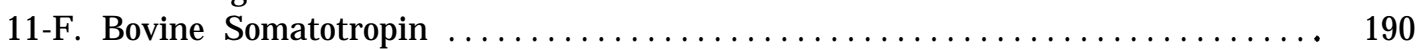

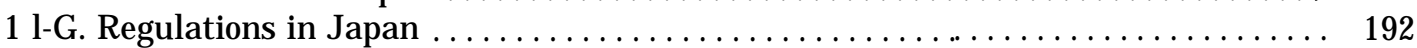

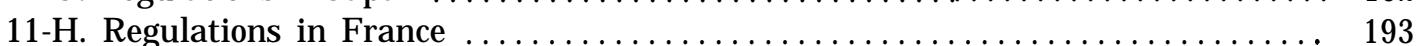

11-1. Regulations in the United Kingdom . . . . . . . . . . . . . . . . . . . . . . . . . . 193

11-J . The Organization for Economic Cooperation and Development . . . . . . . . . . . . . 195 


\section{INTRODUCTION}

Health and environmental regulations aimed at reducing risks associated with a new technology impose direct costs on industry and administrative costs on government. These regulations also result in indirect costs to the public, in the form of higher prices and, perhaps, decreased benefits from innovation. Governments impose regulations, however, to avert the costs associated with mitigating adverse effects that might result from the use of the technology. Ideally, the imposition of regulations results in a net benefit to society. But, balancing the costs of regulation against the benefits of risk reduction through regulation is difficult when a technology is new, and the risks associated with it are uncertain or poorly understood.

Oversight of biotechnology in the United States began in the mid-1970s when concerned scientists asked the National Institutes of Health (NH-I) to implement a set of laboratory-safety guidelines for biomedical research using recombinant organisms (7). Although no evidence existed that these organisms were more harmful than naturally occurring organisms, there was uncertainty about the risk associated with the use of recombinant organisms in the laboratory and concern about rapid, widescale use of the new techniques. Therefore, the NIH Guidelines, published in 1976, outlined conditions for research that would reduce the possibility of recombinant organisms escaping the laboratory or infecting laboratory personnel.

The NIH Guidelines were comprehensive. They detailed proper laboratory procedures for handling various kinds of organisms in different kinds of experiments. They also described systems for containment, using specialized equipment and disabled organisms unable to survive outside the laboratory and, therefore, less likely to transfer deoxyribonucleic acid (DNA) to other organisms (see box 1 l-A). Experiments perceived to entail more risk or uncertainty than others were assigned to higher categories of containment with concomitantly more safety equipment and procedures.

Over the next several years, the guidelines were revised and relaxed as more organisms and experi- ments were shifted to lower risk categories. The later guidelines also established a graduated oversight procedure. Experiments thought to entail the most risk (e.g., those involving human subjects or the production of highly toxic substances) were reviewed by NIH's Recombinant DNA Advisory Committee (RAC); experiments thought to be less risky (e.g., those using certain pathogens) were reviewed by local institutional biosafety committees. Today, most recombinant DNA (rDNA) laboratory research in the United States is exempt from review and subject to minimal restrictions.

The guidelines are not Federal regulations and cannot be enforced through the imposition of fines or penalties. They are based solely on NIH's contract-making authority. All institutions receiving NIH funding are subject to the provisions of the guidelines, and noncompliance can result in a loss of NIH funding. Other Federal funding agencies have also adopted the guidelines for use by their grant recipients, and the guidelines have been amended by RAC to encourage voluntary compliance by researchers in the private sector. About one-half of all firms conducting rDNA research have voluntarily registered their biosafety committees with $\mathrm{NIH}$, and these firms have been found to follow the guidelines more closely than their public-sector counterparts (70). Because the guidelines are thorough, rational, and relatively easy to implement, they were quickly accepted by scientists and became the standard in most industrialized nations.

In the early 1980s, when new biotechnologybased products approached the marketplace, many of these new products became subject to regulations promulgated by Federal agencies other than NIH, because of the products' intended uses (40). Microorganisms, for example, whether or not they are genetically altered, are subject to Environmental Protection Agency (EPA) regulations if they are to be used as pesticides. Plants and animals used as food are subject to Food and Drug Administration (FDA) and U.S. Department of Agriculture (USDA) regulations.

To coordinate the regulatory activities of the Federal agencies involved, a Biotechnology Science Coordinating Committee (BSCC), recently reorgan- 


\section{Box 11-A--Containment}

The NIH Guidelines for Research Involving Recombinant Molecules prescribe increasing levels of containment for experiments of increasing risk or uncertainty. The lowest level of containment, BL1, is similar to ordinary laboratory facilities; the highest, BL4, resembles laboratory conditions appropriate for handling deadly pathogens. Methods used to confine organisms to the laboratory are listed in the guidelines; they are based on existing procedures, commonly used in research on pathogens. The methods include:

- Good microbiological practice, as described in a number of standard texts. At the lowest levels of containment, these practices include: restricting access to the laboratory; cleaning and decontaminating the lab daily or after a spill; forbidding eating, drinking, or smoking in the lab; wearing lab coats; decontaminating wastes; controlling insects and rodents; and instructing laboratory personnel in aseptic techniques-to lower the risk of contamination and infection. Good practice appropriate for experiments entailing more risk, such as experiments using human pathogens, may include serological monitoring of lab personnel or vaccination, if such vaccination is available.

- Laboratory design or equipment that prevent physical exposure. At the lowest levels of containment, for example, labs should be equipped with sinks, window screens, and sterilization equipment; and the lab should also be easy to clean. At higher levels of containment, labs might be designed to be separate from traffic flow, with windows sealed shut, and special ventilation systems installed.

- Biological containment of micro-organisrns. Experiments use micro-organisms unable to grow outside the laboratory and limited in their ability to transfer DNA to other organisms.

These containment procedures are complementary; standard practices can be combined with various combinations of physical and biological barriers.

The containment principles outlined in the NIH Guidelines have formed the basis for most regulations in the United States which govern the use of genetically modified organisms. They have also been adopted by other countries. Combining physical and biological containment is also possible and appropriate for higher organisms. Plants and their pollen, for example, may be contained by removing reproductive organs (detasseling corn); using plant mutants that do not form reproductive organs (cytoplasmic male sterility); using herbicides and insecticides; geographically, isolating experimental plants from similar plants, by staggering planting dates, or physically separating plants by growing them indoors or in a greenhouse.

SOURCES: 51 Fed. Reg. 16958; 52 Fed. Reg. 31848; 53 Fed. Reg. 43410; 54 Fed. Reg. 10508; 55 Fed. Reg. 7438; National Research Council, Field-Testing Genetically Modified Organisms: Framework for Decisions (Washington DC: National Academy Press, 1989).

ized and renamed the Biotechnology Research Subcommittee (BRS) (see box 1 1-B), was established under the aegis of the President's Office of Science and Technology Policy (OSTP). Many questions of agency jurisdiction were settled with OSTP's 1986 publication of the "Coordinated Framework for Regulation of Biotechnology." The document describes how new biotechnological products will be regulated under existing law. Although it can be argued that products made using biotechnology are not always treated exactly as their nonengineered counterparts are treated, in general, an effort has been made to base regulations on the intended use of the products, rather than on the method by which they are produced.

Many other countries have adapted existing laws and institutions, originally developed for the oversight of chemicals and to protect agriculture and the environment, to accommodate advances in biotechnology. However, it is no simple matter to base scientifically sound biotechnology regulation on legislation written for other purposes. New legislation specific to the regulation of biotechnology was enacted in Denmark, Germany, and the United Kingdom (U.K.). Existing legislation has been amended in The Netherlands, and further legislation is under consideration (31). The European Community (EC) has also enacted two new directives regulating biotechnology: one concerns the contained uses of genetically modified organisms and the other regulates deliberate releases of such organisms.

An exhaustive description of these evolving biotechnology laws and regulations is not appropriate here. Instead, this chapter offers a broad view of national regulatory policies. Scientific assessments of risks associated with different applications of biotechnology are summarized, along with the U.S. approach to regulating these applications. Finally, international trends in regulation are outlined. These 
differences in approach from nation-to-nation, particularly through their effects on investment and innovation, will influence the ability of the United States to remain competitive in biotechnology on the international scene.

\section{BIOTECHNOLOGY RISK AND REGULATION IN THE UNITED STATES}

The first step in conventional risk assessment is hazard identification, that is, analyzing the specific threat to health or the environment associated with a substance or process. Much of the controversy surrounding the regulation of biotechnology has focused on hazard identification, as agencies attempt to evaluate the type of hazard posed by this new technology $(53,68)$. Because there have been no examples of adverse effects caused by biotechnology, projecting potential hazards rests on extrapolations from problems that have arisen using naturally occurring organisms. The consensus among scientists is that the risks associated with genetically engineered organisms are similar to those associated with nonengineered organisms or organisms genetically modified by traditional methods, and that these risks may be assessed in the same way $(18,34,49,50,53)$.

Many uses of biotechnology are similar to classical technologies or extend these technologies. Micro-organisms, plants, and animals that have been genetically altered through selective breeding or by treatment with chemical mutagens are widely used in U.S. agriculture and in the fermentation industry. The newer techniques also result in genetic alterations, but genetic engineering enables researchers to make more precise, well-characterized changes than are possible using classical techniques. The new techniques are unique, however, because they allow the transfer of genetic material across species.

Where similar technologies have been used extensively, past experience can bean important guide for risk assessment. The most familiar application of biotechnology is its use in the production of biochemical, especially proteins. Safety procedures developed for protecting chemical production workers can be adapted to biotechnology, and most countries have no special regulations governing the use of biochemical produced using biotechnology. Wide experience with the introduction of new varieties of plants has also helped scientists pinpoint potential problems in introducing genetically engineered plants.

In other cases, however, experience is uneven. Although certain micro-organisms-for example, the nitrogen-fixing bacteria Rhizobia-have been widely used in agriculture, experience with many other micro-organisms is more limited. The smaller research base has made planned introductions of engineer ed micro-organisms into the environment more controversial than the introduction of new plants. Information on the structure and function of microbial communities is often lacking, making it difficult to assess the effects of environmental introductions. In addition, micro-organisms are relatively difficult to confine and track $(50,68)$.

Because experience with similar technologies and applications can be useful in assessing risk, it is reasonable to regulate biotechnology-derived products under existing legislation via established agencies that have experience in regulating specific applications. This policy, usually referred to as "product-based regulation," has often been repeated in U.S. agency and interagency policy statements.

\section{Biochemical Products}

Biotechnological processes can be used to produce proteins that are found in small amounts in nature and that can be difficult to isolate and purify. Instructions for making proteins are contained in the genetic material, the DNA, of each cell, and a set of DNA instructions for making a protein can be transferred from one organism to a single cell of another organism. From that cell, the new organism, usually bacteria or cultured mammalian cells, can be grown in large quantities in a production facility and their protein products isolated. These products can be enzymes, which are specific catalysts produced in cells to speed up intracellular chemical reactions, proteins with other life-sustaining properties, or other biochemical. The commercial product is a purified biochemical, not a living organism.

Some of these genetically engineered products are substitutes for commercially available products. Biotechnology, however, provides a faster, safer, or more economical means of obtaining comparatively large amounts of the product. Before the development of genetic engineering for example, human growth hormone isolated from human cadavers was scarce. Ultimately, it was withdrawn from the 


\section{Box 11-B-Federal Coordination}

The Biotechnology Science Coordinating Committee (BSCC) was founded by the Office of Science and Technology Policy (OSTP) in 1985 to:

... serve as a coordinating forum for addressing scientific problems, sharing information, and developing consensus; promote consistency in the development of Federal agencies' review procedures and assessments; facilitate continuing cooperation among Federal agencies on emerging scientific issues; and identify gaps in scientific knowledge.

The committee consisted of the Commissioner of the FDA, the NIH Director, the Assistant Secretary of Agriculture for Marketing and Inspection Services, the Assistant Secretary of Agriculture for Science and Education, the Assistant Administrator of the EPA for Pesticides and Toxic Substances, the Assistant Administrator of the EPA for Research and Development, and the Assistant Director for Biological, Behavioral, and Social Sciences of the National Science Foundation.

Rather than being a forum for discussion, however, BSCC became the center of interagency disagreements about regulatory policy. Internal dissension reached a climax in 1988, when EPA sent its proposed rule for regulation of genetically modified micro-organisms under TSCA to the Office of Management and Budget (OMB) for review before publication in the Federal Register. The chairman of BSCC wrote to OMB requesting that OMB withhold clearance until BSCC could consider the proposed rule. A series of interagency meetings and memoranda resulted in deadlock. The chairman informed OMB, and OMB refused to approve EPA's draft rule. In response, the EPA representative to BSCC stopped attending meetings and placed the draft rule and interagency memoranda in a public docket. As of mid-1991, no proposed rules for EPA regulation of micro-organisms under TSCA and FIFRA had been published.

One major area of disagreement was the precise definition of organisms that would be subject to EPA regulations. In 1989, various approaches to this problem were discussed by BSCC and by the agencies' scientific advisory committees. Not surprisingly, BSCC failed to reach a consensus. The issue was turned over to a higher level committee, the Biotechnology Working Group of the President's Council on Competitiveness, chaired by Vice President Quayle. The OSTP's proposed principles for the scope of oversight for the planned introduction of organisms were published in J uly 1990.

In late 1990, BSCC was replaced by the Biotechnology Research Subcommittee (BRS) of the Committee on Health and Life Sciences, a standing interagency committee of the Federal Coordinating Council on Science, Engineering, and Technology (FCCSET). The FCCSET, like OSTP, is headed by the President's science advisor. The BRS's charge is said to be similarto that of BSCC. Its membership is broader and includes representatives from the Department of Energy (DOE), NIH, FDA, the State Department and its Agency for International Devel opment (AID), EPA, USDA, NSF, the National Aeronautics and Space Administration (NASA), the Department of Commerce (DOC), the Department of Defense (DoD), the Department of the Interior, OMB, and OSTP.

(Continued on next page)

market, because it presented the risk of contamination by infectious agents. Today, human growth hormone is uncontaminated and more plentiful, because it is isolated from bacteria engineered to carry the human growth hormone gene and make the growth hormone protein.

Biotechnology can also be used to produce new products, for use as drugs or as industrial or food processing enzymes. Some proteins, like tissue plasminogen activator (tPA) and erythropoietin (EPO), occur naturally but are too expensive to synthesize chemically and too difficult to isolate from tissue. Biotechnology makes their production feasible. Biotechnology can also be used to produce modified forms of proteins with altered biological properties or more resistance to degradation than naturally occurring proteins.

Basing the regulation of biochemical produced through biotechnology on existing legislation is widely accepted. Many regulations govern the manufacture and uses of chemicals, regardless of the method of production. Most proteins produced using biotechnology, thus far, however, are intended for use as drugs, diagnostic products, or food additives. Therefore, before they may be sold, they must meet FDA requirements under the Federal Food, Drug, and Cosmetic Act (FDCA) (21 U.S.C. $\$ 301-392)$. All drugs must undergo years of testing in animals and in clinical trials, followed by FDA review of test results. The kind, size, and length of 
The Council on Competitiveness made further recommendations in their 1991 Report on National Biotechnology Policy, which contains "F our Principles of Regulatory Review. "Vice President Quayle announced President Bush's approval of these principles in J uly 1990.

. Federal Government regulatory oversight should focus on the characteristics and risks of the biotechnology product-not the process-by which it is created.

- For biotechnology products that require review, regulatory review should be designed to minimize regulatory burden while assuring protection of public health and welfare.

. Regulatory programs should be designed to accommodate the rapid advances in biotechnology. Performance-based standards are, therefore, generally preferred over design standards.

- In order to create opportunities for the application of innovative new biotechnology products, all regulation in environmental and health areas-whether or not they address biotechnology-should use performance standards rather than specifying rigid controls or specific designs for compliance.

The first of these principles restates long-standing Federal policy, while the second, on the importance of minimizing undue regulatory burdens, is obvious. The third and fourth principles, promoting the use of performance-based standards, are new to the discussion of biotechnology regulations. While this has been an important consideration in the development of other environmental regulations in the United States, rigid controls and specific designs have not been mandated for compliance with biotechnology regulations.

Another advisory committee was established by NIH at the behest of Congress. The National Biotechnology Policy Board is to make recommendations to the President and to Congress on policies to enhance basic and applied research; to enhance the competitiveness of the United States in development of commercial biotechnology-related industries and products; to assure the training of sufficient scientists, engineers, and laboratory personnel for both research and commercial development; and to enhance the transfer of technology from university and Federal research laboratories to commercial laboratories. The board is also expected to make recommendations on Federal participation in cooperative research initiatives and on regulatory policies. The board, which met for the first time in October 1990, consists of representatives from Federal agencies, industry, universities, State biotechnology centers, and foundations.

SOURCES: 50F.R. 47174; S.A. Shapiro, "Biotechnology and the Design of Regulation"Ecology Law Quarterly, vol. 17,1990, pp. 1-70; The President's Council on Competitiveness, Report on National Biotechnology Policy February 1991; U.S. Senate, Report to Accompany H.R. 4783, Departments of Labor, Health and Human Services, and Education and Related Agencies Appropriations Bill, 1989; Department of Health and Human Services, Public Health Service, National Institutes of Health, "National Biotechnology Policy Board," unpublished, December 1990; Biotechnology Newswatch, Oct. 15, 1990, p. 9.

tests depend on the nature of the drug, but approval may take as long as 10 years. So far, 15 drugs and biologics based on biotechnology have been approved for human use, and more than 100 are in clinical trials awaiting approval. Diagnostic products that are not taken internally require less stringent testing, because they do not pose similar risks. Over 200 diagnostic tests based on biotechnology have been approved by FDA. Food additives are approved based on manufacturer tests demonstrating their safety under the conditions of use. In 1990, FDA approved its first food additive produced using an engineered micro-organism: it is chymosin, an enzyme used in cheesemaking (29). It also appears that FDA may consider food ingredients that are generally recognized as safe (GRAS) when produced by conventional means to also be considered GRAS when produced using biotechnology $(37,38)$.

\section{Altered Micro-organisms}

\section{Contained Uses}

The organisms most commonly used in production facilities are neither pathogenic nor toxic and present little or no risk to workers or surrounding communities. In fact, many strains of micro-organisms fare poorly outside specialized growth facilities. Nevertheless, oversight may exist in the form of restrictions on laboratory or other contained uses of micro-organisms. Through relatively simple procedures that include the use of seals, inters, sterilization equipment, and protective clothing, containment measures can be used to limit the survival of the organisms outside the growth facility and minimize human contact with these organisms. 
The Occupational Safety and Health Administration (OSHA) of the U.S. Department of Labor announced in its guidelines in the Coordinated Framework that no new regulations appeared to be necessary to protect the safety of laboratory workers (51 Fed. Reg. 23347). In the United States, the Government regulates large-scale industrial production using recombinant micro-organisms depending on how the final product is regulated. Thus, FDA has standards for facilities that use micro-organisms to produce proteins, and EPA can regulate commercial production under the Toxic Substances Control Act (TSCA) (15 U.S.C. \$2601 et seq.).

\section{Planned Introductions}

Micro-organisms are used commercially in waste treatment and agriculture. The first such genetically engineered micro-organism to reach the market was a microbial pesticide engineered in Australia, and introduced in 1989 (75). A derivative of an organism that had a long history of safe use, its only modification was a deletion that impaired its ability to transfer the pesticide trait (71). Biotechnology promises improved versions of such microorganisms and further applications to the degradation of toxic substances.

A consensus seems to exist that the vast majority of altered organisms pose minimal or no risk; nevertheless, certain environmental introductions could warrant concern. This judgment is based on prior experiences with somewhat analogous situations: the introduction of other species, including exotics; the spread of novel traits in existing populations; and the agricultural use of plants genetically altered through traditional techniques, such as selective breeding $(15,18,49,50,53$, $57,68)$. Potential problems include the creation or enhancement of pests; unintended harm to nontarget species, either directly or through competition for resources; and changes in the basic biochemical processes that support the ecosystem, such as nutrient cycling $(18,53)$.

In evaluating environmental risk, the type or amount of genetic alteration is less important than how that change affects the characteristics (phenotype) of the organism and the interaction of the organism with the environment. Several studies list risk criteria and attempt to weigh or prioritize them $(18,50)$. These criteria include:
- familiarity with the parent organism and its modified derivatives,

- likelihood of the organism's persisting in the environment or spreading to new environments,

- likelihood of the organism competing successfully against other important organisms,

- ease with which the organism can transfer its genetic material to other organisms,

- direct involvement of the organism in basic ecosystem processes, (e.g., nutrient cycling and respiration),

- response of the organism to selective pressures in the new environment, and

- size and frequency of the releases, because greater size or frequency can increase the probability of long-term survival $(18,68)$.

Because characteristics of the organism and the environment must both be considered, a case-bycase review process is generally viewed as necessary $(18,50,68)$. Scaling the level of review to the level of risk is appropriate, however, such as the approach taken by NIH in overseeing laboratory research. A faster, less-detailed review may be sufficient for low-risk introductions. For example, microorganisms judged similar to past introductions and returned to their native environment might eventually be assigned to a low-risk category or exempted from review $(18,50,53,68)$. Another proposal suggests considering how a genetic modification alters an organism's safety, compared with that of a parental strain (48).

In the United States, most planned introductions of genetically engineered micro-organisms are subject to EPA regulations. Some introductions, however (e.g., vaccines and plant pest derivatives) are regulated by FDA and USDA.

Vaccines-The FDA regulates vaccines for human use. Many vaccines are viruses, but because they are weakened strains and have been used safely under FDA regulation for many years, regulation of human vaccines has aroused relatively little controversy.

Animal vaccines and other animal biologics are regulated by USDA under the Virus-Serum-Toxin Act (21 U.S.C. §151-158). Some local officials have voiced concern about the safety of proposed tests of new vaccines. In 1989, a proposed test of an orally administered recombinant rabies vaccine, intended to immunize wild animals, was abandoned after 
State public health officials raised objections in South Carolina, but a similar test took place in Virginia in mid-1990. Other outdoor tests of recombinant animal rabies vaccines have taken place in Bel gium, Canada, and France $(25,27)$. The USDA granted 42 licenses for veterinary biologic products through the end of 1990.

Plant Pest Derivatives--Release of genetically engineered micro-organisms derived from plant pests is regulated by the Animal and Plant Health Inspection Service (APHIS) of USDA, under the authority of the Federal Plant Pest Act (PPA) and the Plant Quarantine Act (PQA) (see box 11-C).

Pesticides-Genetically engineered micro-organisms intended for use as pesticides are regulated by EPA under the Federal Insecticide, Fungicide, and Rodenticide Act (FIFRA) (7 U.S.C. §136 et seq.). Under this law, all pesticides, whether chemical or microbial, genetically engineered or not, must be registered by EPA before being sold and may only be distributed and used under the conditions approved in the registration. The EPA also grants an Experimental Use Permit (EUP) to allow limited use of unregistered pesticides for premarket testing. EUPs are usually presumed not to be required for testing new chemical pesticides on less than 10 acres, but EPA has concluded that evaluation of small-scale testing of certain genetically engineered micro-organisms is needed. To determine if an EUP will be required, EPA is amending the existing EUP rule to require that it (the EPA) be notified of plans for small-scale testing of certain categories of micro-organisms. Until a new rule is promulgated, EPA has requested voluntary compliance. In the case of micro-organisms that are pesticides and are also derived from plant pests, EPA has been designated the lead agency under the Coordinated Framework, but USDA's Animal and Plant Health Inspection Service (APHIS) also takes part in the review. As of March 1991, EPA had approved 10 applications for small-scale testing of genetically engineered microbial pesticides under FIFRA. In addition, two applications had been withdrawn, and another review had been suspended.

Other Micro-organisms-Other releases of micro-organisms into the environment may be regulated by EPA under TSCA, which is a gapfilling law enabling EPA to quickly screen chemicals that will not be reviewed under other statutes for health hazards. The act gives EPA authority to collect information on chemical substances and mixtures of chemical substances, so it can identify potential hazards and exposures. The TSCA gives EPA jurisdiction over manufacturing, processing, distribution, use, and disposal of all chemicals in commerce or intended for entry into commerce that are not specifically covered by other regulatory authorities. In practice, firms are required to provide EPA with information on the characteristics of any new chemical 90 days before commercial manufacture of the chemical begins. These requirements do not apply to small amounts of chemicals produced for research or analysis, as long as workers are informed of health risks. Noncommercial work, such as academic research, is not regulated under TSCA.

The EPA has announced, in its policy statement in the Coordinated Framework (51 Fed. Reg. 23301), that it considers certain types of micro-organisms to be chemical substances subject to regulation under TSCA if they are not regulated under other statutes. The EPA has requested voluntary compliance with its policy until formal rules are in place. Premanufacture notification is requested for intergeneric micro-organisms, that is, those containing DNA, derived from organisms of different genera, unless the transferred DNA consists of a well-characterized, noncoding regulatory region. The EPA has announced that it will amend its regulations so that the research and development (R\&D) exemption would not apply to field releases of microorganisms. It has also stated its intention to develop a significant new-use rule for pathogenic microorganisms, and it has requested voluntary notification in the interim. Further rulemaking is needed to implement the policy, so EPA's current policy may change. As of March 1991, nine applications for field tests of genetically engineered microorganisms had been approved by EPA under TSCA, mainly for nitrogen-fixing bacteria.

Some environmentalists charge that TSCA is inadequate for regulating environmental releases of genetically engineered organisms $(39,46)$. The EPA's authority to regulate organisms as chemicals under TSCA has not been legally tested. Another difficulty some environmentalists find with TSCA is that it is not applicable to academic research. In addition, TSCA is a notification statute, not a licensing statute. Under TSCA, firms inform EPA of their intention to manufacture a chemical; EPA, in turn, has 90 days to review the submission. As TSCA has been applied to the manufacture of 


\section{Box 11-C-Regulation Under the Federal Plant Pest Act and the Plant Quarantine Act}

Under the authority of the Federal Plant Pest Act (PPA)(7 USC. §150aa-jj) and the Plant Quarantine Act (PQA) (7 U.S.C. §151-164a, \$166-167), the Animal and Plant Health Inspection Service (APHIS) of USDA is responsible for regulating plants, plant products, and plant pests that may threaten U.S. agriculture. Under these laws, APHIS also has the authority to regulate the import, interstate movement, and release of genetically engineered organisms derived from plant pests into the environment. The definition of plant pests is broad, encompassing any organism that directly or indirectly causes disease or damage to plants (e.g., bacteria, viruses, protozoa, fungi, and other parasitic plants, insects, mites, snails, nematodes, and slugs).

APHIS uses a permit system to restrict entry, dissemination, and establishment of plant pests into the United States. A permit is required for any organism if it has been genetically altered using rDNA techniques; if it is being imported, moved interstate, or released to the environment; and if the donor, vector, or recipient is a plant pest or is unclassified. APHIS may also regulate genetically engineered organisms or products altered or produced using genetic engineering that the deputy administrator determines are plant pests or has reason to believe are plant pests.

To receive a permit for a small-scale, planned introduction into the environment, an applicant must submit detailed information on the identity of the organism and how it was produced; a description of the changes in the organism resulting from introduction of new genetic material; a statement on the purpose of the introduction and details of the experimental protocol, including the size and schedule of releases; and a description of the methods used to prevent dissemination beyond the test site.

Before a permit for an introduction maybe issued, APHIS prepares an environmental assessment based on the submitted information and must notify and coordinate its review with the appropriate agency in the State where the release is planned. This process takes up to 120 days. Through mid-1991, USDA had issued more than 150 permits for the release of genetically engineered plants into the environment.

To receive a permit to import a regulated organism or to transfer a regulated organism across State lines, an applicant must submit an application containing information on the identity of the organisms and where and how they were produced, a description of how they will be transported and how they will be maintained and used at their final destination, a description of the safeguards that will be used to prevent their dissemination, and a description of the final disposition of the organisms. For interstate movement alone, an application for a single permit, good for 1 year, can cover multiple interstate transfers of multiple organisms. The USDA has issued more than 650 permits for movement.

To sell a genetically engineered plant or micro-organism that is a regulated article under PPA and PPQ, a firm must petition APHIS for an exemption from these regulations. The firm must submit data establishing that the organism is not a plant pest and is not otherwise deleterious to the environment+ No petitions have been received yet, and it is not yet clear precisely what data must be submitted to receive approval.

Individuals may also submit petitions to amend the list of organisms regulated as plant pests by adding or deleting any genus, species, or subspecies. The petition must include copies of papers from scientific literature or unpublished data that support the petitioner's contention that an organism is a plant pest and should be added to the list or that the organism is not a plant pest and should be deleted from the list. After publication in the Federal Register and an opportunity for public comment, the Deputy Administrator will approve or deny the petition completely or in part.

SOURCES: 51 F.R. 23352; 52 F.R. 22892; 7 CFR 340; H.G. Purchase and D.R. MacKenzie (eds.), Agricultural Biotechnology: Introduction to Field Testing (Washington, DC: Office of Agricultural Biotechnology, USDA, March 1990); J.W. Glasser, testimony before the House Committee on Agriculture, Subcommittee on Department Operations, Research, and Foreign Agriculture, Oct. 2, 1990.

chemicals, the burden of proof is on the agency, not on the manufacturer. Critics would prefer to see a statute that requires a manufacturer to demonstrate safety of a new product before a permit is issued $(39,46,62)$.

The Scope Issue-Rules under FIFRA and TSCA have been under development since the Coordinated Framework was published. The most controversial aspect of the new rules has been the precise definition of the organisms whose release into the environment would be subject to review. A definition needs to meet several standards. It must be very clear to the regulated community which organisms are subject to the regulations and which are not. For example, in setting some types of regulations, agencies often rely on precise lists of items that are subject to regulation. In addition, a good definition 
would make regulation easy for the agency to administer. It should also focus the agency's resources on those organisms most likely to be hazardous, while exempting or focussing less attention on organisms presenting minimal risk.

Developing a product- or risk-based rule, however, is more difficult than it appears. It has always been hard to define the risks posed by modified organisms. Defining risky organisms in an administratively simple way, that will be clear to the regulated community is extremely difficult. In 1988, this issue became the focus of acrimonious interagency debate (see box 11-B) (61). As a result, BSCC and the agencies' scientific advisory committees considered several alternative definitions. Some proposals were criticized for being process based, that is, that the organisms to be reviewed were identified by the process by which they were made.

Such process-based definitions maybe construed to mean that certain types of genetically engineered organisms carry inherently greater risk than their nonengineered counterparts, a view that critics charge is unscientific. On the other hand, unlike classical techniques, biotechnology can be used to produce organisms carrying traits derived from organisms of different species, potentially raising more regulatory questions (18,50). In addition, there are particular difficulties in using a risk-based definition to describe organisms subject to review under TSCA. The TSCA applies to all commercial chemicals, not only hazardous ones. It can be argued that the fact that a chemical is subject to EPA notification under section 5 of TSCA implies nothing about its risk, since TSCA is used as a method of screening all new chemicals.

In mid-1990, a proposed Federal policy, developed by BSCC and the President's Council on Competitiveness, was issued (55 Fed. Reg. 31118). The aim of the policy was to promote consistency among the agencies. The OSTP recognized, however, that the agencies may take different approaches in promulgating specific rules and guidelines under existing legislation. The OSTP acknowledged that agencies had difficulty in developing operational definitions of BSCC's 1986 proposal, namely, that organisms whose introduction should be subject to review would be either intergeneric organisms or those derived from pathogens. The new proposal outlines the general principle that agencies should use in determining whether a planned introduction should be subject to oversight:

To the extent permitted by law, planned introductions into the environment of organisms with deliberately modified hereditary traits should not be subject to oversight ... . unless information concerning the risk posed by the introduction indicates that oversight is necessary.

The specific definition that was proposed, however, is not risk-based. The proposed scope includes "organisms deliberately modified by the introduction of genetic material into, or manipulation of genetic material within, their genomes," excluding:

- plants and animals resulting from natural reproduction or from the use of traditional breeding techniques;

- micro-organisms modified through physical or chemical mutagenesis, physiological processes such as conjugation, or spontaneous deletion;

- vascular plants regenerated from tissue culture;

- organisms modified through the introduction of noncoding, nonexpressed sequences that cause no physiological or phenotypic changes; or

- other organisms that could have been produced using these techniques or for which there exists sufficient familiarity to determine that their environmental effects are equivalent to those of past safe introductions.

The OSTP listed examples of risk criteria that agencies may use to evaluate planned introductions; these criteria are similar to those recommended in other recent reports from scientific societies $(18,50)$.

In defining the scope of organisms whose introductions into the environment will be subject to regulation, OSTP ultimately proposed a largely process-based definition. The proposed scope includes all genetically modified organisms, while excluding a number of defined categories of organisms. It is unclear, however, how much this policy will change by the time it is published in its final form. In a widely leaked memorandum in May 1991, OSTP officials discussed abandoning the processbased definition for one based solely on risk. While this is an intellectually sound and internally consistent approach, it would lack administrative simplicity and could result in burdensome regulations. 


\section{Food Uses}

Micro-organisms have been used since prehistoric times in baking, brewing, and fermenting. The organisms can die or be removed before the food is sold, or, as in the case of yogurt, live cultures may remain when the food is consumed. Strictly speaking, using micro-organisms in food processing is an environmental release. But because of familiarity with these organisms, their long history of safe use, their use in relatively small amounts, and their specialized environmental niches, micro-organisms in food have elicited less concern than large-scale environmental releases of genetically engineered organisms.

When Congress gave FDA authority to regulate food additives in 1958, many micro-organisms and other materials in use were recognized by FDA to have a special status-GRAS, or "generally recognized as safe'-because of their long record of safe use in food. Those entering the market since have either achieved GRAS status or received FDA clearances as food additives, based on submission of extensive information on their physical and chemical properties, intended use, and safety (21 CFR part 173 subpart B).

The FDA has decided that "the use of a new micro-organism found in a food could be considered a food additive" (51 Fed. Reg. 23310). Furthermore, a micro-organism can lose its GRAS status if it is produced or modified by new biotechnology that alters it, so that it is no longer generally recognized as safe by qualified experts. Such micro-organisms would then be considered food additives and thus, subject to premarket FDA review and clearance(51 Fed. Reg. 23313). One genetically modified microorganism, a variety of baker's yeast, has been approved for food use in the United Kingdom (2).

\section{Transgenic Plants}

For generations, plants have been genetically altered using traditional methods of selective breeding, bringing enormous benefits to farmers and consumers. Biotechnology promises to extend these benefits by providing a means of endowing plants with new traits that are difficult or impossible to transfer using classical techniques. These new traits could result in plants more resistant to disease and insect pests or more amenable to food processing technology. Current research is also aimed at pro-

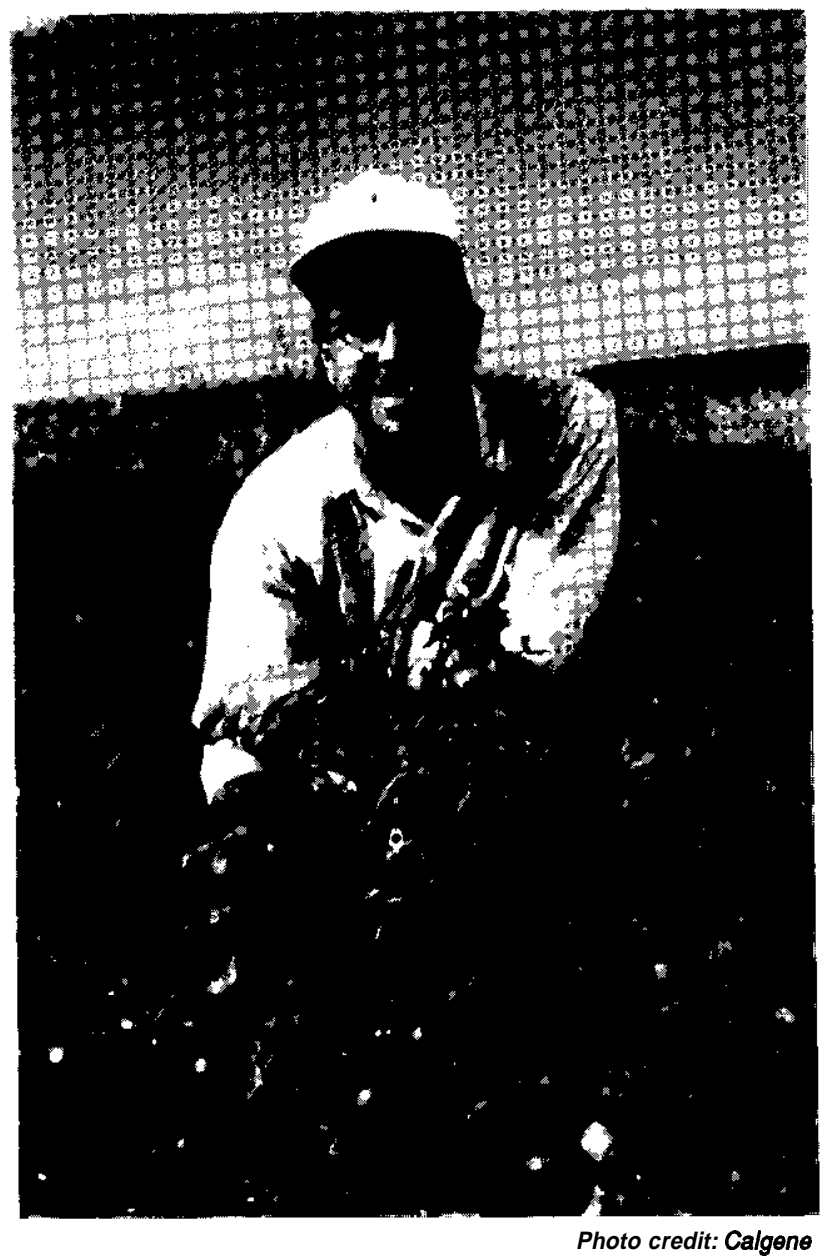

Genetically engineered tomatoes from a Yolo (CA) County field trial conducted in 1990.

ducing foods that are more nutritious and that have a longer shelf life.

Much less concern has been voiced about the agricultural use of transgenic plants than planned introductions of micro-organisms. Larger organisms are much easier to track, and more techniques are available to ensure their confinement. In addition, a broader, deeper range of experience exists for agricultural uses of altered plants. In the United States, over 150 field tests have been approved by USDA and have been carried out without incident. In The Netherlands and Germany, however, pressure groups protested against field tests of transgenic plants in 1989 and $1990(44,77)$.

\section{Planned Introductions}

New strains of plants are usually tested in a stepwise fashion, beginning with small-scale field 
tests, followed by increasingly larger tests, and finally commercial sale. Potential problems can often be recognized while the plant is being tested on a small scale. Similar procedures can be effectively used to test genetically engineered plants.

A major concern associated with the use of transgenic plants is enhanced weediness. Although domesticated crops are unlikely to become weeds, it is possible they can transfer advantageous traits to wild, weedy relatives by cross-pollination $(18,19)$. This is not a major problem in the United States, however, where few crop plants are native species, and many crop plants have no wild or weedy relatives $(50,53)$. Of the 15 major U.S. field crops, only sorghum, sunflower, clover, and tobacco have wild, weedy relatives in the United States (9). Some minor crop plants also have wild relatives in the United States, such as those in the crucifer family, which includes broccoli, cauliflower, kale, and rapeseed, as well as weedy yellow mustards (69).

Field trials of genetically engineered plants that carry pesticidal traits will be subject to EPA review under FIFRA. Other recombinant plants are currently reviewed USDA under the authority of PPA and PQA (See box 11-C).

Thus far, these laws have only been applied to transgenic plants containing rDNA derived from plant pests. The earliest method of transferring DNA to plants resulted in the transfer of some DNA derived from a plant pest, Agrobacterium tumefaciens. Therefore, virtually all transgenic plants to date have been subject to USDA regulation. More recently, however, new techniques for transferring DNA to plants have been developed that do not necessarily result in the incorporation of plant-pest DNA. Eventually, plants devel oped through these newer techniques will be ready for field testing, but unless the nature of the inserted trait triggers a review, they will not be subject to USDA regulation under PPA and PQA. Such transgenic plants that have been developed with Federal support would probably be subject to review under NIH Guidelines or USDA's research guidelines, but privately funded research would not be covered (54).

\section{Food Uses}

The FDA will regulate genetically modified plants used as foods in the same way it oversees the rest of the food supply. Whole foods (e.g., fruits, vegetables, and grains) are not subject to premarket review. The FDA, however, has authority to seize adulterated food and take steps to halt its distribution. This authority is generally used to remove foods from the market that have become contaminated. It could be used, although this has never happened, against new varieties of plants containing harmful substances.

In its policy statement in the Coordinated Framework, FDA states that a food produced using biotechnology could be in violation of FDCA if it contains a harmful substance not ordinarily found in the food or if it contains an abnormally high level of a substance that can be injurious to health. Beyond this, however, FDA has given little indication of its approach to ensuring safety of new food plants. Industry representatives have expressed a desire for more guidance. In December 1990, Calgene, a California plant biotechnology firm, asked FDA to approve its use of kanamycin, a marker gene that makes plants resistant to the antibiotic, (59).

An industry consortium, the International Food Biotechnology Council (34), has proposed a set of scientific principles for evaluating the safety of food and food ingredients derived from plants and microorganisms altered through the application of biotechnology. The proposal is based on existing law and practice. A decision-tree for each category of product-food derived from micro-organisms; single chemical entities and simple, chemically defined mixtures; and whole foods and complex mixturesencompasses a series of detailed questions about the food. The answers would lead to a decision to accept or reject the food or subject it to further study (34).

Food safety is likely to be an increasingly important topic of public concern. Appropriate FDA regulation of genetically altered products is critical if a public already suspicious of food additives and pesticide residues is to be confident about the benefits of biotechnology-derived foods.

\section{Transgenic Animals}

Genetic alteration of animals to serve human needs is also a centuries-old process. Biotechnology has the potential to accelerate this process and produce animals with increased growth performance, feed conversion efficiency, leanness, or disease resistance. Transgenic animals can also be used to produce pharmaceutical proteins, much in the way bacteria or cultured cells are used. For example, a gene can be altered so that the protein appears in the 


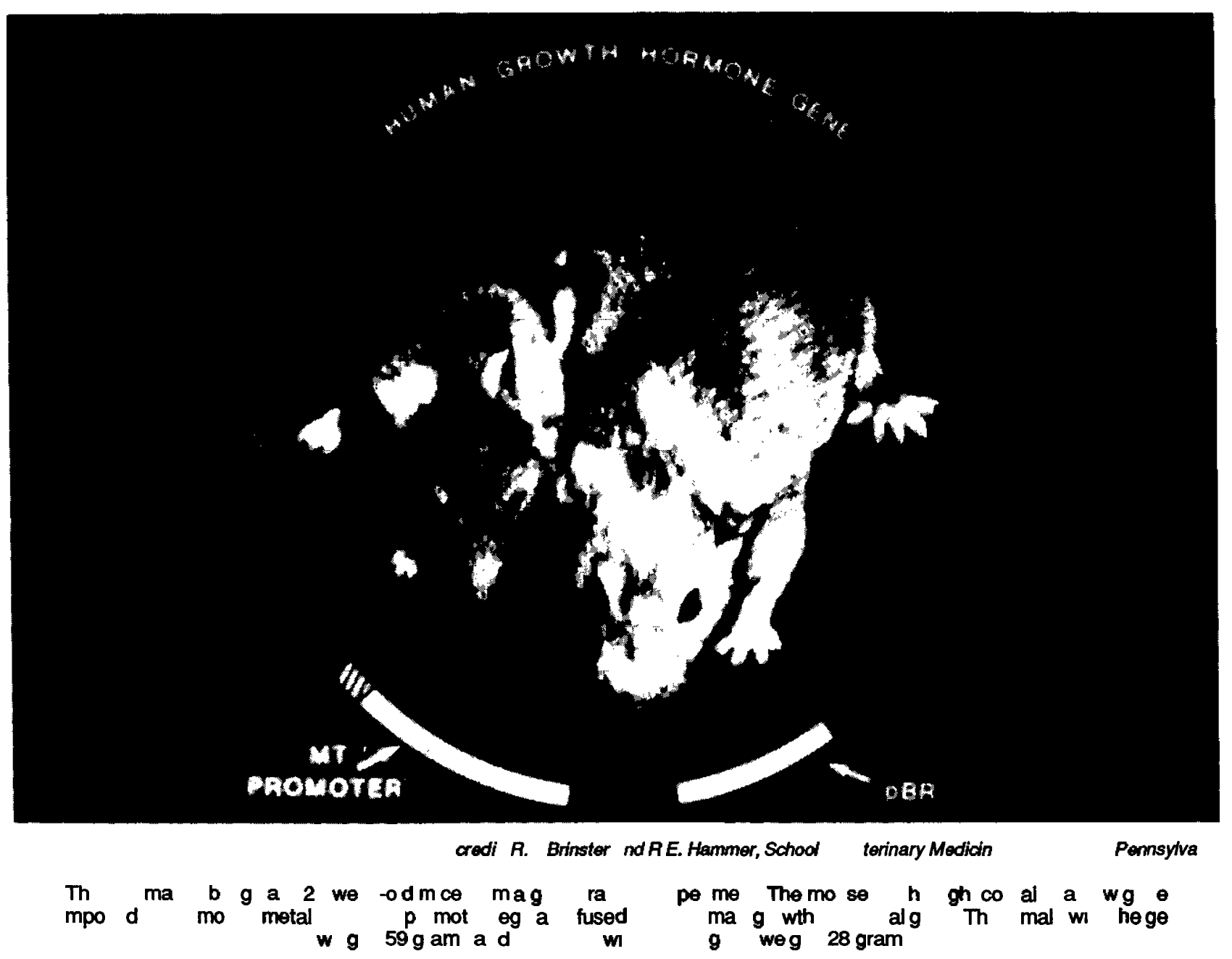

transgenic animal's milk, from which it may be purified (47). Eventually, this process may provide a cheaper alternative to protein production in mammalian cell culture, which remains expensive. Transgenic animal models of disease, containing genes that mimic human genetic defects, are also an increasingly important research tool.

The regulation of transgenic animals is still uncertain. Activities potentially subject to regulation under existing legislation were outlined in the Coordinated Framework, but no rules have been proposed and little guidance given.

\section{Planned Introductions}

Environmental releases of a few types of animals, mainly insects or worms considered to be plant pests or animals containing genetic material from plant pests, may be regulated under PPA. Transgenic animals derived from infectious, contagious, patho- genic, or oncogenic organisms may be subject to regulation under the Animal Quarantine Statutes and the Virus-Serum-Toxin Act. Federally funded research is subject to research guidelines of the funding agency (54). Releases of genetically engineered fish are not regulated under Federal law (35).

\section{Food Uses}

The Food Safety and Inspection Service (FSIS) of USDA is responsible for ensuring the safety, wholesomeness, and proper labeling of food products prepared from livestock and poultry, under the authority of the Federal Meat Inspection Act (21 U.S.C. $\$ 601$ et seq.) and the Poultry Products Inspection Act (21 U.S.C. $\$ 451$ et seq.). The FSIS inspects cattle, sheep, swine, goats, horses and other equines; poultry; and food products prepared from these animals, but it has no oversight over fish or other aquatic animals. According to USDA's policy 

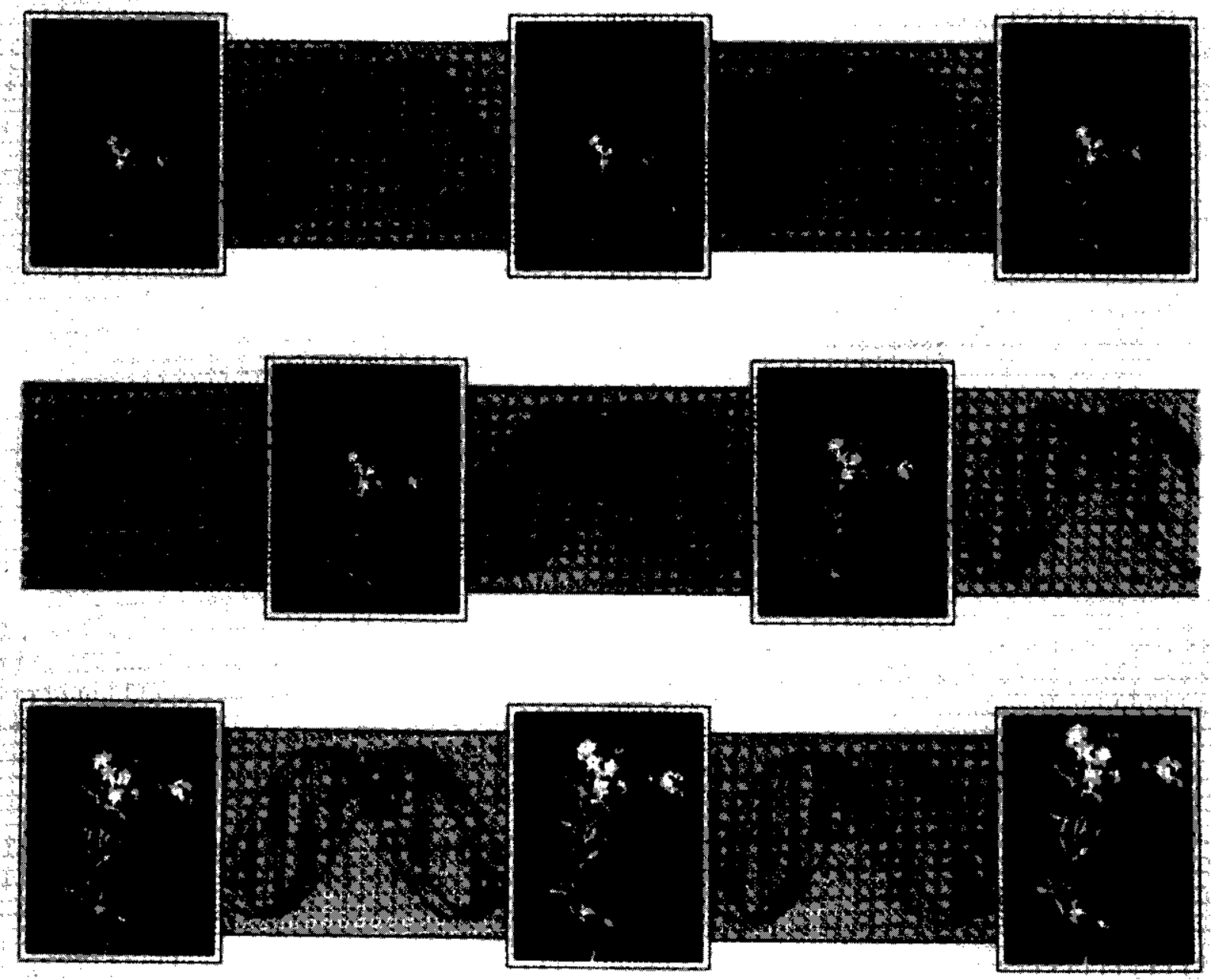

Photo credit: The U.S. Department of Agriculture

The U.S. Department of Agriculture (USDA) has developed a user's guide for introducing genetically engineered plants and organisms. As of July 1991, USDA had approved 165 permits for field test in 34 states and Puerto Rico. 
statement, published in the Coordinated Framework, genetically engineered food animals would be treated like new breeds-subject to the same inspection procedures as traditionally inspected animals. The FSIS could also amend its regulations to ensure that genetically engineered organisms intended for use as food are not adulterated(51 Fed. Reg. 23343). The safety of transgenic animals could be evaluated by considering the primary and secondary effects of the gene product, much as drug or pesticide residues in food are evaluated (8).

\section{Implementation and Coordination of Regulations}

The Coordinated Framework has settled a number of issues concerning agency jurisdiction. For many products it is clear which agency has primary responsibility. The FDA has adapted existing procedures for the regulation of drugs, biologics, and medical devices to the regulation of products developed using biotechnology; EPA and USDA have established procedures for reviewing small-scale field tests of genetically engineered micro-organisms and plants. The review process is functioning more smoothly as the agencies have gained experience $(30,58,64,67)$.

Nevertheless, the system is not without its problems. From the outset, the regulatory system has been criticized as too confusing for the regulated community, particularly for scientists working in universities or small firms who have little experience with regulation. This situation is made worse by the lack of published guidelines and rules. The USDA did not issue its research guidelines until early 1991 (56 Fed. Reg. 4134). The EPA's proposed rules for small-scale field testing under FIFRA and TSCA have faced long delays. Although field tests are being conducted, the policy is subject to change, making long-range planning difficult for industry. In addition, the organisms now being tested in small scale will soon be ready for large-scale testing and, eventually, product approval. But regulatory requirements for gaining approval to market certain types of products, particularly foods, are unclear (14). The FDA has given industry little indication of the regulatory barriers it will face in bringing new foods to market.

One reason agencies can be slow to confront new regulatory issues is an inability to anticipate new problems and novel areas of research. In addition, regulatory procedures are cumbersome and do not readily lend themselves to new and rapidly changing technologies. Another problem, long recognized by students of the regulatory process, is the strong incentives bureaucracies have to move slowly or not at all. Indeed, agencies face criticism if in acting quickly they make mistakes (55).

Academic researchers, especially agricultural re searchers, also find agency requirements, which officials of large firms accept as a part of the cost of doing business, to be burdensome $(20,24)$. This situation tends to discourage academic biotechnology research that would lead to an encounter with a regulatory agency, thus discouraging work on subjects with little potential for commercial rewardincluding products aimed at small markets, environmental research, and research addressing agricultural problems of the Third World $(24,66,71)$. The cost of meeting regulatory requirements has a similar effect on industry, discouraging research on products whose commercial potential is relatively small (26). Some critics maintain that the major problem with regulation is even more fundamental; that is, the resources that must be devoted to meeting regulatory requirements are disproportionate to risks as currently perceived $(23,26,42,65)$.

\section{NATIONAL REGULATORY POLICIES}

Several industrial nations and the EC are developing and implementing biotechnology regulations, based in part on international scientific criteria. Strong incentives favor international harmonization of such regulations. Export-oriented countries, especially small countries without large home markets, need regulations compatible with those of potential importers of their products.

Regulations, however, are also influenced by public opinion and cultural attitudes toward risk, health, and the environment (17). Substantial country-to-country differences in public opinion on environmental concerns are common. This can be seen, for example, in the different public responses to the use of nuclear power in France and Germany (51). In Germany, the Green Party platform calls for a total ban on biotechnology research, development, and production; the organization has been particularly influential in this regard (see box 1 I-D). 


\section{Box 11-D-Green Parties}

The Green parties, although still a small minority, have been increasingly successful in local and parliamentary elections throughout Europe. In the J une 1989 elections to the European Parliament, the number of seats held by members of Green parties more than doubled, compared with the previous election, reaching 39 out of 518. Until recently, the former West Germany's Die Gr nen was the most successful Green party in Europe in terms of membership, electoral votes, and financial strength. They received 5.6 percent of the vote in the March $1983 \mathrm{Federal}$ parliamentary el ection and increased its share to 8.3 percent in J anuary 1987. In December 1990, however, in the first election after German reunification, the western German Greens suffered a resounding setback The party, which had taken no formal position on reunification, received only 3.9 percent of the vote. Because they failed to capture the required 5 percent of the vote, all 46 Green members of the Bundestag lost their seats. An eastern German coalition of Greens and civic movements, however, won 8 seats. Racked by internal dissention, the Green Party's future in Germany is uncertain.

An outgrowth of local environmental groups of the early 1970s, the Greens have become an umbrella group for organizations whose concerns are often unaddressed by the major parties. They draw support from peace and disarmament activists, antinuclear-power protesters, and supporters of equal rights for gay people, women, and members of minority groups. Some of their success may be due to the Greens' position as an alternative to established parties and thus, the obvious choice for the disillusioned voter. Green supporters tend to be, for the most part, moderate-to-radical left politically, well-educated, and employed in the white-collar service sector of the economy, in particular, universities. Although some of their supporters are radical leftists, one Green party slogan proclaims: "We are neither left nor right, but out in front."

The Greens are less an organization than a movement. The beliefs of their members vary, and policies supported by Green parties in different countries vary as well. Tensions within Green parties are similar to those among U.S. environmentalists-between the most radical environmentalists (deep ecologists) and those who put the needs of people first. Some generalizations are possible, however. Policies supported by the Greens include: presentation of the natural environment; unilateral disarmament; a nonaligned, nuclear-free Europe; and aid to the Third World targeting the devel opment of self-sufficient economies. Central to the Greens' philosophy is dissatisfaction with traditional political organizations and representative democracy. The Greens maintain that government policy often reflects the interests of the military and industry, rather than the will of the people. Therefore, they favor decentralization of decisionmaking power, including the use of plebiscites to decide major issues. The organization of Green parties reflects this support for "direct democracy." Local party branches are autonomous, and their leadership is either collective or rotates among members. Meetings are open to the public, and grassroots participation is encouraged. Since their recent losses in Germany, however, some Greens who disagree with this lack of organization have become more vocal in their support for a more-established leadership.

The Greens part company with traditional leftists in their emphasis on alternative lifestyles, based less on material well-being and modern technology and more on individualism, community solidarity, and selfdetermination. Because many Greens are skeptical about the benefits of new technology and increases in economic growth and industrial productivity, they often reject attempts to weigh risks to the environment against the needs of industry. One spokesman, a specialist on the chemicals industry for the British Green Party, stated that "economic growth should be limited and that the health and safety of the planet should become the chief criteria by which to judge the worth of any activity."

The Greens strongly favor increased controls on the chemical and energy industries and a phase-out of nuclear power. Now that the expansion of the nuclear power industry has come to a virtual standstill in many countries, their attention has turned to biotechnology. Like their positions on other environmental issues, the position of the most extreme Greens concerning biotechnology is not based on estimates of risk to public health or ecological balance. Rather, they oppose biotechnology because it is unnatural and "speeds up evolution." To the Greens, the protection and preservation of the natural environment is sacrosanct.

SOURCES: A. Coghlan, “Chemicals Industry: Guilty until Proven Innocent,” New Scientist, vol. 123, No. 1678, Aug. 19, 1989, p. 23 ; K.J. Kelley "A Green Fringe," The Progressive, vol. 54, No. 4, 1990, pp. 30-33; F. M ller-Rommel, "The German Greens in the 1980's: Short-Term Cyclical Protest or Indicator of Transformation?” Political Studies, vol. 37, 1989, pp. 114-122; M.G. Renner, "Europe'sGreenTide," World-Watch, vol. 3, No. 1,1990, pp. 23-27; S. Schmemann, "GermanGreens, Still Fighting One Another, Survey Election Debacle," The New York Times, Dee. 7, 1990; J.H. Vaughan, "The Greens' Vision of Germany," Orbis, vol. 32, 1988, pp. 83-9S; H.J. Veen, "Prom Student Movement to Ecopax: The Greens," The Washington Quarterly, vol. 10, 1987, pp. 29-39. 


\section{Box 11-E--State Regulations}

Several States have considered new legislation or have developed regulations based on existing legislation regulating field tests of genetically modified organisms or the use of certain products developed using biotechnology. This is due to a perception of gaps in Federal legislation and oversight, to the fact that Federal agencies do not require notification of local officials or citizens in the area of test sites, and to a belief that Federal agencies are not attuned to local needs.

Hawaii, Illinois, and Wisconsin require notification before the release of genetically engineered organisms into the environment. Two other States, Minnesota and North Carolina, have more formal permit systems for field tests. Minnesota has empowered its Environmental Quality Board to coordinate State and Federal regulations pertaining to field tests and to issue permits for field tests not regulated elsewhere by the State government. A recent North Carolina law mandates an in-State review of proposed fieldtests. A 10-member Genetic Engineering Review Board will write detailed regulations to be used by North Carolina's State Department of Agriculture when evaluating field trials for both research and commercial purposes. Under these regulations, researchers would submit essentially the same information that they now supply to Federal agencies.

The North Carolina law has received mixed reviews. Some fear that other States will follow North Carolina's lead, resulting in a confusing patchwork of laws that will impede research and slow the course of commercialization. Others see benefits. Although the new law adds an extra layer of review, it imposes no new data requirements on researchers. The law may also hel $p$ ensure public confidence in the regulatory system while prohibiting additional regulation on the part of local communities, It has also been argued that by submitting to State laws, companies may protect themselves from legal challenges.

Two States, Wisconsin and Minnesota, have enacted legislation imposing a temporary ban on the use of bovine somatotropin, a product derived from a genetically engineered micro-organism (see box 1 I-F).

SOURCES: Industrial Biotechnology Association, Survey of State Government Legislation on Biotechnology, May 15, 1990 and fall 1990; G. Blumenstyk, "States Are Seeking Mom Regulation of Biotechnology," The Chronicle of HigherEducation, Aug. 8,1990, p. A13; M. Crawford, "Should States Regulate Biotechnology?" Science, vol. 245, 1989, p. 466; J.L. Fox, "Wide Acclaim for North Carolina Regulations," Biotechnology, vol. 7, 1989, p. 1002.

Prior incidents, related or unrelated, have raised public awareness and political sensitivities. For example, initial concerns about the hazards of rDNA research arose in the mid-1970s, roughly coinciding with an accidental release of smallpox virus from a London laboratory in 1973. The incident, unrelated to rDNA research, also coincided with the election of a Labour Government and an increase in parliamentary interest in workplace safety. Consequently, in the United Kingdom the first controls on biotechnology were based on general workplace legislation (6).

In the United States, sporadic concern about particular aspects of biotechnology regulatory policy has arisen. Local protests against releases of genetically engineered micro-organisms occurred in 1986 and 1987 in California and Missouri, respectively (68). Although general opposition has since dissipated, several States have introduced and in some cases enacted legislation regulating planned introductions (see box 1 l-E). More recently, farm, consumer, and environmental groups have raised concerns about the use of bovine somatotropin (BST), a hormone that increases milk production (see box 11-F). Some scientists attribute public concern about biotechnology to scientific illiteracy in the general population. In addition, according to cross-national studies of health, safety, and environmental regulations, increasing public concern about such hazards tends to coincide with public distrust of those responsible for ensuring public safety: scientific experts, the civil service, and the business community (73).

Worldwide, there have been three basic approaches to the regulation of biotechnology; they generally parallel approaches to controlling environmental pollution and nuclear power.

. No regulations. A number of countries with active investment in biotechnology have no regulations specific to biotechnology. In most growth-oriented countries (NICs) of the Pacific Rim (e.g., Taiwan, South Korea, and Singapore), biotechnology has been targeted as a strategic industry. Some industrialized European Nations, including Italy and Spain, which have no regulations specifically dealing with biotechnology, expect to develop them to 
harmonize with EC directives on biotechnology.

- Stringent biotechnology-Specific regulations. Some northern European countries have responded to public pressure to impose stringent regulations specific to biotechnology by enacting new legislation. Under a 1986 law, Denmark prohibits the deliberate release of genetically engineered organisms without the express permission of the Minister of the Environment. Germany enacted new legislation imposing tight restrictions in 1990. The EC's 1990 directives on contained use and deliberate release of modified organisms, while not as restrictive as the Danish or German laws, follow a similar approach, i.e., directives specifically regulate the use of biotechnology.

- Limited restrictions. Australia, Brazil, France, J apan, The Netherlands, the United Kingdom, and the United States allow the use of biotechnology with some restrictions and oversight (see boxes 11-G; 11-H; and 11-1). In these countries, regulations based on existing or amended legislation governing drugs, worker health and safety, agriculture, and environmental protection are being applied to the use of biotechnology. Stringency varies, as do the enforcement mechanisms.

\section{No Regulations}

The newly industrializing countries of the Pacific Rim (e.g., South Korea, Singapore, and Taiwan) are consciously imitating J apan's postwar route to economic success. These governments place heavy emphasis on economic growth and development, with particular interest in the production of hightechnology exports. Years of neglecting the environment in Pacific Rim countries, however, have resulted in severe industrial pollution, and, in recent years, public awareness of environmental problems has risen. There is increasing evidence of public interest in regulations designed to protect health and safety and the environment. Some observers expect the Pacific Rim countries will eventually follow $\mathrm{J}$ apan's lead in the development of biotechnology regulations as well $(28,32)$.

\section{Stringent Biotechnology-Specific Regulations}

\section{Denmark}

In contrast to the approach of most Pacific Rim Nations, Denmark and Germany have enacted new legislation specifically regulating biotechnology products and techniques. In Denmark, the Environment and Gene Technology Act (EGTA), passed by the parliament in 1986, gives the Minister of the Environment broad power to regulate the use of genetically modified organisms. The law restricts biotechnology research with these organisms to registered laboratories. The production, marketing, use, or import of substances or products containing genetically manipulated organisms or cells is not permitted, except with the approval of the Minister. Pharmaceuticals and feedstuffs, however, are exempt from this provision.

In addition, the deliberate release of genetically modified organisms is specifically prohibited in Denmark, although the Minister of the Environment may make exceptions. The Minister of the Environment has agreed not to grant approval for releases without the consent of the parliament committee for the environment (3). Approval for field testing two strains of genetically engineered sugar beets was granted in J uly $1989(41,60)$.

A 1987 order covers small- and large-scale research and production facilities using engineered micro-organisms and is largely aimed at protecting worker health and safety. Administered by the National Labor Inspectorate, it specifies containment conditions for R\&D.

The EGTA was amended in 1989, easing some restrictions that industry found most onerous. For example, pilot plants are now treated as research laboratories, rather than as production facilities, and, as such, are subject to fewer regulations. A second change allows a company to continue working after a complaint has been lodged against it with the Environmental Appeals Board. Previously, such work had to cease until the complaint was dismissed.

Nevertheless, industry representatives charge that the approval process is still too time-consuming and burdensome (52). However, the 1989 amendments and field-test approvals suggest that, in practice, the regulations may come to be no more severe than those in other European countries.

\section{Germany}

New legislation enacted in Germany in 1990 was welcomed by the regulated community, because it ended a period of regulatory uncertainty (56). In 1989, the Administrative Supreme Court for the State of Hesse ruled that because there was no law 


\section{Box 11-F--Bovine Somatotropin}

Bovine somatotropin (bST), also known as bovine growth hormone, is a naturally occurring peptide hormone produced by cattle. Among other functions, it regulates the production of cows' milk. The hormone can be manufactured using genetically engineered organisms in a standard fermentation process, resulting in a nearly identical copy of the natural substance. When supplemental injections of small doses of bST are administered to dairy cows, milk production increases by as much as 10 to 25 percent. The cows may eat more feed, but there is an increase in milk production per unit of feed. The increased production results in a significant decrease in the production cost of a unit of milk.

Like all animal drugs, whether or not genetically engineered, the use of bST is subject to FDA regulation. To receive approval to market any animal drug, the manufacturer must demonstrate that the drug is safe and effective when used in accordance with the label directions. It must also be shown that the drug and its metabolizes do not appear as unsafe residues in the edible tissues of the animal at the time of slaughter or in other animal products, e.g., milk or eggs. Although FDA has not yet approved bST for marketing, the agency found, in 1985, that the meat and milk from experimental herds are safe for human consumption. A NIH panel reached the same conclusion in 1990. The FDA must evaluate the hormone's effects on the health of cows before it can grant final approval.

In addition to concerns about the effects of bST on human health and animal welfare, concerns also exist about consumer acceptance. A 1990 survey of Wisconsin consumers found that 77 percent would prefer to drink milk from untreated cows, and 67 percent would pay as much as 22 cents additionally per half-gallon for non-bST milk.

The strongest resistance to bST in the United States probably comes from farm activists who believe that bST will increase economic pressures on small farmers already pressured by increased farm productivity by larger farms. Since the 1950s, dairy farming has changed considerably, as a result of technologies that save time and labor such as, bulk milk handling, silo unloaders, and improved milking equipment+ Higher quality feeds, artificial insemination, and better disease control have also contributed to productivity increases. In 1955, the average cow in the United States produced less than 6,000 pounds of milk per year. By 1985, average milk production was close to 13,000 pounds yearly. This increase in productivity has resulted in a dramatic decrease in the number of dairy farms and a corresponding increase in their size. With or without the use of bST, this trend is expected to continue.

Industry officials, however, emphasize bST's "size neutrality." Unlike other new technologies, use of bST does not require a large investment or impose along delay before benefits are realized. Therefore, bST can be used profitably by operators of both large and small farms. Farmers who are poor managers, however, and whose cows are badly nourished or unhealthy are unlikely to realize benefits from bST use. A 1987 USDA study found:

(Continued on next page)

to "expressly permit the application of genetic engineering, such facilities may not be built and operated" (4). The ruling prevented the use of a Frankfurt production facility, operated by Hoechst AG, from manufacturing genetically engineered human insulin. Although this decision was binding only in the State of Hesse, new investment in production facilities in Germany ceased afterward. The 1990 law will allow biotechnology production to proceed.

The new law is based on the findings of a parliamentary commission, which spent 2 years compiling a thorough report on all uses of biotechnology. Although the commission reached consensus on a wide variety of issues, the Green Party representative took exception to many conclusions. The commission strongly supported the use of biotechnology in developing pharmaceuticals, diagnostic products, chemicals, and foodstuffs-- including transgenic plants and animals. But, the commission, also concerned about contained uses of micro-organisms, favored extending the current controls on government-funded, contained uses to apply also to industrial production facilities. The commission was emphatically opposed to the environmental release of genetically engineered microorganisms and viruses, except for vaccines (15).

The comprehensive Genetic Technology Law, largely based on the report of the parliamentary commission, is broad in scope, covering recombinant micro-organisms, viruses, cells, plants, and animals, in addition to plasmid vectors. The law specifies conditions for building and operating production facilities, releasing engineered organisms into the environment, and transporting organisms. Specific requirements are outlined for both research and commercial production. 
Adoption of bST, when viewed at the national level, simply reinforces the 30-year trend toward increased milk production per cow and declining dairy farm numbers. When viewed at the farm level, bST use could prove profitable for almost all commercial dairy farms. But inefficient producers who lack management skills and who do not adjust feeding and health procedures to reflect increased milk production from bST-treated cows are not likely to capture all of bST's potential benefits. Hence, bST will not significantly affect the national trend towards large dairy farms in all regions.

Nonetheless, temporary bans on the sale and use of bST were in effect in Wisconsin and Minnesota until mid-1991.

Similar issues are being addressed in Europe. The U.K.'s Veterinary Products Committee sees no risk to human health or to the environment stemming from bST use, but it has recommended that bST not be licensed for sale because of questions about the manufacturing process and bST's effects on animal welfare. The European Community (EC) is also hesitating to approve bST use. In 1989, the EC placed a 15-month moratorium on the use of bST and later extended the moratorium until the end of 1991, so that the EC Commission could complete its studies. In March 1991, the EC's Committee for Veterinary Medicinal Products found that milk and meat nom treated cows are safe. Some members of the committee, however, recommended further studies on the effects of bST on the health of cows. But EC! member nations are now free to authorize the use of bST.

The ultimate impact of the use of bST on international trade is undear. If bST is used in the United States but not in other countries, opportunities for commercial export might grow, as domestic U.S. prices may fall below international prices. It is not known, however, whether potential importers would accept milk from bST-treated cows.

SOURCES: Office of Technology Assessment, U.S. Dairy Industry at a Crossroad: Biotechnology and Policy Choices, 1991. J. Juskevich and C.G.Guyer, "Bovine Growth Hormone: Human Food Safety Evaluation" Science, vol. 249, 1990, pp. 875-884; R, Fallert et al., bST and the Dairy Industry: A National, Regional and Farm-level Analysis, Economic Research Service, U.S.Department of Agriculture, Agricultural Economic Report No. 579, October 1987; D.P. Blayney and R.F. Fallert, Biotechnology and Agriculture: Emergence of Bovine Somatotropin, Commodity Economics Division, Economic Research Service, U.S. Department of Agriculture, Staff Report AGES 9037, June 1990; "Thumbs Down for Milk Hormone," New Scientist, vol. 127, No. 1728, Aug. 4,1990, p. 25; The Economist "Bad Moos," vol. 316, No. 7667, Aug. 11, 1990, pp. 66-70; G. Gugliotta, "A Wonder Drug or a Threat?" The Washington Post, June 24, 1990; B.W. Marion and RL. Wills, "A Prospective Assessment of the Impacts of Bovine Somatotropin: A Case Study of Wisconsin," American Journal of Agricultural Economics, vol.72, 1990, pp. 326-336; R. Jennings, personal communication, December 1990; Technology Assessment Conference, "NTH Technology Assessment Conference Statement on Bovine Somatotropin," Journal of the American Medical Association, vol. 265, 1991, pp. 1423-1425.

The law divides work with rDNA into four safety levels, depending on the source of the DNA, the host organism, and the vector. The most widely used organisms are included in the lowest safety level. At this level, authorities must be notified of plans to open facilities for research. Research considered to be riskier, requires formal approval before work can be undertaken. All industrial or commercial work is also subject to formal approval, but disclosure and public hearings are required only for work at Safety Levels 2 through 4 . The law also holds operators of facilities liable for damages, and it requires operators of facilities approved for work at Safety Levels 2 through 4 to arrange for liability coverage.

The Lender, or State governments, are responsible for implementing and enforcing the regulations, an approach which is typical of German regulatory policy. The Advisory Board for Biological Safety (ZKBS), a part of the Federal Ministry of Health, plays an advisory role. Some fear that this places the burden of enforcement on local agencies lacking necessary expertise $(16,45)$. In the last half of 1990 , however, five firms received permission to operate production facilities (76).

The law also grants authority to the health ministry for regulating deliberate releases of genetically engineered organisms and for approving products containing genetically modified organisms. It lists information that manufacturers must provide and requires that public hearings precede releases of genetically engineered organisms whose spread cannot be limited. Germany's first release of genetically engineered organisms, a field test of altered petunias at the Max Planck Institute in Cologne, took place in summer 1990, after a year's delay due to public opposition (63).

\section{The European Community}

The EC has enacted two directives that deal specifically with biotechnology regulation: one directive regulates contained use of genetically modified micro-organisms and the other regulates the deliberate release into the environment of genetically modified organisms $(12,13)$. Member 


\section{Box 11-G-Regulations in Japan}

J apan's regulations on biotechnology generally follow international standards. The research guidelines, based on early versions of NIH Guidelines, were developed by the Ministry of Education, Science, and Culture and by the Science and Technology Agency to cover research in public and private institutions, respectively. Because the procedure for updating guidelines in J apan is relatively slow, the research guidelines tend to be more stringent than NIH Guidelines.

Guidelines for industrial applications are generally consistent with OECD recommendations. These guidelines were issued by the Ministry of International Trade and Industry in J une 1986 and were followed by the publication by the Ministry of Health and Welfare of guidelines for producing pharmaceuticals and biologics.

The first regulations covering the deliberate release of recombinant plants were issued in the summer of 1989 by the Ministry of Agriculture, Forestry, and Fisheries. The Environment Agency has drafted safety guidelines for fieldtests of genetically modified micro-organisms, and rules for the release of transgenic animals are in preparation. The Ministry of Health and Welfare is developing guidelines for assessing the safety of food and food additives produced using rDNA technology. There is no body attempting to coordinate these various activities.

Reports about public perception of biotechnology in Japan are varied. Although some products advertised as biotech products have been well-received, community protests against the building of new research facilities have occurred, and surveys show that the public is wary of the technology. One survey of the readership of a Japanese science magazine, for example, found that respondents had serious misgivings about biotechnology, especially about food products and environmental introductions of modified organisms. Almost three-quarters had reservations about the marketing of genetically engineered fish, and 78 percent were very apprehensive about the prospect of planned releases of genetically engineered microbial pesticides in the United States.

SOURCES: H. Uchida, "Evolution of Recombinant DNA Guidelines in Japan," Safety Assurance for Environmental Introductions of Genetically-Engineered Organisms, J. Fiksel and V.T. Covello (eds.) (New York, NY: Springer-Verlag, 1988); C.C. Martin,

"Japanese Bioindustry rends Turn Into Firmly Established Strategies," Genetic Engineering News, vol. 10, No. 2, 1990, pp. 2\&21; Bulletin of the Atomic Scientists, "Biotech Lab Recalls Biowar," Bulletin of the Atomic Scientists, vol. 46, No. 1, 1990, p. 6; D. McCormick, "Not As Easy As It Looked," Bio/Technology, vol. 7, 1989, p. 629; N.S. Shimbun, "Environment Agency Drafts Safety Guidelines," Nikkei Sangyo Shimbun, Mar. 24, 1990, p. 13; Pharma Japan, "MAW to Prepare Safety Standard for 'Bio

Foods,' " Pharma Japan, vol. 1222, Sept. 24, 1990, p. 18.

countries must review their laws to bring them into harmony with EC directives by October 1991.

Contained Use-The directive on contained use is based in part on the Organization for Economic Cooperation and Development (OECD) recommendations, and it sets minimum standards for R\&D and for industrial operations. Member countries must adopt regulations on the contained use of genetically modified micro-organisms that are at least as stringent as those in the directive.

Regulatory requirements depend on whether the modified micro-organism is associated with high or low risk and whether the work is large-scale or small-scale, noncommercial research. Records of the research must be kept for the use of low-risk organisms at the small-scale level. For small-scale work with high-risk organisms or large-scale work with low-risk organisms, researchers must notify the appropriate national authority, which then has 60 days for review. Large-scale uses of high-risk organisms are not permitted without the explicit approval of the national authority. The authorities must also be notified before a new facility using these micro-organisms may be used. EC member states must periodically provide information obtained from these notifications to the European Commission, the EC's executive branch.

Because the directive sets a minimum standard and member countries may impose more stringent standards, regulatory requirements are likely to differ among countries. These differences may provide incentives for firms to establish production facilities in countries with the least restrictive regulations, thereby defeating one of the purposes of economic integration.

Planned Introduction-Unlike the directive on contained use, the directive on deliberate release of genetically modified organisms is not a minimum standard; the ministers ruled that this directive is primarily a measure to regulate trade rather than to protect the environment. This ruling limits the ability of member states to impose stricter regulations. 


\section{Box 11-H-Regulations in France}

In France, where little public concern exists about the use of biotechnology, a committee in the Ministry of Research and Higher Education must be notified of an intent to perform rDNA research. The Ministry of Agriculture reviews releases of genetically modified organisms, but notification is voluntary and the committee's recommendations are not compulsory. Government agencies are now working with trade associations to develop a set of voluntary guidelines for research, contained use, and deliberate release.

SOURCES: Office of Technology Assessment, 1991.

The directive on deliberate release is also based on OECD recommendations. Before a modified organism may be released, the relevant national authority must give approval, based on a case-bycase review of the researcher's detailed environmental assessment. The appropriate authorities in other member states must be kept informed and may, within 90 days, suggest improvements in the proposed experimental protocol. The authorities in other member states, however, do not have veto power.

The directive on deliberate release also describes requirements for placing genetically modified organisms on the market. The manufacturer or importer must obtain the approval of the national authorities in the country where the product will first be sold, and the national authority must inform other member nations of its approval. If there are no objections from the other states, the product may be sold throughout the EC. If many member countries raise objections, approval to market the product may be revoked. Alternatively, the dispute may be resolved through binding arbitration by a committee of national representatives and a chamber of the Council of Ministers.

In enacting directives that specifically regulate genetically modified organisms, the EC has established a regulatory procedure that is significantly different from that of the United States. In the EC, regulation is explicitly based on the method by which the organism has been produced, rather than on the intended use of the product. This implies that the products of biotechnology are inherently risky, a view that has been rejected by regulatory authorities in the United States. In addition, manufacturers are concerned that their new biotechnology-derived

\section{Box n-I-Regulations in the United Kingdom}

In the United Kingdom, the Health and Safety Executive has issued guidelines under the general authority of the Health and Safety at Work Act of 1978. It is mandatory to notify the Health and Safety Executive, and hence, the Advisory Committee on Genetic Manipulation (ACGM) of the intent to carry out genetic manipulation for research or planned introductions. Employers are requested to provide substantial information on the details of the experiment or production process.

Guidelines for planned releases were issued by ACGM in 1986. At first, only notification was required, and ACGM provided guidance on detailed procedure. Since November 1989, ACGM notification of proposed releases has been required by statute. Under the Environmental Protection Act of 1990, ACGM, now renamed the Advisory Committee on Genetic Modification, continues to oversee industrial $R \& D$ and basic scientific research. Its subcommittee responsible for case-by-case reviews has become an independent statutory committee, called the Advisory Committee on Release to the Environment (ACRE). It advises both the Health and Safety Executive and the Secretary of State for the Environment on human health and safety issues and, in particular, environmental issues associated with proposed releases. New regulations are to be put in place under the Health and Safety at Work Act and the new Environmental Protection Act. ACRE and ACGM share six common members and a common secretariat.

SOURCES: Environmental protection Act 1990; B. Ager, "The Oversight of Planned Release in the U.K.," Safety Assurance for Environmental Introductions of Genetically-Engineered Organisms, J. Fiksel and V.T. Covello (eds.) (New York, NY: Springer-Verlag, 1988); R Jennings, British Embassy, Washington, DC; personal communication, December 1990.

products may face additional regulatory barriers before they can be marketed, for the product may also be subject to further regulations based on its intended use (1).

Industry officials also fear that one country could delay product approval for the whole EC by forcing lengthy reviews (43). In addition, they are concerned that national authorities may institute burdensome requirements. Because EC directives leave considerable discretion to national authorities, much depends on how national laws are written and implemented. 
An industry group has identified another 12 regulatory initiatives, either proposed or being discussed by the European Commission, that could influence the use of biotechnology (11). One of these, a directive on the protection of workers from risks related to exposure to biological agents, was adopted by the Council of Ministers in November 1990.

Another EC legislative proposal would add a new requirement for regulatory approval for veterinary products. Although it is not specifically directed at regulating biotechnology, it could have an effect on some biotechnology products. In addition to the standard requirements of safety, quality, and efficacy, the legislation would require a firm to address the socioeconomic consequences of the use of its product. Such a requirement, known as the "fourth hurdle," could prevent the introduction of bST, because bST could increase production of milk, a product often in surplus in the EC. An amendment to the Veterinary Products Directive that would require the inclusion of socioeconomic criteria in the approval process for veterinary products was approved by a small majority of the European Parliament at its frost reading, but it was rejected at the second reading in November 1990. A similar requirement, however, is still under consideration in a draft proposal for a Community regulation concerning the use of substances and techniques stimulating the productivity of animals $(21,22)$.

\section{Limited Restrictions}

The use of biotechnology began long after most industrial nations had developed laws and administrative procedures-including laws pertaining to drugs, agriculture, the environment, and worker safety-for regulating hazardous substances. In general, regulation of biotechnology began with an evaluation of how biotechnology could be regulated under existing law and whether new legislation was necessary at all (53). Australia, Belgium, Brazil, Canada, France, J apan, The Netherlands, Switzerland, and the United States, for example, have applied existing laws to biotechnology.

Also important has been the development of a scientific basis for regulating engineered organisms, an area in which OECD has been influential (see box $1 \mathrm{I}-\mathrm{J}$ ). The OECD's recommendations comprise the basis of biotechnology regulations in many member nations.
Since OECD's 1986 report, other analyses of biotechnology safety issues, particularly planned introductions of modified organisms, have been developed by government task forces or scientific societies in OECD member nations $(15,49,50,57$, 68). Most country-to-country differences in biotechnology regulation among OECD members stem from legal, procedural, and administrative differences. These differences affect the design and implementation of all regulations for health and safety or environmental protection, not just biotechnology.

Several studies comparing U.S. and European regulations concerning pesticides, food additives, industrial chemicals, workplace safety, and air and water pollution have found that regulatory systems in other industrial nations are markedly different from the U.S. system $(10,36,73,74)$. In other countries, bureaucrats are more likely to be granted discretion in implementing and enforcing regulations, and they often enjoy good working relationships with representatives of regulated industries as a result. Fines and litigation are rare. Agencies are more likely to use informal cooperative methods to obtain compliance, and these agencies see their interactions with the regulated community less as an adversarial relationship and more as an opportunity to provide advice and information. This is possible because, in other countries, agencies rarely have to justify their decisions. There is little oversight by legislatures and courts, and there are few provisions for public notification or participation.

This situation is beginning to change, however, particularly with respect to issues of great public concern, such as nuclear power and biotechnology (72). Nevertheless, biotechnology regulations probably will not be implemented or enforced using procedures similar to those used in the United States.

Biotechnology regulatory policies in France, the United Kingdom, and the United States, for example, vary widely in terms of complexity and enforcement. The French procedures not only are the simplest but are also voluntary. In the United Kingdom, the Advisory Committee on Genetic Manipulation, now called the Advisory Committee on Genetic Modification, has been overseeing the use of biotechnology on a case-by-case basis and has issued guidelines, rather than more inflexible regulations. But the committee has now, apparently, introduced a more formal system. 


\section{Box 11-J-The Organization for Economic Cooperation and Development}

The OECD, an international organization founded in 1\%1, is the major forum for discussion of economic policy by member States. These include most of the industrial world: Australia, Austria, Belgium, Canada, Denmark, Finland, France, Germany, Greece, Iceland, I reland, Italy, J apan, Luxembourg, The Netherlands, New Zeal and, Norway, Portugal, Spain, Sweden, Switzerland, Turkey, the United Kingdom, and the United States.

The OECD is committed to economic development and the expansion of world trade, in addition to achieving the "highest sustainable economic growth and employment" possible, while maintaining financial stability. The OECD has limited power but often works behind the scenes to promote international understanding of the economic impact of national policies.

In addition to holding regular meetings attended by each country's permanent representative, and yearly meetings at the ministerial level, OECD maintains a number of committees on specific issues, such as economic policy and development assistance, Delegates from national governments may also meet as expert bodies to discuss particular issues, such as biotechnology.

In 1983, OECD member countries setup a committee of experts to examine safety issues associated with the use of engineered organisms in large-wale industrial applications and agricultural and environmental applications. Recommendations on contained uses were issued in 1986.

The report's conceptual framework resembles the NIH Guidelines. It describes containment requirements for organisms, based on the level of estimated risk. It outlines a control standard known as Good Industrial Large-Scale Practice (GILSP), based on extending industrial experience and practice with micro-organisms to widely used, low-risk genetically engineered organisms. The containment requirements for low-risk organisms are minimal. More stringent containment strategies are recommended for organisms that present increased risk. The report lists criteria for determining whether an organism should be grown under GILSP or under more stringent standards, but it does not assign specific organisms to risk categories.

The OECD report also recommends a case-by-case review of environmental and agricultural applications of biotechnology. A stepwise progression of experiments--from the laboratory, to the greenhouse, to the small-scale field test, and then to larger field tests-is recommended, so that experience can be gained and safety evaluated. Detailed recommendations on conducting small-scale, low-risk field tests are being prepared.

SOURCE: Office of Technology Assessment, 1991.

The development of biotechnology regulations in the United States has been more difficult. Local protests have taken place at release sites, and periodic litigation has been brought by environmental groups. Infighting has also taken place among the Federal agencies responsible for developing regulations and policy statements $(14,61)$, which rely more on precise definitions and detailed standards than French and British regulations (see box $11-B)$.

\section{EFFECT OF REGULATION ON COMPETITIVENESS}

At best, regulations that effectively reduce risk can result in an overall benefit to society. But measuring the benefits of biotechnology regulations are difficult. These regulations are intended to prevent problems that have never actually occurred; this means that assessing the probability of an adverse effect of biotechnology cannot be based on precedent. But some of the benefits derived from Federal biotechnology regulations can be listed.

- Some products produced using biotechnology warrant premarket review and approval to reduce risk to health or the environment.

- A Federal review process enables agencies to act as clearinghouses for safety information.

- A thorough Federal regulatory system can alleviate public concern and ensure public confidence in biotechnology.

- The absence of Federal regulations could result in a confusing array of State and local regulations that, in turn, could stifle commercial innovation and development while also increasing costs.

Whether the benefits derived from regulating biotechnology outweigh the costs of regulation is the subject of debate. Reduction of risk through more stringent regulation may increase direct and indirect costs to industry, government, and ultimately the 
public. When regulations differ from the international norm, either in policy approach or in stringency, investors and researchers may move to other locations or shift to other investments. This general problem of regulation is especially acute in biotechnology, because of the wide variety of regulatory approaches around the world. The direct and indirect costs associated with biotechnology regulations include:

- the cost of filing applications and planning and performing field tests;

- benefits lost as a result of keeping useful products off the market;

- delays in product introduction, resulting in lost revenues, reduced market share, and delayed returns on investments;

- inappropriate health and safety regulations that pose barriers to trade; and

- another layer of uncertainty added to an already risky investment-for a potential product to be commercially viable, it must not only meet the criterion of competitiveness in the marketplace but must first meet regulatory criteria (33).

Large, diversified corporations are usually better able to shoulder the costs of regulation than start-up companies, which may find the costs prohibitive. It is quite common for small biopharmaceutical firms to license potential products to larger corporations, not only for marketing and distribution but also because the larger firms can finance environmental assessments and clinical trials more easily.

Regulations may bring on changing patterns of investment. Several major German corporations are building plants and research facilities in the United States and J apan rather than Germany partly because of the less stringent regulatory environment. For example, BASF AG is building its new genetic engineering research facility in Massachusetts, Bayer AG is expanding a biotechnology laboratory in Connecticut, and Henkel KGAA is building a new facility in California (5).

An uncertain regulatory climate also inhibits investment. Long delays in developing regulations make analysis of the potential return on an investment much more difficult. The time involved in establishing a reasonable yet comprehensive oversight mechanism in the United States, particularly a mechanism applicable to field testing, may have already contributed to depressing investment in U.S. agricultural and environmental applications of bio- technology. Ultimately, this loss of investment results in less innovation and lower technological competitiveness.

\section{SUMMARY}

Internationally, there have been three approaches to regulation: no biotechnology-specific regulations in most of the growth-oriented countries of the Pacific Rim and in some European nations, stringent regulations in countries with high levels of public concern about biotechnology (e.g., Denmark and Germany), and limited restrictions in most industrialized Nations, including Canada, France, J apan, the United Kingdom, and the United States. The EC has enacted directives that are specific to biotechnology-derived products. In Europe there has also been proposals for adding an additional criterion for regulatory approval of veterinary products. This "fourth hurdle" would require socioeconomic assessments of new products. American manufacturers fear that this criterion will be used to keep their products off the market in Europe.

In the United States, new legislation is considered unnecessary because the risks posed by the new products are thought to be similar in kind to those associated with similar products developed using other techniques. Under existing legislation, FDA has approved many new products, and USDA and EPA have established procedures for reviewing field tests of modified plants and micro-organisms. Although farm activists are concerned about the potential economic effects of BST, public concern about the contained uses of modified organisms and their testing in the field has dissipated in the United States. However, some problems remain:

- Mechanisms established to provide Federal coordination of activities related to biotechnology have, instead, become the center of interagency, ideological disputes over the scope of proposed regulations.

- The time required for clinical trials necessary for FDA approval of new drugs and biologics hurts young firms attempting to commercialize their first products.

- The EPA has yet to publish proposed rules for the regulation of micro-organisms under TSCA and FIFRA.

- The EPA considers micro-organisms to be chemical substances subject to TSCA, an interpretation that could be legally challenged. 
- There is a lack of information necessary to assess the risks associated with some planned introductions, most particularly in microbial ecology.

- The FDA has given little indication of its intentions concerning the development of regulations and procedures for evaluating the food safety of genetically modified plants and animals.

- Field-testing requirements have been criticized as too burdensome, especially for the academic community, and disproportionate to the small risk associated with these organisms, particularly transgenic crops with no nearby wild, weedy relatives.

The problems associated with developing regulations add to the costs borne by fins, and are especially burdensome for small biotechnologybased firms. Despite these difficulties, there is anecdotal evidence that some European firms have decided to open research and production facilities in Japan and the United States, in part, because of the more favorable regulatory climate.

\section{CHAPTER 11 REFERENCES}

1. Ager, B., director, Senior Advisory Group on Biotechnology, European Chemical Industry Federation, personal communication, February 1991.

2. Aldous, P., "Modified Yeast Fine for Food," Nature, vol. 344, 1990, p. 186.

3. Andersen, M. B., personal communication, August 1990.

4. Bachtler, B., "Court Blocks German Biotech Plant," Science, vol. 246, 1989, p. 881.

5. Baily, R., "Brain Drain," Forbes, vol. 144, No. 12, Nov. 11, 1989, pp. 261-262.

6. Bennett, D. et al., The Politics of Uncertainty: Regulating Recombinant DNA Research in Britain (Boston, MA: Routledge \& Kegan Paul, 1986).

7. Berg, P. et al., "Potential Hazards of Recombinant DNA Molecules," Science, vol. 185, 1974, p. 303, Nature, vol. 250, 1974, p. 175; Proceedings of the National Academy of Sciences USA, vol. 71, 1974, pp. 2593-2594.

8. Berkowitz, D. B., "The Fuod Safety of Transgenic Animals," Biotechnology, vol. 8, 1990, pp. 819825.

9. Boyce Thompson Institute, Regulatory Considerations: Genetically-Engineered Plants, summary of a workshop held at Boyce Thompson Institute for Plant Research at Cornell University, Oct. 19-21, 1987 (San Francisco, CA: Center for Science Information, undated).
10. Brickman, R. et al., Controlling Chemicals: The Politics of Regulation in Europe and the United States (Ithaca, NY: Cornell University Press, 1985).

11. Cantley, M.F., "Managing an Invisible Elephant," Biofutur, vol. 84, 1989, pp. 8-16.

12. Crawford, M. "Biotech Companies Lobby for Federal Regulation," Science, vol. 248, 1990, pp. 546-547.

13. Deutscher Bundestag, "Report of the Enquete Commission of Enquiry on 'Prospects and Risks of Genetic Engineering' “ (J anuary 1987).

14. Dickman, S., "New Law Needs Changes Made," Nature, vol. 343, 1990, p. 298.

15. Douglas, M., and Wildavsky, A., Risk and Culture: An Essay on the Selection of Technical and Environmental Dangers (Berkeley, CA: University of California Press, 1981).

16. Ecological Society of America, "The Rel ease of Genetically Engineered Organisms: A Perspective From the Ecological Society of America," Tiedje, J.M., et al., "The Planned Introduction of Genetically Engineered Organisms: Ecological Considerations and Recommendations,' Ecology, vol. 70,1989, pp. 278-315.

17. Ellstrand, N. C., "Pollen as a Vehicle for the Escape of Engineered Genes?" Trends in Ecology and Evolution, vol. 3, No. 4, pp. S30-S32; Trends in Biotechnology, vol. 6, No. 4, 1988, pp. S30-S32, special publication.

18. Emlay, D., director, regulatory affairs, Calgene, personal communication, June 1990.

19. The Council of the European Communities, 90/219/ EEC, "Council Directive on the Contained Use of Genetically Modified Organisms," Official Journal of the European Communities, vol. 117, No. L, May 8, 1990, pp. 1-14.

20. The Council of the European Communities, 90/220/ EEC, "Council Directive on the Deliberate Release into the Environment of Genetically Modified Organisms," Official Journal of the European Communities, vol. 117, No. L, May 8, 1990, pp. 15-27.

21. European Biotechnology Information Service, "Impact Assessments ('Fourth Criterion') Characterized, 'European Biotechnology Information Service, vol. 1, 1991, pp. 8-9.

22. European Biotechnology Information Service, "The Parliament: 'Fourth Hurdle' Falls at Second Reading in European Parliament," European Biotechnology Information Service, vol. 1, 1991, p. 9.

23. Farnham, P., public affairs officer, American Society for Biochemistry and Molecular Biology, personal communication, July 1990.

24. Fedoroff, N., Chameigie Institute of Washington, personal communication, June 1990.

25. Fox, J. L., "U.S. Test Languishes, Europeans Proceeding," Biotechnology, vol. 8, 1990, p. 495. 
26. Frey, N., product development manager, Pioneer $\mathrm{Hi}$-Bred International, personal communication, December 1990.

27. Gershon, D., "Better Late Than Never for Start of Tests," Nature, vol. 346,1990, p. 785

28. Giddings, L.V., U.S. Department of Agriculture, personal communication, Feb. 8, 1990.

29. Gladwell, M., "FDA Approves Bioengineered Cheese Enzyme," The Washington Post, Mar. 24, 1990, p. 1.

30. Glass, D.J., Testimony before the House Agriculture Committee, Subcommittee on Department Operations, Research, and Foreign Agriculture, Oct. 2, 1990.

31. Hodgson, J., "Dutch Regulations Now in Force," Biotechnology, vol. 8, 1990, p. 284.

32. Hsu, M., president, Asia/Pacific Bioventures Co., personal communication, October 1990.

33. Huber, P.W., "Biotechnology and the Regulation Hydra," Technology Review, vol. 90, 1987, pp. 57-65.

34. International Food Biotechnology Council, "Biotechnologies and Food: Assuring the Safety of Foods Produced by Genetic Modification," Regulatory Toxicology and Pharmacology, vol. 12, No. 3, part 2, 1990.

35. Kapuscinski, A.R., and Hallerman, E.M., "'Transgenic Fishes,” Fisheries, vol. 15, No. 4, 1990, pp. 2-5.

36. Kelman, S., Regulating America, Regulating Sweden (Cambridge, MA: MIT Press, 1981).

37. Korwek, E.L., "Food Biotechnology Regulation: Overview and Selected Issues," Food Technology, vol. 40, No. 10, 1990, pp. 76-80.

38. Korwek, E.L., "FDA Oversight of Biotechnology Into the 21st Century," Biotechnology Laws for the 1990s: Analysis and Perspective, Special Report No. 4 (Washington, DC: Bureau of National Affairs, 1989).

39. Krimsky, S. et al., "Controlling Risk in Biotech," Technology Review, vol. 92, No. 5, 1989, pp. 62-70.

40. Kriz, M.E., "Growing Biotechnology Industry Sparks Governmental Turf Battle Over Federal Regulation of Potential Health and Environmental Risks," Chemical Regulation Reporter, vol. 8, No. 14,1984, p. 393.

41. Laake, M., "Regulation and Risk Assessment for Environmental Release of Genetically Engineered Micro-organisms in Denmark,' Safety Assurancefor Environmental Introductions of GeneticallyEngineered Organisms, J. Fiksel and V.T. Covello (eds.) (New York, NY: Springer-Verlag, 1988).

42. Leighton, C. C., senior vice president, Merck, Sharp \& Dohme Research Laboratories, personal communication, June 1990.
43. Levine, J.B., and Carey, J., "Cutting the Heart out of European Biotech?"' Business Week, J une 18,1990, pp. 177-178.

44. Linskens, M. S., State University of Leiden, personal communication, December 1990.

45. MacKenzie, D., "Germany Bows to Pressure Over Gene Research," New Scientist, vol. 125, 1990, p. 28.

46. Marchant, G., "Modified Rules for Modified Bugs: Balancing Safety and Efficiency in the Regulation of Deliberate Release of Genetically Engineered Organisms," Harvard Journal of Law and Technology, vol. 1 (spring 1988), pp. 163-208.

47. Meade, H. et al., "Bovine Alpha ${ }_{\mathbf{s 1}}$-Case in Gene Sequences Direct High Level Expression of Active Human Urokinase in Mouse Milk," Biotechnology, vol. 8, 1990, pp. 443-446.

48. Miller, H.I. et al., "Risk-Based Oversight of Experiments in the Environment," Science, vol. 250, 1990, pp. 401-491.

49. National Research Council, National Academy of Sciences, Introduction of Recombinant DNAEngineered Organisms Into the Environment: Key Issues (Washington, DC: National Academy Press, 1987).

50. National Research Council, Field-Testing Genetically Modified Organisms: Frameworkfor Decisions (Washington, DC: National Academy Press, 1989).

51. Nelkin, D., and Pollak, M., The Atom Besieged: Extraparliamentary Dissent in France and Germany (Cambridge MA: MIT Press, 1981).

52. Newmark, P., "Danish Law to be Less Rigid," Nature, vol. 339, 1989, p. 653.

53. Organization for Economic Co-operation and Development, Recombinant DNA Safety ConsiderationsSafety Considerations for Industrial, Agricultural and Environmental Applications of Organisms derived by Recombinant DNA Techniques (Paris, 1986).

54. Purchase, H.G., and MacKenzie, D.R. (eds.), Agricultural Biotechnology: Introduction to Field Testing (Washington, DC: Office of Agricultural Biotechnology, U.S. Department of Agriculture, 1990).

55. Quirk, P.J., "Food and Drug Administration," Politics of Regulation, J.Q. Wilson (cd.) (New York, NY: Basic Books, 1980).

56. Rau, N., "German Gene Technology Law Provides Biotech Guidelines," Genetic Engineering News, vol. 10, No. 7, 1990, pp. 1-14.

57. Royal Commission on Environmental Pollution, Thirteenth Report, The Release of Genetically Engineered Organisms to the Environment (London: Her Majesty's Stationery Office, July 1989).

58. Salquist, R.H., Testimony before the House Agriculture Committee, Subcommittee on Department Oper- 
ations, Research, and Foreign Agriculture, Oct. 2, 1990.

59. Schaefer, E., “Tables Laid for Transgenic Tomatoes," Nature, vol. 348, 1990, p. 470.

60. Shackley, S., University of Sussex, personal communication, August 1990.

61. Shapiro, S.A., "Biotechnology and the Design of Regulation," Ecology Law Quarterly, vol. 17,1990, pp. 1-70.

62. Shapiro, S.A., visiting professor, University of North Carolina School of Law, personal communication, June 1990

63. Specter, M., "West Germany's Anguished Science," The Washington Post, Apr. 11,1990.

64. Springer, W., Testimony before the House Agriculture Committee, Subcommittee on Department Operations, Research, and Foreign Agriculture, Oct. 2, 1990.

65. Tolin, S.A., Testimony before the House Agriculture Committee, Subcommittee on Department Operations, Research, and Foreign Agriculture, Oct. 2, 1990.

66. Tolin, S.A., and Vidaver, A.K., "Guidelines and Regulations for Research With Genetically Modified Organisms: A View From Academe," Annual Reviews in Phytopathology, vol. 27, 1989, pp. 551-581.

67. Townsend, R., Testimony before the House Agriculture Committee, Subcommittee on Department Operations, Research, and Foreign Agriculture, Oct. 2, 1990.

68. U.S. Congress, Office of Technology Assessment, New Developments in Biotechnology: Field-Testing
Engineered Organisms: Genetic and Ecological Issues, OTA-BA-350 (Springfield, VA: National Technical Information Service, May 1988).

69. U.S. Department of Agriculture, Workshop on Safeguards for Planned Introductions of Transgenic Oilseed Crucifiers, held at Cornell University, Ithaca, New York, Oct. 9, 1990.

70. U.S. General Accounting Office, Biotechnology: Role of Institutional Biosafety Committees (Washington, DC: U.S. Government Printing Office, December 1987).

71. Vidaver, A., head, Department of Plant Pathology, University of Nebraska, personal communication, August 1990.

72. Vogel, D., Department of Political Science, University of California at Berkeley, personal communication, November 1989.

73. Vogel, D., National Styles of Regulation: Environmental Policy in Great Britain and the United States (Ithaca, NY: Cornell University Press, 1986).

74. Wilson, J. Q., Bureaucracy: What Government Agencies Do and Why They Do It (New York, NY: Basic Books, 1989).

75. Wright, B., "Gene-spliced Pesticide Uncorked in Australia," New Scientist, vol. 121, No. 1654, Mar. 4, 1989, p. 23.

76. Ziehr, H., Gesellschaft $f r$ Biotechnologische Forschung, personal communication, December 1990.

77. Zen, R., and MacKenzie, D., "Germany Lays Down the Law on Genes," New Scientist, vol. 123, No. 1674, July 22, 1989, p. 20. 
Chapter 12

\section{Intellectual Property Protection}

"Ingenuity should receive a liberal encouragement."

Thomas J efferson

"Congress intended statutory subject matter to include anything under the sun made by man.

Chief J ustice Warren Burger majority opinion, Diamond v. Chakrabarty

"What has been is what will be, and what has been done is what will be done; and there is nothing new under the sun.'

Ecclesiastes 1:9 


\section{CONTENTS}

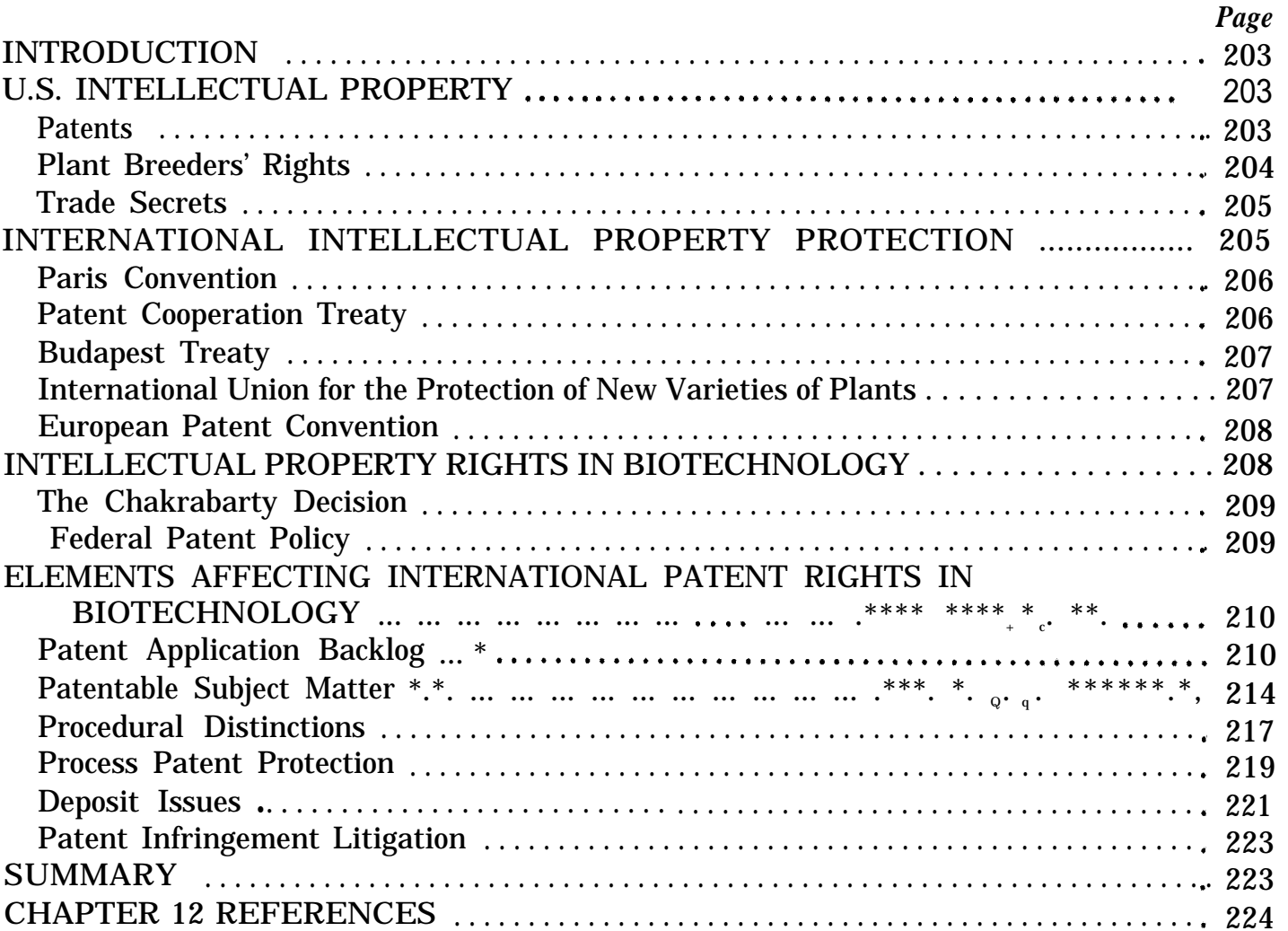

\section{Boxes}

Box Page

12-A. What Can Be Patented? ....................................... 209

12-B. PTO Plan To Reduce Biotechnology Patent Backlog ..................... 213

12-C. Patenting ofAńimals: The Legislative Response ...., ....* ., . . . ...,***** 216

12-D. The Harvard Mouse Goes to Europe .............................. 217

$12-\mathrm{E}$, The Race to the Home Patent Office ............................. 218

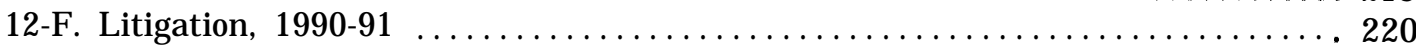

Table Page

12-1. Types of Intellectual Property Protection for Plants ..4****.**.......,....*., 204

12-2. International Intellectual Property Agreements $\ldots \ldots \ldots \ldots \ldots \ldots \ldots \ldots \ldots \ldots . \ldots \ldots$

12-3. Member Countries, Paris Union Convention ....................... 206

12-4. Member Countries, Patent Cooperation Treaty ........................ 207

12-5. Member Countries, Budapest Treaty on the International Recognition of

Micro-organisms for the Purposes of Patent Procedure . . . . . . . . . . . . . . . . 207

12-6. U.S. Depositories Recognized Under the Budapest Treaty .* .+* ....**,..... 208

12-7. Member Countries, Union for the Protection of New Varieties of Plants . . . . . . 208

12-8. Member Countries, European Patent Convention .......................... 208

12-9. Average Waiting Period, Application to Issue, for

Biotechnology Patents, 1989 


\section{Intellectual Property Protection}

\section{INTRODUCTION}

Intellectual property law, which provides a personal property interest in the work of the mind, is of increasing importance to people who use biotechnology to create new inventions. Intellectual property involves several areas of the law: patent, copyright, trademark, trade secret, and plant variety protection. All affect emerging hightechnology industries because they provide incentives for individuals and organizations to invest in and carry out research and development $(R \& D)$, while adding important technological information and products into commerce.

The 1980s provided a harvest of new biotechnological processes and products as well as incentive for research for future inventions. In industries affected by biotechnology, old law is merging with new biological technology, resulting in novel questions regarding the ownership of intellectual property. For example:

1. Which areas of intellectual property are most relevant to biotechnology?

2. What can be patented?

3. How broad in scope can a patent be?

4. Is U.S. Iaw adequate to protect inventions created through biotechnology?

5. Will inventors receive adequate worldwide protection for their discoveries?

When discussing a nation's competitiveness in industries fostered by the new biology, protection of intellectual property is seen by many as a paramount consideration. This chapter briefly outlines the types of intellectual property protection available in the United States to protect biological inventions, the international agreements that may affect intellectual rights in biotechnology, how U.S. patent law impacts on new inventions created through biotechnology, and emerging issues that affect commercialization of biotechnology-related patents.

\section{U.S. INTELLECTUAL PROPERTY}

Intellectual property protection encompasses several areas of statutory and common law: patent, copyright, trademark, trade secret, and plant variety protection. Three categories-patents, trade secrets, and plant variety protection-are particularly important to biotechnology and are the focus of this chapter's discussion.

\section{Patents}

United States (U. S.) patent law has its roots in the Constitution, which gives Congress broad powers to "promote the Progress of Science and useful Arts, by securing for limited times to authors and inventors the exclusive right to their respective writings and discoveries' (Article I, Section 8). The first patent act was enacted by Congress in 1790 and, though amended several times, has retained its broad scope as to what can be patented.

A patent is a grant issued by the U.S. Government that gives the patent owner the right to exclude all others from making, using, or selling the invention within the United States, its territories, and possessions, during the term of the patent (35 U.S.C. 154). There are three types of patents. The most common type-sometimes referred to as a utility patentcovers processes, machines, manufactures, and compositions of matter. A second category, patents for plants, includes cultivated sports, mutants, hybrids, and newly found seedlings. A third category, patents for designs, is not relevant to biotechnology-related inventions. To qualify for utility patent protection in the United States, an invention must meet several requirements:

. it must be a process, machine, manufacture, or composition of matter (35 U.S.C. 101);

- it must be new, useful, and not obvious (35 U.S.C. 101-103); and

- it must be disclosed in sufficient detail to enable a person skilled in the same or the most clearly related area of technology to construct and operate it (35 U.S.C. 112).

Patents serve two important policy objectives:

- by rewarding successful efforts, a patent provides inventors and their backers with incentive to risk time and money in R\&D; and

- by requiring disclosure of the manner and process of making an invention, a patent encourages public disclosure of otherwise se- 
cret information, so that others are able to use it.

Although a patent gives the inventor the right to exclude others from making, using, or selling the invention for 17 years, it does not grant the inventor any affirmative right to make or use an invention. Commercial use of a patented invention, just like other products, can be regulated by Federal, State, or local law.

Once obtained, a patent has a term of 17 years, assuming that maintenance fees are paid (35 U.S.C. 154). One exception to this general term of 17 years is relevant to biotechnology: where a patent claims a human drug product, medical device, food, or col or additive that has undergone regulatory review prior to approval for commercial marketing or use by the Food and Drug Administration (FDA), the patent may be eligible for an extension of up to 5 years, if certain conditions are satisfied (35 U.S.C. 156).

\section{Plant Breeders' Rights}

Intellectual property protection for plant life is based on several statutes (e.g., the Plant Patent Act, Plant Variety Protection Act, and 35 U.S.C. 101), a decision by the U.S. Patent and Trademark Office (PTO) Board of Appeals, and recognized trade secret and contract law. These provide a variety of protection for inventions that constitute plant life (see table 12-1).

\section{Plant Patent Act of 1930}

Prior to 1930, no intellectual property rights existed for protecting new plant varieties. Plant breeding and research were conducted primarily by federally funded agricultural experiment stations and, to a limited extent, by amateur breeders. Financial incentives for private breeders were inadequate, since the breeders' sole financial reimbursement was through high sales prices of comparatively few reproductions during the first 2 or 3 years after the variety's initial availability. Once the plant left a breeders' hands, it could be reproduced in unlimited quantity by anyone.

In 1930, Congress passed the Plant Patent Act (PPA) (35 U.S.C. 161-164) to extend patent protection to most new and distinct asexually propagated varieties. The PPA was the first, and to date, only law passed by Congress specifically providing patent protection for living matter. Since then, more than 6,500 plant patents have been issued by
Table 12-1-Types of Intellectual Property Protection for Plants

\begin{tabular}{|c|c|c|}
\hline Type & Citation & Subject matter \\
\hline Plant patent . . & $\ldots \ldots \ldots 35$ U.S.C. 161- & $\begin{array}{l}\text { Asexually repro- } \\
\text { duced varieties }\end{array}$ \\
\hline $\begin{array}{l}\text { Plant variety pr } \\
\text { certificate... }\end{array}$ & $\begin{array}{l}\text { protection } \\
\ldots \ldots \ldots \ldots 7 \text { U.S.C. } 2321 \\
\text { et seq. }\end{array}$ & $\begin{array}{l}\text { Sexually reproduced } \\
\text { varieties }\end{array}$ \\
\hline Utilitypatent. . & $\begin{array}{c}\ldots \ldots 735 \text { U.S.C. } 101 \\
\text { et seq. }\end{array}$ & $\begin{array}{l}\text { Process, machine, } \\
\text { manufacture, } \\
\text { composition of } \\
\text { matter }\end{array}$ \\
\hline Trade secret . & ........ State law & $\begin{array}{l}\text { Information used in } \\
\text { trade or business } \\
\text { that is kept secret }\end{array}$ \\
\hline
\end{tabular}

PTO covering flowering plants, ornamental and fruit trees, nut trees, grapes, and vegetable crops. Plant patents cannot be obtained for seeds, tubers, biotechnology processes, recombinant DNA (rDNA), or genes (23). On average, more than 225 plant patents are issued each year (34).

\section{Plant Variety Protection Act of 1970}

Commercial and international developments between 1930 and 1970 influenced deliberations in the United States to protect sexually reproduced plants. Plant breeders had developed new sexually reproducing plants that could replicate 'true-to-type' but could not be patented under the PPA. In 1961, several European countries formed the International Union for the Protection of New Varieties of Plants (UPOV) to protect breeders' rights. Unlike breeders in UPOV countries, U.S. breeders had no law protecting their inventions, except for asexually reproduced plants covered by the PPA.

The Plant Variety Protection Act (PVPA) (7 U.S.C. 2321 et seq.) was enacted by Congress in 1970 , to provide patent-like protection for certain types of new, sexually reproduced plant species. It is mainly of interest to breeders and farmers of such sexually reproduced crops as: wheat, alfalfa, soybeans, cotton, corn, lettuce, soybeans, and watermelon (9).

Although PVPA is not a patent statute, the protection it provides to breeders of new plant varieties is similar in concept to patent protection. The act is administered by the U.S. Department of Agriculture (USDA). Upon application to USDA and examination by this agency, a plant variety protection certificate may be issued on any novel 
variety of sexually reproduced plant--other than fungi, bacteria, or a frost-generation hybrid. The novel variety must have distinctiveness, uniformity, and stability. Amendments in 1980 (Public Law 96-574) added protection for six vegetable crops and extended coverage to 18 years so the PVPA would be consistent with UPOV provisions.

Under PVPA, the breeder can exclude others from selling, offering for sale, reproducing (sexually or asexually), producing a hybrid from the variety, and importing or exporting the protected variety.

PVPA contains two important exclusions to a certificate holder's protection:

. a research exemption that precludes a breeder from excluding others from using the protected variety to develop new varieties; and

a farmers' exemption which allows an individual whose primary occupation is growing crops for sale, for other than reproductive purposes, to save protected seed for use on his or her farm or to sell to people whose primary occupation also is growing crops.

From 1970 through 1988, 2,783 applications for plant variety protection certificates were filed with the USDA for some 100 different crops. By December 31, 1988,2,133 certificates had been issued, and 274 applications were pending. Another 376 applications had been abandoned, withdrawn, declared ineligible, or denied (34).

\section{Utility Patents for Plants}

In addition to specified plant patent and plant variety protection, U.S. inventors may also seek utility patent protection for plants. In 1985, the PTO Board of Appeals and Interferences ruled, in Ex parte Hibberd (16), that a corn plant containing an increased level of tryptophan, an amino acid, was patentable subject matter under 35 U.S.C. 101. Since the Hibberd ruling, utility patents have been granted on plants.

\section{Trade Secrets}

Trade secrets extend protection to information used in one's trade or business, that is maintained in secret by its owner and provides a competitive business advantage over those not having the information. A plan, process, tool, mechanism, recipe, chemical compound, customer list, or for-
Table 12-2-International Intellectual Property Agreements

\begin{tabular}{|c|c|c|}
\hline Agreement & $\begin{array}{l}\text { Entered } \\
\text { into force }\end{array}$ & $\begin{array}{l}\text { Number of } \\
\text { signatories }\end{array}$ \\
\hline Paris Union Convention . ...... & July 1884 & 100 \\
\hline $\begin{array}{l}\text { Union for the Protection } \\
\text { New Varieties of Plants. }\end{array}$ & August 1968 & 19 \\
\hline European Patent Convention .. & October 1977 & 14 \\
\hline Patent Cooperation Treaty ... & January 1978 & 45 \\
\hline Budapest Treaty . . . . . . & August 1980 & 23 \\
\hline
\end{tabular}

SOURCE: Office of Technology Assessment, 1991.

mula, all are examples of information that can be maintained as trade secrets.

Unlike patents (which are governed exclusively by Federal law), trade secrets are the subject of State law. The theft of a trade secret is a tort, and action lies against the thief for misappropriation. Trade secret law promotes two beneficial ends: it encourages commercial morality and fair dealing, and it encourages research and innovation. Unlike patent law, however, trade secret law does not encourage public disclosure of technical information.

If a trade secret is disclosed in a nonconfidential reamer, it is lost forever. Trade secret rights require that a trade secret be disclosed in confidence only to those having a reasonable need to know (e.g., employees). Measures must be taken to prevent disclosure of the trade secret to the public or to competitors (e.g., expressly identifying the information as a trade secret and prohibiting its disclosure).

\section{INTERNATIONAL INTELLECTUAL PROPERTY PROTECTION}

The need for protection of intellectual property is well accepted inmost nations. Formal patent statutes were first enacted by England in the 1600s; the United States and France adopted laws in the late 1700s. With the development of international trade, patent protection was formally adopted by other nations, and mechanisms were adopted to harmonize intellectual property rights among-trading nations.

Several international agreements are relevant to protecting biological inventions (see table 12-2). These agreements provide comity, in the area of patents, plant breeders' rights, and deposit of biological materials. 
Table 12-3--Member Countries, Paris Union Convention

\begin{tabular}{|c|c|c|c|}
\hline $\begin{array}{l}\text { Algeria } \\
\text { Argentina } \\
\text { Australia } \\
\text { Austria } \\
\text { Bahamas } \\
\text { Bangladesh } \\
\text { Barbados } \\
\text { Belgium } \\
\text { Benin } \\
\text { Brazil } \\
\text { Bulgaria } \\
\text { Burkina Faso } \\
\text { Burundi } \\
\text { Cameroon } \\
\text { Canada } \\
\text { Central African Republic } \\
\text { Chad } \\
\text { China } \\
\text { Congo } \\
\text { Cuba } \\
\text { Cyprus } \\
\text { Czech and Slovak Federal } \\
\quad \text { Republic } \\
\text { Denmark } \\
\text { Dominican Republic } \\
\text { Egypt }\end{array}$ & $\begin{array}{l}\text { Finland } \\
\text { France } \\
\text { Gabon } \\
\text { Germany } \\
\text { Ghana } \\
\text { Greece } \\
\text { Guinea } \\
\text { Guinea-Bissau } \\
\text { Haiti } \\
\text { Holy See } \\
\text { Hungary } \\
\text { Iceland } \\
\text { Indonesia } \\
\text { Iran } \\
\text { Iraq } \\
\text { Ireland } \\
\text { Israel } \\
\text { Italy } \\
\text { Ivory Coast } \\
\text { Japan } \\
\text { Jordan } \\
\text { Kenya } \\
\text { Korea, Democratic People's } \\
\text { Republic of } \\
\text { Korea, Republic of } \\
\text { Lebanon }\end{array}$ & $\begin{array}{l}\text { Lesotho } \\
\text { Libya } \\
\text { Liechtenstein } \\
\text { Luxembourg } \\
\text { Madagascar } \\
\text { Malawi } \\
\text { Malaysia } \\
\text { Mali } \\
\text { Malta } \\
\text { Mauritania } \\
\text { Mauritius } \\
\text { Mexico } \\
\text { Monaco } \\
\text { Mongolia } \\
\text { Morocco } \\
\text { The Netherlands } \\
\text { New Zealand } \\
\text { Niger } \\
\text { Nigeria } \\
\text { Norway } \\
\text { Philippines } \\
\text { Poland } \\
\text { Portugal } \\
\text { Romania } \\
\text { Rwanda } \\
\text { San Marino }\end{array}$ & $\begin{array}{l}\text { Senegal } \\
\text { South Africa } \\
\text { Soviet Union } \\
\text { Spain } \\
\text { Sri Lanka } \\
\text { Sudan } \\
\text { Suriname } \\
\text { Sweden } \\
\text { Switzerland } \\
\text { Syria } \\
\text { Togo } \\
\text { Trinidad and Tobago } \\
\text { Tunisia } \\
\text { Turkey } \\
\text { Uganda } \\
\text { United Kingdom } \\
\text { United Republic of Tanzania } \\
\text { United States } \\
\text { Uruguay } \\
\text { Viet Nam } \\
\text { Yugoslavia } \\
\text { Zaire } \\
\text { Zambia } \\
\text { Zimbabwe }\end{array}$ \\
\hline
\end{tabular}

SOURCE: Office of Technology Assessment, 1991.

\section{Paris Convention}

The Paris Convention for the Protection of Industrial Property, first adopted in 1883, is the major international agreement providing basic rights for protecting industrial property. It covers patents, industrial designs, service marks, trade names, indications of source, and unfair competition. The United States ratified this treaty in 1903, and many other nations have adopted it (see table 12-3).

The treaty provides two fundamental rights:

- The principle of national treatment provides that nationals of any signatory nation shall enjoy in all other countries of the union the advantages that each nation's laws grant to its own nationals. The purpose is to eliminate discrimination against foreigners, who, in turn, must observe the conditions and formalities imposed on nationals of the member country in which protection is sought.

- The right of priority enables any resident or national of a member country to, frost, file a patent application in any member country and, thereafter, to file a patent application for the same invention in any of the other member countries within 12 months of the original filing and receive benefit of the original filing date. The effect is to give subsequently filed applications the right of priority established by the first filing date.

The convention permits member nations to enter into separate agreements for the protection of industrial property-as long as the agreements do not contravene the provisions of the convention. This provision has permitted the ratification of other bilateral and multilateral agreements, between nations, addressing specific areas of intellectual property protection.

\section{Patent Cooperation Treaty}

The Patent Cooperation Treaty (PCT) is a worldwide convention, open to the members of any Paris Convention country. It entered into force in 1978, and has been ratified or acceded by 45 countries (see table 12-4). Unlike the Paris Convention, which addresses substantive intellectual property rights, the PCT addresses procedural requirements, aiming to simplify the filing, searching, and publication of international patent applications.

After an application is filed with the patent office of a member nation (usually the national patent office of the country in which the applicant is a resident or national), the application is transmitted to the international bureau of the World Intellectual Property Organization (WIPO) in Geneva. An inter- 
Table 12-4-Member Countries, Patent Cooperation Treaty

\begin{tabular}{ll}
\hline Australia & Korea, Democratic People's \\
Austria & Republic of \\
Barbados & Korea, Republic of \\
Belgium & Liechtenstein \\
Benin & Luxembourg \\
Brazil & Madagascar \\
Bulgaria & Malawi \\
Burkina Faso & Mali \\
Cameroon & Mauritania \\
Canada & Monaco \\
Central African Republic & The Netherlands \\
Chad & Norway \\
Congo & Romania \\
Denmark & Senegal \\
Finland & Soviet Union \\
France & Spain \\
Gabon & Sri Lanka \\
Germany & Sudan \\
Great Britain & Sweden \\
Greece & Switzerland \\
Hungary & Togo \\
Italy & United Kingdom \\
Japan & United States \\
\hline SOURCE: & Rffice of Technology Assesment, \\
\hline
\end{tabular}

SOURCE: Office of Technology Assessment, 1991.

national search is conducted by an appropriate international searching authority (ISA). In the case of U.S.-initiated applications, the ISA is the U.S. Patent and Trademark Office or the European Patent Office. Following the international search, the application and the search report are published by WIPO, and copies are provided to each of the designated offices in the countries where protection is sought. These countries then subject the application to their own national procedures.

\section{Budapest Treaty}

United States patent law requires applicants to file a specification (i.e., a writing, specifying in clear, concise terms how to make and use the invention and the best mode contemplated by the applicant for carrying out the invention). The patenting of living organisms presents a unique administrative problem, because it is the only known art where-in some instances-this requirement cannot be satisfied with words alone. In these instances, it is necessary to deposit micro-organisms and plants for patent purposes. This practice has become commonplace internationally, leading to the need to harmonize deposit requirements worldwide.

The Budapest Treaty on the International Recognition of the Deposit of Microorganisms for the Purposes of Patent Procedure is a vehicle harmonizing such requirements. It entered into force in 1980,
Table 12-5-Member Countries, Budapest Treaty on the International Recognition of Micro-organisms for the Purposes of Patent Procedure

\begin{tabular}{ll}
\hline Australia & Japan \\
Austria & Korea, Republic of \\
Belgium & Liechtenstein \\
Bulgaria & The Netherlands \\
Czech and Slovak Federal & Norway \\
Republic & Philippines \\
Denmark & Soviet Union \\
Finland & Spain \\
France & Sweden \\
Germany & Switzerland \\
Hungary & United Kingdom \\
Italy & United States \\
\hline SOURCE: Office of Technology Assessment, 1991.
\end{tabular}

and provides that member states recognize a deposit of a micro-organism strain made in another country for their own patent procedures. Currently, 23 nations are members of the Budapest Treaty (see table 12-5).

The key element of the treaty is the establishment of a series of approved International Depositary Authorities (IDAs). These depositories are recognized by all member countries for deposit purposes. Once a viable deposit is made in an IDA, two facts are recognized: the deposit was made on the indicated date, and any sample furnished by the IDA is a sample of the organism or other replicable material deposited on that date. As of J anuary 1990, a total of 20 depository institutions had acquired IDA status; three are located in the United States (see table 12-6).

\section{International Union for the Protection of New Varieties of Plants}

With the development of plant sciences came the realization that the rights of plant breeders were entirely overlooked in many countries. The patent laws of many countries, for example, specifically excluded the patenting of any type of lifeform. An international conference in 1957, led to the drafting of the International Union for the Protection of $\mathrm{New}$ Varieties of Plants (UPOV); it was signed by several nations in 1961, and entered into force in 1968. Currently, 19 nations are members of UPOV (see table 12-7).

The International Union for the Protection of New Varieties of Plants was designed "to recognize and to ensure the breeder of a new plant variety. . . the right to a special title of protection or of a patent. " The goal was to provide a model for the adoption of 
Table 12-6--U.S. Depositories Recognized Under the Budapest Treaty

\begin{tabular}{l}
\hline American Type Culture Collection \\
12301 Parklawn Drive \\
Rockville, MD 20852 \\
A private, nonprofit institution organized in 1925 for the \\
purposes of acquiring, preserving, and distributing cultures of \\
micro-organisms to scientists. Currently holds an estimated \\
8,000 deposits for patent purposes. \\
Northern Regional Research Laboratory \\
$1815 \mathrm{~N}$. University Street \\
Peoria, IL 61604 \\
Established in 1940 as part of the U.S. Department of \\
Agriculture for the study of micro-organisms of agricultural and \\
industrial importance. currently has approximately 3,000 \\
cultures on deposit. \\
In Vitro International, Inc. (IVI) \\
611 (P) Hammonds Ferry Road \\
Linthicum, MD 21090 \\
Incorporated in 1983 as a for-profit company for the purpose of \\
accepting cultures for patent purposes. Approximately 100 \\
cultures are on deposit. \\
SouRCE: Office of Technology Assessment, 1991.
\end{tabular}

breeders' rights statutes in individual countries and to assure reciprocity between countries in the convention.

To obtain protection in each member country, it is currently necessary to file a separate application in each country. There is no central filing system, and international protection is not available by filing in only one member country. While both sexually and asexually reproduced plants can be protected, the UPOV convention requires that each protected variety have a specific, unique name for registration purposes. In all member nations except the United States, new varieties are subject to official inspection establishing that conditions for protection are satisfied.

The UPOV Convention is presently under consideration for revision. A recent diplomatic conference, held in March 1991, may lead to revision of Article 2 , which currently does not allow both patent and breeders' rights for the same botanical species or genus (35).

\section{European Patent Convention}

The European Patent Convention (EPC) is an agreement between European nations to centralize and standardize patent law and procedure. To date, 14 countries are members of the EPC, which took effect in 1977 (see table 12-8).

Because the patchwork of traditional national patent systems in Europe was recognized as creating
Table 12-7-Member Countries, Union for the Protection of New Varieties of Plants

\begin{tabular}{ll}
\hline Australia & The Netherlands \\
Belgium & New Zealand \\
Denmark & Poland \\
France & South Africa \\
Germany & Spain \\
Hungary & Sweden \\
Ireland & Switzerland \\
Israel & United Kingdom \\
Italy & United States \\
Japan & \\
\hline
\end{tabular}

SOURCE: Office of Technology Assessment, 1991.

Table 12-8-Member Countries, European Patent Convention

\begin{tabular}{ll}
\hline Austria & Italy \\
Belgium & Liechtenstein \\
France & Luxembourg \\
Denmark & The Netherlands \\
Germany & Spain \\
Great Britain & Sweden \\
Greece & Switzerland \\
\hline
\end{tabular}

SOURCE: Office of Technology Assessment, 1991.

a potential conflict with the need for free trade, EPC established the so-called "European patent," a single, supranational patent obtained by filing one application with the European Patent Office in Munich. Once granted, the patent matures into a bundle of individual patents-one in each member country. The ultimate goal is for each member country to adopt, in its national law, the same substantive and procedural law of patents established by the EPC agreement.

EPC streamlines procedural requirements for applicants seeking a European patent. It avoids duplicate filing, searching, and examination costs; minimizes the number of translations that must be made; and economizes on the use of professional time, both on the part of the applicant's domestic patent representative and representatives in countries where protection is sought (3).

\section{INTELLECTUAL PROPERTY RIGHTS IN BIOTECHNOLOGY}

The merging of intellectual property law and biotechnology represents the joining of old law with new technology. In theory, statutes designed to facilitate creation of unforeseen technologies and reward inventors for their creativity should blend easily with the inventions of biotechnology. Although intellectual property laws have fostered 
$R \& D$ in biotechnology, novel legal and social questions have also arisen.

During the 1980s, events in the United States shaped the application of intellectual property law to biotechnology. First, the Supreme Court was called on to determine whether a living organism could be patented. Second, Congress and the executive branch took actions making it easier for federally funded inventions to become commercialized. These actions ignited a flood of biotechnology patent activity. By 1989, an examining unit specifically for biotechnology was established at the PTO.

\section{The Chakrabarty Decision}

The development of rDNA technology in the 1970's led to debate regarding what constitutes a patentable invention. Although patents on biotechnological processes had been issued since the 1800 's, PTO did not permit patents on living products created by the technology, on the grounds that such matter were "products of nature" and not statutory subject matter as defined by 35 U.S.C. 101 (see box 12-A).

Although proposed patent claims were rejected if directed to living organisms per se, patent protection was granted for many compositions containing living things (e.g., sterility test devices containing living microbial spores, food yeast compositions, vaccines containing attenuated bacteria, milky spore insecticides, and various dairy products) (29).

The issue of whether a genetically engineered organism could be patented was addressed by the Supreme Court in 1980, in Diamond v. Chakrabarty (10). In this case, the patent applicant had developed a genetically engineered, but not recombinant, bacterium capable of breaking down multiple components of crude oil. Because no naturally occurring bacterium possessed this property, Chakrabarty's bacterium was thought to have significant value for the cleanup of oil spills.

Chakrabarty filed a patent application with 36 claims. Process claims for the method of producing the bacteria were allowed by the PTO; but claims for the bacterium, itself, were rejected on two grounds: 1) micro-organisms are 'products of nature,' and 2) as living things, micro-organisms are not patentable subject matter under 35 U.S.C. 101. The case was eventually heard by the Supreme Court; the justices, in a 5-4 ruling, held that a live, human-made

\section{Box 12-A-What Can Be Patented?}

One section of the U.S. patent law, 35 U.S.C. 101, was part of the first U.S. patent law enacted by Congress in 1790, It defines what constitutes a patentable invention:

Whoever invents or disoovers any new and useful process, machine, manufacture, or composition of matter, or any new and useful improvement thereof, may obtain a patent therefore, subject to the conditions and requirements of this title.

This section of the patent Code has changed little, and its broad language has made possible the issuance of more than 5 million U.S. patents.

SOURCE: Mice of Technology Assessment, 1991.

micro-organism is patentable subject matter under section 101 as a "manufacture" or "composition of matter.

The Chakrabarty decision provided a judicial framework for subsequent PTO decisions to issue patents under 35 U.S.C. 101 for plants and nonhuman animals. The decision also provided great stimulus for the economic development of biotechnology processes and products in the 1980's.

\section{Federal Patent Policy}

Other revisions in Federal patent policy encouraged increased patent activity from federally funded research. Prior to 1980, no single patent policy existed for such research, resulting in the development of 26 separate patent policies by various government agencies (33).

To promote efforts to develop a uniform patent policy that would encourage cooperative relationships and to commercialize government-funded inventions, Congress passed the Patent and Trademark Amendments of 1980 (Public Law 96-517) and amendments in 1984 (Public Law 98-260). The law allows nonprofit institutions (including universities) and small businesses to retain title to patents arising out of federally funded research, with the Federal agency retaining a nonexclusive, worldwide license. Universities are required to share royalties with the inventor and to use any net income for research and education (35 U.S.C. 202).

The law, which gave statutory preference to small businesses and nonprofit organizations, was extended by executive order to larger businesses (with 
some exceptions) in 1983 (24). The Technology Transfer Act of 1986 (Public Law 99-502) granted Federal authority to form consortia with private concerns. Executive order 12591, issued in 1987, further encouraged technology-transfer programs, including the transfer of patent rights to government grantees.

\section{ELEMENTS AFFECTING INTERNATIONAL PATENT RIGHTS IN BIOTECHNOLOGY}

A number of differences exist among nations, regarding intellectual property protection for biotechnological inventions. International agreements have set norms for substantive intellectual property protection (e.g., national treatment under the Paris Convention) and for procedures for obtaining patents (e.g., simplified searching and filing under the Patent Cooperation Treaty and deposits under the Budapest Treaty), but further harmonization of intellectual property law is seen by many as necessary for improved trade and effective protection of intellectual property in a global marketplace.

Biotechnology is a particularly good example of technology where patent questions are raised by rapid scientific and technological change. The major international agreements governing intellectual property were ratified prior to the development of new biotechnological inventions (25). As legal issues are developed and dealt with in various nations, a primary consideration arises: what impact do these issues have on the development of an international marketplace for inventions developed by biotechnological means?

Intellectual property is an important component of U.S. competitiveness in fields relying on biotechnology. Without adequate international protection, this valuable asset is seriously tarnished and diminished in value, and future investment is discouraged. American competitiveness in this area focuses largely on securing patents, both in the United States and abroad, while understanding and operating smoothly within the procedural requirements for obtaining substantive patent rights.

This section focuses on six elements that affect U.S. competitiveness based on international intellectual property rights for biotechnology:
1. the patent application backlog,

2. patentable subject matter,

3. procedural distinctions,

4. process patent protection,

5. deposit issues, and

6. patent infringement litigation.

\section{Patent Application Backlog}

\section{The Process}

When a patent application is received by the PTO, it is assigned to 1 of 16 examining groups in the agency. Each examining group includes a number of art units, each responsible for a specific area of technology. Examiners in the art units review patent applications to decide whether the invention claimed in the application is entitled to patent protection. The examination process includes a search through U.S. patents, available foreign patent documents, and relevant nonpatent literature.

After the examiner decides whether to grant a patent, the PTO, through a procedure called an action, notifies the applicant of the examiner's decision, or any objection or requirement, and provides information that may assist the applicant in judging whether to pursue the application. If the invention is not considered patentable subject matter, the claims will be rejected. Some or all of the claims may be rejected on the first action by the examiner; relatively few applications result in patents as originally filed (31).

If an application is rejected or objected to, the applicant can either abandon the application or request a reconsideration, responding in writing to every rejection raised by the PTO. The PTO then issues a second action, which is normally final. Following a second action rejection, the applicant is normally limited to administrative review (either through the PTO Board of Patent Appeals and Interferences or Federal court action) or to filing a continuing application.

Continuing applications are an alternative to appealing the rejected application. If the application is filed within an allotted period of time and refers to an earlier application, the applicant is entitled to the date of the earliest filed application for subject matter common to both applications (35 U.S.C. 120). The ability to maintain the earliest filing date is an important benefit to the applicant, since the earlier priority date determines patent rights. 


\section{Patent Examiners}

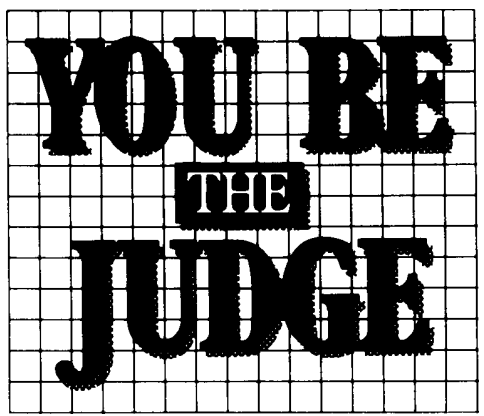

You could play a vital role in the advancement of microbiology as a Patent Examiner at the U.S. Patent and Trademark Office. You'll continue a 200-year old tradition of fostering American innovation by evaluating patent applications involving recombinant DNA, molecular and cellular immunology, molecular genetics, microorganisms, cell biology, cell culture, fermentation, enzymology and clinical chemistry.

This challenge requires a minimum of a four-year degree in Molecular Biology,

Biochemistry, Immunology, Enzymology, Embryology, Protein Chemistry, Microbiology or Cell Biology.

$\mathrm{A} \mathrm{PhD}$ or MS degree with relevant research experience preferred. A BS degree with significant research experience will be considered. These research areas would be beneficial: DNA cloning, protein chemis- try, gene expression, sequencing techniques, muteins, hybridoma technologies, monoclinal antibody applications, mammalian or plant cell lines, cell culture, immunossays, hybridization techniques, fermentation, enzymatic reaction, diagnostics, and automation of clinical analysis.

We offer a salary commensurate with experience, complete benefits and an excellent location in Arlington, VA. Contact the Patent \& Trademark Office, Office of Personnel, One

Crystal Park, Suite 700, Washington, D.C. 20231. Or call toll-free: 800-368-3064 or (703) 557-3631 in the Washington, D.C. area. An equal opportunity employer.

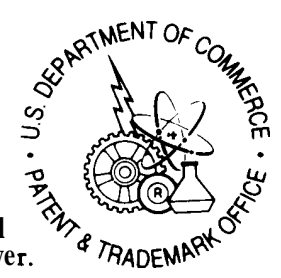

Photo credit: Patent and Trademark Office

PTO add for patent examiners.

\section{The Problem}

The abnormally long patent application review and action by PTO is frequently cited as the primary impediment to commercialization of biotechnology-related processes and products. Recent congressional reports reveal the pendency period for biotechnology patent applications is longer than that of any other technology (average pendency is 36.1 months from the date of application to the date of issue, compared to 21.0 months for all patents issued (30). Several reasons have been cited:

. due to the nature of the technology, its newness, and its rapid development, the level of technical scrutiny required to process an application for a biotechnology patent exceeds that required to process patent applications in most other areas of technology (30);
- high turnover among patent examiners, lured to the private sector by higher pay (8);

- failure to retain senior staff, well-trained in biotechnology patent prosecution, results in a lack of continuity, increased examination time per application, and inconsistent examination; and

- the pressure on examiners to meet certain efficiency quotas results in increased pressure and job disenchantment, further causing depletion of personnel.

Two key elements play a part in the patent application backlog: 1) the number of applications received by PTO and 2 ) the amount of time it takes for an application to be acted on. The number of biotechnology applications filed has grown at a significantly higher average rate-20 percent-than 
that for all patent applications-2.9 percent-from 1983 through 1988 (30). On the other hand, the amount of time between filing and first action dedined-from 14.5 months in 1989 to 13.1 months in $1990(30,31)$. Despite the improved performance by PTO in reaching first actions, total pendancy appears to be increasing.

The effect of delays in obtaining patents varies between different subgroups in the biotechnology examining area. Although the average pendency of a biotechnology patent application is 36.1 months, the average time is shorter for applications related to plants and animals (24.9 months) and longer for applications related to genetic engineering (47.4 months) (see table 12-9). The actual time required to process inventions disclosed in patent applications is longer than the pendancy reported by the PTO, because they measure pendancy of applications, not inventions. A patent granted on an invention may be the result of a chain of replacement applications, or continuing applications. For example, during 1989, about one-third of all backlogged patent applications resulted from a chain of continuing applications. Factoring in the chain of continuing applications adds 9 months to PTO's reported average patent pendance of 26.3 months (31).

While there is clearly a difference between the average pendancy in biotechnology, as compared to an average pendancy for all technologies in the PTO, patents, even in biotechnology, are granted faster in the United States than in any major examining office in the world-and faster by a significant amount of time (35). In J apan and Europe, for example, pendancy time does not normally include the 18 months prior to publication of the application. In J apan, publication often leads to oppositions being filed against the applicationnearly 30 such oppositions were filed against the patent for human tissue plasminogen activator (tPA) in J apan-further delaying the issuance of the patent (35).

\section{Effect on Commercialization}

Because patents are one of the most important assets of a startup, high-technology company, failure to procure timely patent protection can adversely affect a company's ability to secure the financing needed to develop processes and products. From the viewpoint of an individual inventor or assignee of a patent, several problems are apparent.
Table 12-9-Average Waiting Period, Application to Issue, for Biotechnology Patents, 1989

\begin{tabular}{|c|c|c|}
\hline Art unit/description & $\begin{array}{l}\text { Total } \\
\text { patents issued }\end{array}$ & $\begin{array}{c}\text { Average } \\
\text { months }\end{array}$ \\
\hline $\begin{array}{l}\text { 181/equipment. } \ldots \ldots \ldots \ldots \ldots \\
\text { 182/immunology } \ldots \ldots \ldots \ldots\end{array}$ & $\begin{array}{l}723 \\
417\end{array}$ & $\begin{array}{l}37.2 \\
44.1\end{array}$ \\
\hline $\begin{array}{l}183 / \text { biochemicals } \ldots \ldots \ldots \ldots \\
184 \text { /plants } \& \text { animals } \ldots \ldots \ldots\end{array}$ & $\begin{array}{l}665 \\
754\end{array}$ & $\begin{array}{l}36.7 \\
24.9\end{array}$ \\
\hline $185 /$ genetic engineering . . . . . & 307 & 47.4 \\
\hline $\begin{array}{l}\text { 186/biochemicals } \ldots \ldots \ldots \ldots \\
187 / \text { equipment and }\end{array}$ & 268 & 37.7 \\
\hline immunology $\ldots \ldots \ldots \ldots$ & 1 & 33.4 \\
\hline 188/microbiology . . . . . . . . & 0 & 0.0 \\
\hline Biotechnology total . . . . . . & 3,135 & 36.1 \\
\hline
\end{tabular}

SOURCE: General Accounting Office, Biotechnology: Processing Delays Continue for Growing Backlog of Patent Applications, 1990.

First, the delay in getting a patent can slow down efforts to commercialize the invention. A second problem involves filing for protection in foreign countries. Under the Paris Convention, an applicant filing in the United States has 1 year to file in foreign countries and obtain the benefit of the U.S. filing date. As a practical matter, this decision is typically postponed until close to the end of the frost year, because of the considerable expense of foreign filing. Thus, it is desirable to have the U.S. patent examiner decide on patentability prior to the close of the 1 year period, so that the applicant has the benefit of the initial PTO search and examiner reaction before deciding whether foreign filing costs are justified. Without the PTO action, the decision is much more difficult and sometimes involves committing substantial funds, even when patent protection is not likely (7).

A third problem relates to the fact that pending U.S. patent applications are secret (35 U.S.C. 122). When an inventor makes a preliminary search, to determine whether the invention is novel, access to information is limited only to the available prior art (i.e., printed scientific and trade publications, foreign published applications, and issued patents). The backlog of patent applications creates a large body of hidden knowledge that may later become prior art. As a result, an inventor may file an application, only to learn years later that the application will be rejected, because a previously filed application made the same claims or claims broad enough to encompass the claims made in the, later application. If the backlog could be shortened, the amount of potentially hidden prior art would be reduced proportionately.

The delay to an inventor caused by the patent application backlog results in increased costs for 
processing the application. Inmost fields, the cost of receiving a U.S. patent runs between $\$ 3,000$ and $\$ 6,000$. Biotechnology patents generally cost between $\$ 8,000$ and $\$ 15,000$. This difference is primarily due to attorney fees and the time involved responding to patent examiners who are not sufficiently skilled in biotechnology patent prosecution (18).

\section{Proposed Solutions}

In an attempt to reduce the backlog of biotechnology patent applications, the PTO instituted a 13point, catch up plan (see box 12-B). The plan has not succeeded in its goal of reducing the backlog of patent applications. During calendar year 1989 and the frost half of 1990, the inventory of unexamined biotechnology patent applications increased by approximately 33 percent (from about 6,200 to about $8,200)(31)$.

The most immediate way for an applicant to avoid the current backlog is to request accelerated examination. This is done with a written petition describing the applicant's preliminary search and description of the prior art. The additional fee of $\$ 72$, to request accelerated examination, is worthwhile for applicants needing to establish a definitive patent position for investors or licensees. Of approximately 5,000 biotechnology-related applications received by the PTO in 1987, only 17 were petitions requesting accelerated examination (30). Legal and business considerations may explain the limited use of accelerated examination. From a legal standpoint, the PTO practice requires that an applicant seeking an accelerated examination provide a complete search report of literature and prior art relevant to the application. Failure to do so can result in a rejected application. (35) From a business perspective, there may be little incentive to have the 17-year patent term begin to run until a product is ready for market. From this perspective, a company wants their patents to issue more slowly than those patents belonging to a competitor (12).

Suggestions for reducing the backlog include:

- increased pay, benefits, and training for PTO personnel to enhance job satisfaction and performance.

- cutting down on the excessive volume of paper that an applicant sometimes provides an examiner to support the application (5) .

\section{Box 12-B-PTO Plan To Reduce Biotechnology Patent Backlog}

In 1988, the Patent and Trademark Office initiated a 13-point plan to process biotechnology patent applications more expeditiously:

1 , Creating a new examining group to deal exclusively with the field of biotechnology. Called "Group 180," this examining unit consolidated units and examiners from preexisting examining groups.

2. Adjusting examiner complexity factors.

3. Obtaining greater hiring authority from the Office of Personnel Management.

4. Obtaining special engineering pay rates for new examiners.

5. Hiring as many new biotechnology examiners as can be trained by senior examiner staff.

6. Increasing overtime for several years to the maximum level sustainable.

7. Liberalizing and publicizing, as necessary, the procedure for requesting accelerated examination.

8. Identifying examiners in other groups who can be transferred and retained to examine biotechnology applications in a reasonable period of time.

9. Improving communication about Patent Office goals and reeds and improving morale in the new biotechnology examining group.

10. Examining search tools-especially for searching DNA, RNA, and protein sequences.

11. Enhancing technical and legal update training for all examiners.

12. Stimulating higher productivity in the new biotechnology examining group.

13. Hiring and initially training new examiners for the biotechnology group in other examining groups.

SOURCE: General Accounting Office, Biotechnology: Backlog of Patent Applications, 1989.

. adoption of a selective examination scheme, whereby applicants select cases for priority treatment and defer less important applications for later examination.

. adoption of the 18-month publication system found in many other countries, whereby all applications are published within a certain time period, thus decreasing the amount of potential hidden prior art; and 
- Adoption of a payback system, similar to Federal medical training grants, whereby, in exchange for educational assistance, Ph.Dlevel graduates would pay back the Federal Government's investment by serving a specified term as an examiner.

As PTO attempts to reduce the patent application backlog, some applicants complain that the quality of patent examination has decreased. Procedural mistakes and a general lack of understanding of the law occasionally results in erroneous actions by patent examiners (e.g., the issuance of overly broad patents, or erroneous rejections). Such errors increase the cost of the patent application process, either through lost opportunities or through refiling and appeal costs.

Others, however, claim that the patent application backlog is not detrimental to U.S. capability in biotechnology for two reasons:

- Despite the U.S. backlog, it takes significantly longer to obtain a biotechnology patent in other countries (35).

. For products that have a long regulatory approval time, the delay in obtaining a patent extends the period of intellectual property protection, since the 17-year term does not begin until the patent is actually issued (l 11 ).

\section{Patentable Subject Matter}

Under U.S. Patent law, four broad areas constitute the core of patentable subject matter: processes, machines, manufactures, and compositions of matter (101). As the Supreme Court noted in Chakrabarty, Congress plainly contemplated that the patent laws would be given wide scope and intended statutory subject matter to include anything under the sun made by man. '

After Chakrabarty, the patenting of microorganisms became commonplace in the United States. In 1985, the PTO's Board of Patent Appeals and Interferences relied on Chakrabarty to rule in Ex parte Hibberd (16) that corn plants, seeds, and plant tissue culture containing an increased level of the amino acid, tryptophan, were patentable subject matter under 35 U.S.C. 101, even though such plants could be protected under the PVPA. Today, a variety of protections-plant patents, plant variety protection certificates, utility patents, and trade secretsexist for inventions that constitute plant life.
In April 1987, the PTO Board of Appeals and Interferences ruled that polyploid oysters were patentable subject matter (15). Subsequently, PTO announced that it would, henceforth, consider nonnaturally occurring, nonhuman, multicellular organisms (including animals) to be patentable subject matter. In April 1988, the first patent on a nonhuman animal was issued to Harvard University for mammals genetically engineered to contain a cancercausing gene (U.S. 4,736,866). Although 120 animal patent applications are pending, no additional patents on animals have issued (35). The PTO policy and the issuance of the sole animal patent initiated a broad public debate and the introduction of legislation in Congress (see box $12-\mathrm{C}$ ).

\section{Europe}

European subject matter law is noteworthy in that 1) a convention exists whereby a number of nations subscribe to one law regarding subject matter patentability; 2) because of a developed science base, the issue of subject matter patentability has arisen in the context of biotechnology; and 3) issues addressed by the European Patent Office highlight similarities and differences with U.S. Iaw.

Article 52(1) of the E.P.C. defines patentable subject matter as inventions that are susceptible to industrial application, are new, and involve an inventive step. In this respect, European and U.S. law both have expansive language defining what can be patented. Unlike U.S. Iaw, which identifies classifications that are patentable (i.e., process, machine, manufacture, and composition of matter), the European provision does not provide a definitive, positive definition of classes of patentable inventions. Instead, Article 52(2) narrows the broad language of Article 52(1) by explicitly excluding from the term "inventions'

- discoveries, scientific theories, and mathematical methods-including naturally occurring products;

- aesthetic creations;

- schemes, rules, and methods for performing mental acts, playing games, or doing business;

- programs for computers; and

- presentations of information.

Article 53(b) stipulates that European patents not be issued for plant or animal varieties and essentially biological processes for the production of plants and animals (with the exception of microbiological 


\section{Stalking}

C.

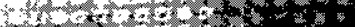

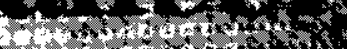

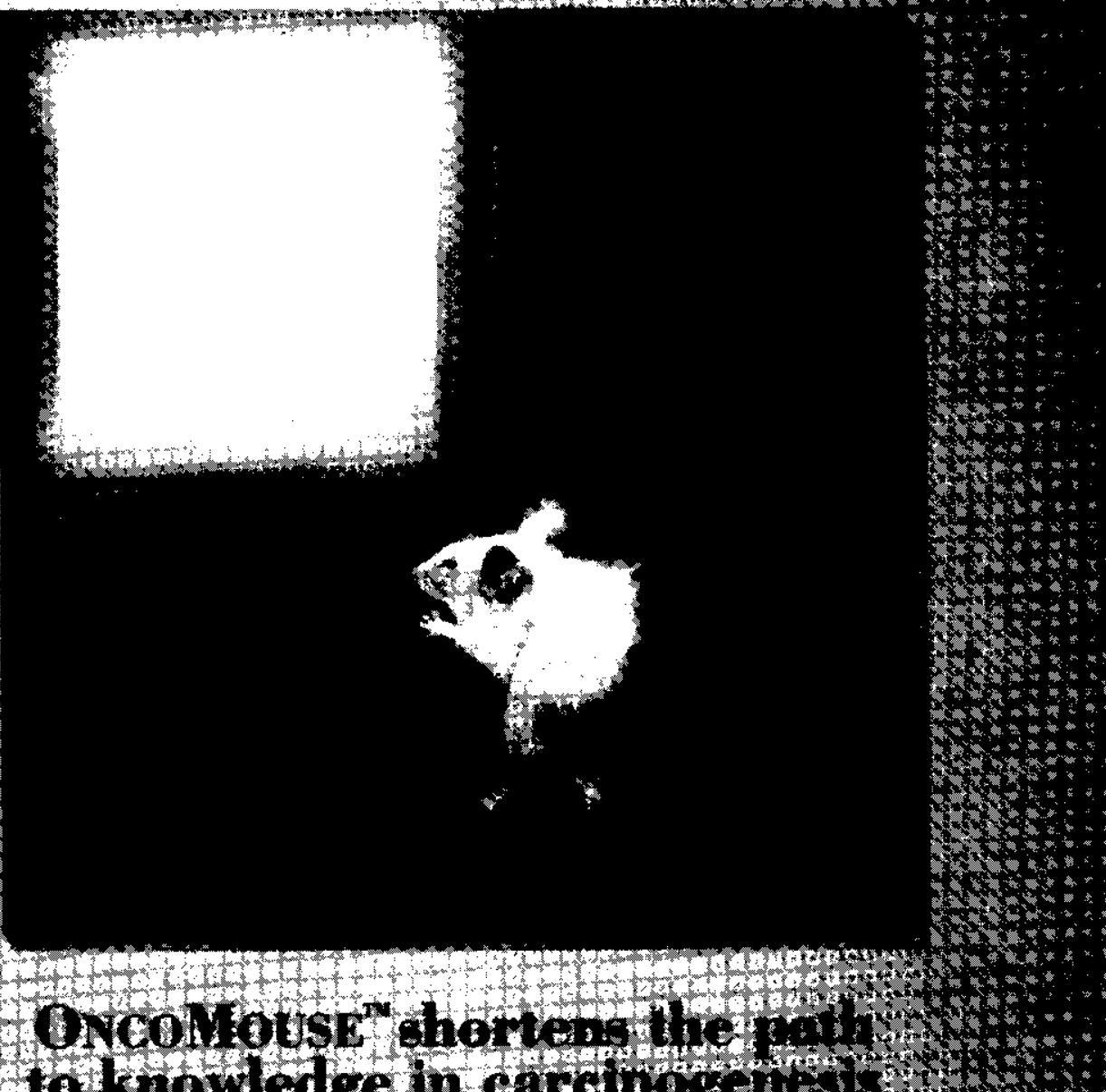

to knowledge in carcin

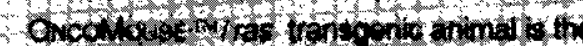

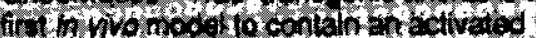

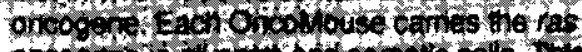

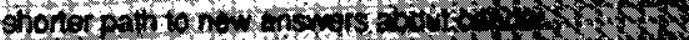

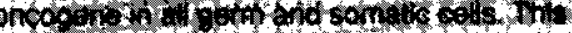
trandome nod avallable commarcially tot W We tist the prosictably undergoes corcino.

- genesis oncol Mouse relably dovolops neo

- plastos within months and ofers you a

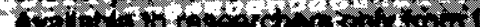

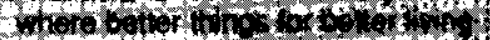

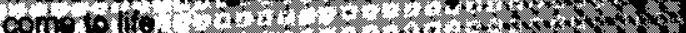

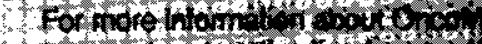

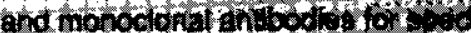

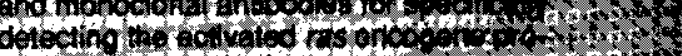
tein oal 1.8005012121
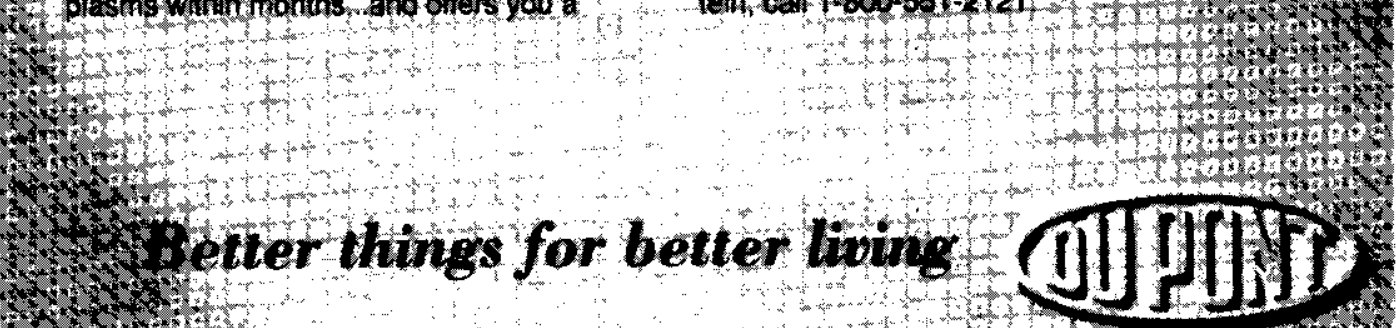

Advertisement for OncoMouse, the subject of the first U.S. patent on a transgenic animal. 


\section{Box 12-C-Patenting of Animals: The Legislative Response}

Several pieces of legislation were introduced in the 100th and 101st sessions of Congress addressing the patentability of animals. The following actions occurred during the 100th Congress (in session during 1987 and 1988):

. An amendment to a supplemental appropriations bill (Senate Amendment 245 to H.R. 1827) to prohibit the use of appropriated funds for the patenting of genetically altered or modified animals. The amendment was adopted by the Senate by voice vote but not adopted by the conference committee.

. H.R. 3119 to establish a 2-year moratorium on the patenting of animals and to revoke previously granted patents.

. S. 2111 to prohibit animal patents and revoke previously granted patents.

-H.R. 4970, the Transgenic Animal Patent Reform Act, to provide that exemptions from infringement for: 1) making or using a patented animal solely for research or experimentation without any commercial intent; or 2) for a person whose occupation is farming, to reproduce through breeding, the use, or to sell a patented transgenic farm animal under certain circumstances; 3) to permit the Patenting and Trademark Office to accept a deposit of biological material; and 4) to declare that human beings are not patentable. The bill was adopted by the House of Representatives, but no action was taken by the Senate.

The following legislation was introduced in the 101st Congress (in session during 1989 and 1990):

-H.R. 1556, similar to H.R. 4970 (see above), later incorporated into H.R. 5598 (a bill addressing several patent-related issues).

-H.R. 3247, to impose a 2-year moratorium on the granting of patents on genetically altered animals, except for animals whose commercialization is subject to a Federal regulatory process that imposes environmental, health and safety, and biomedical ethical standards.

. S. 2169, similar to H.R. 3247 (see above).

SOURCE: Office of Technology Assessment, 1991.

processes or the products thereof). There are two reasons for this approach, adopted in 1973. First, granting patents in this area would create legal and administrative difficulties. Second, plant variety protection enacted in several European nations is the only system applicable to that category of inventions (1).

The question of whether a process is essentially biological depends on the extent of technical human intervention in the process. If such intervention plays a significant part in determining or controlling the desired result, the process is not excluded. According to the EPC, essentially biological processes and specific plant varieties, regardless of whether they were produced by breeding or genetic engineering, are not patentable.

Despite the exclusions in the EPC, patents have issued on microbiological inventions. Plant variety protection statutes generally offer more limited protection than that provided by U.S. law, since protection generally extends only to those varieties specifically set forth in varietal lists compiled by each country.

\section{Comparison of Subject Matter Laws}

The principle of patenting micro-organisms is now widely accepted by many nations $(25,34)$. Plant protection generally falls into the domain of national plant variety rights statutes, which usually apply to plant products obtained by traditional breeding methods-that could not be patented. United States law offers a plant breeder the most generous menu of choices for intellectual property protection of inventions that constitute plant life.

To date, the United States is the only country to both state a patent policy regarding animals and to issue a patent for a transgenic animal. The subject matter of the sole U.S. patent is currently pending at the European Patent Office (see box 12-D). The patent offices of Japan and Australia may per-r-nit animal patents, because their statutes lack subject matter restrictions analogous to EPC's Article 53(b).

United States patent law is also noteworthy because it is, generally, neutral about any potential use of patented inventions. Such social considerations are left, instead, to Federal, State, and local laws that regulate the development and use of 


\section{Box 12-D-The Harvard Mouse Goes to Europe}

On April 8,1988, the first U.S. patent on an animal was issued to Harvard University for transgenic nonhuman mammals genetically engineered to contain a cancer-causing gene (U.S. Patent No. 4,736,866).

The so-called "Harvard Mouse Patent" was filed with the European Patent Office on June 24, 1985. In examining the application, two substantial issues were raised by the patent examiner:

. Article 53(b) of the European Patent Convention (EPC) does not permit claims to animals, per se.

Article 83 of the EPC, which relates to sufficiency, is satisfied only if any embodiment of the invention, as defined in the broadest claim, is substantially capable of being realized on the basis of the disclosure. The application in this case "unduly extrapolated to transgenic non-human eukaryotic animals from what has actually been carried out, namely transgenic mice.

In response to these concerns, the applicant reformulated the application in order to emphasize the microbiological nature of the invention and to request that "eukaryotic animals" be restricted to "nonhuman mammalian animals.

Despite these reformulations, the EPO patent examiner rejected the application in July 1989. The decision stated that Article 53(b), which bars the patenting of animal varieties, was conceived in 1962, when "the question of patenting transgenic animals was scarcely conceivable." Although the EPO Board of Appeals had interpreted plant varieties, which are also excluded under 53(b) as "excluding from patentability only plants in the genetically fixed form of a plant variety,' this interpretation is based, in part, on a desire not to permit double protection under patenting and plant variety protection. Because no similar situation exists for animal varieties, "the idea behind this exclusion was that animal varieties are not appropriate subject matter for patent protection."

In finding the application objectionable under Article 83, the decision said:

"The Applicant has carried out his experiments withone oncogene, the mouse mycgene, by using a mouse as the nunhuman mammalian animal. The invention as disclosed in its broadest concept, however, relates to any oncogene and any conceivable mammalian animal. . . The claims [refer not only to mice] but to any kind of mammals such as anthropoid apes or elephants, all of which have a highly different number of genes and a differently developed immune system. . . the success with the transgenic mouse cannot be reasonably extrapolated to all mammals."

The examiner's decision was later reversed on appeal, and the application was remanded to the examining unit for further examination. As of August 1991, the application was still pending at EPO.

SOURCE: European Patent Office, In re President and Fellows of Harvard College, Decision to Refuse a European Patent Application, European Patent Application No. 85304490.7, Refusal Under Art. 97(1) EPC, 1989; European Patent Office, Boards of Appeal, Case T 19/90-3.3.2, Decision, Oct. 3, 1990.

commercial products. In contrast, Article 53(a) of the EPC states, that patents shall not be granted if the exploitation of the patent would be contrary to public order or morality.

Absent congressional action restricting subject matter patentability, U.S. Iaw is more generous from an inventor's perspective than the law of any other nation. The concept of patenting animals has, however, resulted in broad public debate, and calls for both a moratorium or prohibition of animal patents and passage of legislation by the House of Representatives (H.R. 4970, 100th Congress) that would specifically preclude the patenting of human beings.

\section{Procedural Distinctions}

The patent statutes of most nations are similar in many respects. This similarity extends to the proce- dural aspects of obtaining a patent. In some respects, however, U.S. law differs from that of other nations. These differences can affect competitive advantage and, thus, have become topics of discussion as nations look for ways to harmonize patent statutes and practices. All these procedural differences affect all areas of inventive inquiry. In some ways biotechnology-related inventions are more vitally affected, due to the novelty of the sciences involved, the number of applications being filed, and the lack of experience in many patent offices for dealing with this art.

The United States has been involved in two sets of negotiations-one under the auspices of the World Intellectual Property Organization (WIPO) and the other as part of the General Agreement on Tariffs and Trade (GATT)-----to discuss harmonization of patent statutes in countries around the world. 
Issues raised in these forums have included priority date, grace period, and patent application publication.

\section{Priority Date}

In all Paris Convention countries, the first practical step for gaining worldwide protection for a patentable invention is to be the first-to-file a patent application in the home country patent office. This basic rule, which appears to create a level playing field for all competitors, becomes muddled when two factors-1) first-to-invent v. first-to-file and 2) filing procedures-are considered.

United States law awards patent priority to the frost inventor to conceive, diligently reduce to practice, and claim the invention. The United States and the Philippines are the only nations that grant priority on this first-to-invent basis. The primary advantage of the first-to-invent system is that it permits a patent applicant to determine some of the scientific implications of an observation before rushing to the PTO, for fear that someone else will frost file a patent application for the same invention. Japan (a first-to-file country), for example, receives in excess of 500,000 patent application-type disclosures each year, almost 40 percent of which do not become the subject of a request for examination (35). If the United States were to adopt a first-to-file system, the number of patent applications would likely increase dramatically.

All other nations provide priority on a frost-to-file basis. Some argue that a patent applicant in a first-to-file nation has an advantage because the key requirement is simply to file a registration or application that can be perfected, as needed, at a later time. Thus, the result, it is argued, is a far lower cost to the inventor per patent application and a speedier filing of each application when compared to U.S. practice (37). However, a first-to-file system can cause disadvantages for foreign applicants if other onerous administrative requirements are present (see box 12-E).

\section{Grace Period}

The United States gives the inventor who publishes patentable information before filing a patent application or who commercially uses the invention a l-year grace period to file the patent application. Other nations either have no grace period or grace periods of varying and more limited duration. Japan, for example, has a grace period of 6 months for

\section{Box 12-E-The Race to the Home Patent Office}

Three competitors--one in Germany, one in Japan, and one in the United States-are working on the same area of polypeptide chemistry. Each works independently of the other, and has completed work on anew polypeptide at about the same time. Which of the three inventors gets worldwide patent protection?

The answer depends on whether the inventor files in a "first-to-file" or "first-to-invent" country. In Japan and Germany (first-to-file), the winner is the inventor who wins the race to a member country's patent office. Even if the American and the German inventors have made their polypeptide before the Japanese inventor, if the Japanese inventor files a patent application in Japan before the German and U.S. inventors file applications in their respective countries, then, under the Paris Convention, the Japanese inventor has worldwide priority before either competitor.

A different result could occur in the United States. If the American inventor made the polypeptide before the Japanese inventor, even if the Japanese inventor was the first to file a patent application, the Japanese inventor would obtain certain procedural advantages in an interference proceeding in the United States but would not be granted a patent if the American inventor was able to show that the invention was made by the American before the Japanese filing date. Under 35 U.S.C. 104, any applicant foreign to the United States is precluded from relying on dates of activities in a foreign country before the filing date of a patent application in a foreign country in order to establish priority of invention. Consequently, the Japanese inventor is not likely to prevail in the United States, in this instance.

SOURCE: Office of Technology Assessment, 1991.

limited public disclosure (i.e., disclosure at a technical meeting in Japan) (4) while Europe has no grace period.

The grace period in U.S. law can aid inventors of biotechnological processes and products, especially smaller companies and individual scientists who feel the need to publish research findings immediately. However, lack of grace periods in other industrialized countries can mean that publication (a de facto professional requirement for many U.S. scientists) can result in forfeiture of patent rights in other countries. 


\section{Publication of Patent Applications}

In the United States, patent applications are, by law, confidential (35 U.S.C. 122). In other countries, a patent application is published 18 months after the initial filing date. Proponents of secrecy point out that publication can give competitors the information necessary to reverse-engineer the invention (i.e., take the idea and, through experimentation, repeat the invention) (13). On the other hand, the secrecy provision in U.S. law makes it difficult to determine whether the invention is being claimed by another inventor waiting approval of a patent application. Either way, in determiningg whether to file for patent protection outside of the United States, the inventor must determine whether it is commercially acceptable to have the application published prior to the grant of a patent.

\section{Process Patent Protection}

A major concern of U.S. biotechnology companies is the adequacy of U.S. law to protect against patent piracy. Process patents constitute the majority of patents issued in the biotechnology area. Such patents can be vital, especially if they cover a new process for making a known product. Purified human insulin, for example, has been produced before and thus, is unpatentable. New processes for making insulin, however, are patentable (22). Concern has mounted that processes patented in the United States are being used abroad and the resulting products then exported to the U nited States. Congress enacted legislation in 1988, to address concerns regarding process patent protection. Debate, however, continues as to whether additional protection is needed.

\section{Process Patent Amendments Act}

Until recently, the import, sale, and use in the United States of a product made abroad according to a process patented in the United States was not considered to be an act of patent infringement. The patent owner had no recourse in a U.S. court of law but could only request an investigation by the International Trade Commission (ITC). The ITC could issue an import exclusion order if it was shown that the responding party had used abroad a process patented in the United States and imported the product into the United States, since such action, by law, was considered to be an unfair method of competition. However, this alternative was seen by some as inadequate; no monetary damages could be obtained, and the U.S. manufacturer had to show injury to an established domestic industry.

In an attempt to correct this problem, Congress in 1988 enacted the Omnibus Trade and Competitiveness Act (Public Law 100-418). The new law holds that whoever without authority imports into the United States or sells or uses within the United States a product made by a process patented in the United States shall be liable as an infringer if the import, sale, or use of the product occurs during the term of such process patent. This provided the U.S. patent holder with access to Federal courts as a means of enforcement action in addition to any ITC action. The legislation noted two limitations: a product made by a patented process will no longer be so considered after 1 ) it is materially changed by subsequent processes, or 2) it becomes a trivial and nonessential component of another product (35 U.S.C. 271(g)).

The legislative record indicates that it will be difficult for an alleged infringer to rely on these two exceptions:

In the biotechnology field it is well known that all living organisms contain within them particular genetic sequences composed of unique structural characteristics. The patented process may be for the process of preparing a DNA molecule comprising a specific genetic sequence. A foreign manufacturer uses the patented process to prepare the DNA molecule which is part of the patented process. The foreign manufacturer inserts the DNA molecule into a plasmid or other vector and the plasmid or other vector containing the DNA molecule is, in turn, inserted into a host organism; for example, a bacterium. The plasmid-containing host organism still containing the specific genetic sequence expresses that sequence to produce the desired polypeptide. Even if a different organism was created by this biotech procedure, it would not have been possible or commercially viable to make the different organism and product expressed therefrom but for the patent process, the product will be considered to have been made by the patented process (32).

Despite the Federal legislation, issues surrounding the scope and use of process patents will continue to arise. In 1988, the ITC instituted an investigation into whether the import of certain recombinant erythropoietin (EPO) constituted an unfair act under the Tariff Act (see box 12-F).

Despite unresolved problems in this area, the Omnibus Trade and Competitiveness Act of 1988, 


\section{Box 12-F-Litigation, 1990-91}

\section{Moore v. Regents of the University of California}

The California Supreme Court, in 1990, ruled that a patient does not have a property right to his body tissues after they were used by researchers to develop a commercially important cell line.

Xoma v. Centocor

On the same day, in May 1990, that the University of California received a U.S. patent covering the therapeutic use of certain monoclinal antibodies for treatment of septic shock, Xoma (Berkeley, CA) (the exclusive licensee of the patent) sued Centecor (Malvern, PA), which had filed its patent application 7 years ago.

\section{Upjohn v. Syntro}

In August 1990, plaintiff and defendant settled their patent dispute over rights to a genetically engineered veterinary product, a vaccine used against pseudorabies disease of swine. Under the terms of the agreement, Synto (San Diego, CA) will take a license under the Upjohn (Kalamazoo, MI) patent and pay a royalty to Upjohn.

\section{Genentech v. Genetics Institute and Wellcome Foundation}

A Federal District Court found that the defendants infringed three Genentech tPA patents.

\section{Cetus v. DuPont}

In February 1991, a Federal court jury upheld two Cetus patents for polymerase chain reaction. Cetus had charged DuPont with patent infringement. DuPont claimed that it should not be liable under Cetus' patents, on the grounds that work done in the early 1970s at the Massachusetts Institute of Technology anticipated PCR technology.

\section{Amgen v. Genetics Institute and Chugai Pharmaceuticals}

In a dispute concerning patent and marketing rights to Erythropoietin (EPO), a naturally occurring glycoprotein produced by the kidneys, Amgen (Thousand Oaks, CA) filed four patent applications and was issued a patent claiming rights to genetic materials and host cells used in the recombinant production of EPO. Genetics Institute (GI) (Cambridge, MA) later filed an application with the Patent and Trademark Office. The GI application claimed a purified and isolated sequence for EPO, the vectors used, and the transected host cells. The PT0 declared two interferences between GI's and Amgen's patent in May 1989. The interference proceeding, which allows the PTO to investigate and determine which company was actually the first to invent, is still pending and is expected to take several years to decide.

Both companies established marketing agreements with other companies to market EPO. Amgen has a joint venture with Kirin Brewery Ltd. of Japan (known as Kirin/Amgen) and GI entered an exclusive licensing agreement with Chugai Pharmaceutical Co., Ltd. of Japan. As a result of these agreements, other subsidiaries and licensing agreements were established.

In January 1988, Amgen filed a complaint before the International Trade Commission (ITC) to prevent the import of EPO by Chugai U.S.A. into the United States for clinical trials. The ITC, in 1989, decided that the importation of EPO into the United States did not violate Section 337 of the Tariff Act of 1930. The ITC investigation marks the first time that a trade law has been used to challenge a product developed through biotechnology and is indicative of the problems of process protection for biotechnology in the United States.

Amgen received FDA approval in June 1989, for the treatment of anemia associated with chronic renal failure, which includes both dialysis and predialysis patients. Genetics Institute has yet to receive approval for its EPO in the United States.

In April 1991, the U.S. Court of Appeals for the Federal Circuit held that Amgen's patents were valid, enforceable, and infringed by GI. The ruling blocks GI from selling its version of EPO in the United States. Following the ruling, Amgen's stock increased by 12 percent, and GI's stock dropped 35 percent.

SOURCE: Office of TechnologyAssessment, 1991

altered the the rules of patent-based Section 337 actions. The requirement that the plaintiff shou injury to i domestic industry was eliminated. Insteat. the patent owner need only establish the existence of a domestic industry relating to the patented invention. Activities such as substantial investment in exploiting the patent. including engineering, research, development, or licensing, is sufficient to establish the existence of at domestic industry (9).

\section{The In re Durden Dilemma}

Another controversy in the area of process patent protection is the so-called Durden Doctrine, named after a 1985 case of increasing importance to 
biotechnology patent applicants (19). Durden involved a challenge to the denial of a patent for a process to make a novel chemical. The process to make the chemical, although similar to that of a previously issued patent, used a novel though related starting material and produced a novel, though related, end-product. Although PTO denied a patent for the process, it did grant a patent for the novel starting materials and the novel end-product. The court, in Durden, concluded that a chemical process, otherwise obvious, is not patentable--even if the specific starting material employed or the product obtained are novel and nonobvious.

Although the technology in Durden was not biotechnology, the Durden decision has been a source of frustration to biotechnology-related patent applicants; examiners are increasingly using the doctrine to deny certain process patents on the basis that a patent should not be issued when the process is old and predictable (38).

Opponents of the application of Durden to biotechnology cases argue that the case applies to chemicals, and its application to biotechnology cases is not warranted. As one commentator notes, expressing a gene in a cell is not always easy or obvious and thus, in certain cases should be patentable (36). Another critic of the doctrine argues, that Durden is in direct conflict with another case (20) in which it was held that a new microbe could not be treated as prior art in determining the patentability of a method of using the microbe to produce an antibiotic, therefrom, by an otherwise standard process. In essence, novelty and unobviousness of the microbe imparted patentability to a method of using it (2). A third commentator questions, why a conventional process using a novel starting material is not patentable, yet a pharmaceutical compound comprising a novel ingredient and a conventional carrier is patentable (4).

Despite widespread dissatisfaction with the Durden doctrine, efforts to legislate a solution have met resistance from some companies and patent attorneys involved in biotechnology R\&D. Some argue, that overruling Durden by legislative action would lead to the issuance of excessive numbers of process patents, thus diluting the obviousness requirement. Another argument is, any legislative action will result in additional uncertainty and additional patent infringement suits. Proponents of legislative change note that until the alleged loophole is closed,

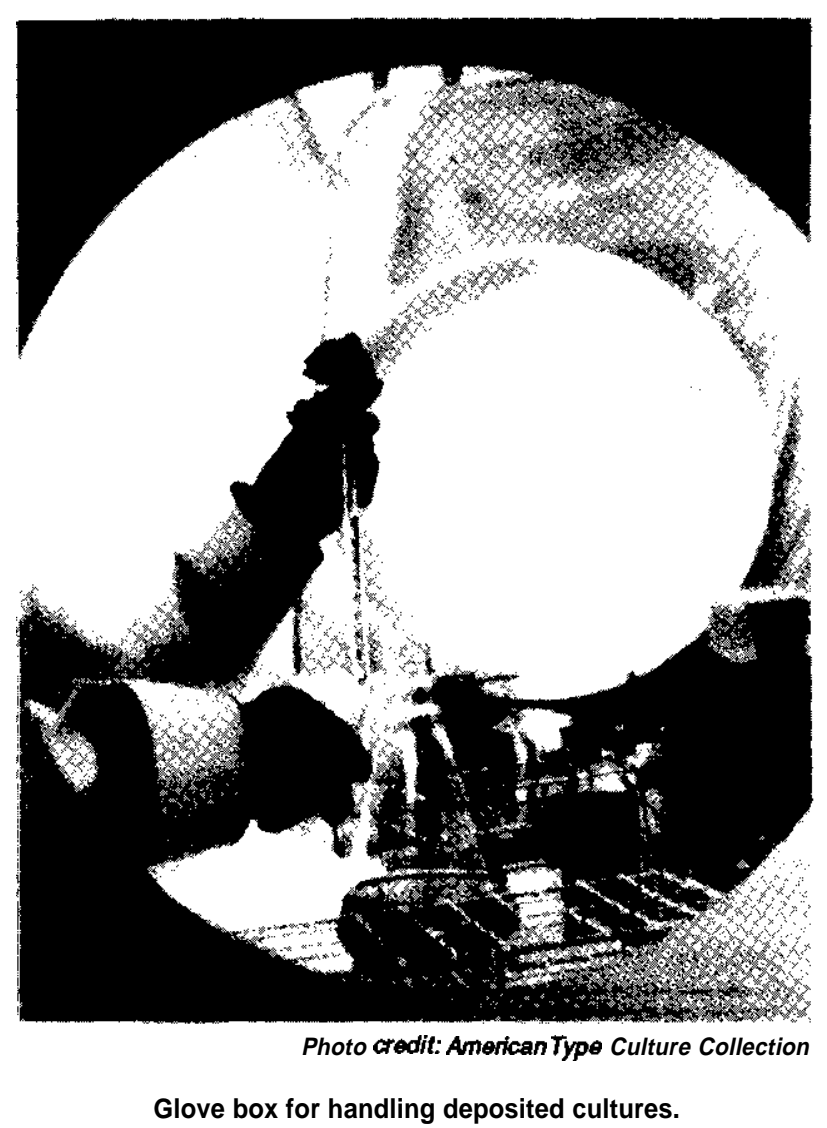

processes using novel and patentable starting materials will be produced outside of the United States and then imported back to the United States. This approach, would deny to product patent holders royalties that would have been required had the product been produced in the United States. The controversy has resulted in public debate among patent practitioners and various companies $(17,36)$.

\section{Deposit Issues}

United States patent law requires a patent application to include a specification-a written description of the invention in such clear, concise, and exact terms that any person skilled in the art to which it pertains can make and use the invention. This requirement, called enablement, presents a unique procedural issue when words alone cannot fully describe the invention.

In 1949, PTO began recommending that patent applications for inventions involving microorganisms include the deposit of the pertinent micro-organism with a culture collection. Although not a formal requirement, patent examiners advised 
applicants that, in cases where words alone were not sufficient to describe the invention adequately, a deposit was advisable. PTO first published guidelines on the deposit of micro-organisms in 1971. In 1977, the Budapest Treaty instituted a system of International Depositary Authorities, making deposits a normal part of international patent practice.

Three issues of deposit practice raise international questions. When is a deposit required? When should a deposit be released to the public? What is the scope of the so-called "research exemption'

\section{When is a Deposit Required?}

All Budapest Treaty nations require deposits when it is not possible to reproduce a claimed invention without reference to deposit. The requirement for a deposit is determined on a case-by-case determination in all countries. When a patent applicant is able to disclose how to re-create the invention with mere words alone, then a deposit is not required (21).

Uniquely, however, the United States requires that the application disclose the best mode for practicing the invention, and thus, the "best" sample may sometimes be required for compliance, if that best sample cannot be recreated from the words of the patent application alone. The best mode requirement is essentially a requirement against concealment. As a result, U.S. patentees are encouraged to err on the safe side; and on issuance of a U.S. patent, deposit their best biotechnology samples, which on patent issuance are then easily available to others, including those who would take such samples outside of the jurisdiction of the United States.

\section{Public Access to Deposits}

The role of the depository is to retain and be a convenient source of an inventor's deposit. The depository is an objective entity-independent of the patent applicant and the PTO. The availability of samples from U.S. depositories for cultures involved in the patenting process is straightforward. If the depository number and the U.S. patent number are known, the culture may be requested and is routinely made available on payment of a minimal fee. There is no record of a U.S. depository ever denying access to someone eligible to receive a culture (34).

Some patent owners contend that free access to a deposit amounts to super-disclosure (giving away the invention itself in addition to the written recipe).
Some owners of hybridoma patents, for example, contend that open access to a hybridoma deposit amounts to giving away their invention plus all the know-how the inventors might have been able to sell separately. This claim of loss may be exaggerated, however, since knowledge of how to produce and maintain hybridoma cells in culture does not generally permit large-scale operation. The latter methods must either be reverse-engineered, or the knowledge must be purchased separately (34). Nevertheless, it is generally easier to reproduce a deposited microorganism than to create it from a written description.

To some patent owners, another issue is the timing of public accessibility to the deposit. For patenting outside of the United States, if a deposit is needed to teach the invention, that deposit must be made before the first priority filing date. In the United States, where patent applications are maintained in secrecy up until the grant of the patent (often several years from the filing date), deposits must be made prior to issuance of the patent. In Europe, however, patent applications are published 18 months from the filing date, which limits any secrecy (both in terms of the contents of the patent application and any enabling deposit) to a specific time-frame. For those desiring a longer period of secrecy, this limited timeframe is seen as inadequate, because biotechnology-related applications take far longer than 18 months for processing. The result is de facto release of the intellectual property before the inventor knows whether a patent will issue. Another potential problem for patent owners involves the export of an accessed deposit to countries where there is no patent protection. This could result in a major loss of property rights (6).

\section{The Research Exemption}

Once a sample that relates to a patented invention is released, there is controversy over the degree to which that sample can be used in the United States and other nations.

Generally, use of a deposited culture that is the enablement of an invention constitutes patent infringement. The United States, J apan, and Europe, however, all have research exemptions that permit various uses of a patented invention for experimental inquiry.

J apan and Europe have statutory exemptions that freely permit the use of a patented invention in the laboratory to create new inventions. Thus, a depos- 
ited sample of a hybridoma may be used without patent infringement to create new technology. Whether the new technology can be commercialized without patent infringement depends on whether or not the claims of the patent cover the new product.

In the United States, the experimental-use defense to patent infringement is a court-created doctrine, holding that an experiment with a patented invention for the sole purpose of gratifying true scientific inquiry or philosophical curiosity does not attack the right of a patentee and thus, does not constitute infringement. In 1984, the Court of Appeals for the Federal Circuit ruled that "the limited use of a patented drug for testing and investigation strictly related to FDA drug approval requirements during the ... term of the patent" did not fall within the experimental-use exemption and thus constituted infringement (26).

In the wake of this case, Congress amended the patent code (Public Law 98-417), which now provides:

It shall not be an act of infringement to make, use, or sell a patented invention (other than a new animal drug or veterinary biological product (as those terms are defined in the Federal Food, Drug, and Cosmetic Act ...) which is primarily manufactured using recombinant DNA, recombinant RNA, hybridoma technology, or other processes involving site specific genetic manipulation techniques) solely for the purposes reasonably related to the development and submission of information under a Federal Law which regulates the manufacture, use, or sale of drugs (35 U.S.C. 271(e)(1).

To date, the courts have been divided on what activities are permissible under $271(\mathrm{e})(\mathrm{I})(14,27$, 28).

\section{Patent Infringement Litigation}

The emergence of biotechnology as an important field in patents has resulted in a surge of litigation, as companies seek to enforce their rights against infringement and defend the patent grant in opposition or revocation proceedings. Such litigation is not surprising, given the web of partially overlapping patent claims, the high-value products, the problem of prior publication, and the fact that many companies are interested in the same products (see box 12-F).

Because biotechnology is a new area in patent law, litigation is not something that Congress can readily alleviate. By its nature, infringement is an area that can only be addressed by Congress in general terms, leaving to the courts the jurisdiction for settling property disputes between companies.

How the courts interpret biotechnology patent claims, and how well U.S. companies protect patent rights abroad will be issues facing biotechnology companies during the years ahead. Uncertainty over patent rights will be costly and will affect the way many biotechnology-related companies structure $R \& D$ strategies. Until precedents are set in court rulings, predicting the outcome of patent litigation will be extremely difficult.

\section{SUMMARY}

Intellectual property law, which provides a personal property interest in the work of the mind, is of increasing importance to people who use biotechnology to create new inventions. Three areas of intellectual property law-patents, plant variety protection, and trade secrets-are particularly important to biotechnology.

Broad patent protection exists for all types of biotechnology-related products and processes in the United States. The Supreme Court holding in Diamond v. Chakrabarty that a living organism was patentable along with action by Congress and the executive branch to change Federal policy to increase patent activity from federally funded research have spurred biotechnology-related patent activity. Internationally, several agreements (e.g., the Paris Union Convention, the Patent Cooperation Treaty, the Budapest Treaty, the Union for the Protection of New Varieties of Plants, and European Patent Convention) provide substantive and procedural protection for inventions created through the use of biotechnology.

Despite a generally favorable international climate, a number of elements affect U.S. competitiveness in protecting intellectual property. The patent application backlog at PTO, uncertainties in the United States and internationally regarding what constitutes patentable subject matter, procedural distinctions in U.S. law (e.g., first-to-invent v. frost-to-file, grace period, secrecy of patent applications, and deposit considerations), uncertainties in interpreting process patent protection, and the spate of patent infringement litigation all constitute unsettled areas that could affect incentives for developing new inventions. 
Congress has considered legislation addressing concerns, such as patentable subject matter and process patent protection. Other problems, particularly scope of patent protection and infringement, will be litigated in the courts as stakeholders in new biological technologies attempt to assert their property rights.

International forums, such as World Intellectual Property organization, General Agreement on Tarriffs and Trade, and bilateral and multilateral trade negotiations, can serve as arenas for discussions relating to harmonization of intellectual property issues.

\section{CHAPTER 12 REFERENCES}

1. Baeumer, L., "Protection of Inventions in the Field of Biotechnology,' Symposium on the Protection of Biological Inventions, World Intellectual Property Organization and Cornell University, Ithaca, New York, June 1987.

2. Beier, D., vice president of governmental affairs, Genentech, "Biotechnology Patent Protection Act," position paper, 1989.

3. Bent, S.A. et. al., National Property Rights in Biotechnology Worldwide (New York, NY: Stockton Press, 1987).

4. Biggart, W., attorney, Sughrue, Mien, Zinn, Macpeak \& Seas, personal communication, August 1990.

5. Bureau of National Affairs, Biotechnology Patents: A Business Manager's Legal Guide (Washington, DC: Bureau of National Affairs, 1989).

6. Cabot, S. S., director, corporate development, DNX, Inc., personal communication, July 1990.

7. Carter, P., director of biotechnology, North Carolina State University, testimony before U.S. Congress, House of Representatives, Subcommittee on Regulation and Business Opportunities, Committee on Small Business, Backlog of Patent Applications at the U.S. Patent and Trademark Office and Its Effect on Small High-Technology Firms, Mar. 29, 1988 (Washington, DC: U.S. Government Printing Office, 1988).

8. Congressional Quarterly, Editorial Research Reports, "Is the U.S. Patent System Out of Date?" vol. 1, No. 19, May 18, 1990.

9. Cooper, I.P., Biotechnology and the Law (New York, NY: Clark Boardman Co, Ltd., 1989).

10. Diamond v. Chakrabarty, 477 U.S. 303 (1980).

11. Ditzel, R., director, technology management, University of California, personal communication, July 1990.
12. Ditzel, R., director, technology management, University of California, personal communication, December 1990.

13. Dryden, S.J., "The U.S. and Japan Look for a Patent Medicine," Business Week, no. 3068, Sept. 5, 1988, p. 28,

14. Eli Lilly \& Co. v, Medtronic, Inc., 110 S. Ct. 2863,15 USPQ2d 1121 (1990).

15. Ex parte Allen, 2 USPQ 2d 1425 (PTO Bd.App. \& Int. 1987).

16. Exparte Hibberd, 227 USPQ 443 (PTO Bd.App. \& Int. 1985).

17. Gershon, D., "Leading Biotechnology Companies Leave the IBA," Nature, vol. 344, No. 5, p. 481, April 1990.

18. Hostetler, W., director of technology transfer, Oregon State University, testimony before U.S. Congress, House of Representatives, Subcommittee on Regulation and Business Opportunities, Committee on Small Business, Backlog of Patent Applications at the U.S. Patent and Trademark Office and Its Effect on Small High-Technology Firms, Mar. 29, 1988 (Washington, DC: U.S. Government Printing Office, 1988).

19. In re Durden, 763 F.2d 1406 (Fed.Cir.,1985).

20. In re Mancy, 499 F.2d 1289, 182 U.S.P.Q. 303 (CCPA 1974).

21. In re Wands, 858 F.2d 731, 8 USPQ 1400 (Fed.Cir. 1988).

22. Industrial Biotechnology Association, "Process Patent Legislation Needed to Protect Against Unfair Trade Practices," Briefing at National Press Club, Washington, DC, March 1987.

23. Jondle, R.J ., "Overview and Status of Plant Proprietary Rights," Intellectual property Rights Associated With Plants (Madison, WI: American Society of Agronomy, 1989).

24. Memorandum dated Feb. 18, 1983, from the President to the Heads of Executive Departments and Agencies on Government Patent Policy, 19 Weekly Comp. Pres. Doe. 252.

25. Organization for Economic Co-Operation and Development, Biotechnology: Economic and Wider Impacts (Paris: OECD, 1989).

26. Roche Products, Inc v. Bolar Pharmaceutical Co., 733 F.2d 858,221 USPQ 937 (Fed.Cir 1984).

27. Scripps Clinic \& Research Foundation v. Baxter Travenol Laboratories, Inc., 7 USPQ 1562 (D.Del. 1988).

28. Scripps Clinic and Research Foundation v. Genentech, Inc., 707 F. Supp. 1547, 11 USPQ2d 1187 (N.D.Cal. 1989).

29. Tanenhöltz, Alvin E., "Genetic EngineeringTechnological Trends From the Perspective of a U.S. PTO Examiner," Fourth Annual Biotechnology Law 
Institute (Clifton, NJ: Prentice Hall Law \& Business, 1988).

30. U.S. Congress, General Accounting Office, Biotechnology: Backlog of Patent Applications (Washington DC: U.S. Government Printing Office, 1989).

31. U.S. Congress, General Accounting Office, Biotechnology: Processing Delays Continue for Growing Backlog of Patent Applications (Washington DC: U.S. Government Printing Office, 1990).

32. U.S. Congress, House Conference Report 100-576 (1988).

33. U.S. Congress, Office of Technology Assessment, New Developments in Biotechnology: Ownership of Human Tissues and Cells_Special Report, OTABA-337 (Washington, DC: U.S. Government Printing Office, April 1989).

34. U.S. Congress, Office of Technology Assessment, New Developments in Biotechnology: Patenting
Life-Special Report, OTA-BA-370 (Washington, DC: U.S. Government Printing Office, April 1989).

35. Van Horn, C.E., patent policy\& programs administrator, U.S. Patent and Trademark Office, personal communication, December 1990.

36. Vaughan, C., "Patent Protection Act Seeks to Improve Competitiveness of U.S. Firms," Genetic Engineering News, April 1990, p. 3.

37. Wegner, H. C., attorney, Wegner \& Bretschneider, Washington, D. C., personal communication, December 1989 .

38. Wiseman, T.G., "Biotechnology Patent Practice-A Primer," AIPLA Quarterly Journal, vol 16, Nos. 3 \& 4(Washington, DC: American Intellectual Property Law Association, 1989). 
Appendixes 


\section{Contents}

Appendix A: A Global Perspective: Biotechnology in 14 Countries ............................ Page

Introduction . . . . . . . . . . . . . . . . . . . . . . . . . . . . . . . . . . . . . . . . . . . . . . . . 229

Biotechnology in 14 Countries .............................................. 229

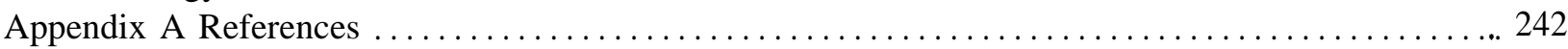

Appendix B: Comparative Analysis: J apan ..... ... ........................... 243

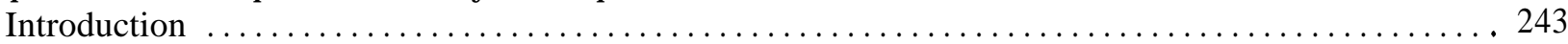

Appendix C: Federal Funding of Biotechnology Research and Development . . . . . . . . . . . . . 249

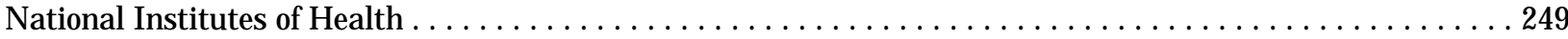

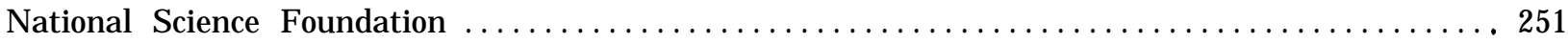

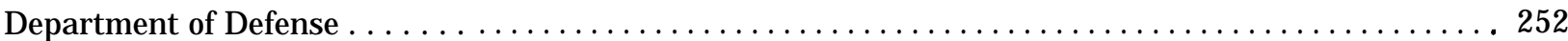

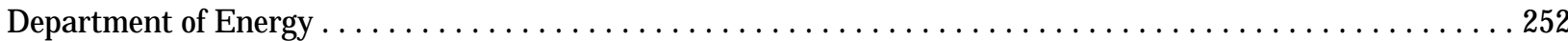

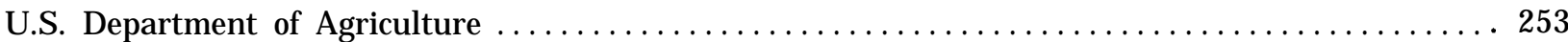

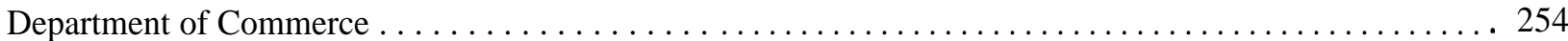

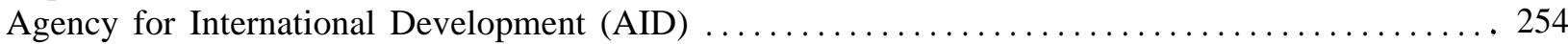

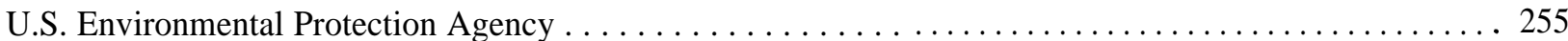

Department of Veterans Affairs .............................................. 255

National Aeronautics and Space Administration .................................. 255

Food and Drug Administration . . . . . . . . . . . . . . . . . . . . . . . . . . . . . . . . . 256

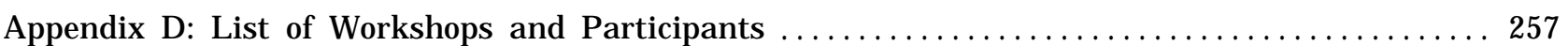

Biotechnology in a Global E conomy: International Conference J uly 6-7, $1989 \ldots \ldots \ldots \ldots \ldots \ldots \ldots .257$

Participants, Workshop on Federal Coordination of Biotechnology Research and

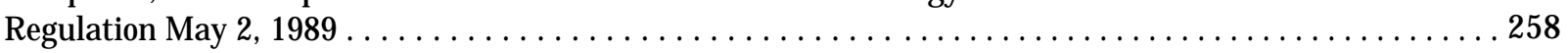

Participants, Workshop on Financial Issues Affecting Biotechnology: At Home and

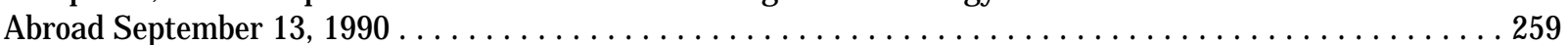

Appendix E: Acknowledgments ..****.*...***................................. 260

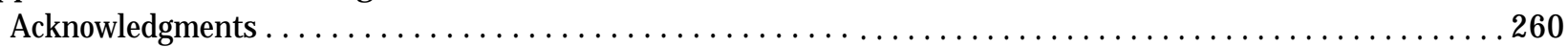

\section{Tables}

Table Page

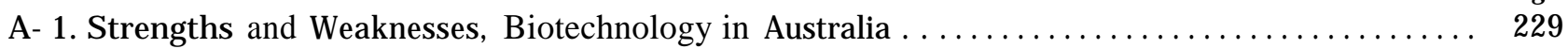

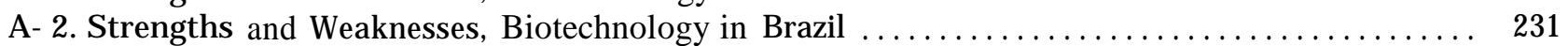

A- 3. Strengths and Weaknesses, Biotechnology in Canada .......................... 231

A- 4. Strengths and Weaknesses, Biotechnology in Denmark . . . . . . . . . . . . . . . . . . . . . . 233

A- 5. Strengths and Weaknesses, Biotechnology in the Federal Republic of Germany . . . . . . . . . . 233

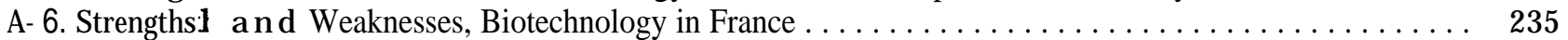

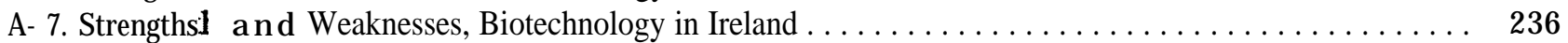

A- 8. Strengths1 and Weaknesses, Biotechnology in The Netherlands . . . . . . . . . . . . . . . 236

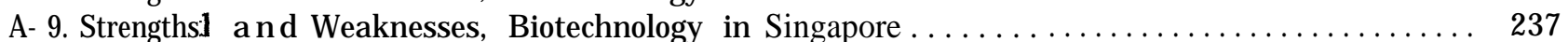

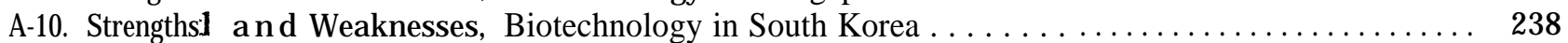

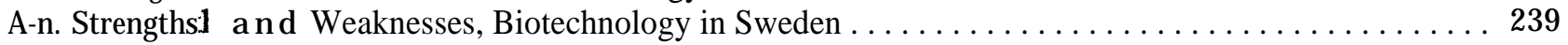

A-12. Strengths $]$ and Weaknesses, Biotechnology in Switzerland ........................ 240

A-13. Strengths] and Weaknesses, Biotechnology in Taiwan (Republic of China) . . . . . . . . . . . . 240

A-14. Strengths] and Weaknesses, Biotechnology in United Kingdom . . . . . . . . . . . . . . . . . . . . . . 241

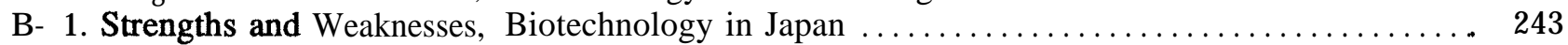

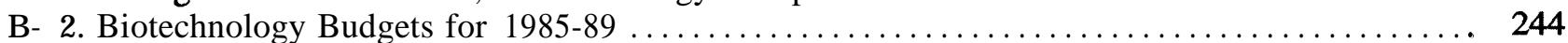




\section{A Global Perspective: Biotechnology in 14 Countries}

\section{Introduction}

Modern biotechnology (i.e., recombinant DNA, cell fusion, and other novel bioprocessing techniques) is now practiced in many nations of the world. Increasing attention has been exerted by nations desiring to develop basic and applied science and commercial development of the new biotechnology.

This appendix provides a brief description of biotechnology in 14 industrialized and newly industrialized nations. Appendix C provides a more detailed description of biotechnology in Japan. These 15 countries were selected to analyze trends in a variety of countries and thus provide material useful in writing the substantive chapters analyzing commercial activity and industrial policy. The inclusion of these 15 nations is not exhaustive-it is recognized that nations not included in this appendix are important to the development of biotechnology in a global economy.

The primary source of information for this chapter was developed from an international conference hosted by the Office of Technology Assessment (OTA) in July 1989 (see app. D). Participants at the conference were asked to describe the development of biotechnology in their countries, with particular emphasis on government funding, industrial policies, the industrial sector, regulations, intellectual property, and public opinion.

\section{Biotechnology in 14 Countries}

\section{Australia}

The Australian economy currently has one of the highest growth rates among industrialized nations. Although Australia is geographically the size of the continental United States, its manufacturing sector is limited by a small domestic population of approximately 17 million people. Government policy aims to redress this difficulty by encouraging the manufacturing and service sectors to be more export oriented (21).

Australia sees itself as a Pacific Rim nation and sees its political and economic future being closely aligned with Japan, Singapore, Korea and, in a geographical sense, with the West Coast of the United States. It is far closer geographically to these nations than to the United Kingdom (U.K.) and Brussels. The Federal Government has realized that it is vital to develop and sustain high-technology, including biotechnology (see table A$1)$.

Government Support-Approximately half of all financial support for biotechnology comes from Federal

\section{Table A-I-Strengths and Weaknesses, Biotechnology in Australia}

\author{
Strengths \\ Strong research base. \\ Biotechnology targeted as enabling technology. \\ Weaknesses \\ Small domestic market. \\ Difficulty in establishing venture capital funding. \\ SOURCE: Office of Technology Assessment, 1991.
}

Government agencies, with the Commonwealth Scientific and Industrial Research Organization (consisting of 6 institutes with 35 divisions) providing the greatest direct government commitment to biotechnology research (19). Australia's public research capability is particularly strong in agriculture and human health, especially in immunology and endocrinology, that have resulted in a number of world-firsts. The discovery of blood cell growth factors, and the cloning of key hormones, such as human growth hormone, and interleukin 3 were made by Australian scientists (6).

In addition to Federal support, some assistance is provided by State governments in New South Wales, Victoria, and West Australia. These efforts range from the establishment of a biotechnology desk in one State to making contacts with other Southeast Asian countries in an attempt to develop new markets (6).

The government, at both the Federal and State levels, supports the development of biotechnology businesses through funding for research, tax incentives for research and development $(R \& D)$, and an immigration policy that encourages the migration of skilled scientists and entrepreneurs. Biotechnology has been designated by the Federal Government as an enabling technology, and a special committee to fund biotechnology research on a competitive basis has been established. Tariffs have been eliminated or substantially lowered, the financial sector has been deregulated, and foreign banks have been admitted. These changes in industrial policy, coupled with an abundance of raw materials and a scientific base that is a leader in immunology, molecular biology, and plant sciences, provide Australia with incentives for the development of biotechnology products and processes.

Industry--Currently, 65 modern biotechnology-based businesses (including brewing but excluding cheese, wine, and food) exist in Australia, supported by approximately 200 companies that provide commercialization, research, and financial support services (21). Total 
private-sector investment in biotechnology is valued at approximately $\$ 45$ million annually.

Biotechnology firms can avail themselves of the benefits of several industry-wide programs, including an R\&D taxation incentive (i.e., companies undertaking appropriate research can receive a tax break at 150 percent of the value of the research), grants, and a range of consulting services through the National Industries Extension Service.

To encourage the development of a venture capital industry, the government provides tax benefits for those who invest in licensed venture capital companies. This scheme, however, has only been modestly successful in raising biotechnology venture capital. Of the 39 investment firms listed in the 1990 Australian Venture Capital Directory, only six had a stated preference for biotechnology investment.

Regulatory Environment--Regulation of biotechnology at the Federal level occurs through the Genetic Manipulation Advisory Committee (GMAC). Established in 1988, to oversee all proposals for research and commercial work involving genetic manipulation, including planned releases, the committee is comprised of university faculty from a wide range of disciplines. Because of its faculty-based membership, GMAC is seen as being independent of interest groups and thus has been accepted by the public (19).

Because biotechnology has a variety of applications in many industries, a number of regulatory agencies are involved. Most of the agencies are based at the State level, and currently, a group of Federal Government officials is working to map the current regulatory climate.

Intellectual Property-The Australian Patent Office (APO) takes a liberal view on patenting issues. As a general rule, anything is patentable if it meets normal patent criteria (e.g., novelty, nonobviousness). The patent law is regarded as helpful by the biotechnology community, which enjoys a good dialogue with APO.

Costs incurred on intellectual property issues are seen as burdensome for small biotechnology companies, particularly when they are dealing with overseas registration. The absence of a common international position on biotechnology patent and registration issues is seen as a problem (19).

\section{Brazil}

Brazil is a large country rich in natural resources. While this nation features traits found in other newly industrialized nations in Latin America-a vast domestic market, a highly stratified income structure, and a huge external debt-Brazil is noteworthy because of its emergence in 1985 from a long period of authoritarian military rule, with a pledge by the new government to alleviate poverty and other social ills. This pledge to "redeem the social debt" has had repercussions on the shaping of industrial policy in Brazil (14).

Brazil is interested in the advancement of biotechnology. This is best demonstrated by the existence of a branch of government devoted solely to biotechnology. However, as a newly industrialized nation, Brazil lags behind many other nations in the number of R\&D professionals supporting biotechnology, and the country is handicapped by weak intellectual property protection for biotechnological products and processes (see table A-2). A program of economic policy reform was introduced in 1990 to promote productivity gains and technological competitiveness. The program includes a doubling of science and technology funding and liberalization of the nation's patent law, both of which would be beneficial to the commercialization of biotechnology (16).

Government Support-The Brazilian Government has targeted biotechnology as one of four areas of scientific priority. A committee for biotechnology has been established to formulate principles for promoting scientific and industrial policy; the committee assists an associate secretariat for biotechnology in the president's secretariat for science and technology. The main issues facing the committee are: regulation of environmental release, safety of laboratory work, intellectual property protection, high-technology development and capitalization, and national and international trade regulations.

The government is currently the largest contributor to biotechnology R\&D. Primary recipients are universities and research institutes (95 percent of the funds) with some funding allocated to industry in the form of risk-free loans (i.e., repayment is made in case of success) and cofinancing schemes. Industry funds biotechnology at a level half that of the Federal Government. The hallmark of Brazil's strategy for the advancement of biotechnology is their program of biotechnology science parks supported by government, academia, and industry. The program calls for the development of biotechnology centers at several major university campuses.

Industry--As a newly industrialized nation, the use of biotechnology is generally limited to basic research conducted by academic research scientists (20). Although classical biotechnology industries (e.g., fermentation, paper and pulp, mining) have developed, modern biotechnological processes and products are limited to plant micropropogation, cell manipulation, and human diagnostics. Nearly 60 companies are struggling toward technological modernization in such areas as plant tissue culture, pharmacological biochemistry, diagnostic kits, cattle embryo transplants, and urban waste treatment.

Although Brazil has yet to market its first product stemming from recombinant DNA (rDNA) or hybridoma technology, the number of companies using modern 
Table A-2-Strengths and Weaknesses, Biotechnology in Brazil

Strengths
Government commitment to biotechnology.
Emergence of biotechnology-related industrial consotia
Weaknesses
Shortage of trained personnel in biotechnology.
No patent protection for biotechnology products or
processes.
Economic constraints.

SOURCE: Office of Technology Assessment, 1991,

biotechnology is increasing. The Brazilian Association of Biotechnology Enterprises counts 36 member companies interested in different sectors of biotechnology with many more nonmember companies interested in modern biotechnology (15).

Regulatory Environment-At present, Brazil follows U.S. National Institutes of Health (NIH) and U.S. Environmental Protection Agency (EPA) guidelines for laboratory and environmental safety.

Intellectual Property-Brazil does not provide patent protection for food or pharmaceutical products and provides only process patents for chemical products. Although no law prohibits the patenting of biotechnological products and processes, the Brazilian Patent Office has been, so far, unwilling to act on the more than 300 biotechnology applications currently pending. As part of a new economic program in Brazil, new legislation to extend patent protection to all areas of industrial endeavor, including biotechnology, is expected in late 1991 (16).

\section{Canada}

Canada has a mixed economy. Although production and services are primarily privately owned and operated, the Federal and Provincial governments are significantly involved in the economy. Canada is the most important trading partner of the United States (25). While biotechnology is becoming a more important tool in Canadian industries, challenges to its continuing development remain. Sources of capital are limited, budgetary cutbacks are beginning to strain Federal support programs, and foreign acquisitions of Canadian enterprises are increasing (see table A-3).

Government Support-A major theme of the Federal Government's general economic policy has been the reduction of the deficit. In general, government programs have been cut, the size of the civil service reduced, and the development of new programs strenuously resisted (2).

Federal funding for biotechnology $R \& D$ is relatively small, amounting to Can $\$ 157$ million in fiscal year 1988-1989, up from Can\$105 million in 1986-1987 (3). Universities and Federal research facilities claimed the

\section{Table A-3-Strengths and Weaknesses, Biotechnology in Canada}

\author{
Strengths \\ Revised patent act. \\ Biotechnology strategy to foster growth. \\ National networks. \\ Weaknesses \\ Federal budget cutbacks. \\ Limited sources of capital. \\ Few large companies.
}

SOURCE: Office of Technology Assessment, 1991.

bulk of Federal funds. Additional funding is available from Provincial governments, the majority of which support research in agriculture, health care, and forestry. Eight Federal agencies are involved in biotechnology research, with the National Research Council and Agriculture Canada playing the largest roles.

Industry--In 1981 a Federal task force on biotechnology, initiated by the Ministry of State for Science and Technology, concluded that "a practically nonexistent biotechnological industrial base, a rapidly shrinking Federal Government research capability and a highly fragmented and unfocused university effort are the major features of Canada's current biotechnological activities. " (2)

In response to these findings, the Canadian Government launched the National Biotechnology Strategy in 1983 to stimulate growth in the biotechnology sector. The strategy included the creation of a national advisory committee, the identification of priority areas, and the creation of networks between researchers from industry, universities, and government. Although the strategy has reaped benefits, several factors continue to threaten the health of Canada's biotechnology base:

- Although many new companies have emerged since 1981, most are very small (less than four employees and annual sales under US\$ million). Such companies face uncertain futures with the increase in international competition.

- The new U.S.-Canada Free Trade Agreement has increased competition for small Canadian ventures.

- The difficulty in raising capital for high-technology enterprises is a continuing problem.

- Complex regulations confront companies exploring new biotechnological applications.

- Process patent protection is unavailable for new varieties of plants or animals (2).

Over 200 commercial firms are involved in biotechnology. However, most are quite small, and only about 30 companies may be fully involved with modern biotechnological techniques. Only one company has more than 100 employees, and firms having the highest amount of 
sales tend to be large traditional companies with interests in biotechnology (2).

Venture capital, a staple of U.S. biotechnology companies, has played only a small role in the development of biotechnology in Canada. Only about one dozen Canadian venture capital funds have backed biotechnology. This limited role hinders the sharing of risks that occur when a number of venture capital firms back a company. In the absence of a strong equity market for raising capital (less than 20 Canadian biotechnology companies have secured financing through public equity markets), most small firms are financed through service contracts and government R\&D grants. With competition increasing and government funding decreasing, an increase in mergers and bankruptcies is likely.

Regulatory Environment-The regulatory framework for biotechnology in Canada consists of seven statutes administered by three Federal agencies. In addition, Provincial restrictions concerning environmental protection and occupational health add additional layers of regulatory complexity. The 1988 Canadian Environmental Protection Act seeks to remedy this quagmire by consolidating the range of legal issues into one law addressing safety in research, production, use, and disposal of products. Specific regulations are still in the drafting stage, however, and many problems remain concerning their application to products and processes. The regulatory problem in Canada is two-fold:

- industry needs a clear set of laws and regulations in order to do business, and

. in the absence of a clear regulatory framework, industry has difficulty in attracting much needed financial support (2).

Intellectual Property-Canada's Patent Act, which previously had empowered the Commissioner of Patents to issue compulsory licenses permitting Canadian generic manufacturers to import, formulate, and market copies of patented pharmaceutical products, has been altered to provide patent protection to brand-named pharmaceutical manufacturers. This change prompted manufacturers to announce spending intentions in excess of $\$ 1$ billion on R\&D over a 10 -year period (2).

Intellectual property protection, in the form of patents is available for microbiological processes and their products, but protection does not extend to processes for producing new genetic strains or varieties of plants and animals. Canada has not yet enacted plant breeders' rights, although pending legislation would amend the Patent Act to provide such protection.

\section{Denmark}

Denmark is a small country with a population of 5 million. Of the five Nordic countries, Denmark is the only one that is a member of the European Community (EC). Denmark's industrial development, which has been linked primarily to agriculture, has been prolonged and more gradual than other Western European nations (17).

Denmark has long been associated with advancements in classical biology. In the late 1800s, Danish companies became the first to use pure yeast strains in fermentation and to market pure bacterial cultures and enzymes for use in cheese production. In the 1920s Denmark launched the production of insulin and now supplies 40 percent of the world's supply of this important protein (see table A-4).

Government Funding for R\&D-Statistics for R\&D funding are gathered biannually in Denmark. The collected data do not provide precise information on biotechnology funding, but rather, for subject-group funding (e.g., medical science, natural science, technical science, agricultural and veterinary science) and subgroups (e.g., genetics, biochemistry, microbiology). Further, 41 percent of government-supported $R \& D$ is performed at universities from their normal budgets.

Direct government funding for biotechnology R\&D in 1987 was approximately $\$ 37$ million. Funding has been provided for two government-led programs-a 5-year program focusing on techniques in molecular biology, launched in 1984 and a much larger program for R\&Din biotechnology, launched in 1987. The latter is by far the largest government-funded R\&D program ever undertaken in Denmark; its 1990 budget equals nearly half the combined budget for the country's six research councils for that year.

Industrial Policy and Sector-Traditionally, the Danish Government has taken a laissez-faire attitude toward private-sector R\&D efforts in biotechnology. While encouraging such efforts, it has not provided much direct support. Now, that is beginning to change, though slowly. The government sponsors 14 "centers without walls" for various aspects of biotechnology that is hoped will lead to increased interaction between academia and industry. Other forms of governmental support include a modest tax incentive and loan programs totaling about $\$ 1.5$ million annually (9).

Industrial efforts are dominated by well-established firms, primarily in pharmaceuticals. The pharmaceutical sector enjoys a trade surplus second only to Switzerland in terms of dollars per capita. Roughly 92 percent of all production is exported, as compared to 60 percent for Danish industry as a whole. One Danish firm, NOVONordisk, today supplies roughly 40 percent of the world's insulin.

By comparison, the foodstuffs industry is weak. This is cause for some concern, given that agriculture accounts for 20 percent of the country's total exports. 


\section{Table A-4-Strengths and Weaknesses, Biotechnology in Denmark}

\begin{tabular}{l}
\hline Strengths \\
Strong tradition in classical biology. \\
Well-established pharmaceutical firms. \\
Biotechnology seen as a priority for public and private \\
sectors. \\
Weaknesses \\
Fragmented research base. \\
Weak university-industry links. \\
Restrictive legislation on use of genetic technology. \\
SOURCE: Office of Technology Assessment, 1991.
\end{tabular}

Regulatory Environment-The Environmental and Gene Technology Act of 1986 sets tough health and safety standards for laboratories experimenting with rDNA. The act requires that processes involving $\mathrm{rDNA}$ receive prior approval from local authorities and prohibits controlled releases. Denmark was the first nation to pass specific legislation requiring that products and processes from rDNA and cell fusion technologies be regulated differently than those obtained by normal biological and chemical processes. This regulatory system is the most stringent one in existence, and some fear it will interfere with the competitiveness of Danish industry. Danish industry has found the 1986 law difficult to live with and is pressing to have a domestic law that is similar to other EC nations. The law was revised in May 1989 to loosen restrictions on pilot plant experiments (9).

Intellectual Property-Denmark is a party to a number of treaties addressing protection of intellectual property, and U.S. citizens are entitled to receive national treatment (25). Patents for food products have been granted since 1989 and for pharmaceuticals since 1984 (9).

\section{Federal Republic of Germany}

The events of 1989 portend immense change as the two German states become one. The speed and sheer complexity of the political and economic mergers of West and East Germany extend to all sectors, including biotechnology.

Germany is Europe's hot spot with regard to biotechnology. Public- and private-sector activity outpaces that of its European neighbors. The domestic chemical and pharmaceutical industries rank among the most profitable in the world. Government policy actively promotes development. And extreme opposition to gene technology thrives to an extent unparalleled in most other countries. Whatever the outcome of its regulatory battles, the Federal Republic of Germany (FRG) is likely to remain a strong player in biotechnology well into the future (see table A-5).

Government Support-Germany became the first country to establish, a government research institute devoted exclusively to biotechnology (the National Research Center for Biotechnology, founded in 1976).
Table A-5-Strengths and Weaknesses, Biotechnology in the Federal Republic of Germany

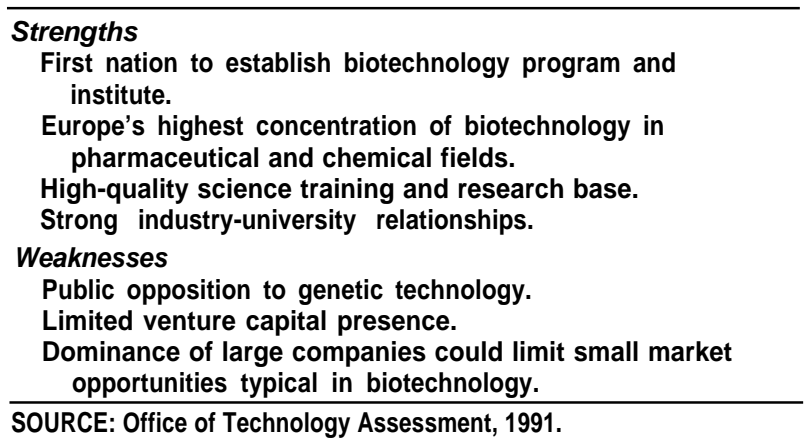

Within the national government the primary body handling the financing of $R \& D$ is the Ministry of Research and Technology. Other ministries (defense, education and science, and research) disseminate the remainder. The ratio of Federal-to-State funding for R\&D is approximately 1 to 2 . Federal outlays go entirely to large-scale centers and smaller public institutes, while States commit their research funding exclusively to $R \& D$ facilities and universities located within their respective borders.

Industry-Germany is the world's largest chemical exporter and boasts Europe's highest concentration of biotechnological activities. In 1974 it became the first nation to launch a national biotechnology program. The next major government action occurred in 1984 when the Federal Ministry of Research and Technology reiterated the government's commitment to biotechnology by launching a research program with six announced objectives:

1. to enable top scientific performance through the proper allocation of political and financial resources,

2. to foster industrial innovation,

3. to promote R\&Din the field of health,

4. to evaluate risks associated with new techniques and to adopt safety regulations accordingly,

5. to increase the pool of $R \& D$ professionals through the support of young scientists, and

6 . to encourage international cooperation and technology transfer (28).

Industry invests heavily in R\&D-58 percent of the national total--and the pattern extends to biotechnology. The majority of biotechnology activities are being conducted by large firms including Bayer, BASF, Boehringer Ingelheim, Boehringer Mannheim, and Hoechst. Some of the firms, such as Bayer and Hoechst, are funding biotechnology R\&D at the rate of $\$ 70$ to $\$ 100$ million a year-amounts equivalent to U.S. companies such as DuPont and Monsanto (18). Licensing agreements, strategic alliances, and even acquisitions involving U.S. firms 
(e.g., BASF's $\$ 1$ billion acquisition of Inmont) may help German firms gain access to cutting-edge technology.

Venture capital companies are usually less than 6 years old in Germany, indicating a much earlier stage of development than their counterparts in the United States. At present, they number approximately 40 and are on average quite small (28).

Regulatory Environment-Many Germans oppose the application of new biotechnological techniques, particularly in regard to genetic manipulation. The Green Party, for example, has made opposition to genetic engineering its second political target, after opposition to nuclear power. The party, which comprises a mix of environmentalists, socialists, anti-technologists, and others generally dissatisfied with other established political parties, currently holds 8.3 percent of the seats in the National Parliament.

In 1984 the National Parliament appointed a commission on the prospects and risks of genetic engineering. In January 1987 the commission issued a report urging more than 170 specific measures, covering such areas as cloning of human beings, release of genetically engineered cells, and genome analysis by employers and law enforcement agencies. This has led to debate on a proposed "Gene law' to rigidly define the legal environment within which industry could conduct R\&D. Some companies have begun shifting investments to more favorable climates in other countries.

A West German State Court dealt a blow to the country's biotechnology industry in November 1989, when it blocked the chemical company Hoechst from completing a plant to manufacture genetically engineered insulin. The court ruled that since German law did not "expressly permit the application of genetic engineering, such facilities may not be built and operated.' The verdict is binding on all States in Germany (1).

The court decision led to passage of a national gene law in 1990, which has provided a legal basis to permit R\&D in genetic engineering. An additional factor that might stem the tide of Germany's growing opposition to biotechnology is the harmonization of European markets in 1992. This could force Germany to adapt its regulations to meet those of other European nations which generally have less restrictive regulatory procedures.

Intellectual Property-Germany is party to major international intellectual property accords. United States firms and citizens are entitled to national treatment (i.e., German law does not distinguish between nationalities of registered property (25).

\section{France}

France is the world's fourth largest industrial economy; its Gross National Product (GNP) is about one-fifth that of the United States. France has a centuries-old tradition of centralized administrative and governmental control of its market economy. This tradition extends to biotechnology, for in the words of one spokesman, "laissez-faire would not work" (see table A-6) (23).

Government Support-In 1982 the French Government established biotechnology as an area of national priority with the creation of the "Mobilization Program: Rise of Biotechnology" within the Ministry of Research and Technology. Over the next 3 years, government funding for biotechnology research increased dramatically. Then, in 1986, it began to decrease. Still, biotechnology is seen as an area of strategic importance for France (23). Despite decreased funding, France has a strong tradition of scientific research (e.g., vaccine development), support of world renowned facilities (e.g., the Pasteur Institute), and other programs (e.g., tax incentives) to nurture scientific activity in the public sector.

Government funding for $\mathrm{R} \& \mathrm{D}$ has been on the decline since reaching a peak in 1985. From 1986 to 1989 the French Government spent an average of US\$215 million annually on biotechnology R\&D. This funding is focused toward national centers for scientific research, agronomic research, health and medical research, and atomic research; the Pasteur Institute (a private institute renowned for its work in immunology); and direct funding to industry.

In addition to direct government funding of biotechnology research, France has set up two logistical tools under the auspices of its national biotechnology program:

. A databank for biotechnology that collects and stores available information on the sequence of biological molecules. This databank is connected to major foreign biotechnology databanks.

- Improved microbial strain collections. A study conducted by the Ministries of Research and Agriculture led to improved collections and the creation of new collections for yeasts and other microorganisms of biotechnological interest.

Industry-Approximately 700 companies are involved to some extent in biotechnology in France. Of these, however, only 100 play a major role (23). Industrial R\&D is generally carried out by large firms, many of which are or were nationalized (5). Agriculture, vaccines, cosmetics, and water treatment are top areas of biotechnological application today (23).

The promotion of technology transfer has been problematic in France. This is due to a traditional separation within academia between basic science (traditionally taught in universities) and technological training (offered only in professional colleges). Furthermore, 
Table A-6-Strengths and Weaknesses, Biotechnology in France

\begin{tabular}{l}
\hline Strengths \\
Government targeting of biotechnology as a priority area. \\
Favorable public attitude toward biotechnology. \\
Historic scientific tradition (e.g., vaccine development) and \\
research facilities (e.g., Pasteur Institute). \\
Weaknesses \\
Decreasing government funding for R\&D. \\
Weak mechanisms for technologv transfer. \\
SOURCE: Office of Technology Assessment, 1991.
\end{tabular}

commercial biotechnology research facilities often lack scientific expertise.

Regulatory Environment-The handling of rDNA is governed by good laboratory practice and good manufacturing practice regulations. In addition, the Genetic Engineering Commission within the Ministry of Research and Technology is responsible for classifying all micro-organisms according to the level of risk associated with their release. A committee is in place to address ethical questions raised by biotechnology. Within the Ministry of Agriculture, the Bimolecular Engineering Commission is in charge of providing preliminary approval of the controlled release of micro-organisms. This commission comprises a collection of representatives from the science community, consumer groups, and France's Green Party. In contrast to the situation in Germany, the French Green Party does not oppose biotechnology (23).

Intellectual Property-France is a strong defender of intellectual property rights and an advocate of improving protection. The nation is a signatory to major international agreements governing patents, copyrights, and trademarks (25).

\section{Ireland}

Ireland's recent economic policy has been directed in large measure to a recovery from an extended period of high international indebtedness. I reland's national debt reached its peak in 1986. In 1987 there was a change of government followed by a period of cooperation among major political parties, labor, and employers toward the government's program for national recovery. Although personal income taxes remain extremely high (the highest rate is 53 percent), the corporate income tax rate of 10 percent is the lowest in Europe. Emigration poses a significant problem. Biotechnology in I reland enjoys public and private support. The government has targeted biotechnology as a matter of national priority, and universities have emerged as major forces for furthering biotechnology (see table A-7).

Government Support-Figures isolating funding for biotechnology per se are not calculated. Further, distinc- tion is not made between classical forms of biology (e.g., agriculture, racehorse breeding, cheese and dairy production) and modern biotechnology. In 1988 the Irish Government spent US\$580 million on science and technology. R\&D funding--US\$1Ol million in 1988had doubled since 1986 (12). Funding is provided for industrial production and technology, agricultural research, and university $R \& D$ programs.

Some 16,000 graduate students and 300 post-graduate students study life sciences at seven universities and nine colleges of technology. However, many of these students emigrate. Still, it is estimated that as many as 60 percent of recent emigrants with graduate qualifications wish to return to Ireland and that 5,000 highly skilled, internationally experienced graduates are available to work in biotechnology-related concerns (12).

The government has also provided startup funding to BioResearch Ireland (BRI), a contract research organization formed in 1987 to facilitate the commercialization of biotechnology. BRI is involved in establishing, equipping, and staffing biotechnology research centers. As of 1989, five centers had been established at existing universities with specialization in diagnostics, pharmaceuticals, food, cell and tissue culture, and agricultural and veterinary biotechnology.

Industry-In 1987 the government created the office of State Science Minister and identified biotechnology, microelectronics, and optronics as areas of strategic priority. A national biotechnology program ensued. Three agencies direct biotechnology policy in Ireland: 1) BRI; 2) IDA Ireland, which supports growth within the Irish manufacturing and service industries and promotes Ireland as a location for foreign investment; and 3) EOLAS, the Irish Science Agency, which promotes science, technology, and the provision of technical services to industry.

The pharmaceutical and food industries rate second and third (behind electronics) as sectors spending the most on $R \& D$. Agriculture is an area of weak industry $R \& D$ funding.

\section{Regulatory Environment}

Ireland's regulatory environment has posed negligible obstacles to industrial development. NIH guidelines have been adopted for use in Ireland for two reasons: 1) the guidelines were seen as being adequate, and 2) U.S. companies based in Ireland are comfortable with them. Ireland applies EC-wide regulatory guidelines and has had a rDNA committee since 1983 (13).

The Irish Government has adopted a vigorous corporatist strategy for the advancement of biotechnology. Its national biotechnology policy is clearly directed toward 
Table A-7-Strengths and Weaknesses, Biotechnology in Ireland

\begin{tabular}{l}
\hline Strengths \\
Strategy for enhancing high-technology and attracting new \\
business from abroad. \\
Lowest corporate tax in Europe. \\
Highly skilled labor force. \\
Weaknesses \\
High emigration rate of skilled personnel. \\
High personal income taxes. \\
Small domestic market.
\end{tabular}

SOURCE: Office of Technology Assessment, 1991.

enhancing the commercial viability of biotechnology industries and luring new business from abroad (12).

Intellectual Property-The government is currently drafting legislation that would allow Ireland to become a signatory to the European Patent Convention (EPC). The legislation will introduce short-term patent protection (10 years) available without detailed searches and is designed to meet the needs of small domestic industries in Ireland.

The Irish Government encourages foreign investment, especially in high-technology industries such as biotechnology. Consequently, protection of intellectual property rights has been an important part of the government's business policy. Protection is generally on a par with other developed countries in Europe, and the government is responsive to problems that arise (25).

\section{The Netherlands}

The Netherlands has an advanced industrial economy with a strong record of prosperity. It is the sixth largest U.S. export market; the United States has traditionally recorded a trade surplus with The Netherlands. The Netherlands is al so the second largest foreign investor in the United States (25). Although The Netherlands got a late start in biotechnology, the nation has a strong science base and a sense of cooperative entrepreneurship that is welcome to outside traders (see table A-8).

Government Support--The Dutch Government plays an active role in coordinating the activities of biotechnology programs. The government funds biotechnology R\&D through two national programs: 1) the Innovation Oriented Program for Biotechnology (IOP-b), targeting universities and research institutes, and 2) the Industrial Stimulation Scheme for Biotechnology, supporting private-sector activity.

IOP-b, which was launched in 1982, helps stimulate multidisciplinary research by engaging the country's five university biotechnology centers in cooperative research. The government directly provides catalytic funding (approximately f.10 per year) that is augmented by additional funding (f.20-f.30 per year) from general research budgets, creating a so-called 'multiplier effect.
Table A-8-Strengths and Weaknesses, Biotechnology in The Netherlands

\author{
Strengths \\ Strong science base. \\ High coordination between government, industry, and \\ academia. \\ Good geographical position. \\ Weaknesses \\ Lack of venture capital industry. \\ Small domestic market. \\ High income and corporate taxes. \\ SOURCE: Office of Technology Assessment, 1991. \\ The Industrial Stimulation Scheme was initiated in \\ 1987 to support high-risk ventures in areas of new \\ biotechnology and to foster technology transfer from the \\ public sector to the private sector. In its first 2 years, the \\ program funded 100 industry projects in such areas as \\ fermentation, pharmaceuticals, waste water treatment, \\ fine chemicals, and biotechnological equipment (26).
}

Industry--In 1988 the Dutch commercial biotechnology sector was formed by four large firms (AKZO, DSM, Shell, Unilever), 12 medium-sized companies, and 34 dedicated biotechnology companies (DBCs). The key sectors are food and dairy (industries of traditional importance in Holland), accounting for 85 percent of Dutch biotechnology sales in 1987. The second largest sector-human and veterinary pharmaceuticals-is expected to play an increasingly important role, accounting for almost half of the new company startups in 1988 (26).

Regulatory Environment-Holland is both economically and politically stable. The Netherlands has enjoyed an extensive public discussion of rDNA technology. Unlike some other European countries, there is no Green Party in Holland (1 1).

Intellectual Property-The Netherlands is a signatory of major international intellectual property accords. The Netherlands Patents act follows the EPC. In the beginning of the 1980s, patenting by universities was virtually nonexistent. By late in the decade, the concept of patenting biotechnology inventions had become accepted, although industry remained more effective in bringing applications to patent than were universities (26).

\section{Singapore}

An island nation of 2.5 million people, Singapore is a leading port and major crossroads of trade, transport, and communications, as well as an important provider of financial and business services. It has a highly developed but narrowly based economy dominated by trade and international services. This city-state is home to more than 3,400 multinational corporations, giving Singapore the region's highest concentration of foreign investment. 
In its aspiration to become a developed country, Singapore has placed priority on developing technology and knowledge-intensive industries that are high-valueadded, skilled, and R\&D oriented. Biotechnology is one such industry that is considered important to Singapore's economic development for the future (see table A-9).

Government Support-Between 1981 and 1987 the Singapore Government spent an average of US\$1.2 million on biological and medical sciences. Since that time the government has taken two actions resulting in increased activity in biotechnology: 1) the establishment, in 1987, of the Institute of Molecular and Cell Biology (IMCB); and 2) the creation of a capital venture fund, Singapore Bio-Innovations, established with US $\$ 10.8$ million to invest in promising startup companies (7).

As a result of these actions, the Singapore Government's annual commitment to biotechnology has risen from the 1987 average of US\$1.2 million to roughly US\$4.5 million (approximately 54 percent of the government's funding for life sciences) in 1989. Two-thirds of this supports basic research at IMCB, while one-third funds industry and joint industry-university projects in applied research (22).

Industrial Policy and Sector-The focal point of Singapore's industrial policy for biotechnology is the National Biotechnology Program, which was initiated in 1988 to strengthen the R\&D base, promote universityindustry collaboration, build up the human resource pool, and spur industrial activity. This policy is supported through tax incentives for industrial R\&D and universityindustry collaboration and available funding. Foreign investment-very important to Singapore given the presence of 3,400 multinational corporations-is encouraged by providing foreign licensers with exemptions on taxes for royalties and know-how fees.

Private-sector development in biotechnology is still in the early stages in Singapore with total annual output estimated at US\$20 million to US\$25 million annually (7). However, the pool of potential investment funds to finance increased industrial participation is significant (22).

Regulation--The regulation of biotechnology has not been seen as a problem to date in Singapore. Government efforts have focused on developing an awareness of biotechnology (22).

Intellectual Property-At present, Singapore does not have its own patent act. Consequently, the country relies on the United Kingdom (U.K.) Patents Act. Under this procedure, domestic or foreign companies must first apply for a patent in the United Kingdom and then register in Singapore within a year to receive patent protection.

\section{Table A-9-Strengths and Weaknesses, Biotechnology in Singapore}

\author{
Strengths \\ Strong international orientation. \\ Favorable entrepreneurial environment. \\ Availability of specifically targeted venture capital. \\ Weaknesses \\ Limited human resources. \\ Inadequate science base. \\ SOURCE: Office of Technology Assessment, 1991.
}

Recognizing the importance of patents in promoting and encouraging $R \& D$ initiatives, the government has taken steps to codify its own patent act. Legislation is now being reviewed by the Patent Bureau and is expected to be finalized in the near future (22).

\section{South Korea}

Beginning in the mid-1960s, the Government of South Korea set out to strengthen the country's infrastructure for science and technology in order to curb the growing volume of high-technology imports. Its first action was to establish the Korea Institute of Science and Technology (KIST), aided by investment from the U.S. Government. The formation of KIST produced several important side effects. It fostered public recognition of the value of high-technology to South Korea's future development, created confidence in the country's R\&D programs, and sparked an upsurge in private-sector research activity. In the 1970s KIST began to promote biotechnology within the government and industry. Since then, biotechnological development has advanced steadily, and business, backed by strong government support, has taken the lead in R\&D activities (see table A-10).

Government Support-Public funding for biotechnology R\&D is carried out by four governmental bodies: the Ministry of Science and Technology, the Ministry of Agriculture and Fishery, the Ministry of Education, and the Ministry of Health and Social Welfare. Of these, the Ministry of Science and Technology spends approximately half of all Federal funds. Government funding totaled US\$7 million in 1988 representing a doubling of the level 3 years earlier. The government's R\&D investment projections call for steadily increasing commitments by both the government and the private sector (27).

Industry-The bulk of biotechnology $\mathrm{R} \& \mathrm{D}$ in Korea has been conducted by industry. In 1988, of a total of US\$46 million invested, US\$39 million came from industry. The government serves largely as conductor, encouraging private activities and orchestrating the direction industrial $R \& D$ will take. In many ways this parallels the Japanese model.

Much of South Korea's biotechnology efforts are linked to its strong fermentation industry (sales in this 


\section{Table A-10--Strengths and Weaknesses, Biotechnology in South Korea}

\author{
Strengths \\ Long tradition in fermentation industry. \\ Strong government targeting. \\ Weaknesses \\ Shortage of technical manpower. \\ SOURCE: Office of Technology Assessment, 1991.
}

area constituted 4 percent of total GNP in 1986). In addition, production of pharmaceuticals is rising. The Korea Institute for Economics and Technology estimates that production of biologically based pharmaceuticals has increased 30 percent each year since 1981, and that by the year 2000, Korea will produce 2 percent of the world's biotechnologically produced pharmaceuticals (27).

No data exist on the breakdown of industrial sources of capital for biotechnology commercialization. Nineteen large firms (members of the Korean Genetic Research Association) dominate industrial activity. No startup DBCs exist in South Korea (27).

Regulatory Environment-The Genetic Engineering Promotion law was passed in 1983. Its purpose was to effectively promote and develop genetic engineering technology by formation of research programs and also to contribute to sound development of the national economy by promotion of industrialization of newly developed technology. The law called for the establishment of a basic plan for the promotion of biotechnology, a yearly enforcing plan, and the creation of a council for genetic engineering policy.

Intellectual Property-South Korea's new patent law took effect in 1987, extending the patent term to 15 years and expanding subject matter coverage to include protection for chemical and pharmaceutical products and micro-organisms. U.S. industry complaints regarding the Korean environment for patent protection focus on interpretation of patent claims by the Korean Patent Office (KPO), possible discrimination by KPO in granting patents, interpretation of patent claims by the Korean courts in patent infringement actions, adequacy of sanctions for patent infringement, and lack of discovery procedures (25). It is likely that these complaints will also be voiced by biotechnology patent practitioners.

\section{Sweden}

In Sweden, the government has not adopted explicit policies for biotechnology nor has it created a department charged exclusively with promoting biotechnological development. Despite this lack of administrative control, the Swedish biotechnology industry has achieved a degree of success, relying largely on access to innovation and free market forces.
Acquiring risk capital in Sweden was not difficult prior to the 1987 stock market crash. Since 1987, risk capital for the biotechnology sector has become more difficult to obtain, especially for small- and medium-sized firms. In addition, public perception of biotechnology has become more volatile, and government regulation is increasing (see table A-n).

Government Support-Between 1986 and 1989 the Swedish Government allocated the equivalent of US\$60 million to biotechnology R\&D. Recipients of these funds include universities, research institutes, and private industries. Funding takes on the form of faculty grants, project grants, and support for public-private ventures.

Several Swedish research councils offer grants to scientists on a research project basis. Funding for university-industry collaboration is available from the National Board for Technical Development, and private funding is secured largely through research parks (supported by a joint foundation with contributions by county councils, local businesses, and universities). At present, there are three science parks that emphasize biotechnological development in Sweden (10).

industry-Unlike many of the countries discussed in this chapter, Sweden has not adopted a national policy for the promotion of commercial biotechnology. Nor has a government body been formed to coordinate biotechnology R\&D. Rather, a collection of public and private entities associated with biotechnological activity carry out development as they see fit.

While not actively promoting biotechnology as a separate area of priority, the government has, nonetheless, taken several policy actions that have indirectly aided biotechnological development. For example, a decision in 1982 to permit the trading of stocks in small- and medium-sized companies on an unofficial stock exchange benefited the biotechnology industry by providing a new way to finance innovative ventures other than through bank loans. In addition, the formation of regional development funds and direct financing schemes targeting small businesses has given biotechnology companies a means of offsetting startup costs.

There are about 40 companies dealing with biotechnology in Sweden. This number has remained constant. Only a few have gone bankrupt. Newcomers have been balanced by those companies that have merged with others. The traditional strengths of Swedish biotechnology have been in the sectors of laboratory equipment, separation, and fermentation. New areas include growth factors, carbohydrate-based substances, and pharmaceuticals. R\&D companies are financed primarily through venture capital. Swedish biotechnology companies are internationally active, a necessity since the domestic market is so small (10). 


\section{Table A-1 I-Strengths and Weaknesses, Biotechnology in Sweden}

\begin{tabular}{l}
\hline Strengths \\
Good university-industry cooperation. \\
Traditional international stance of Swedish firms. \\
Weaknesses \\
Increasing difficulty in obtaining private capital. \\
Overly stringent regulation. \\
\hline SOURCE: Office of Technology Assessment, 1991.
\end{tabular}

Regulatory Environment-The regulatory environment concerning biotechnology has until recently been entirely favorable to industry. No specific legislation concerning biotechnology R\&D existed prior to 1988 . Industry largely regulated itself through adherence to NIH guidelines for laboratory safety and Organization for Economic Co-operation and Development (OECD) guidelines covering rDNA. The only official body currently charged with monitoring laboratory work is the Swedish Delegation for rDNA, an advisory body to industry and government.

The climate, however, has begun to change. In 1988 animal protection legislation took effect regulating the use of gene technology in mammals and animal experiments as well as the use of hormones in cattle breeding. A 1989 amendment to the Plant Protection Act was passed that gives the government a mandate to restrict the use of gene technology in plants, genetically modified plants, and genetically modified organisms in plant breeding. In 1990 the government decided that a permit would be required for growing genetically altered plants. The government further appointed a commission with representatives from both political parties and the scientific community to conduct a 2-year study on the use of gene technology and release of genetically engineered organisms. The commission commenced its study in fall 1990 $(10)_{0}$

Intellectual Property-Sweden is a signatory to major international agreements providing for patent protection. A Swedish patent is valid for 20 years. Undercurrent law, plant varieties, animal species, or essentially biological procedures are not patentable. On the other hand, microbiological processes and plants or seeds that have been treated for a specific reason (e.g., disease resistance) are patentable. In addition, pharmaceuticals and feedstuffs are patentable.

In academia, university scientists are given ownership of their patents and therefore have the right to commercialize their inventions (10).

\section{Switzerland}

In Switzerland, the government does not espouse any direct industrial policy regarding biotechnology. Instead, emphasis is on basic research within universities and
Federal research institutes. Public perception of biotechnology remains relatively benign, which is reflected in the Swiss attitude toward regulation. This nation is home to several major multinational corporations that conduct biotechnology domestically. These factors, coupled with Switzerland's strong infrastructure in basic sciences, make future growth within the biotechnology sector probable (see table A-12).

Government Support-Support for biotechnologyrelated $\mathrm{R} \& \mathrm{D}$ is dominated by the private sector. Government accounts for only about one-fourth of the national commitment. This, coupled with the absence of an official strategy for biotechnology, means that industry makes most of the decisions concerning development in the biotechnology sector. Federal Government funding goes exclusively to universities and government research centers and primarily targets basic research. The Swiss Federal Institutes of Technology, in Zurich, receives the largest amount of Federal funding (8).

Industrial Policy and Sector-Industry policy is limited to the establishment of a favorable political and regulatory climate. Direct mechanisms (e.g., R\&D grants, tax incentives, and incentives for foreign investment) do not exist. This philosophy pertains to all sectors, including biotechnology.

Industry accounts for 75 percent of all $R \& D$ investment in Switzerland (approximately US\$3.25 billion annually). Commercial investment in biotechnology goes toward basic research. Because of production costs, most Swiss companies prefer to produce products abroad. Switzerland, which has often been termed the pharmaceutical capital of the world, is home to large international chemical companies, including Ciba-Geigy, Sandoz, and Hoffman-LaRoche.

Regulatory Environment-There are no specific laws regulating biotechnology products or processes. At the present time, public perception is generally favorable toward biotechnology. In its capacity as advisory panel for biotechnology regulation, the Swiss Commission for Biological Safety in Research and Application takes public reaction into account. Concerns for public safety and moral concerns, therefore, have an official outlet for expression. The emergence of the Green Party as a minor political force in Switzerland will likely escalate the debate on biotechnology in the future (8).

Intellectual Property-Patent applications filed in Switzerland must be made in one of the country's three official languages (German, French, and Italian). Under Swiss patent law, the following items are not patentable: species of plants and animals and biological processes for their breeding; surgical, therapy, and diagnostic processes for application on humans and animals; and inventions liable to offend "good morals." Drugs and foodstuffs are patentable. 
Table A-12-Strengths and Weaknesses, Biotechnology in Switzerland

\begin{tabular}{l}
\hline Strengths \\
Availability of pharmaceutical capital. \\
International outlook spurred by multinational \\
corporations. \\
Strong university-industry links. \\
Weaknesses \\
Lack of specific government programs for enhancing high \\
technology. \\
SOURCE: Office of Technology Assessment, 1991.
\end{tabular}

Taiwan (Republic of China)

Taiwan's economy is export-oriented; the nation is the United States' fourth largest trade partner and trails only Japan in the amount of its trade surplus with the United States.

Biotechnology has been pronounced one of eight strategic sciences and, as such, receives priority funding for R\&D. In addition, the government has labeled biotechnology as one of the country's four strategic industries, thereby entitling relevant companies to a generous array of financial incentives (see table A-13).

Government Support-Eight strategic sciences are targeted for R\&D funding (energy, automation, materials, information, biotechnology, hepatitis control, electrooptics, and food technology) by the Taiwanese Government. Of the national expenditure of US\$808 million in 1986 for all R\&D, these eight areas received over US\$346 million.

Of the money spent on strategic sciences, roughly 80 percent is channeled into applied research, with the remainder going toward basic research. Applied research is primarily conducted at strategic science institutes funded by the Ministry of Economic Affairs, while basic research is funded by the National Science Council and occurs mainly at universities. Biotechnology has claimed an average of 5 percent of the government's $R \& D$ budget for strategic science and technology since 1985 .

At the time biotechnology was labeled as a strategic area of science, a four-pronged effort was initiated:

- Funding for biotechnology was increased. By 1985, 37 college departments around the country had begun offering advanced academic degrees in biotechnology, graduating approximately 200 master's and 30 doctoral students per year.

- Developmental institutions were strengthened, and in 1984 the Development Center for Biotechnology was established to promote the biotechnology industry and develop internationally competitive products.

- Training courses in genetic engineering, cell fusion, fermentation control, and bioreactor design were
Table A-I Strengths and Weaknesses, Biotechnology in Taiwan (Republic of China)

\author{
Strengths \\ Strong government targeting of new technology. \\ Receptive public opinion toward biotechnology. \\ Broad base of graduates trained in Taiwan and foreign \\ universities. \\ Weaknesses \\ Lack of experienced managers. \\ Lack of regulatory program. \\ SOURCE: Office of Technology Assessment, 1991. \\ initiated. \\ - A venture capital funding system was developed to \\ help finance new startup companies. Government \\ banks led the investment effort, and special income \\ tax exemptions were launched. Thirteen venture \\ capital firms have been established since 1986 under \\ this program (24).
}

Industry-Three years after making biotechnology a strategic science priority, the Taiwanese Government designated it as a strategic industry. Criteria for inclusion in this category included high-technology-based, highvalue-added potential, large market potential, large economic fringe benefits, low-energy requirements, and low-pollution production. Other strategic industries at present include machinery manufacturing, information and electronics, and materials (e.g., metals, fiber optics, and industrial plastics).

As a result of receiving this designation, biotechnology firms became eligible for a raft of financial incentives, including government support covering half of technical development and management costs on approved projects, free technical or management consulting from designated public institutes, preferred investment consideration and long-ten-n loans from government banks at reduced interest rates, and corporate income tax deductions.

Capitalizing on governmental incentives, three biotechnology firms were chartered in 1984 with a handful of firms starting later. In terms of total sales, Taiwanese biotechnology companies reached \$22 million in 1987. By the year 2000, Taiwan aims to have taken 2 percent of the worldwide market for biotechnology products (24).

Regulatory Environment-As a strategic industry, the focus of government efforts is on promoting biotechnology as opposed to regulating it (24).

Intellectual Property-Taiwan's patent law was amended in 1987 so that pharmaceutical ingredients and chemicals are now patentable. The defendant in a patent action now bears the burden of proof in a legal action, and in a few prominent cases, convicted violators received jail sentences (24). 
Pirating of new technologies has been cited as a problem for U.S. inventors (25). However, OTA is not aware of any problem in this area affecting inventors of biotechnological products and processes.

\section{United Kingdom}

In the United Kingdom, the government has never adopted a national leadership role in biotechnology. Rather, it has allowed government agencies to develop their own policy schemes within tight budget constraints. The result has been a relatively successful policy emphasizing university-industry links and the promotion of small companies. However, some friction between agencies has occurred over the issue of where priorities should lie, particularly in respect to support for basic versus applied science (see table A-14). This problem has tended to blur priorities.

Government Support-As in the United States, government support for R\&D in the United Kingdom generally targets basic research. Applied research is funded largely through university-industry programs.

The government's direct annual spending on all biotechnology for 1987-88 was approximately $\$ 130$ million, of which 30 percent went to applied research and 70 percent to basic research. Government funding for biotechnology R\&D is handled by the Department of Education and science (DES) and the Department of Trade and Industry (DTI). Within DES, money is allocated by research councils, three of which share a major interest in biotechnology: 1) the Medical Research Council, 2) the Agricultural and Food Research Council, and 3) the Science and Engineering Research Council. The Natural Environmental Research Council supports biotechnology R\&D to a lesser degree.

Applied research support has come primarily from DTI, whose Biotechnology Unit (established in 1982) has been the prime source of aid to firms seeking help with novel investments and innovation. During most of the 1980s, DTI provided innovation funding (up to 25 percent of each proposal); this scheme has, however, been withdrawn on the grounds that there is no need for government to support near-market research. The only support now available for firm-based research is linked to collaborative programs run in conjunction with one or more of the research councils or with other European firms via EC programs (18).

Industry--In general, the U.K. Government's policy toward the development of biotechnology has been one of laissez-faire. In response to a 1980 report arguing for a coordinated policy to promote biotechnology in the United Kingdom, the government took the view that if biotechnology promoted such riches, then the private sector would promote it, thus limiting the government

\section{Table A-14-Strengths and Weaknesses, Biotechnology in United Kingdom}

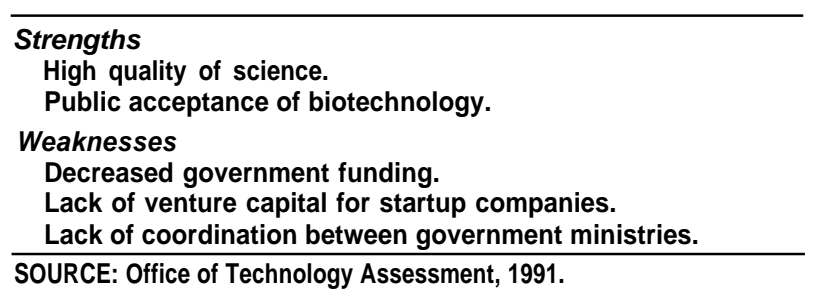

role to providing an environment conducive to its development.

Four points today constitute the main planks of the U.K. Government's policy toward biotechnology:

- Supporting the science base. Although the government claims to have increased the science budget by 10 percent in real terms since 1982, many academics disagree, maintaining that no real budgetary growth has occurred.

- Creating university-industry links. Establishing closer links between the public and private sectors has been accomplished through a number of industrial liaison efforts instituted by government research councils. These ventures have made academicindustry links much more prevalent than a decade ago. However, there has, at times, also been some hostility between research councils that has limited the potential of some schemes.

- Promoting the venture capital market. The establishment of unlisted securities and over the counter markets in the early 1980s has helped increase the financing of new technology enterprises in general. Still, it is difficult for small startup companies with no proven track record to obtain pilot financing.

- Providing a regulatory environment. Safety in drugs and food, environmental release, and health and safety in the workplace constitute the three main categories of regulatory concern in the United Kingdom. In all three areas, present U.K. regulations demand a case-by-case approach, and the mix of statutory and voluntary powers has generally worked successfully. The United Kingdom has been at the forefront of experiments involving environmental release. With these experiments being subject to scrutiny by the Advisory Committee on Genetic Manipulation, there has been no public resistance to deliberate release experiments of genetically modified organisms. Approximately 12 have occurred since 1986 (18).

Although nearly 300 British firms are involved in some form of biotechnology, only about 40 companies actively engage in genetic engineering or monoclinal antibody engineering. One British company, Celltech, with a current value of roughly $\$ 190$ million has emerged as the 
world leader in monoclinal antibody production. In general, large firms predominate in British biotechnology, although the United Kingdom boasts more small innovative firms than any other European country (18).

Intellectual Property-United Kingdom intellectual property laws are strict, comprehensive, and rigorously enforced. The government's positions in international forums, such as the World Intellectual Property Organization and the General Agreement on Tariffs and Trade talks (Uruguay Round) have been virtually identical to U.S. positions (25).

\section{Appendix A References}

1. Bachter, B., "Court Blocks German Biotech Plant," Science vol. 246, No. 4932, 1989, p. 881.

2. Farina, C., director, Investment Prospecting Group, Investment Canada, presentation before U.S. Congress, Office of Technology Assessment, International Conference on Biotechnology in a Global Economy, July 6, 1989.

3. Farina, C., director, Investment Prospecting Group, Investment Canada, personal communication, December 1990.

4. Fujimara, R., Biotechnology in Japan: U.S. Department of Commerce (Springfield, VA: National Technical Informaion Service, 1988).

5. Genesis Technology Group, "Capital Availability for Commercial Biotechnology," contract or report prepared for the Office of Technology Assessment, November 1989.

6. Green, G., "Biotechnology in Australia-1990, The Genetic Engineer \& Biotechnologist vol. 10, No. 2, May/June 1990.

7. Hsu, M., president, Asia/Pacific Bioventures Co., personal communication, October 1990.

8. Hütter, R., Vizepräsident Forschung, Eidgenossische Technische Hochschule, Zurich, presentation before U.S. Congress, Office of Technology Assessment, International Conference on Biotechnology in a Global Economy, July 6, 1989.

9. Larsen, P.O., director, Danish Research Administration, Ministry of Research and Education, presentation before U.S. Congress, Office of Technology Assessment, International Conference on Biotechnology in a Global Economy, July 6, 1989.

10. Larsson, A., Technical R\&D Division, Ministry of Industry, Stockholm, presentation before U.S. Congress, Office of Technology Assessment, International Conference on Biotechnology in a Global Economy, July 6, 1989.

11. McCormick, D., "Holland Is Busy in Biotechnology," Biotechnology vol. 5, No. 9, 1987, pp. 911-913.

12. McSweeney, B., director, BioResearch Ireland, presentation before U.S. Congress, Office of Technology Assessment, International Conference on Biotechnology in a Global Economy, July 6, 1989.

13. McSweeney, B., director, BioResearch Ireland, personal communication, December 1990.

14. Organization for Economic Cooperation and Development (OECD), The Newly Industrialized Countries: Challenge and Opportunity for OECD Industries (Paris, France: OECD Publications Office, 1988).

15, Paes De Carvalho, A., president, Associacao Brasileira Das Empresas de Biotechnologia, Rio de Janiero, presentation before U.S. Congress, Office of Technology Assessment, International Conference on Biotechnology in a Global Economy, July 6, 1989.

16. Paes De Carvalho, A., president, Associacao Brasileira Das Ernpresas de Biotechnologia, Rio de Janiero, personal communication, August 1990.

17. Pedersen, J. L., and Wiegrnan, I.M., Biotechnology in Denmark (Jyngby: Institute of Socialk Sciences, Technical University of Denmark, 1987).

18. Sharp, M., senior research fellow, Science Policy Research Unit, University of Sussex, Brighton, presentation before U.S. Congress, Office of Technology Assessment, International Conference on Biotechnology in a Global Economy, July 6, 1989 .

19. Smith, B., Australia Department of Industry, Technology and Commerce, presentation before U.S. Congress, Office of Technology Assessment, International Conference on Biotechnology in a Global Economy, July 6, 1989.

20. Sorj, B., and Wilkinson, R.J., "Brazilian Policies in Biotechnologies: A Post-Ethanol Strategy?" Bio/ Technology vol. 6, No. 2, 1988, pp. 150-155.

21. Stark, P., Biotechnology and Environment Management Industries, Department of Industry, Technology and Commerce, Canberra, Australia, personal communication, September 1990.

22. Teoh, Y.S., director, National Biotechnology Programrne, Singapore Economic Development Board, presentation before U.S. Congress, Office of Technology Assessment, International Conference on Biotechnology in a Global Economy, July 6, 1989.

23. Thomas, D. F., professeur, Université de Compiègne, Laboratoire de Technologies Enzymatique, Compiègne, France, presentation before U.S. Congress, Office of Technology Assessment, International Conference on Biotechnology in a Global Economy, July 6, 1989.

24. Tien, W., president, Development Center for Biotechnology, Taipai, presentation before U.S. Congress, Office of Technology Assessment, International Conference on Biotechnology in a Global Economy, July 6, 1989.

25. U.S. Department of State, Country Reports on Economic Policy and Trade Practices, report submitted to the Committee on Foreign Affairs and Committee on Ways and Means, U.S. House of Representatives, Joint Committee Print, 101st Congress, 1st sess. (Washington, DC: U.S. Government Printing Office, March 1989).

26. van der Meer, R.R., project manager, HOM Consultancy BV, Scheveningseweg, The Netherlands, presentation before U.S. Congress, Office of Technology Assessment, International Conference on Biotechnology in a Global Economy, July 6, 1989.

27. Yun, Y.G., executive vice president, Korea Development Investment Corp., Seoul, presentation before U.S. Congress, Office of Technology Assessment, International Conference on Biotechnology in a Global Economy, July 6 , 1989.

28. Ziehr, H., assistant director, Gesellschaft fiir Biotechnologische Forschung, Braunschweig, Federal Republic of Germany, presentation before U.S. Congress, Office of Technology Assessment, International Conference on Biotechnology in a Global Economy, July 6, 1989. 


\section{Introduction}

This appendix, which accompanies appendix A, is a summary of information regarding biotechnology in Japan that is found in chapters 2 through 12 of this report.

The commercialization of biotechnology in Japan, as in the United States, has matured and developed over abroad range of industries. In 1984, the Office of Technology Assessment (OTA) identified Japan as the major potential competitor to the United States in biotechnology commercialization. In the view of some, Japan continues to be the United States' main competitor in the early 1990s. Others, however, assert that Japan, in the immediate past and for the near term is not a threat. However, the diffusion of biotechnology into several industrial sectors, the changing financial markets, the emergence of the European Community (EC) as a single economic and political force, and the increasing internationalization of business (e.g., communications, strategic alliances, and technology transfers) blur geographical lines and make simple comparison of the competitiveness of various countries more difficult than in the past (see table B-1).

In Japan, industry dominates biotechnology research and development (R\&D). Industrial researchers working in the field of natural sciences outnumber their government and university counterparts nearly two to one, and the majority of biotechnology research facilities are corporate-led. In addition, government strategies for advancement of biotechnology in Japan consistently target commercial development. Most government funding for $R \& D$ is channeled toward applied research, and government-led initiatives invariably enjoy wide industry participation.

These circumstances contrast sharply with the United States, where government and academia represent the driving forces behind advancement in biotechnology, and basic research claims a larger share of public R\&D funds.

\section{Table B-I-Strengths and Weaknesses, Biotechnology in Japan}

\footnotetext{
Strengths

Fermentation and bioprocess industry.

Strong domestic market for pharmaceuticals.

Strong applied research base.

Strong government support.

Weaknesses

Insufficient basic research science base.

Lack of innovative basic research personnel.

Lack of venture capital.

Rivalry between ministries inhibits cooperation.

SOURCE: Office of Technology Assessment, 1991.
}

Additionally, U.S. Government policy tends not to provide direct industry leadership.

There are notable differences between R\&D expenditures in Japan and in the United States. Japan directs a relatively small amount of government funding to $R \& D$ and very little of those funds go to defense. The government's share of total $R \& D$ spending in Japan has continued to fall over the last decade. Industrial sponsorship is four times greater than government sponsorship and continues to grow as a percentage of the Gross National Product (GNP). As a percentage of GNP, Japan's investment in R\&D has already reached an international high of 2.8 percent. Still, Japan's research expenditure in absolute numbers is only 38 percent of that spent by the United States.

Research relevant to economic growth is sponsored more frequently in Japan than in the United States. Japan gives less emphasis to basic research compared to applied research, a not surprising situation given the dominance of industry funding. Trends in Japan have actually been toward relatively more spending by industry on basic research (up from 5 percent of total industrial R\&D in 1978 , to 6.6 percent in 1988) but less spending by the government (down from 14.5 percent of total R\&D in 1980, to less than 13 percent in 1988).

Japanese universities and staff are more oriented toward teaching than research. Japanese Government funding goes primarily to institutions and senior researchers, who control funding, rather than to individual researchers thus, perpetuating what many feel is a rigid, hierarchical system that stifles innovation. Despite strong formal and informal ties existing between senior faculty and industry, barriers to cooperation remain between the universities and industry. Until 1990, national university professors were considered to be government employees and were prohibited from receiving industry funds. However, many professors have acted and continue to act as industrial consultants. Industry funding of university research is only 2.6 percent of total university research in Japan, as compared to 6.2 percent in the United States.

\section{Government Funding}

The Japanese Government funds approximately 20 percent of biotechnology-related R\&D-a much smaller portion than the U.S. Federal Government's stake (which is approximately 50 percent). Japanese Government spending for biotechnology was Y82.5 billion in 1989, an increase of Y12 billion (US\$900 million) from the previous year (see table B-2). This total includes expenditures by seven ministries. The Japanese Government's 
Table B-2-Biotechnology Budgets for $1985-89$ (In billions of Yen)

\begin{tabular}{|c|c|c|c|}
\hline 1986 & 1987 & 1988 & 1989 \\
\hline 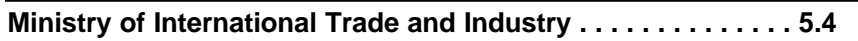 & 5.8 & 5.7 & 7.6 \\
\hline Ministry of Agriculture, Forestry, and Fisheries. . . . . . . 3.1 & 3.2 & 6.6 & 7.4 \\
\hline Ministry of Health and Welfare $\ldots \ldots \ldots \ldots \ldots \ldots \ldots .4$ & 12.1 & 31.1 & 34.5 \\
\hline 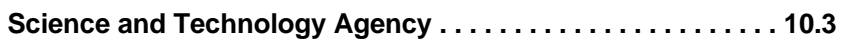 & 12.0 & 13.8 & 18.2 \\
\hline Ministry of Education $\ldots \ldots \ldots \ldots \ldots \ldots \ldots \ldots \ldots \ldots \ldots \ldots \ldots$ & 13.6 & 14.0 & 14.4 \\
\hline Environmental Protection Agency $\ldots \ldots \ldots \ldots \ldots \ldots \ldots .1$ & 0.1 & 0.3 & 0.3 \\
\hline Ministry of Construction $\ldots \ldots \ldots \ldots \ldots \ldots \ldots \ldots \ldots \ldots .1$ & 0.1 & 0.1 & 0.1 \\
\hline
\end{tabular}

SOURCE: Nikkei Biotechnology, Mar. 13, 19S9; JPRS Report, Nov. 1, 1990.

current pattern of investment in biotechnology $R \& D$ is to provide limited seed money, as a catalyst to encourage companies to explore new R\&D options.

The Ministry of International Trade and Industry (MITI) sponsors two important collaborative applied research programs.

- the Japan BioIndustry Association (JBA), a nonprofit organization dedicated to the promotion of biotechnology and bioindustry, involving $320 \mathrm{com}-$ panies from many industrial areas; and

. the Research Association for Biotechnology which includes large Japanese firms, such as Ajinomoto, Mitsui, and Mitsubishi Chemicals.

MITI also provides core funding in diverse areas, such as chemicals, pharmaceuticals, food, marine biotechnology, and alcohol fuel production.

Other ministries funding biotechnology-related programs include the Science and Technology Agency (promotion activities); the Ministry of Health and Welfare (research in dementia, acquired immunodeficiency syndrome, circulatory diseases, cancer, maternal and child health, food safety, and drugs); the Ministry of Agriculture, Forestry, and Fisheries (development of leadingedge biotechnology in agricultural, forestry, fishery, and food industries); and the Environment Agency (to cope with environmental problems associated with biotechnology).

The government supports biotechnology indirectly through tax incentives with $R \& D$ tax credits and attractive depreciation schedules on equipment, loans, and education, as well as training for personnel. Often, however, incentives for R\&D are more attractive overseas than in Japan. These incentives have driven several firms, such as Otsuka Pharmaceuticals and Hitachi Chemicals, to establish R\&D branches in the United States. Another important factor is lower prices on higher quality research abroad.

In contrast to Japan, the Federal Government is the driving force behind R\&D funding for biotechnology in the United States. In fiscal year 1990, the U.S. Govern- ment provided $\$ 3.4$ billion to support R\&Din biotechnology-related areas (see app. C). As in Japan, funding supports a diverse portfolio of potential commercial applications; unlike Japan's focus on applied research, the bulk of U.S. Federal R\&D is targeted toward basic research. Several other factors differentiate the U.S. and Japanese approach to funding:

- The U.S. system of authorization and appropriation of Federal programs is inherently driven by pluralism in the political process. The U.S. Congress plays afar stronger role in funding and oversight than does the Japanese Diet, and executive agencies have markedly less discretion than their counterparts in Japan.

- The structure of the U.S. research and technology base is also vastly different. The U.S. Federal Government provides significantly more funding than does the government of Japan, in both relative and absolute amounts. The United States has a decentralized research system, and several cabinetlevel departments have internal research divisions responsible for the research needs of their particular missions (e.g., enhancing health).

- The system for setting research budgets in the United States is inherently political. Each Federal agency has its own culture. These cultures contribute to their success, perhaps simply by embodying the "way things are done." However, the culture is a powerful determinant of future directions, and specific goals may only be reflected in the collective knowledge of agency personnel.

\section{Targeting of Technology and Financing}

In 1981, MITI designated biotechnology to be a strategic area of science research, marking the first official pronouncement encouraging the industrial development of biotechnology in Japan. Over the next few years, several ministries undertook programs to fund and support biotechnology.

Of particular interest, today, is governmental activity in the pharmaceutical industry. The Ministry of Health and Welfare (MHW) annually lowers prices on existing drugs, 
while allowing premium prices for innovative or important new drugs, thus forcing companies to be innovative and to seek larger markets. This trend is reinforced by the emergence of new foreign and domestic competitors. The push toward innovation is part of the government's overall effort to provide care for its aging populationwithout bankrupting the national health insurance program.

Despite well-coordinated efforts on the part of government to stimulate biotechnology $R \& D$, several weaknesses persist. For example, overall funding levels remain comparatively low, and competition among ministries and agencies has developed. This state of affairs has resulted in some duplication of research and also has created a situation in which companies wishing to test various processes may need authorization from more than one ministry. Furthermore, this rivalry among governmental bodies tends to inhibit coordination between universities (performing basic research) and firms (focusing on applied research).

Approximately 300 Japanese firms report some type of activity related to biotechnology. A 1985 survey, placed this number at 268; of these, 19 used recombinant DNA (rDNA) techniques commercially. Large, traditional firms dominate the commercial sector. The few startup companies that do exist usually show some link to traditional firms.

Current figures on Japanese private spending for biotechnology are hard to obtain from Japanese sources. Estimates for 1987, place industrial biotechnology R\&D at US\$1 billion, roughly half the amount of U.S. industrial spending.

The Japanese stock market has played only a small role in allocating capital. Most capital is heavily concentrated in the banking system. Venture capital plays a limited role in high-technology and biotechnology financing. However, most Japanese venture capital fund managers lack entrepreneurial management skills and usually operate out of their parent headquarters (e.g., banks, security houses, or giant corporations), and these managers invest conservatively. Most American venture capitalists would hold that Japanese venture capital really isn't venture capital in the U.S. sense. Indeed, Japanese venture capitalists are willing to accept returns at two-fifths or even less than the level that U.S. venture capitalists typically expect. Several other reasons exist for the conservative nature of Japanese venture capitalists. These include the stigma of failure and the emphasis on personal relationships rather than depersonalized sales of equity, resulting in equity sales primarily occurring between cooperating firms-a condition hardly conducive to U.S. style venture capital.

Although MITI in 1981 announced its goal of matching U.S. biotechnology within 5 years, its catch-up, get-ahead motto has fallen flat in recent months. The initial positive public perception of biotechnology-demonstrated by sales of products such as bio-lipsticks, genetically modified eels, BeWell bread, and other everyday items whose sales were bolstered by advertising their biotech origins-is changing. According to a recent survey, 90 percent of respondents were dubious about biotechnologists' claims of environmental safety, and 77 percent felt that biotechnology would eventually develop into a major social problem. This development combined with the Illustrations of young scientists over not getting enough support, led one writer to note that: Japan may not be the "land of tPA milk and recombinant honey."

Recent disenchantment with biotechnology at a commercial level goes back to a failure by several companies to rapidly commercialize products. Although biotechnology is losing its luster among Japanese investors, one analyst projects that funding will not decline, but instead will be spent in a more focused fashion on fewer projects.

With one exception, the purchase of Gen-Probe by Chugai Pharmaceuticals of Japan, international biotechnology-related mergers and acquisitions have not involved the purchase of a U.S. company by a Japanese company or vice versa. By comparison, 33 biotechnology-related acquisitions between 1982 and 1988 involved a firm from the United States and a firm from Europe.

North Carolina Biotechnology Center (NCBC) databases reveal 12 cases of U.S.-Japanese equity arrangements. Of these, six explicitly mention marketing or research funding. This seems to indicate that most foreign biotechnology companies believe that the only route to the Japanese market is by teaming up with a large Japanese corporation. As biotechnology companies grow to have product sales and their own sales forces, some of the marketing agreements can even switch direction. Genentech is the leader in what may become a more commonplace occurrence by the early to mid-1990s: in 1987 the Japanese chemical firm Mitsubishi Kasei selected Genentech to develop and market some of its Pharmaceutical products in the United States.

Japanese companies are investing in U.S. dedicated biotechnology companies (DBCs). Examples include:

- Chugai Pharmacautical's arrangements with Genetics Institute and Upjohn, and Chugai's acquisition of Gen-Probe for $\$ 110$ million;

- Tokyo's Institute for Immunology's \$20 million investment in IDEC pharmaceuticals; and

- the collaboration between Genetics Institute and Japan's Yamanouchr' Pharmaceutical Co., and CalBio's deal with Daiichi Pharmaceutical Co. 


\section{Industrial Sector: Health}

The United States is the largest pharmaceutical market in the world, with an estimated value of \$29 billion in 1987. It is followed, closely, by Japan at $\$ 25$ billion. It is important to remember, however, that the population of the United States is 2.5 times larger than the population of Japan. Three of the top five brand name pharmaceuticals in Japan are produced by U.S. companies. Of the top 50 brand names, U.S. companies produce 23; Japan produces only 5 . The United States is very competitive and has maintained a positive trade balance in this high-technology sector. Japan is increasing the strength of its pharmaceutical industry and placed second in the number of new drugs introduced between the years 1981 and 1985.

Historically, the Japanese market has been difficult to enter without a Japanese partner. Just 20 years ago, foreign companies were prohibited from operating independently in Japan. It was not until 1984, that foreign drug companies could go directly to the Konseisho, the Japanese equivalent of the U.S. Food and Drug Administration, for drug approval. To ensure market presence, U.S. and European companies have collaborated with the Japanese companies that dominate the Japanese market. For many years, U.S. and European companies have been increasing their presence in Japan by establishing their own marketing forces and, in a few cases, building research facilities or acquiring a Japanese company. Very recently, efforts have begun to establish joint $R \& D$ programs between U.S. companies and their Japanese counterparts.

At the same time, Japanese companies faced with sharply rising health care costs that have involved drastically reduced reimbursement levels for drugs, are feeling the push to increase their export markets and are slowly beginning to globalize their operations. In the last 2 years, Japanese firms have acquired four smaller U.S. pharmaceutical concerns.

Despite these developments, the main competitors for the world market in pharmaceuticals are U.S. and European companies. These organizations are large multinationals with research, manufacturing, and marketing operations worldwide, particularly in the United States, Europe, and Japan, the three major markets. Focus on leadership in world markets, not only domestic markets, is key to success in the pharmaceutical industry. Although the Japanese share of foreign markets is currently behind the United States and Europe, considerable time, effort, and money could increase the Japanese share of the U.S. pharmaceutical market. It is unlikely, however, that serious inroads will be made by the Japanese into the U.S. market during the 1990s.

\section{Industrial Sector: Agriculture}

Because biotechnology products for agricultural use are still in development, it is not possible to compare the numbers of products manufactured in different countries. Field tests of many products, however, are regulated by national agricultural or environmental authorities. There is no official census of such tests, but the U.S. Department of Agriculture (USDA) keeps an unofficial tally.

Through the summer of 1990, 93 field tests of transgenic plants with potential commercial value had been approved in the United States-far more than in any other country. In contrast, there is little activity in Japan. In general, transgenic plants are being developed in nations that are major exporters of agricultural products, with the greatest activity in the United States. However, the Japanese have made important advances in the area of ornamental plants and flowers, and serious work is underway with vegetables and rice.

\section{Industrial Sector: Chemicals}

In both the United States and Japan, biotechnology's greatest impact in the chemical industry is likely to have little to do with the production per se of industrial chemicals. Instead, its greatest impact will be the result of the industry's expanding investment in pharmaceuticals and agriculture. Recent trends in the chemical industry have forced restructuring worldwide. In response, chemical firms are emphasizing the development and production of high-value-added products, such as specialty chemicals, advanced materials, pharmaceuticals, pesticides, and related agricultural products (e.g., seeds).

The use of biological means for producing chemicals has, historically, received a great of deal of attention in Japan. Unlike the United States, Japan lacks large deposits of coal or oil, the raw materials on which the chemical industry in the rest of the world is based. Thus, Japanese firms have always had a financial incentive to explore alternatives. When Japan's MITI targeted biotechnology in 1980, three research areas were specifically named: rDNA, mass cell culture, and bioreactors. Although in the United States, the word "bioreactor" usually refers to large chambers used for mass cell culture, MITI defines bioreactors, more generally, as fermentation vessels. The more advanced research in bioreactor development funded by MITI emphasizes the use of microorganisms or immobilized enzymes for the production of fine chemicals. Six Japanese chemical firms have taken part in a government-sponsored joint research effort in this area.

Biosensors combine biotechnology with materials science and electronics to produce sophisticated monitoring devices, an area of active R\&D, especially in Japan. Potential applications of biosensors include: human diagnostics, agricultural and veterinary diagnostics, food 
testing, environmental monitoring, and industrial process control.

\section{Industrial Sector: Environmental Applications}

In the nascent bioremediation field, microbial products packaged for sale are available in both the United States and Japan; these, however, have developed only small markets to date. Both nations have been pursuing biotechnology R\&D in improved waste treatment. Still, research efforts are generally minimal, and the diffusion of research results into commercial applications has been slow for a variety of reasons, including lax regulations that encourage the payment of fines by industry for waste emission rather than the use of systems to reduce pollution.

In the United States, several Federal agencies support biological research related to waste management. In 1987, eight Federal agencies spent $\$ 11$ million on environmental biotechnology-related research. In Japan, the Ministry of Construction launched a 5-year, $¥ 5$ billion (US\$40 million) project on waste water treatment through biotechnological processes during the 1980s.

\section{Regulation}

In Japan, relevant policymaking is dominated by tension between competing bureaucracies and powerful industries. In the United States, policymaking is driven by the dynamics of interest-group politics. Although Japan is far from monolithic, the sheer number of actors in the United States makes achieving consensus and continuity much more difficult.

As elsewhere, responsibility for regulating biotechnology in Japan is divided among several ministries.

- University research is regulated by the Ministry of Education, Science, and Culture's (MESC) "Guidelines to Experiments in DNA Recombination in relation to University Research," first introduced in 1979.

- Research organizations other than universities rely on the Science and Technology Agency's (STA's) "Guidelines to Experiments in DNA Recombination," also introduced in 1979.

- The MITI oversees the "Guidelines for Industrial Application of Recombinant DNA Technology," introduced in 1986.

- The MHW applies "Guidelines to the Technical Application of DNA Recombination in the Production of Pharmaceuticals," introduced in 1986.

- The Ministry of Agriculture, Forestry, and Fisheries (MAFF) employs "Guidelines to the Usage of Recombined Substances in the Fields of Agriculture, Forestry, and Fisheries," proposed in 1986, and published in 1989.
Both the United States and Japan allow the use of biotechnology with some restrictions and oversight. In both countries, regulations based on existing legislation governing drugs, worker health and safety, agriculture, and environmental protection are being developed to cover the use of biotechnology.

\section{Intellectual Property}

Japan is a party to the major international treaties designed to protect intellectual property. Still, Japanese patent practice presents several problems.

- Dozens of firms in Japan file well over 5,000 patent applications annually. The top three filers in the United States in 1987 were Japanese firms. As a result, a U.S. filer often finds that Japanese patent rights are closely circumscribed by applications already filed for a similar invention or process.

- On average, the Japanese Patent Office (JPO) takes 3 years to examine a patent application, compared to 21 months in the United States. Anecdotal evidence indicates that the slow pace of patent examination is even worse for biotechnology-related patent applications.

- The permissible scope of claims in a Japanese patent application is narrower than that permitted in U.S. applications. Delays in resolving scope problems can keep applications in limbo for years.

- Adjudication of patent infringement is also slow. Direct evidence cannot be obtained through the discovery process, and infringement can be difficult to prove.

Although there have been some negotiations between the U. S., Japanese, and European patent offices regarding harmonization of patent practice, major differences remain that hinder inventors in high-technology fields, including biotechnology. In part, to avoid some of the tangles of patent practice in Japan, U.S. firms tend to license their patents to Japanese companies in lieu of exporting a product.

Pharmaceutical and health care patents accounted for greater than half of the biotechnology patents issued in 1988. Over three-quarters of genetic-related patents granted were related to pharmaceuticals and health care. U.S. corporations were the largest source of genetic engineering patents. They garnered twice as many health and pharmaceutical genetic engineering patents as U.S. universities and six times as many as U.S. nonprofit research institutions. Thirty-six percent of biotechnology patents were issued to foreigners in 1988, as compared to 47 percent of all patents. Japan is the United States' leading competitor, followed by Western Europe.

In recent years, legislation was passed in the United States and Japan to extend patent protection to make up for the years lost during clinical development. Similar 
draft legislation is being considered by the EC. This extension of effective patent life recognizes the importance of patent protection, the effect of the regulatory process on new product development, and the need for public policies to provide incentives for companies to continue investing in $R \& D$. Unfortunately, there still remains a serious interagency controversy in Japan, which hampers the predictability of plant patent protection. The key issue is whether new plants are to be protected by a Japanese patent or by a registration under the Japanese Seeds and Saplings Act, the latter resembling the U.S. Plant Variety Protection Act.
The interagency dispute, therefore, is between JPO and MAFF. JPO urges that Japanese patent law should not exclude plants per se from patent protection. MAFF, on the other hand, argues that the Seed and Saplings law should protect plants, as well as plant varieties. Similar to what has happened worldwide, Japanese applicants seeking broad protection for a generic agricultural biotechnology invention are critical of the weak protection currently afforded under the Japanese Seeds and Saplings Act. 


\section{Federal Funding of Biotechnology Research and Development}

Historically, the United States, both in absolute dollar amounts and as a percentage of its research budget, has had the largest commitment to basic research in the biological sciences worldwide. The vast majority of Federal research support in the biological sciences goes to university scientists conducting basic research, whereas applied research and development (R\&D) has always been considered the responsibility of industry. This appendix catalogues the extent to which 12 Federal agencies are funding research in biotechnology-related areas.

Basic research is the primary mission of several of these agencies, such as the National Institutes of Health $(\mathrm{NIH})$ and the National Science Foundation (NSF). The National Aeronautics and Space Administration (NASA), the Department of Energy (DOE), and the National Oceanic and AtmosphericAdministration (NOAA) have large technological development programs but are also substantial supporters of basic research, including biotechnology. Other agencies with diverse missions, such as the Department of Defense (DoD) and the U.S. Department of Agriculture (USDA), fund large numbers of R\&D projects related to biotechnology. In addition, agencies with substantial regulatory functions, such as the Food and Drug Administration (FDA) and the U.S. Environmental Protection Agency (EPA), fund research relevant to their regulatory and scientific missions. Finally, agencies traditionally viewed as service oriented, such as the Veterans Administration (VA), the National Institute of Standards and Technology (NET), and the Agency for International Development (AID), fund biotechnology research relevant to their service roles.

\section{National Institutes of Health}

While the biotechnology industry is rapidly becoming one of the most significant "growth industries" in the United States, its creation and sustained expansion over the recent past is in large part due to the major role in support of basic research and research training played by several Federal agencies, in particular, NIH. The NIH supports research conducted either within its own laboratories, or, through a system of grants, contracts, and training awards at academic institutions, research institutes, and industrial organizations throughout the country.

In the area of biotechnology, NIH-supported research can be divided in two categories. The first is basic research directly related to biotechnology, which includes recombinant DNA techniques; gene mapping and DNA sequencing; isolation, separation, and detection of DNA; the creation of hybridomas; the production of monoclinal antibodies; protein engineering; production of antibody- tom chimeras (immunotoxins); and the computer analysis of DNA and protein sequences. The second category relates to the broad research base underlying biotechnology and refers to studies in the fields of genetics, cellular and molecular biology, biological chemistry, biophysics, immunology, virology, macromolecular structure, and pharmacology. For the basic research studies directly related to biotechnology, NIH provided an estimated $\$ 1.19$ billion in fiscal year 1990. For the broadly based research area, NIH provided an estimated $\$ 1.7$ billion in fiscal year 1990. Thus, for fiscal year 1990, NIH provided an estimated \$2.9 billion for biotechnological research through its research grants and contracts mechanisms and its intramural component.

The basic research discoveries made over the past several years have led to an era of astounding biotechnological progress. These achievements include:

- the elucidation of DNA structure;

- chromosomal sorting methodologies;

- improved techniques for the molecular cloning of large DNA fragments;

- the genetic mapping of human disease genes by the use of restriction fragment length polymorphisms;

- the construction of physical maps of several complex genomes;

- improved DNA sequencing methodologies and microchemical instrumentation;

- enhanced technologies for hybridoma and monoclonal antibody production;

- the discovery of, and highly specific use of, restriction endonucleases;

- methods for amplification of gene expression for site-directed mutagenesis and chemical synthesis of DNA probes;

- new methodologies for the detection, separation and characterization of DNA;

- development of posttranscriptional RNA splicing methods and of synthesis, posttranslational processing, modification, transport, and secretion of proteins;

- protein structure and design;

- elucidation of hormone and cell surface receptor molecules;

- tissue and cell culture methodologies;

- separation technologies; and

- informatics for gene mapping, DNA sequencing, and protein structure.

Advances in basic understanding of biological processes and the development of methodologies for manipulating both biological and chemical processes at the molecular level have created numerous opportunities for 
commercial biotechnology companies. The rapid coalescence of basic science knowledge and advanced technologies have decreased the time interval between scientific discoveries and their application to the development of commercially significant products and/or diagnostic tests. New products developed as a result of basic molecular genetic research have enabled biotechnology firms to diagnose human genetic disorders otherwise not detectable by conventional methods. A substantial number of such diagnostic tests are currently available and many others are under investigation.

$\mathrm{NIH}$ also supports biotechnology research in several other ways. NIH contributes significant funds to the Small Business Innovation Research (SBIR) Program, which funds industry research. It supports research collaborations with industry, which facilitate the translation of basic research discoveries to the development of commercially significant products. These collaborations, usually in the form of cooperative agreements between NIH scientists and biotechnology companies, have focused on several areas, including: molecular genetics, DNA cloning, genetic-based diagnosis, hybridoma, monoclinal antibody, immunology, and virology research, and the development of therapeutic agents.

NIH provides research resources to university scientists, state-sponsored biotechnology organizations, and biotechnology companies. These resources include the Genetic Sequence Data Bank (GenBank), the Human Genetic Mutant Cell Repository (Cell Bank), the Protein Identification Resource, the American Type culture Collection of Microorganisms and Cell cultures, the Hybridoma Data Bank, the Human DNA Probe Repository, BIONET, large-scale cell production facilities, an Instrumentation Grants program, and a central database of biotechnology databases. In addition, NIH supports research training at both the predoctoral and postdoctoral levels in basic biomedical disciplines that serve to fuel growth in biotechnology. In addition to institutional training programs, NIH funds predoctoral training specifically for biotechnology through the Lawton Chiles Fellowships in Biotechnology program.

As the new biotechnology has emerged, so have new partnerships between the developing industries and universities, the institutional sites for most NIH-funded extramural basic research relevant to biotechnology. These interactions, established between research universities and chemical, agricultural, and pharmaceutical firms, range from informal exchanges of information and consulting arrangements to research contracts, formal partnerships, and the creation of private corporations. There are many university-industry biotechnology research programs encompassing industry sponsored university research; cooperative industry-university research; joint commercial ventures; research consortia; and biotechnology research training centers.
NIH supports the interaction of universities with industry as long as safeguards against conflicts of interest are maintained and government-supported research results are disseminated freely. NIH awards grants to institutions in support of investigators who have meritorious proposals, regardless of whether the research will be done at a university, a private company, some combination of the two, or involves support by another Federal agency. All evidence indicates that this arrangement is working well for both universities and the biotechnology industry whether it is a part of the private sector or is state-sponsored.

There is substantial interest in the nature and scope of collaborative relationships between NIH, its academic grantees, and biotechnology companies. This interest is partly due to the remarkable basic science achievements that have occasioned commercial interests in marketing the products of biotechnology; a desire to enhance the transfer of research findings to commercial applications; and the desire to effectively utilize Federal biomedical research funds not only for basic research but also to support private industry in the translation of such research to the development of products. NIH interacts with industry in diverse ways. NIH grants over $\$ 6$ billion per year to academic research institutions with the grantee retaining invention rights for licensing to industry. Through these means, the Federal Government transfers knowledge and commercial products to the private sector. Inventions made by government investigators in the course of intramural research are patented and licensed to companies under provisions of the patent law and are transfered to industry with the aid of the Federal Technology Transfer Act of 1986 (FTTA).

The Federal Technology Transfer Act of 1986 (Public Law 99-502), was designed to promote the transfer of government-developed technology into the private sector. The FTTA authorizes the Cooperative Research and Development Agreement (CRADA). Under a CRADA, Federal laboratories and private sector companies conduct research jointly and the collaborating company acquires patent rights at the outset of the collaboration. As an incentive and a reward, the FTTA also provides for the sharing of royalties with government inventors from the licensing of inventions developed under CRADAs and from inventions made through an Agency's intramural research programs. NIH currently has roughly 150 patent license agreements and over 100 CRADAs in effect, and about 100 additional CRADAs in various stages of negotiation.

NIH provides the lion's share of Federal support for the basic research that is critical to the continued vitality and growth of biotechnology in the United States. In addition, NIH promotes the development of productive relationships between scientists in the public and private sectors. All of these efforts will permit the pooling of resources 
and expertise under well-defined conditions and thereby facilitate the transfer of basic science findings to commercial research and development activities.

\section{National Science Foundation}

The NSF, until 1991, generically described its biotechnology efforts by categorizing research related to biotechnology. This included activities in fundamental genetics, cell physiology, cell culture biology, basic biochemistry and enzymology, and bioprocessing engineering, which are generally regarded as being directly related to the further development of biotechnology. In 1991, an internal task force study was completed that redefined the biotechnology research being done at NSF. NSF's current definition of biotechnology is consistent with that used by the Office of Technology Assessment: a technique that uses living organisms or par\&s of organisms to make or modify products, to improve plants or animals, or to develop micro-organisms for specific uses. In addition, it encompasses the development of materials that mimic structure and functions occurring in living systems. NSF's work categorized as research related to biotechnology includes all activities listed in the old definition plus microbial ecology, bimolecular materials, bioelectronics, and bionetworks. Funding figures for fiscal year 1990 reflect the new definition.

NSF's mission is the support of basic research in colleges and universities in the United States. The NSF budget accounted for approximately 7 percent of the fiscal year 1990 Federal nondefense budget for research and development. Approximately 94 percent of the NSF budget goes to basic research, with only 6 percent awarded for applied research.

In addition to Engineering Research Centers, first established in 1985 to facilitate technology transfer and multidisciplinary research, NSF established the Science and Technology Centers program (STC) in 1987 as a mechanism to exploit opportunities in science and engineering requiring complex approaches, to facilitate cooperation among students, faculty, and industry; and to encourage rapid and timely transfer of knowledge. Twenty-five centers have been established-n in fiscal year 1989 and 14 in fiscal year 1991. The central focus of four of those centers is biotechnology-plant resistance to pathogens (University of California, Davis), protein and nucleic acid technology (California Institute of Technology), light microscope imaging (Carnegie Mellon University), and microbial ecology (Michigan State University).

NSF monitors its biotechnology spending by using a data collection system based on review of all new awards for biotechnology relatedness on a subjective scale from none to all, by one-third increments. NSF specifies a category of work as related to biotechnology if it includes research activities related to the following: environmental applications; bioprocessing and bioconservation; bimolecular materials; bioelectronics and bionetworks; agricultural applications; medical applications; and impact of biotechnology.

Biotechnology research is supported by all NSF research directorates: Biological, Behavioral, and Social Sciences; Engineering; Mathematical and Physical Sciences; Computer and Information Science and Engineering; Geosciences; and Scientific, Technological, and International Affairs.

The Directorate for Biological, Behavioral, and Social Sciences (BBS) supports basic research that provides the basic underpinnings for biomaintenance, bioremediation, biology-based waste management, environmental diagnostics, bioprocessing and bioconversion, bimolecular materials, bioelectronics, and bionetworks. In addition, within BBS are programs in Ethics and Values Studies, the History of Science, and Social and Economic Sciences, which offer an opportunity for scholarly work on the impact of biotechnology.

The Engineering Directorate's (ENG) largest amount of support for biotechnology is in bioprocessing and bioconversion. The Divisions of Biological and Critical Systems (BCS) and Chemical and Thermal Systems (CTS) support bioseparations for downstream processing. The Bioengineering Program supports research to seek engineering solutions to health-related problems with an emphasis on research leading to new technology or to novel applications of exising technology. The Environmental and Ocean Systems program supports projects using micro-organisms for detoxification of contaminated water sources.

The Directorate for Mathematical and Physical Sciences (MI\%) supports basic research that provides the chemical and mathematical underpinning of biotechnology, and that uses the methods of biotechnology in the formulation of new biomolecular materials. Relevant research is conducted in the Division of Materials Research (DMR), the Chemistry Division (CHE), and the Division of Mathematical Sciences (DMS).

The Directorate for Computer and Information Science and Engineering (CISE) supports research in the areas of bioelectronics and bionetworks and medical applications. Bioelectronics projects include work on algorithms and devices for vision/imaging and speech/auditory processes, as well as neuron/silicon circuits and devices. Support is provided for work in computer algorithms, techniques, and software tools pertinent to bimolecular data modeling and management in high-performance, networked computing environments.

The Oceanography Division (OCE) of the Geosciences Directorate (GEO) is involved in marine biotechnology and supports research in: the basic biochemistry and 
physiology of organisms from extreme environments; chemically mediated interactions between organisms; development of methods for rapid taxa-specific characterization and identification of marine microbial populations; microbial decomposition and degradative processes; molecular studies of the nitrogenase genes of marine nitrogen-fixing cyanobacteria; and marine viruses.

The Directorate for Scientific, Technological, and International Affairs (STIA) supports biotechnology in three divisions. The Science Resource Studies (SRS) Division studies biotechnology trends and research and development activities in industry, creating a database to be used in monitoring the trends of biotechnology and its industrial applications. The International Division (INT) supports projects in biotechnology through its bilateral agreements with many countries such as Japan and Mexico. The Division of Industrial Science and Technological Innovation (ISTI), through its Small Business Innovation supports research projects in molecular and cell biology, environmental applications, aquiculture, waste management, water treatment, biochemical and bioprocess engineering, biomass processing, and biomedical engineering.

NSF's total support for biotechnology-related research in fiscal year 1990 was $\$ 167.9$ million. The total is broken down as follows:

- Environmental Applications, \$34.93 million;

- Bioprocessing and Bioconversion, \$34.02 million;

- Bimolecular Materials, \$12.85 million;

- Bioelectronics and Bionetworks, \$23.12 million;

- Agricultural Applications, \$39.69 million;

- Medical Applications, \$20.69 million; and

- Impact of Biotechnology, \$2.54 million.

\section{Department of Defense}

DOD defines biotechnology to be any technique that uses living organisms (or parts of organisms) to make or modify products, to improve plants, or to develop micro-organisms for specific uses. The technologies specifically included in this definition are recombinant DNA, novel bioprocessing techniques, cell fusion technology including hybridomas, and somatic cell genetics.

DOD's efforts in biotechnology are divided between medical and materials efforts. The Army is the principal participant in medical biotechnology, with the Navy contributing to the effort through an extramural contract program. In materials biotechnology, the Navy is the principal participant, with the Army, Air Force, and Defense Advanced Research Projects Agency providing additional support.

Medical biotechnology is primarily directed toward characterization of etiologic agents of disease, develop- ment of vaccines, and improved diagnosis of disease and identification of agents. Vaccine development is targeted against militarily relevant diseases that are not of U.S. public health concern, but occur primarily in overseas areas. Examples of this work include vaccine development for dengue, malaria, anthrax, and Rift Valley Fever. Malaria vaccine research is a collaborative effort between DOD and NIH. The diagnostics efforts focus on use of DNA probes and monoclinal antibodies, which are also utilized by DOD for its chemical/biological defense program. The materials biotechnology programs in DOD are diverse. The spectrum of effort includes work on biopolymers, fibers, adhesives, intermediate compounds for synthesis of composites, biosensors, biocorrosion, biofouling control, compliant coatings, and bimolecular electronics.

In fiscal year 1990, DOD's support for both medical and nonmedical biotechnology research and development was about $\$ 98$ million. The funding was divided about evenly between intramural and extramural programs. Medically related biotechnology R\&D accounted for approximately $\$ 60$ million, nonmedical expenditures totaled $\$ 38$ million.

\section{Department of Energy}

The DOE's total expenditures for biotechnology R\&D were approximately $\$ 82.2$ million in fiscal year 1990 . DOE supports both basic and applied research relevant to biotechnology research. DOE has three main programs that fund biotechnology: Basic Energy Sciences and Biological and Environmental Research, which are part of the Office of Energy Research, and Conservation and Renewable Energy.

The Basic Energy Sciences program includes Energy Biosciences and is focused on understanding the fundamental mechanisms of how plants produce biomass, and on the biological transformation of crude, abundant biomass into other usable forms. The program provides the foundation for the broad exploitation of new sophisticated knowledge in molecular genetics. Fiscal year 1990 funding for Energy Biosciences was approximately \$20.4 million.

The bulk of DOE's biotechnology funding is from the Office of Energy Research's Biological and Environmental Research program. This program was funded at $\$ 54.9$ million in fiscal year 1990. The primary biotechnology efforts are the human genome and structural biology programs. These programs are directed at accelerating the mapping of the entire human genome by improving DNA sequencing technology, developing new instrumentation, applying robotics technology, and exploiting unique Departmental facilities to investigate the structurefunction relationships of biomolecules. Research is also conducted to investigate cellular processes, such as 
growth and protein synthesis, by molecular approaches, and development of monoclinal antibody technologies labeled with radionuclides for diagnostic and therapeutic applications.

The Conservation and Renewable Energy Program funded $\$ 6.9$ million of biotechnology research in fiscal year 1990. Research in biotechnology is focused on the application of bioprocessing to industrial and municipal wastes to produce fuels. The conversion processes are environmentally benign. The products, such as methane fuel or biodegradable agricultural mulch, are substitutes for fossil liquids and gases.

\section{U.S. Department of Agriculture}

Four agencies of USDA fund biotechnology R\&D:

. the Agricultural Research Service (ARS);

. the Cooperative State Research Service (CSRS);

- the Forest Service; and

. the Economic Research Service (ERS).

In fiscal year 1990, the four agencies reported combined funding of just under $\$ 116$ million. A description of each agencies' commitment to biotechnology follows.

\section{Agricultural Research Service}

The ARS is the primary research agency within USDA. It funds both intramural research programs and cooperative agreements. ARS conducts research for specific user groups within USDA, including the Animal and Plant Health Inspection Service, Food Safety Inspection Service, and Soil Conservation Review. ARS uses biotechnology to study and understand fundamental biological processes, and to modify and regulate these processes for the solution of agricultural problems.

ARS' biotechnology efforts include projects that use techniques such as gene cloning in micro-organisms, nucleic acid hybridization, biological and biochemical synthesis of nucleic acids and proteins, use of monoclinal antibodies, affinity column separation of antigens, use of immobilized enzymes and cells, protoplast fusion, regeneration of plants from tissue culture, transfer of embryos, gene mapping, and synthesis of peptide neurohormones. In fiscal year 1990, ARS projects using biotechnology totaled about $\$ 59.5$ million. By the end of 1990, it was estimated that about 400 scientists would be using the tools of molecular biology to address agricultural problems.

\section{Cooperative State Research Service}

The CSRS is the USDA's liaison to the State university system for the conduct of agricultural research. Of all the Federal agencies, CSRS handles the most diverse types of research funding, including formula funds, such as the Hatch Act funds, McIntire-Stennis Cooperative Forestry funds, 1890 Colleges and Tuskegee University funds, and the Animal Health and Disease Section 1433 funds. In addition, CSRS provides competitive grants through its Special Research Grants program and the Competitive Research Grants program. The Competitive Research Grants program received funding through fiscal year 1990. A new program, the National Research Initiative, started receiving funds in fiscal year 1991. There are biotechnology programs in all of these funding categories.

According to CSRS, biotechnology refers to the improved or modified organism, microbe, plant, or animal, and "new research techniques' or 'technology" refers to contemporary "tools" available to scientists for the purpose of biotechnology development. CSRS's total funding for biotechnology amounted to $\$ 52.2$ million in fiscal year 1990. The individual funding figures for 1990, and estimates for 1991, follow:

- Hatch Act: \$13.3 million (1990);

- McIntire-Stennis Cooperative Forestry: \$617,000 (1990);

- 1890 Colleges and Tuskegee University: \$1.0 million (1990);

- Special Research Grants: \$10.9 million (1990);

- Competitive Research Grants: \$24.9 million (1990);

- National Research Initiative: \$0 (1990); and

- Animal Health and Disease Section 1433: \$1.5 million (1990).

\section{Forest Service}

The Forest Service is the primary forestry research agency within USDA and conducts the largest forestry biotechnology research program in the United States. Current biotechnology research is directed toward developing and testing basic techniques to employ biotechnology in accelerating tree growth and in improving the quality of woody plants. Research is also directed to understanding stress and disease resistance mechanisms; the development of improved natural biological control agents; and the development and testing of new and efficient industrial processes for wood use. The Forest Service's biotechnology research budget was $\$ 3.6$ million for all phases of the program in fiscal year 1990, and included both matching and cooperative funding. Approximately 90 percent of this funding was allotted to in-house activities and 10 percent to support college and university research.

\section{Economic Research Service}

The ERS monitors developments in agricultural technology and assesses their potential economic impacts on farmers, resource use, national and international commodity markets, consumers, and the general economy. ERSs analyses provide information for assessing the social, environmental, and economic tradeoffs for new 
technologies. In the area of biotechnologies, research has ranged from assessing the economic conditions under which animal growth hormones are most likely to be adopted, to the potential consumer impacts of biotechnology, to the examination of strategies for regulating the risks of biotechnology. The technology program at ERS includes two research sections and 7 staff-years, plus technology components of programs throughout ERS. In total, technology program expenditures were $\$ 500,000$ in fiscal year 1990, with about one-half, focused on economic analyses of biotechnology.

\section{Department of Commerce}

The National Oceanic and Atmospheric Administration (NOAA) and the National Institute of Standards and Technology (NIST) operate within the Department of Commerce and fund biotechnology research.

\section{National Oceanic and Atmospheric Administration}

NOAA defines biotechnology as the application of scientific and engineering principles to the processing of materials by biological agents to provide goods and services. For the past several years, the National Sea Grant College Program of NOAA has invested a small but significant share of its budget in the development of fundamental science which will provide the basis for biotechnological development of marine resources. NOAA's biotechnology research falls in four categories: biochemistry and pharmacology, molecular biology, biochemical engineering, and microbiology and phycology.

Research in biochemistry and pharmacology is directed toward the isolation, identification, and biological evaluation of novel marine substances of potential use in medicine or industry. Biochemical engineering research results are also being applied in the commercial sector. For example, estuarine bacteria have been adapted to efficiently metabolize, and thereby detoxify, certain organic substances in industrial effluents that are severely impacting coastal areas. The technology is also being applied to toxic substances. Basic studies in molecular biology are directed to providing the science for genetic engineering of fish and algae and developing diagnostic reagents and vaccines for use in aquaculture. Research in microbiology aims to control biologically mediated corrosion and biofouling.

In fiscal year 1990, there were 47 active projects in these categories. They were supported with $\$ 2.0$ million in Federal funds and an additional \$1.6 million in non-Federal matching funds. The level of Federal support and number of projects are down 11 percent from fiscal year 1989.
National institute of Standards and Technology

NIST's current biotechnology efforts are based on a number of perceived industrial needs including:

- the development of clinical standards for testing new biotechnology products, such as standards used to calibrate scientific instruments and to validate and evaluate data;

- knowledge and measurement methods for understanding protein structure-function, modification, and expression;

- traceability to national standards for key measurement parameters in commercial fermenters (parameters such as cell mass and activity level, product population, glucose and oxygen concentration, and $\mathrm{pH}$ );

- measurement methods, databases, and predictive models for effective and efficient separation/purification of bioproducts and for optimizing the design of commercial processes;

- kinetics, thermochemical, and thermophysical properties data for biochemical solutions needed for process design and control; and,

- improved analytical measurement methods, standards, and standard reference materials for use in determining composition of biological solutions.

NIST (formerly the National Bureau of Standards-NBS) funded $\$ 4.8$ million of biotechnology-related research in 1990.

\section{Agency for International Development (AID)}

AID broadly defines biotechnology to be cellular and molecular biology and the new techniques derived from them for improving the genetic makeup and/or management of human and animal health care, crops, livestock and microbes. In accounting for biotechnology research spending, AID also used a narrower definition of biotechnology that refers only to research using genetic engineering or cell fusion.

AID is an agency of the State Department and is the foreign assistance arm of the U.S. Government. It is not, per se, a research agency. The Agency's mandate is to work with developing countries in their efforts to improve economic development and meet basic human needs-to overcome the problems of hunger, illiteracy, disease, and early death. Technology development and transfer, including biotechnology, is one of the basic components in the Agency's strategy to achieve its goal. Given the nature of this goal, the research supported by AID is clearly directed to the development of specific products or systems that will be useful in improving human health conditions, agricultural production, and rural development in developing countries. AID supports projects in the United States and overseas. In general, AID finances 
research that is expected to produce usable results within 3 to 5 years.

The overall research portfolio is comprised of projects supported from several offices within AID, and reflect the Agency's organization. AID is divided into central and regional bureaus and independent offices. Regional bureaus focus on the needs of a specific geographic region and serve as the Washington coordinating arm of the field activities conducted by AID missions. Central bureaus address agencywide questions, e.g., private enterprise. The central Bureau for Science and Technology provides technical assistance for the entire agency, and supports and initiates worldwide programs in science and technology. This bureau also coordinates AID's support of the 13 International Agricultural Research Centers. An additional locus of research activity was established in 1980, with the creation of the Office of the Science Adviser. The purpose of this office is specifically to encourage an innovative and collaborative approach to development research, technology transfer, and related capacity building.

The latest available funding information is for fiscal year 1989. In fiscal year 1989, biotechnology funding figures were \$24.0 million (broad definition) and \$4.7 million (narrow definition).

\section{U.S. Environmental Protection Agency}

EPA is primarily a regulatory agency, although it maintains a significant $R \& D$ budget for research programs providing a scientific basis for its regulatory activities. Much of the research conducted by EPA deals with biotechnology risk assessment. The research program attempts to develop the capabilities for the regulatory programs within EPA to predict, and thus avoid, unreasonable adverse effects on the environment. The strategy for program development has, as a critical component, the establishment of an in-house, scientific staff to conduct risk assessments. Concurrently, the staff scientists share responsibility for developing a complimentary extramural program, and fostering interactive information exchange with outside scientists. Extramural funding comprises approximately 75 percent of the total resources expended for biotechnology risk assessment research.

Certain micro-organisms fall within the regulatory framework of EPA under the Toxic Substances Control Act (TSCA) and the Federal Insecticide, Fungicide, and Rodenticide Act (FIFRA). For regulatory purposes, EPA is developing procedures to assess the potential risks and benefits of the use of these micro-organisms. As a cooperative adjunct, the Office of Research and Development (ORD) initiated a research program to develop evaluative methodology and gather scientific information that would identify and adequately describe effects on human health or the environment that may result from the introduction of genetically altered micro-organisms into the environment.

With the emphasis of the program on risk assessment, six areas of research were identified as essential:

1. development of methods for the detection and enumeration of novel organisms in complex environmental samples;

2. determination of survival and growth in the environment;

3. assessment of the stability and transfer frequency of introduced genetic material in the intra- and extracellular environment;

4. development of data and predictive models for transport from the point of application or release to other locations;

5. detection of adverse environmental response (e.g., ecological effects, toxicity, host range change) due to introduced organisms; and

6. determination of changes in host range.

The program deals with both recombinant and nonrecombinant bacteria, fungi, and viruses. In all areas, a primary objective is to produce appropriate scientific information for developing protocols. In fiscal year 1991, two additional areas of research will be pursued. One area deals with environmental studies on pollution prevention through the application of bioregulation techniques. The second new area of research will develop testing procedures, cell bioassays and screening methods to elucidate the potential effects of biotechnology products on human health. EPA's total biotechnology funding for fiscal year 1990 was $\$ 8.3$ million.

\section{Department of Veterans Affairs}

The Department of Veterans Affairs adopted the OTA definition of biotechnology-any technique that uses living organisms (or parts of organisms) to make or modify products, to improve plants or $*$ s, or to develop micro-organisms for specific use-for the purpose of accounting. Specifically, funding data were provided for projects involving cell fusion, gene splicing, monoclinal antibodies, and recombinant DNA.

The VA's expenditures in biotechnology-related research for fiscal year 1990 were $\$ 7.5$ million.

\section{National Aeronautics and Space Administration}

Space biotechnology uses biological materials, such as cells and proteins, to examine how the reduced gravity environment affects these materials, to examine what unique products or factors are produced by cells in reduced gravity, and to use this unique environment to 
improve processes already done on Earth, such as protein crystallization and separations of cells or proteins.

Biotechnology research at NASA is conducted principally within the Microgravity Science and Applications Program. The program objectives are:

- improve methods for the crystallization of proteins in space and their complexes with other biological materials.

- utilize the microgravity environment to perform fundamental research on basic biological processes in cells and tissues.

- investigate new separation processes and approaches for purification of biological materials, and

- improve methods for the formation of complex biological systems such as fused cells, liposomes, and biopolymer films and matrices.

Funded at a level of $\$ 4.5$ million in fiscal year 1990, the program includes nine investigators from universities and three investigators from NASA research centers. The largest and most active laboratory for doing biotechnology in space is at the University of Alabama, Birmingham, where the effort to refine techniques for growing better protein crystals in space is centered.

Of the $\$ 4.5$ million, NASA spent $\$ 2.0$ million on research on protein crystal growth and macromolecular crystallography; $\$ 1.0$ million on separation techniques, theoretical flow analysis, cell culture, and productivity in reduced gravity; and $\$ 1.5$ million was spent between the Marshall Space Flight Center and the Johnson Space Center to support the above research areas or to develop flight hardware that will support taking these experiments to space.

\section{Food and Drug Administration}

FDA is a scientific, regulatory agency responsible for the safety of the Nation's foods, cosmetics, drugs, biologics, medical devices, and radiological products. In this role, FDA monitors and evaluates the manufacturing industry to assure the consumer that the products produced are safe as well as effective. Evaluation of product safety requires, in part, that FDA conduct scientific research focused on developing technology, such as biotechnology. Since biotechnology affects all of FDA's product areas, all products evolving from biotechnology must be evaluated from the appropriate scientific perspective in order to judge their safety and efficacy. FDA's research efforts, including those related to biotechnology, are targeted toward:

- product testing;

- scientific review of new product applications;

- identification of hazards;

- development of new or improved physical, biological, toxicological, or chemical tests;

- determination and establishment of standards, and product compliance with those standards; and

- clarification of mechanisms underlying toxicologic and pharmacologic effects.

Biotechnology is already having a major impact on the development of products that FDA regulates; and the agency's focus is to maintain a research expertise in the field in order to have the knowledge necessary to approve new pharmaceuticals, new food products, and other items regulated by FDA in a minimum of time. In fiscal year 1990, FDA spent approximately $\$ 19.4$ million on biotechnology research. 


\section{List of Conference and Workshop Participants}

\section{Biotechnology in a Global Economy: International Conference} July 6-7,1989

Steven C. Bent, Conference Chair Foley and Lardner Alexandria, VA

Chummer Farina

Investment Canada

Ottawa, Ontario, Canada

Ralf Hutter

Eidgenossische Technische Hochschule

Ziirich, Switzerland

Peder Olesen Larsen

Danish Research Administration

Copenhagen, Denmark

Asalie Larsson

Ministry of Industry

Stockholm, Sweden

Barry McSweeney

BioResearch Ireland

Dublin, Ireland

Antonio Paes De Carvalho

Associagao Brasileira Das Empresas De Biotechnologia

Rio de Janeiro, Brazil

Margaret Sharp

University of Sussex

Brighton, East Sussex, United Kingdom

Barry Smith

Department of Industry, Technology, and Commerce

Canberra, Australia

\author{
Yong-Sea Teoh \\ Economic Development Board \\ Singapore \\ Daniel F. Thomas \\ Universite de Compiegne \\ Compiegne, France \\ Weichen Tien \\ Development Center for Biotechnology \\ Taipei, Taiwan \\ Ryuichiro Tsugawa \\ Ajinomoto Co., Inc. \\ Kawasaki, Japan \\ Robert R. van der Meer \\ HOM Consultancy B.V. \\ Den Haag, Holland \\ Yeo-Gyeong Yun \\ Korea Development Investment Corp. \\ Seoul, Korea \\ Holger Ziehr \\ Gesellschaft fur Biotechnologische Forschung \\ Braunschweig, Germany
}

NOTE: OTA appreciates and is grateful for the valuable assistance and thoughtful critiques provided by the conference participants. The conference participants do not, however, necessarily approve, disapprove, or endorse this report. OTA assumes full responsibility for the report and the accuracy of its contents. 


\title{
Workshop Participants-Federal Coordination of Biotechnology Research and Regulation May 2,1989
}

\author{
Nanette Newell, Workshop Chair \\ Synertech Group, Inc. \\ Research Triangle Park, NC
}

Beverly Berger

Office of Science and Technology Policy

Washington, DC

Harry Broadman

Senate Governmental Affairs Committee

Washington, DC

Mary Clutter

National Science Foundation

Washington, DC

John Cohrssen

Council on Environmental Quality

Washington, DC

Janet Dorigan

Office of Science and Technology Policy

Washington, DC

Robert Frederick

U.S. Environmental Protection Agency

Washington, DC

Elke Jordan

National Institutes of Health

Bethesda, MD

Ruth Kirschstein

National Institutes of Health

Bethesda MD

Rachel Levinson

National Institutes of Health

Washington, DC

Waker Lockwood

U.S. Department of State

Washington, DC
Terry Medley

U.S. Department of Agriculture

Hyattsville, MD

Kathleen Merrigan

Senate Agriculture Committee

Washington, DC

Elizabeth Milewski

U.S. Environmental Protection Agency

Washington, DC

Henry Miller

U.S. Food and Drug Administration

Rockville, MD

Mike Miller

Office of Management and Budget

Washington, DC

Joseph Osterman

U.S. Department of Defense

Washington, DC

Greg Simon

House Committee on Science and Technology

Washington, DC

David Smith

U.S. Department of Energy

Washington, DC

Greg Thies

Senate Agriculture Committee

Washington, DC

Alvin Young

U.S. Department of Agriculture

Washington, DC

NOTE: OTA appreciates and is grateful for the valuable assistance and thoughtful critiques provided by the workshop participants The workshop participants do not, however, necessarily approve, disapprove; or endorse this report. OTA assumes full responsibility for the report and the accuracy of its contents. 


\title{
Workshop Participants-Financial Issues Affecting Biotechnology: At Home and Abroad Sept. 13,1990
}

\author{
Peter Drake, Workshop Chair \\ Vector Securities \\ Deerfield, Illinois
}

Kenneth Bate

Biogen

Cambridge, MA

M. Kathy Behrens

Robertson, Coleman, \& Stephens

San Francisco, CA

Fred Frank

Shearson Lehman Hutton, Inc.

New York NY

Cary Garner

Transgenic Sciences, Inc.

Worcester, MA
Grant Heidrich

Mayfield Fund

Menlo Park CA

Bruce Peacock

Centocor, Inc.

Malvern, PA

David Shaw

IDEXX

Portland, ME

NOTE: OTA appreciates and is grateful for the valuable assistance and thoughtful critiques provided by the workshop participants. The workshop participants do not, however, necessarily approve, disapprove, or endorse this report. OTA assumes full responsibility for the report and the accuracy of its contents. 


\section{Appendix E}

\section{Acknowledgments}

OTA thanks the members of the advisory panel, conference and workshop participants, contractors, and the many individuals and organizations that supplied information for this report. In addition, OTA acknowledges the following individuals for their comments on drafts of this report:

Toni K. Allen

Piper \& Marbury

Washington, DC

Mads Bryde Andersen

University of Copenhagen

Copenhagen, Denmark

Bruce I. Andrews

cyanamid International

Wayne, NJ

Ludwig Baeumer

World Intellectual Property Organization

Geneva, Switzerland

Robert F. Barnes

American Society of Agronomy

Madison, WI

John Barton

Stanford Law School

Stanford, CA

M. Kathy Behrens

Robertson, Coleman, \& Stephens

San Francisco, CA

David Beier

Genentech, Inc.

Washington, DC

Evan Berman

University of Miami

Coral Gables, FL

Waddell A. Biggart

Sughrue, Mien, Zinn, Macpeak \& Seas

Washington, DC

Daniel F. Burton

Council on Competitiveness

Washington, DC

L.J. (Bees) Butler

University of California at Davis

Davis, CA

Noel J. Byrne

University of London

London, England
Mark F. Cantley

Commission of the European Communities

Brussels, Belgium

Mason C. Carter

Louisiana State University

Baton Rouge, LA

Ananda M. Chakrabarty

University of Illinois

Chicago, IL

David Cheney

Council on Competitiveness

Washington, DC

Mary Dell Chilton

Ciba-Geigy Corp.

Research Triangle Park NC

Ralph E. Christoffersen

SmithKline Beecham

King of Prussia PA

Mary Clutter

National Science Foundation

Washington, DC

Tom Copmann

Pharmaceutical Manufacturers Association

Washington, DC

James H. Davis

Crop Genetics International

Hanover, MD

Lois Davis

Sybron Chemicals, Inc.

Salem, VA

Sue Markland Day

University of Tennessee

Knoxville, TN

Dreux de Nettancourt

Commission des Communautes Europeennes

Brussels, Belgium

Kate Devine

Applied BioTreatment Association

Washington, DC 
Mark Dibner

North Carolina Biotechnology Center

Research Triangle Park NC

R. Dietz

Laboratory of the Government Chemist

Teddington, England

Roger Ditzel

University of California

Alameda CA

Harvey Drucker

Argonne National Laboratory

Argonne, IL

George D. Duda

U.S. Department of Energy

Washington, DC

William H. Duffey

Monsanto Co.

St. Louis, MO

Donald N. Duvick

Johnston, IA

Gary B. Ellis

Institute of Medicine

Washington, DC

Don Emlay

Calgene

Davis, CA

Guilherme Emrich

Biobras-Bioquimica De Brasil

Belo Horizonte, Brazil

Bruce Eisen

Genetics Institute

Cambridge, MA

Kenneth H. Evans

U.S. Department of Agriculture

Beltsville, MD

Ron Evans

U.S. Environmental Protection Agency

Washington, DC

Chummer Farina

Investment Canada

Ottawa, Ontario

Peter Farnham

American Society for Biochemistry and Molecular Biology

Bethesda MD

Nina Federoff

Carnegie Institute of Washington

Baltimore, MD
Walter Fehr

Iowa State University

Ames, IA

Robert A. Fildes

Danville, CA

J. Lawrence Fox

Texas Research and Technology Foundation

San Antonio, TX

Fred Frank

Shearson Lehman Hutton, Inc.

New York NY

Paul E. Freiman

Syntex Corp.

Palo Alto, CA

Nicholas Frey

Pioneer Hi-Bred International

Des Moines, IA

Akira Fujiyoshi

Eisai America, Inc.

Teaneck NJ

Jean-Christophe Galloux

Lyon, France

Cary Garner

Transgenic Sciences, Inc.

Worcester, MA

Luther Val Giddings

U.S. Department of Agriculture

Hyattsville, MD

David J. Glass

Biotechnica International, Inc.

Cambridge, MA

Rebecca J. Goldburg

Environmental Defense Fund

New York NY

Norman Gomm

Embassy of Australia

Washington, DC

James D. Grant

T Cell Sciences, Inc.

Cambridge, MA

Jones Grubbs

Solmar Corp.

Orange, CA

Leonard Guarraia

Monsanto Co.

St. Louis, MO 
Robert Z. Gussin

Johnson \& Johnson

New Brunswick NJ

Susan K. Harlander

University of Minnesota

St. Paul, MN

Zsolt P. Harsanyi

Porton International, Inc.

Washington, DC

Patricia Hoben

Howard Hughes Medical Institute

Bethesda, MD

Michael Hooker

University of Maryland

Baltimore, MD

Ralf Hutter

ETH-Zentrum

Zurich, Switzerland

Roger D. Jennings

British Embassy

Washington, DC

Daniel F. Jones

U.S. Department of Agriculture

Washington, DC

Nigel Jones

Linklaters \& Paines

London, England

Elke Jordan

National Institutes of Health

Bethesda, MD

Yoshiki Kaneiwa

Sumitomo pharmaceuticals Co., Ltd.

Osaka Japan

John Kirschman

FSC Associates

Lewisville, NC

Ruth L. Kirschstein

National Institute of General Medical Sciences

Bethesda, MD

Arthur Klausner

Domain Associates

Princeton, NJ

Edward L. Korwek

Hogan \& Hartson

Washington, DC

Sheldon Krimsky

Tufts University

Medford, MA
Asalie Larrson

Swedish Patent and Registration Office

Stockholm, Sweden

Peder Olesen Larsen

Danish Research Administration

Copenhagen, Denmark

Robert Leach

Genencor International

South San Francisco, CA

Charles C. Leighton

Sharp \& Dohme Research Laboratories

West Point, PA

William Lesser

Cornell University

Ithaca, NY

M.S. Linskens

State University of Leiden

Leiden, The Netherlands

David MacKenzie

U.S. Department of Agriculture

Washington, DC

William E. Marshall

Pioneer Hi-Bred International, Inc.

West DeMonies, IA

Don Marzullo

Alexandria, VA

Barbara Mazur

DuPont Experimental Station

Wilmington, DE

John McClelland

U.S. Department of Agriculture

Washington, DC

Barry McSweeney

BioResearch Ireland

Dublin, Ireland

Laura R. Meagher

Rutgers, The State University of New Jersey

New Brunswick NJ

Terry L. Medley

U.S. Department of Agriculture

Hyattsville, MD

Margaret Mellon

National Wildlife Federation

Washington, DC

Steven Mendell

XOMA Corp.

Berkeley, CA 
Chris Messina

Genesis Technology Group, Inc.

Cambridge, MA

Elizabeth Milewski

U.S. Environmental Protection Agency

Washington, DC

Michael J. Montague

Monsanto Co.

St. Louis, MO

David Mowery

University of California

Berkeley, CA

John T. Neilson

University of Florida

Gainesville, FL

Nan Newell

Synertech Group, Inc.

Research Triangle Park, NC

Ashok Nimgade

Genesis Technology Group, Inc.

Cambridge, MA

Suzanne M. Nowak

The Upjohn Co.

Kalamazoo, MI

Kirsten A. Nyrop

KPMG Peat Marwick

Chicago, IL

Gilbert S. Omenn

University of Washington

Seattle, WA

Michael Ostrach

Cetus Corp.

Emeryville, CA

Antonio Paes De Carvalho

Associacao Brasileira Das Empresas De Biotechnologia

Rio de Janeiro, Brazil

Bruce Peacock

Centocor, Inc.

Malvern, PA

Walter Plosilla

Montgomery County High Technology Council, Inc.

Rockville, MD

Isaac Rabino

Empire State College

New York NY

Lisa Raines

Industrial Biotechnology Association

Washington, DC
George Rathmann

ICOS

Bothell, WA

Craig J. Regelbrugge

National Association of Plant Patent Owners

Washington, DC

Alice Sapienza

Simmons College

Boston, MA

Gabriel Schmergel

Genetics Institute

Cambridge, MA

John W. Schneller

Spencer \& Frank

Washington, DC

Sidney A. Shapiro

University of North Carolina

Chapel Hill, NC

Margaret Sharp

University of Sussex

Brighton, East Sussex, England

Frances E. Sharples

Martin Marietta Energy Systems, Inc.

Oak Ridge, TN

David Shaw

IDEXX

Portland, ME

Robert Shaw

Franklin Pierce Law Center

Concord, NH

David A. Smith

U.S. Department of Energy

Washington, DC

Martha Steinbeck

U.S. Department of Agriculture

Washington, DC

Robert E. Stevenson

American Type Culture Collection

Rockville, MD

Jacob C. Stucki

Upjohn Co.

Kalamazoo, MI

Tadao Suzuki

Daiichi Pharmaceutical Co., Ltd.

Tokyo, Japan

Paul Tauber

Ithaca, NY 
James Tavares

National Research Council

Washington, DC

Yong-Sea Teoh

Economic Development Board

Singapore

David T. Thelwall

Prospect Management Services

North Yorkshire, England

James Thompson

State University of New York

Alfred, NY

Weichen Tien

Development Center for Biotechnology

Taipei, Taiwan

Ryuichiro Tsugawa

Ajinomoto Co., Inc.

Tokyo, Japan

Robert R. van der Meer

Florigene

Aalsmeer, The Netherlands

Charles E. Van Horn

Patent and Trademark Office

Washington, DC

D. Vandergheynst

Commission of the European Communities

Brussels, Belgium

Anne K. Vidaver

University of Nebraska

Lincoln, NE

Judith Wagner

Office of Technology Assessment

Washington, DC
Bill Westermeyer

Office of Technology Assessment

Washington, DC

William J. Whelan

Miami Biotechnology Winter Symposium

Miami, FL

Thomas G. Wiggins

Serono Laboratories, Inc.

Norwell, MA

Bernard Wolnak

Bernard Wolnak \& Associates

Chicago, IL

Akihiro Yoshikawa

Stanford University

Palo Alto, CA

Yeo-Gyeong Yun

Korea Development Investment Corp.

Seoul, Korea

Holger Ziehr

Gesellschaft fr Biotechnologische Forschung mbH Braunschweig, Germany

Raymond Zilinskas

Maryland Biotechnology Institute

Baltimore, MD

Robert G. Zimbleman

American Society of Animal Science

Bethesda MD 


\begin{tabular}{|c|c|}
\hline & List of Acronyms \\
\hline ACGM & $\begin{array}{l}\text { —Advisory Committee on Genetic } \\
\text { Manipulation (U.K.) }\end{array}$ \\
\hline ACRE & $\begin{array}{l}\text {-Advisory Committee on Release to the } \\
\text { Environment (U.K.) }\end{array}$ \\
\hline ADAMHA & $\begin{array}{l}\text {-Alcohol, Drug Abuse, and Mental Health } \\
\text { Administration (DHHS) }\end{array}$ \\
\hline AID & $\begin{array}{l}\text {-Agency for International Development, } \\
\text { U.S. (State Department) }\end{array}$ \\
\hline AIDS & —acquired immunodeficiency syndrome \\
\hline ANDA & -Abbreviated New Drug Application (FDA) \\
\hline APHIS & $\begin{array}{l}\text {-Animal and Plant Health Inspection } \\
\text { Service (USDA) }\end{array}$ \\
\hline APO & -Australian Patent Office \\
\hline ARC & -AIDS-related complex \\
\hline ARS & -Agriculture Research Service (USDA) \\
\hline ATCC & -American Type Culture Collection \\
\hline BAP & -Biotechnology Action Program (EC) \\
\hline BBS & $\begin{array}{l}\text {-Biological, Behavioral, and Social } \\
\text { Sciences Directorate (NSF) }\end{array}$ \\
\hline BEP & -Biomolecular Engineering Program (EC) \\
\hline BIDEC & -Biotechnology Development Center (Japan) \\
\hline BMFT & $\begin{array}{l}\text {-Federal Ministry of Research and } \\
\text { Technology (Germany) }\end{array}$ \\
\hline BRI & -BioResearch Ireland \\
\hline BRIDGE & $\begin{array}{l}\text {-Biotechnological Research for Industrial } \\
\text { Development and Growth in Europe (EC) }\end{array}$ \\
\hline BRS & $\begin{array}{l}\text {-Biotechnology Research Subcommittee } \\
\text { (OSTP) }\end{array}$ \\
\hline BSC & $\begin{array}{l}\text { - Biological and Critical Systems Division } \\
\text { (NSF, ENG) }\end{array}$ \\
\hline BSCC & $\begin{array}{l}\text {-Biotechnology Science Coordinating } \\
\text { committee (OSTP) }\end{array}$ \\
\hline bST & -bovine somatotropin \\
\hline BT & —Bacillus thuringiensis \\
\hline CAA & —Clean Air Act (U. S.) \\
\hline CAP & —Common Agricultural Policy (EC) \\
\hline CCL & —Commodity Control List (U.S.) \\
\hline Cell Bank & -Human Genetic Mutant Cell Repository \\
\hline CEN & - Committee for European Standardization \\
\hline CERCLA & $\begin{array}{l}\text {-Comprehensive Environmental Response, } \\
\text { Compensation, and Liability Act (U.S.) }\end{array}$ \\
\hline CHE & —Chemistry Division (NSF, MPS) \\
\hline CISE & $\begin{array}{l}\text {-Computer and Information Science and } \\
\text { Engineering Directorate (NSF) }\end{array}$ \\
\hline CoCom & $\begin{array}{l}\text {-Coordinating Committee on Multilateral } \\
\text { Export Controls }\end{array}$ \\
\hline CRADA & $\begin{array}{l}\text {-Cooperative Research and Development } \\
\text { Agreement }\end{array}$ \\
\hline
\end{tabular}

CSRS

CTS

-CooperativeResearch Service (USDA)

CUBE

(NSF, ENG)

CWA -Clean Water Act (U.S.)

DARPA -Defense Advanced Research Projects Agency (DoD)

DBC - dedicated biotechnology company

DECHEMA,-German Society for Chemical Equipment,

DES - Chemical Technology and Biotechnology (U.K.)

DGxxII -Directorate General for Science, Research and Development (EC)

DHHS -Department of Health and Human Services, U.S.

DMR -Division of Materials Research (NSF, MPS)

DMS -Division of Mathematical Sciences (NSF, MPS)

DNA -deoxyribonucleic acid

DOC -Department of Commerce, U.S.

DoD -Department of Defense, U.S.

DOE -Department of Energy, U.S.

DTI -Department of Trade and Industry (U.K.)

EC -European Community

ECLAIR -European Collaborative Linkage of Agriculture and Industry through Research (EC)

EGTA -Environmental and Gene Technology Act (Denmark)

EMS -Eosinophilia-Myalgia Syndrome

ENG -Engineering Directorate (NSF)

EOLAS - Irish Science Agency

EPA -Environmental Protection Agency, U.S.

EPC -European Patent Convention

EPO -erythropoietin

ERATO -Promotion of Exploratory Research for

ERS Advanced Technology System (STA,Japan)

ERS—Economic Research Service (USDA)

EUP -Experimental Use Permit (EPA)

EUREKA -European Research Coordination Agency

FASB -Financial Accounting Standards Board

FCCSET -Federal Coordinating Council for Science, Engineering and Technology

FDA -Food and Drug Administration, U.S.

FDCA -Federal Food, Drug, and Cosmetic Act (U.S.)

FIFRA - Federal Insecticide, Fungicide, and Rodenticide Act (U.S.) 


\begin{tabular}{|c|c|c|c|}
\hline FLAIR & $\begin{array}{l}\text {-Food-Linked Agro-Industrial Research } \\
\text { program (EC) }\end{array}$ & $\begin{array}{l}\mathrm{MPBC} \\
M P_{S}\end{array}$ & $\begin{array}{l}\text {-Midwest Plant Biotechnology Consortium } \\
\text { —Mathematical and Physical Sciences }\end{array}$ \\
\hline FRG & -Federal Republic of Germany & & Directorate (NSF) \\
\hline FSIS & —Food Safety and Inspection Service (USDA) & MSG & —monosodium glutamate \\
\hline FTC & -Federal Trade Commission, U.S. & NASA & -National Aeronautics and Space \\
\hline FTTA & $\begin{array}{l}\text {-Federal Technology Transfer Act of } 1986 \\
\text { (U.S.) }\end{array}$ & $N B S$ & $\begin{array}{l}\text { Administration, U.S. } \\
\text { —National Bureau of Standards (DOC) }\end{array}$ \\
\hline GAAP & $\begin{array}{l}\text { generally accepted accounting principles } \\
\text { (FASB) }\end{array}$ & $\begin{array}{l}\text { NCBC } \\
\text { NDA }\end{array}$ & $\begin{array}{l}\text {-North Carolina Biotechnology Center } \\
\text {-New Drug Application (FDA) }\end{array}$ \\
\hline $\begin{array}{l}\text { GAO } \\
\text { GATT }\end{array}$ & $\begin{array}{l}\text {-General Accounting Office, U.S. } \\
\text {-General Agreement on Tariffs and Trade }\end{array}$ & NEPA & $\begin{array}{l}\text {-National Environmental Protection Act } \\
\text { (U.S.) }\end{array}$ \\
\hline G-CSF & - granulocyte-colony stimulating factor & $\mathrm{NICs}$ & —Newly Industrializing Countries \\
\hline GDR & -German Democratic Republic & NIH & —National Institutes of Health (U. S.) \\
\hline $\begin{array}{l}\text { GenBank } \\
\text { GEO }\end{array}$ & $\begin{array}{l}\text {-Genetic Sequence Data Bank } \\
\text {-Geosciences Dictorate (NSF) }\end{array}$ & NIST & $\begin{array}{l}\text { - National Institute of Standards and } \\
\text { Technology (DOC) }\end{array}$ \\
\hline GILSP & $\begin{array}{l}\text {-Good Industrial Large-Scale Practice } \\
\text { (OECD) }\end{array}$ & NOAA & $\begin{array}{l}\text {-National Oceanic and Atmospheric } \\
\text { Administration (DOC) }\end{array}$ \\
\hline GMAC & $\begin{array}{l}\text {-Genetic Manipulation Advisory } \\
\text { Committee (Australia) }\end{array}$ & $\begin{array}{l}\text { NRC } \\
\text { NRRL }\end{array}$ & $\begin{array}{l}\text {-National Research Council (U.S.) } \\
\text { —Northern Regional Research Laboratory }\end{array}$ \\
\hline GM-CSF & $\begin{array}{l}\text { - granulocyle macrophage colony } \\
\text { stimulating factor }\end{array}$ & $\stackrel{\mathrm{NSF}}{O C E}$ & $\begin{array}{l}\text {-National Science Foundation (U. S.) } \\
\text {-Oceanography Division (NSF, GEO) }\end{array}$ \\
\hline $\begin{array}{l}\text { GNP } \\
\text { GRAS }\end{array}$ & $\begin{array}{l}\text {-Gross National Product } \\
\text { _ generally recognized as safe }\end{array}$ & OECD & $\begin{array}{l}\text {-Organisation for Economic Co-operation } \\
\text { and Development }\end{array}$ \\
\hline HIV & - human immunodeficiency virus & $O M B$ & -Office of Management and Budget (U. S.) \\
\hline $\begin{array}{l}\text { IDAs } \\
\text { IFBC }\end{array}$ & $\begin{array}{l}\text {-International Depositary Authorities } \\
\text {-International Food Biotechnology Council }\end{array}$ & OPEC & $\begin{array}{l}\text {-Organization of Petroleum Exporting } \\
\text { Countries }\end{array}$ \\
\hline IMCB & $\begin{array}{l}\text {-Institute of Molecular and Cell Biology } \\
\text { (Singapore) }\end{array}$ & $\begin{array}{l}\text { ORD } \\
\text { OSHA }\end{array}$ & $\begin{array}{l}\text {-Office of Research and Development (EPA) } \\
\text {-Occupational Safety and Health }\end{array}$ \\
\hline INT & -International Division (NSF, STIA) & & Administration (U. S.) \\
\hline IOP-b & $\begin{array}{l}\text {-Innovation Oriented program for } \\
\text { Biotechnology (The Netherlands) }\end{array}$ & OSTP & $\begin{array}{l}\text { Office of Science and Technology Policy } \\
\text { (White House) }\end{array}$ \\
\hline $\begin{array}{l}\text { IPO } \\
\text { ISA }\end{array}$ & $\begin{array}{l}\text {-initial public offering } \\
\text {-international searching authority }\end{array}$ & OTA & $\begin{array}{l}\text {-Office of Technology Assessment (U.S. } \\
\text { Congress) }\end{array}$ \\
\hline ISTI & $\begin{array}{l}\text {-Industrial Science and Technological } \\
\text { Innovation Divison (NSF, STIA) }\end{array}$ & $\begin{array}{l}\text { PCBs } \\
\text { PCR }\end{array}$ & $\begin{array}{l}\text { - polychlorinated biphenyls } \\
\text { - polymerase chain reaction }\end{array}$ \\
\hline ITC & -International Trade Commission & PCT & -Patent Cooperation Treaty \\
\hline $\begin{array}{l}\text { JBA } \\
\text { JPO }\end{array}$ & $\begin{array}{l}\text {-Japan Bio-Industry Association } \\
\text {-Japanese Patent Office }\end{array}$ & PERI & $\begin{array}{l}\text {-Protein Engineering Research Institute } \\
\text { (Japan) }\end{array}$ \\
\hline JRDC & $\begin{array}{l}\text {-Japanese Research Development } \\
\text { Corporation }\end{array}$ & $\begin{array}{l}\text { PHS } \\
\text { PLA }\end{array}$ & $\begin{array}{l}\text {-Public Health Service, U.S. (DHHS) } \\
\text {-Product License Application (FDA) }\end{array}$ \\
\hline KIST & $\begin{array}{l}\text { - Korea Institute of Science and Technology } \\
\text { (South Korea) }\end{array}$ & PMA & $\begin{array}{l}\text {-Pharmaceutical Manufacturers } \\
\text { Association }\end{array}$ \\
\hline KOGERA & $\begin{array}{l}\text { - Korean Genetic Research Association } \\
\text { (South Korea) }\end{array}$ & $\begin{array}{l}\text { PPA } \\
\text { PQA }\end{array}$ & $\begin{array}{l}\text {-Plant Patent Act (U.S.) } \\
\text { _Plant Quarantine Act (U.S.) }\end{array}$ \\
\hline KPO & -Korean Patent Office (South Korea) & PTO & -Patent and Trademark Office (U. S.) \\
\hline MAFF & $\begin{array}{l}\text {-Ministry of Agriculture, Forestry, and } \\
\text { Fisheries (Japan) }\end{array}$ & $\begin{array}{l}\text { PVPA } \\
\text { R\&D }\end{array}$ & $\begin{array}{l}\text {-Plant Variety Protection Act (U.S.) } \\
\text {-research and development }\end{array}$ \\
\hline $\begin{array}{l}\text { MC } \\
\text { MCTL }\end{array}$ & $\begin{array}{l}\text {-Ministry of Construction (Japan) } \\
\text {-Militarily Critical Technologies List (U.S.) }\end{array}$ & $\mathrm{RAC}$ & $\begin{array}{l}\text { —Recombinant DNA Advisory Committee } \\
(\mathrm{NIH})\end{array}$ \\
\hline $\begin{array}{l}\text { MEOR } \\
M E S C\end{array}$ & $\begin{array}{l}\text { - microbial enhanced oil recovery } \\
\text {-Ministry of Education, Science and } \\
\text { Culture (Japan) }\end{array}$ & $\begin{array}{l}\text { RCRA } \\
\text { RDLP }\end{array}$ & $\begin{array}{l}\text { - Resource Conservation and Recovery Act } \\
\text { - research and development limited } \\
\text { partnership }\end{array}$ \\
\hline MHW & -Ministry of Health and Welfare (Japan) & rDNA & -recombinant DNA \\
\hline MITI & $\begin{array}{l}\text {-Ministry of International Trade and } \\
\text { Industry (Japan) }\end{array}$ & $\begin{array}{l}\text { RFLP } \\
\text { SARA }\end{array}$ & $\begin{array}{l}\text { - restriction fragment length polymorphism } \\
\text { - Superfund Amendments and }\end{array}$ \\
\hline MOs & -Market-Oriented Sector Selective talks & & - t. t. \\
\hline
\end{tabular}




\begin{tabular}{|c|c|}
\hline 3IR & $\begin{array}{l}\text { —Small Business Innovation Research } \\
\text { Agency }\end{array}$ \\
\hline SDI & $\begin{array}{l}\text {-Strategic Defense Initiative (Star Wars) } \\
\text { (U.S.) }\end{array}$ \\
\hline SIC & $\begin{array}{l}\text { —standard industrial classification system } \\
\text { (DOC) }\end{array}$ \\
\hline & -Supplementary Protection Certificate (EC) \\
\hline & $\begin{array}{l}\text {-Science Resource Studies Division (NSF, } \\
\text { STIA) }\end{array}$ \\
\hline & -Science and Technology Agency (Japan) \\
\hline & -Science and Technology Centers (NSF) \\
\hline & - Scientific, Technological, and \\
\hline & - Tumor Necrosis Factor \\
\hline & tivator \\
\hline$C$ & -Toxic Substances Control Act of 1976 \\
\hline & -United Kingdom \\
\hline & -United Nations \\
\hline 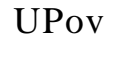 & $\begin{array}{l}\text {-International Union for the Protection of } \\
\text { New Varieties of Plants }\end{array}$ \\
\hline & -Department of Agriculture, U.S. \\
\hline & -Union of Soviet Socialist Republics \\
\hline & -United States Trade Representative \\
\hline & -Veteran's Administration (U. S.) \\
\hline & —World Health Organization (U.N.) \\
\hline & —World Intellectual Property Organization \\
\hline & $\begin{array}{l}\text { —Advisory Board for Biological Safety } \\
\text { (Germany) }\end{array}$ \\
\hline
\end{tabular}

\section{Glossary of Terms}

Acquisition: One company taking controlling interest in another company. Investors are always looking for companies that are likely to be acquired because those who want to acquire such companies are often willing to pay more than the market price for the shares they need to complete the acquisition.

Aerobic: Living or acting only in the presence of oxygen. Allele: Alternative form of a genetic locus (e.g., at a locus for hair color there may be alleles for blonde or black hair); alleles are inherited separately from each parent.

Amino acid: Any of a group of 20 molecules linked together in various combinations to form proteins. Each different protein is made up of a specific sequence of these molecules with the unique sequence coded for by DNA.

Amortization: Accounting procedure that gradually reduces the cost-value of a limited life or intangible asset through periodic charges to income.

Anaerobic: Living or acting in the absence of oxygen.

Animal: A nonhuman living being with a capacity for spontaneous movement and a rapid motor response to stimulation Arímals can be divided into two groups, invertebrates (animals without backbones) and vertebrates (animals with backbones).
Animal patents: The patenting of nonhuman transgenic animal life forms. The United States is currently the only country that has issued a patent for an animal developed using biological techniques. The ability to patent animals introduces a new legal concept of animal ownership and raises a number of ethical, economic, and practical issues.

Antibody: A protein (immunoglobulin) produced by the immune system of humans and higher animals in response to exposure to a specific antigen and characterized by specific reactivity with its complementary antigen. (See also antigen and monoclinal antibodies.)

Antigen: A molecule (usually a protein or carbohydrate) that when introduced into an organism (usually humans or higher animals) is recognized as a foreign substance and elicits an immune response (antibody production, lymphokine production, or both) directed specifically against that molecule. (See also antibody and monoclinal antibodies.)

Applied research: Research done to gain knowledge or understanding necessary for determining $g$ the means by which a recognized and specific need may be met. In biotechnology, it is the use of rDNA, hybridomas, and other tools to develop specific products or processes (e.g., rDNA use to develop vaccines for specific antigens, such as malaria or HIV; the transfer of herbicide or pesticide resistance to a particular plant species; or the use of monoclinal antibodies as purification tools in bioprocessing). (See also generic applied research.)

Asexual reproduction: Reproduction of plants by purely vegetative means without the function and interaction of the two sexes. Examples of asexually produced plants are roses, peach trees, and lilies.

Assets: Anything having commercial or exchange value that is owned by a business, institution, or individual.

B lymphocyte: A specialized white blood cell involved in the immune system response of vertebrates that originates in the bone marrow and produces antibody molecules after challenge by an antigen. In hybridoma technology, these cells contribute antibody-producing capability to the hybridoma. (See also $T$ lymphocyte.)

Bacterium (p]. bacteria): Any of a group of unicellular or noncellular micro-organisms having round, rodlike, spiral, or filamentous bodies that are enclosed by a cell wall or membrane and lack fully differentiated nuclei. Bacteria may exist as free-living organisms in soil, water, organic matter, or as parasites in the live bodies of plants or animals.

Base pair: Two complementary nucleotides (adenosine and thymidine or guanosine and cytidine) held together by weak bonds. Two strands of DNA are held together in the shape of a double helix by the bonds between base pairs.

Basic research: Research performed to gain fuller knowledge or understanding of the fundamental as- 
pects of phenomena and of observable facts, without specific applications toward products or processes in mind. In biotechnology it is the use of its component tools (e.g., DNA and hybridomas) to study ways in which biological systems work and to identify the mechanisms that govern how they work.

Biologics: Vaccines, therapeutic serums, toxoids, antitoxins, and analogous biological products used to induce immunity to infectious diseases or harmful substances of biological origin.

Biomass: All organic matter that grows by the photosynthetic conversion of solar energy.

Bioprocess engineering: Process that uses complete living cells or their components (e.g., enzymes, chloroplasts) to effect desired physical or chemical changes.

Bioreactor: A vessel used for bioprocessing.

Bioremediation: A strategy that uses biotechnological methods to cleanup wastes. These methods involve engineering systems that use biological processes to degrade, detoxify, or accumulate contaminants. Bioremediation, or biotreatment, systems can use naturally occurring or laboratory-altered microbes, or both.

Biosynthesis: Production, by synthesis or degradation, by a chemical or living organism.

Biotechnology: Any technique that uses living organisms or substances from those organisms to make or modify a product, to improve plants or animals, or to develop micro-organisms for specific uses. These techniques include the use of novel technologies such as recombinant DNA, cell fusion, and other bioprocesses. (See also genetic engineering and recombinant DNA.)

Black Monday: October 19, 1987, when the Dow Jones Industrial Average plunged a record 508 points following sharp drops the previous week-reflecting investor anxiety about inflated stock price levels, Federal budget and trade deficits, and foreign market activity.

Book value: Net asset value of a company's securities, calculated as total assets minus intangible assets (goodwill, patents, etc.), minus current liabilities, minus any long-term liabilities and equity issues that have prior claim. The total net asset figure, divided by the number of bonds, shares of preferred stock, or shares of common stock, gives the net asset value, or book value, per bond or per share of preferred or common stock Book value can be a guide in selecting stocks and is an indication of the ultimate value of securities in liquidation.

Capital gain: The difference between an asset's purchase price and selling price, when the difference is positive.

Carrier: See vector.

Cash burn rate: The rate at which a company uses cash, i.e., cash flow. Biotechnology companies are generally cash users, not generators. Cash burn rates are very high in the years before the first profits are made.
Cell: The smallest component of life. A membrane-bound protoplasmic body capable of carrying on all essential life processes.

Cell culture: The in vitro growth of cells isolated from multicellular organisms; also used to refer to any particular individual sample. (See also tissue culture.)

Cell fusion: The joining of the membrane of two cells, thus creating a hybrid cell that contains the nuclear matter from the parent cells.

Chloroplasts: Cellular organelles where photosynthesis occurs.

Chromosome: A thread-like structure contained in the nucleus of a cell that carries the genes that convey hereditary characteristics.

Claim: The part of a patent that points out and distinctly specifies the subject matter that the applicant regards as the invention. Claims represent the metes and bounds of the property to be protected.

Clone: A group of genetically identical cells or organisms produced asexually from a common ancestor.

Cloning: The process of producing clones. In rDNA technology, the process of using a variety of DNA manipulation procedures to produce multiple copies of a single gene or segment of DNA.

Common law: Law created by judicial decisions, as distinguished from law created by the enactments of legislatures. In the United States, common law encompasses that portion of the common law of England (including such acts of Parliament as were applicable) that had been adopted and was in force (in the United States) at the time of the American Revolution.

Common stock: Units of ownership of a public corporation. Owners typically are entitled to vote on the selection of directors and other important matters as well as to receive dividends on their holdings. In the event that a corporation is liquidated, the claims of secured and unsecured creditors and owners of bonds and preferred stock take precedence over the claims of those who own common stock. For the most part, however, common stock has more potential for appreciation.

Convertible debt: Debt that is exchangeable in another form for a prestated price. Convertible debt is appropriate for investors who want higher income than is available from common stock Most commonly corporate securities (usually preferred shares or bonds) are purchased and later traded for common shares.

Copyright: A patent-like instrument that protects the expression of the idea, not the idea itself.

Cost of capital: The rate of return that a business could earn if it chose another investment with equivalent risk-in other words, the opportunity cost of the funds employed as the result of an investment decision or actual debt costs as part of the capital structure of the company. 
Cultivar: Often used to refer to plant strains. (See strain.)

Culture deposits: See \&posits.

Cytoplasm: The substance within a cell, external to the nuclear membrane.

Deoxyribonucleic acid (DNA): 20 The molecule that is the repository of genetic information in all organisms (with the exception of a small number of viruses in which the hereditary material is ribonucleic acidRNA). The information coded by DNA determines the structure and function of the organism.

Deposit: Placement of micro-organisms, vectors, cells, plant tissues, seeds, and other biological materials that are newly isolated, novel, manmade, or not generally available to the public on a long-term basis in recognized patent depositories as part of the patent application process.

Depositories: A facility that accepts, maintains, classifies, and distributes cultures of micro-organisms, viruses, cells, and other genetic or biological material. Since 1983, a few depositories have begun to accept seeds and plant tissue cultures, but to date no depository has accepted any animal. Depositories can be public, private, for-profit, or nonprofit. Three depositories in the United States are recognized as International Depositary Authorities (IDAs) for patent purposes.

Enablement: A patent requirement for adequate public disclosure of an invention, enabling others in the relevant field to build or use the invention.

Endotoxin: A poison produced by some gram-negative bacteria present in the cellular membrane and released only on cell rupture; it is composed of complex lipopolysaccharide and is more heat-stable than protein exotoxins. (See also exotoxin).

Enzyme: A protein that acts as a catalyst, speeding the rate at which a biochemical reaction proceeds, but not altering its direction or nature and without itself being destroyed.

Equity: In economics, the monetary value of property, or of an interest in a property, in excess of claims or liens against it. Also, ownership interest possessed by shareholders in a corporation stock as opposed to bonds. Shares can be common or preferred. In law, a body of law separate from common law that is designed to achieve a lawful result when legal procedure is inadequate.

Equity capital: Capital proceeds arising from the sale of company stock.

Equity investment: An investment made in a company in exchange for a part ownership of that company.

Eukaryote: A cell or organism with membrane-bound, structurally discrete nuclei and well-developed cell organelles. Eukaryotes include all organisms except viruses, bacteria, and blue-green algae. (See prokaryote.)
Exit opportunities: A term commonly used by venture capitalists to describe opportunities for investors to realize their investment or pullout of a deal. Examples are the public markets, mergers, and acquisitions.

Exotoxin: A poison excreted by some gram-negative or gram-positive organisms; it is composed of protein. (See also endotoxin.)

Fermentation: An anaerobic process used for growing micro-organisms for the production of various chemical or pharmaceutical compounds. Microbes are normally incubated under specific conditions in the presence of nutrients in large tanks called fermenters.

Gamette: A mature reproductive cell (haploid set of chromosomes) capable of fusing with a similar cell of the opposite sex to yield a zygote; it is also called a sex cell.

Gene: The fundamental physical and functional unit of heredity; an ordered sequence of nucleotide base pairs that produce a specific product or have an assigned function.

Gene pool: The sum total of genes in a breeding population.

Gene probe: A molecule of known structure and/or function used to locate and identify a specific region or nucleotide sequence of a genome. It is usually a piece of complementary DNA that has been labeled with a tracer substance, such as a dye or radioactive label.

Generic applied research: Research that falls between the extremes of basic and applied research. This research may be characterized as follows: 1) it is not committed to open-ended expansion of knowledge as university-like basic research usually is but is less specific than the typical industrial product or process development effort; 2) it has more well-defined objectives than basic research but is long term, relative to product or process development; and 3) it is high risk, in the sense that the stated objectives may fail and the resources committed may be lost for practical purposes.

Genetic engineering: Technologies (including rDNA methods) used to isolate genes from an organism, manipulate them in the laboratory,, and insert them stably in another organism. (See also recombinant DNA and biotechnology.)

Genome: All the genetic material in the chromosomes of a particular organism: its size is generally given as its total number of base pairs.

Genome projects: Research and technology development efforts aimed at mapping and sequencing some or all of the genome of human beings and other organisms.

Genotype: The genetic constitution of an organism as distinguished from its physical appearance (phenotype). 
Germ line: The earliest, primitive stage of development; $\mathrm{P}$ e " $\mathrm{g}$ to tissues or cell lineages producing gametes. (See also somatic.)

Germplasm: The total genetic variability available to a species.

Gram negative/positive: A classification of bacteria based on differential staining utilizing the GramWiegert procedure.

Host: A cell whose metabolism is used for growth and reproduction of a virus, plasmid, or other form of foreign DNA.

Hybrid: An offspring of a cross between two genetically unlike individuals.

Hybridization: The act or process of producing hybrids. More specifically, in cell culture, the formation of new cells as a result of the fusion of whole cells or cell parts of different parental origin. In rDNA, a procedure in which single-stranded nucleic acid segments are allowed to bind to identical or nearly identical sequences, forming double-stranded heleices.

Hybridoma: A cell produced by fusing a myeloma cell (a type of tumor cell that divides continuously in culture and is ' 'immortal' and a lymphocyte (an antibody-producing cell). The resulting cell grows in culture and produces the specific antibody produced by the parent lymphocyte (a monoclonal antibody).

Immune response: The reaction of an organism to invasion by a foreign substance. Immune responses are often complex and may involve the production of antibodies in special cells (lymphocytes), as well as the removal of the foreign substance by other cells.

Immunoglobulin: See antibody.

In vitro: Literally, in glass; pertaining to a biological reaction taking place in an artificial apparatus.

In vivo: Literally, in life; pertaining to a biological reaction taking place in a living cell or organism.

Intellectual property: The area of law encompassing patents, trademarks, trade secrets, copyrights, and plant variety protection.

Linkage: The proximity of two or more markers (e.g., genes, RFLP markers) on a chromosome; the closer together the markers are, the lower the probability that they will be separated during meiosis and hence the greater the probability they will be inherited together.

Liquidity: Ability of an individual or company to convert assets into cash or cash equivalents without significant loss. Having a good amount of liquidity means being able to meet maturing obligations promptly, earn trade discounts, benefit from a good credit rating, and take advantage of market opportunities.

Locus (pi. loci): A specific, physical position on a chromosome occupied by a particular gene or its alleles.

Lymphocytes: See B lymphocytes and T lymphocytes.

Lymphokines: Proteins that mediate interactions among lymphocytes and are vital to proper immune function.
Microphage: A large specialized cell that originates in the bone marrow and is involved in many stages of the immune response, including consumption of foreign particles such as viruses and lymphokine production.

Marker: A gene with a known location on a chromosome and a clear-cut phenotype that is used as a point of reference when mapping another locus.

Market capitalization: Value of a corporation as determined by the market price of its issued and outstanding common stock It is calculated by multiplying the number of outstanding shares by the current market price of a share. Institutional investors often use market capitalization as one investment criterion. Analysts look at market capitalization in relation to book or accounting value for an indication of how investors value a company's future prospects.

Meiosis: The process of two consecutive cell divisions in the diploid progenitors of sex cells. Meiosis results in four rather than two daughter cells, each with a haploid set of chromosomes.

Merger: Combination of two or more companies, either through a pooling of interests, where the accounts are combined; a purchase, where the amount paid over and above the acquired company's book value is carried on the books of the purchaser as goodwill; or a consolidation, where anew company is formed to acquire the net assets of the combining companies.

Mitochondria: Structures, or organelles, within cells where energy is produced and stored; they contain DNA molecules, inherited from the mother only, that replicate independently.

Monoclinal antibodies: Identical antibodies that recognize a single antigen; they are produced by a clone of specialized cells.

Mutation: Any change in DNA sequence that results in a new characteristic that can be inherited. (See also polymorphism.)

National treatment: A principle which provides that, with regard to the protection of industrial property, nationals of any country are to enjoy the advantages of the laws concerning industrial property granted to nationals of the country in which protection is being sought.

Neoplasm: A growth of tissue serving no physiological function (e.g., a tumor).

Nitrogen fixation: A biological process (usually associated with plants) whereby certain bacteria convert nitrogen in the air to ammonia, thus forming a nutrient essential for growth.

Novelty: One of the criteria used in the evaluation of patent applications. The invention or discovery must be new and not have previously existed through the work of others in order to be accepted on the grounds of novelty.

Obviousness: One of the criteria used in the evaluation of patent applications. Obviousness addresses the degree 
of difference between the invention being evaluated and that which is already known or available. (See also prior art.)

Oncogene: A gene, one or more forms of which is associated with cancer. Many oncogenes are involved, directly or indirectly, in controlling the rate of cell growth.

Operating profit (or loss): The difference between the revenues of a business and the related costs and expenses, excluding income derived from sources other than its regular activities and before income deductions.

Organelle: A structure in the cytoplasm of a cell that is specialized in its ultrastructure and biochemical composition to serve a particular function (e.g., mitochondria, chloroplast).

Pathogenic: Able to cause disease; often utilized to express inactivation or lethality.

Phenotype: The observable characteristics of an organism produced by the interaction of the genotype and the environment

Plant patents: Plant patents protect asexually reproduced plant varieties, including cultivated sports, mutants, hybrids, and newly found seedlings. They cannot be obtained for tubers or wild varieties found in nature that are not asexually reproduced.

Plant variety protection: Patent-like protection for certain sexually produced plants.

Plasmid: An extrachromosomal, circular piece of DNA found in the cytoplasm and capable of replicating and segregating independently of the host chromosome.

Polymerase chain reaction (PCR): An in vitro process, through which repeated cycling of the reaction reproduces a specific region of DNA, yielding millions of copies from the original.

Polymorphism: Difference in DNA sequence among individuals. Genetic variation in more than 1 percent of a population would be considered useful for genetic linkage analysis. (See also mutation.)

Preferred stock: A class of stock that pays dividends at a specific rate and that has preference over common stock in the payment of dividends and the liquidation of assets. Preferred stock does not ordinarily carry voting rights.

Prior art: That which is already known or available, part of the criteria of obviousness used in evaluating patent applications. (See also obviousness.)

Prokaryote: An organism (e.g., bacteria, virus, and blue-green algae) whose DNA is not enclosed within a nuclear membrane. (See eukaryote.)

Protein: A polypeptide consisting of amino acids whose structure is determined by the sequence of nucleotides in DNA. Proteins, in their biologically active states function as catalysts in metabolism and as structural elements of cells and tissues.
Recombinant DNA (rDNA): A broad range of techniques involving the manipulation of the genetic material in organisms. The term is often used synonymously with genetic engineering. It is also used to described a DNA molecule constructed by genetic engineering techniques composed of DNA from different individuals on species. (See also biotechnology and genetic engineering.

Restriction enzymes: Certain bacterial enzymes that recognize short sequences of DNA and cut the DNA where these sites occur. Restriction enzymes can be used to isolate a gene that has been identified in the heredity material of an organism.

Restriction Fragment Length Polymorphisms (RFLPs): Variation in DNA fragment sizes cut by restriction enzymes; polymorphic sequences that are responsible for RFLPs are used as markers on genetic linkage maps.

Retrovirus: A family of viruses whose genetic material is RNA and is further characterized by the presence of reverse transcriptase in the viron; it is also called tumor virus.

Reverse transcriptase: An enzyme capable of directing the production of a single strand DNA copy from an RNA template.

Ribonucleic acid (RNA): A molecule existing in three forms-messenger RNA, transfer RNA, and ribosomal RNA-responsible for translating the genetic information encoded by an organism (i.e., DNA) into a protein product; the heredity material of some viruses.

Right of priority: A right that enables any resident or national regardless of nationality to first file a patent application in a country and thereafter file the same patent application in another country, thus ensuring that the subsequently filed applications enjoy the right of priority established by the first filing date.

Royalty: Payment to the holder for the right to use property such as a patent, copyrighted material, or natural resources. Royalties are set in advance as a percentage of income arising from the commercialization of the owner's rights or property.

Somatic: Pertaining to all diploid cells of an organism except the germ line, i.e., sex cells-sperm and eggs (See also germ.)

Species: Reproductive communities and populations that are distinguished by their collective manifestation of ranges of variation with respect to many different characteristic and qualities.

Specifications: In law, relating to patents, machinery, and building contracts, a particular or detailed statement of the various elements involved.

Statute: A law enacted and established by the legislative branch of a government. 
Strain: A pure culture of organisms within a species, characterized by one or more particular physical or genetic properties.

Strategic alliances: Associations between separate business entities that fall short of a formal merger but that unite certain agreed on resources of each entity for a limited purpose. Examples include equity purchase, licensing and marketing agreements, research contracts, and joint ventures.

$\mathrm{T}$ lymphocyte: Specialized white blood cells involved in the immune response of vertebrates that originate in the bone marrow, mature in the thymus gland, and produce some lymphokines. Subclasses of T lymphocytes are important to antibody production and the enhancement or suppression of an immune response. (See also B lymphocyte.)

Technology transfer: The process of converting scientific knowledge into useful products. This most often refers to the flow of information between public and private sectors or between countries.

Tissue culture: In vitro growth in a nutrient medium of cells isolated from tissue. (See also cell culture.)

Tissue plasminogen activator (tPA): A genetically engineered protein drug that helps to dissolve blood clots.

Tort law: Derived from legal principles governing wrongful acts, except those involving a breach of contract, committed against a person or property for which civil action would be valid.

Toxin: See endotoxin and exotoxin.

Transgenic animals: Animals whose hereditary DNA has been augmented by the addition of DNA from a source other than parental germplasm, usually from another animal or human, and done in a laboratory using rDNA techniques.

Transgenic plants: Plants whose hereditary DNA has been augmented by the addition of DNA from a source other than parental germplasm, usually from a related species, using rDNA techniques.

Utility patents: These are patents issued to inventors of any new and useful process, machine, manufacture, or composition or any new and useful improvement thereof.

Vector: A DNA molecule used to introduce foreign DNA into host cells.

Venture capital: An important source of financing for start-up companies that entails some investment risk but offers the potential for above-average future profits.

Virus: Any of a large group of organisms containing genetic material but unable to reproduce outside a host cell. 


\section{Index}


Abbreviated New Drug Application (ANDA), 93

Acquisitions, 54-57

defined, 8

foreign participation in, $54-56$

of independent seed companies, 108

premium paid for stock during, 57

See also Consolidation

Advisory Board for Biological Safety (ZBKS)-Germany, 191

Advisory Committee on Genetic Modification (ACGM)-United Kingdom, 193

Advisory Committee on Release to the Environment (ACRE)United Kingdom, 193

Agriculture

biopesticides for, 102-103, 105-106

biotechnology-related R\&D directed toward, 10,11,103-105, 108, 109-110

biotechnology's commercial applications to, 8-10, 11, 100107

cell culture and, 104-105

environmental applications of biotechnology to, 8-10, 11, 103-105, 108, 109-110, 129-131

public opinion on biotechnology applied to, 10, 112-113

Agricultural Research Service (ARS)--USDA, 104

Agrigenetics, 109

Agroceres SA, 108,109

AIDS (acquired immunodeficiency syndrome), biotechnology research to combat, 76-77,78, 79

Alcohol, Drug Abuse, and Mental Health Administration (ADAMHA), conflict of interest regulations of, 24

American Bionetics, Inc., 124

American Cyanamid Co.

consolidations by, 57

diversification by, 123

product marketing arrangements by, 8

Amgen, 88,92

cost of biotechnology products of, 84

financing strategies, $6,48,49,50,56,59,61,63$

product marketing arrangements by, 80

Animal and Plant Health Inspection Service (APHIS), deliberate release regulation by, 179,180

Applied Biosystems, 156

Applied Biotechnology, 124

Ares-Serono Group, 57

Argentina

food exports by, 112

intellectual property protection in, 92

seed company subsidiaries in, 108

Asgrow Seed Co.

acquisition of, 109

patent infringements and, 110

Asia

consolidations involving companies in, 55

public opinion of agricultural biotechnology, 10, 112-113

strategic alliances involving companies in, 58,59,60,61

See also individual countries in

Australia

pharmaceutical cost-containment in, 84

plant patenting in, 110 research policies and regulation in, 15, 151

seed company subsidiaries in, 108

Austria, 108

Bacillus thuringiensis (BT), 113

gene transferred to plant, 105, 106-107

use in biopesticides of, 102-103

Bager, 89

Bangu Pharmaceutical, 85

Belgium

biotechnology infrastructure in, 21

centralized waste treatment facilities in, 135

patent term extension proposal in, 93

Biogen, financing strategies used by, 47

Bio-oriented Technology Research Advancement Institution, 156-157

Biopesticides

agricultural use of, 105-106

approval of Mycogen's, 103

market for, 102-103

BioProbe International, Inc., 124

Bioremediation

advantages of, 136-137

case study, 131-140

constraints on use of, 12,40

environmental protection laws effect on use of, 40

Biotechnica International Diversification of, 109

Biotechnology

in chemical industry, 120-122

commercial activity overview, 3-12, 29-32,39-41

defining, 3,5,29,33

environmental applications of, 129-140

intellectual property rights in, 208-210

in pharmaceutical industry, 73-94

policy overview concerning industrial commercialization of, 13-19,31-32, 147

products under development, 79

as a singular coherent entity, 3,31,39

Biotechnology Development Center (BIDEC), 157

Biotechnology Directorate (U.K.), 160

Biotechnology General Corp, 124

Biotechnology Joint Research Association, 153

Biotechnology Research for Industrial Development and Growth in Europe (BRIDGE) program, 104

Biotechnology Research Subcommittee (BRS)-OSTP, 23,174

Biotechnology Science Coordinating Committee (BSCC)OSTP, 22-23

interagency agreements concerning regulatory policy and, 173,176

See also Biotechnology Research Subcommittee

"Black Monday" effect on biotechnology financing of, 6-7,46,47, 51,54

See also Financing; Wall Street

Boehringer-Mannheim Corp., 60,89

Bovine somatotropin (bST), 102, 190-191, 194, 1\%

farmer resistance to, 40

See also Agriculture; Pharmaceuticals

Boyer, Herbert, 56 
Brazil

food exports by, 112

intellectual property protection for pharmaceuticals in, 92-93

pharmaceutical cost-containment policy in, 84

regulation of biotechnology in, 15

seed company subsidiaries in, 108

Bristol-Myers Squibb Corp., 88

Budapest Treaty on the International Recognition of the Deposit of Microorganisms for the Purposes of Patent Procedure, 207

Burroughs Wellcome Co., 60,82

Bush, George (President), 177

Calgene, Inc.

diversification of, 109

product approval requested by, 183

California

DBCs in, 89

deliberate release protests in, 188

California Biotechnology, Inc., 89

Canada, 51

animal vaccine development and approval in, 101

biohydrometallurgy program in, 131

intellectual property protection in, 92-93

pharmaceutical cost-containment policy in, 84

seed company subsidiaries in, 108

Canadian Center for Mineral and Energy Technology, 131

Cancer, biotechnology research on, 76

Capital

variations in cost of (international), 6,50,51-53

See also Costs; Economics; Financing

Cardo, 109

Cargill, 109

Celanese Research Co., 123

Cellular Products, 124

Center for Biologics Evaluation and Research (FDA), 75,90

Center for Drug Evaluation and Research (FDA), 75

Centocor

FDA product regulation and, 79

marketing alliance by, 84,85

Cetus Corp.

FDA regulatory decision effect on, 79,90

marketing alliance by, 89

merger with Chiron, 6,54

Proleukin export by, 91

chemical industry, 119-124

biotechnology's commercial applications in, 10-12, 120-122

restructuring of, 10-11,40, 122-124

See also Industry

Chile, 108

Chiron Corp.

financing strategies and market value of, $48-49$

merger with Cetus by, 6, 54

Chugai Pharmaceutical, Inc., 7,54,57,89

Ciba-Geigy Corp., 58,59,60,82,89,108

Cistron, 124

Clause Co., acquisition of, 109

Clean Water Act (CWA), 138

Commercialization

activity concerning biotechnological, 3-12,29-32,39-41

barriers to bioremediation, 137-139

congressional options to promote biotechnology, 22 factors affecting biotechnology, 31,32

national (worldwide) policies effecting biotechnological, 13-19,31-32, 147, 151,

$152,161-166,169$

U.S. policy effects on industrial biotechnological, 151, 152, $161-166,169$

U.S. policy concerning technology transfer and biotechnological, 166-167,169

Competitiveness, 19-21,3941

European industrial biotechnology commercialization's, 21

Japanese industrial biotechnology commercialization's, 1921

prerequisites for biotechnology, 14

U.S. industrial biotechnology commercialization's, 19

See also Commercialization

Comprehensive Environmental Response, Compensation, Liability Act (CERCLA), 138

Congress, U.S.

global biotechnology competitiveness interest by, 32

Orphan Drug Act amendment attempt by, 92

policy options for, 21-25

USDA basic research finding increase by, 111

Consolidation

of seed companies, 108

trends in biotechnology, 6-7,53-57

See also Acquisitions

Containment

EC regulations covering, 192

of genetically altered micro-organisms, 177-178

NIH Guidelines for, 173,174, 186

Coordinated Framework for Regulation of Biotechnology, 180

OSHA Guidelines in, 178, 179

product approval under, 15-16

regulation under, 22, 184, 186

Corporate relationships. See Acquisitions; Consolidation;

costs Strategic alliances

bioremediation, 136

pollution cleanup, 131, 139-140

of receiving a U.S. patent, 215-214

See also Economics; Financing

Crick, Francis H.C., 31

Crop Genetics International, Inc. (CGI), 103

Cytel Co., 89

Cytogen Corp., 124

Dedicated biotechnology companies (DBCs) acquisition of U.S. pharmaceutical, 87,88 agreements with established pharmaceutical companies for marketing by, 84-85

capital acquisition methods of U.S., 3-6,7,39,50-51,53

consolidation trends of, 6-7,53-57, 87, 88

patent piracy problems of, 19, 110,223

strategic alliances' use by U.S., 88-89

tax law changes to aid, $24-25$

venture capital available for, 3-6,7,39, 50

DeKalb Seed Co., 108

Denmark

biotechnology regulation development in, 15,40, 189

centralized waste treatment facilities in, 135

pharmaceutical cost-containment policy in, 84

public opinion of agricultural biotechnology, 10 
research policies in, 151

Department of Agriculture, U.S. (USDA)

plant genome mapping program, 104

product approval by, 15

regulation of plants and animals for food by, 172, 180

Department of Commerce, Us. (DOC), 119

Department of Energy, U.S. (DOE)

genome project funding by, 104

MEOR incentives of, 131

Department of Health and Human Services, U.S. (DHHS)

biotechnology regulation by (proposed), 24

FDA review by, 90

See also commission's and programs under jurisdiction of

d'Estaing, Giscard, 159

Developed countries. See Industrialized nations

Developing countries

difficulty in meeting regulatory requirements by, 186

field-tests in, 112

food exports by, 112

See also Newly Industrializing Countries; individual countries

Development. See Commercialization

Diamond v. Chakrabarty, importance and effects of, 16,209, 214,223

Dow chemical Co., diversification by, 123

Dow Jones Industrial Average. See Black Monday; Wall Street

DNA Plant Technology Corp.

agricultural cell culture R\&D by, 105

diversification by, 123

Drugs. See Pharmaceuticals

Drug Export Amendments Act of 1986,91

Drug Price Competition and Patent Term Restoration Act of 1984,93

du Pent\& Nemours Co., E.I.

agricultural cell culture R\&D by, 105

diversification by, 123, 124

Eastman Kodak Co., 59

Economics

of bioremediation's commercialization, 139

of biotechnology companies (worldwide), 6,45-53

of consolidation involving biotechnology companies, 53-64

of resource use, 12

See also Costs; Financing

Elf Aquitaine Corp. diversification by, 124

Eli Lilly \& Co.

acquisitions by, 88

licensing deals by, 80

Enimont Corp., diversification by, 124

Environment

applications of biotechnology to, 12,129-140

planned introductions of genetically altered micro-organisms into, 21, 177-182

Environment and Gene Technology Act (EGTA)--Denmark, 189

Environmental Protection Agency (EPA)

bioremediation use by, 139

Exxon Valdez cleanup involvement by, 134

micro-organism regulation by, 15-16, 17,23, 172, 181

pesticide regulation by, 102-103, 172, 181

regulation of field testing by, 40

waste disposal R\&D conducted by, 137
Ernst \& Young, biotechnology survey by, 45,50,82,88

-Erythropoietin (EPO)

orphan drug status and profitability of, 92

price of, 84

See also Pharmaceuticals

Europe

animal vaccine development and approval in, 101

biotechnology programs in, 160-161, 162,163-164

biotechnology regulation and promotion policies in, 14, 15, $21,40,112,151, .152,191-194$

chemical industry in, 10, 123-124

food exports from, 112

intellectual property protection for plants in, 110

national technology policies in, $14,151,152,158-160$

pharmaceutical market competition by, 21,85

pollution cleanup costs in Western, 131

public opinion of biotechnology in, 10,40, 112

seed trade by, 108

strategic alliance Use in, 58,59,60,61, 89

See also European Community; individual countries in

European Community (EC)

biotechnology programs in, 160-161, 162,163-164

biotechnology promotion in, 14, 152

biotechnology regulation in, 15,21,112\$191-194

bST moratoriums in, 102

contamination inventories in countries of, 135-136

financial-related information on countries in, 50,52-53

food exports by, 112

gene mapping work by, 104

market for drugs in, 85

pharmaceutical patent term extension legislation in, 93

See also Europe; member countries of

European Patent Convention (EPC), requirements of, and rights protected under, 208

Experimental Use Permit (EUP), 179,180

Exxon Valdez

bioremediation project, 134

public attention on bioremediation after oil spill in, 129

Federal Coordinating Council on Science, Engineering, and Technology (FCCSET), 176

Federal Insecticide, Fungicide, and Rodenticide Act (FIFRA), deliberate release regulation under, 16, 179, 180

Federal Meat Inspection Act, U.S., 184

Federal Register, 23

Federal Trade Commission (FTC), 56

Field tests

countries performing agricultural biotechnology-related, 10, 11

EPA regulation of U. S., 15-16, 17,40

See also Agriculture; Regulation

Financial Accounting Standards Board (FASB), 25

Financing

biotechnology R\&D strategies, 45-53

biotechnological environmental cleanup research efforts, 137, 139,140

congressional options for biotechnology research, 21-22

German biotechnology, 160

Japanese biotechnology research and development, 154,155, 157,158

overview of biotechnology, 3-7

supporting microbiological mining, 131 
Swiss biotechnology, 160

U.S. Government R\&D 3,19,20,21-22,111,131, 137,140

See also Costs; Economics

Food

biotechnological applications to processing, 107

uses of transgenic animals, 184-186

uses of transgenic plants, 182, 183

Food and Drug Administration (FDA)

basis of biotechnology-based product regulation authority by, $15,16,22,76$,

107, 111, 176-177

biotechnology-based drug approval process of, 7,56,75-78, 79

bST approved by, 102

L-tryptophan recall by, 120

orphan drug approval by, 92

regulation effects on financial status of DBCs, 52,75-76,78, 79

regulation of plants and animals as food, 173, 176-177, 178, 182

regulatory delay's effect on biotechnology-based industry, 75-76,78,79,90-91

review by HHS, 90

Food, Drug, and Cosmetic Act (FDCA), FDA regulation of biotechnology products under, 15,16,22,76, 107, 111, 176-177, 183

Food Safety and Inspection Service (FSIS), 185, 186

France

biotechnology infrastructure in, 21

biotechnology policy in, 159

biotechnology regulations in, 15, 193

biotechnology R\&D in, 83, 135

patent term extension proposal in, 93

pharmaceutical cost-containment policy in, 84

seed company subsidiaries based in, 108

Fresh World Venture, 105, 123

Fuji Film, 156

Funai Pharmaceuticals Co., Ltd., 123

Funding. See Financing

Funk Seed Corp., acquisition of, 108

Garst Co., consolidation activity by, 108

Gen-Probe, Inc., acquisition of, 54,57,89

Genentech

biotechnology product pricing by, 84

FDA regulatory decision's effect on, 90

financing strategies and market value of, 47,4849,50,53,80

merger with Hoffmann-La Roche by, 6, 54, 56, 57, 82, 89

Ministry of Health and Welfare (Japan) grant to, 156

product marketing arrangements by, 80

General Agreement on Tariffs and Trade (GATT, 217-218,224

patent law harmonization effort using, 23-24

pharmaceutical industry protection under, 91

See also Regulation

Generally recognized as safe (GRAS), 177,182

Genetic Systems, 54,57,88

Genetic Technology Law (Germany), 190

Genetics Institute, Inc., merger by, 48,89,92

Genex, Inc., merger by, 47

Genofit SA, 124

Genzyme Corp., proposed takeover by, 57

Germany biotechnology infrastructure in, 21

biotechnology policy and regulation in, 15,40, 160,189

biotechnology R\&D funding in, 83, 135

centralized waste treatment facilities in, 135

Green Party's strength in, 186-187

pharmaceutical market competition by, 83,85

public opinion of biotechnology commercialization in, 10,40, 186,187

seed company subsidiaries in, 108

Gilead Sciences, 89

Gist-Brocades, Inc., industrial enzyme production by, 121

Glaxo, InC.

multilateral nature of, 81,82

$\mathrm{R} \& \mathrm{D}$ investments by, 93

strategic alliance use by, 89

Goodwill, amortizing, 25,67

Goodwill Industrial Large-Scale Practice (GILSP), 180, 195

Government, U.S. See United States

Granulocyte colony stimulating factors. See Pharmaceuticals

Greece, pharmaceutical cost-containment in, 84

Green parties, makeup, policies, and opinions of biotechnology by, $186-187$

Gross national product (GNP)

chemical industry and, 122

See also Wall Street

Growth hromones. See Human growth hormone

Guidelines

NIH laboratory safety, 174, 195.

NIH standards as basis for industrializedhations', 173, 174, 175

technology transfer, 165

See also Regulation

Hansens Co., industrial enzyme production by, 121

Harmonization. See Intellectual property; Patents

Hawaii, deliberate release regulation in, 188

History

of chemical industry growth rate compared to GNP, 122

of seed companies, 108

of U.S. commercial biotechnology, 45-48

Hitachi Corp., second-generation genome sequencer, 156

Hixson, Harry, 61

Hoechst Chemical Corp., diversification by, 123

Hoffmann-La Roche, Inc.

licensing deals by, 80

mergers by, 6,7,48,56,57,82, 89

multilateral nature of, 82

Holden's Foundation Corn Seeds, 108

Human growth hormone

orphan drug status and profitability of, 92

price of, 84

See also Pharmaceuticals

Human immunodeficiency virus (HIV). See Acquired immunodeficiency syndrome

Hybrids

developing new, 107, 110

RFLP techniques for producing, 103, 104

seed, 109, 110

See also Agriculture; Plant breeders' rights

Hybritech, Inc., 88 
ICI Chemical Corp.

diversification by, 123-124

seed company subsidiaries of, 108

Illinois, deliberate release regulation in, 188

Immunex Corp., product marketing arrangements by, 80

Immunomedics, Inc., 89

Incentives

bioremediation product development, 140

biotechnological R\&D, 64-66,91-93

intellectual property protection, 91-93

investment and cooperation in biotechnology, 64-66,153-154

microbial enhanced oil recovery use, 131

India

intellectual property protection in, 92

seed company subsidiaries in, 108

Industrialized nations

agricultural applications of biotechnology in, 9-10

biotechnology regulation in, 14-15, 188-195

financial health of biotechnology companies in, 50-64

food exports by, 112

See also Newly Industrializing Countries; individual nations

Industry

biotechnology as a singular, coherent, 3,31,39

case study of seed, 107-112

congressional options for improving university relationships with, 24

consolidation within, 53-64

facility location and regulation of European, 16

financing and market values of "biotechnology", 46-53

international biotreatment, 135-136

Japanese weakness in biotechnology-related sectors of, 20

policy concerning biotechnology's commercialization by, 13-19,31-32, 147

R\&D focus of "biotechnology", 4546

U.S. biotreatment, 132-135

See also Commercialization; individual industries

In re Durden, 220-221

Institute for Immunology (Japan), DBC investment by, 89

Institute of Life Sciences, 153

Institute of Molecular and Cell Biology, 154

Integrated Genetics, Inc., 57

Intellectual property protection, 203-224

agricultural-related, 110

biotechnology commercialization and, 16-19,208-210

congressional options concerning; 23-24

international agreements concerning, 205-208

See also individual forms of

Interleukin II

export of, 91

FDA regulatory decision on, 90

See also Pharmaceuticals

International agreements

on intellecual property, 205-208

See also individual conventions, treaties

International Trade Commission (ITC), 24, 219

International Union for the Protection of Plant Varieties

(UPOV),requirements of,and rights provided under, 110, 207-208

Investigational New Drug (IND) application, 76

Italy

biotechnology regulation in, 14-15

pharmaceutical cost-containment in, 84 pharmaceutical R\&D funding by, 83

seed company subsidiaries in, 108

Japan, 151

biotechnology promotion and commercialization in, 13-14, $19-21,152$

biotechnology regulation development in, 15,40,91, 192

chemical industry in, 120-121, 123, 124

consolidation activity in, 88

economic growth policies of, $84,152,153,155,158$

economics of biotechnology companies in, 50,53

government-industry relations in, 157-158

market penetration in, $85,86,91$

pharmaceutical industry in, 83,84,85,86,88

pharmaceutical patent-term extension legislation in, 93

plant patenting in, 110

public opinion of biotechnology in, 10, 112-113

research in, 83, 155

seed company subsidiaries in, 108

strategic alliances use in, 89

waste treatment in, 135

Japan Association of Industrial Fermentation, 157

Japan Development Bank, 20, 154

Japan Health Sciences Foundation, 156-157

Japan Research Development Corp. (JRDC), 156

Johnson \& Johnson, 59,82,88

Key Technology Center, 157

Keyworth, George, 164

Korea, South, biotechnology policy\& research in, 13-14, 154

Korea Genetic Research Association (KOGERA), 154

Latin America

seed trade in, 108

See also individual countries in

Legislation

bioremediation-relevant, U.S., 138

biotechnology-related, 15,214

patent term extension, 93

process patent protection (proposed), 24

See also individual statutes

Limagrain, 108

Litigation

biotechnology-related, 219,220,223

financial drain from patent-related, 19

See also individual cases

Lubrizol Enterprises

diversification by, 124

seed company acquisition by, 109

Market-Oriented Sector-Selective (MOSS) talks, 86

Massachusetts General Hospital, 123

Max Planck Institute (Germany), 191

Medicaid, 84

Medicare, 83,84,92

Medicare Pharmaceutical and Prudent Purchasing Act, 84

Merck \& Co., Inc.

licensing deals by, 80,89

multinational nature of, 82

Merck Frosst, 93

Mergers. See consolidation

Merrill (U.S.), 123 
Mexico, 108

Microbial Enhanced Oil Recovery (MEOR), state of and challenges to, 131, 132

Midwest Plant Biotechnology Consortium (MPBC), 166

Mining, microbiological, 131

Ministry of Agriculture, Forestry, and Fisheries (MAFF)Japan

biotechnology support by, 156-157

field testing regulated by, 111

gene mapping work by, 104

Ministry of Education, Science and Culture (MESC)--Japan, biotechnology support by, 153, 154-155

Ministry of Health and Welfare (MHW)--Japan, biotechnology support by, 86, 156

Ministry of International Trade and Industry (MITI)--Japan biotechnology initiatives of, 19-20, 153-154

biotechnology's targeting by, 11-12, 19, 120-121, 154

industry-government cooperation and, 157-158

Next Generation projects of, 153

Minnesota, bST moratorium in, 102

Missouri, deliberate release protests in, 188

Mitsubishi chemical Industries, agricultural cell culture R\&D by, 105

Mitsubishi Kasei Corp., 153

Mitsubishi Knowledge Industry, 156

Mitsui Toatsu Chemical Co., agricultural cell culture R\&D by, 105

Molecular Biosystems, Inc., 124

Molecular Genetics

diversification by, 124

original genetically engineered vaccine introduced by, 101

Monosodium glutimate (MSG), 120

Monsanto Agricultural Co.

diversification by, 123-124

relationship with Oxford University by, 160

Morita, Katsura, 157

Morocco, 108

Mycogen

biopesticide development by, 103

financing strategies used by, 48

Nakasone (Prime Minister Japan), 155

National Biotechnology Policy Board, 177

National Institute of Agrobiological Resources, 157

National Institute of Genetics (Japan), 154

National Institutes of Health (NIH)

basic research funding by, 21-22, 164-165

bST safety confirmed by, 102

conflict of interest regulations of, 24

genome project funding by, 104

laboratory-safety guidelines of 173, 174, 195

recombinant DNA-Advisory Committee (RAC), 173

National Program in Biotechnology-Singapore, 154

National Research Initiative, 111

National Science Foundation (NSF), genome project funding by, 104

National Technical Information Service (NTIS), 32

Netherlands, The, 15

pharmaceutical cost-containment in, 84

seed company subsidiaries in, 108

waste treatment research by, 135

New Developments in Biotechnology: Patenting Life, 23
New Developments in Biotechnology: U.S. Investment in Biotechnology, 24,74

New Drug Application (NDA )--PTO, 76,93

Newly Industrializing Countries (NICs)

biotechnology promotion and research polices of, 151-152

biotechnology regulation in, $14,188-189$

contaminated areas in, 135-136

economic growth policies of, 152, 154

intellectual property protection in, 92

See also individual countries

Nippon Telephone \& Telegraph, 157

Northrup King, 109

Nova Pharmaceutical Corp., 89

Novo-Nordisk, industrial enzyme production by, 121

Office of Management and Budget (OMB), role in BSCC dissension of, 176

Office of Scientific and Technical Policy (OSTP)

BSCC and BRS formation by, 23, 176, 181

regulatory policy promulgated by, 15

Office of Technology Assessment (OTA), 5,23,29,31

biotechnology funding conclusions in reports by, 151, 152

international competitiveness measurement by, 19,20

planned introduction report by, 131

workshops and conferences conducted by, 32-33

Okazaki National Research Institute (Japan), 154-155

Omnibus Budget Reconciliation Act of 1990,25,66

Organization of Economic Co-operation and Development (OECD)

basis of differences in biotechnology regulation in, 194

EC biotechnology directives based on recommendations by, 191-195

waste treatment $R \& D$ in countries of, 135-136

See also individual member nations of

Organization of Petroleum Exporting Countries (OPEC), 122

Orphan Drug Act

biotechnology products and, 91,92

cost-containment and, 83, 84, 85

intentions of, 40

tax credits and, 66-67

See also Pharmaceuticals

Ortho Biotech, 88

FDA product regulation and, 79

licensing deals by, 80

Oxford University, 160

Pacific Rim countries. See Newly Industrializing Countries

Paris Convention for the Protection of Industrial Property, 206

Patents

biotechnology protection under, 17-18,203-204,205,210223

farmers exemptions to, 222-223

harmonization of procedural requirements worldwide for, 18-19,23-24,203-204

legislation affecting, 18-19,23-24,93

piracy of U.S., 19,213-214

plant protection using utility, 205

requirements for, objectives of, and protection offered by, 203-204

See also Intellectual property protection

Patent and Trademark Office, U.S. (FTO)

application backlog effects, 16-17,212-124 
See also Intellectual property protection; Patents

Patent Cooperation Treaty (PCT), requirements of and rights provided by, 206-207

Personnel

brain-drain of experienced English biotechnology, 160

shortage of trained bioremediation, 139

Pesticides

nonchemical, nonrecombinant, 102-103

recombinant, 105-106

regulation of genetically engineered, 173, 179, 181

Pfizer, Inc., 107

Pharmaceutical industry, 7-16

acquisition activity in, 7-8,9, 10,54-59,85-87

biotechnology used in, 73-94

characteristics, 7,10, 81-82

Japan's, 85,86, 156

multinational nature of, $81-82$

regulation of, 89-91

strategic alliance use by, $88-89$

Pharmaceutical Manufacturer's Association (PMA), biotechnology-derived drug survey by, 75-78,79

Pharmaceuticals

approval of biotechnology-based, 75,76-78

cost-containment and, 83, 84, 85

marketing, 81,85,86

orphan drug status and price of, 84,85

patent term extension for, 93

planned use of recombinant, 178-179

price manipulation in Japan of, 156, 158

See also Pharmaceutical industry

Philippines, 108

Pioneer Hi-Bred International, 108, 109

Planned introductions

criteria for risk assessment of, 179

of genetically altered micro-organisms, 178-182, 183

of plant pest derivatives, 179

of transgenic animals, 182

of transgenic plants, 182-183

of vaccines, 178-179

regulation of, 189

See also Regulation

Plant breeders' rights, 110,204-205

Plant Genetic Systems

hybrid development by, 110

transfer of insecticide resistant gene by, 106

Plant genome projects, 103,104

Plant Patent Act of 1930, requirements for and protection under, 110,204

Plant Pest Act (PPA), deliberate release regulation under, 179, 180

Plant Quarantine Act (PQA), deliberate release regulation under, 179, 180

Plant Variety Protection Act of 1970 (PVPA)

intentions of, 40, 110

requirements of and protection under, 31,204-205

Policy

categories of, and examples of national biotechnology R\&D, 152-166

national regulatory, 186-195

options concerning industrial commercialization of

biotechnology for Congress, 21-25,41

overview of biotechnological industrial commercialization,
13-19,31-32, 147

overview of biotechnological R\&D, 13-14, 147

U.S. national, in a global environment, 166-167

Pollution

control using biotechnological techniques, 129, 134

See also Toxic waste

Poultry Products Inspection Act, 184

Praxis Biologic

American Cyanamid's takeover of, 57

product marketing arrangements by, 80

Product License Application (PLA), 76

Protein Engineering Research Institute (PERI), 153, 157,158

Provisional Council for Educational Reform (Japan), 155

Public Health Service (PHS)--(DHHS), 24

Public Opinion of risks and ethics of biotechnology-related R\&D, 10,40, 112-113, 129, 136-137, 186, 187

Quayle, Dan (Vice President, U.S.) 176,177

Raab, Kirk, 56

Recombinant DNA Advisory Committee (RAC), 173

Regeneron Pharmaceuticals, 7

Regulation

agricultural, 111

bioremediation commercialization and, 138-139

congressional options for developing industrial biotechnology, 22-23

of contained uses of micro-organisms, 177-178

effect on competitiveness of, 14-16, 111, 195-196

national policies for, 186-195

pesticide, 103-104,173, 179,181

pharmaceutical industry, 89-91

planned release, 178-182, 183, 189

State biotechnology-related, 180

Remet, 107

Repligen, Inc., 89

Research

associations (Japan), 157

biotechnology-related product, 3-7,21-22,45-46,79,154, $155,157,158$

congressional options for funding biotechnology, 21-22

environmental applications of biotechnology, 131-132, 134$135,137,139-140$

funding biotechnology, 45-68

importance of Japanese cooperative, 157, 158

Japanese search for access to foreign, 20

microbiological mining, 131

problems with bioremediation, 137

regulation's effect on locating facilities for, 16

seed industry, 109-110

types of, 31

U.S. Government biotechnology, 3,19,20,21-22, 111, 131, 137,150

Research and development (R\&D). See Commercialization; Research

Research and Development Limited Partnerships (RDLPs), biotechnology investment using, 53

Research and Development Tax Credit, 24-25,64-67

Research base

French, 159

German, 160

Japanese, 153, 155, 156 
relative strength of European, Japanese, and United States, 20, 40

Swiss, 160-161

United Kingdom's, 160

Resource Conservation and Recovery Act (RCRA), 138

Restriction fragment length polymorphism (RFLP) analysis, plant breeding using, 103, 104

Rhone-Poulenc

diversification by, 124

seed company acquisition by, 108-109

Risk assessments

biotechnological, based on similar technologies, 14

See also Guidelines; Regulation

Roche Holdings, Ltd., acquisition of Genentech by, 56,82,89

Rohm \& Haas

diversification by, 123

industrial enzyme production by, 121

Royol Dutch-Shell, diversification by, 124

San Diego, 31

Sandoz, Inc.

diversification by, 124

in-home biotechnology expertise by, 89

intellectual property protection's effect on R\&D investment by, 93

seed company acquisition by, 109

Sanofi (France), 88

Schering AS, 57

Schering-Plough Corp.

acquisitions by, 57

licensing deals by, 80

Science and Technology Agency (STA)--Japan, biotechnology support by, 153,156

Seiko, human genone mapping research by, 156

Shearson Lehman Hutton, survey of biotechnology use in companies, 4849,50,51,58,59

Showa Denko (Japan), 120

Singapore

biotechnology policies of, 154

biotechnology promotion in, 13-14

regulation in, 14-15

Small Business Finance Corp. (Japan), 20, 154

SmithKline Beckman, merger by, 82

SmithKline Beecham PLC, licensing deals by, 80

South Africa, biohydrometallurgy program in, 131

South Korea, regulation in, 14-15

Spain

regulation in, 14-15

seed company subsidiaries in, 108

Standard industrial classification (SIC), 119

Standards. See Guidelines; Regulation; individual agencies'

Standard and Poors 500. See Financing; Wall Street

Start-up companies. See Dedicated biotechnology companies

States

biotechnology regulation by individual, 188

See also individual States

Stauffer Seeds, 109

Stoneville, acquisition of, 109

Strategic alliances

European companies use of, 58,59,60,61,89

increased use of, 57-60

types of and trends in, 8,57-67
U.S. pharmaceutical DBCs' use of, 88-89

Strategies. See Policy

Subsidies

European Community agricultural, 161

See also incentives

Superfund Amendments and Reauthorization Act (SARA), 138

Supplementary protection certificate (SPC), 93

Swanson, Robert, 56

Switzerland

biotechnology infrastructure in, 21

biotechnology policy of, 160-161

pharmaceutical firms in, 81,82,83,85

Synergen, 124

Syntex Corp., multinational nature of, 82

System for Promotion of Exploratory Research for Advanced. Technology (ERATO), 156, 158

T Cell Sciences, Inc., 89

Taiwan

biotechnology promotion in, 13-14, 154

regulation in, $14-15$

Takeda, 153

Tanox Biosystems, 89

Tax Reform Act of 1986,24

Taxes

congressional options for structuring coherent policies concerning, 24-25

R\&D financing influenced by, 64-67

Technology transfer restructuring, 167

U.S. policy concerning, 166-167, 168

Thailand

food exports by, 112

seed company subsidiaries in, 108

Third-party payers,phannaceutical cost-containment and, 83-84

Third World. See Developing countries; Newly Industrializing Countries

Tissue plasminogen activator (tPA)

FDA regulatory decision on, 90

See also Pharmaceuticals

Toxic Substances Control Act of 1976 (TSCA), EPA regulation of micro-organisms under, 16,23, 179, 180, 181

Toxic Waste

biotechnology's use in treating, 129

cleanup costs for, 131, 139-140

See also Pollution

Toyo Soda 156

Trade secrets. See Intellectual property protection, 205

Training, Japanese need for foreign, 20

Transgenic animals, 183-186,214-216,217

Transgenic plants, 105-107, 182, 183

Tsukuba, Japan, 104

UCLA (University of California at Los Angeles), hybrid development by, 110

Union for the Protection of New Varieties of Plants (UPOV), 24, $207,208,217,218$

United Kingdom (U.K.)

biohydrometallurgy program in, 131

biotechnology-altered baker's yeast approved in, 107

biotechnology infrastructure in, 21

biotechnology policy in, 15,159-160,182, 193 
gene mapping work by, 104

pharmaceutical industry in, $81,82,83,84,85$

R\&D funding in, 83

united states (Us.)

acquisition activity in, 85-89

agricultural biotechnology applications in, 108, 112

biohydrometallurgy program, 131

biotechnology policy in, 14,15-16,152,161-167

chemical industry in, 10, 122-123, 124

commercialization trends in, 3, 19-20, 165

cooperative research in, 164-167

drug approval process in, 75,76-77,101

environmental cleanup in, 131, 136

financial situation of biotechnology companies in, 48-50,51

historical view of commercial biotechnology in, 45-48

intellectual property variety and protection in, 16-18, 19,93, 203-205

patent policy in, 93,209-210

pharmaceutical industry characteristics and trends in, 81,82 , $83,85-89,93$

research funding in, 3,21-22,83, 111-112

strategic alliances' use in, 88-89

university-industry research agreements in, 164-165, 167

Universities

congressional options for improving industrial relationships with, 24

hybrid development by, 110

relationship with industry of, 164-165, 167

role of Japan's national, 154-155

See also individual universities
Upjohn Co., The, 89, 109

U.S. Department of Agriculture (USDA)

basic research funding by, 3,21-22,83, 111

field test estimate by, 112, 113

PVPA administrationb $\mathrm{y}, 10$

Vaccines. See Pharmaceuticals

Venture capital financing in the United States, 3-6,7,39,50-51

role of, in Europe and Japan, 40,51-53

trends in availability to DBCs, 3-6,7

See also Costs; Economics; Financing

Virus-Serum-Toxin Act, 178, 184

Volvo, 109

\section{wall Street}

analyses of biotechnology firms, 6,7,49-50

effects of regulatory decisions on, 90

See also, "Black Monday"

Watson, James D., 31

Wellcome Foundation Ltd., The, 82

Wisconsin, bST moratorium in, 102, 191

World Intellectual Property Organization (WIPO), patent harmonization effort by, 23-24,207,217-218,234

World War II, 73

Wyngaarden, James, 164

Xoma Corp., $79,84,85,89$ 


\section{Other Related OTA Reports}

. Ownership of Human Tissues and Cells-Special Report

OTA-BA-337, March 1987; 176p.

GPO stock \#052-003-01060-7; $\$ 7.50$ per copy

NTIS order \#PB 87-207536

. Public Perceptions of Biotechnology

OTA-BP-BA-45, May 1987; 136p.

NTIS order \#PB 87-207544

- Field-Testing Engineered organisms: Genetic and Ecological Issues-Special Report

OTA-BA-350, May 1988; 160p.

NTIS order \#PB 88-214101

-U.S. Investment in Biotechnology-Special Report

Free summary available from OTA

OTA-BA-360, July 1988; 304p.

NTIS order \#PB 88-246939

- Patenting Life-Special Report

OTA-BA-370, April 1989; $204 p$.

GPO stock \#052-003-01 137-9; $\$ 8.50$ per copy

NTIS order \#PB 89-1\% 612

- Commercial Biotechnology: An International Analysis

OTA-BA-218, January 1984; 616p.

NTIS order \#PB 84-173608

- Impacts of Applied Genetics: Micro-Organisms, Plants, and Animals

OTA-HR-132, April 1981; 332p.

NTIS order \#PB 81-206609.

- Mapping Our Genes:Genome Projects—How Big? How Fast?

OTA-BA-373, April 1988; 232p.

NTIS order \#PB 88-212402 